\title{
Phosphorus Retention and Transformation in Floodplain Forests of the Southeastern United States
}

John A. Navaratnam

West Virginia University

Follow this and additional works at: https://researchrepository.wvu.edu/etd

\section{Recommended Citation}

Navaratnam, John A., "Phosphorus Retention and Transformation in Floodplain Forests of the Southeastern United States" (2013). Graduate Theses, Dissertations, and Problem Reports. 666.

https://researchrepository.wvu.edu/etd/666

This Dissertation is protected by copyright and/or related rights. It has been brought to you by the The Research Repository @ WVU with permission from the rights-holder(s). You are free to use this Dissertation in any way that is permitted by the copyright and related rights legislation that applies to your use. For other uses you must obtain permission from the rights-holder(s) directly, unless additional rights are indicated by a Creative Commons license in the record and/ or on the work itself. This Dissertation has been accepted for inclusion in WVU Graduate Theses, Dissertations, and Problem Reports collection by an authorized administrator of The Research Repository @ WVU.

For more information, please contact researchrepository@mail.wvu.edu. 
Phosphorus Retention and Transformation in Floodplain Forests of the Southeastern United States

John A. Navaratnam

Dissertation submitted to the

Eberly College of Arts and Sciences

at West Virginia University

in partial fulfillment of the requirements

for the degree of

Doctor of Philosophy

in

Biology

Richard B. Thomas, Ph.D., Chair

Mark R. Walbridge, Ph.D.

William T. Peterjohn, Ph.D.

Kevin C. Daly, Ph.D.

R. Kelman Wieder, Ph.D.

\section{Department of Biology}

Morgantown, WV

Keywords: Phosphorus Biogeochemistry, Wetland, Floodplain Forest, Alluvial, Blackwater, River, Soil, DNA, Bacteria, Fungi, Isotope, 31P-NMR

Copyright 2013 John A. Navaratnam 


\section{ABSTRACT \\ Phosphorus Retention and Transformation in Floodplain Forests of the Southeastern United States}

\section{John A. Navaratnam}

Phosphorus (P) commonly limits productivity in freshwater ecosystems; thus, increased $\mathrm{P}$ loading, either in dissolved (DP) or particulate (PP) form, can lead to eutrophication. In riverine ecosystems, floodplain forests (FFs) provide an important ecosystem service, that of improved water quality downstream, by either removing $\mathrm{P}$ from these incident floodwaters (retention) or by transforming $\mathrm{P}$ prior to export. The central goal of my dissertation research is to understand these biogeochemical mechanisms of $\mathrm{P}$ retention and transformation in rivers and streams and their associated FFs in the Atlantic Coastal Plain of the southeastern US (VA, NC, SC, GA).

To assess the nature of $\mathrm{P}$ removal during flooding events, I conducted a detailed study of $D P$ and $P P$ forms (inorganic, $P_{i}$ and organic, $P_{o}$ ) in waters from alluvial $(A L)$ and blackwater $(B W)$ FFs. At each FF site, floodwaters were collected both from the river inflow point (RI), from within the floodplain (FP) near the outflow point, and analyzed $\mathrm{P}$ forms by ${ }^{31} \mathrm{P}$ nuclear magnetic resonance (NMR) spectroscopy. In both AL and BW samples, total DP and dissolved orthophosphate $\left(\mathrm{DP}_{\mathrm{i}}\right)$ declined significantly from RI to FP, while dissolved pyrophosphate (complex $\mathrm{DP}_{\mathrm{i}}$ ) and total $\mathrm{DP}_{\mathrm{o}}$ were significantly higher in FP than in RI waters. Orthophosphate monoesters comprised the majority of the $\mathrm{DP}_{\mathrm{o}}$ pool and were significantly higher in FP floodwaters in both $\mathrm{AL}$ and $\mathrm{BW}$ systems. This suggests that in both $\mathrm{AL}$ and $\mathrm{BW}$ systems, $\mathrm{DP}_{\mathrm{i}}$ was converted to $\mathrm{DP}_{\mathrm{o}}$ form during flooding events, reducing its bioavailability and potential to cause the eutrophication of downstream waters.

In a second study, I added ${ }^{32} P_{i}$ dissolved in river water to soil cores collected $A L$ and $B W$ FFs to identify specific mechanisms of $P$ retention and transformation during flooding. As much as $77 \%$ of added ${ }^{32} \mathrm{P}_{\mathrm{i}}$ was transformed to ${ }^{32} \mathrm{P}_{\mathrm{o}}$ within $2 \mathrm{~h}$ of addition in $\mathrm{BW}$ river waters, while in $\mathrm{AL}$ river waters, all added ${ }^{32} \mathrm{P}_{\mathrm{i}}$ remained in inorganic form. However, when labeled river waters were added to soil cores, upon contact with the soil surface, additional transformation was observed resulting in an increase in the proportion of ${ }^{32} \mathrm{P}_{\mathrm{o}}$ in headwaters, averaging 68 and $80 \%$ of total ${ }^{32} \mathrm{P}$ recovered in $\mathrm{AL}$ and $\mathrm{BW}$ cores, respectively. Across all soil cores, average 12 and $0.5 \%$ of the total ${ }^{32} \mathrm{P}$ added was recovered from head- and drain-waters, respectively. The remaining $87.5 \%$ of added ${ }^{32} \mathrm{P}$ was recovered in soils, distributed within the soil fractions $(73$ $\%)$, microbial biomass $(9 \%)$ and roots $(6 \%)$. The proportion of ${ }^{32} \mathrm{P}_{\mathrm{i}}$ and ${ }^{32} \mathrm{P}_{\mathrm{o}}$ in cores averaged 69 and $31 \%$ in AL compared to 53 and $47 \%$ of total ${ }^{32} \mathrm{P}$ recovered in BW cores. These result suggest that floodplain soils act as a second line of defense protecting water quality, by retaining $\mathrm{P}$ inputs that are not initially transformed within the water column (river- and head-waters) during flooding events.

Despite our knowledge of the significant role of microorganisms in wetland soil $\mathrm{P}$ dynamics, little is known about the metabolic processes or taxonomic composition of the bacteria and fungi involved in the retention and transformation of $\mathrm{P}$ in wetlands, especially FFs. In a third study, I compare changes in microbial community composition in AL and BW FFs. Soil chemical properties reveal that total $\mathrm{P}$ (TP) concentrations were significantly higher in AL compared to BW soils, whereas total C (TC) was significantly higher in BW compared to AL FF soils. Similarly, the bacterial and fungal community composition was taxonomically different in AL compared BW FF soils. Detrended correspondence analyses of the microbial profiles and 
the subsequent fitting of environmental variables to ordination plots, revealed that $\mathrm{TP}$ and $\mathrm{pH}$ were associated with the composition of bacterial and fungal communities in AL soils, whereas, TC was strongly correlated with the microbial community profiles in BW FFs. These results indicate that differences in FF type (AL vs. BW) are associated with differences in soil TC, TP and $\mathrm{pH}$, that are important predictors of microbial composition.

My findings clearly indicate that FFs are indeed valuable ecosystems that have profound effects on the biogeochemical retention and transformation of excess P loadings carried with floodwaters, playing an important role in maintaining water quality in downstream aquatic ecosystems. It is forecasted that by 2025 as much as two-thirds (an estimated 5 out of the 8 billion people) of the world population will experience severe water scarcity due to climate change impacts and poor water quality resulting from the eutrophication of potable freshwater reservoirs. North America is likely to be impacted by these trends, and as such future policy decisions may be dependent on the prioritization of riparian wetlands (particularly FFs) based on their ecosystems functions and values. Despite their importance, in the southeastern US alone, bottomland hardwood forests (including FFs) continue to be lost at a rapid rate. This destruction of FF wetlands and their associated biogeochemical function is likely to add substantially to the eutrophication problem, and will continue to do so unless measures are taken to assess the sustainability of the ecosystem services they provide, and successfully replicate them through conservation, creation, and/or restoration of these wetland types. 


\section{ACKNOWLEDGEMENTS}

I would like to express my gratitude to Dr. Mark R. Walbridge for his encouragement and support during the course of this dissertation. His editorial advice was essential to the completion of this document. I would also like to thank the members of my advisory committee; Dr. Richard B. Thomas, Dr. R. Kelman Wieder, Dr. Kevin C. Daly, Dr. William T. Peterjohn, and as well as Dr. Barbara J. Cade-Menun, for providing much-appreciated encouragement and support following Mark's departure from WVU within a year of my studies. Over the years, I have been privileged to mentor several undergraduate students with research projects, and am especially indebted to the diligent efforts made by Neha A. Kumar, Joseph D. Lynch, John L. McClannahan, and Hasan Shahid. I would also like to acknowledge the faculty, administrative staff, and graduate students of our department, both past and present. Finally, I would like to thank my family and friends for their unconditional love, patience, and unyielding support, especially during some of the more difficult times over the course of this degree. 


\section{TABLE OF CONTENTS}

$\begin{array}{lll}\text { ABSTRACT } & \text { ii }\end{array}$

ACKNOWLEDGEMENTS iv

TABLE OF CONTENTS $\quad$ v

LIST OF FIGURES vii

LIST OF TABLES $\quad$ x

LIST OF APPENDICES C xii

$\begin{array}{ll}\text { Chapter } 1 & 1\end{array}$

General Introduction 1

$\begin{array}{ll}\text { References } & 19\end{array}$

$\begin{array}{ll}\text { Chapter } 2 & 37\end{array}$

Distribution of Phosphorus Forms during Spring Flooding Events in Alluvial and Blackwater Rivers and their Adjacent Floodplain Forests in the Southeastern US

$\begin{array}{ll}\text { Abstract } & 38\end{array}$

$\begin{array}{ll}\text { Introduction } & 40\end{array}$

$\begin{array}{ll}\text { Methods } & 49\end{array}$

$\begin{array}{ll}\text { Results } & 52\end{array}$

$\begin{array}{ll}\text { Discussion } & 58\end{array}$

$\begin{array}{ll}\text { Conclusions } & 68\end{array}$

$\begin{array}{ll}\text { References } & 71\end{array}$

$\begin{array}{lr}\text { Chapter } 3 & 108\end{array}$

Retention and Transformation of ${ }^{32} \mathrm{PO}_{4}{ }^{3-}$ during Simulated Flooding of Floodplain Forest Soil Mesocosms

Abstract 
Introduction $\quad 111$

$\begin{array}{ll}\text { Methods } & 120\end{array}$

$\begin{array}{ll}\text { Results } & 126\end{array}$

$\begin{array}{ll}\text { Discussion } & 132\end{array}$

$\begin{array}{ll}\text { Conclusions } & 144\end{array}$

$\begin{array}{ll}\text { References } & 146\end{array}$

$\begin{array}{ll}\text { Chapter } 4 & 184\end{array}$

Microbial Diversity and Function in Floodplain Forests of the Southeastern US

$\begin{array}{ll}\text { Abstract } & 185\end{array}$

$\begin{array}{ll}\text { Introduction } & 187\end{array}$

$\begin{array}{ll}\text { Methods } & 198\end{array}$

$\begin{array}{ll}\text { Results } & 209\end{array}$

$\begin{array}{ll}\text { Discussion } & 214\end{array}$

$\begin{array}{lr}\text { Conclusions } & 229\end{array}$

$\begin{array}{ll}\text { References } & 231\end{array}$

$\begin{array}{ll}\text { Chapter } 5 & 318\end{array}$

$\begin{array}{ll}\text { General Conclusions } & 318\end{array}$

$\begin{array}{ll}\text { References } & 324\end{array}$

$\begin{array}{ll}\text { Appendices } & 327\end{array}$ 


\section{LIST OF FIGURES}

Figure 1.1: Biogeochemical transformation and retention of $P$ in the sediment and the water column in floodplain forests (FFs) during flooding events.

Figure 2.1: Operationally defined $P$ forms in freshwater aquatic systems.

Figure 2.2: Examples and structures of ${ }^{31} \mathrm{P}-\mathrm{NMR}$ resolved inorganic and organic P forms.

Figure 2.3: Solution ${ }^{31} \mathrm{P}$ nuclear magnetic resonance spectra of water samples collected in an alluvial system at the Pee Dee River, SC.

Figure 2.4: Solution ${ }^{31} \mathrm{P}$ nuclear magnetic resonance spectra of water samples collected in a blackwater system at the Blackwater River, NC.

Figure 2.5: Solution ${ }^{31} \mathrm{P}$ nuclear magnetic resonance spectra of a water sample collected at the Satilla River, GA.

Figure 2.6: Mean $( \pm \mathrm{SE})$ of the a) proportion of total $\mathrm{P}$ in dissolved form, b) $\mathrm{Al}, \mathrm{c}) \mathrm{Fe}$, and c) particulate phytate concentrations in alluvial and blackwater river inlets and floodplain waters.

Figure 2.7: Mean $( \pm \mathrm{SE})$ of NMR visible dissolved inorganic and organic $\mathrm{P}$ :

a) sum of dissolved inorganic $\mathrm{P}, \mathrm{b}$ ) dissolved orthophosphate, and

c) dissolved inorganic pyrophosphate, d) sum of dissolved organic phosphorus, e) sum of dissolved orthophosphate monoesters, and f) dissolved phytate concentrations in alluvial and blackwater river inlets versus floodplain waters.

Figure 2.8: Mean $( \pm \mathrm{SE})$ of the a) sum of particulate orthophosphate monoesters and b) particulate scyllo-inositol phosphates in alluvial and blackwater river inlets and floodplain waters.

Figure 3.1: Sequential fractionation method used to extract $\mathrm{P}$ and ${ }^{32} \mathrm{P}$ from floodplain forest soils.

Figure 3.2: Specific activity of soil pools/fractions in flooded soil cores collected from the a. Pee Dee R., b. Wateree R., c. Black R., d. Drowning Crk. sites, and $\mathbf{e}$. average of all cores across FF sites.

Figure 3.3: Comparison of the molar ratio of Fe: $\mathrm{P}$ vs $\mathrm{Al}: \mathrm{P}$ in $\mathrm{H}_{2} \mathrm{O}(\mathbf{a}-\mathbf{b}), \mathrm{NaOH}(\mathbf{c})$, Res (e), $\mathrm{BD}(\mathbf{f}), \mathrm{HCl}(\mathbf{g}), \mathrm{HA}(\mathbf{h})$ extractable fractions and $\mathrm{NaOH}-{ }^{32} \mathrm{P}_{\mathrm{i}}$ vs soil clay content associated with the $\mathrm{Al} /$ clay vs. soil clay content (d) in cores collected from alluvial and blackwater FFs. 
Figure 4.1: Maximum-parsimony tree showing phylogenetic relationships of cloned

(a) bacterial 16S rDNA, and (b) fungal ITS sequences, from pooled DNA in soils collected in an alluvial (Wateree R., SC) and a blackwater (Black R., NC) FF, to related sequences from GenBank.

Figure 4.2: Maximum-parsimony tree showing phylogenetic relationships of cloned (a) bacterial 16S rDNA, and (b) fungal ITS sequences, from from ridge and swale soils in four alluvial (Wateree R., SC; Pee Dee R., SC; Nottaway R., VA; Ocmulgee R., GA) and four blackwater (Black R., NC; Drowning Cr., NC; Satilla R., GA; Salkehatchie R., SC) FFs, to related sequences from GenBank.

Figure 4.3: Bacterial 16S rDNA DGGE fingerprint profile of soils collected from one alluvial (Wateree R., SC) and one blackwater (Black R., NC) FF.

Figure 4.4: Fungal ITS rDNA DGGE fingerprint profile of soils collected from one alluvial (Wateree R., SC) and one blackwater (Black R., NC) FF.

Figure 4.5: Bacterial 16S rDNA DGGE fingerprint profile of soils collected from four alluvial (Wateree R., SC; Pee Dee R., SC; Nottaway R., VA; and Ocmulgee R., GA) and four blackwater (Black R., NC; Drowning Cr., NC; Satilla R. GA; and Salkehatchie R., SC) FF.

Figure 4.6: Fungal ITS rDNA DGGE fingerprint profile of soils collected from four alluvial (Wateree R., SC; Pee Dee R., SC; Nottaway R., VA; and Ocmulgee R., GA) and four blackwater (Black R., NC; Drowning Cr., NC; Satilla R. GA; and Salkehatchie R., SC) FFs.

Figure 4.7: Dendrogram showing clustering of (a) bacterial 16S rDNA, and (b) fungal ITS rDNA DGGE fingerprint profiles of soils collected from one alluvial (Wateree R., SC) and one blackwater (Black R., NC) FF.

Figure 4.8: Dendrogram showing clustering of (a) bacterial 16S rDNA, and (b) fungal ITS rDNA DGGE fingerprint profiles, of four alluvial (Wateree R., SC; Pee Dee R., SC; Nottaway R., VA; and Ocmulgee R., GA) and four blackwater (Black R., NC; Drowning Cr., NC; Satilla R., GA; and Salkehatchie R., SC) FFs.

Figure 4.9: Detrended correspondence analysis ordination diagram of (a) bacteria, and (b) fungal communities, associated with environmental variables (soil moisture, TN, TC, TP, microbial $\mathrm{P}$, and $\mathrm{pH}$ ) in soils collected from one alluvial (Wateree R., SC) and one blackwater (Black R., NC) FF. 
Figure 4.10: Detrended correspondence analysis ordination diagram of (a) bacteria, and (b) fungal, communities associated with environmental variables (soil moisture, TN, TC, TP, microbial $\mathrm{P}$, and $\mathrm{pH}$ ) in soils collected from four alluvial (Wateree R., SC; Pee Dee R., SC; Nottaway R., VA; and Ocmulgee R., GA) and four blackwater (Black R., NC; Drowning Cr., NC; Satilla R., GA; and Salkehatchie R., SC) FFs. 


\section{LIST OF TABLES}

Table 2.1: Locations and characteristics of the river systems in the southeastern U.S. Stream flow River data from USGS gauging stations located near each study site.

Table 2.2: Distribution of a) dissolved and particulate total $\mathrm{P}, \mathrm{MRP}, \mathrm{C}, \mathrm{Al}, \mathrm{Fe}, \mathrm{pH}$, and conductivity measured by chemical analysis, b) NMR visible dissolved $P$ forms, and c) NMR visible particulate $P$ forms in individual river inlet and floodplain samples collected at alluvial and blackwater systems in the southeastern U.S.A.

Table 3.1: Locations and characteristics of the study sites.

Table 3.2: Total $\mathrm{P}$ and ${ }^{32} \mathrm{P}$, inorganic and organic $\mathrm{P}$ and ${ }^{32} \mathrm{P}$, and TOC, TN, and $\mathrm{pH}$ in river waters collected at each alluvial and blackwater floodplain forest.

Table 3.3: Mean $( \pm \mathrm{SE})$ total $\mathrm{P}$ content and ${ }^{32} \mathrm{P}$ activity recovered in headwater, soils, and drainwater in alluvial and blackwater cores, non-flooded, and cores flooded for $40 \mathrm{~h}$ and $8 \mathrm{~d}$.

Table 3.4: Mean $( \pm \mathrm{SE})$ total $\mathrm{P}$ content and general soil physical and chemical characteristics in control cores, and cores inundated for $40 \mathrm{~h}$ and $8 \mathrm{~d}$ across all alluvial and blackwater cores.

Table 3.5: Mean $( \pm \mathrm{SE})$ of total $\mathrm{P}$ content in sequentially extracted fractions within control cores and soils flooded for $40 \mathrm{~h}$ and $8 \mathrm{~d}$ across all alluvial and blackwater cores.

Table 3.6: Mean $( \pm \mathrm{SE}){ }^{32} \mathrm{P}$ recovered in sequentially extracted fractions within control cores and soils flooded for $40 \mathrm{~h}$ and $8 \mathrm{~d}$ across all alluvial and blackwater cores.

Table 3.7: Mean ( \pm SE) of the proportion of organic $\mathrm{P}$ in TP measured in headwater, drainwater, microbial biomass, and sequentially extracted soil fractions within control cores and soils flooded for $40 \mathrm{~h}$ and $8 \mathrm{~d}$ across all alluvial and blackwater cores.

Table 3.8: Specific Activity $\left(\mathrm{SA}:{ }^{32} \mathrm{P} / \mathrm{P}, \mathrm{SA}_{\mathrm{i}}:{ }^{32} \mathrm{P}_{\mathrm{i}} / \mathrm{P}_{\mathrm{i}}, \mathrm{SA}_{\mathrm{o}}:{ }^{32} \mathrm{P}_{\mathrm{o}} / \mathrm{P}_{\mathrm{o}}\right)$ in sequentially extracted fractions in soils flooded for $40 \mathrm{~h}$ and $8 \mathrm{~d}$ across all alluvial and blackwater cores.

Table 3.9: Mean $( \pm \mathrm{SE})$ distribution of total $\mathrm{Al}$ and Fe in sequentially extracted fractions within control cores and soils flooded for $40 \mathrm{~h}$ and $8 \mathrm{~d}$ across all alluvial and blackwater cores. 
Table 3.10: Relationships between soil properties, $\mathrm{Al}, \mathrm{Fe}$, and ${ }^{32} \mathrm{P}$ activity, $\mathrm{P}$ concentrations, and SA were determined by Pearson's correlation analysis with Bonferroni probabilities reported.

Table 4.1: Locations and characteristics of the study sites.

Table 4.2: Oligonucleotide primers for targeting bacterial 16S rDNA and fungal $18 \mathrm{~S}$ rDNA/ITS genes from total genomic DNA extracted from soils.

Table 4.3: (a) Chemical analysis of soils sampled in ridge, dry swale, and/or flooded swale microsite elevations in one alluvial and one blackwater FF; and (b) Results of a 2-way ANOVA for the effects of floodplain type, ridge or swale microsite elevations, and the interaction term, on soil chemical characteristics.

Table 4.4: (a) Chemical analysis of soils sampled in ridge, dry swale, and/or flooded swale microsite elevations in soils collected from four alluvial (Wateree R., SC; Pee Dee R., SC; Nottaway R., VA; and Ocmulgee R., GA) and four blackwater (Black R., NC; Drowning Cr., NC; Satilla R., GA; and Salkehatchie R., SC) FFs; and (b) Results of the 2-way ANOVA of the effects of floodplain type, microsite elevation, and the interaction term, on soil chemical characteristics.

Table 4.5: Similarities of dominant (a) bacterial 16S rDNA: and (b) fungal ITS rDNA, sequences from excised DGGE bands, to clone library sequences and their closes relatives to sequences retrieved from GenBank, of soils collected from one alluvial (Wateree R., SC) and one blackwater (Black R., NC) FF.

Table 4.6: Similarities of dominant (a) bacterial 16S rDNA; and (b) fungal ITS rDNA, sequences from excised DGGE bands, to clone library sequences and their closes relatives, to sequences retrieved from GenBank, of soils collected from four alluvial (Wateree R., SC; Pee Dee R., SC; Nottaway R., VA; and Ocmulgee R., GA) and four blackwater (Black R., NC; Drowning Cr., NC; Satilla R., GA; and Salkehatchie R., SC) FFs.

Table 4.7: Shannon diversity index $(H)$, richness $(S)$, and evenness $(E)$, of bacterial and fungal DGGE fingerprint profiles, in soils from ridge (RD), dry swale (SWD), and/or flooded swale (SWF) microsite elevations, from one alluvial (AL) and one blackwater (BW) FF.

Table 4.8: Shannon diversity index, richness, and evenness, of bacterial and fungal DGGE fingerprint profiles of soils from ridge, dry swale, and/or flooded swale microsites in four alluvial and four blackwater FFs. 


\section{LIST OF APPENDICES}

Appx. Table 2.1: Results of a 2-way ANOVA for floodplain type and sampling location and interaction term in: a) dissolved and particulate Total P, MRP, C, Al, Fe, pH, and conductivity measured by chemical analysis, b) NMR visible dissolved $\mathrm{P}$ forms, and c) NMR visible particulate $P$ forms.

Appx. Table 3.1: Results of a 2-way ANOVA for floodplain type, incubation period, and interaction term for total $\mathrm{P}$ concentration and ${ }^{32} \mathrm{P}$ activity recovered in soils, headwater, and drainwater.

Appx. Table 3.2: Results of a 2-way ANOVA for floodplain type, incubation period, and interaction term for total $\mathrm{P}$ content and soil chemical and physical characteristics.

Appx. Table 3.3: Results of a 2-way ANOVA for floodplain type, incubation period, and interaction term for total $\mathrm{P}$ content in sequentially extracted fractions.

Appx. Table 3.4: Results of a 2-way ANOVA for floodplain type, incubation period, and interaction term for ${ }^{32} \mathrm{P}$ recovered in sequentially extracted fractions.

Appx. Table 3.5: Results of a 2-way ANOVA for floodplain type, incubation period, and interaction term for the proportion of organic P in TP measured in headwater, drainwater, microbial biomass, and sequentially extracted soil fractions.

Appx. Table 3.6: Results of a 2-way ANOVA for floodplain type, incubation period, and interaction term for Specific Activity $\left(\mathrm{SA}:{ }^{32} \mathrm{P} / \mathrm{P}, \mathrm{SA}_{\mathrm{i}}:{ }^{32} \mathrm{P}_{\mathrm{i}} / \mathrm{P}_{\mathrm{i}}\right.$, $\left.\mathrm{SA}_{\mathrm{o}}:{ }^{32} \mathrm{P}_{\mathrm{o}} / \mathrm{P}_{\mathrm{o}}\right)$ in sequentially extracted fractions.

Appx. Table 3.7: Results of a 2-way ANOVA for floodplain type, incubation period, and interaction term for the distribution of total $\mathrm{Al}$ and $\mathrm{Fe}$ in sequentially extracted fractions.

Appx. Figure 4.1: Maximum-parsimony tree showing phylogenetic relationships of bacterial 16S rDNA sequences cloned from soils from one alluvial (Wateree R., SC) and one blackwater (Black R., NC) FF.

Appx. Figure 4.2: Maximum-parsimony tree showing phylogenetic relationships of fungal ITS sequences cloned from soils from one alluvial (Wateree R., SC) and one blackwater (Black R., NC) FF. 
Appx. Figure 4.3: Maximum-parsimony tree showing phylogenetic relationships of bacterial 16S rDNA sequences cloned from soils from ridge and swale microsite elevations in four alluvial (Wateree R., SC; Pee Dee R., SC; Nottaway R., VA; Ocmulgee R., GA) and four blackwater (Black R., NC; Drowning Cr., NC; Satilla R., GA; Salkehatchie R., SC) FFs.

Appx. Figure 4.4: Maximum-parsimony tree showing phylogenetic relationships of fungal ITS sequences cloned from soils from ridge and swale microsites in four alluvial (Wateree R., SC; Pee Dee R., SC; Nottaway R., VA; Ocmulgee R., GA) and four blackwater (Black R., NC; Drowning Cr., NC; Satilla R., GA; Salkehatchie R.,SC) FFs. 349

Appx. Table 4.1: Identities of (a) bacterial 16S rDNA, and (b) fungal ITS rDNA, OTUs in clone libraries in soils collected from one alluvial (Wateree R., SC) and one blackwater (Black R., NC) FF.

Appx. Table 4.2: Identities of (a) bacterial 16S rDNA, and (b) fungal ITS rDNA, OTUs in clone libraries in soils collected from four alluvial (Wateree R., SC; Pee Dee R., SC; Nottaway R., VA; and Ocmulgee R., GA) and four blackwater (Black R., NC; Drowning Cr., NC; Satilla R., GA; Salkehatchie R., SC) FFs. 


\section{CHAPTER 1}

\section{General Introduction}

Phosphorus, an essential macronutrient in the environment, is vital to both biological structures (phospholipid membranes) and processes (replicating polymers (DNA and RNA) and cellular metabolism (energy transfer, ATP)) (Sterner and Elser 2002). In addition to its role in the transfer and storage of energy, $\mathrm{P}$ is important for mechanisms involved in cell growth and reproduction in plants, bacteria, and phytoplankton. Biological productivity is contingent upon the availability of $\mathrm{P}$ to photosynthetic organisms, as well as microbes that form the base of the food web in both terrestrial and aquatic ecosystems (Sterner and Elser 2002, Elser et al. 2007).

Phosphorus has a special function among the substances assimilated by living things: carbon, hydrogen, oxygen, and nitrogen are the elements of biological frameworks, phosphorus is the instrument of their manufacture (Pautard 1976).

Despite its biological importance, $\mathrm{P}$ often limits primary production in both terrestrial (Walker and Syers 1976, Vitousek and Howarth 1991, Vitousek 2004) and freshwater aquatic ecosystems (Schindler 1978, Hecky and Kilham 1988, Carpenter et al. 1992), and despite the importance of nitrogen $(\mathrm{N})$ recognized generally as a limiting nutrient in estuaries and saline systems, $\mathrm{P}$ has been found to limit primary productivity in some marine and brackish environments as well (Hecky 1998, Hellström 1998, Sanudo-Wilhelmy et al. 2001, Sundareshwar et al. 2003, Boesch et al. 2005, Sanudo-Wilhelmy 2006). Although $\mathrm{P}$ is an essential nutrient for all aquatic organisms, increased P loading to aquatic ecosystems can have negative effects. When nutrient inputs to aquatic ecosystems exceed the uptake capacity of primary producers, $\mathrm{P}$ loading can lead to eutrophication of freshwater and marine ecosystems. Eutrophication and its associated effects 
- degraded water quality, toxic algal blooms, anoxia, and loss of aquatic biodiversity, are primarily the result of anthropogenic (or human enhanced) nutrient inputs, mainly $\mathrm{N}$ and $\mathrm{P}$ (Carpenter 2005, Dodds et al. 2009). Phosphate (or dissolved inorganic P, DIP) is a common agent of cultural eutrophication in aquatic ecosystems, and is the form most likely to increase as natural landscapes are converted to culturally dominated ones (Carpenter et al. 1998, Withers and Jarvie 2008). Eutrophication can affect entire ecosystems and due to its occurrence across a wide geographical range, is regarded as one of the largest threats to the environment today (Bennett et al. 2001, Smith 2003, Carpenter 2005).

Changes in land use have been identified as an important component of global change that can alter an ecosystem's structure, function, and interactions with the atmosphere and other terrestrial and aquatic ecosystems on the landscape (Vitousek 2004). As natural landscapes are converted to culturally dominated ones (with a significant proportion of land use in agriculture, urban/suburban development, etc.), nutrient loadings (e.g. P), particularly to aquatic ecosystems, increase (Matson et al. 1997, Basnyat et al. 1999, Carpenter 2005). In addition to land use change, fertilizer use, deforestation, increased cultivation, and urban and industrial waste disposal all have enhanced $\mathrm{P}$ transport from terrestrial to aquatic ecosystems by as much as a threefold increase in riverine-P flux over pre-agricultural levels (Caraco 1995, Melack 1995, Withers and Jarvie 2008). About $80 \%$ of all nutrients in the sea come from land-based activities, including sewage and runoff from agriculture and urban areas (Ruttenberg 2005). Well over $90 \%$ of the $\mathrm{P}$ delivered by rivers to the ocean is as particulate $\mathrm{P}$ and the remaining total dissolved $\mathrm{P}$ component occurs in both inorganic and organic forms, where dissolved organic $\mathrm{P}$ (DOP) may account for as much as $50 \%$ of the dissolved riverine-P input (Maybeck 1982, 
Ruttenberg 2005). Excess P loading has led to changes in the biodiversity and nutrient status of marine and freshwater ecosystems across a wide geographic range (Smith 2003, Elser et al. 2007). Certain plants and animals thrive with excess nutrient loading, enabling them to increase in number and geographic extent, frequently at the expense of other native or economically important species (Pretty et al. 2003, Carpenter 2005, Dodds et al. 2009). Excessive growth of filamentous algae can result in oxygen depletion that leads to fish kills and changes in fish species composition, where economically less valuable freshwater and marine fishes thrive and sustainable fisheries are severely affected (Wilson and Carpenter 1999, Carpenter 2005, Dodds et al. 2009). In addition to causing anoxia and fish kills, certain marine dinoflagellate blooms (e.g., red/brown tides in the Baltic Sea and elsewhere) produce toxins that impact biodiversity, while in freshwater systems blue/green cyanobacteria can release neuro- and hepato-toxins that kill live-stock and harm humans (Kotak et al. 1993, Hoagland et al. 2002, Carpenter 2005).

Although the vulnerability of natural waters to anthropogenic $\mathrm{P}$ enrichment has long been

recognized, successful remediation strategies to provide a sound basis for the management of aquatic ecosystems are much needed (Fisher et al. 1995, Costanza et al. 1997). The nutrient retention and transformation capacities of riparian wetlands (including floodplain forests (FFs)) may be one mode of defense against reducing water-associated contaminants and excess nutrients (such as $\mathrm{P}$ ), to achieve the required $\mathrm{P}$ load reduction in riverine systems, and mitigate the consequent eutrophication of aquatic ecosystems.

\subsection{Wetland Ecosystem Services}

Located in stream and river floodplains, riparian wetlands (including FFs) occupy low-lying 
areas on the landscape, and as a consequence, are periodically inundated by waters from overbank flooding (Brinson 1993, Walbridge 1993, Mitsch and Gosselink 2007). As such riparian wetlands are transitional between terrestrial (upland) and open-water aquatic ecosystems, giving them the potential to regulate nutrient exchange between terrestrial and adjacent aquatic ecosystems, with beneficial effects on water quality in aquatic systems downstream (Kleiss 1996, Mitsch and Gosselink 2007). It is well known that FFs can improve water quality by removing nutrients, particularly $\mathrm{N}$ and $\mathrm{P}$ (Lowrance et al. 1984, Faulkner and Richardson 1989, Kuenzler 1989, Johnston 1991, Walbridge and Lockaby 1994, Lockaby and Walbridge 1998) from incident surface (overbank flooding - in addition to surface flows from surrounding uplands) and subsurface (ground) waters. While $\mathrm{N}$ is removed from soils primarily through denitrification, particularly during periods of low redox potential in wetland soils (DeLaune et al. 1996), the removal of DIP may involve several biotic and abiotic mechanisms (Walbridge 1991, Walbridge et al. 1991, Mitsch and Gosselink 2007). The P cycle is fundamentally different from the $\mathrm{N}$ cycle in that it has no substantial gaseous phase to facilitate the removal of P from wetlands (Reddy et al. 1999). This lack of gaseous phase means that DIP entering a FF is either stored in wetland sediment/soil or plant and microbial biomass, or remains in solution and may be carried out of the FF during flooding events (Hupp et al. 2005). Floodplain forests improve water quality by storing DIP received in floodwaters within the wetland (retention), and/or converting it in form (transformation) and then exporting it from the wetland ecosystem via hydrologic pathways (Richardson 1989, Lockaby and Walbridge 1998, Mitsch and Gosselink 2007). Thus the phosphate (DIP) carried in floodwaters that can lead to eutrophication of aquatic ecosystems is either retained within the wetland ecosystem, through sediment deposition, soil adsorption, plant uptake, or microbial immobilization (Johnston 1991, 
Lockaby and Walbridge 1998, Khoshmanesh et al. 1999), or transformed to organic P form(s) and then exported downstream (Lockaby and Walbridge 1998, Noe and Hupp 2007, Dierberg and DeBusk 2008). Any DIP not processed via these pathways would pass through the wetland ecosystem and then be exported downstream as DIP. High molecular weight organic P forms are less bioavailable than DIP, because they require enzymatic hydrolysis before they can be utilized by aquatic microorganisms, and are thus less likely to cause eutrophication of downstream aquatic ecosystems (Pant et al. 2002, McDowell and Koopmans 2006). While it has been wellestablished that FFs can both retain and/or transform DIP (Yarbro 1983, Lockaby and Walbridge 1998, Hupp et al. 2005), little is known about the relative contributions of these $\mathrm{P}$ retention/transformation mechanisms or how these functions are accomplished. Understanding the detailed mechanisms of $\mathrm{P}$ retention and transformation in FFs is critical to assessing the sustainability of these ecosystem services, as well as replicating them through wetland creation and restoration (Kuenzler 1989). Although, FFs currently represent a substantial 83 million ha of the world's wetlands, large expanses of these wetlands have been destroyed over the past few decades, primarily for conversion (draining and clearing of forests) to agriculture and urbanization (Turner et al. 1981, Hupp et al. 2005)

\subsection{Floodplain Forests of the Southeastern US}

Floodplain forests are found in many landscapes worldwide (e.g., Marion et al. 1993, Schoor 1994, Cey et al. 1999, Maingi and Marsh 2001, Amoros and Bornette 2002, Capon 2005, Brunet and Astin 2008, Lu and Yin 2008) and represent $14.5 \%$ (Aselmann and Crutzen 1989) of the global distribution of wetlands (USDA estimates an area of 83 million ha of wetlands on the Earths surface (Mitsch and Gosselink 2007). An estimated 66, 21, and $11 \%$ of global FFs are 
found in South America, Africa, and the United States, respectively (Aselmann and Crutzen 1989). Currently, riparian forests and freshwater wetlands, which include FFs, cover $22-25$ million ha in the conterminous US (Mitsch and Gosselink 2007). Overall, about $53 \%$ of the wetlands in the US were lost between 1780's and 1980's, amounting to a decrease from 89 to 42 million ha over this period (Kress et al. 1996, Mitsch and Gosselink 2007). Freshwater marshes and forested wetlands were the hardest hit, with loss rates of 7 and $5 \%$ per decade, respectively. Despite their importance, in the southern US alone, bottomland hardwood forests (including FFs) continue to be lost at a rapid rate, having declined by 6.5 million ha ( $77 \%$ loss) between 1883 and 1991 (Mitsch and Gosselink 2007). This destruction of FF wetlands and their associated biogeochemical functions (e.g. nutrient retention and/or transformation capacity) has added substantially to the eutrophication problem (Carpenter 2005, Mitsch and Gosselink 2007, Dodds et al. 2009), and will continue to do so unless measures are taken to assess the sustainability of the ecosystem services they provide, and successfully replicate them through conservation, creation, and/or restoration (c.f., Erwin, 2009). In the southeastern US alone, a greater understanding of the P retention and transformation capacities of FFs would assist in making regulatory decisions as to their value in controlling eutrophication.

In the southeastern US (Virginia, North and South Carolinas, and Georgia), FF ecosystems are associated primarily with two types of river systems: 1) alluvial (AL) rivers, whose waters arise in the Piedmont or in montane physiographic provinces; and 2) blackwater (BW) rivers, whose waters arise entirely within the Coastal Plain (Wharton and Brinson 1979, Lockaby and Walbridge 1998, Hupp 2000). Blackwater rivers tend to be smaller than AL rivers, with lower gradient flows that have limited potential to entrain or erode sediments (Burke et al. 2003, 
Howitt et al. 2007). Alluvial rivers have higher sediment loads and higher concentrations of inorganic ions, but lower concentrations of total organic $\mathrm{C}$ compared to $\mathrm{BW}$ rivers; $\mathrm{pH}$, hardness, and specific conductance also tend to be higher in AL versus BW rivers (Wharton and Brinson 1979, Hupp et al. 2005). The floodplains of southeastern US Coastal Plain rivers are inundated periodically, often for prolonged periods. During bankfull discharge or overbank flooding, when river waters begin to overflow onto the floodplain, floodwaters impact both the biogeochemical processes and overall productivity in these wetlands (Walbridge and Lockaby 1994, Lockaby and Walbridge 1998, Mitsch and Gosselink 2007). In both AL and BW floodplains, flooding events can vary in intensity, duration, and in the number of events from year-to-year, although the probability of flooding in our FF sites in the southeastern US, where approximately $60 \%$ of annual flooding events occur between January and April, is fairly predictable (Dress et al. in preparation).

The hydrology of FFs, particularly the influence of overbank flooding, is important for the maintenance of FF structure and function (Brinson 1993, Walbridge and Lockaby 1994, Hupp 2000). Flooding events can affect many biotic and abiotic patterns and processes in these ecosystems, including species composition and richness, primary productivity, organic matter accumulation, and nutrient cycling and availability (Hupp 2000, Hein et al. 2003, Hupp et al. 2005). Hydrology leads to unique vegetation composition and diversity, where depending on the frequency, duration, physical energies of floodwaters, and the hydroperiod following flooding events, flooding regimes can influence species richness (Lockaby and Walbridge 1998, Hupp 2000). The hydrology of frequently flooded wetlands acts to select water-tolerant vegetation (e.g. bald cypress), while excluding flood-intolerant species (Schlesinger 1978, Lowrance et al. 
1984, Burke et al. 2003). Floodplain forests that sustain long hydroperiods (with stagnant waters), tend to have lower plant species richness than do less frequently flooded areas (Lockaby and Walbridge 1998, Hupp et al. 2005). In contrast, flowing water (sheet flow) stimulates vegetation species diversity by increasing sediment deposition and associated nutrient inputs, reducing anaerobic conditions, and creating spatial heterogeneity when the action of flowing water and sediment deposition creates a variety of ecological niches (Yarbro 1983, Lockaby and Walbridge 1998, Burke and Chambers 2003, Hupp et al. 2005).

Soil microbial communities also are constrained by both water depth and the duration and frequency of flooding events (Stoeckel and Miller-Goodman 2001, Bruland and Richardson 2005, Carreira et al. 2008). Prolonged flooding events that result in reduced soil conditions will favor microbes capable of metabolizing in anoxic conditions, but may exclude facultative anaerobes that dominate the soil during the growing season when flooding events are less-likely and soil moisture levels decline (Stoeckel and Miller-Goodman 2001, Lockaby et al. 2005). Microorganisms belonging to these two functional groups process nutrients differently when mediating P transformation and catalyzing chemical changes that control nutrient availability to plants as well as the overall productivity of wetland soils (Groffman et al. 1996, Fernandez et al. 2008). Floodplain forest hydrology also contributes to the accumulation of organic material through its influence on microbial decomposition rates, wetland primary productivity, and particulate organic matter export (Tockner et al. 1999, O'Connell et al. 2000, Neatrour et al. 2004, de Neiff et al. 2006, Turner et al. 2007). Globally, wetland soils represent an important carbon sink, and FFs are no exception, where frequent short-duration flooding events can result in the accumulation of organic matter (or peat) due to increased primary productivity and/or 
decreased decomposition and organic matter export (Robertson et al. 1999, Bridgham et al. 2006). In summary, flooding events in FFs determine many factors -- soil moisture is dependent on flooding regime, while flowing waters aerate roots and transport nutrients resulting in increased productivity within the wetland, in turn affecting many biotic and abiotic factors, including species composition and richness, primary productivity, organic matter accumulation, and nutrient cycling and availability.

In addition to modifying the biological and chemical properties of FFs, overbank flooding alters the physical properties of the floodplain by entraining and eroding the sediment to create a spatially heterogeneous surface (Jones et al. 1996, Bruland and Richardson 2005, Brunet and Astin 2008, Carreira et al. 2008, Karssenberg and Bridge 2008). This topographically heterogeneous environment, in turn, has a direct influence on hydroperiod at the meso- and micro-topographic scale (Walbridge and Lockaby 1994, Stanturf and Schoenholtz 1998, Carreira et al. 2008). In general, topographic lows (swales) have comparatively long hydroperiods and fine-textured, clayey soils typical of sediments underlying low energy waters (Hupp and Morris 1990, Cowell 1993, Bruland and Richardson 2005); topographic highs (ridges), as remnants of old levees and meander scrolls, have comparatively short hydroperiods and coarse, sandy soils typical of sediments underlying high energy waters (Stoeckel and Miller-Goodman 2001). At the Ogeechee River, GA, Darke and Walbridge (2000) found that inorganic P retention and transformation processes were dominated by organic matter - metal ( $\mathrm{Al}, \mathrm{Fe})$ - phosphate complexation (described under 'P retention' below), and were significantly greater in topographic lows (swales) within the floodplain. Total P concentrations (including microbial biomass P) were also consistently higher in swales, suggesting that swales may function as 
microbial 'hotspots' of P immobilization (retention) and transformation (Stoeckel and MillerGoodman 2001, Wright et al. 2001).

\subsection{Biogeochemistry: Phosphorus transformation}

Phosphorus in floodwaters can occur in both inorganic and organic forms, in either the dissolved/soluble (DP) or insoluble/suspended (or particulate, PP) fractions, which vary in their bioavailability in aquatic ecosystems. Dissolved and particulate $\mathrm{P}$ fractions are operationally defined by passing through 0.2 (colloidal P) or $0.45 \mu \mathrm{m}(\mathrm{PP})$ filters, repectively. Forms of inorganic $\mathrm{P}$ in floodwaters can occur as particulate inorganic orthophosphate (PIP) associated with mineral sediment, and as dissolved orthophosphate which is also referred to as dissolved inorganic P (DIP) or soluble reactive P (SRP). Organic P forms include both particulate (Kutuzova et al. 2009) and dissolved organic P (DOP). Floodplain forests not only store (retain) nutrients, but also transform nutrients from biologically available forms to less biologically available forms (Nikolaidis et al. 1993, Mander et al. 1995, Lockaby and Walbridge 1998, Lockaby and Conner 1999, Maine et al. 2004, Noe and Hupp 2007).

Phosphorus pools in river waters flowing into FFs are often dominated by inorganic P forms, while those in outflow waters are often dominantly in organic P forms (e.g., (Craft and Casey 2000, Darke and Walbridge 2000, Stoeckel and Miller-Goodman 2001, Bruland and Richardson 2005, Noe and Hupp 2007). These observations suggest that the transformation of inorganic $P$ to less bioavailable high molecular weight organic $\mathrm{P}$ forms is an important process during flooding events that improves water quality downstream. Both abiotic and biotic mechanisms can 
regulate the relative sizes of $\mathrm{P}$ pools and the transformation of DIP to organic $\mathrm{P}$ forms in floodwaters transiting FFs. While $\mathrm{P}$ retention and transformation processes occur during flooding events in the water column (Evans and Johnes 2004, Benitez-Nelson et al. 2007), a substantial proportion of inorganic to organic $\mathrm{P}$ transformation takes place in sediments/soils, and the resultant DOP and POP forms are re-suspended by the scouring of material from the floodplain surface in subsequent sheet-flow flooding events (Reddy et al. 1999, Radke et al. 2004, Zehetner et al. 2008). One mechanism of P biogeochemical processing in FFs involves the biotic uptake or immobilization of DIP (Brinson et al. 1984, Khoshmanesh et al. 1999, Reddy et al. 1999, Hupp 2000, Stoeckel and Miller-Goodman 2001, Wright et al. 2001). Both plants and microorganisms (Figure $\mathbf{1 . 1}$ a-b) actively compete with processes of physicochemical precipitation and geochemical adsorption reactions of DIP and DOP in the water column and in the sediment/soil solution (Tate 1984, Lee et al. 1990, Reddy et al. 1999). Phosphorus uptake, storage, and release in plants is dependent on the type of vegetation, translocation of $\mathrm{P}$ from leaves, leaching of $\mathrm{P}$ from detrital tissue, and the capacity and rates of decomposition of senesced leaves, through which phosphate is subsequently released (Schlesinger 1978, Yarbro 1983, Mitsch and Gosselink 2007). Evergreen and deciduous shrubs play a significant role in P assimilation and storage, whereas trees, which are the dominant vegetation in FFs, represent approximately $10 \%$ of gross P uptake (Mitsch et al. 1979, Reddy and DeBusk 1987, Mitsch and Reeder 1991); annual rates of plant $\mathrm{P}$ uptake and storage range from $0.4-3.8 \mathrm{~kg} / \mathrm{ha}$ in FFs of the southeastern US (cf., Lockaby and Walbridge, 1998). Although DIP is removed from solution by plants, plant uptake is predominantly a seasonal sink since net assimilation of $\mathrm{P}$ in wood is small when compared to leaves, with the remaining $\mathrm{P}$ recycled to the soil surface via litter fall decomposition (Brinson et al. 1981, Polunin 1984, Reddy et al. 1999, de Neiff et al. 2006). 
Thus, over the short term, rapid turnover rates and cycling can release bioavilable $\mathrm{P}$ from the decomposition of plant detrital material. Microorganisms, however, play a major role in immobilizing and subsequently transforming P (upon cell lysis) in FFs (Richardson et al. 1988, Johnston 1991, Reddy et al. 1999, Stoeckel and Miller-Goodman 2001, Wright et al. 2001). Richardson et al. (1988) estimated that microbial immobilization of P ranged from $35.0-40.0$ $\mathrm{kg} / \mathrm{ha} / \mathrm{yr}$, which is considerably higher than plant uptake and storage of $\mathrm{P}$ in riparian forests in the southern US. Although microbes are generally considered decomposers that simply mineralize organic P (Figure 1.1), they actively incorporate (immobilize) DIP into their biomass (forming polyphosphates) from the water column and sediment/soil interface during favorable environmental conditions, but release less bioavailable POP forms upon cell lysis during unfavorable conditions (Kleeberg and Schlungbaum 1993, Khoshmanesh et al. 1999, Qualls and Richardson 2000) (Figure 1.1 b). Microbially produced organic P forms range from easily decomposable orthophosphate monoesters to complex molecules (i.e. phosphonates), which are of limited bioavailability and can only be utilized by a few microorganisms possessing a suit of specialized enzymes (Kononova and Nesmeyanova 2002, Dyhrman et al. 2006, Fox and Mendz 2006).

Some biologically available organic $\mathrm{P}$ forms may also contribute to eutrophication of downstream waters, particularly when readily available DIP forms are depleted (Chu 1946, Cotner and Wetzel 1992, Quiquampoix and Mousain 2005, Turner et al. 2005, Dyhrman et al. 2006). Low molecular weight organic P compounds (e.g. phosphate monoesters) which are labile to enzymatic hydrolysis, are preferentially utilized by heterotrophic organisms over more complex organic P forms such as orthophosphate diesters (e.g. phosphoproteins, DNA, and other 
polyneucleotides) that require extensive exoenzymatic breakdown prior to uptake; as a result, the latter are less likely to contribute to eutrophication (Cembella et al. 1984a, Suzumura and Kamatani 1995, Turner et al. 2002, Turner and Newman 2005, Lovdal et al. 2007, El-Rifai et al. 2008). Phosphonates, which contain a C-P bond rather than the C-O-P bond characteristic of ester phosphates (one $\mathrm{C}$ monoesters and two $\mathrm{C}$ diesters) are more stable/resistant to biodegradation (Kolowith et al. 2001, Kononova and Nesmeyanova 2002, Dyhrman et al. 2006, Fox and Mendz 2006). Common organic P species (phospholipids, phosphonates, and nucleic acids) are products of biological activity (Selig et al. 2002, Eixler et al. 2005) that can be used to assess the importance of biological processes in P transformation in FFs.

Since organic $\mathrm{P}$ forms vary in their bioavailability, understanding the effectiveness of FF processes in improving water quality and the potential fate (or contribution to eutrophication) of $\mathrm{P}$ once it leaves the FF requires detailed information about both the identities and relative proportions of organic P forms (Cade-Menun et al. 2006). However, studies to date have determined organic P concentrations by indirect techniques; total P (TP) is generally determined by digestion and colorimetric techniques (Murphy and Riley 1962) or inductively coupled plasma atomic emission spectroscopy (ICP-AES) (Holliday and Gartner 2007), with inorganic P [or soluble reactive phosphorus (SRP)] determined colorimetrically, and organic $\mathrm{P}$ as simply the difference between TP and SRP. By this method, both true organic P compounds (i.e., products of biotic synthesis such as orthophosphate monoesters and diesters) and the abiotic complexation of phosphate by organic matter via metal ( $\mathrm{Al}, \mathrm{Fe})$ ligands (described under 'P retention' below) are identified as 'organic P'. In addition, inorganic $\mathrm{P}$ forms such as pyrophosphate and polyphosphate are not molybdate-reactive (like SRP) and thus will also be designated as organic 
$\mathrm{P}$ using colorimetric techniques. These methods may contribute to an overestimation of the amount of true organic P found in floodwaters (Darke and Walbridge 1994, McKelvie et al. 1995, Benitez-Nelson et al. 2007). More importantly, these techniques provide no information on P speciation (inorganic, organic monoesters vs. diesters, or phosphonates). Few studies have detailed the P chemistries of inflow vs. outflow floodwaters, particularly with respect to organic P (Cade-Menun et al. 2006). Therefore, in my first experiment (Chapter 2), I will use a recently developed extraction technique (Cade-Menun et al. 2006) for ${ }^{31} \mathrm{P}$ nuclear magnetic resonance (NMR) spectroscopy to characterize the various forms and relative proportions of inorganic and organic P chemistries in inflow and outflow floodwaters across four alluvial and four blackwater FF systems in the southeastern US.

\subsection{Biogeochemistry: Phosphorus retention}

Retention of nutrients in FFs decreases the load to downstream aquatic systems, which includes lakes and the sea (Johnston 1991, Mitsch et al. 1995, Axt and Walbridge 1999, Bruland and Richardson 2004, Noe and Hupp 2007). Phosphorus retention in soils and sediments is controlled by both biological (plant uptake and microbial immobilization) and geochemical (P sorption) factors. Suspended materials (POP and PIP adsorbed to mineral sediments) are removed from the water column by sedimentation, a physical process associated with the decline in flow velocity that occurs as floodwaters encounter increased resistance from the floodplain surface (Kleiss 1996, Craft and Casey 2000, Hupp et al. 2005, Benitez-Nelson et al. 2007, Brunet

and Astin 2008) (Figure 1.1 c). Previous research in the southeastern US also has suggested that complexation with organic matter via metal (Al, Fe) ligands may be an important mechanism of 
inorganic P retention and transformation in FFs (Darke and Walbridge 1994, Axt and Walbridge 1999, Lamers et al. 2006). Given their lower rates of sediment deposition, this mechanism could be particularly important in BW FFs (Burke et al. 2003) as compared to AL systems, where sediment deposition is expected to be a major component of $\mathrm{P}$ retention (Darke and Walbridge 2000, Hupp et al. 2005).

Soil and sediment $\mathrm{Al}$ and $\mathrm{Fe}$ minerals range from poorly ordered (amorphous or poorly crystalline) to highly structured (crystalline) forms (Darke and Walbridge 1994, Axt and Walbridge 1999). In the acid soils typical of FFs, poorly crystalline or amorphous forms of $\mathrm{Al}$ and $\mathrm{Fe}$ (in comparison with more crystalline forms) have been shown to control the adsorption and precipitation of dissolved inorganic $\mathrm{P}$ because of their comparatively large surface area per unit soil volume (Lee et al. 1990, Walbridge and Struthers 1993, Darke and Walbridge 1994, Axt and Walbridge 1999, Darke and Walbridge 2000, Hogan et al. 2004, Hogan and Walbridge 2007, Fernandez et al. 2008) (Figure 1.1 d). In addition to simple amorphous mineral forms of Al and/or Fe, both metals form complexes with soil organic matter (OM) that can also sorb DIP (Axt and Walbridge 1999, Darke and Walbridge 2000, Hupp et al. 2005) (Figure 1.1 d). The formation and/or persistence of $\mathrm{OM}-$ metal $(\mathrm{Al}, \mathrm{Fe})-\mathrm{P}$ complexes is strongly influenced by flooding regime (Lockaby and Walbridge 1998, Axt and Walbridge 1999, Darke and Walbridge 2000, Wright et al. 2001, Bruland and Richardson 2004, Lamers et al. 2006), suggesting that the role of complexation in $\mathrm{P}$ retention within FFs requires further investigation. Microbial immobilization also can result in the retention of a substantial amount of inorganic $\mathrm{P}$, but this pool often turns over rapidly due to the lysis of microbial biomass during unfavorable environmental conditions (e.g., prolonged anaerobic conditions following a flooding event) 
(Khoshmanesh et al. 1999, Stoeckel and Miller-Goodman 2001, Wright et al. 2001) (Figure 1.1

b). Although both biological and geochemical processes can be important pathways of DIP removal, little is known about how in situ physical and chemical factors influence the relative role that each process plays in controlling P retention and transformation in FF ecosystems. To address this, in my second experiment (Chapter 3), I will assess the dominant fate(s) of inorganic $\mathrm{P}$ received in floodwaters by adding ${ }^{32} \mathrm{PO}_{4}{ }^{3-}$ to soil mesocosms during simulated flooding events in the laboratory. Results from this study were used to specifically identify whether dissolved inorganic P retention is driven by mineral adsorption, organic matter - metal (Al, Fe) - P complexation, or microbial immobilization.

\subsection{Microbial Community Composition and Ecosystem Function}

Microbial processes are an important and yet comparatively unexplored component of $\mathrm{P}$ retention and transformation in FF soils. Recent attempts to describe microbial communities in floodplain soils have been limited to targeting major microbial subdivisions at the Elbe River, Germany, using group specific phospholipid fatty acid profiles (Rinklebe and Langer 2006, Rinklebe and Langer 2008), or 16S rRNA terminal restriction fragment length polymorphism in FF soils along the Danube River, Austria (Besemer et al. 2005) and Murray River, Australia (Baldwin et al. 2006). Quantification of the microbial contribution to $\mathrm{P}$ retention has been limited to estimating microbial biomass in floodplain soils along the Coosawatchie River, SC, USA (Stoeckel and Miller-Goodman 2001), Ogeechee River, GA, USA (Wright et al. 2001), and Falthead River, MO, USA (Ellis et al. 1998). Other studies have used enrichment techniques, such as BIOLOG ecoplates on soils collected from a FF adjacent to the Watarase River, Japan 
(Kamitani et al. 2006), and culture based characterizations of specific bacterial species at Four Mile Creek, SC (Leff et al. 2003), and in the Okavango Delta, Botswana (Mubyana et al. 2003). However, detailed studies of microbial community structure using molecular techniques are comparatively rare and limited to assessing archaeal methanogenic microbes in anoxic soils in the Rhine River floodplain, The Netherlands, (Kemnitz et al. 2004), bacterioplankton communities in filterate collected from the Parana River, Brazil (Lemke et al. 2009), and biofilm communities in the Clohoge River, Ireland (Anderson, 2005). Despite the importance of spatial heterogeneity to the microbial contribution to P retention/transformation processes (Wright 1998, Stoeckel and Miller-Goodman 2001), there have been no attempts to date to understand spatial changes in the soil microbial community composition of dominant FF types in the southeastern US. Therefore, the overall focus of my research in Chapter 4, is to understand how floodplain type (AL vs. BW) and microtopographic relief (ridges vs. swales) control variation in microbial community composition in FFs, and how this variation, in turn, are related to the retention and transformation of $\mathrm{P}$ received in floodwaters.

Although Kemnitz et al. (2004) targeted archaeal populations in their soils, their investigation was limited to estimating potential methanogenic activity under flooded soils (anoxic conditions); they did not assess changes in dominant bacterial and fungal identities with variations in microsite elevation or hydroperiod within the FF. In Chapter 4 I will develop and validate a method for assessing soil bacterial and fungal communities in FFs using a combination of two molecular approaches: (1) 16S-/18S-rDNA cloning to obtain a detailed community analysis; and (2) denaturing gradient gel electrophoresis (DGGE) to screen clone libraries and identify dominant group members. The results from this study will provide a detailed 
characterization of bacterial and fungal communities in ridge (less-frequently flooded topographic highs) and swale (more-frequently flooded topographic lows) microsites in one AL (Wateree River, SC) and one BW (Black River, NC) FF. Following this initial study, I will examine additional replicates of each site type, as well as ridge vs. swale variation within each site, to compare bacterial and fungal community composition as a function of floodplain type (AL vs. BW) and microtopographic elevation (ridge vs. swale) in eight FFs ( $\mathrm{n}=4$ per floodplain type). In this study, microbial community composition will be assessed in composite soils from ridge and swale microsites ( 3 soil samples per composite) collected at each study site.

\section{Research Objectives}

1. Characterize the various forms and relative proportions of inorganic and organic $P$ chemistries (using ${ }^{31} \mathrm{P}$ nuclear magnetic resonance (NMR) spectroscopy) in inflow and outflow floodwaters of FFs in the southeastern US (Chapter 2).

2. Assess the dominant fate(s) of inorganic $\mathrm{P}$ received in floodwaters by adding ${ }^{32} \mathrm{PO}_{4}{ }^{3-}$ to soil mesocosms during simulated flooding events in the laboratory (Chapter 3).

3. Develop and validate a method for assessing soil bacterial and fungal community structures using a combination of 16S-/18S-rDNA cloning and denaturing gradient gel electrophoresis (DGGE), to provide a detailed characterization of bacterial and fungal communities in two FFs in the southeastern US, and to compare bacterial and fungal community composition as a function of floodplain type and microtopographic elevation in eight FFs in the southeastern US (Chapter 4). 


\subsection{REFERENCES}

Amoros, C. and G. Bornette. 2002. Connectivity and biocomplexity in waterbodies of riverine floodplains. Pages 761-776 in M. H. Iriondo, J.C. Paggi, and J. Parma, editors. The Middle Paraná river: Limnology of a subtropical wetland. Blackwell Publishing Ltd.

Anderson, M. B. 2005. Microbial ecology of riverine biofilm communities in the Cloghoge River, Co. Wicklow, Ireland. University College Dublin, Ireland.

Aselmann, I. and P. J. Crutzen. 1989. Global distribution of natural freshwater wetlands and rive paddies, their net primary productivity, seasonality and possible methane emissions. Journal of Atmospheric Chemistry 8:307-358.

Axt, J. R. and M. R. Walbridge. 1999. Phosphate removal capacity of palustrine forested wetlands and adjacent uplands in Virginia. Soil Science Society of America Journal 63:1019-1031.

Baldwin, D. S., G. N. Rees, A. M. Mitchell, G. Watson, and J. Williams. 2006. The short-term effects of salinization on anaerobic nutrient cycling and microbial community structure in sediment from a freshwater wetland. Wetlands 26:455-464.

Basnyat, P., L. D. Teeter, K. M. Flynn, and B. G. Lockaby. 1999. Relationships between landscape characteristics and nonpoint source pollution inputs to coastal estuaries. Environmental Management 23:539-549.

Benitez-Nelson, C. R., L. P. O. Madden, R. M. Styles, R. C. Thunell, and Y. Astor. 2007. Inorganic and organic sinking particulate phosphorus fluxes across the oxic/anoxic water column of Cariaco Basin, Venezuela. Marine Chemistry 105:90-100.

Bennett, E. M., S. R. Carpenter, and N. F. Caraco. 2001. Human impact on erodable phosphorus and eutrophication: A global perspective. Bioscience 51:227-234.

Besemer, K., M. M. Moeseneder, J. M. Arrieta, G. J. Herndl, and P. Peduzzi. 2005. Complexity of bacterial communities in a river-floodplain system (Danube, Austria). Applied and Environmental Microbiology 71:609-620. 
Boesch, D., R. Hecky, C. O’Melia, S. D.W., and S. Seitzinger. 2005. Expert evaluation of the eutrophication of seas surrounding Sweden. Swedish Enivrionmental Protection Agency report.

Bridgham, S. D., J. P. Megonigal, J. K. Keller, N. B. Bliss, and C. Trettin. 2006. The carbon balance of North American wetlands. Wetlands 26:889-916.

Brinson, M. M. 1993. Changes in the functioning of wetlands along environmental gradients. Wetlands 13:65-74.

Brinson, M. M., H. D. Bradshaw, and E. S. Kane. 1984. Nutrient assimilative-capacity of an alluvial floodplain swamp. Journal of Applied Ecology 21:1041-1057.

Brinson, M. M., A. E. Lugo, and S. Brown. 1981. Primary productivity, decomposition and consumer activity in fresh-water wetlands. Annual Review of Ecology and Systematics 12:123-161.

Bruland, G. L. and C. J. Richardson. 2004. A spatially explicit investigation of phosphorus sorption and related soil properties in two riparian wetlands. Journal of Environmental Quality 33:785-794.

Bruland, G. L. and C. J. Richardson. 2005. Hydrologic, edaphic, and vegetative responses to microtopographic reestablishment in a restored wetland. Restoration Ecology 13:515523.

Brunet, R. C. and K. B. Astin. 2008. A comparison of sediment deposition in two adjacent floodplains of the River Adour in southwest France. Journal of Environmental Management 88:651-657.

Burke, M. K. and J. Chambers. 2003. Root dynamics in bottomland hardwood forests of the Southeastern United States Coastal Plain. Plant and Soil 250:141-153.

Burke, M. K., S. L. King, D. Gartner, and M. H. Eisenbies. 2003. Vegetation, soil, and flooding relationships in a blackwater floodplain forest. Wetlands 23:988-1002. 
Cade-Menun, B. J., J. A. Navaratnam, and M. R. Walbridge. 2006. Characterizing dissolved and particulate phosphorus in water with P-31 nuclear magnetic resonance spectroscopy. Environmental Science \& Technology 40:7874-7880.

Capon, S. J. 2005. Flood variability and spatial variation in plant community composition and structure on a large and floodplain. Journal of Arid Environments 60:283-302.

Caraco, N. F. 1995. Influence of humans on P transfers to aquatic systems: A regional scale study using large rivers. Pages 235-244 in H. Tiessen, editor. Phosphorus cycles in terrestrial and aquatic ecosystems. SCOPE. Wiley \& Sons, Chichester.

Carpenter, S. R. 2005. Eutrophication of aquatic ecosystems: Bistability and soil phosphorus. Proceedings of the National Academy of Sciences of the United States of America 102:10002-10005.

Carpenter, S. R., N. F. Caraco, D. L. Correll, R. W. Howarth, A. N. Sharpley, and V. H. Smith. 1998. Nonpoint pollution of surface waters with phosphorus and nitrogen. Ecological Applications 8:559-568.

Carpenter, S. R., S. G. Fisher, N. B. Grimm, and J. F. Kitchell. 1992. Global change and freshwater ecosystems. Annual Review of Ecology and Systematics 23:119-139.

Carreira, J. A., B. Vinegla, R. Garcia-Ruiz, V. Ochoa, and M. B. Hinojosa. 2008. Recovery of biochemical functionality in polluted flood-plain soils: The role of microhabitat differentiation through revegetation and rehabilitation of the river dynamics. Soil Biology \& Biochemistry 40:2088-2097.

Cembella, A. D., N. J. Antia, and P. J. Harrison. 1984a. The utilization of inorganic and organic phosphorus-compounds as nutrients by eukaryotic microalgae - A multidisciplinary perspective .1. CRC Critical Reviews in Microbiology 10:317-391.

Cey, E. E., D. L. Rudolph, R. Aravena, and G. Parkin. 1999. Role of the riparian zone in controlling the distribution and fate of agricultural nitrogen near a small stream in southern Ontario. Journal of Contaminant Hydrology 37:45-67. 
Chu, S. P. 1946. Utilization of organic phosphorus by phytoplankton. Journal of the Marine Biological Association of the UK 26:285.

Costanza, R., R. dArge, R. deGroot, S. Farber, M. Grasso, B. Hannon, K. Limburg, S. Naeem, R. V. Oneill, J. Paruelo, R. G. Raskin, P. Sutton, and M. vandenBelt. 1997. The value of the world's ecosystem services and natural capital. Nature 387:253-260.

Cotner, J. B. and R. G. Wetzel. 1992. Uptake of dissolved inorganic and organic phosphoruscompounds by phytoplankton and bacterioplankton. Limnology and Oceanography 37:232-243.

Cowell, C. M. 1993. Environmental gradients in secondary forests of the Georgia Piedmont, USA. Journal of Biogeography 20:199-207.

Craft, C. B. and W. P. Casey. 2000. Sediment and nutrient accumulation in floodplain and depressional freshwater wetlands of Georgia, USA. Wetlands 20:323-332.

Darke, A. K. and M. R. Walbridge. 1994. Estimating non-crystalline and crystalline aluminum and iron by selective dissolution in a riparian forest soil. Communications in Soil Science and Plant Analysis 25:2089-2101.

Darke, A. K. and M. R. Walbridge. 2000. Al and Fe biogeochemistry in a floodplain forest: Implications for P retention. Biogeochemistry 51:1-32.

de Neiff, A. P., J. J. Neiff, and S. L. Casco. 2006. Leaf litter decomposition in three wetland types of the Parana River floodplain. Wetlands 26:558-566.

DeLaune, R. D., R. R. Boar, C. W. Lindau, and B. A. Kleiss. 1996. Denitrification in bottomland hardwood wetland soils of the Cache River. Wetlands 16:309-320.

Dierberg, F. E. and T. A. DeBusk. 2008. Particulate phosphorus transformations in south Florida stormwater treatment areas used for Everglades protection. Ecological Engineering 34:100-115. 
Dodds, W. K., W. W. Bouska, J. L. Eitzmann, T. J. Pilger, K. L. Pitts, A. J. Riley, J. T. Schloesser, and D. J. Thornbrugh. 2009. Eutrophication of US Freshwaters: Analysis of Potential Economic Damages. Environmental Science \& Technology 43:12-19.

Dyhrman, S. T., P. D. Chappell, S. T. Haley, J. W. Moffett, E. D. Orchard, J. B. Waterbury, and E. A. Webb. 2006. Phosphonate utilization by the globally important marine diazotroph Trichodesmium. Nature 439:68-71.

Eixler, S., U. Selig, and U. Karsten. 2005. Extraction and detection methods for polyphosphate storage in autotrophic planktonic organisms. Hydrobiologia 533:135-143.

El-Rifai, H., M. Heerboth, T. E. Gedris, S. Newman, W. Orem, and W. T. Cooper. 2008. NMR and mass spectrometry of phosphorus in wetlands. European Journal of Soil Science 59:517-525.

Ellis, B. K., J. A. Stanford, and J. V. Ward. 1998. Microbial assemblages and production in alluvial aquifers of the Flathead River, Montana, USA. Journal of the North American Benthological Society 17:382-402.

Elser, J. J., M. E. S. Bracken, E. E. Cleland, D. S. Gruner, W. S. Harpole, H. Hillebrand, J. T. Ngai, E. W. Seabloom, J. B. Shurin, and J. E. Smith. 2007. Global analysis of nitrogen and phosphorus limitation of primary producers in freshwater, marine and terrestrial ecosystems. Ecology Letters 10:1135-1142.

Evans, D. J. and P. Johnes. 2004. Physico-chemical controls on phosphorus cycling in two lowland streams. Part 1 - the water column. Science of the Total Environment 329:145163.

Faulkner, S. P. and C. J. Richardson. 1989. Physical and chemical characteristics of freshwater wetland soils. Pages 41-72 in D. A. Hamner, editor. Constructed Wetlands for Wastewater Treatment: Municipal, Industrial and Agricultural. Lewis Publishers, Chelsea, MI.

Fernandez, I. E., R. F. Novais, F. N. Nunes, and J. C. Ker. 2008. Reversibility of non-labile phosphorus in soils under microbial and chemical reduction: I - Chemical and mineralogical alterations. Revista Brasileira de Ciencia do Solo 32:2307-2317. 
Fisher, S. G., J. L. Melack, J. U. Grobbelaar, and R. W. Howarth. 1995. Nutrient limitation of phytoplankton and eutrophication of inland, estuarine and marine waters Pages 301-322 in $\mathrm{H}$. Tiessen, editor. Phosphorus in the Global Environment - Transfers, Cycles and Management. Wiley \& Sons, Chichester.

Fox, E. A. and G. L. Mendz. 2006. Phosphonate degradation in microorganisms. Enzyme and Microbial Technology 40:145-150.

Groffman, P. M., G. C. Hanson, E. Kiviat, and G. Stevens. 1996. Variation in microbial biomass and activity in four different wetland types. Soil Science Society of America Journal 60:622-629.

Hecky, R. E. 1998. Low N:P ratios and the nitrogen fix: Why watershed nitrogen removal will not improve the Baltic. Pages 85-115. in Effects of nitrogen in the aquatic environment. Royal Swedish Academy of Sciences report, Stockholm.

Hecky, R. E. and P. Kilham. 1988. Nutrient limitation of phytoplankton in freshwater and marine environments: a review of recent evidence on the effects of enrichment. Limnology and Oceanography 33:796-822.

Hein, T., C. Baranyi, G. J. Herndl, W. Wanek, and F. Schiemer. 2003. Allochthonous and autochthonous particulate organic matter in floodplains of the River Danube: the importance of hydrological connectivity. Freshwater Biology 48:220-232.

Hellström, T. 1998. Why nitrogen is not limiting production in the seas around Sweden. Pages 11-12. in Effects of nitrogen in the aquatic environment. Royal Swedish Academy of Sciences report, Stockholm.

Hoagland, P., D. M. Anderson, Y. Kaoru, and A. W. White. 2002. The economic effects of harmful algal blooms in the United States: Estimates, assessment issues, and information needs. Estuaries 25:819-837.

Hogan, D. M., T. E. Jordan, and M. R. Walbridge. 2004. Phosphorus retention and soil organic carbon in restored and natural freshwater wetlands. Wetlands 24:573-585. 
Hogan, D. M. and M. R. Walbridge. 2007. Urbanization and nutrient retention in freshwater riparian wetlands. Ecological Applications 17:1142-1155.

Holliday, V. T. and W. G. Gartner. 2007. Methods of soil P analysis in archaeology. Journal of Archaeological Science 34:301-333.

Howitt, J. A., D. S. Baldwin, G. N. Rees, and J. L. Williams. 2007. Modelling blackwater: Predicting water quality during flooding of lowland river forests. Ecological Modelling 203:229-242.

Hupp, C. R. 2000. Hydrology, geomorphology, and vegetation of Coastal Plain rivers in the south-eastern USA. Hydrological Processes 14:2991-3010.

Hupp, C. R. and E. E. Morris. 1990. A dendrogeomorphic approach to measurement of sedimentation in a forested wetland, Black Swamp, Arkansas. Wetlands 10:107-124.

Hupp, C. R., M. R. Walbridge, and B. G. Lockaby. 2005. Fluvial geomorphic processes and landforms, water quality, and nutrients in Bottomland Hardwood Forests of southeastern USA. Pages 37-55 in L. H. Fredrickson, S. L. King, and R. M. Kaminski, editors. Ecology and Management of Bottomland Hardwood Systems. University of Missouri, Puxico, MO.

Johnston, C. A. 1991. Sediment and nutrient retention by freshwater wetlands: Effects on surface water quality. Critical Reviews in Environmental Control 21:491-565.

Jones, R. H., B. G. Lockaby, and G. L. Somers. 1996. Effects of microtopography and disturbance on fine-root dynamics in wetland forests of low-order stream floodplains. American Midland Naturalist 136:57-71.

Karssenberg, D. and J. S. Bridge. 2008. A three-dimensional numerical model of sediment transport, erosion and deposition within a network of channel belts, floodplain and hill slope: extrinsic and intrinsic controls on floodplain dynamics and alluvial architecture. Sedimentology 55:1717-1745.

Kemnitz, D., K. J. Chin, P. Bodelier, and R. Conrad. 2004. Community analysis of methanogenic archaea within a riparian flooding gradient. Environmental Microbiology 6:449-461. 
Khoshmanesh, A., B. T. Hart, A. Duncan, and R. Beckett. 1999. Biotic uptake and release of phosphorus by a wetland sediment. Environmental Technology 20:85-91.

Kleeberg, A. and G. Schlungbaum. 1993. In situ phosphorus release experiments in the Warnow River (Mecklenburg, northern Germany). Hydrobiologia 253:263-274.

Kleiss, B. A. 1996. Sediment retention in a bottomland hardwood wetland in Eastern Arkansas. Wetlands 16:321-333.

Kolowith, L. C., E. D. Ingall, and R. Benner. 2001. Composition and cycling of marine organic phosphorus. Limnology and Oceanography 46:309-320.

Kononova, S. V. and M. A. Nesmeyanova. 2002. Phosphonates and their degradation by microorganisms. Biochemistry-Moscow 67:184-195.

Kotak, B. G., S. L. Kenefick, D. L. Fritz, C. G. Rousseaux, E. E. Prepas, and S. E. Hrudey. 1993. Occurrence and toxicological evaluation of cyanobacterial toxins in Alberta lakes and farm dugouts. Water Research 27:495-506.

Kress, M. R., M. R. Graves, and S. G. Bourne. 1996. Loss of bottomland hardwood forests and forested wetlands in the Cache River Basin, Arkansas. Wetlands 16:258-263.

Kuenzler, E. J. 1989. Value of forested wetlands as filters for sediments and nutrients. Pages 8596 in The Forested Wetlands of the Southern United States. USDA-Forest Service, Southeastern Forest Experiment Station, Asheville, North Carolina., North Carolina.

Kutuzova, R. S., N. I. Vorob'ev, M. V. Gamova, L. A. Popova, and Y. V. Kruglov. 2009. Microbiological characterization of soddy soils of the Severnaya Dvina River floodplain. Eurasian Soil Science 42:225-234.

Lamers, L. P. M., R. Loeb, A. M. Antheunisse, M. Miletto, E. Lucassen, A. W. Boxman, A. J. P. Smolders, and J. G. M. Roelofs. 2006. Biogeochemical constraints on the ecological rehabilitation of wetland vegetation in river floodplains. Hydrobiologia 565:165-186. 
Lee, D., X. G. Han, and C. F. Jordan. 1990. Soil-phosphorus fractions, aluminum, and waterretention as affected by microbial activity in an ultisol. Plant and Soil 121:125-136.

Lemke, M. J., E. K. Lienau, J. Rothe, T. A. Pagioro, J. Rosenfeld, and R. DeSalle. 2009. Description of freshwater bacterial assemblages from the Upper Parana River floodpulse system, Brazil. Microbial Ecology 57:94-103.

Lockaby, B. G. and W. H. Conner. 1999. N : P balance in wetland forests: Productivity across a biogeochemical continuum. Botanical Review 65:171-185.

Lockaby, B. G., R. Governo, E. Schilling, G. Cavalcanti, and C. Hartsfield. 2005. Effects of sedimentation on soil nutrient dynamics in riparian forests. Journal of Environmental Quality 34:390-396.

Lockaby, B. G. and M. R. Walbridge. 1998. Biogeochemistry. Pages 149-172 in M. G. Messina and W. H. Conner, editors. Southern Forested Wetlands: Ecology and Management. Lewis Publishers, Boca Raton, FL, USA.

Lovdal, T., T. Tanaka, and T. F. Thingstad. 2007. Algal-bacterial competition for phosphorus from dissolved DNA, ATP, and orthophosphate in a mesocosm experiment. Limnology and Oceanography 52:1407-1419.

Lowrance, R., R. Todd, J. Fail, O. Hendrickson, R. Leonard, and L. Asmussen. 1984. Riparian forests as nutrient filters in agricultural watersheds. Bioscience 34:374-377.

Lu, H. M. and C. Q. Yin. 2008. Shallow groundwater nitrogen responses to different land use managements in the riparian zone of Yuqiao Reservoir in North China. Journal of Environmental Sciences-China 20:652-657.

Maine, M. A., N. L. Sune, and C. Bonetto. 2004. Nutrient concentrations in the Middle Parand River: Effect of the floodplain lakes. Archiv Fūr Hydrobiologie 160:85-103.

Maingi, J. K. and S. E. Marsh. 2001. Assessment of environmental impacts of river basin development on the riverine forests of eastern Kenya using multi-temporal satellite data. International Journal of Remote Sensing 22:2701-2729. 
Mander, U., V. Kuusemets, and M. Ivask. 1995. Nutrient dynamics of riparian ecotones: A case study from the Porijõgi River catchment, Estonia. Landscape and Urban Planning 31:333-348.

Marion, G. M., K. Vancleve, C. T. Dyrness, and C. H. Black. 1993. The soil chemical environment along a forest primary successional sequence on the Tanana River floodplain, interior Alaska. Canadian Journal of Forest Research-Revue Canadienne De Recherche Forestiere 23:914-922.

Matson, P. A., W. J. Parton, A. G. Power, and M. J. Swift. 1997. Agricultural intensification and ecosystem properties. Science 277:504-509.

Maybeck, M. 1982. Carbon, nitrogen, and phosphorus transport by world rivers. American Journal of Scicence 282:401-450.

McDowell, R. W. and G. F. Koopmans. 2006. Assessing the bioavailability of dissolved organic phosphorus in pasture and cultivated soils treated with different rates of nitrogen fertiliser. Soil Biology \& Biochemistry 38:61-70.

McKelvie, I. D., D. M. W. Peat, and P. J. Worsfold. 1995. Techniques for the quantification and speciation of phosphorus in natural waters. Analytical Proceedings 32:437-445.

Melack, J. M. 1995. Transport And Transformations Of P, Fluvial And Lacustrine Ecosystems. Pages 245-249 in H. Tiessen, editor. Phosphorus in the Global Environment - Transfers, Cycles and Management. Wiley \& Sons, Chichester.

Mitsch, W. J., J. K. Cronk, X. Y. Wu, R. W. Nairn, and D. L. Hey. 1995. Phosphorus Retention in Constructed Freshwater Riparian Marshes. Ecological Applications 5:830-845.

Mitsch, W. J., C. L. Dorge, and J. R. Wiemhoff. 1979. Ecosystem dynamics and a phosphorus budget of an Alluvial cypress swamp in Southern Illinois. Ecology 60:1116-1124.

Mitsch, W. J. and J. G. Gosselink. 2007. Wetlands. 4th edition. John Wiley \& Sons, New York. 
Mitsch, W. J. and B. C. Reeder. 1991. Modelling nutrient retention of a freshwater coastal wetland : estimating the roles of primary productivity, sedimentation, resuspension and hydrology. Ecological Modelling 54:151-187.

Mubyana, T., M. Krah, O. Totolo, and M. Bonyongo. 2003. Influence of seasonal flooding on soil total nitrogen, organic phosphorus and microbial populations in the Okavango Delta, Botswana. Journal of Arid Environments 54:359-369.

Murphy, J. and J. P. Riley. 1962. A modified single solution method for determination of phosphate in natural waters. Analytica Chimica Acta 27:31-36.

Neatrour, M. A., J. R. Webster, and E. E. Benfield. 2004. The role of floods in particulate organic matter dynamics of a southern Appalachian river-floodplain ecosystem. Journal of the North American Benthological Society 23:198-213.

Nikolaidis, N. P., H. Shen, H. Heng, H. L. Hu, and J. C. Clausen. 1993. Movement of nitrogen through an agricultural riparian zone: 2. Distributed modeling. Water Science and Technology 28: 613-623.

Noe, G. B. and C. R. Hupp. 2007. Seasonal variation in nutrient retention during inundation of a short-hydroperiod floodplain. River Research and Applications 23:1088-1101.

O'Connell, M., D. S. Baldwin, A. I. Robertson, and G. Rees. 2000. Release and bioavailability of dissolved organic matter from floodplain litter: influence of origin and oxygen levels. Freshwater Biology 45:333-342.

Pant, H. K., K. R. Reddy, and F. E. Dierberg. 2002. Bioavailability of organic phosphorus in a submerged aquatic vegetation-dominated treatment wetland. Journal of Environmental Quality 5:1748-1756.

Pautard, F. G. E. 1976. The structure and genesis of calcium phosphates in vertebrates and invertebrates. In Colloques Internationaux CNRS Physico-chemie et Crystallographie des Apatites d'Intereãt Biologique 230:93-100.

Polunin, N. V. C. 1984. The decomposition of emergent macrophytes in fresh water. Advances in Ecological Research 14:115-166. 
Pretty, J. N., C. F. Mason, D. B. Nedwell, R. E. Hine, S. Leaf, and R. Dils. 2003. Environmental costs of freshwater eutrophication in England and Wales. Environmental Science \& Technology 37:201-208.

Qualls, R. G. and C. J. Richardson. 2000. Phosphorus enrichment affects litter decomposition, immobilization, and soil microbial phosphorus in wetland mesocosms. Soil Science Society of America Journal 64:799-808.

Quiquampoix, H. and D. Mousain. 2005. Enzymatic hydrolysis of organic phosphorus. Pages 89112 in B. L. Turner, E. Frossard, and D. S. Baldwin, editors. Organic phosphorus in the environment. CABI Publ., Cambridge.

Radke, L. C., I. P. Prosser, M. Robb, B. Brooke, D. Fredericks, G. B. Douglas, and J. Skemstad. 2004. The relationship between sediment and water quality, and riverine sediment loads in the wave-dominated estuaries of south-west Western Australia. Marine and Freshwater Research 55:581-596.

Reddy, K. R. and W. F. DeBusk. 1987. Nutrient storage capabilites of aquatic and wetland plants. Pages 337-357 in K. R. Reddy and W. H. Smith, editors. Aquatic plants for water treatment and resource recovery. Magnolia Publ., Orlando, FL.

Reddy, K. R., R. H. Kadlec, E. Flaig, and P. M. Gale. 1999. Phosphorus retention in streams and wetlands: A review. Critical Reviews in Environmental Science and Technology 29:83146.

Richardson, C. J. 1989. Freshwater wetlands: Transformers, filters or sinks? Pages 25-46 in Freshwater Wetlands and Wildlife. Conf-8603101. DOE Symposium Series NO. 61, U.S. DOE. Oak Ridge, TN.

Richardson, C. J., M. R. Walbridge, and A. Burns. 1988. Soil chemistry and phosphorus retention capacity of North Carolina coastal plain swamps receiving sewage effluent., Water Resources Research Institute of the University of North Carolina, Raleigh, NC.

Rinklebe, J. and U. Langer. 2006. Microbial diversity in three floodplain soils at the Elbe River (Germany). Soil Biology \& Biochemistry 38:2144-2151. 
Rinklebe, J. and U. Langer. 2008. Floodplain soils at the Elbe river, Germany, and their diverse microbial biomass. Archives of Agronomy and Soil Science 54:259-273.

Robertson, A. I., S. E. Bunn, P. I. Boon, and K. F. Walker. 1999. Sources, sinks and transformations of organic carbon in Australian floodplain rivers. Marine and Freshwater Research 50:813-829.

Ruttenberg, K. C. 2005. The global phosphorus cycle. Pages 585-644 in W. H. Schlesinger, editor. Treatise on Geochemistry: Biogeochemistry. Elsevier Publ., Amsterdam.

Sanudo-Wilhelmy, S. A. 2006. Oceanography - A phosphate alternative. Nature 439:25-26.

Sanudo-Wilhelmy, S. A., A. B. Kustka, C. J. Gobler, D. A. Hutchins, M. Yang, K. Lwiza, J. Burns, D. G. Capone, J. A. Raven, and E. J. Carpenter. 2001. Phosphorus limitation of nitrogen fixation by Trichodesmium in the central Atlantic Ocean. Nature 411:66-69.

Schindler, D. W. 1978. Factors regulating phytoplankton production and standing crop in the world's freshwaters. Limnology and Oceanography 23:478-486.

Schlesinger, W. H. 1978. Community structure, dynamics and nutrient cycling in the Okefenokee cypress swamp-forest. Ecological Monographs 48:43-65.

Schoor, M. M. 1994. The relation between vegetation and hydrology/geomorphology in the Gemenc floodplain forest, Hungary. Water Science and Technology 29:289-291.

Selig, U., T. Hubener, and M. Michalik. 2002. Dissolved and particulate phosphorus forms in a eutrophic shallow lake. Aquatic Sciences 64:97-105.

Smith, V. H. 2003. Eutrophication of freshwater and coastal marine ecosystems - A global problem. Environmental Science and Pollution Research 10:126-139.

Stanturf, J. A. and S. H. Schoenholtz. 1998. Soils and landforms. Pages 123-147 in M. G. Messina and W. H. Conner, editors. Southern forrested wetlands: Ecology and management. Lweis Publ., New York. 
Sterner, R. W. and J. J. Elser. 2002. Ecological Stoichiometry: The Biology of Elements from Molecules to the Biosphere. Princeton University Press, Princeton, NJ.

Stoeckel, D. M. and M. S. Miller-Goodman. 2001. Seasonal nutrient dynamics of forested floodplain soil influenced by microtopography and depth. Soil Science Society of America Journal 65:922-931.

Sundareshwar, P. V., J. T. Morris, E. K. Koepfler, and B. Fornwalt. 2003. Phosphorus limitation of coastal ecosystem processes. Science 299:563-565.

Suzumura, M. and A. Kamatani. 1995. Mineralization of inositol hexaphosphate in aerobic and anaerobic marine sediments: Implications for the phosphorus cycle. Geochimica et Cosmochimica Acta 59:1021-1026.

Tate, K. R. 1984. The biological transformation of P in soil. Plant and Soil 76:245-256.

Tockner, K., D. Pennetzdorfer, N. Reiner, F. Schiemer, and J. V. Ward. 1999. Hydrological connectivity, and the exchange of organic matter and nutrients in a dynamic riverfloodplain system (Danube, Austria). Freshwater Biology 41:521-535.

Turner, B. L., L. M. Condron, S. J. Richardson, D. A. Peltzer, and V. J. Allison. 2007. Soil organic phosphorus transformations during pedogenesis. Ecosystems 10:1166-1181.

Turner, B. L., E. Frossard, and D. S. Baldwin. 2005. Organic phosphorus in the environment. CABI Publ., Wallingford, UK.

Turner, B. L. and S. Newman. 2005. Phosphorus cycling in wetland soils: The importance of phosphate diesters. Journal of Environmental Quality 34:1921-1929.

Turner, B. L., M. J. Paphazy, P. M. Haygarth, and I. D. McKelvie. 2002. Inositol phosphates in the environment. Philosophical Transactions of the Royal Society of London Series BBiological Sciences 357:449-469. 
Turner, R. E., S. W. Forsythe, and N. J. Craig. 1981. Bottomland hardwood forest land resources of the southern Unites States. Pages 13-28 in J. R. Clark and J. Benforado, editors. Wetlands of Bottomland Hardwood Forests Elsevier Scientific, Amsterdam.

Vitousek, P. M. 2004. Nutrient cycling and limitation. Hawai'i as a model system. Princeton University Press, Princeton, NJ.

Vitousek, P. M. and R. W. Howarth. 1991. Nitrogen limitation on land and in the sea: How can it occur? Biogeochemistry 13:87-115.

Walbridge, M. R. 1991. Phosphorus availability in acid organic soils of the lower North-Carolina coastal-plain. Ecology 72:2083-2100.

Walbridge, M. R. 1993. Functions and values of forested wetlands in the southern United-States. Journal of Forestry 91:15-19.

Walbridge, M. R. and B. G. Lockaby. 1994. Effects of forest management on biogeochemical functions in southern forested wetlands. Wetlands 14:10-17.

Walbridge, M. R., C. J. Richardson, and W. T. Swank. 1991. Vertical-distribution of biological and geochemical phosphorus subcycles in two southern Appalachian forest soils. Biogeochemistry 13:61-85.

Walbridge, M. R. and J. P. Struthers. 1993. Phosphorus retention in non-tidal palustrine forested wetlands of the mid-Atlantic region. Wetlands 13:84-94.

Walker, T. W. and J. K. Syers. 1976. The fate of phosphorus during pedogenesis. Geoderma 15:1-19.

Wharton, C. H. and M. M. Brinson. 1979. Characteristics of southeastern river systems. Pages 32-40 in R. R. Johnson and J. F. McCormick, editors. Strategies for protection and management of floodplain wetlands and other riparian ecosystems. USDA Forest Service, Washington, DC. 
Wilson, M. A. and S. R. Carpenter. 1999. Economic valuation of freshwater ecosystem services in the United States: 1971-1997. Ecological Applications 9:772-783.

Withers, P. J. A. and H. P. Jarvie. 2008. Delivery and cycling of phosphorus in rivers: A review. Science of the Total Environment 400:379-395.

Worsfold, P. J., P. Monbet, A. D. Tappin, M. F. Fitzsimons, D. A. Stiles, and I. D. McKelvie. 2008. Characterisation and quantification of organic phosphorus and organic nitrogen components in aquatic systems: A review. Analytica Chimica Acta 624:37-58.

Wright, R. B., B. G. Lockaby, and M. R. Walbridge. 2001. Phosphorus availability in an artificially flooded southeastern floodplain forest soil. Soil Science Society of America Journal 65:1293-1302.

Yarbro, L. A. 1983. The influence of hydrologic variations on phosphorus cycling and retention in a swamp stream ecosystem. Pages 223-245 in T. D. Fontaine and S. M. Bartell, editors. Dynamics of Lotic Ecosystems. Ann Arbor Science, Ann Arbor, MI.

Zehetner, F., G. J. Lair, F. J. Maringer, M. H. Gerzabek, and T. Hein. 2008. From sediment to soil: floodplain phosphorus transformations at the Danube River. Biogeochemistry 88:117-126. 
Figure 1.1: Biogeochemical transformation and retention of $P$ in the sediment and the water column in floodplain forests during flooding events. POP: particulate organic P; DOP: dissolved organic P; PIP: particulate inorganic P; DIP: dissolved inorganic P. Inorganic $\mathrm{P}$ inputs with floodwaters are subject to four initial fates: a, plant uptake; b, microbial immobilization and release; c, suspended materials (POP and PIP) removed from the water column by sedimentation; d, P sorption by $\mathrm{Al}$ and Fe minerals or $\mathrm{P}$ complexation with organic matter through metal (Al, Fe) ligands. Figure adapted from (Reddy et al. 1999, Worsfold et al. 2008). 


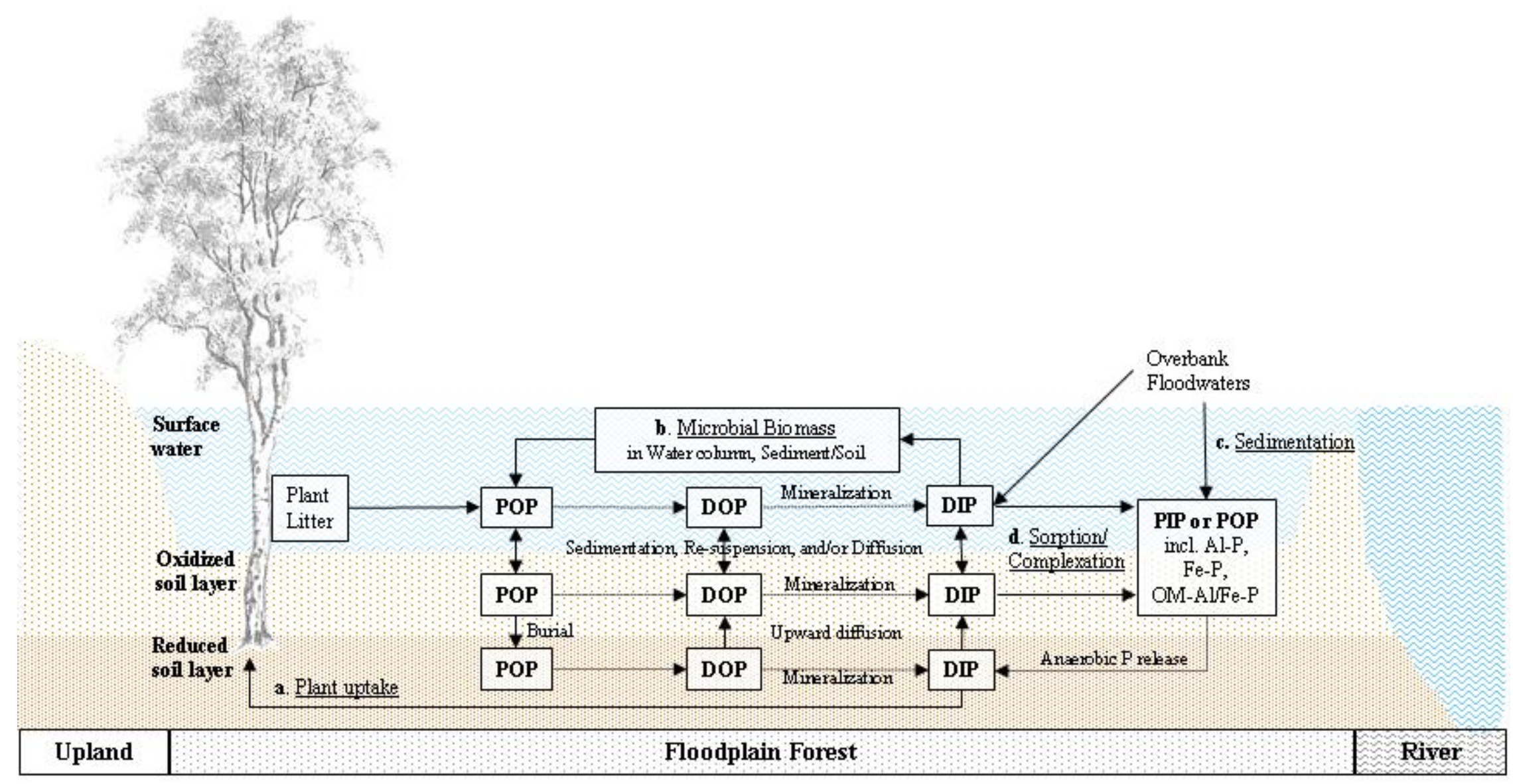




\section{CHAPTER 2}

Distribution of Phosphorus Forms during Spring Flooding Events in Alluvial and Blackwater Rivers and their Adjacent Floodplain Forests in the Southeastern US 


\begin{abstract}
Phosphorus (P) commonly limits productivity in freshwater ecosystems; thus, increased $\mathrm{P}$ loading, either in dissolved (DP) or particulate (PP) form, can lead to eutrophication. In riverine ecosystems, floodplain forests (FFs) provide an important ecosystem service, that of improved water quality downstream, by either removing $\mathrm{P}$ from these incident floodwaters (retention) or by transforming $\mathrm{P}$ prior to export. To assess the nature of $\mathrm{P}$ removal during flooding events, I conducted a detailed study of P forms in waters from alluvial (AL) and blackwater (BW) FFs in the Atlantic Coastal Plain of the southeastern US ( $n=4$ per river type). At each site, $12 \mathrm{~L}$ samples were collected both from the river inlet inflow point (RI), and from within the floodplain (FP) near the outflow point. These were filtered $(0.45-\mu \mathrm{m})$ and analyzed for $\mathrm{pH}$, dissolved $\mathrm{C}, \mathrm{Al}, \mathrm{Fe}$, total DP (TDP), total PP and particulate C. Dissolved and particulate samples were also characterized by ${ }^{31} \mathrm{P}$ nuclear magnetic resonance (NMR) spectroscopy. Blackwater samples were significantly lower in $\mathrm{pH}$ and higher in dissolved $\mathrm{C}, \mathrm{Al}$ and $\mathrm{Fe}$, than $\mathrm{AL}$ samples. Total $\mathrm{P}$ averaged $86 \mu \mathrm{g} \mathrm{P} \mathrm{L}^{-1}$ (52\% PP) in BW samples, and $76 \mu \mathrm{g} \mathrm{P} \mathrm{L}^{-1}$ (70\% PP) in AL samples. Although average TDP concentrations were similar in AL and BW river waters, concentrations in AL systems were $53 \%$ lower in FP $\left(11 \mu \mathrm{g} \mathrm{P} \mathrm{L}{ }^{-1}\right)$ than in RI $\left(23 \mu \mathrm{g} \mathrm{P} \mathrm{L}^{-1}\right)$ waters during flooding events. Dissolved P pools were predominantly inorganic, ranging from $66-73 \%$ of extracted $\mathrm{P}$ in RI and $58-59 \%$ of extracted P in FP waters in both AL and BW systems. Across both AL and BW systems during flooding events, the sum of NMR-visible DIP forms was significantly lower in FP (58\% of extracted P) than in RI (69\% of extracted P) waters. In AL floodplains, dissolved Al concentrations were significantly lower, and dissolved organic matter content was higher, in FP than in RI waters. In combination these trends suggest organic matter - metal (Al) - phosphate complexation as a potential mechanism of P transformation in AL FFs during overbank flooding events. There were no significant differences in DP forms in BW and AL samples, but BW samples were significantly higher in particulate orthophosphate monoesters, including phytate and scyllo-inositol P. In both AL and BW samples, TDP and dissolved orthophosphate declined significantly from RI to FP, while dissolved pyrophosphate (3 $\%$ of extracted P in RI and $7 \%$ of extracted P in FP waters) and total DOP (31\% of extracted P in RI and $42 \%$ of extracted $\mathrm{P}$ in FP) were significantly higher in FP than in RI waters. Orthophosphate monoesters comprised the majority of the DOP pool and were significantly
\end{abstract}


higher in FP (39 \% of extracted P) than in RI (29\% of extracted P) floodwaters in both AL and BW systems. This suggests that in both $\mathrm{AL}$ and $\mathrm{BW}$ systems, dissolved inorganic $\mathrm{P}$ was converted to organic form during flooding events, reducing its bioavailability and potential to cause the eutrophication of downstream waters. 


\subsection{INTRODUCTION}

\subsubsection{Floodplain Forests of the Southeastern US}

In riverine landscapes, floodplain forests (FFs) are important locations for nutrient retention and transformation (Johnston 1991, Hupp et al. 2005, Noe and Hupp 2007). Periodic inundation by floodwaters provides an opportunity for FFs to process nutrients received from uplands outside of their immediate watersheds (Brinson 1993, Lockaby and Walbridge 1998, Mitsch and Gosselink 2007). This is particularly important in agricultural and urbanizing landscapes, where river water P concentrations tend to be elevated (Matson et al. 1997, Carpenter 2005, Hupp et al. 2005) by pollutants from both point (primarily industrial or municipal waste) and non-point (diffuse) sources (Carpenter et al. 1998, Withers and Jarvie 2008). Because P commonly limits productivity in freshwater ecosystems (Schindler 1978, Hecky and Kilham 1988, Sterner 2008), increased P loadings, either in dissolved or particulate form, often lead to eutrophication, with associated effects that include degraded water quality, toxic algal blooms, anoxia, and loss of aquatic biodiversity (Kotak et al. 1993, Carpenter 2005, Dodds et al. 2009). By removing P from these incident floodwaters (hereafter referred to as retention) (Yarbro 1983, Brinson 1993, Walbridge and Struthers 1993, Darke and Walbridge 2000, Bruland and Richardson 2005, Noe and Hupp 2005) or transforming P prior to export (Richardson 1989, Lockaby and Walbridge 1998, Hupp et al. 2005, Mitsch and Gosselink 2007), FFs provide an important ecosystem service, that of improved water quality downstream (Walbridge 1993, Brinson and Rheinhardt 1996, Lockaby and Walbridge 1998, Hupp et al. 2005).

A number of studies have examined rates of P retention and transformation in FFs (Mitsch et al. 1979, Brinson et al. 1984, Craft and Casey 2000, Stoeckel and Miller-Goodman 2001, Bruland 
and Richardson 2005, Noe and Hupp 2007), and yet none have detailed the various forms and concentrations of $\mathrm{P}$, particularly organic $\mathrm{P}$, in inflow versus outflow floodwaters during overbank flooding. Studies using state-of-the-art measurements to quantify changes in inorganic and organic P forms during sheet-flow flooding events should be of vital interest in understanding the functions of FF ecosystems.

Most previous research on $\mathrm{P}$ retention and transformation processes in forested wetlands has focused on floodplains of alluvial (AL) river systems in the southeastern US (Yarbro 1983, Brinson 1993, Walbridge and Struthers 1993, Darke and Walbridge 2000, Stoeckel and MillerGoodman 2001, Noe and Hupp 2005). Alluvial rivers, whose waters arise in the Piedmont or montane physiographic provinces, generally have higher sediment loads and higher concentrations of inorganic ions (including P) than blackwater (BW) rivers (Wharton and Brinson 1979, Hupp et al. 2005), the second most common type of river system in the southeastern US. Blackwater rivers are relatively unstudied with respect to $\mathrm{P}$ processing during flooding events. Overall, BW systems tend to be smaller in drainage area than AL systems, with lower gradient flows and limited potential to entrain or erode sediments. Thus they are likely to receive relatively low concentrations of sediment-associated PP inputs during flooding events (Burke et al. 2003, Howitt et al. 2007). In addition, BW river waters have high concentrations of dissolved organic matter released from terrestrial vegetation and/or soils, and thus they also typically have higher concentrations of total organic $\mathrm{C}$, but lower $\mathrm{pH}$, hardness, and specific conductance, than AL river waters (Wharton and Brinson 1979, Hupp et al. 2005). 


\subsubsection{Phosphorus Forms and Mechanisms of Phosphorus Retention and Transformation}

Phosphorus in floodwaters can occur in both inorganic and organic forms that vary in their bioavailability in aquatic ecosystems. These forms can be found in both the dissolved/soluble (DP) and the suspended/insoluble (particulate, PP) fractions (Figure 2.1). Phosphorus forms are usually defined operationally, by filtration through 0.2 (colloidal P) or $0.45 \mu \mathrm{m}$ (PP) filters. Inorganic $\mathrm{P}$ forms in floodwaters include particulate inorganic phosphate (PIP), associated with mineral sediments, and dissolved inorganic P (DIP), which includes dissolved orthophosphate (primarily $\mathrm{HPO}_{4}{ }^{2-}$ or $\mathrm{H}_{2} \mathrm{PO}_{4}{ }^{-}$at the $\mathrm{pH}$ of floodwaters; Figure 2.2 a), also referred to as soluble reactive $\mathrm{P}(\mathrm{SRP})$ or molybdate reactive $\mathrm{P}(\mathrm{MRP})$, as well as dissolved complex inorganic $\mathrm{P}$ forms such as pyrophosphate and polyphosphate (Figure 2.2 b, c). Organic $\mathrm{P}$ forms include both particulate (Kutuzova et al. 2009) and dissolved (DOP) organic P (Figure 2.1). A number of studies have found that $\mathrm{P}$ pools in river waters flowing on to a floodplain often are dominated by inorganic $\mathrm{P}$ forms, while $\mathrm{P}$ pools in outflow floodwaters are dominated by organic $\mathrm{P}$ forms (Elder 1985, Craft and Casey 2000, Darke and Walbridge 2000, Stoeckel and Miller-Goodman 2001, Bruland and Richardson 2004, Van Der Lee et al. 2004, Bruland and Richardson 2005). Therefore, FFs are frequently thought of both as net sinks for inorganic $\mathrm{P}$ and net sources of organic P (Richardson et al. 1988, Brinson 1993, Lockaby and Walbridge 1998, Darke and Walbridge 2000, Bruland and Richardson 2004, Hupp et al. 2005).

In both the water column and at the sediment/soil interface, retention and transformation of DIP can occur by both biological (plant uptake and microbial immobilization) and geochemical (P sorption) processes. Suspended materials (both inorganic and organic P associated with mineral sediments, POP and PIP, and colloidal P) may be removed from the water column by 
sedimentation, a physical process associated with the decline in flow velocity that occurs as floodwaters encounter increased resistance from the floodplain surface (Kleiss 1996, Craft and Casey 2000, Hupp et al. 2005, Benitez-Nelson et al. 2007, Brunet and Astin 2008). Sedimentation of PP is accompanied by the sorption and precipitation of DIP bound to amorphous (or poorly crystalline) aluminum (Al) and iron (Fe) oxides (Lee et al. 1990, Walbridge and Struthers 1993, Darke and Walbridge 1994, Axt and Walbridge 1999, Darke and Walbridge 2000, Hogan et al. 2004, Hogan and Walbridge 2007, Fernandez et al. 2008). In addition to simple amorphous mineral forms of $\mathrm{Al}$ and/or $\mathrm{Fe}$, both metals form complexes with soil organic matter $(\mathrm{OM})$ that can also sorb DIP, forming $\mathrm{OM}$ - metal $(\mathrm{Al}, \mathrm{Fe})-\mathrm{P}$ compounds (Axt and Walbridge 1999, Darke and Walbridge 2000, Hupp et al. 2005).

Dissolved inorganic P entering FFs via overbank flooding also can be transformed (by uptake and subsequent conversions to organic form) through biosynthetic pathways associated with plants and/or microorganisms, and then exported downstream as DOP and/or POP. Microbial immobilization may also retain a substantial amount of DIP, but this pool can turn over rapidly due to the lysis of microbial biomass during unfavorable environmental conditions, such as prolonged anaerobic conditions following a flooding event (Khoshmanesh et al. 1999, Stoeckel and Miller-Goodman 2001, Wright et al. 2001). Although microorganisms generally mineralize organic P (releasing DIP), they also regulate $\mathrm{P}$ flux across the sediment-water interface (Kleeberg and Schlungbaum 1993, Qualls and Richardson 2000) and contribute to P burial through production of POP forms, some of which are refractory (Gachter and Meyer 1993). Although both biological and geochemical processes can be important pathways of DIP removal, little is known about the relative contribution that each process plays in transforming $\mathrm{P}$ during 
flooding events, or the relative proportion of organic $\mathrm{P}$ forms that result from these transformations. Using state-of-the-art techniques to examine changes in inorganic and organic P forms in floodwaters transiting a forested floodplain could provide valuable information about the relative importance of these various processes.

\subsubsection{Techniques for Determining Phosphorus in Water}

Routinely, organic P in aqueous samples is quantified indirectly: Total P (TP) is determined colorimetrically (Murphy and Riley 1962) following digestion, or by inductively coupled plasma atomic emission spectroscopy (ICP-AES) (Holliday and Gartner 2007), and then organic P calculated as the difference between total and inorganic P (dissolved/molybdate reactive P (D/MRP), measured colorimetrically before digestion) (Figure 2.1 a). Complex inorganic $\mathrm{P}$ forms such as pyrophosphate and polyphosphate (Figure $2.2 \mathbf{b}$-c) are not molybdate-reactive, and are thus also identified as organic $\mathrm{P}$ when inorganic $\mathrm{P}$ is determined colorimetrically. Additionally, both "true" organic P compounds (e.g., orthophosphate monoesters and diesters, and phosphonates) and $\mathrm{OM}$ - metal (Fe/ $\mathrm{Al})$ - $\mathrm{P}$ complexes would be identified as 'organic $\mathrm{P}$ '. Thus, traditional methods are not able to distinguish between important inorganic and organic $\mathrm{P}$ forms that may be present in a water sample (Figure 2.1 a). In fact, these methods likely overestimate the amount of "true" organic P present in floodwaters or other water samples (Darke and Walbridge 1994, McKelvie et al. 1995, Benitez-Nelson et al. 2007), while providing little information on $\mathrm{P}$ speciation, particularly in terms of organic $\mathrm{P}$ forms. 
Because in nature, all $\mathrm{P}$ is found as the stable isotope ${ }^{31} \mathrm{P}$ and is therefore NMR-visible, solution ${ }^{31}$ P-nuclear magnetic resonance (NMR) spectroscopy can identify species of both organic and inorganic P in floodwaters (Cade-Menun et al. 2006) (Figure 2.1 b), allowing the determination of a range of $\mathrm{P}$ forms with a single extraction and analysis protocol. The first use of ${ }^{31} \mathrm{P}-\mathrm{NMR}$ spectroscopy in determining organic $\mathrm{P}$ forms in environmental samples was by Newman and Tate (1980). Since then, solution ${ }^{31} \mathrm{P}$ NMR has become an increasingly powerful tool for the characterization of organic $\mathrm{P}$ in agricultural and forest soils, marine and lake sediments, manure, compost, and sludge (c.f. Cade-Menun 2005b, a, Worsfold et al. 2008). Although solution ${ }^{31} \mathrm{P}$ NMR has been used extensively for identifying P forms in extracts of soils and sediments, there have been relatively fewer applications of this technique in marine (Clark et al. 1999, Kolowith et al. 2001) or freshwater (Nanny and Minear 1994, 1997, Selig et al. 2002) samples, particularly in FFs and associated river waters (Cade-Menun et al. 2006). An improvement in the use of ${ }^{31} \mathrm{P}$ NMR spectroscopy to characterize dissolved forms of $\mathrm{P}$ in freshwaters (Cade-Menun et al. 2006) facilitates these types of analyses.

Since organic P forms vary in their bioavailability (Pant et al. 2002, Turner et al. 2003a, CadeMenun et al. 2006, McDowell and Koopmans 2006, Worsfold et al. 2008), understanding the effectiveness of FF processes in improving water quality (and the potential fate of $\mathrm{P}$ once it leaves the floodplain) requires detailed information about both the identities and concentrations of organic P species (Cade-Menun et al. 2006). While simple DIP forms like orthophosphate are readily available for biological uptake, increasing the risk of eutrophication, some biologically available organic P forms can also cause eutrophication of downstream waters (Chu 1946, Cotner and Wetzel 1992, Quiquampoix and Mousain 2005, Turner et al. 2005b, Turner and 
Newman 2005, Dyhrman et al. 2006). Most organic P forms identified in freshwater ecosystems are ester phosphates (mono- or diesters) that vary in their bioavailability to aquatic organisms (Cembella et al. 1984a, Suzumura and Kamatani 1995, Lovdal et al. 2007). When orthophosphate concentrations are low, monoesters (Figure 2.2 d) are preferentially utilized by heterotrophic organisms over more complex forms (e.g., diesters -- phosphoproteins, DNA, and other polynucleotides) (Figure 2.2 e), which require extensive exoenzymatic breakdown prior to uptake. As a result, these forms are less likely to contribute to eutrophication of aquatic ecosystems (Turner and Newman 2005, El-Rifai et al. 2008). Phosphonates, which contain a C$\mathrm{P}$ bond rather than the C-O-P bond characteristic of ester phosphates, are more stable and therefore resistant to biodegradation (Kolowith et al. 2001, Kononova and Nesmeyanova 2002, Dyhrman et al. 2006, Fox and Mendz 2006) (Figure 2.2 f). Because organic P species are the products of biological activity (Selig et al. 2002, Eixler et al. 2005), their presence would suggest the importance of biological processes in FF P transformations. Plant material in agricultural systems can contain significant amounts of orthophosphate diesters (52\% in nucleic acids and 23 $\%$ in phospholipids) and the remainder $(25 \%)$ as orthophosphate monoesters (Magid et al. 1996). Microbial (bacterial and fungal) biomass has been shown to contain large but variable amounts of polyphosphates, including pyrophosphate (the smallest form of polyphosphate) (Kornberg et al. 1999, Makarov et al. 2005). Increases in these compounds in outflow floodwaters would suggest the importance of plant and/or microbial processes as mechanisms of P transformation. 


\subsubsection{Objectives and Hypotheses}

I examined changes in the forms of $\mathrm{P}$ in floodwaters during overbank flooding events in eight $\mathrm{AL}$ and BW FFS ( $\mathrm{n}=4$ per river type) in the southeastern US Coastal Plain, to determine if BW and AL floodplains retain and/or transform P during flooding events (Spring 2005), and if river type affects these processes. Surface waters were sampled both at the inflow or river inlet (RI), and within the FF (FP), prior to the point of export to downstream aquatic ecosystems (i.e, outflow waters); concentrations of inorganic and organic $\mathrm{P}$ forms in both dissolved and

particulate fractions were quantified by ${ }^{31} \mathrm{P}$ NMR spectroscopy (Cade-Menun et al. 2006). I hypothesized that:

1. In both $A L$ and BW systems, floodwater TP would be significantly lower in outflow (FP) vs. inflow (RI) floodwaters, suggesting that DP and/or PP received in floodwaters is retained via biotic and abiotic processes within the FF prior to export downstream. I tested this hypothesis against two alternative hypotheses - that TP entering the floodplain via overbank flooding:

1a. would be significantly higher in FP than in RI waters, due to the mobilization and re-suspention of DP and PP by the scouring of material and associated $P$ from the floodplain surface.

1b. would not differ significantly between RI and FP waters.

2. In both $A L$ and BW systems, DIP in FP waters will be significantly lower, and DOP significantly higher, than in RI waters, suggesting that P transformation occurs via biotic synthesis (conversion of Pi to Po). 
This hypothesis will be tested against an alternative hypothesis:

2a. Where DIP forms would be significantly higher and DOP forms would be significantly lower in FP vs. RI floodwaters, due to microbial mineralization of DOP and mobilization of DIP from surface soil/sediment organic matter or dissolved organic substances containing $P$.

2b. DIP and DOP forms would not differ significantly between RI and FP waters.

3. Because of the characteristically high sediment loads, the majority of inorganic and organic $P$ in $A L$ river waters would likely be present in particulate form, with sedimentation likely to be the primary mechanism of particulate phosphorus removal during flooding events.

This hypothesis will be tested against two alternative hypotheses - that PP concentration in floodwaters:

$3 a$. would be significantly higher in FP than in RI waters, suggesting sedimentation as the dominant mechanism of $P$ retention.

3b. would not differ significantly between RI and FP waters during high discharge flooding events where flow velocities are too high for PP sedimentation to occur. 


\subsection{METHODS}

\subsubsection{Site Description, Sample Collection and Preparation}

Water samples were collected from AL and BW FFs $(n=4$ per river type) in the Atlantic Coastal Plain of the southeastern US (Table 2.1) during March and April, 2005, during peak flood stage as indicated by USGS gauge data (http://water.usgs.gov/waterwatch/). The AL rivers sampled in this study were significantly larger in drainage area and mean daily stream flow than BW rivers. At each site, grab samples (one $12 \mathrm{~L}$ sample per location) were collected from the river inflow point $(\mathrm{RI})$ or, near the upstream end of the wetland, and from within the floodplain (FP), near the downstream (outflow) end of the wetland, just prior to the point where floodwaters reentered the river channel. Within $48 \mathrm{hr}$ of collection, $11 \mathrm{~L}$ of each sample were filtered through $0.45 \mu \mathrm{m}$ membrane filters $(500 \mathrm{~mL}$ per filter, Cat\# 141118, Whatman Inc., Clifton, NJ, USA) by vacuum filtration, to separate dissolved from particulate P. Ten L of each filtrate were frozen in ice cube trays and subsequently lyophilized (FreeZone 12 L console, Labconco, Kansas City, MO); $1 \mathrm{~L}$ was retained for chemical analysis; filters were refrigerated for later processing. A 500-mL subsample of the remaining unfiltered water was sequentially filtered through 0.45 $\mu \mathrm{m}$, followed by $0.20 \mu \mathrm{m}$ (Pall polypropylene) membrane filters, to separate particulate and colloidal, $\mathrm{P}$ respectively. The remaining $500 \mathrm{~mL}$ was used for other chemical analyses.

\subsubsection{Chemical Analyses}

Water samples were analyzed for $\mathrm{pH}$, conductivity, dissolved and particulate organic $\mathrm{C}$, total P (TP), MRP, aluminum (Al), calcium (Ca), and iron (Fe). Molybdate reactive $\mathrm{P}$ concentrations were measured colorimetrically on a Bran \& Luebbe autoanalyzer (Norderstedt, 
Germany) by the molybdate blue color reaction (Murphy and Riley 1962). Total P, Al, Ca, and Fe concentrations in filtrate solutions were measured on an ICP-AES (Thermo-Jarell Ash; IRIS Advantage). Particulate P (PP) retained on the $0.45 \mu \mathrm{m}$ filters was quantified colorimetrically, after filters were oven-dried and digested (Parkinson and Allen 1975). Dissolved organic C (DOC) concentrations were determined on a Shimadzu TOC analyzer (Shimadzu, Columbia, MD). Particulate organic C (POC) concentrations on the $0.45 \mu \mathrm{m}$ filters were measured on a Carlo Erba NA1500 Series II elemental analyzer.

\subsubsection{NMR Extraction and Analysis}

Lyophilized water samples were extracted in $25 \mathrm{~mL}$ of a $1: 1$ solution of $0.5 \mathrm{M} \mathrm{NaOH}$ and $0.1 \mathrm{M} \mathrm{Na}_{2}$ EDTA overnight, and then centrifuged for $20 \mathrm{~min}$ at $3700 \mathrm{rpm}$ (Cade-Menun and Preston 1996, Cade-Menun et al. 2002, Turner et al. 2005a). For each water sample, fifteen of a total of twenty-two filters (not dried) were similarly extracted (5 filters per $25 \mathrm{~mL}$ of extractant) and then combined to produce $75 \mathrm{~mL}$ of extract. A $1-\mathrm{mL}$ aliquot of the combined extract (diluted to $10 \mathrm{~mL}$ ) of each solution was analyzed by ICP-AES to determine total extracted P and $\mathrm{Ca}$; and the remaining $74 \mathrm{~mL}$ were lyophilized. Lyophilized samples were dissolved in a solution of $1.2 \mathrm{~mL}$ (particulate samples) or $0.8 \mathrm{~mL}$ (dissolved P samples) deionized water, 0.8 $\mathrm{mL}$ deuterium oxide, and $0.4 \mathrm{~mL} 10 \mathrm{M} \mathrm{NaOH}$, then allowed to stand at room temperature for 20 min with periodic vortex mixing, and then centrifuged at $3700 \mathrm{rpm}$ for $20 \mathrm{~min}$. Spectra were acquired within $12 \mathrm{~h}$ of sample preparation at $242.75 \mathrm{MHz}$ on a Varian ${ }^{\text {UNITY }}$ INOVA $600 \mathrm{MHz}$ spectrometer equipped with a $10-\mathrm{mm}$ broadband probe. Parameters were: $20^{\circ} \mathrm{C} ; 90^{\circ}$ pulse; 0.68 $\mathrm{s}$ acquisition time; $4.32 \mathrm{~s}$ relaxation delay; and $12 \mathrm{~Hz}$ spinning; collecting 5800 scans for PP and 8500 scans for DP samples (Cade-Menun et al. 2006). Forms of $\mathrm{P}$ were identified by their 
chemical shifts (ppm) relative to an external standard (orthophosphoric acid); the orthophosphate peak for each sample was standardized to 6 ppm (Figure 2.3 and 2.4). Peaks were processed using NUTS software (Acorn NMR, Livermore, CA, 2000 edition) with $7 \mathrm{~Hz}$ line-broadening for coarse identification and $2 \mathrm{~Hz}$ line-broadening for fine identification; peak identification was based on the literature (Cade-Menun 2005b, Turner et al. 2005b) and spiking of related samples (Cade-Menun et al. 2006).

\subsubsection{Statistical Analysis}

Chemical composition, drainage area, and mean daily stream flow (http://water.usgs.gov/waterwatch/) of $\mathrm{AL}$ and $\mathrm{BW}$ rivers were compared using a two-sample ttest analysis $(p=0.05)$. Differences in the chemistries of RI and FP water samples were analyzed by two-way ANOVA ( $p=0.05)$, with main effects of floodplain type (AL vs. BW), location on each FF (RI vs. FP), the interaction term, and floodplain type nested within site. Data were log transformed where necessary to meet assumptions of normality. All statistical analyses were performed using SYSTAT version 12 (SSI, San Jose, CA). Accumulation or retention rates of $\mathrm{P}$ forms were calculated using the following equation:

$\%$ retention of riverine $\mathrm{P}$ load $=[(\% \mathrm{P}$ in $\mathrm{RI}-\% \mathrm{P}$ in $\mathrm{FP}) / \% \mathrm{P}$ in $\mathrm{RI}] \times 100$ 


\subsection{RESULTS}

\subsubsection{Alluvial vs. Blackwater Rivers}

Results for the chemical characteristics of individual AL and BW rivers are listed in Table 2.2 a. River water $\mathrm{pH}$ ranged from 5.3 to 7.0 , and when averaged across river types was significantly higher in $\mathrm{AL}(6.4 \pm 0.6)$ than in $\mathrm{BW}(5.6 \pm 0.2)$ rivers (floodplain type: $F=24.272, p=0.003$, Appendix Table 2.1 a). As expected, dissolved organic C concentrations were significantly higher in BW than in AL systems $(F=9.856, p=0.020$, Appendix Table 2.1 a). Across sites and samples, Al concentrations were significantly higher than Fe concentrations, with the exception of the Pee Dee River, SC, and the FP sample from the Ocmulgee River, GA. Aluminum concentrations were also significantly higher in BW than in AL systems (floodplain type: $F=12.787, p=0.012)$, and lowest in FP samples in the AL system (RI/FP location: $F=$ 13.602, $p=0.010$ and interaction between the two factors: $F=13.735, p=0.010$ ) (Appendix Table 2.1 a, Figure 2.6 b). Dissolved Fe varied widely (10.8 to $490.4 \mu \mathrm{g} \mathrm{Fe} \mathrm{L}^{-1}$ ) and when averaged was significantly higher, by as much as ten fold, in BW $\left(305.7 \pm 97.2 \mu \mathrm{g} \mathrm{Fe} \mathrm{L}{ }^{-1}\right)$

compared to $\mathrm{AL}\left(31.1 \pm 11.9 \mu \mathrm{g} \mathrm{Fe} \mathrm{L}^{-1}\right)$ river waters (floodplain type: $F=11.676, p=0.014$, Appendix Table 2.1 a, Figure 2.6 e). Total P in AL river waters, calculated as the sum of the DP and PP fractions, was $75.7( \pm 14.4) \mu \mathrm{g} \mathrm{P} \mathrm{L}{ }^{-1}$, of which $70 \%$ was in particulate form. Total P

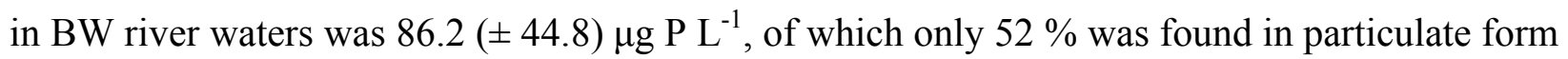
(Table 2.2 a).

Typical spectra from NMR experiments are shown in Figures 2.3 - 2.4. An expanded view of a P spectrum is depicted in Figure 2.5, showing more detail in the orthophosphate, orthophosphate 
monoester and diester, and pyrophosphate regions and is representative of the $\mathrm{P}$ forms observed in flood waters in this spectra region in all samples. A majority of the peaks representing specific P compounds and compound groups was identified in a previous study (Cade-Menun et al. 2006) by spiking river water samples (Pee Dee River, SC) with analogous standard inorganic and organic P compounds. All spectra show peaks for the P compound groups (from left to right): inorganic orthophosphate (6.5 to $5.5 \mathrm{ppm}$ ); organic orthophosphate monoesters (5.5 to 3.0 ppm); orthophosphate diesters (ranged from 3.0 to $-0.1 \mathrm{ppm}$ ); and inorganic pyrophosphate $(-4.0$ to $-4.3 \mathrm{ppm}$ ) (Figure $2.2 \mathbf{a}, \mathbf{b}, \mathbf{d}$, e; and 2.5). In the orthophosphate monoester chemical shift range, phytate (salts of myo-inositol hexakisphosphate, Figure 2.2 d) has four peaks, which were found in these samples at 5.2, 4.3, 3.9, and $3.7 \mathrm{ppm}$ (Figure 2.5). Identification of phytate in these samples was based on the presence of the P2 peak at 5.2, and its area was multiplied by six to determine the total phytate peak area, as per Turner (2004).

Inositol phosphates, including scyllo-inositol phosphates (3.3 ppm, Figure 2.5), are highly-stable P-rich molecules having a high anionic charge. These compounds adsorb strongly to clays, mineral surfaces, and organic matter in soil and sediment, thus resisting hydrolysis and biodegradation (Turner and Richardson 2004). Additionally, signals in the monoester region include degradation products of orthophosphate diesters such as mononucleotides resulting from the hydrolysis of RNA, or glycerophosphates (GP at $4.7 \mathrm{ppm}$, Figure 2.5), which are degradation product of phospholipids (Doolette et al. 2009). Orthophosphates diesters were detected in all samples (Table 2.2 b, c) and divided into DNA at $0.1 \mathrm{ppm}$ and "other" diesters (3.0 to $0.5 \mathrm{ppm}$ ), which include RNA and intact phospholipids (Figure $2.2 \mathrm{e}$; and 2.5). Both polyphosphates (Figure 2.2 c) and phosphonates (Figure 2.2 f) were detected in some samples, 
but their relative contribution to total $\mathrm{P}$ in floodwaters ranged from undetectable to $1.3 \%$ of extracted P (Table 2.2 b, c).

As measured by ${ }^{31} \mathrm{P}-\mathrm{NMR}$ analysis, in both the dissolved and particulate fractions, inorganic $\mathrm{P}$ (orthophosphate + pyrophosphate + polyphosphate) was the largest constituent of the total $\mathrm{P}$ pool; and inorganic $\mathrm{P}$ concentrations were similar in $\mathrm{AL}$ and $\mathrm{BW}$ rivers. Orthophosphate in both DIP and PIP ranged from 52.1 to $77.5 \%$ of total P. MRP content in $\mathrm{AL}\left(35.1 \pm 8.9 \mu \mathrm{g} \mathrm{L}^{-1}\right)$ and BW $\left(22.1 \pm 5.9 \mu \mathrm{g} \mathrm{L}^{-1}\right)$ unfiltered river waters were consistent with concentrations of orthophosphate detected by NMR analysis. Although the majority of $\mathrm{P}$ in both river types was in inorganic form, a variety of organic P forms (phosphonates, orthophosphate monoesters, and orthophosphate diesters) was also present (Table 2.2 b, c). In both dissolved and particulate P fractions, the sums of both orthophosphate monoesters and orthophosphate diesters were consistently higher in BW compared to AL rivers, although differences were only statistically significant for the particulate orthophosphate monoesters: scyllo-inositol phosphate (scyllo-IP) and glycerophosphate (Schoch et al.) (Appendix Table 2.1 c).

\subsubsection{River Inlet versus Floodplain Waters:}

\subsubsection{Recovery of total dissolved and particulate P in floodwaters}

In total, lyophilization of $10 \mathrm{~L}$ of RI filtrate produced $361.7 \mathrm{mg}(\mathrm{AL})$ and $437.1 \mathrm{mg}(\mathrm{BW})$ of dried powder (particulate fraction); and lyophilization of FP filtrate produced $411.9 \mathrm{mg}(\mathrm{AL})$ and $472.7 \mathrm{mg}$ (BW) of dried powder. Total DP recovered following NaOH-EDTA extraction 
averaged $41 \%$ across all water samples, and was comparable to the average recovery of $\mathrm{Ca}$ ( 49 $\%$ in these waters. Dry weights of particulates from $10 \mathrm{~L}$ of water were $177.7 \mathrm{mg}$ (RI) and $168.5 \mathrm{mg}(\mathrm{FP})$ in AL samples, and $101.3 \mathrm{mg}(\mathrm{RI})$ and $105.8 \mathrm{mg}$ (FP) in BW systems. After extraction with $\mathrm{NaOH}-\mathrm{EDTA}$, the average recovery of PP was $67 \%$ across all water samples collected.

\subsubsection{Dissolved P Forms}

Total P (measured by ICP-AES) concentrations (calculated as the sum of the DP and PP fraction, Table 2.2 a) were similar in both floodplain types, averaging $75.7 \pm 14.4 \mu \mathrm{g} \mathrm{L}^{-1}$ in RI and $84.6 \pm 21.2 \mu \mathrm{g} \mathrm{L}^{-1}$ in FP for AL systems, and $86.2 \pm 44.8 \mu \mathrm{g} \mathrm{L}^{-1}$ and $85.2 \pm 36.5 \mu \mathrm{g} \mathrm{L}^{-1}$ for RI and FP, respectively, for waters collected at the BW systems. Although TDP did not differ between RI and FP locations in the BW systems, there was a significant decrease in TDP in FP $\left(10.8 \pm 2.7 \mu \mathrm{g} \mathrm{L}^{-1}\right)$ compared to RI $\left(22.8 \pm 5.4 \mu \mathrm{g} \mathrm{L}^{-1}\right)$ waters (Table $\left.2.2 \mathrm{a}\right)$ in the AL systems (two-way ANOVA, floodplain type $\times \mathrm{RI} / \mathrm{FP}$ location interaction: $F=15.912, p=0.007$, Appendix Table 2.1 a and Figure 2.6 a). The proportion of total $\mathrm{P}$ in colloidal $(<0.20 \mu \mathrm{m})$ form showed little variation between floodplain types, averaging $11.7 \pm 6.0 \mu \mathrm{g} \mathrm{L}^{-1}$ in RI and 8.1 $\pm 1.9 \mu \mathrm{g} \mathrm{L}^{-1}$ in FP for AL systems, and $9.0 \pm 5.1 \mu \mathrm{g} \mathrm{L}^{-1}$ in RI and $15.2 \pm 6.6 \mu \mathrm{g} \mathrm{L}^{-1}$ in FP waters collected at BW systems. Colloidal P did not differ by floodplain type $(F=0.105, p=0.756)$, $\mathrm{RI} / \mathrm{FP}$ location $(F=0.207, p=0.665)$, or an interaction between the two factors $(F=2.990, p=$ $0.134)$. 
In both AL and BW systems, the majority of DP was inorganic (Table 2.2 b), and the proportion of DIP forms (measured by NMR) also significantly decreased from $69.3 \pm 6.1 \%$ in RI to $58.3 \pm$ $8.9 \%$ in FP waters (location effect: $F=6.449, p=0.044$, Appendix Table $2.1 \mathbf{b}$ and Figure 2.7 a), largely due to significantly higher dissolved orthophosphate concentrations in RI (65.6 \pm 5.9 \%) than in FP $(51.5 \pm 4.8 \%)$ waters (RI/FP location effect: $F=10.145, p=0.019$, Appendix Table 2.1 b and Figure 2.7 b). Dissolved pyrophosphate was present in most samples at levels as high as $13.6 \%$ of extracted P (Table $2.2 \mathbf{~ b}$ ), but showed the opposite trend to orthophosphate, and was significantly higher in FP $(6.7 \pm 1.4 \%)$ than in RI $(3.4 \pm 1.1 \%)$ waters (RI/FP location effect: $F=9.996, p=0.020$, Appendix Table $2.1 \mathbf{b}$ and Figure 2.7 c) in both AL and BW river systems.

Although the majority of DP was orthophosphate, which decreased significantly in FP vs. RI waters, the sum of DOP forms significantly increased in FP (41.7 $\pm 5.9 \%)$ compared to RI (30.6 \pm 6.1 ) waters (RI/FP location effect: $F=6.449, p=0.044$, Appendix Table 2.1 b, Figure $2.7 \mathrm{~d}$ ) in both $\mathrm{AL}$ and $\mathrm{BW}$ systems. Orthophosphate monoesters were the largest constituents of the DOP fraction, averaging 25.7 to $39.7 \%$ of extracted P (Table 2.2 b). Both dissolved orthophosphate monoesters and diesters were higher in FP waters in both AL and BW systems, though only the differences in monoesters $(39.0 \pm 5.8$ and $28.8 \pm 3.1 \%$ in FP and RI waters, respectively) were statistically significant (RI/FP location effect: $F=5.831, p=0.048$, Appendix Table 2.1 b, Figure 2.7 e) in both FF types. Although most forms of dissolved orthophosphate monoesters, phytate, scyllo-IP, glycerophosphate, and other monoesters) generally increased (but were not statistically significant) in FP waters, phytate concentrations were significantly higher in FP $(6.2 \pm 2.0 \%)$ than in RI $(2.6 \pm 1.3 \%)$ waters (RI/FP location 
effect: $F=18.127, p=0.005$, Appendix Table $2.1 \mathrm{~b}$, Figure 2.7 e) in both AL and BW floodplain forests. Phosphonates and inorganic polyphosphates were detected in some samples, but their relative contributions to total P ranged from 0.0 to $1.3 \%$ (Table $2.2 \mathbf{b}$ ).

\subsubsection{Particulate P Forms}

Total PP concentrations did not differ significantly between RI and FP waters in AL or BW systems (Appendix Table 2.1 a). Similarly, the sum of NMR visible PIP and POP pools were similar between sampling locations within FFs, and between AL and BW floodplain systems (Appendix Table 2.1 c). However, concentrations of particulate orthophosphate monoesters were significantly higher in BW than in AL systems (floodplain effect: $F=6.847, p=0.040$, Appendix Table 2.1 c, Figure 2.8 a). Individual forms of particulate orthophosphate monoesters were generally higher in $\mathrm{BW}$ than in $\mathrm{AL}$ systems, although only differences in particulate scyllo-IP (RI/FP location effect: $F=13.040, p=0.011$, Appendix Table 2.1 c, Figure 2.8 b) and phytate (floodplain type $\times \mathrm{RI} / \mathrm{FP}$ location interaction: floodplain $F=6.000, p$ $=0.049$, Appendix Table 2.1 c, Figure 2.6 d) were statistically significant . 


\subsection{DISCUSSION}

While a number of studies have examined rates of $\mathrm{P}$ retention and transformation in FF soils (e.g., Mitsch et al. 1979, Brinson et al. 1984, Craft and Casey 2000, Stoeckel and MillerGoodman 2001, Bruland and Richardson 2005, Noe and Hupp 2007), and to a lesser degree in floodwaters (Wright et al. 1996, Valett et al. 2005, Krah et al. 2006, Noe and Hupp 2007, Loeb et al. 2008, Tian et al. 2008, Weilhoefer et al. 2008), little is know about the relative contribution of biological and geochemical retention and/or transformation mechanisms in improving downstream water quality, or how these processes vary across the major FF types associated with AL and BW rivers in the southeastern US. My estimates of TP concetrations in river water, during spring (March - April, 2005) flooding, averaging $75.7 \mu \mathrm{g} \mathrm{P} \mathrm{L}^{-1}$ in $\mathrm{AL}$ and $86.2 \mu \mathrm{g} \mathrm{P} \mathrm{L}^{-1}$ in BW rivers, fall within the range of values recorded for these rivers (USGS-Water Resources Archive, Table 2.1), as well a those observed in other AL and BW rivers in the southeastern US Coastal Plain (c.f., Lockaby and Walbridge 1998, Hupp et al. 2005, Noe and Hupp 2009). Total $\mathrm{P}$ concetrations did not differ significantly between river types. The majority of the TP in both river types studied here was present in particulate form, and the differences in TPP concentrations (measured by chemical analysis) between $\mathrm{AL}$ and $\mathrm{BW}$ rivers were statistically indistinguishable (Table 2.2 a). The range of TDP concentrations in both AL (16.3 - 34.0 $\mu \mathrm{g} \mathrm{P}$

$\left.\mathrm{L}^{-1}\right)$ and $\mathrm{BW}\left(8.0-97.7 \mu \mathrm{g} \mathrm{L}^{-1}\right)$ rivers is consistent with DP measured in other rivers in the southeastern US Coastal Plain (c.f., Lockaby and Walbridge 1998, Hupp et al. 2005). Average TDP concentrations were also statistically indistinguishable in AL and BW rivers. Despite the inherent differences between AL and BW rivers, TP, TDP, and TPP concetrations were similar, and as a result, rates of inorganic P retention will be dependent on how physical, geochemical, and biological processes differ in their associated FFs. 
Within AL floodplains, TDP concentrations significantly decreased as RI waters entered the FP during flooding events, suggesting that $53 \%$ (ranging from $39-68 \%$ ) of the riverine TDP load was retained (Table 2.2 a, Figure 2.6). These estimates are comparable to values reported by Noe and Hupp (2009) across seven floodplains in the Chesapeake Bay watershed, USA (59 \% retention rate), and in floodplains of the River Adour, southwestern France (60 - $90 \%$ retention) (Brunet and Astin 2000). No statistically significant changes in TDP between RI and FP were detected in BW samples. Noe and Hupp (2009) suggested that larger floodplain areas and longer flood durations increase retention rates of river P inputs. Thus, the efficiency of DIP removal from the water column may in part depend on increased biogeochemical reactivity due to a larger physical contact area between floodwaters and the FF surface. As is typical in the southeastern US Coastal Plain, AL systems in this study had significantly larger drainage areas, up to 8.7 fold larger than BW floodplains, providing the first line of evidence for greater TDP retention capacity during high-discharge flooding events in AL systems (Table 2.1) (Lockaby and Walbridge 1998, Hupp et al. 2005).

\subsubsection{P Transformation in Floodplain Forests:}

\subsubsection{1 ${ }^{31}$ P NMR Detected Inorganic P Forms in Floodwaters}

As in most environmental samples (Filippelli 2008, Liu et al. 2008), majority of the extracted DP pool in floodwaters was inorganic P, ranging from $66.0-72.7 \%$ of extracted P in RI and 57.8 to $58.8 \%$ of extracted $\mathrm{P}$ in FP waters at AL and BW FFs (Table $2.2 \mathbf{b}$ ). In addition, the sum of NMR-visible DIP forms decreased significantly in FP as compared to RI waters during flooding 
events, suggesting transformation rates of 21 and $11 \%$ of river DIP loads in AL and BW systems, respectively (Figure 2.7 a). Brunet and Astin (2000) reported an average $7.4 \%$ of DIP (or MRP) retention within River Adour floodplains during spring flooding. Reactive orthophosphate (MRP, measured colorimetrically) behaved similarly and decreased in concentration from RI water upstream of the floodplain to FP waters exiting the floodplain (Table 2.2 b). The overall decrease or retention of DIP (or MRP) is in agreement with previous studies that have assessed phosphate removal from incident floodwaters in riparian systems in the southeastern US (Richardson et al. 1988, Brinson 1993, Lockaby and Walbridge 1998, Darke and Walbridge 2000, Bruland and Richardson 2004, Hupp et al. 2005). This decrease could be due in part to adsorption and precipitation reactions with mineral forms of $\mathrm{Al}$ and/or $\mathrm{Fe}$, or to the complexation and precipitation of DIP with organic matter in solution, via $\mathrm{OM}$ - metal $(\mathrm{Al}, \mathrm{Fe})-$ P complexation (Axt and Walbridge 1999, Darke and Walbridge 2000, Hogan et al. 2004, Hupp et al. 2005). Dissolved Al decreased (up to 57 fold) in FP compared to RI floodwaters in AL systems (Figure 2.6 b), and DOC concentrations were higher in the FP than in RI waters in AL systems (Table 2.2 a), possibly the result of solubilization associated with flood-induced DOC entrainment in the water column (Reddy et al. 1999, Neatrour et al. 2004, Kleeberg et al. 2007). Walbridge and Huang (unpublished data), observed similar decreases in DIP occurring concomitantly with increases in DOC content, which was significantly positively correlated with organically-bound $\mathrm{Al}(\mathrm{r}=0.96, P<0.0001)$ in inflow and outflow floodwater that were collected in $\mathrm{AL}$ systems during the same flooding events. In combination, these trends -- the increase in DOC concentrations, the significant decrease in Al concentration, and the significant decrease in DIP -- suggest OM - Al - P complexation (Cheng et al. 2004, Giesler et al. 2005, Jensen et al. 2005, Guan et al. 2006, Novak and Watts 2006, de Vicente et al. 2008) as a plausible mechanism 
of inorganic P transformation during flooding events in AL systems (Novak and Watts 2006). Although similar trends were not observed in FP waters within BW systems, $\mathrm{Al}$ and $\mathrm{Fe}$ concentrations was significantly higher in BW compared to AL systems, and higher DOC content in BW RI compared to FP waters, suggesting that DIP sorption/precipitation reactions with $\mathrm{Al} / \mathrm{Fe}$ cations and/or complexation with $\mathrm{OM}-\mathrm{Al} / \mathrm{Fe}$ may have occurred in the floodwater column prior to entering BW floodplains.

\subsubsection{2 ${ }^{31}$ P NMR Detected Inorganic (Condensed) and Organic P Forms in Floodwaters}

Floodplain forests are frequently thought of as sinks for inorganic $\mathrm{P}$ and sources of organic $\mathrm{P}$ pools (Richardson et al. 1988, Brinson 1993, Lockaby and Walbridge 1998, Darke and Walbridge 2000, Bruland and Richardson 2004, Hupp et al. 2005), yet previous studies have estimated organic $\mathrm{P}$ pools using traditional methods (Figure 2.1 a) that are likely to overestimate of the amount of "true" organic P found in floodwaters (Darke and Walbridge 1994, McKelvie et al. 1995, Benitez-Nelson et al. 2007), while providing little information on $\mathrm{P}$ speciation. In addition to the chemical transformation of $\mathrm{P}$ with $\mathrm{OM}$ via metal ( $\mathrm{Al}$ and/or $\mathrm{Fe}$ )

ligands, biotic transformation of inorganic $\mathrm{P}$ to organic $\mathrm{P}$ could act as an additional line of defense for reducing DIP loads to downstream aquatic ecosystems. The majority of the DIP pool and most of the P extracted from these water samples was orthophosphate (Table 2.2 b, Figure 2.3 - 2.4). This is the simplest ionic form of $\mathrm{P}$ to occur naturally, hence dissolved orthophosphate is the most readily bioavailable P form (McKelvie et al. 1995, Paytan et al. 2003, Cade-Menun 2005a, He et al. 2006, McDowell and Koopmans 2006, Bourke et al. 2008). Both DIP in general and dissolved orthophosphate specifically decreased significantly in FP as 
compared to RI waters in both FF types (Figure 2.7 b), averaging 26 and $17 \%$ of river dissolved orthophosphate concetrations in AL and BW floodplains, respectively.

Dissolved pyrophosphates on average ranged from 1.6 to $8.6 \%$ of total extracted P (Table $2.2 \mathbf{b}$ ) and were significantly higher in FP than in RI waters in AL and BW systems (Figure 2.7 c). Pyrophosphates (Figure 2.2 b), which are the smallest chemical form of polyphosphates, are common in soils (Makarov 1998, Cardoso et al. 2003a, Chiu et al. 2005, McDowell et al. 2007a, Dou et al. 2009), marine (Carman et al. 2000, Cade-Menun et al. 2005, Ahlgren et al. 2006b) and freshwater sediments (Hupfer et al. 2004, Ahlgren et al. 2006a, Reitzel et al. 2006, Ahlgren et al. 2007, Liu et al. 2009), estuarine sediments (Sundareshwar et al. 2001), and marine sediment porewater and water column (Kolowith et al. 2001, Paytan et al. 2003). Pyrophosphates are produced by microbial activity (Gerlitz and Gerlitz 1997, Watts et al. 2002, Makarov et al. 2005) and recent evidence indicates a higher concentration of pyrophosphate in fungal (endophytic and saprotrophic) vs. bacterial biomass in soil isolates (Makarov et al. 2005, Bunemann et al. 2008). Soil drying and rewetting, such as can occur during periodic flooding events, can lyse microbial cells due to osmotic shock upon rapid rewetting resulting in the release of water-extractable $\mathrm{P}$ forms, including pyrophosphates (Turner et al. 2003c). Significant and consistently higher dissolved pyrophosphate concentration in FP waters across AL and BW systems may be the first specific identification of the primary mechanisms associated with biotic uptake of DIP and subsequent release of condensed pyrophosphates in FFs. Pyrophosphates are utilized by both plants and soil microbes, through the use of pyrophosphatases (Sundareshwar et al. 2001, Cheesman et al. 2010), but the presence of this enzyme or the ability to hydrolyze pyrophosphate extracellularly in the water column has only been characterized in two marine dinoflagellates 
(Oh et al. 2002).

The overall concentration decrease in DIP forms, particularly with respect to a decrease in readily available orthophosphate concentrations along the flow path from RI to FP floodwaters, occurred concomitantly with significant increases in the sum of DOP forms in FP compared to RI waters during flooding events in both $\mathrm{AL}$ and $\mathrm{BW}$ floodplain forests (Figure $2.7 \mathrm{~d}$ ). Orthophosphate monoesters comprised the majority of this DOP pool in floodwaters, which also increased significantly in FP vs. RI waters (Figure 2.7 e). Orthophosphate monoesters are biologically synthesized compounds (Makarov et al. 2005, Bunemann et al. 2008, Koukol et al. 2008), and are the most common organic P compounds found in soils in both managed (Cardoso et al. 2003b, Toor et al. 2005, McDowell and Koopmans 2006, Dou et al. 2009) and natural ecosystems (Cade-Menun et al. 2000, Turner et al. 2004, McDowell et al. 2007b), and in both marine particulates (Clark et al. 1999, Carman et al. 2000, Paytan et al. 2003, Cade-Menun et al. 2005) and freshwater sediments (Turner and Newman 2005, Reitzel et al. 2006, Liu et al. 2009, Zhang et al. 2009). Orthophosphate monoesters include several compound types, such as sugar phosphates (e.g. glycerophosphate), mononucleotides, and inositol phosphates of varying degrees of phosphorylation (e.g. scyllo-IP). The majority of the dissolved orthophosphate monoesters present (averaging 22.8 to $32.8 \%$ of extracted P in RI and FP waters, respectively) were in the undistinguished "other" category (Table 2.2 b). These may represent glucose phosphate and mononucleotide degradation products of RNA and/or phospholipids (Turner et al. 2003b), and were consistently higher in FP than in RI waters in both AL and BW systems. Glycerophosphate and scyllo-IP were present, but in small proportions $(<3 \%$ of extracted $\mathrm{P})$ and in only some water samples (Table 2.2 b), whereas the average phytate concentrations ranged 
from 1.7 to $7.2 \%$ of extracted P and were significantly higher in FP than in RI waters in both AL and BW floodplain forests (Figure 2.7 f). Inositol phosphates are complex molecules composed of phosphate groups attached to a six carbon ring, and in terrestrial environments they are synthesized by plants and accumulate in soils because of their high charge density that form strong interactions with clays and $\mathrm{Al} / \mathrm{Fe}$ minerals (Turner et al. 2002, Turner and Weckström 2008). Although orthophosphate is released from the dephosphorylation of inositol phosphates by plant and microbially produced extracellular phytases in soils, inositol phosphates are less prone to hydrolysis in freshwater ecosystems which may be due to the low $\mathrm{pH}$ requirement $\mathrm{pH}$ 2.5 - 5) for phytase activity (Selig et al. 2002, Turner et al. 2002, Turner and Weckström 2008).

Dissolved orthophosphate diesters, predominantly DNA, were present in most samples (Table 2.2 b), and were generally higher in FP than in RI waters at both AL and BW floodplain forests. The actual amount of diester P forms may have been underestimated, because some peaks detected in the monester region, such as glycerophosphates, are degradation products of phospholipids, which are orthophosphate diesters (Buenemann et al. 2008, Doolette et al. 2009) and were also generally higher in FP waters at both FF types.

Total PP recovery following NaOH-EDTA extraction averaged $67 \%$ in all water samples, whereas TDP recovery averaged $41 \%$ and was similar to the recovery of $\mathrm{Ca}(49 \%)$ in these waters. The range of recoveries was comparable to values obtained for TP (60-90\%) (Minear $1972)$ in lake water, DOP (25-50\%), and POP $(23-32 \%)$ in marine water samples (Kolowith et al. 2001). It is likely that the larger the volume of extractant used for the filters increased total P recovery of PP relative to DP. It is possible that the EDTA was saturated with cations with the 
smaller volume of extractant used for DP, limiting the recovery of DP and Ca. Although the total $\mathrm{P}$ was not recovered from either PP or DP, the extracted $\mathrm{P}$ is expected to be representative of all the P forms in the sample, with no selected extraction (Paytan et al. 2003).

\subsubsection{Particulate P Forms in Floodwaters}

Previous research in AL floodplain forests has suggested that one mechanism for P retention involves sedimentation or the precipitation of suspended material (primarily POP and PIP adsorbed to mineral sediments) from the water column (Kleiss 1996, Craft and Casey 2000, Hupp et al. 2005, Benitez-Nelson et al. 2007, Brunet and Astin 2008). I had hypothesized PP pools to decrease as upstream (RI) floodwaters flowed over the floodplain surface and exited at the downstream (FP) location, suggesting PP removal from the water column by sedimentation, but differences in PP in RI and FP waters were statistically indistinguishable across both AL and BW systems. ANOVA results of differences in TPP concentrations between RI and FP waters across FFs did not show significant differences by floodplain type (AL and BW systems), location (RI and FP), or the interaction term (floodplain type $\times$ RI/FP location) (Appendix Table

2.1 c). The same was true for the proportion of total $P$ in colloidal form, which did not differ by floodplain type $(F=0.105, p=0.756), \mathrm{RI} / \mathrm{FP}$ location $(F=0.207, p=0.665)$, or an interaction between the two factors $(F=2.990, p=0.134)$. Additionally, the sum of NMR-visible PIP and POP pools did not differ between sampling locations (RI versus FP) within FFs, or across AL and BW floodplain systems (Appendix Table 2.1 c). These observations are consistent with Venterink et al. (2003), who concluded that the flow velocity of a tributary of the river Rhine (Muyzer et al.) in the Netherlands was too high for PP removal compared to the relatively slower 
flow rate of the river Ijssel. The efficiency of PP removal from the water column depends on the contact area between water and soil, the flow velocity of the floodwaters over floodplain surface, and the size of the suspended particles. I collected and analyzed floodwaters at peak discharge onto the FFs, where the flow velocity of floodwaters may have been too high for PP precipitation to occur as floodwaters transited the FFs. In AL floodplains, average PP increased (though not significantly) as RI $\left(52.9 \pm 10.0 \mu \mathrm{g} \mathrm{L}^{-1}\right)$ waters entered the FP $\left(73.9 \pm 18.9 \mu \mathrm{g} \mathrm{L}^{-1}\right)$. This may be typical of rivers with high discharge rates, such as $\mathrm{AL}$ rivers. In contrast, average $\mathrm{PP}$ concentrations showed the opposite trend (i.e., were higher in RI than in FP waters) in BW floodplain forests (Table 2.2 c). Blackwater systems have smaller drainage areas than AL systems, with lower gradient flows that have limited potential to entrain or erode sediments. In tributaries of the Mississippi river, Alexander et al. (2000) found that nutrient retention increased with decreasing water depth. Shallow waters with maximum contact between water and floodplain surface are favorable for sedimentation or the removal PP from the water column (Johnston 1991, Brunet and Astin 1998). Floodwater energy influences the balance between sedimentation (retention) vs. sediment entrainment - the scouring of PP from the FFs surface during peak discharge (peak) or high velocity floodwaters. The time required for processing (filtering and lyophilizing) $10 \mathrm{~L}$ of water per location (within the analytical parameters assigned for P analysis) or the relatively high costs of NMR analysis on extracts limits the number of floodwater samples that can be collected and analyzed throughout the duration of the flooding events. Measuring fluxes in P pools over the course of the flooding events or the hydroperiod on the floodplain, particularly during the falling limb of the flood stage height when floodwater velocity is relatively slower, may capture higher amounts of precipitating PP adsorbed to suspended mineral sediments (Noe and Hupp 2007, 2009). Finally, differences between 
dissolved and particulate $\mathrm{P}$ fractions were assessed at each location within each FF to determine the origin of NMR-visible P forms. The ANOVA results of the differences in dissolved and particulate pyrophosphate at each sampling location were statistically significant and higher in FP $(3.7 \pm 1.7 \%)$ than in RI $(-2.8 \pm 1.4 \%)$ waters $(\mathrm{RI} / \mathrm{FP}$ location effect: $F=15.284, p=0.008)$ at both AL and BW floodplain types (data not shown). Similarly, differences in dissolved and particulate phytate was significantly higher in FP $(0.8 \pm 2.3 \%)$ compared to RI $(-3.7 \pm 1.8 \%)$ waters (RI/FP location effect: $F=9.230, p=0.023)$ at both floodplain forest types. Higher dissolved pyrophosphate and phytate content in FP waters may indicate that these compounds are either transported from terrestrial material (phytate) or formed by aquatic organisms (pyrophosphate).

Overall, a significant decrease in total DIP pools and a concurrent increase in DOP forms in inflow (RI) versus outflow (FP) waters suggest increased biogeochemical reactivity of DIP in the floodplain. Higher total DIP concentrations in floodwaters entering the floodplain, along with the net increase in biogenic DOP forms in outflow waters, is consistent with the theory that floodplain forests regulate river water nutrient concentrations through the biotic transformation of nutrients during flooding events (Brunet and Astin, 1998; Lockaby and Walbridge 1998). 


\subsection{CONCLUSIONS}

Solution ${ }^{31} \mathrm{P}-\mathrm{NMR}$ spectroscopy is routinely used to identify $\mathrm{P}$ forms in soils and sediments, including orthophosphate monoesters, orthophosphate diesters, phosphonates, polyphosphates and pyrophosphates. However, only a few have been conducted for freshwaters (Nanny and Minear 1994, 1997, Selig et al. 2002, Cade-Menun et al. 2006). This study demonstrates the feasibility of ${ }^{31} \mathrm{P}-\mathrm{NMR}$ as a method for characterizing and quantifying forms of inorganic and organic $\mathrm{P}$ in freshwater samples, and that readily available orthophosphate is converted to less available organic $\mathrm{P}$ forms in floodwaters, suggesting biological transformation of inorganic $\mathrm{P}$ to organic P in FF ecosystems. Although the conceptual model of FFs is that they reduce TP concetrations from riverine inputs, some floodplains exhibit the opposite trend and are sources of TP (and/or DIP or MRP) (Bonetto et al. 1994, Villar et al. 1998, Carlyle and Hill 2001, Noe and Hupp 2007, Tian and Zhou 2007, Loeb et al. 2008). In this study, TP concentrations were similar in both floodplain types, and although I had expected (in my first hypothesis) TP to decrease in RI vs FP waters, results support the alternative hypothesis where TP (the sum of DP and $\mathrm{PP}$ ) pools were neither an overall sink nor source from $\mathrm{AL}$ and $\mathrm{BW}$ floodplains.

Although TDP did not differ between RI and FP locations in the BW systems, there was a significant decrease in TDP in FP $\left(10.8 \pm 2.7 \mu \mathrm{g} \mathrm{L}^{-1}\right)$ compared to RI $\left(22.8 \pm 5.4 \mu \mathrm{g} \mathrm{L}^{-1}\right)$ waters (Table 2.2 a) in the AL systems (Appendix Table 2.1 a and Figure 2.6 a). In AL systems that are characteristically larger in drainage area compared to BW floodplains, TDP inputs decreased as river waters entered the floodplain during flooding events, contributing to an average $53 \%$ reduction in river TDP load. Alluvial FFs were net sinks for reactive DIP forms (retaining $21 \%$ 
of total floodwater DIP inputs). The increase in DOC and dissolved Al content, and the accompanied decrease in DIP forms, may suggest $\mathrm{OM}$ - metal (Al, Fe) - P complexation as one possible mechanism of inorganic P removal from the water column.

During flooding events, AL and BW floodplains transform 21 and $11 \%$ of the sum of NMRvisible DIP forms, respectively. Of these DIP forms, the most readily bioavailable orthophosphate in river waters was transformed at rates of 26 and $17 \%$ within $\mathrm{AL}$ and $\mathrm{BW}$ floodplains, respectively. I had expected (in my second hypothesis) that P pools in river waters flowing into FFs were dominated by inorganic $\mathrm{P}$ forms, while the $\mathrm{P}$ in outflow waters was predominantly organic P. This conversion of DIP forms (e.g. orthophosphate) to dissolved condensed inorganic P forms (pyrophosphates) and low molecular weight DOP compounds (e.g. orthophosphate monoesters) suggests biological $\mathrm{P}$ transformation, a second important process occurring during flooding events, and likely leads to less available P forms downstream of these FFs.

In my third hypothesis, I expected AL rivers that carry higher sediment loads, to retain larger amounts of PP within the floodplain, but in both AL and BW systems, PP in RI and FP waters, and the sum of NMR-visible PIP and POP pools in these waters did not differ significantly between sampling locations. Because samples were collected during peak flood discharge, flow velocities may have been too high for PP precipitation to occur. Additional measurements over the course of a flooding event, as floodwater velocity declines, might capture larger amounts of precipitating PP. Nevertheless, NMR results clearly indicate that FFs in the southeastern US 
provide an important ecosystem service, capable of strong $\mathrm{P}$ transformation potential, which underlines the benefits of maintaining these wetlands. This knowledge will be critical to assessing the sustainability of FF ecosystem services, as well as replicating them through wetland creation or restoration. 


\subsection{REFERENCES}

Ahlgren, J., H. De Brabandere, K. Reitzel, E. Rydin, A. Gogoll, and M. Waldeback. 2007. Sediment phosphorus extractants for phosphorus-31 nuclear magnetic resonance analysis: A quantitative evaluation. Journal of Environmental Quality 36:892-898.

Ahlgren, J., K. Reitzel, R. Danielsson, A. Gogoll, and E. Rydin. 2006a. Biogenic phosphorus in oligotrophic mountain lake sediments: Differences in composition measured with NMR spectroscopy. Water Research 40:3705-3712.

Ahlgren, J., K. Reitzel, L. Tranvik, A. Gogoll, and E. Rydin. 2006b. Degradation of organic phosphorus compounds in anoxic Baltic Sea sediments: A P-31 nuclear magnetic resonance study. Limnology and Oceanography 51:2341-2348.

Alexander, R. B., R. A. Smith, and G. E. Schwarz. 2000. Effect of stream channel size on the delivery of nitrogen to the Gulf of Mexico. Nature 403:758-761.

Axt, J. R. and M. R. Walbridge. 1999. Phosphate removal capacity of palustrine forested wetlands and adjacent uplands in Virginia. Soil Science Society of America Journal 63:1019-1031.

Benitez-Nelson, C. R., L. P. O. Madden, R. M. Styles, R. C. Thunell, and Y. Astor. 2007. Inorganic and organic sinking particulate phosphorus fluxes across the oxic/anoxic water column of Cariaco Basin, Venezuela. Marine Chemistry 105:90-100.

Bonetto, C., L. Decabo, N. Gabellone, A. Vinocur, J. Donadelli, and F. Unrein. 1994. Nutrient dynamics in the deltaic floodplain of the Lower Paraná River. Archiv Fūr Hydrobiologie 131:277-295.

Bourke, D., P. Dowding, H. Tunney, J. E. O'Brien, and D. W. Jeffrey. 2008. The organic phosphorus composition of an Irish grassland soil. Biology and Environment-Proceedings of the Royal Irish Academy 108B:17-28.

Brinson, M. M. 1993. Changes in the functioning of wetlands along environmental gradients. Wetlands 13:65-74.

Brinson, M. M., H. D. Bradshaw, and E. S. Kane. 1984. Nutrient assimilative-capacity of an alluvial floodplain swamp. Journal of Applied Ecology 21:1041-1057. 
Brinson, M. M. and R. Rheinhardt. 1996. The role of reference wetlands in functional assessment and mitigation. Ecological Applications 6:69-76.

Bruland, G. L. and C. J. Richardson. 2004. A spatially explicit investigation of phosphorus sorption and related soil properties in two riparian wetlands. Journal of Environmental Quality 33:785-794.

Bruland, G. L. and C. J. Richardson. 2005. Hydrologic, edaphic, and vegetative responses to microtopographic reestablishment in a restored wetland. Restoration Ecology 13:515523.

Brunet, R. C. and K. B. Astin. 1998. Variation in phosphorus flux during a hydrological season: The River Adour. Water Research 32:547-558.

Brunet, R. C. and K. B. Astin. 2000. A 12-month sediment and nutrient budget in a floodplain reach of the River Adour, southwest France. Regulated Rivers-Research \& Management 16:267-277.

Brunet, R. C. and K. B. Astin. 2008. A comparison of sediment deposition in two adjacent floodplains of the River Adour in southwest France. Journal of Environmental Management 88:651-657.

Buenemann, E. K., R. J. Smernik, A. L. Doolette, P. Marschner, R. Stonor, S. A. Wakelin, and A. M. McNeill. 2008. Forms of phosphorus in bacteria and fungi isolated from two Australian soils. Soil Biology \& Biochemistry 40:1908-1915.

Bunemann, E. K., R. J. Smernik, P. Marschner, and A. M. McNeill. 2008. Microbial synthesis of organic and condensed forms of phosphorus in acid and calcareous soils. Soil Biology \& Biochemistry 40:932-946.

Burke, M. K., S. L. King, D. Gartner, and M. H. Eisenbies. 2003. Vegetation, soil, and flooding relationships in a blackwater floodplain forest. Wetlands 23:988-1002.

Cade-Menun, B. J. 2005a. Characterizing phosphorus in environmental and agricultural samples by P-31 nuclear magnetic resonance spectroscopy. Talanta 66:359-371.

Cade-Menun, B. J. 2005b. Using phosphorus-31 nuclear magentic resonance spectroscopy to characterize organic phosphorus in environmental samples. CABI Publishing, New York. 
Cade-Menun, B. J., C. R. Benitez-Nelson, P. Pellechia, and A. Paytan. 2005. Refining P-31 nuclear magnetic resonance spectroscopy for marine particulate samples: Storage conditions and extraction recovery. Marine Chemistry 97:293-306.

Cade-Menun, B. J., S. M. Berch, C. M. Preston, and L. M. Lavkulich. 2000. Phosphorus forms and related soil chemistry of Podzolic soils on northern Vancouver Island. I. A comparison of two forest types. Canadian Journal of Forest Research-Revue Canadienne De Recherche Forestiere 30:1714-1725.

Cade-Menun, B. J., C. W. Liu, R. Nunlist, and J. G. McColl. 2002. Soil and litter phosphorus-31 nuclear magnetic resonance spectroscopy: Extractants, metals, and phosphorus relaxation times. Journal of Environmental Quality 31:457-465.

Cade-Menun, B. J., J. A. Navaratnam, and M. R. Walbridge. 2006. Characterizing dissolved and particulate phosphorus in water with P-31 nuclear magnetic resonance spectroscopy. Environmental Science \& Technology 40:7874-7880.

Cade-Menun, B. J. and C. M. Preston. 1996. A comparison of soil extraction procedures for P-31 NMR spectroscopy. Soil Science 161:770-785.

Cardoso, I. M., P. Van der Meer, O. Oenema, B. H. Janssen, and T. W. Kuyper. 2003a. Analysis of phosphorus by (PNMR)-P-31 in Oxisols under agroforestry and conventional coffee systems in Brazil. Geoderma 112:PII S0016-7061(0002)00293-00298.

Cardoso, I. M., P. Van der Meer, O. Oenema, B. H. Janssen, and T. W. Kuyper. 2003b. Analysis of phosphorus by (PNMR)-P-31 in Oxisols under agroforestry and conventional coffee systems in Brazil. Geoderma 112:51-70.

Carlyle, G. C. and A. R. Hill. 2001. Groundwater phosphate dynamics in a river riparian zone: effects of hydrologic flowpaths, lithology and redox chemistry. Journal of Hydrology 247:151-168.

Carman, R., G. Edlund, and C. Damberg. 2000. Distribution of organic and inorganic phosphorus compounds in marine and lacustrine sediments: a P-31 NMR study. Chemical Geology 163:101-114.

Carpenter, S. R. 2005. Eutrophication of aquatic ecosystems: Bistability and soil phosphorus. Proceedings of the National Academy of Sciences of the United States of America 102:10002-10005. 
Carpenter, S. R., N. F. Caraco, D. L. Correll, R. W. Howarth, A. N. Sharpley, and V. H. Smith. 1998. Nonpoint pollution of surface waters with phosphorus and nitrogen. Ecological Applications 8:559-568.

Cembella, A. D., N. J. Antia, and P. J. Harrison. 1984a. The utilization of inorganic and organic phosphorus-compounds as nutrients by eukaryotic microalgae - A multidisciplinary perspective .1. CRC Critical Reviews in Microbiology 10:317-391.

Cheesman, A. W., B. L. Turner, P. W. Inglett, and K. R. Reddy. 2010. Phosphorus Transformations during Decomposition of Wetland Macrophytes. Environmental Science \& Technology 44:9265-9271.

Cheng, W. P., F. H. Chi, and R. F. Yu. 2004. Effect of phosphate on removal of humic substances by aluminum sulfate coagulant. Journal of Colloid and Interface Science 272:153-157.

Chiu, C. Y., C. W. Pai, and K. L. Yang. 2005. Characterization of phosphorus in sub-alpine forest and adjacent grassland soils by chemical extraction and phosphorus-31 nuclear magnetic resonance spectroscopy. Pedobiologia 49:655-663.

Chu, S. P. 1946. Utilization of organic phosphorus by phytoplankton. Journal of the Marine Biological Association of the UK 26:285.

Clark, L. L., E. D. Ingall, and R. Benner. 1999. Marine organic phosphorus cycling: Novel insights from nuclear magnetic resonance. American Journal of Science 299:724-737.

Cotner, J. B. and R. G. Wetzel. 1992. Uptake of dissolved inorganic and organic phosphoruscompounds by phytoplankton and bacterioplankton. Limnology and Oceanography 37:232-243.

Craft, C. B. and W. P. Casey. 2000. Sediment and nutrient accumulation in floodplain and depressional freshwater wetlands of Georgia, USA. Wetlands 20:323-332.

Darke, A. K. and M. R. Walbridge. 1994. Estimating non-crystalline and crystalline aluminum and iron by selective dissolution in a riparian forest soil. Communications in Soil Science and Plant Analysis 25:2089-2101.

Darke, A. K. and M. R. Walbridge. 2000. Al and Fe biogeochemistry in a floodplain forest: Implications for P retention. Biogeochemistry 51:1-32. 
de Vicente, I., H. S. Jensen, and F. O. Andersen. 2008. Factors affecting phosphate adsorption to aluminum in lake water: Implications for lake restoration. Science of the Total Environment 389:29-36.

Dodds, W. K., W. W. Bouska, J. L. Eitzmann, T. J. Pilger, K. L. Pitts, A. J. Riley, J. T. Schloesser, and D. J. Thornbrugh. 2009. Eutrophication of US Freshwaters: Analysis of Potential Economic Damages. Environmental Science \& Technology 43:12-19.

Doolette, A. L., R. J. Smernika, and W. J. Doughertyb. 2009. Spiking Improved Solution Phosphorus-31 Nuclear Magnetic Resonance Identification of Soil Phosphorus Compounds. Soil Science Society of America Journal 73:919-927.

Dou, Z. X., C. F. Ramberg, J. D. Toth, Y. Wang, A. N. Sharpley, S. E. Boyd, C. R. Chen, D. Williams, and Z. H. Xu. 2009. Phosphorus Speciation and Sorption-Desorption Characteristics in Heavily Manured Soils. Soil Science Society of America Journal 73:93-101.

Dyhrman, S. T., P. D. Chappell, S. T. Haley, J. W. Moffett, E. D. Orchard, J. B. Waterbury, and E. A. Webb. 2006. Phosphonate utilization by the globally important marine diazotroph Trichodesmium. Nature 439:68-71.

Eixler, S., U. Selig, and U. Karsten. 2005. Extraction and detection methods for polyphosphate storage in autotrophic planktonic organisms. Hydrobiologia 533:135-143.

El-Rifai, H., M. Heerboth, T. E. Gedris, S. Newman, W. Orem, and W. T. Cooper. 2008. NMR and mass spectrometry of phosphorus in wetlands. European Journal of Soil Science 59:517-525.

Elder, J. F. 1985. Nitrogen and phosphorus speciation and flux in a large Florida river wetland system. Water Resources Research 21:724-732.

Fernandez, I. E., R. F. Novais, F. N. Nunes, and J. C. Ker. 2008. Reversibility of non-labile phosphorus in soils under microbial and chemical reduction: I - chemical and mineralogical alterations. Revista Brasileira de Ciencia do Solo 32:2307-2317.

Filippelli, G. M. 2008. The global phosphorus cycle: Past, present, and future. Elements 4:89-95.

Fox, E. A. and G. L. Mendz. 2006. Phosphonate degradation in microorganisms. Enzyme and Microbial Technology 40:145-150. 
Gachter, R. and J. S. Meyer. 1993. The role of microorganisms in mobilization and fixation of phosphorus in sediments. Hydrobiologia 253:103-121.

Gerlitz, T. G. M. and A. Gerlitz. 1997. Phosphate uptake and polyphosphate metabolism of mycorrhizal and nonmycorrhizal roots of pine and of Suillus bovinus at varying external pH measured by in vivo P-31-NMR. Mycorrhiza 7:101-106.

Giesler, R., T. Andersson, L. Lovgren, and P. Persson. 2005. Phosphate sorption in aluminumand iron-rich humus soils. Soil Science Society of America Journal 69:77-86.

Guan, X. H., C. Shang, and G. H. Chen. 2006. Competitive adsorption of organic matter with phosphate on aluminum hydroxide. Journal of Colloid and Interface Science 296:51-58.

He, Z. Q., T. Ohno, B. J. Cade-Menun, M. S. Erich, and C. W. Honeycutt. 2006. Spectral and chemical characterization of phosphates associated with humic substances. Soil Science Society of America Journal 70:1741-1751.

Hecky, R. E. and P. Kilham. 1988. Nutrient limitation of phytoplankton in freshwater and marine environments: a review of recent evidence on the effects of enrichment. Limnology and Oceanography 33:796-822.

Hogan, D. M., T. E. Jordan, and M. R. Walbridge. 2004. Phosphorus retention and soil organic carbon in restored and natural freshwater wetlands. Wetlands 24:573-585.

Hogan, D. M. and M. R. Walbridge. 2007. Urbanization and nutrient retention in freshwater riparian wetlands. Ecological Applications 17:1142-1155.

Holliday, V. T. and W. G. Gartner. 2007. Methods of soil P analysis in archaeology. Journal of Archaeological Science 34:301-333.

Howitt, J. A., D. S. Baldwin, G. N. Rees, and J. L. Williams. 2007. Modelling blackwater: Predicting water quality during flooding of lowland river forests. Ecological Modelling 203:229-242.

Hupfer, M., B. Rube, and P. Schmieder. 2004. Origin and diagenesis of polyphosphate in lake sediments: A P-31-NMR study. Limnology and Oceanography 49:1-10.

Hupp, C. R., M. R. Walbridge, and B. G. Lockaby. 2005. Fluvial geomorphic processes and 
landforms, water quality, and nutrients in Bottomland Hardwood Forests of southeastern USA. Pages 37-55 in L. H. Fredrickson, S. L. King, and R. M. Kaminski, editors. Ecology and Management of Bottomland Hardwood Systems. University of Missouri, Puxico, MO.

Jensen, H. S., N. Caraco, J. Hansen, and K. K. Christensen. 2005. Humic-bound phosphorus in soil and sediment. Pages 99-107 in H. L. Golterman and L. Serrano, editors. Phosphate in Sediments. Backhuys Publishers, Leiden.

Johnston, C. A. 1991. Sediment and nutrient retention by freshwater wetlands: Effects on surface water quality. Critical Reviews in Environmental Control 21:491-565.

Khoshmanesh, A., B. T. Hart, A. Duncan, and R. Beckett. 1999. Biotic uptake and release of phosphorus by a wetland sediment. Environmental Technology 20:85-91.

Kleeberg, A., M. Hupfer, and G. Gust. 2007. Phosphorus entrainment due to resuspension in a lowland river, spree, NE Germany - A laboratory microcosm study. Water Air and Soil Pollution 183:129-142.

Kleeberg, A. and G. Schlungbaum. 1993. In situ phosphorus release experiments in the Warnow River (Mecklenburg, northern Germany). Hydrobiologia 253:263-274.

Kleiss, B. A. 1996. Sediment retention in a bottomland hardwood wetland in Eastern Arkansas. Wetlands 16:321-333.

Kolowith, L. C., E. D. Ingall, and R. Benner. 2001. Composition and cycling of marine organic phosphorus. Limnology and Oceanography 46:309-320.

Kononova, S. V. and M. A. Nesmeyanova. 2002. Phosphonates and their degradation by microorganisms. Biochemistry-Moscow 67:184-195.

Kornberg, A., N. N. Rao, and D. Ault-Riche. 1999. Inorganic polyphosphate: A molecule of many functions. Annual Review of Biochemistry 68:89-125.

Kotak, B. G., S. L. Kenefick, D. L. Fritz, C. G. Rousseaux, E. E. Prepas, and S. E. Hrudey. 1993. Occurrence and toxicological evaluation of cyanobacterial toxins in Alberta lakes and farm dugouts. Water Research 27:495-506. 
Koukol, O., F. Novak, and R. Hrabal. 2008. Composition of the organic phosphorus fraction in basidiocarps of saprotrophic and mycorrhizal fungi. Soil Biology \& Biochemistry 40:2464-2467.

Krah, M., T. S. McCarthy, P. Huntsman-Mapila, P. Wolski, H. Annegarn, and K. Sethebe. 2006. Nutrient budget in the seasonal wetland of the Okavango Delta, Botswana. Wetlands Ecology and Management 14:253-267.

Kutuzova, R. S., N. I. Vorob'ev, M. V. Gamova, L. A. Popova, and Y. V. Kruglov. 2009. Microbiological characterization of soddy soils of the Severnaya Dvina River floodplain. Eurasian Soil Science 42:225-234.

Lee, D., X. G. Han, and C. F. Jordan. 1990. Soil-phosphorus fractions, aluminum, and waterretention as affected by microbial activity in an ultisol. Plant and Soil 121:125-136.

Liu, J. Y., H. Wang, H. J. Yang, Y. J. Ma, and O. C. Cai. 2009. Detection of phosphorus species in sediments of artificial landscape lakes in China by fractionation and phosphorus-31 nuclear magnetic resonance spectroscopy. Environmental Pollution 157:49-56.

Liu, Y., G. Villalba, R. U. Ayres, and H. Schroder. 2008. Global phosphorus flows and environmental impacts from a consumption perspective. Journal of Industrial Ecology 12:229-247.

Lockaby, B. G. and M. R. Walbridge. 1998. Biogeochemistry. Pages 149-172 in M. G. Messina and W. H. Conner, editors. Southern Forested Wetlands: Ecology and Management. Lewis Publishers, Boca Raton, FL, USA.

Loeb, R., L. P. M. Lamers, and J. G. M. Roelofs. 2008. Prediction of phosphorus mobilisation in inundated floodplain soils. Environmental Pollution 156:325-331.

Lovdal, T., T. Tanaka, and T. F. Thingstad. 2007. Algal-bacterial competition for phosphorus from dissolved DNA, ATP, and orthophosphate in a mesocosm experiment. Limnology and Oceanography 52:1407-1419.

Magid, J., H. Tiessen, and L. M. Condron. 1996. Dynamics of organic phosphorus in soils under natural and agriculture ecosystems Pages 429-466 in A. Piccolo, editor. Humic substances in terrestrial ecosystems. Elsevier, Amsterdam.

Makarov, M. I. 1998. Organic phosphorus compounds in alpine soils of the northwestern 
Caucasus. Eurasian Soil Science 31:778-786.

Makarov, M. I., L. Haumaier, W. Zech, O. E. Marfenina, and L. V. Lysak. 2005. Can P-31 NMR spectroscopy be used to indicate the origins of soil organic phosphates? Soil Biology \& Biochemistry 37:15-25.

Matson, P. A., W. J. Parton, A. G. Power, and M. J. Swift. 1997. Agricultural intensification and ecosystem properties. Science 277:504-509.

McDowell, R. W., B. Cade-Menun, and I. Stewart. 2007a. Organic phosphorus speciation and pedogenesis: analysis by solution P-31 nuclear magnetic resonance spectroscopy. European Journal of Soil Science 58:1348-1357.

McDowell, R. W., B. Cade-Menun, and I. Stewart. 2007b. Organic phosphorus speciation and pedogenesis: Analysis by solution P-31 nuclear magnetic resonance spectroscopy. European Journal of Soil Science 58:1348-1357.

McDowell, R. W. and G. F. Koopmans. 2006. Assessing the bioavailability of dissolved organic phosphorus in pasture and cultivated soils treated with different rates of nitrogen fertiliser. Soil Biology \& Biochemistry 38:61-70.

McKelvie, I. D., D. M. W. Peat, and P. J. Worsfold. 1995. Techniques for the quantification and speciation of phosphorus in natural waters. Analytical Proceedings 32:437-445.

Minear, R. A. 1972. Characterization of naturally occurring dissolved organophosphorus compounds. Environmental Science and Technology 6:431-437.

Mitsch, W. J., C. L. Dorge, and J. R. Wiemhoff. 1979. Ecosystem dynamics and a phosphorus budget of an Alluvial cypress swamp in Southern Illinois. Ecology 60:1116-1124.

Mitsch, W. J. and J. G. Gosselink. 2007. Wetlands. 4th edition. John Wiley \& Sons, New York.

Murphy, J. and J. P. Riley. 1962. A modified single solution method for determination of phosphate in natural waters. Analytica Chimica Acta 27:31-36.

Muyzer, G., E. C. Dewaal, and A. G. Uitterlinden. 1993. Profiling of complex microbialpopulations by denaturing gradient gel-electrophoresis: Analysis of polymerase chain reaction amplified genes-coding for $16 \mathrm{~S}$ ribosomal-RNA. Applied and Environmental 
Microbiology 59:695-700.

Nanny, M. A. and R. A. Minear. 1994. Use of lanthanide shift reagents with 31P FT-NMR spectroscopy to analyze concentrated lake-water samples. Environmental Science \& Technology 28:1521-1527.

Nanny, M. A. and R. A. Minear. 1997. Characterization of soluble unreactive phosphorus using P-31 nuclear magnetic resonance spectroscopy. Marine Geology 18:77-94.

Neatrour, M. A., J. R. Webster, and E. E. Benfield. 2004. The role of floods in particulate organic matter dynamics of a southern Appalachian river-floodplain ecosystem. Journal of the North American Benthological Society 23:198-213.

Newman, R. H. and K. R. Tate. 1980. Soil-phosphorus characterization by P-31 nuclear magnetic-resonance. Communications in Soil Science and Plant Analysis 11:835-842.

Noe, G. B. and C. R. Hupp. 2005. Carbon, nitrogen, and phosphorus accumulation in floodplains of Atlantic Coastal Plain rivers, USA. Ecological Applications 15:1178-1190.

Noe, G. B. and C. R. Hupp. 2007. Seasonal variation in nutrient retention during inundation of a short-hydroperiod floodplain. River Research and Applications 23:1088-1101.

Noe, G. B. and C. R. Hupp. 2009. Retention of Riverine Sediment and Nutrient Loads by Coastal Plain Floodplains. Ecosystems 12:728-746.

Novak, J. M. and D. W. Watts. 2006. Phosphorus sorption by sediments in a southeastern coastal plain in-stream wetland. Journal of Environmental Quality 35:1975-1982.

Oh, S. J., T. Yamamoto, Y. Kataoka, O. Matsuda, Y. Matsuyama, and Y. Kotani. 2002. Utilization of dissolved organic phosphorus by the two toxic dinoflagellates, Alexandrium tamarense and Gymnodinium catenatum (Dinophyceae). Fisheries Science 68:416-424.

Pant, H. K., K. R. Reddy, and F. E. Dierberg. 2002. Bioavailability of organic phosphorus in a submerged aquatic vegetation-dominated treatment wetland. Journal of Environmental Quality 31:1748-1756.

Parkinson, J. A. and S. E. Allen. 1975. A wet oxidation procedure suitable for the determination 
of nitrogen and mineral nutrients in biological material. Communications in Soil Science and Plant Analysis 6:1-11.

Paytan, A., B. J. Cade-Menun, K. McLaughlin, and K. L. Faul. 2003. Selective phosphorus regeneration of sinking marine particles: evidence from P-31-NMR. Marine Chemistry 82:55-70.

Qualls, R. G. and C. J. Richardson. 2000. Phosphorus enrichment affects litter decomposition, immobilization, and soil microbial phosphorus in wetland mesocosms. Soil Science Society of America Journal 64:799-808.

Quiquampoix, H. and D. Mousain. 2005. Enzymatic hydrolysis of organic phosphorus. Pages 89112 in B. L. Turner, E. Frossard, and D. S. Baldwin, editors. Organic phosphorus in the environment. CABI Publ., Cambridge.

Reddy, K. R., R. H. Kadlec, E. Flaig, and P. M. Gale. 1999. Phosphorus retention in streams and wetlands: A review. Critical Reviews in Environmental Science and Technology 29:83146.

Reitzel, K., J. Ahlgren, A. Gogoll, H. S. Jensen, and E. Rydin. 2006. Characterization of phosphorus in sequential extracts from lake sediments using P-31 nuclear magnetic resonance spectroscopy. Canadian Journal of Fisheries and Aquatic Sciences 63:16861699.

Richardson, C. J. 1989. Freshwater wetlands: Transformers, filters or sinks? Pages 25-46 in Freshwater Wetlands and Wildlife. Conf-8603101. DOE Symposium Series NO. 61, U.S. DOE. Oak Ridge, TN.

Richardson, C. J., M. R. Walbridge, and A. Burns. 1988. Soil chemistry and phosphorus retention capacity of North Carolina coastal plain swamps receiving sewage effluent., Water Resources Research Institute of the University of North Carolina, Raleigh, NC.

Schindler, D. W. 1978. Factors regulating phytoplankton production and standing crop in the world's freshwaters. Limnology and Oceanography 23:478-486.

Schoch, C. L., P. W. Crous, J. Z. Groenewald, E. W. A. Boehm, T. I. Burgess, J. de Gruyter, G. S. de Hoog, L. J. Dixon, M. Grube, C. Gueidan, Y. Harada, S. Hatakeyama, K. Hirayama, T. Hosoya, S. M. Huhndorf, K. D. Hyde, E. B. G. Jones, J. Kohlmeyer, A. Kruys, Y. M. Li, R. Lucking, H. T. Lumbsch, L. Marvanova, J. S. Mbatchou, A. H. McVay, A. N. Miller, G. K. Mugambi, L. Muggia, M. P. Nelsen, P. Nelson, C. A. Owensby, A. J. L. 
Phillips, S. Phongpaichit, S. B. Pointing, V. Pujade-Renaud, H. A. Raja, E. R. Plata, B. Robbertse, C. Ruibal, J. Sakayaroj, T. Sano, L. Selbmann, C. A. Shearer, T. Shirouzu, B. Slippers, S. Suetrong, K. Tanaka, B. Volkmann-Kohlmeyer, M. J. Wingfield, A. R. Wood, J. H. C. Woudenberg, H. Yonezawa, Y. Zhang, and J. W. Spatafora. 2009. A class-wide phylogenetic assessment of Dothideomycetes. Studies in Mycology:1-15.

Selig, U., T. Hubener, and M. Michalik. 2002. Dissolved and particulate phosphorus forms in a eutrophic shallow lake. Aquatic Sciences 64:97-105.

Sterner, R. W. 2008. On the phosphorus limitation paradigm for lakes. International Review of Hydrobiology 93:433-445.

Stoeckel, D. M. and M. S. Miller-Goodman. 2001. Seasonal nutrient dynamics of forested floodplain soil influenced by microtopography and depth. Soil Science Society of America Journal 65:922-931.

Sundareshwar, P. V., J. T. Morris, P. J. Pellechia, H. J. Cohen, D. E. Porter, and B. C. Jones. 2001. Occurrence and ecological implications of pyrophosphate in estuaries. Limnology and Oceanography 46:1570-1577.

Suzumura, M. and A. Kamatani. 1995. Mineralization of inositol hexaphosphate in aerobic and anaerobic marine sediments: Implications for the phosphorus cycle. Geochimica et Cosmochimica Acta 59:1021-1026.

Tian, J., L. Liu, H.-s. Ding, and T. Chen. 2008. Mobilization and transformation of phosphorus from water-soil interface of flooded soil. Huanjing Kexue 29:1818-1823.

Tian, J. R. and P. J. Zhou. 2007. Phosphorus fractions of floodplain sediments and phosphorus exchange on the sediment-water interface in the lower reaches of the Han River in China. Ecological Engineering 30:264-270.

Toor, G. S., L. M. Condron, B. J. Cade-Menun, H. J. Di, and K. C. Cameron. 2005. Preferential phosphorus leaching from an irrigated grassland soil. European Journal of Soil Science 56:155-167.

Turner, B. L., R. Baxter, N. Mahieu, S. Sjogersten, and B. A. Whitton. 2004. Phosphorus compounds in subarctic Fennoscandian soils at the mountain birch, (Betula pubescens) tundra ecotone. Soil Biology \& Biochemistry 36:815-823. 
Turner, B. L., B. J. Cade-Menun, L. M. Condron, and S. Newman. 2005a. Extraction of soil organic phosphorus. Talanta 66:294-306.

Turner, B. L., B. J. Cade-Menun, and D. T. Westermann. 2003a. Organic phosphorus composition and potential bioavailability in semi-arid arable soils of the western United States. Soil Science Society of America Journal 67:1168-1179.

Turner, B. L., J. A. Chudek, B. A. Whitton, and R. Baxter. 2003b. Phosphorus composition of upland soils polluted by long-term atmospheric nitrogen deposition. Biogeochemistry 65:259-274.

Turner, B. L., J. P. Driessen, P. M. Haygarth, and I. D. McKelvie. 2003c. Potential contribution of lysed bacterial cells to phosphorus solubilisation in two rewetted Australian pasture soils. Soil Biology \& Biochemistry 35:187-189.

Turner, B. L., E. Frossard, and D. S. Baldwin. 2005b. Organic phosphorus in the environment. CABI Publ., Wallingford, UK.

Turner, B. L. and S. Newman. 2005. Phosphorus cycling in wetland soils: The importance of phosphate diesters. Journal of Environmental Quality 34:1921-1929.

Turner, B. L., M. J. Paphazy, P. M. Haygarth, and I. D. McKelvie. 2002. Inositol phosphates in the environment. Philosophical Transactions of the Royal Society of London Series BBiological Sciences 357:449-469.

Turner, B. L. and A. E. Richardson. 2004. Identification of scyllo-inositol phosphates in soil by solution phosphorus-31 nuclear magnetic resonance spectroscopy. Soil Science Society of America Journal 68:802-808.

Turner, B. L. and K. Weckström. 2008. Phytate as a novel phosphorus-specific paleo-indicator in aquatic sediments. Journal of Paleolimnology 42:391-400.

Valett, H. M., M. A. Baker, J. A. Morrice, C. S. Crawford, M. C. Molles, C. N. Dahm, D. L. Moyer, J. R. Thibault, and L. M. Ellis. 2005. Biogeochemical and metabolic responses to the flood pulse in a semiarid floodplain. Ecology 86:220-234.

Van Der Lee, G. E. M., H. O. Venterink, and N. E. M. Asselman. 2004. Nutrient retention in floodplains of the Rhine distributaries in The Netherlands. River Research and Applications 20:315-325. 
Venterink, H. O., F. Wiegman, G. E. M. Van der Lee, and J. E. Vermaat. 2003. Role of active floodplains for nutrient retention in the river Rhine. Journal of Environmental Quality 32:1430-1435.

Villar, C. A., L. de Cabo, P. Vaithiyanathan, and C. Bonetto. 1998. River-floodplain interactions: nutrient concentrations in the Lower Parana River. Archiv Für Hydrobiologie 142:433450 .

Walbridge, M. R. 1993. Functions and values of forested wetlands in the southern United-States. Journal of Forestry 91:15-19.

Walbridge, M. R. and J. P. Struthers. 1993. Phosphorus retention in non-tidal palustrine forested wetlands of the mid-Atlantic region. Wetlands 13:84-94.

Watts, E. E., P. A. W. Dean, and R. R. Martin. 2002. P-31 Nuclear Magnetic Resonance study of sediment microbial phospholipids. Canadian Journal of Analytical Sciences and Spectroscopy 47:127-133.

Weilhoefer, C. L., Y. D. Pan, and S. Eppard. 2008. The effects of river floodwaters on floodplain wetland water quality and diatom assemblages. Wetlands 28:473-486.

Wharton, C. H. and M. M. Brinson. 1979. Characteristics of southeastern river systems. Pages 32-40 in R. R. Johnson and J. F. McCormick, editors. Strategies for protection and management of floodplain wetlands and other riparian ecosystems. USDA Forest Service, Washington, DC.

Withers, P. J. A. and H. P. Jarvie. 2008. Delivery and cycling of phosphorus in rivers: A review. Science of the Total Environment 400:379-395.

Worsfold, P. J., P. Monbet, A. D. Tappin, M. F. Fitzsimons, D. A. Stiles, and I. D. McKelvie. 2008. Characterisation and quantification of organic phosphorus and organic nitrogen components in aquatic systems: A review. Analytica Chimica Acta 624:37-58.

Wright, A. L., R. W. Weaver, and J. W. Webb. 1996. Concentrations of N and P in floodwater and uptake of N-15 by Spartina alterniflora in oil contaminated mesocosms. Bioresource Technology 56:257-264.

Wright, R. B., B. G. Lockaby, and M. R. Walbridge. 2001. Phosphorus availability in an 
artificially flooded southeastern floodplain forest soil. Soil Science Society of America Journal 65:1293-1302.

Yarbro, L. A. 1983. The influence of hydrologic variations on phosphorus cycling and retention in a swamp stream ecosystem. Pages 223-245 in T. D. Fontaine and S. M. Bartell, editors. Dynamics of Lotic Ecosystems. Ann Arbor Science, Ann Arbor, MI.

Zhang, R. Y., F. C. Wu, Z. Q. He, J. A. Zheng, B. A. Song, and L. H. Jin. 2009. Phosphorus composition in sediments from seven different trophic lakes, China: A phosphorus-31 NMR study. Journal of Environmental Quality 38:353-359. 
Figure 2.1: Operationally defined $P$ forms in freshwater aquatic systems. Figure adapted from (Worsfold et al. 2008). 


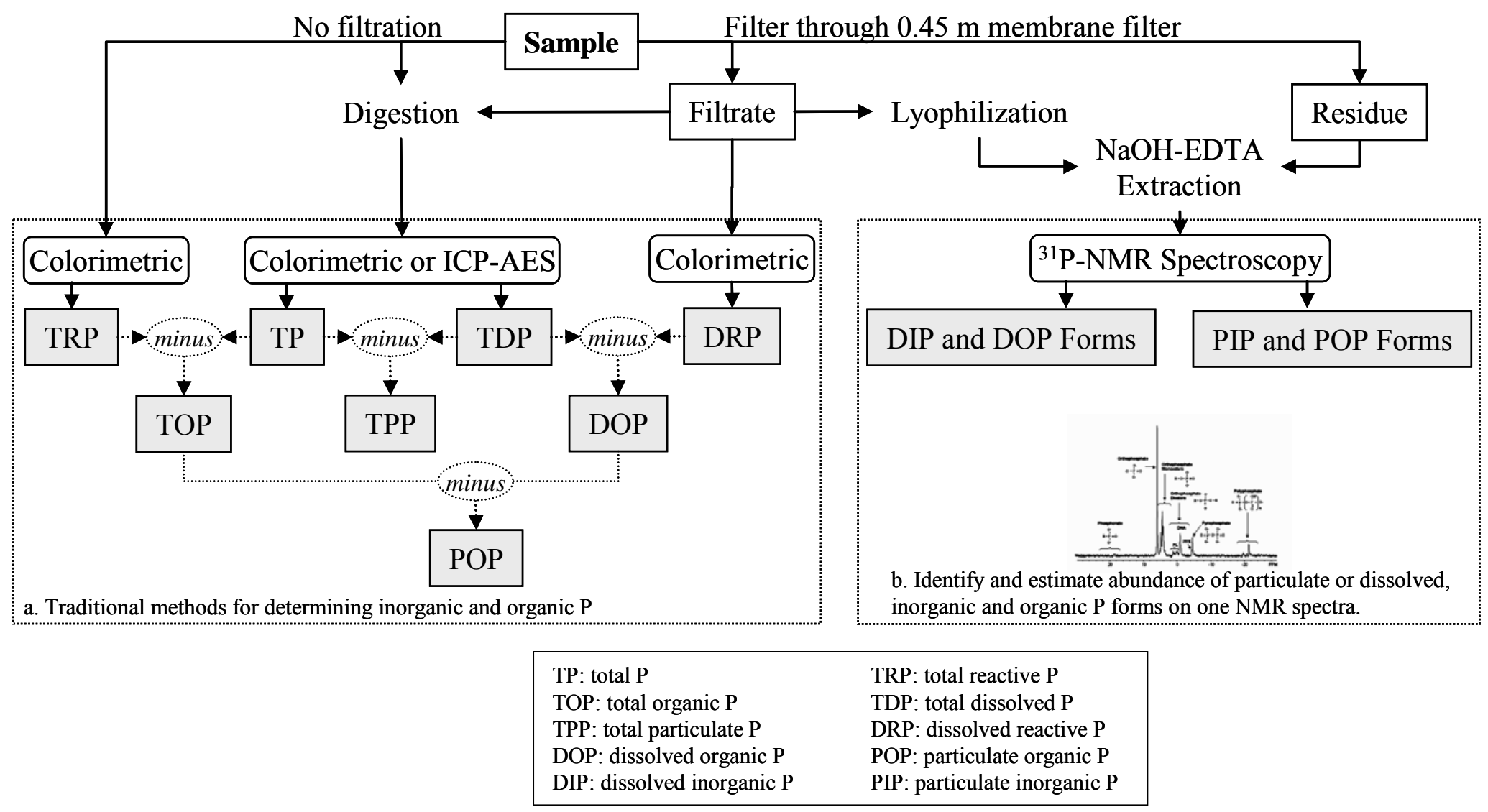


Figure 2.2: Examples and structures of ${ }^{31} \mathrm{P}-\mathrm{NMR}$ resolved inorganic and organic $\mathrm{P}$ forms. Figure adapted from (Cade-Menun 2005a, Worsfold et al. 2008) . 


\begin{tabular}{|c|c|c|}
\hline $\begin{array}{c}\text { Name } \\
\text { (abbreviation) }\end{array}$ & General Structure & Examples \\
\hline $\begin{array}{l}\text { a. } \\
\text { Orthophosphate } \\
(\text { Ortho }-\mathrm{P})\end{array}$ & 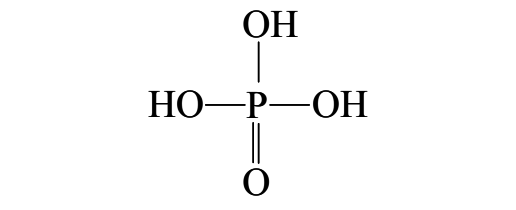 & \\
\hline $\begin{array}{l}\text { b. } \\
\text { Pyrophosphate } \\
(\text { Pyro - P) }\end{array}$ & 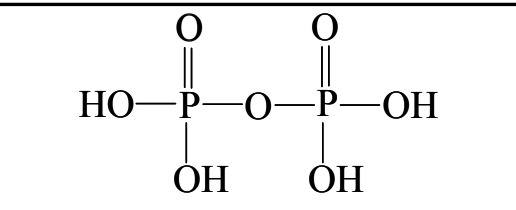 & \\
\hline $\begin{array}{l}\text { c. } \\
\text { Inorganic } \\
\text { Polyphosphates } \\
(\text { Poly }-\mathrm{P})\end{array}$ & 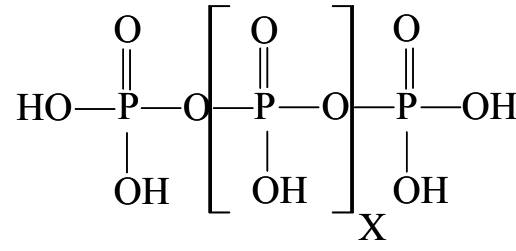 & $\begin{array}{l}\text { Organic polyphosphates such as } \\
\text { Adenosine 5-phosphate } \\
\left(\mathrm{C}_{10} \mathrm{H}_{16} \mathrm{~N}_{5} \mathrm{O}_{13} \mathrm{P}_{3}\right) \text { may also occur }\end{array}$ \\
\hline $\begin{array}{l}\text { d. } \\
\text { Orthophosphate } \\
\text { monoesters } \\
(\text { Mono - P) }\end{array}$ & 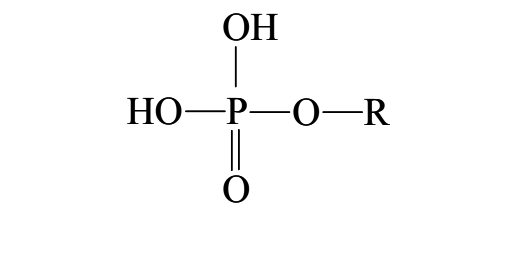 & $\underbrace{\mathrm{H}_{2} \mathrm{O}_{3} \mathrm{PO}}_{\substack{\mathrm{OPO}_{3} \mathrm{H}_{2} \\
\text { Phytate }}}$ \\
\hline $\begin{array}{l}\text { e. } \\
\text { Orthophosphate } \\
\text { diesters } \\
\text { (Diester }-\mathrm{P})\end{array}$ & 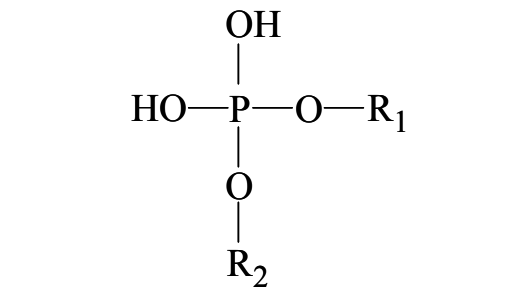 & $\begin{array}{l}\text { Deoxyribonucleic acid (DNA) } \\
\qquad\left(\mathrm{C}_{2} \mathrm{H}_{8} \mathrm{NO}_{4} \mathrm{P}\right)\end{array}$ \\
\hline Phosphonates & 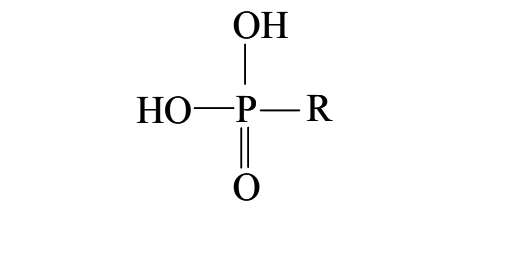 & $\begin{array}{c}\mathrm{HO}-\left.\right|_{\mathrm{O}} ^{\mathrm{P}}-\mathrm{CH}_{2}-\mathrm{CH}_{2}-\mathrm{H}_{2} \mathrm{~N} \\
\text { 2-Aminoethyl phosphoric acid }\end{array}$ \\
\hline
\end{tabular}


Figure 2.3: Solution ${ }^{31} \mathrm{P}$ nuclear magnetic resonance spectra of water samples collected in an alluvial system at the Pee Dee River, SC. Panels represent: a, particulate P forms and; b, dissolved $\mathrm{P}$ forms in water samples collected from the floodplain; c, particulate $\mathrm{P}$ forms and; d, dissolved $\mathrm{P}$ forms in water samples collected from the river inlet. Spectra were

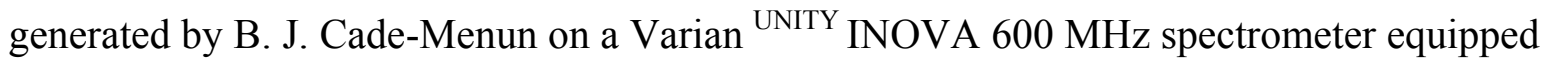
with a $10-\mathrm{mm}$ broadband probe. Parameters were: temperature of $20^{\circ} \mathrm{C}$; using a $90^{\circ}$ pulse; $0.68 \mathrm{~s}$ acquisition time; $4.32 \mathrm{~s}$ relaxation delay; $12 \mathrm{~Hz}$ spinning; and an external $\mathrm{H}_{3} \mathrm{PO}_{4}$ standard, collecting 5800 scans for particulate and 8500 scans for dissolved P samples. 


\section{Alluvial system; Pee Dee River, SC}

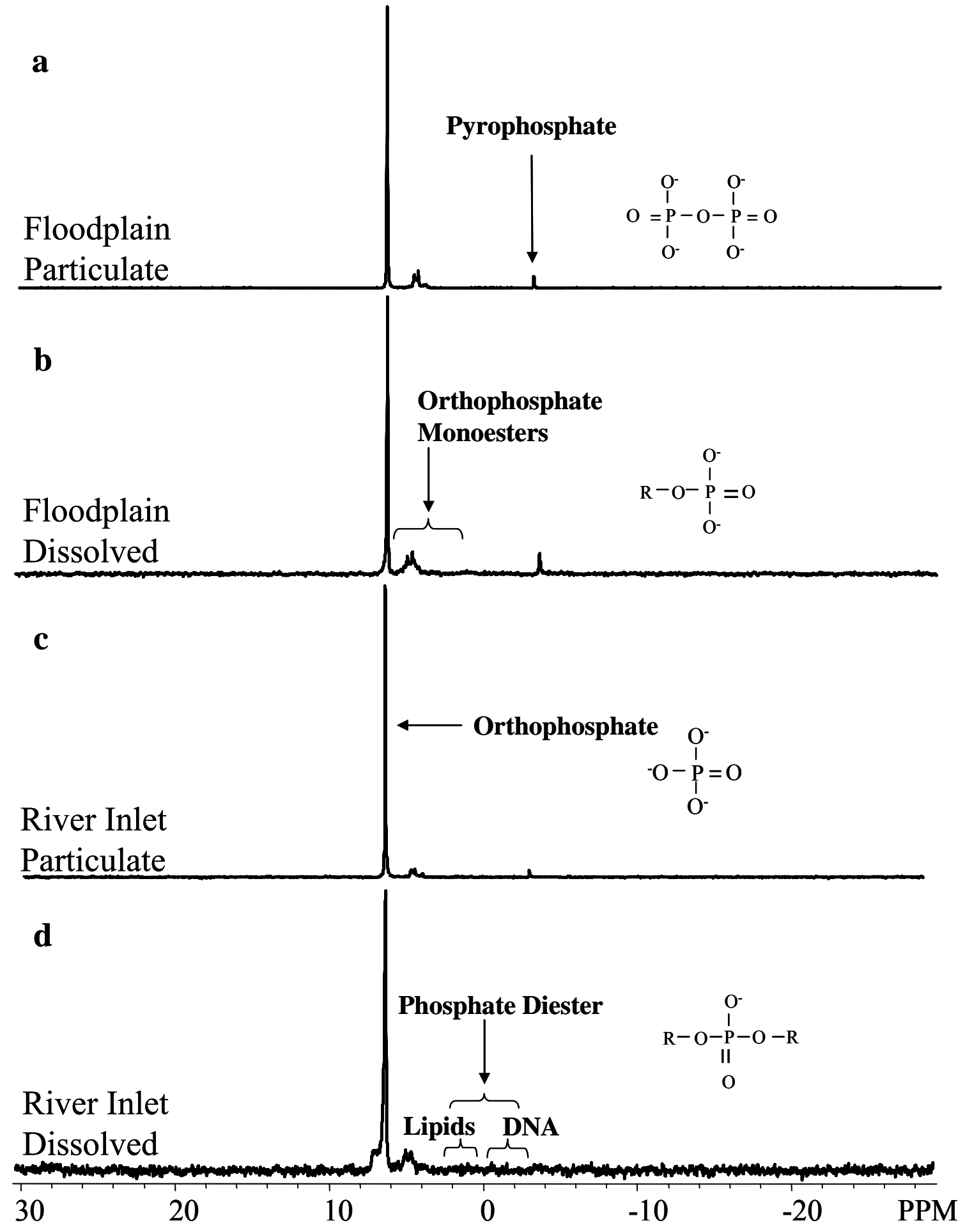


Figure 2.4: Solution ${ }^{31} \mathrm{P}$ nuclear magnetic resonance spectra of water samples collected in a blackwater system at the Blackwater River, NC. Panels represent: a, particulate P forms and; $\mathbf{b}$, dissolved $\mathrm{P}$ forms in water samples collected from the floodplain; $\mathbf{c}$, particulate $\mathrm{P}$ forms and; d, dissolved $\mathrm{P}$ forms in water samples collected from the river inlet. Spectra

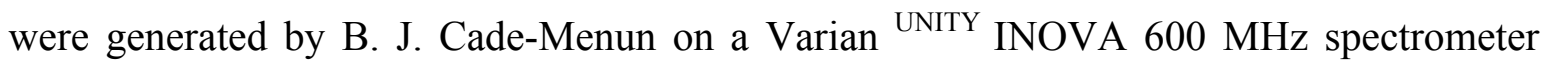
equipped with a $10-\mathrm{mm}$ broadband probe. Parameters were: temperature of $20^{\circ} \mathrm{C}$; using a $90^{\circ}$ pulse; $0.68 \mathrm{~s}$ acquisition time; $4.32 \mathrm{~s}$ relaxation delay; $12 \mathrm{~Hz}$ spinning; and an external $\mathrm{H}_{3} \mathrm{PO}_{4}$ standard, collecting 5800 scans for particulate and 8500 scans for dissolved $\mathrm{P}$ samples. 


\section{Blackwater system; Black River, NC}

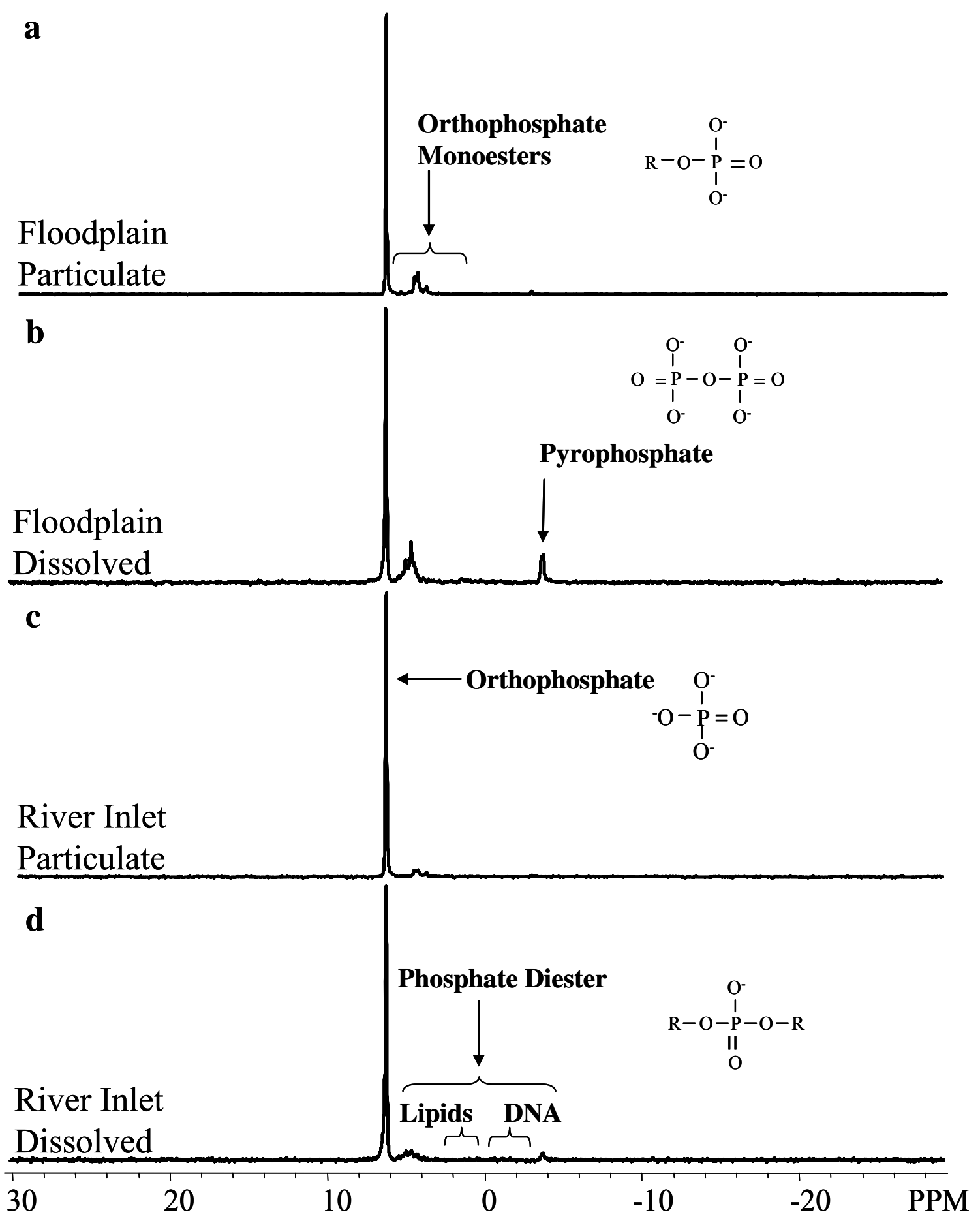


Figure 2.5: Solution ${ }^{31} \mathrm{P}$ nuclear magnetic resonance spectra of a water sample collected at the Satilla River, GA with the identified particulate $\mathrm{P}$ forms (from $\mathrm{L}$ to R): Orthophosphate, orthophosphate monoesters (phytate, glycerophosphate (GP), scyllo-inositol phosphate), orthophosphate diesters (including DNA), and inorganic pyrophosphate. Spectra were generated by B. J. Cade-Menun on a Varian UNITY INOVA $600 \mathrm{MHz}$ spectrometer equipped with a 10-mm broadband probe. Parameters were: temperature of $20^{\circ} \mathrm{C}$; using a $90^{\circ}$ pulse; $0.68 \mathrm{~s}$ acquisition time; $4.32 \mathrm{~s}$ relaxation delay; $12 \mathrm{~Hz}$ spinning; and an external $\mathrm{H}_{3} \mathrm{PO}_{4}$ standard, collecting 5800 scans for particulate P samples. The large orthophosphate peak was truncated so that smaller peaks could be visualized. 


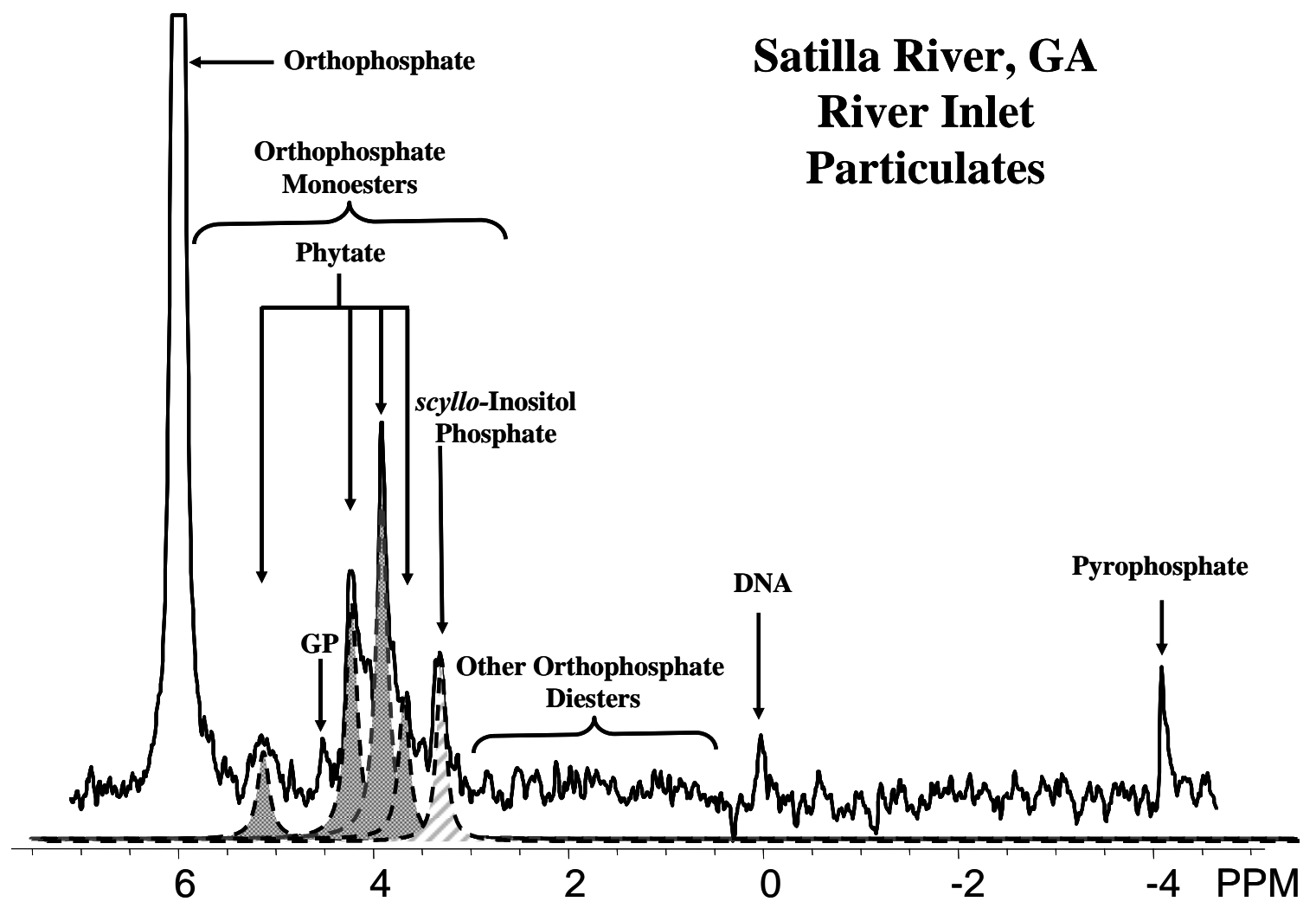


Figure 2.6: Mean ( $\pm \mathrm{SE})$ of the a) proportion of total $\mathrm{P}$ in dissolved form, b) $\mathrm{Al}, \mathrm{c}) \mathrm{Fe}$, and c) particulate phytate concentrations in alluvial (AL) and blackwater (BW) river inlets (RI) and floodplain (FP) waters. A 2-way ANOVA with floodplain type (AL vs. BW) and location (RI vs. FP) showed significant main effects in floodplain type and an interaction between the two factors. Bars marked with the same upper-case letters are not significantly different from each other $(P<0.05$, Tukeys HSD test for a posteriori comparison). For complete results showing significant effects and interaction terms of the 2-way ANOVA see Appendix Table 2.1 
a.

Total Dissolved Phosphorus by Chemical Analysis

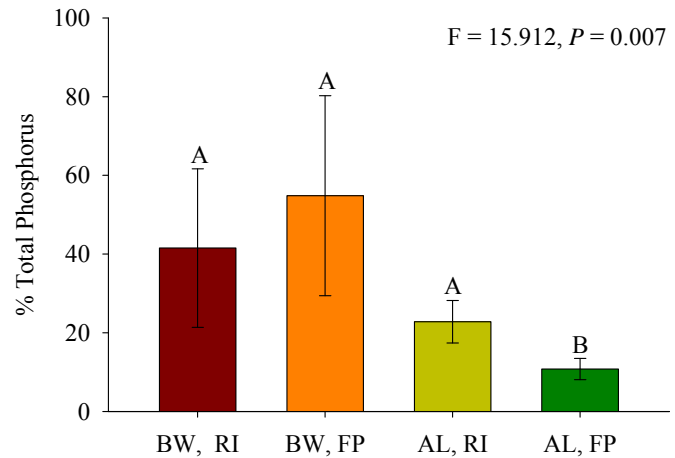

c.

Iron Concetrations

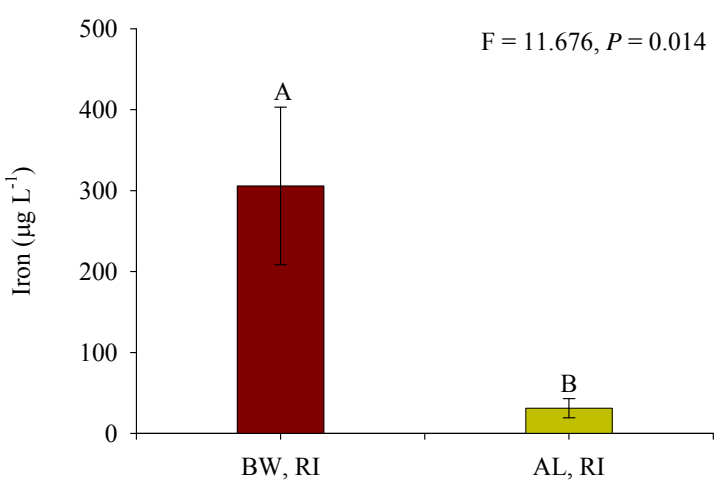

b.

Aluminum Concetrations

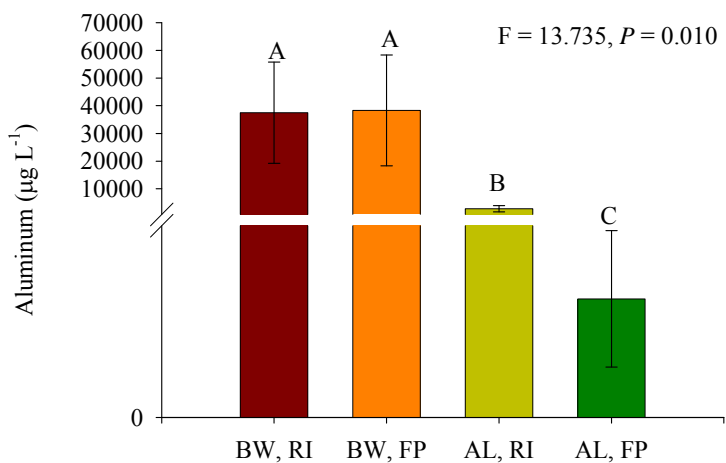

d.

Particulate Phytate

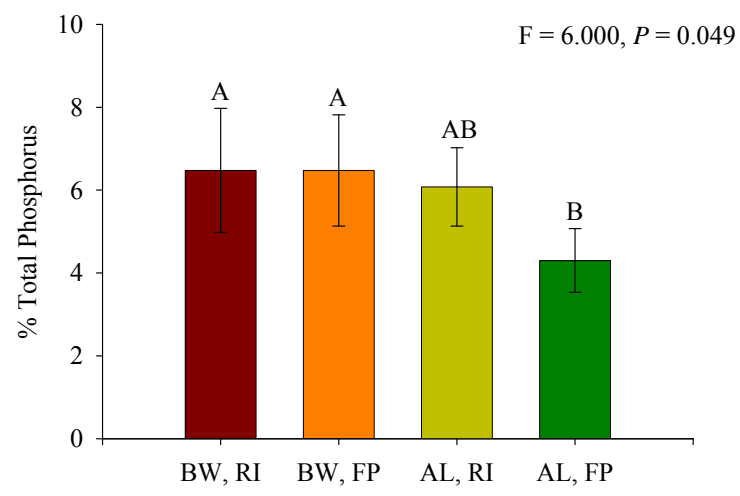


Figure 2.7: Mean ( \pm SE) of NMR visible dissolved inorganic and organic P: a) sum of dissolved inorganic $\mathrm{P}, \mathrm{b}$ ) dissolved orthophosphate, and c) dissolved inorganic pyrophosphate, d) sum of dissolved organic phosphorus, e) sum of dissolved orthophosphate monoesters, and f) dissolved phytate concentrations in alluvial (AL) and blackwater (BW) river inlets (RI) versus floodplain (FP) waters. A 2-way ANOVA with floodplain type (AL vs. BW) and location (RI vs. FP) showed significant main effect by RI/FP location $(P<0.05$, students t-test for a posteriori comparison). For complete results showing significant effects and interaction terms of the 2-way ANOVA see Appendix Table 2.1 
a.

Sum of NMR Visible Dissolved Inorganic Phosphorus

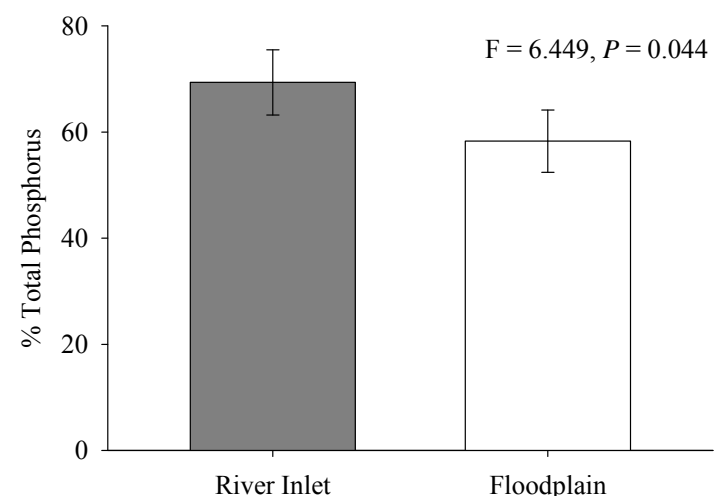

c.

Dissolved Inorganic Pyrophosphate

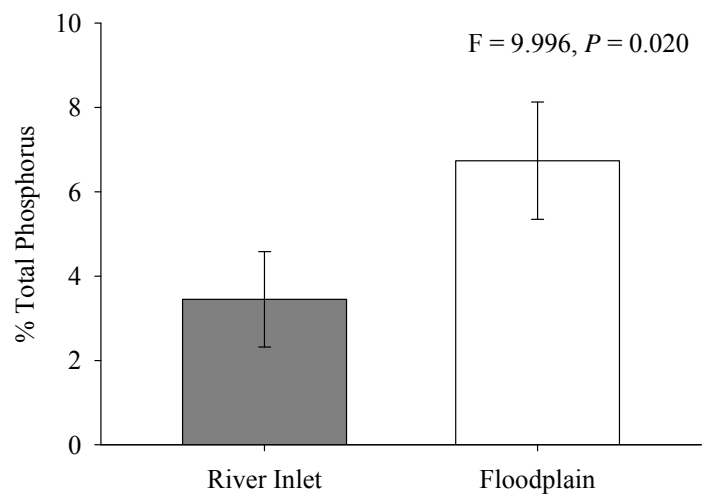

e.

Sum of Dissolved Orthophosphate Monoesters

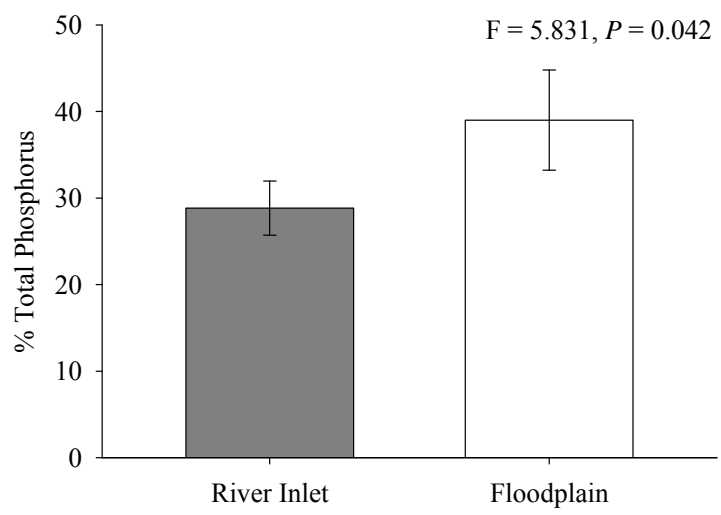

b.

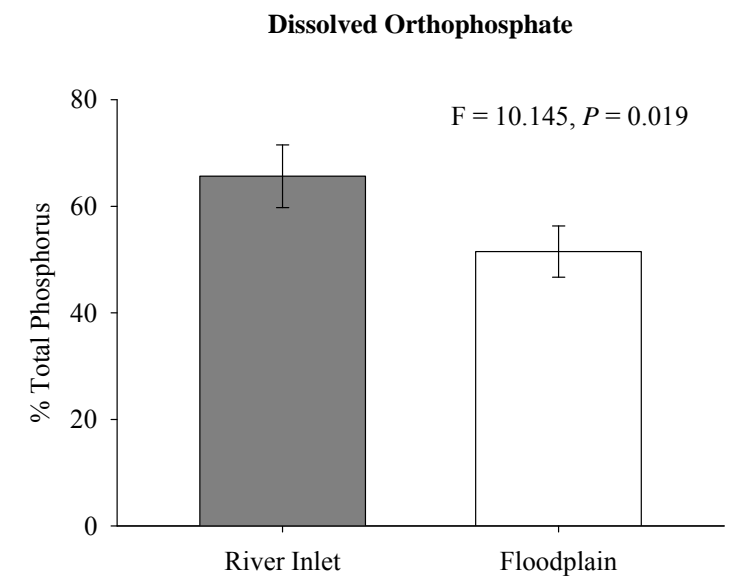

d.

Sum of Dissolved Organic Phosphorus

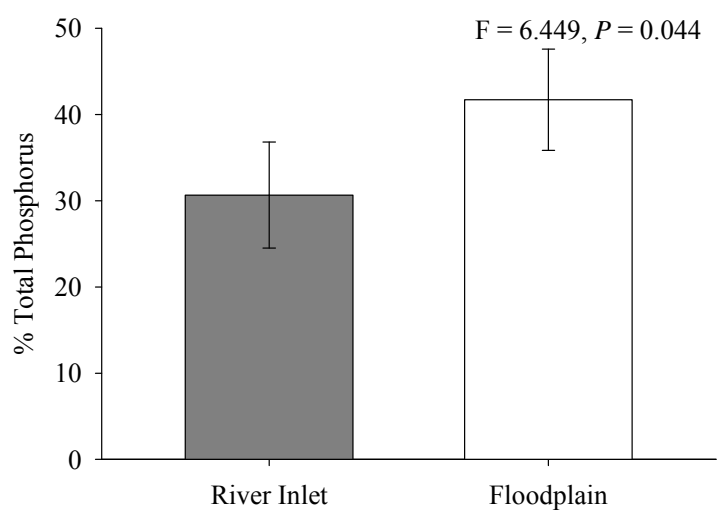

f.

Dissolved Phytate

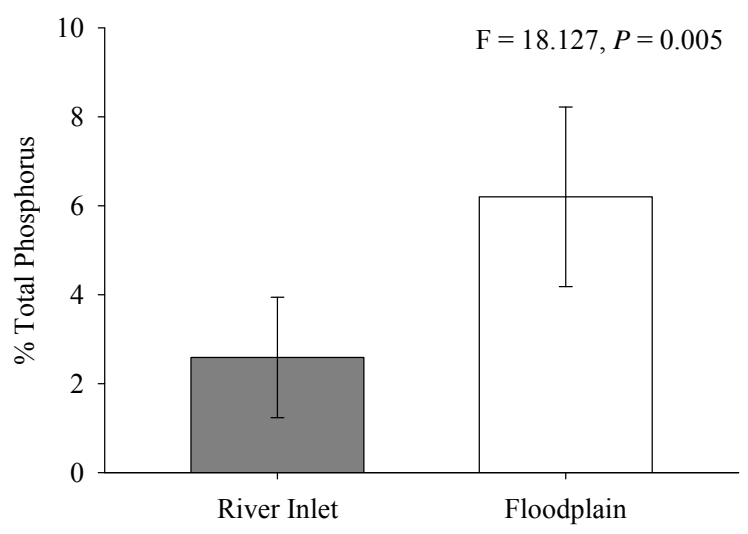


Figure 2.8: Mean ( $\pm \mathrm{SE}$ ) of the a) sum of particulate orthophosphate monoesters and b) particulate scyllo-inositol phosphates in alluvial (AL) and blackwater (BW) river inlets (RI) and floodplain (FP) waters. A 2-way ANOVA with floodplain type (AL vs. BW) and location (RI vs. FP) showed significant main effect by floodplain type $(P<0.05$, students t-test for $a$ posteriori comparison). For complete results showing significant effects and interaction terms of the 2-way ANOVA see Appendix Table 2.1 
a.

Sum of Particulate Orthophosphate Monoesters

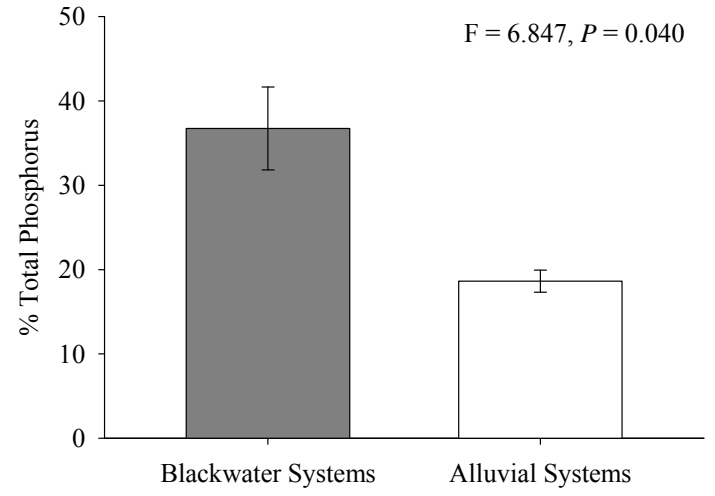

b.

Particulate scyllo-Inositol Phosphate

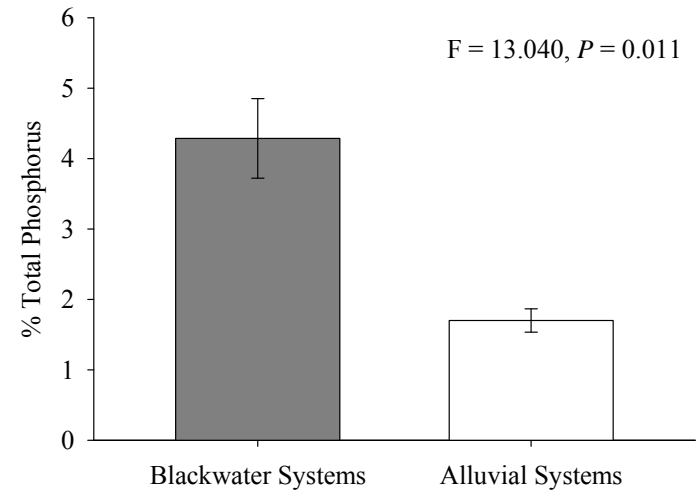


Table 2.1: Locations and characteristics of the river systems in the southeastern U.S. Stream flow River data from USGS gauging stations located near each study site. 


\begin{tabular}{|c|c|c|c|c|c|c|c|}
\hline River type & Site & Latitude & Longitude & Drainage area $\left(\mathrm{km}^{2}\right)$ & Mean daily stream flow $\left(\mathrm{m}^{3} \mathrm{~s}^{-1}\right)$ & TP range $\left(\mu \mathrm{g} \mathrm{L}^{-1}\right)$ & TP sampling date \\
\hline Alluvial & Nottoway River, VA & $36^{\circ} 46^{\prime} \mathrm{N}$ & $77^{\circ} 09^{\prime} \mathrm{W}$ & 3,732 & 410 & $67.0-129.0$ & 9/1999 \\
\hline --- " --- & Pee Dee River, SC & $34^{\circ} 12^{\prime} \mathrm{N}$ & $79^{\circ} 32^{\prime} \mathrm{W}$ & 22,870 & 2,995 & $60.0-160.0$ & $1 / 1995-9 / 1995$ \\
\hline --- " --- & Oconee River, GA & $32^{\circ} 32^{\prime} \mathrm{N}$ & $82^{\circ} 53^{\prime} \mathrm{W}$ & 11,396 & 1,474 & 60.0 & $11 / 1976$ \\
\hline --- " --- & Ocmulgee River, GA & $31^{\circ} 55^{\prime} \mathrm{N}$ & $82^{\circ} 40^{\prime} \mathrm{W}$ & 13,416 & 1,665 & $30.0-70.0$ & $3 / 2005-7 / 2005$ \\
\hline \multicolumn{5}{|c|}{ Mean (SE) } & $1,636(530)^{*}$ & $75.6(12.6)$ & \\
\hline Blackwater & Black River, NC & $34^{\circ} 45^{\prime} \mathrm{N}$ & $78^{\circ} 18^{\prime} \mathrm{W}$ & 1,751 & 242 & $62.0-332.0$ & $5 / 2009-12 / 2009$ \\
\hline --- " --- & Drowning Creek, NC & $35^{\circ} 03^{\prime} \mathrm{N}$ & $79^{\circ} 29^{\prime} \mathrm{W}$ & 474 & 76 & n.a. & \\
\hline --- " --- & Big Swamp, NC & $34^{\circ} 42^{\prime} \mathrm{N}$ & $78^{\circ} 50^{\prime} \mathrm{W}$ & 593 & 67 & n.a. & \\
\hline --- " --- & Satilla River, GA & $31^{\circ} 14^{\prime} \mathrm{N}$ & $82^{\circ} 19 \mathrm{~W}$ & 3,108 & 311 & 50.0 & $7 / 1974$ \\
\hline \multicolumn{5}{|c|}{ Mean (SE) } & $174(61)$ & $109(59.0)$ & \\
\hline
\end{tabular}

* Indicates significant differences between alluvial and blackwater rivers $(\mathrm{p} \leq 0.05)$. 
Table 2.2: Distribution of a) dissolved and particulate total P, MRP, C, Al, Fe, pH, and conductivity measured by chemical analysis, b) NMR visible dissolved P forms, and c) NMR visible particulate P forms in individual river inlet (RI) and floodplain (FP) samples collected at alluvial and blackwater systems in the southeastern U.S. * Indicates significant differences between alluvial and blackwater rivers $(\mathrm{RI})$ for measured components $(\mathrm{p} \leq 0.05)$ using a two-sample t-test analysis. For complete results showing significant effects and interaction terms of the 2-way ANOVA see Appendix Table 2.1. Abbreviations: TDP, total dissolved P; MRP, molybdate reactive P; C, carbon; Al, aluminum; Fe, iron; Cond, conductivity; TPP, total particulate P; orthoP, orthophosphate; pyroP, pyrophosphate; polyP, polyphosphate; PA, phytate; scyllo-IP, scyllo-inositol phosphate; GP, glycerophosphate; DNA, deoxyribonucleic acid; phon, phosphonate. 
Table 2.2 a: Dissolved and particulate Total P, MRP, C, Al, Fe, as well as pH and conductivity.

\begin{tabular}{|c|c|c|c|c|c|c|c|c|c|c|}
\hline \multirow{2}{*}{ Alluvial systems } & & \multicolumn{7}{|l|}{ Dissolved } & \multicolumn{2}{|l|}{ Particulate } \\
\hline & & TDP $\left(\mu \mathrm{g} \mathrm{L}^{-1}\right)$ & $\operatorname{MRP}\left(\mu \mathrm{g} \mathrm{L}^{-1}\right)$ & $\mathrm{C}\left(\mu \mathrm{g} \mathrm{L}^{-1}\right)$ & $\mathrm{Al}\left(\mu \mathrm{g} \mathrm{L}^{-1}\right)$ & $\mathrm{Fe}\left(\mu \mathrm{g} \mathrm{L}^{-1}\right)$ & $\mathrm{pH}$ & Cond. & $\mathrm{TPP}\left(\mu \mathrm{g} \mathrm{L}^{-1}\right)$ & $\mathrm{C}\left(\mu \mathrm{g} \mathrm{L}^{-1}\right)$ \\
\hline \multirow[t]{2}{*}{ Nottoway River, VA } & RI & 11.1 & 7.1 & 9600.0 & 5146.0 & 24.3 & 5.9 & 25.5 & 48.6 & 5340.0 \\
\hline & $\mathrm{FP}$ & 6.6 & 6.4 & 2573.0 & 106.4 & 6.6 & 6.2 & 27.8 & 52.9 & 5580.0 \\
\hline \multirow[t]{2}{*}{ Pee Dee River, SC } & RI & 34.0 & 21.0 & 5170.0 & 4.9 & 65.4 & 7.0 & 90.3 & 64.7 & 3300.0 \\
\hline & FP & 11.0 & 14.2 & 8197.0 & 0.0 & 19.3 & 6.6 & 69.3 & 103.4 & 16570.0 \\
\hline \multirow[t]{2}{*}{ Oconee River, GA } & RI & 29.8 & 22.0 & 3523.0 & 4012.0 & 23.7 & 6.9 & 71.1 & 71.5 & 3820.0 \\
\hline & FP & 18.3 & 6.8 & 14050.0 & 90.5 & 34.7 & 6.6 & 66.5 & 107.9 & 7800.0 \\
\hline \multirow[t]{2}{*}{ Ocmulgee River, GA } & RI & 16.3 & 5.8 & 4468.0 & 2139.0 & 10.8 & 6.9 & 36.9 & 26.8 & 2830.0 \\
\hline & FP & 7.2 & 5.5 & 13340.0 & 0.9 & 22.3 & 7.0 & 39.1 & 31.2 & 1260.0 \\
\hline \multirow{4}{*}{$\operatorname{Mean}\left(S . E_{.}\right)$} & RI & 22.8 & 14.0 & $5,690.2$ & $2,825.5$ & 31.1 & $6.4^{*}$ & 56.0 & 52.9 & $3,823.3$ \\
\hline & & (5.4) & (4.4) & $(1,346.2)$ & $(1,126.2)$ & (11.9) & $(0.6)$ & $(15.0)$ & $(10.0)$ & $(770.4)$ \\
\hline & $\mathrm{FP}$ & 10.8 & 8.2 & $9,540.0$ & 49.5 & 20.7 & 6.5 & 50.7 & 73.9 & $7,803.3$ \\
\hline & & $(2.7)$ & $(2.0)$ & $(2,663.4)$ & $(28.5)$ & $(5.8)$ & $(0.2)$ & $(10.2)$ & (18.9) & $(4,557.3)$ \\
\hline \multicolumn{11}{|l|}{ Blackwater systems } \\
\hline \multirow[t]{2}{*}{ Black River, NC } & RI & 97.7 & 25.0 & 23210.0 & 64300.0 & 389.7 & 6.0 & 79.0 & 119.3 & 14300.0 \\
\hline & $\mathrm{FP}$ & 127.4 & 10.8 & 11730.0 & 88310.0 & 382.6 & 5.3 & 48.5 & 60.2 & 9880.0 \\
\hline \multirow[t]{2}{*}{ Drowning Creek, NC } & RI & 8.0 & 6.3 & 101700.0 & 73480.0 & 305.6 & 5.3 & 18.6 & 10.7 & 2650.0 \\
\hline & $\mathrm{FP}$ & 8.8 & 5.8 & 28020.0 & 52970.0 & 382.6 & 5.4 & 21.9 & 5.5 & 7970.0 \\
\hline \multirow[t]{2}{*}{ Big Swamp, NC } & RI & 17.2 & 7.0 & 9983.0 & 4293.0 & 36.9 & 5.9 & 59.7 & 23.4 & 22730.0 \\
\hline & FP & 42.7 & 5.9 & 17280.0 & 7323.0 & 84.0 & 5.3 & 72.4 & 25.4 & 23040.0 \\
\hline \multirow[t]{2}{*}{ Satilla River, GA } & RI & 43.2 & 22.6 & 19630.0 & 7903.0 & 490.4 & 5.7 & 40.9 & 25.4 & 7640.0 \\
\hline & $\mathrm{FP}$ & 40.3 & 22.2 & 8207.0 & 4870.0 & 176.6 & 5.7 & 42.2 & 30.7 & 5590.0 \\
\hline \multirow{4}{*}{ Mean (S. E.) } & RI & 41.5 & 15.2 & $38,630.8$ & $37,494.0$ & $305.7 *$ & 5.6 & 49.6 & 44.7 & $11,830.0$ \\
\hline & & $(20.2)$ & $(5.0)$ & $(21,207.8)$ & $(18,238.0)$ & (97.2) & $(0.2)$ & (12.9) & $(25.1)$ & $(4,346.8)$ \\
\hline & FP & 54.8 & 11.2 & $16,309.3$ & $38,368.3$ & 256.5 & 5.4 & 46.2 & 30.4 & $11,620.0$ \\
\hline & & (25.4) & (3.8) & $(4,327.2)$ & $(19,986.1)$ & $(75.2)$ & $(0.1)$ & (10.4) & (11.3) & $(3,906.5)$ \\
\hline
\end{tabular}


Table 2.2 b: NMR visible dissolved P forms.

\begin{tabular}{|c|c|c|c|c|c|c|c|c|c|c|c|c|c|c|c|}
\hline \multirow{2}{*}{$\begin{array}{c}\begin{array}{c}\text { Dissolved P forms } \\
(\%)\end{array} \\
\text { Alluvial systems }\end{array}$} & & \multicolumn{4}{|c|}{ Inorganic P } & \multicolumn{5}{|c|}{ Orthophosphate monoesters } & \multicolumn{3}{|c|}{$\begin{array}{c}\text { Orthophosphate } \\
\text { diesters }\end{array}$} & \multirow[b]{2}{*}{ phon } & \multirow[b]{2}{*}{$\sum \boldsymbol{P}_{o}$} \\
\hline & & orthoP & pyroP & polyP & $\sum \boldsymbol{P}_{\boldsymbol{i}}$ & PA & $\begin{array}{l}\text { Scyllo- } \\
\text { IP }\end{array}$ & GP & $\begin{array}{l}\text { Other } \\
\text { mono }\end{array}$ & $\sum_{\text {mono }}$ & DNA & other di & $\sum d i$ & & \\
\hline \multirow[t]{2}{*}{ Nottoway River, VA } & $\mathrm{RI}$ & 72.8 & 0.0 & 0.0 & 72.8 & 0.0 & 0.0 & 0.0 & 24.2 & 24.2 & 3.0 & 0.0 & 3.0 & 0.0 & 27.2 \\
\hline & $\mathrm{FP}$ & 57.6 & 3.4 & 0.0 & 61.0 & 0.0 & 0.0 & 0.0 & 37.2 & 37.3 & 1.7 & 0.0 & 1.7 & 0.0 & 39.0 \\
\hline \multirow[t]{2}{*}{ Pee Dee River, SC } & $\mathrm{RI}$ & 77.5 & 0.0 & 0.0 & 77.5 & 0.0 & 0.0 & 0.9 & 20.4 & 21.3 & 1.2 & 0.0 & 1.2 & 0.0 & 22.5 \\
\hline & FP & 58.3 & 7.8 & 0.0 & 66.1 & 4.5 & 0.0 & 0.7 & 26.8 & 32.0 & 1.9 & 0.0 & 1.9 & 0.0 & 33.9 \\
\hline \multirow[t]{2}{*}{ Oconee River, GA } & RI & 84.6 & 3.1 & 0.0 & 87.7 & 2.1 & 0.7 & 0.0 & 8.5 & 11.3 & 1.0 & 0.0 & 1.0 & 0.0 & 12.3 \\
\hline & FP & 51.0 & 4.8 & 0.0 & 55.8 & 4.9 & 1.6 & 1.6 & 33.2 & 41.3 & 1.9 & 1.0 & 2.9 & 0.0 & 44.2 \\
\hline \multirow[t]{2}{*}{ Ocmulgee River, GA } & $\mathrm{RI}$ & 49.4 & 3.4 & 0.0 & 52.8 & 4.8 & 1.6 & 1.6 & 38.0 & 46.0 & 0.0 & 1.2 & 1.2 & 0.0 & 47.2 \\
\hline & FP & 44.7 & 3.5 & 0.0 & 48.2 & 11.3 & 0.0 & 2.8 & 34.0 & 48.2 & 2.4 & 1.2 & 3.6 & 0.0 & 51.8 \\
\hline \multirow{3}{*}{$\operatorname{Mean}\left(S . E_{.}\right)$} & RI & 71.1 & 1.6 & 0.0 & 72.7 & 1.7 & 0.6 & 0.6 & 22.8 & 25.7 & 1.3 & 0.3 & 1.6 & 0.0 & 27.3 \\
\hline & & $(7.6)$ & $(0.9)$ & $(0.0)$ & (7.3) & (1.1) & $(0.4)$ & $(0.4)$ & $(6.1)$ & $(7.3)$ & $(0.6)$ & $(0.3)$ & $(0.5)$ & $(0.0)$ & (7.3) \\
\hline & FP & $\begin{array}{l}52.9 \\
(3.2)\end{array}$ & $\begin{array}{l}4.9 \\
(1.0)\end{array}$ & $\begin{array}{l}0.0 \\
(0.0)\end{array}$ & $\begin{array}{l}57.8 \\
(3.8)\end{array}$ & $\begin{array}{l}5.2 \\
(2.3)\end{array}$ & $\begin{array}{l}0.4 \\
(0.4)\end{array}$ & $\begin{array}{c}1.3 \\
(0.6)\end{array}$ & $\begin{array}{l}32.8 \\
(2.2)\end{array}$ & $\begin{array}{r}39.7 \\
(3.4)\end{array}$ & $\begin{array}{l}2.0 \\
(0.1)\end{array}$ & $\begin{array}{l}0.6 \\
(0.3)\end{array}$ & $\begin{array}{l}2.5 \\
(0.4)\end{array}$ & $\begin{array}{l}0.0 \\
(0.0)\end{array}$ & $\begin{array}{l}42.2 \\
(3.8)\end{array}$ \\
\hline \multicolumn{16}{|l|}{ Blackwater systems } \\
\hline \multirow[t]{2}{*}{ Black River, NC } & RI & 77.2 & 5.1 & 0.8 & 83.1 & 2.8 & 1.0 & 1.0 & 10.5 & 15.3 & 0.8 & 0.0 & 0.8 & 0.8 & 16.9 \\
\hline & FP & 55.0 & 11.6 & 0.0 & 66.6 & 6.1 & 1.0 & 1.0 & 21.4 & 29.5 & 1.6 & 2.3 & 3.9 & 0.0 & 33.4 \\
\hline \multirow[t]{2}{*}{ Drowning Creek, NC } & RI & 42.7 & 2.7 & 0.0 & 45.4 & 0.0 & 0.0 & 0.0 & 50.6 & 50.6 & 2.7 & 1.3 & 4.0 & 0.0 & 54.6 \\
\hline & FP & 46.1 & 5.6 & 0.0 & 51.7 & 2.7 & 0.9 & 0.0 & 39.1 & 42.7 & 5.6 & 0.0 & 5.6 & 0.0 & 48.3 \\
\hline \multirow[t]{2}{*}{ Big Swamp, NC } & RI & 46.3 & 3.2 & 0.0 & 49.5 & 11.0 & 0.0 & 1.8 & 37.5 & 50.5 & 0.0 & 0.0 & 0.0 & 0.0 & 50.5 \\
\hline & $\mathrm{FP}$ & 26.2 & 3.6 & 0.0 & 29.8 & 17.7 & 0.3 & 2.0 & 46.3 & 69.0 & 1.2 & 0.0 & 1.2 & 0.0 & 70.2 \\
\hline \multirow[t]{2}{*}{ Satilla River, GA } & RI & 74.6 & 10.1 & 1.3 & 86.0 & 0.0 & 0.0 & 0.0 & 11.4 & 11.4 & 1.3 & 1.3 & 2.6 & 0.0 & 14.0 \\
\hline & $\mathrm{FP}$ & 73.5 & 13.6 & 0.0 & 87.1 & 2.4 & 0.8 & 0.8 & 8.0 & 12.0 & 0.9 & 0.0 & 0.9 & 0.0 & 12.9 \\
\hline \multirow{3}{*}{$\operatorname{Mean}\left(S . E_{.}\right)$} & RI & 60.2 & 5.3 & 0.5 & 66.0 & 3.5 & 0.3 & 0.7 & 27.5 & 32.0 & 1.2 & 0.7 & 1.9 & 0.2 & 34.0 \\
\hline & & $(9.1)$ & $(1.7)$ & $(0.3)$ & $(10.8)$ & $(2.6)$ & $(0.3)$ & $(0.4)$ & $(9.9)$ & $(10.8)$ & $(0.6)$ & $(0.4)$ & $(0.9)$ & $(0.2)$ & $(10.8)$ \\
\hline & FP & $\begin{array}{l}50.2 \\
(9.8)\end{array}$ & $\begin{array}{l}8.6 \\
(2.4)\end{array}$ & $\begin{array}{l}0.0 \\
(0.0)\end{array}$ & $\begin{array}{l}58.8 \\
(12.1)\end{array}$ & $\begin{array}{l}7.2 \\
(3.6)\end{array}$ & $\begin{array}{l}1.4 \\
(0.5)\end{array}$ & $\begin{array}{l}1.0 \\
(0.4)\end{array}$ & $\begin{array}{l}28.7 \\
(8.7)\end{array}$ & $\begin{array}{r}38.3 \\
(12.0)\end{array}$ & $\begin{array}{l}2.3 \\
(1.1)\end{array}$ & $\begin{array}{l}0.6 \\
(0.6)\end{array}$ & $\begin{array}{l}2.9 \\
(1.1)\end{array}$ & $\begin{array}{l}0.0 \\
(0.0)\end{array}$ & $\begin{array}{l}41.2 \\
(12.1)\end{array}$ \\
\hline
\end{tabular}


Table 2.2 c: NMR visible particulate $\mathrm{P}$ forms.

\begin{tabular}{|c|c|c|c|c|c|c|c|c|c|c|c|c|c|c|c|}
\hline \multirow{2}{*}{$\begin{array}{c}\begin{array}{c}\text { Particulate P forms } \\
(\%)\end{array} \\
\text { Alluvial systems }\end{array}$} & & \multicolumn{4}{|c|}{ Inorganic $\mathbf{P}$} & \multicolumn{5}{|c|}{ Orthophosphate monoesters } & \multicolumn{3}{|c|}{$\begin{array}{c}\text { Orthophosphate } \\
\text { diesters }\end{array}$} & \multirow[b]{2}{*}{ phon } & \multirow[b]{2}{*}{$\sum \boldsymbol{P}_{\boldsymbol{o}}$} \\
\hline & & orthoP & pyroP & polyP & $\sum \boldsymbol{P}_{i}$ & $\mathrm{PA}$ & $\begin{array}{l}\text { scyllo- } \\
\text { IP }\end{array}$ & GP & $\begin{array}{l}\text { other } \\
\text { mono }\end{array}$ & $\sum_{\text {mono }}$ & DNA & other di & $\sum d i$ & & \\
\hline \multirow[t]{2}{*}{ Nottoway River, VA } & RI & 81.9 & 1.7 & 0.0 & 83.6 & 5.2 & 1.7 & 1.7 & 7.8 & 16.4 & 0.0 & 0.0 & 0.0 & 0.0 & 16.4 \\
\hline & FP & 83.2 & 1.8 & 0.9 & 85.9 & 2.6 & 1.8 & 7.9 & 0.9 & 13.2 & 0.9 & 0.0 & 0.9 & 0.0 & 14.1 \\
\hline \multirow[t]{2}{*}{ Pee Dee River, SC } & RI & 78.2 & 2.5 & 0.0 & 80.7 & 8.8 & 1.9 & 0.9 & 6.9 & 18.5 & 0.8 & 0.0 & 0.8 & 0.0 & 19.3 \\
\hline & FP & 69.9 & 3.5 & 0.0 & 73.4 & 5.5 & 1.8 & 1.0 & 16.5 & 24.8 & 0.9 & 0.0 & 0.9 & 0.9 & 26.6 \\
\hline \multirow[t]{2}{*}{ Oconee River, GA } & RI & 71.9 & 7.5 & 0.0 & 79.4 & 5.8 & 1.0 & 1.0 & 8.7 & 16.5 & 4.1 & 0.0 & 4.1 & 0.0 & 20.6 \\
\hline & FP & 68.3 & 4.8 & 0.0 & 73.1 & 5.7 & 1.0 & 1.0 & 15.1 & 22.8 & 4.1 & 0.0 & 4.1 & 0.0 & 26.9 \\
\hline \multirow[t]{2}{*}{ Ocmulgee River, GA } & RI & 78.0 & 1.6 & 0.0 & 79.6 & 4.5 & 2.2 & 1.5 & 10.5 & 18.8 & 0.8 & 0.0 & 0.8 & 0.8 & 20.4 \\
\hline & FP & 75.0 & 3.0 & 0.0 & 78.0 & 3.4 & 2.2 & 1.1 & 11.3 & 18.0 & 3.0 & 1.0 & 4.0 & 0.0 & 22.0 \\
\hline \multirow{3}{*}{ Mean (S. E.) } & RI & 77.5 & 3.3 & 0.0 & 80.8 & 6.1 & 1.7 & 1.3 & 8.5 & 17.6 & 1.4 & 0.0 & 1.4 & 0.2 & 19.2 \\
\hline & & (2.1) & (1.4) & $(0.0)$ & $(1.0)$ & (0.9) & $(0.3)$ & $(0.2)$ & $(0.8)$ & $(0.6)$ & $(0.9)$ & $(0.0)$ & (0.9) & $(0.2)$ & (1.0) \\
\hline & FP & $\begin{array}{l}74.1 \\
(3.4)\end{array}$ & $\begin{array}{l}3.3 \\
(0.6)\end{array}$ & $\begin{array}{l}0.2 \\
(0.2)\end{array}$ & $\begin{array}{l}77.6 \\
(3.0)\end{array}$ & $\begin{array}{l}4.3 \\
(0.8)\end{array}$ & $\begin{array}{l}1.7 \\
(0.3)\end{array}$ & $\begin{array}{l}2.8 \\
(1.7)\end{array}$ & $\begin{array}{l}11.0 \\
(3.5)\end{array}$ & $\begin{array}{r}19.7 \\
(2.6 .)\end{array}$ & $\begin{array}{l}2.2 \\
(0.8)\end{array}$ & $\begin{array}{l}0.3 \\
(0.3)\end{array}$ & $\begin{array}{l}2.5 \\
(0.9)\end{array}$ & $\begin{array}{l}0.2 \\
(0.2)\end{array}$ & $\begin{array}{c}22.4 \\
(3.0)\end{array}$ \\
\hline \multicolumn{16}{|l|}{ Blackwater systems } \\
\hline \multirow[t]{2}{*}{ Black River, NC } & RI & 82.1 & 1.9 & 0.0 & 84.0 & 5.5 & 1.9 & 7.5 & 1.0 & 16.0 & 0.0 & 0.0 & 0.0 & 0.0 & 16.0 \\
\hline & FP & 68.1 & 0.9 & 0.0 & 69.0 & 5.2 & 3.4 & 19.8 & 1.7 & 30.1 & 0.9 & 0.0 & 0.9 & 0.0 & 31.0 \\
\hline \multirow[t]{2}{*}{ Drowning Creek, NC } & RI & 30.0 & 6.0 & 0.0 & 36.0 & 4.3 & 7.2 & 2.2 & 35.3 & 49.0 & 12.0 & 3.0 & 15.0 & 0.0 & 64.0 \\
\hline & $\mathrm{FP}$ & 37.8 & 5.1 & 0.0 & 42.9 & 5.2 & 5.2 & 1.8 & 34.7 & 46.9 & 8.2 & 2.0 & 10.2 & 0.0 & 57.1 \\
\hline \multirow[t]{2}{*}{ Big Swamp, NC } & RI & 28.1 & 5.6 & 0.0 & 33.7 & 5.2 & 3.5 & 2.6 & 46.0 & 57.3 & 7.9 & 1.1 & 9.0 & 0.0 & 66.3 \\
\hline & FP & 53.3 & 3.7 & 0.0 & 57.0 & 5.0 & 4.2 & 1.7 & 29.3 & 40.2 & 2.8 & 0.0 & 2.8 & 0.0 & 43.0 \\
\hline \multirow[t]{2}{*}{ Satilla River, GA } & RI & 68.0 & 3.0 & 0.0 & 71.0 & 10.9 & 3.6 & 2.6 & 10.9 & 28.0 & 1.0 & 0.0 & 1.0 & 0.0 & 29.0 \\
\hline & FP & 71.1 & 1.7 & 0.0 & 72.8 & 10.5 & 5.3 & 1.7 & 8.8 & 26.3 & 0.9 & 0.0 & 0.9 & 0.0 & 27.2 \\
\hline \multirow{2}{*}{$\operatorname{Mean}\left(S . E_{.}\right)$} & RI & $\begin{array}{c}52.1 \\
(13.6)\end{array}$ & $\begin{array}{c}4.1 \\
(1.0)\end{array}$ & $\begin{array}{c}0.0 \\
(0.0)\end{array}$ & $\begin{array}{c}56.2 \\
(12.6)\end{array}$ & $\begin{array}{c}6.5 \\
(1.5)\end{array}$ & $\begin{array}{l}4.1 * \\
(1.1)\end{array}$ & $\begin{array}{l}3.7 * \\
(1.3)\end{array}$ & $\begin{array}{c}23.3 \\
(10.5)\end{array}$ & $\begin{array}{l}37.6 \\
(9.5)\end{array}$ & $\begin{array}{c}5.2 \\
(2.9)\end{array}$ & $\begin{array}{c}1.0 \\
(0.7)\end{array}$ & $\begin{array}{c}6.3 \\
(3.5)\end{array}$ & $\begin{array}{c}0.0 \\
(0.0)\end{array}$ & $\begin{array}{c}43.8 \\
(12.6)\end{array}$ \\
\hline & FP & $\begin{array}{l}57.6 \\
(7.7)\end{array}$ & $\begin{array}{l}2.9 \\
(1.0)\end{array}$ & $\begin{array}{l}0.0 \\
(0.0)\end{array}$ & $\begin{array}{c}60.4 \\
(6.7)\end{array}$ & $\begin{array}{l}6.5 \\
(1.3)\end{array}$ & $\begin{array}{l}4.5 \\
(0.5)\end{array}$ & $\begin{array}{l}6.3 \\
(4.5)\end{array}$ & $\begin{array}{r}18.6 \\
(7.9)\end{array}$ & $\begin{array}{r}35.9 \\
(4.7)\end{array}$ & $\begin{array}{l}3.2 \\
(1.7)\end{array}$ & $\begin{array}{l}0.5 \\
(0.5)\end{array}$ & $\begin{array}{l}3.7 \\
(2.2)\end{array}$ & $\begin{array}{l}0.0 \\
(0.0)\end{array}$ & $\begin{array}{l}39.6 \\
(6.7)\end{array}$ \\
\hline
\end{tabular}




\section{CHAPTER 3}

Retention and Transformation of ${ }^{32} \mathrm{PO}_{4}{ }^{3-}$ During Simulated Flooding of Floodplain Forest Soil Mesocosms 


\begin{abstract}
Floodplain forests (FFs) reduce the eutrophication of aquatic systems downstream by retaining or
\end{abstract} transforming phosphorus $(\mathrm{P})$ received in floodwaters, but little is known about the pathways of $\mathrm{P}$ retention and/or transformation during flooding. The objective of this research was to identify specific mechanisms of $\mathrm{P}$ retention and transformation during flooding in FFs typical of the southeastern (SE) United States (US). To accomplish this objective, I added ${ }^{32} \mathrm{PO}_{4}{ }^{3-}$ dissolved in river water to soil cores collected from topographic lows (swales) $(\mathrm{n}=12$ per site) at 2 Alluvial (AL) (Pee Dee; Wateree) and 2 Blackwater (BW) (Black River; Drowning Creek) FFs in the SE US. Cores were flooded with labeled river water and then incubated for $40 \mathrm{~h}$ or $8 \mathrm{~d}$ prior to sequential fractionation to extract $\mathrm{P}$ and associated aluminum (Al) and iron (Fe) cations in six soil $\mathrm{P}$ fractions. I hypothesized that ${ }^{32} \mathrm{PO}_{4}{ }^{3-}$ would be transformed to organic form $\left(\mathrm{P}_{\mathrm{o}}\right)$ in river and headwaters by physico-chemical complexation with organic matter (OM) via metal (Al and/or Fe) ligands (OM-metal-P), and/or by biological (microbial) uptake and conversion to $\mathrm{P}_{\mathrm{o}}$. Although I had expected transformation processes to occur within the water column in both AL and $\mathrm{BW}$ rivers, $77 \%$ of added ${ }^{32} \mathrm{PO}_{4}{ }^{3-}$ was transformed to $\mathrm{P}_{\mathrm{o}}$ within $2 \mathrm{~h}$ of addition in $\mathrm{BW}$ river waters, while in AL river waters, all added ${ }^{32} \mathrm{PO}_{4}{ }^{3-}$ remained in inorganic form. However, when labeled river waters were added to soil mesocosms, upon contact with the soil surface, additional transformation was observed resulting in a increase in the proportion of ${ }^{32} \mathrm{P}_{\mathrm{o}}$ in headwaters, averaging 68 and $80 \%$ of total ${ }^{32} \mathrm{P}$ recovered in $\mathrm{AL}$ and BW cores, respectively. Across all soil cores, average 12 and $0.5 \%$ of the total ${ }^{32} \mathrm{P}$ added was recovered from head- and drain-waters, respectively. The remaining $87.5 \%$ of added ${ }^{32} \mathrm{P}$ was recovered in soils, distributed within the soil fractions $(73 \%)$, microbial biomass $(9 \%)$ and roots $(6 \%)$. The proportion of ${ }^{32} \mathrm{P}_{\mathrm{i}}$ and ${ }^{32} \mathrm{P}_{\mathrm{o}}$ in cores (sum of $\mathrm{P}$ in the soil fractions + microbial biomass + roots + drainwaters) averaged 69 and $31 \%$ in $\mathrm{AL}$ compared to 53 and $47 \%$ of total ${ }^{32} \mathrm{P}$ recovered in BW cores. These results suggest that while physico-chemical processes dominate the retention of $\mathrm{P}$ in AL soils, $\mathrm{P}$ transformation and retention in BW systems are likely a combination of both biological and physico-chemical processes in BW soils. I also hypothesized that soil fractions would differ with respect to their $\mathrm{P}, \mathrm{Al}$, and $\mathrm{Fe}$ chemistries, and that the dominant mechanism of $\mathrm{P}$ retention in FF soils will be linked primarily to $\mathrm{Al}$, clay minerals, and/or Fe sorption. The majority of ${ }^{32} \mathrm{P}$ recovered in soils was associated with $\mathrm{Al} /$ clay bound $(\mathrm{NaOH}-\mathrm{P})$, reductant-soluble (BD-P), residual (Res-P), and humic acid (HA-P) fractions. More Al than Fe was extracted in the $\mathrm{NaOH}$ 
and Res fractions, and ${ }^{32} \mathrm{P}$ recovered in these fractions was positively correlated with total $\mathrm{Al}$ and soil clay content. Higher concentrations of Fe than $\mathrm{Al}$ were extracted in the BD- and Ca-bound (HCl-extractable) fractions. The ${ }^{32} \mathrm{P}$ recovered in these fractions was significantly positively correlated to Fe content, suggesting that in these acidic soils, $\mathrm{P}$ in these fractions is most likely bound to Fe. Although ${ }^{32} \mathrm{P}$ recoveries were dominated by the $\mathrm{NaOH}, \mathrm{BD}$, Res, and $\mathrm{HA}$ fractions, specific activity was highest in the water-soluble $\mathrm{P}$ fraction, root/rhizosphere and microbial pools, suggesting the importance of these biologically mediated (readily available $\mathrm{P}$ ) pools in the short term retention of $\mathrm{P}$ during flooding events. These results confirm the importance of $\mathrm{Al}$, clay content, and Fe in controlling P retention in FF soils, particularly in the SE US, and are consistent with previous reports of the importance of biological and physico-chemical in controlling short-term P retention and transformation in AL and BW FFs in the SE US. 


\subsection{INTRODUCTION}

\subsubsection{Floodplain Forests of the Southeastern US}

Floodplain forests (FFs) are located in stream and river floodplains that are periodically inundated by overbank flooding (Brinson 1993, Mitsch and Gosselink 2007). In the southeast (SE) United States (US) (i.e.,Virginia, North Carolina, South Carolina, and Georgia), FF ecosystems are associated primarily with two types of river systems: 1) alluvial (AL) rivers, whose waters arise in Piedmont or montane physiographic provinces; and 2) blackwater (BW) rivers, whose waters arise entirely within the Coastal Plain (Wharton and Brinson 1979, Hupp et al. 2005).

Blackwater rivers tend to be smaller than AL rivers, with lower gradient flows that have limited potential to entrain or erode sediments. Alluvial rivers have higher sediment loads and higher concentrations of inorganic ions, but lower concentrations of total organic carbon (TOC) compared to $\mathrm{BW}$ rivers; $\mathrm{pH}$, hardness, and specific conductance also tend to be higher in $\mathrm{AL}$ than in BW rivers (Wharton and Brinson 1979, Hupp et al. 2005). Blackwater rivers have greater bacterial production rates and higher microbial biomass as compared to AL rivers (Edwards and Meyer 1986, Edwards et al. 1990, Meyer 1990, Leff and Meyer 1991, Entry 2000, Ochs et al. 2010).

Previous research in FFs of the SE US has suggested that complexation with organic matter via metal (Al, Fe) ligands (OM-metal-P) may be an important mechanism of inorganic phosphorus $\left(\mathrm{P}_{\mathrm{i}}\right)$ retention and/or transformation in FFs (Lockaby and Walbridge 1998, Axt and Walbridge 
1999, Darke and Walbridge 2000, Hogan et al. 2004). This mechanism could be particularly important in BW FFs, where sediment deposition is expected to play a minor role in P retention as compared to AL systems (Axt and Walbridge 1999, Darke and Walbridge 2000). Plant tissue, litterfall, and soil nitrogen $(\mathrm{N}): \mathrm{P}$ ratios suggest that primary productivity in SE US FFs is generally N-limited (Lockaby and Walbridge 1998). Lower average litterfall N:P ratios in AL as compared to BW FFs, averaging 7.8 and 13.0 respectively (Lockaby and Walbridge 1998, Hupp et al. 2005), suggest that AL systems may be more strongly N-limited than BW systems, perhaps due to the higher sediment-associated $\mathrm{P}$ inputs received in floodwaters.

Floodplain forests are topographically heterogeneous environments in which microsite elevation has a direct influence on hydroperiod (Walbridge and Lockaby 1994, Stanturf and Schoenholtz 1998). In general, topographic lows (swales) have comparatively long hydroperiods and finetextured, clayey soils typical of sediments underlying low energy waters (Hupp and Morris 1990, Craft and Casey 2000); topographic highs (ridges), as remnants of old levees and meander scrolls, have comparatively short hydroperiods and coarse, sandy soils typical of sediments underlying higher energy waters (Stoeckel and Miller-Goodman 2001, Hupp et al. 2005). In an Ogeechee River, GA FF, Darke and Walbridge (2000) found significant positive correlations between oxalate-extractable $\mathrm{Al}$ and soil $\mathrm{OM}$, suggesting that the $\mathrm{Al}$ active in $\mathrm{P}_{\mathrm{i}}$ retention could be in organic form (i.e., complexed to OM). Concetrations of OM-Al- $\mathrm{PO}_{4}{ }^{3-}$ complexes were significantly greater in swale microsites that experience longer hydroperiods and have higher OM contents than higher elevation ridges. Because total P concentrations are consistently higher in swale microsites, swales may function as 'hotspots' of P retention and transformation (Darke and Walbridge 2000, Stoeckel and Miller-Goodman 2001, Wright et al. 2001). 


\subsubsection{Phosphorus Retention and Transformation}

In both natural and constructed wetland soils and sediments, $\mathrm{P}$ retention capacity is controlled by both biological (plant uptake; microbial immobilization) and geochemical (P sorption) factors that affect the retention of both $\mathrm{P}_{\mathrm{i}}$ and $\mathrm{P}_{\mathrm{o}}$ forms (Richardson 1985, House et al. 1995, Nguyen et al. 1997). Suspended materials (particulate $P_{o}$ and $P_{i}$ adsorbed to mineral sediments) are removed from the water column during flooding by sedimentation, a physical process associated with a decline in the energy of floodwaters as they encounter increased resistance from the floodplain surface (Kleiss 1996, Hupp et al. 2005). Phosphorus retention in wetland soils is variously attributed to $\mathrm{P}$ sorption by $\mathrm{Al}$ and $\mathrm{Fe}$ minerals, OM-metal-P complexation, and/or interactions with clay minerals (Richardson 1985, Furumai et al. 1989, Paludan and Jensen 1995, Nguyen 2000, Hoffmann et al. 2009, Vu et al. 2010).

Soil Al and Fe minerals range from poorly ordered (amorphous or poorly crystalline) to highly structured (crystalline) forms. Because of their comparatively large surface area per unit soil volume, poorly crystalline (amorphous) forms of $\mathrm{Al}$ and $\mathrm{Fe}$, rather than more crystalline forms, have been suggested to control the adsorption and precipitation of dissolved $\mathrm{P}_{\mathrm{i}}$ in acid soils typical of FFs (Walbridge and Struthers 1993, Lockaby and Walbridge 1998). In addition to poorly crystalline mineral forms of $\mathrm{Al}$ and/or Fe, both metals form complexes with soil organic matter that can also sorb $\mathrm{P}_{\mathrm{i}}$ (Axt 1997, Darke et al. 1997, Lockaby and Walbridge 1998, Axt and Walbridge 1999, Darke and Walbridge 2000). The formation and/or persistence of OM-metal-P complexes is strongly influenced by flooding regime (Peretyazhko and Sposito 2005), suggesting a potential role for soil organic matter and OM-metal-P complexation in controlling P sorption in 
FFs. Many wetland studies have cited either total or oxalate-extractable $\mathrm{Al}$ as the best predictor of P sorption in wetland soils (Richardson 1985, Axt 1997, Darke and Walbridge 2000, Hogan et al. 2004). While the higher sediment loads carried by AL rivers and flood waters contribute to the greater observed rates of $\mathrm{P}$ retention in AL floodplains, the higher OM contents of $\mathrm{BW}$ river waters could promote $\mathrm{P}$ retention through the formation of OM-metal-P complexes.

Microorganisms can also retain (immobilize) a substantial amount of $\mathrm{P}_{\mathrm{i}}$, but this pool turns over rapidly, possibly due to the lysis of microbial cells during unfavorable environmental conditions (e.g., prolonged anaerobic conditions following a flooding event) (Richardson 1985, Walbridge and Vitousek 1987). Studies have shown that adding inorganic or low molecular weight organic $\mathrm{P}\left(\mathrm{P}_{\mathrm{o}}\right)$ to river waters can significantly increase bacterial abundance and production rates in both BW (Mallin et al. 2001, Mallin et al. 2004) and AL (Mohamed et al. 1998, Castillo et al. 2003) streams and rivers. Higher microbial biomass and bacterial production rates in BW (compared to $\mathrm{AL}$ ) rivers could also control $\mathrm{P}_{\mathrm{i}}$ retention and immobilization in these systems (Edwards et al. 1990, Basu and Pick 1997, Ensign and Mallin 2001, Ochs et al. 2010).

Phosphorus pools in river waters flowing into FFs are characteristically dominated by $\mathrm{P}_{\mathrm{i}}$ forms, while the $\mathrm{P}$ in outflow waters is predominantly $\mathrm{P}_{\mathrm{o}}$ (Elder 1985, Van Der Lee et al. 2004, Noe and Hupp 2007). Although some forms of $P_{o}$ can also cause the eutrophication of downstream waters (Chu 1946, Turner and Newman 2005, Dunne et al. 2006), in general these observations suggest that the transformation of $\mathrm{P}_{\mathrm{i}}$ to $\mathrm{P}_{\mathrm{o}}$ could be an important process occurring during flooding events that improves water quality downstream. Dissolved $\mathrm{P}_{\mathrm{i}}$ entering a FF via 
overbank flooding could be transformed to $\mathrm{P}_{\mathrm{o}}$ through biosynthetic pathways associated with plant and/or microbial uptake, or by OM-metal-P complexation (an abiotic process), prior to its export downstream (Cembella et al. 1984a, 1984b, Ridal and Moore 1993). The higher OM content, greater bacterial production rates, and higher microbial biomass of $\mathrm{BW}$ versus $\mathrm{AL}$ rivers could be partially responsible for the higher observed rates of $\mathrm{P}_{\mathrm{i}}$ transformation in BW rivers (Edwards and Meyer 1986, Edwards et al. 1990, Meyer 1990, Leff and Meyer 1991, Entry 2000, Mallin et al. 2004, Ochs et al. 2010), but in both AL and BW systems, the potential importance of OM-metal-P complexation must also be considered.

\subsubsection{Use of radioactive tracers and sequential fractionation schemes to assess $P$ retention and transformation processes in wetland soils}

Radioisotope studies have revealed important biological and geochemical processes in wetland $\mathrm{P}$ cycling, particularly with respect to $\mathrm{P}$ transformation processes in the water column of rivers, streams, and lakes, the retention and/or transformation of $\mathrm{P}$ in soils/sediments, and the soil/sediment-water interface of wetland ecosystems. Several studies have documented the importance of inorganic $\mathrm{P}$ (carrier-free $\mathrm{H}_{3}{ }^{32} \mathrm{PO}_{4}$ ) uptake by microbes in the water column, and the subsequent transformation and release of $P_{o}$ in rivers and streams (Newbold et al. 1983, Mulholland et al. 1985, Freeman and Lock 1995, Tate et al. 1995). The proportion of added $\mathrm{H}_{3}{ }^{32} \mathrm{PO}_{4}$ converted to $\mathrm{P}_{\mathrm{o}}$ form has been shown to correspond with increases in microbial biomass and/or TOC concentrations (as a proxy for OM content) in coastal river waters (Sabater et al. 1993, van Beusekom and Brockmann 1998, Pakulski et al. 2000, Flynn 2008). Transformation of inorganic to organic $\mathrm{P}$ in waters upon contact with surface soil/sediment has 
been documented in rice paddies that were drained and flooded with $\mathrm{Ca}\left(\mathrm{H}_{2} \mathrm{PO}_{4}\right)_{2}-\mathrm{H}_{2} \mathrm{O}$ (Sah and Mikkelsen 1986), and with $\mathrm{H}_{3}{ }^{32} \mathrm{PO}_{4}$ added to surface sediment suspensions of a shallow lake (Istvanovics 1993), who noted that the transformation of inorganic to organic P was completely inhibited in sterilized (formalin treated) sediment.

While applying radioisotope tracers to lake, stream, river, or floodwaters has effectively quantified the microbial contribution to $\mathrm{P}$ transformation in the water column, assessing the biological vs. geochemical contribution to $\mathrm{P}$ retention and transformation in soils requires combining ${ }^{32} \mathrm{P}$ addition with a detailed sequential fractionation technique. Combining such schemes (e.g., Hedley et al. 1982, Psenner et al. 1984, Paludan and Jensen 1995) with the partitioning of inorganic and organic ${ }^{32} \mathrm{P}$ in soil pools (Jayachandran et al. 1992), allows discrimination and quantification of the amounts of P retained and/or transformed in specific soil fractions (Furumai et al. 1989, Di et al. 1997, Nguyen 2000). Phosphorus fractionation is routinely used to characterize soil $\mathrm{P}_{\mathrm{i}}$ and $\mathrm{P}_{\mathrm{o}}$ (see reviews by Cross and Schlesinger 1995, Levy and Schlesinger 1999, Reddy et al. 1999), but only a few fractionation methods distinguish between inorganic $\mathrm{P}$ associated with $\mathrm{Al}$ oxides and reducible $\mathrm{Fe}$, as well as $\mathrm{P}$ bound to organic matter or humic acids, in wetland soils and sediments. One such scheme is a modified version of the Paludan and Jensen technique (Axt 1997, Hogan et al. 2004), that identifies P, Al, and Fe associated with six soil $\mathrm{P}$ fractions (Figure 3.1) -- water soluble $\mathrm{P}\left(\mathrm{H}_{2} \mathrm{O}-\mathrm{P}\right)$, bicarbonate dithionite extractable P (BD-P), sodium hydroxide extractable P (NaOH-P), humic acid P (HA$\mathrm{P}$ ), hydrochloric acid extractable $\mathrm{P}$ (HCl-P), and residual $\mathrm{P}$ (Res-P). The $\mathrm{H}_{2} \mathrm{O}-\mathrm{P}$ fraction estimates of loosely sorbed porewater P. The BD fraction extracts $\mathrm{P}$ adsorbed onto the surfaces of oxidized Fe and manganese. Sodium hydroxide-extractable P includes $\mathrm{P}$ sorbed onto the 
surfaces of clays and $\mathrm{Al}$ oxides. The HA fraction estimates $\mathrm{P}$ associated with organic matter (i.e., humic acids), isolated via acidification of the previous NaOH-P fraction followed by filtration of the organic matter precipitate. Hydrochloric acid P primarily accounts for calciumbound $\mathrm{P}$ in alkaline soils where $\mathrm{Ca}$ is a predominant cation, however, in acidic soils (typical of FFs) Ca-phosphates are unstable and $\mathrm{P}$ sorption to $\mathrm{Fe}$ and $\mathrm{Al}$ are favored (Freeman and Rowell 1981, Pierzynski et al. 1990). The Res-P fraction estimates both refractory organic and inorganic (i.e., occluded) P. While demonstrating the relative distribution of soil $\mathrm{P}$ into various inorganic and organic pools, fractionation schemes alone cannot provide information on the mechanisms of $\mathrm{P}$ retention and transformation. However, radioactive tracers (e.g., ${ }^{32} \mathrm{P}$ or ${ }^{33} \mathrm{P}$ ) combined with $\mathrm{P}$ fractionation can identify the specific retention and/or transformation of added P into these soil fractions (Furumai et al. 1989, Di et al. 1997, Nguyen 2000).

Several studies have described rapid and substantial incorporation of ${ }^{32} \mathrm{P}$ or ${ }^{33} \mathrm{P}$ into wetland soil/sediment P pools (Richardson and Marshall 1986, Furumai et al. 1989, Walbridge 1991, Cooke 1992, Istvanovics 1993, Nguyen 2000, Kellogg and Bridgham 2003, Scinto and Reddy 2003, Vu et al. 2010) and mineral soil P fractions (Di et al. 1997, He and Zhu 1997, Daroub et al. 2000, Blake et al. 2002, Buehler et al. 2002, Asfary et al. 2004, Bunemann et al. 2004, Olander and Vitousek 2004). However, few studies have used a detailed sequential P fractionation scheme (like the Paludan and Jensen 1995 procedure) to track the fate of ${ }^{32} \mathrm{P}$ introduced to wetland soils. In a sewage impacted (Nguyen 2000) and coastal (Vu et al. 2010) wetland, total ${ }^{32} \mathrm{P}$ recovered by sequential P fraction (i.e., Olsen and Sommers (1982); Tiessen and Moir (1993), respectively) was highest in the $\mathrm{NaOH}$ and bicarbonate extractable fractions. Phosphorus sorption capacities in wetland soils have been found to be largely correlated with 
amounts of $\mathrm{Al}$ and/or Fe extracted and soil clay fraction, or to a lesser extent soil $\mathrm{Ca}$ and $\mathrm{OM}$ content (Richardson 1985, Paludan and Jensen 1995, Hoffmann et al. 2009). The assumption is that the correlation between elements $(\mathrm{Al}, \mathrm{Fe}$, and $\mathrm{Ca})$ and/or clay content in each fraction of a sequential extraction procedure, or in associated extracts (total $\mathrm{Al}, \mathrm{Fe}, \mathrm{Ca}$, and $\mathrm{OM}$, clay content), indicates that $\mathrm{P}$ is likely bound to these reactants. Although added $\mathrm{P}$ bound by geochemical reactants in the less-available (BD-P, NaOH-P, HA-P, and HCl-P) and occluded (Res-P) soils fractions may also be important for long-term P storage in soils, many studies have reported that readily available or biologically mediated $\left(\mathrm{H}_{2} \mathrm{O}-\mathrm{P}\right.$, root/rhizosphere, and/or microbial) pools are equally important, due to their higher ${ }^{32} \mathrm{P}$ compared to $\mathrm{P}$ content (specific activity), indicative of the sink strengths of these pools and their effectiveness as short-term stores for P (Richardson 1985, Walbridge 1991, Nguyen 2000, Kellogg and Bridgham 2003, Vu et al. 2010).

\subsubsection{Objectives and Hypotheses}

Although it is well established that FFs remove inorganic P from incident surface and subsurface waters, storing it within the wetland ecosystem (retention), and/or converting it to less biologically active forms (transformation), the specific pathways of $\mathrm{P}$ retention and transformation, and their relative contributions to improving water quality, have not been unequivocally demonstrated. The overall objective of this research was to elucidate specific mechanisms of $\mathrm{P}$ retention and transformation in FFs in the SE US. To accomplish this objective, I conducted an artificial flooding experiment in the laboratory with intact soil cores collected from four FFs ( $\mathrm{n}=2$ per river type) in the SE US Coastal Plain, adding ${ }^{32} \mathrm{P}$ to river 
waters prior to experimental flooding, and then using a detailed sequential $\mathrm{P}$ fractionation technique (Psenner et al. 1984, Paludan and Jensen 1995), identifying inorganic and organic ${ }^{32} \mathrm{P}$ in each soil pool (Jayachandran et al. 1992), to determine if AL and BW FFs retain and/or transform $\mathrm{P}$ during flooding events, if river/floodplain type affects these processes, and to identify the dominant mechanism(s) whereby inorganic $\mathrm{P}$ received in floodwaters is either retained in soil or transformed in the water column and/or at the sediment/soil interface, prior to export downstream. Because they are considered to be hotspots of $\mathrm{P}$ retention/transformation (Darke and Walbridge 2000, Stoeckel and Miller-Goodman 2001, Wright et al. 2001), I used soils collected from swale microsites only. Soil cores were flooded with water collected from the adjacent river at each site, that was subsequently labeled with carrier free $\mathrm{H}_{3}{ }^{32} \mathrm{PO}_{4}$. I measured $\mathrm{P}$ and ${ }^{32} \mathrm{P}, \mathrm{Al}$, and $\mathrm{Fe}$ in each soil fraction, as determined by sequential fractionation (Paludan and Jensen 1995). I also estimated microbial biomass and root-/rhizosphere-associated $\mathrm{P}$ in soils. These data were used to test two hypotheses:

\section{1) Mechanisms of $P_{i}$ retention and transformation in FFs will be dominated by:}

1a. biological processes - e.g., retention via biotic uptake and subsequent transformation of $P_{i}$ to $P_{o}$.

1b. physico-chemical processes - e.g., complexation to OM via metal ( $\mathrm{Al}, \mathrm{Fe}$ ) ligands and/or sorption to Al and/or Fe cations.

1c. some combination of biological and physico-chemical processes.

$1 d$.

2) Processes of $P_{i}$ retention and/or transformation in river waters and soils:

2a. would differ predictably between AL and BW FF systems 
2b. would not differ between the two FF systems

\subsection{METHODS}

\subsubsection{Site Description, Sample Collection and Preparation}

Sites were selected in part, based on similarities in geological substrate (Dress et al., in preparation). The Pee Dee (PD) and Wateree (WT) sites are FFs found adjacent to AL river systems; the Black River (BL) and the Drowning Creek (DC) sites are floodplains adjacent to BW rivers. Although the probability of flooding in these sites is fairly predictable $(\sim 60 \%$ of annual flooding events occur between January and April), flooding events can vary in intensity, duration, and number from year-to-year. Due to an unusually dry winter in 2006 and spring in 2007, however, no flooding events were recorded at any of these sites prior to or during soil collection. Location, drainage area, soil type, and dominant woody vegetation for each site are described in Table 3.1.

Soils samples were collected in May 2006. At each site, intact soil cores $(n=18$ per site) were collected to a depth of $10 \mathrm{~cm}$ (excluding surface litter) in topographic lows (swales) using $5 \mathrm{~cm}$ diameter PVC cores. Cores were sealed at each end with rubber caps, and then stored on ice until returning to the laboratory, where they were stored at $4{ }^{\circ} \mathrm{C}$. For each site, two randomly selected cores were used to estimate the volume of labeled solution that would be needed to saturate soils, and ensure standing water above the soil surface, and four cores were randomly selected for pre-flooding measurements of $\mathrm{pH}$, moisture content, total $\mathrm{C}(\mathrm{TC}), \mathrm{N}, \mathrm{P}$, and soil $\mathrm{P}$ fractionation (methods described in detail below). Bulk density was estimated by measuring the 
field-moist weight of each core and converting it to dry-mass equivalent per unit volume of soil based on percent moisture and core volume.

\subsection{2 ${ }^{32} P$ radioactive tracer experiment:}

River water collected from each site was labeled with ${ }^{32} \mathrm{P}$ and then used to flood each soil core. These artificial flooding solutions were prepared by adding $185 \mathrm{MBq}$ of carrier-free $\mathrm{H}_{3}{ }^{32} \mathrm{PO}_{4}$ to $1.5 \mathrm{~L}$ of river water. Each core $(\mathrm{n}=8$ per site) was flooded with $150 \mathrm{~mL}$ of labeling solution, determined to completely flood cores as identified above, delivering approximately $7.0 \mathrm{MBq}$ of

${ }^{32} \mathrm{P}$ per core. The actual activity added to each core was subsequently determined by counting $0.5 \mathrm{~mL}$ aliquots of each solution following labeling. Following flooding, cores were incubated in darkness at room temperature in plexi-glass boxes for $40 \mathrm{~h}$ or $8 \mathrm{~d}(\mathrm{n}=4$ per incubation time) in the laboratory prior to soil $\mathrm{P}$ fractionation and ${ }^{32} \mathrm{P}$ analysis. Differences in the ${ }^{32} \mathrm{P}$ content of head-waters, drain-waters, and various soil $\mathrm{P}$ fractions were used to estimate the relative importance of $\mathrm{P}$ physico-chemical and biological retention and transformation processes occurring during flooding.

\subsubsection{Soil sequential extraction and analysis:}

At the end of each incubation period, $2 \mathrm{~mL}$ of head-water solution were removed for analysis from each core. Cores were then allowed to drain (by gravity or occasionaly with vaccum suction applied), drainwaters collected, and the soil in each core was extruded from its PVC container. Following homogenization and the removal of large roots and rhizomes, duplicate 0.5 
g dry weight equivalent (Pretty et al. 2003) subsamples of each soil sample were extracted using the sequential fractionation procedure of Paludan and Jensen (1995), as modified by Axt (1997) (Figure 3.1), and the $\mathrm{P}$ content and ${ }^{32} \mathrm{P}$ activity of each extract was estimated. Unless otherwise noted all extractions were performed in acid-washed $50 \mathrm{~mL}$ centrifuge tubes at $21{ }^{\circ} \mathrm{C}$ under continuous horizontal shaking. Water soluble $\mathrm{P}$ was extracted by shaking soil samples with 30 $\mathrm{mL}$ of deionized water for $1 \mathrm{hr}$. The residue from this step was extracted for $1 \mathrm{hr}$ with $30 \mathrm{~mL}$ of $0.1 \mathrm{M} \mathrm{Na}_{2} \mathrm{~S}_{2} \mathrm{O}_{4} / \mathrm{NaHCO}_{3}$, a strong reducing agent, to extract reductant-soluble (primarily Feand Mn-bound) P. Water soluble and bicarbonate/dithionate extracts received 1.2 and $5.6 \mathrm{~mL}$ of $\mathrm{H}_{2} \mathrm{SO}_{4}$, respectively, to prevent microbial activity and the precipitation of desorbed $\mathrm{P}$ in reaction. In the third step of the sequential extraction procedure, $\mathrm{P}$ associated with clay minerals and oxides of $\mathrm{Al}$ was extracted with $30 \mathrm{~mL}$ of $0.1 \mathrm{M} \mathrm{NaOH}$ for $16 \mathrm{hr}$. Humic acids were precipitated from the $\mathrm{NaOH}$ supernatant by acidification to $\mathrm{pH} 1$ with $1 \mathrm{M}_{2} \mathrm{SO}_{4}$, filtered, combusted at $500{ }^{\circ} \mathrm{C}$ in a muffle furnace overnight, and then boiled in $1 \mathrm{M} \mathrm{HCl}$ in block digester for $1 \mathrm{hr}$. Residual P was recovered by oven-drying the remaining soil residue, grinding it with a mortar and pestle, and then combusting it at $550{ }^{\circ} \mathrm{C}$ for $14 \mathrm{hr}$ in a muffle furnace. Approximately $0.2 \mathrm{~g}$ of this residue were extracted with $20 \mathrm{~mL}$ of $1 \mathrm{M} \mathrm{HCl}$ in a block digester for $1 \mathrm{hr}$. After each extraction, soil residues were centrifuged (15 min, $3400 \mathrm{rpm})$, filtered (Supor $0.45 \mu \mathrm{m}$ filters), and the supernatants stored at $4{ }^{\circ} \mathrm{C}$ for further analysis. Also after each extraction, remaining soil pellets were rinsed by shaking with $30 \mathrm{~mL}$ of deionized water for 5 min, centrifuging for $10 \mathrm{~min}$ at $3400 \mathrm{rpm}$, and then, filtering (using the same filters used for the original extraction), and the resulting supernatants combined with the original supernatants. Bicarbonate/dithionate and $\mathrm{NaOH}$ fractions were washed once with their respective reagents, and then subsequently with deionized water as described above. 


\subsubsection{Microbial biomass P:}

In addition to the six sequential fractions, $\mathrm{P}$ held in microbial biomass was estimated on separate, duplicate $0.5 \mathrm{~g}$ soil subsamples from each core by the chloroform-fumigation direct extraction technique (Brookes et al. 1982). One subsample was extracted with $30 \mathrm{~mL}$ of $0.5 \mathrm{M}$ sodium bicarbonate $\left(\mathrm{NaHCO}_{3}\right)$ for $16 \mathrm{hrs}$ to estimate available $\mathrm{P}$, while a second subsample was fumigated with $0.5 \mathrm{~mL}$ chloroform $\left(\mathrm{CHCl}_{3}\right)$ overnight, and then extracted with $\mathrm{NaHCO}_{3}$ as described above. Total $\mathrm{P}$ was determined for both samples colorimetrically after persulfate digestion of the solution (Qualls 1989), and microbial biomass P was calculated as the difference in P extracted from fumigated and non-fumigated sub-samples.

\subsubsection{Analytical and chemical analysis:}

Total ${ }^{32} \mathrm{P}$ radioactivity was measured on duplicate $0.5 \mathrm{~mL}$ aliquots of head- and drain-waters, and all soil extracts from both the sequential fractionation and microbial biomass $\mathrm{P}$ procedures, using a liquid scintillation counter (LS 6500 Liquid Scintillation Counter, Beckman Coulter, Fullerton, CA). Prior to counting, ${ }^{32} \mathrm{P}_{\mathrm{i}}$ was separated from ${ }^{32} \mathrm{P}_{\mathrm{o}}$ in head- and drain-waters, microbial-P extracts, and $\mathrm{H}_{2} \mathrm{O}, \mathrm{BD}, \mathrm{NaOH}$, and $\mathrm{HCl}$ soluble fractions, by the butanol separation method of Jayachandran et al. (1992). Aliquots $(5 \mathrm{~mL})$ of each extract were shaken with acidified ammonium molybdate dissolved in isobutanol. Inorganic ${ }^{32} \mathrm{P}$ complexed with ammonium molybdate is soluble in isobutanol; ${ }^{32} \mathrm{P}_{\mathrm{o}}$ remains in the aqueous phase. Inorganic ${ }^{32} \mathrm{P}$ activity was measured in duplicate extractions $(0.5 \mathrm{~mL})$ from the isobutanol phase by liquid scintillation as described above. The proportion of ${ }^{32} \mathrm{P}_{\mathrm{o}}$ was determined as the difference between total ${ }^{32} \mathrm{P}$ and MR- ${ }^{32} \mathrm{P}$. The ${ }^{32} \mathrm{P}$ radioactivity (counts per minute, $\mathrm{cpm}$ ) was measured by $\beta$ counting using the 
external standard method of quench correction. Total ${ }^{32} \mathrm{P}$ incorporated in roots and larger organic matter (separated from the bulk soil in each core) was measured by Cerenkov scintillation counting. Activities were adjusted for background and decay using the built-in ${ }^{32} \mathrm{P}$ half-life correction in the LS 6500 Liquid Scintillation Counter. Total P in labeled river-, headand drain-waters, and in all soil $\mathrm{P}$ fractions, was determined after persulfate digestion of each extract (Qualls 1989). Digested extracts were then and analyzed for inorganic P using the molybdate blue color reaction (Murphy and Riley 1962) on an Autoanalyzer 3 colorimeter (Method \#G-175-96, Braun \& Lubbe, Norderstedt, Germany). Organic P for these fractions was then estimated as the difference in molybdate reactive $\mathrm{P}$ (MRP) in digested vs. non-digested solution.

Total $\mathrm{Al}$ and $\mathrm{Fe}$ concentrations in soil extracts from the sequential fractionation procedure (both ${ }^{32} \mathrm{P}-$ labeled and non-labeled cores) were measured on a Varian Spectra 220FS atomic absorption spectrophotometer with a GTA-110 graphite tube atomizer (Varian Corp. Adelaide, Au). Soil $\mathrm{pH}$ was measured on fresh soils in a 1:2 slurry with deionized water. Total soil $\mathrm{P}$ was determined on duplicate sub-samples $(0.2 \mathrm{~g})$ from each ${ }^{32} \mathrm{P}$-labeled and non-labeled core using a modified Kjeldahl digest technique (Parkinson and Allen 1975). Total P in the digest solutions was measured colorimetrically by the molybdate blue reaction (Method \# G-189-97, Braun \& Lubbe, Norderstedt, Germany). TOC and TN concentrations in unfiltered river water samples were measured on a TOC-V/TNM-1 analyzer (Shimadzu Scientific Instruments, Columbia, MD). Soil TC and TN concentrations were measured on dried soils from each core by dry combustion on a NC2500 elemental analyzer (ThermoQuest Italia S.P.A, Italy). Subsamples (10 g) of wet soil from each core were dried $\left(110^{\circ} \mathrm{C}\right)$ to a constant mass to determine soil moisture content. Soil texture was determined on one composite sample for each site (non-labeled cores) 
by the Bouyoucos method (Bouyoucos 1962).

\subsubsection{Statistical Analysis}

Significant differences in ${ }^{32} \mathrm{P}$ activity $\left(\right.$ core $\left.^{-1}\right), \mathrm{P}$ concentrations $\left(\mathrm{g} \mathrm{m}^{-2}\right)$, specific activity $\left(\mathrm{SA}={ }^{32} \mathrm{P} / \mathrm{P}\right), \mathrm{Al}, \mathrm{Fe}, \mathrm{N}, \mathrm{C}$, and soil moisture at each site were determined by two-way ANOVA $(\alpha=0.05)$, with main effects of floodplain type (AL vs. BW) and incubation time (unlabelled, 0 h, and $8 \mathrm{~d}$ ), with site nested within floodplain type, and the interaction terms. Data were log transformed where necessary to meet the assumption of normality. Relationships between soil properties, $\mathrm{Al}, \mathrm{Fe}$, and ${ }^{32} \mathrm{P}$ activity, $\mathrm{P}$ concentrations, and SA were determined by Pearson's correlation analysis with Bonferroni probabilities reported. All statistical analyses were performed using SYSTAT version 12 (SSI, San Jose, CA). 


\subsection{RESULTS}

\subsubsection{General characteristics of river water and ${ }^{32} P$ addition}

River water $\mathrm{pH}$ averaged 5.6, was highest in the WT (7.1) and lowest in DC (pH 5.0) (Table 3.2). Average $\mathrm{pH}$ in AL rivers was 7.0, and was significantly higher than $\mathrm{pH}$ in $\mathrm{BW}$ rivers (5.7). Total dissolved P concentrations ranged from 12.9 (DC river) to $61.2(\mathrm{BL}) \mu \mathrm{g} \mathrm{L}^{-1}$. Average TDP, MRP, and $\mathrm{P}_{\mathrm{o}}$ did not differ significantly between $\mathrm{AL}$ and $\mathrm{BW}$ rivers. Total $\mathrm{N}$ concentrations in river waters averaged $0.85 \pm 0.1 \mathrm{mg} \mathrm{L}^{-1}$, and did not differ significantly between AL and BW rivers. However, river water TOC concentrations were significantly higher in BW compared to AL systems (Table 3.2).

Within $2 \mathrm{~h}$ of adding an average $190 \mu \mathrm{Ci}$ of carrier-free $\mathrm{H}_{3}{ }^{32} \mathrm{PO}_{4}$ to each $1.5 \mathrm{~L}$ river water sample, 24 to $77 \%$ of the $\mathrm{H}_{3}{ }^{32} \mathrm{PO}_{4}$ added to $\mathrm{BW}$ river waters was converted to organic form (Table 3.2), but $100 \%$ of the ${ }^{32} \mathrm{P}$ added to AL river waters remained in inorganic form. Both total ${ }^{32} \mathrm{P}$ and $\mathrm{MR}_{-}{ }^{32} \mathrm{P}$ concentrations were significantly higher in $\mathrm{AL}$ compared to $\mathrm{BW}$ river waters.

\subsubsection{Head and drain water and soil $P$ over $40 \mathrm{~h}$ and $8 \mathrm{~d}$ of incubation}

Average total $\mathrm{P}$ contents and ${ }^{32} \mathrm{P}$ recoveries in head- and drain-waters or associated with the roots and microbial biomass did not differ significantly by floodplain type, site, or incubation time (Table 3.3). Averaged across all cores, TDP was significantly higher in drainwaters $(70.7 \pm 6.8$

$\left.\mu \mathrm{g} \mathrm{L}^{-1}\right)$ than in headwaters $\left(27.2 \pm 5.2 \mu \mathrm{g} \mathrm{L}^{-1}\right)$. Total soil $\mathrm{P}$ estimate as the sum of $\mathrm{P}$ extracted in 
the six soil fractions or by Kjeldahl digest was significantly higher at the WT, but similar in PD, BL, and DC soils (Table 3.3 and 3.4). Total soil P estimated by these two techniques did not differ significantly (paired t-test, $p=0.496$ ).

Average total ${ }^{32} \mathrm{P}$ recoveries in soil fractions (sum of $\mathrm{P}$ extracted from the six soil fractions in the Paludan and Jensen scheme minus microbial biomass P) did not differ significantly by floodplain type, site, or incubation time (Table 3.3). Across all soil cores, only 12 and $0.5 \%$ of the total ${ }^{32} \mathrm{P}$ added was recovered from head- and drain-waters, respectively. The remaining $87.5 \%$ of added ${ }^{32} \mathrm{P}$ was recovered in soils, distributed within the soil fractions $(72.7 \%)$, microbial biomass $(8.9$ $\%$ ) and roots $(5.9 \%)$. A majority of the ${ }^{32} \mathrm{P}$ recovered in headwaters was ${ }^{32} \mathrm{P}_{\mathrm{o}}$, averaging $68 \%$ vs. $80 \%$ of total ${ }^{32} \mathrm{P}$ activity in the headwaters of AL and BW cores, respectively (Table 3.7). Whereas the proportion of ${ }^{32} \mathrm{P}_{\mathrm{o}}$ vs. ${ }^{32} \mathrm{P}_{\mathrm{i}}$ recovered in the remaining core (sum of $\mathrm{P}$ in the soil fractions + microbial biomass + roots + drainwaters), averaged 69 and $31 \%$ in AL cores and 53 vs. $47 \%$ in BW cores.

\subsubsection{General chemistry and distribution of $P$ in soil fractions:}

\subsubsection{General soil chemistry}

Similar to river waters, $\mathrm{pH}$ was significantly higher in AL (5.1) than in BW (4.8) soils (Table 3.4). Soil $\mathrm{pH}$ in non-flooded cores was 4.7 and increased significantly in cores inundated with labeling solution, measuring 5.0 at both $40 \mathrm{~h}$ and $8 \mathrm{~d}$ after inundation. Total soil $\mathrm{C}$ and $\mathrm{N}$ concentrations averaged $2,469.6 \pm 146.1 \mathrm{~g} \mathrm{~m}^{-2}$ and $217.8 \pm 23.9 \mathrm{~g} \mathrm{~m}^{-2}$ respectively across all 
sites, and were not significantly different as a function of floodplain type, site, or incubation time. Average clay content in AL soils $(49.3 \pm 2.8 \%)$ was significantly higher (t-test, $P<0.008)$ than in BW soils $(37.1 \pm 3.3 \%)$. Moisture content was highest in BL soils, followed by WT, PD and DC soils (Table 3.4).

\subsubsection{P content and ${ }^{32} \mathrm{P}$ recovered in soil fractionation scheme}

The majority of soil $\mathrm{P}$ was found in the $\mathrm{NaOH}$-extractable fraction $(47.2 \pm 1.4 \%)$, followed by $\operatorname{Res}(20.2 \pm 1.9 \%) \approx$ BD- $(18.7 \pm 2.2 \%)>\mathrm{HA}-(12.0 \pm 0.6 \%)>>\mathrm{HCl}-(1.9 \pm 0.1 \%) \approx \mathrm{H}_{2} \mathrm{O}-$ extractable $(0.1 \pm 0.0 \%)$ fractions (Tables 3.5). Concentrations of $\mathrm{H}_{2} \mathrm{O}-\mathrm{P}, \mathrm{NaOH}-\mathrm{P}, \mathrm{HA}-\mathrm{P}$, HCl-P, and Res-P differed significantly among the four sites, and similar to trends seen with total soil P, concentrations were highest at the WT site, followed by the BL and PD sites, and lowest at the DC site. Flooding of soil cores resulted in a significant decrease in BD-extractable $\mathrm{P}$ in cores inundated for $8 \mathrm{~d}$. The $\mathrm{P}$ in the $\mathrm{NaOH}$-extractable fraction was predominantly organic, $\mathrm{P}$ pools in the $\mathrm{H}_{2} \mathrm{O}$-extractable fraction was predominantly inorganic (Tables 3.7).

Similar to trends seen with the dominant soil $\mathrm{P}$ fractions, the majority of added ${ }^{32} \mathrm{P}$ was recovered in the $\mathrm{NaOH}$-extractable, followed by the $\mathrm{BD}->$ Res $\approx \mathrm{HA}->>\mathrm{HCl}-\approx \mathrm{H}_{2} \mathrm{O}-$

extractable fractions (Tables 3.6). Average total ${ }^{32} \mathrm{P}$ recoveries in individual soil fractions did not differ significantly by floodplain type, site, or incubation time. The ${ }^{32} \mathrm{P}_{\mathrm{o}}$ content $(\%$ of total ${ }^{32} \mathrm{P}$ ) ranged from 2.9 to $28 \%$ across all fractions; ${ }^{32} \mathrm{P}$ associated with the $\mathrm{H}_{2} \mathrm{O}-, \mathrm{BD}-, \mathrm{NaOH}-$, and $\mathrm{HCl}$-extracatable fractions was predominantly inorganic (Tables 3.7). 


\subsubsection{Specific Activity $\left({ }^{32} \mathrm{P} / \mathrm{P}\right.$ ratio) in soils}

Specific activities ( $\mathrm{SA}={ }^{32} \mathrm{P} / \mathrm{P}$ ratio) were used to assess whether soil $\mathrm{P}$ pools (soil $\mathrm{P}$ fractions, microbial biomass $\mathrm{P}$, and root $\mathrm{P}$ ) had reached isotopic equilibrium (Table 3.8). Averaged across all soil cores, SAs were highest in the $\mathrm{H}_{2} \mathrm{O}$ extractable fraction, followed by root biomass $>>$ the microbial pool, followed by the $\mathrm{BD} \approx \mathrm{NaOH} \approx \mathrm{HA} \approx \mathrm{HCl} \approx$ Res soil fractions. While average SAs across all soil cores did not significantly differ in individual soil fractions/pools between 40 $\mathrm{h}$ and $8 \mathrm{~d}$ of flooding, statistically significant differences in SAs were observed within each site over the incubation period (ANOVA, site $\times$ incubation interaction, Appendix Table 3.6, Figure 3.2). The $\mathrm{SAs}$ in the $\mathrm{H}_{2} \mathrm{O}$ and $\mathrm{HCl}$ extractable fractions in the PD soils, and the microbial biomass and Res-P fractions in the DC soils, decreased significantly over $8 \mathrm{~d}$ of flooding; similar decreases were also observed in $\mathrm{H}_{2} \mathrm{O}-\mathrm{P}_{\mathrm{i}}\left(\mathrm{H}_{2} \mathrm{O}-\mathrm{SA}_{\mathrm{i}}\right)$ and microbial $\mathrm{P}_{\mathrm{o}}$ (microbial-SA $\mathrm{A}_{\mathrm{o}}$ ) pools in both the PD and DC soils (Appendix Table 3.6, Figure 3.2 a, d).

\subsubsection{Distribution of total Al and Fe in soil fractions}

Soil Al content averaged 2,489.3 $\pm 387.1 \mathrm{~g} \mathrm{~m}^{-2}$, and was significantly higher (paired t-test, $P<$ $0.000)$ than soil $\mathrm{Fe}$ content $\left(1,656.8 \pm 235.2 \mathrm{~g} \mathrm{~m}^{-2}\right)$, largely due to significantly higher $\mathrm{Al}$ compared to $\mathrm{Fe}$ concentrations in the Res, $\mathrm{NaOH}$, and $\mathrm{H}_{2} \mathrm{O}$ extractable fractions (paired t-test, $P$ $<0.000$ ) (Table 3.9). Fe extracted from the $\mathrm{BD}$ and $\mathrm{HCl}$ fractions was significantly larger than the $\mathrm{Al}$ content in these fractions (paired t-test, $P<0.000$ ). Concentrations of $\mathrm{Al}$ and $\mathrm{Fe}$ extracted in the HA fraction were not statistically different (paired t-test, $P<0.910$ ). Total Al (estimated as the sum of the six soil fractions) was significantly higher in WT, as compared to BL, PD, and DC soil (ANOVA, site effect: $F=14.097, p=0.012)$. The majority $(71.9 \%)$ of $\mathrm{Al}$ was found in 
the Res $\left(2247.9 \pm 377.0 \mathrm{~g} \mathrm{~m}^{-2}\right)$ fraction, followed by the $\mathrm{NaOH}(11.2 \%)>\mathrm{HA}(4.8 \%) \approx \mathrm{HCl}$ $(4.7 \%)>>\mathrm{BD}(4.5 \%)>>>\mathrm{H}_{2} \mathrm{O}(2.9 \%)$ extractable fractions (Table 3.9). Total $\mathrm{Al}$ and $\mathrm{Al}$ extracted from the $\mathrm{HA}, \mathrm{HCl}$, and Res fractions were not significantly different in non-flooded cores versus cores flooded for $40 \mathrm{~h}$ or $8 \mathrm{~d}$. Average $\mathrm{Al}$ extracted from the $\mathrm{NaOH}, \mathrm{BD}$, and $\mathrm{H}_{2} \mathrm{O}$ fractions was highest in non-flooded cores, but decreased significantly in flooded cores (Table 3.9).

The majority of soil Fe was found in the BD-extractable (43\% of total soil Fe) and Res (37.6 \%) fractions, followed by the $\mathrm{HCl}-(13.1 \%)$, HA- $(3.3 \%), \mathrm{NaOH}-(1.9 \%)$, and $\mathrm{H}_{2} \mathrm{O}$-extractable $(0.9 \%)$ fractions (Table 3.9). Fe extracted from soil fractions were generally higher in AL compared to BW soils. Average Fe extracted from the BD and HA fractions of AL floodplain soils was $951.3 \pm 80.5$ and $79.9 \pm 9.2 \mathrm{~g} \mathrm{~m}^{-2}$, respectively; these Fe concentrations in AL soils were significantly higher than Fe concentrations in the same fractions of BW soils $(203.5 \pm 30.8$ and $12.8 \pm 2.1 \mathrm{~g} \mathrm{~m}^{-2}$, respectively). Iron concentrations in the $\mathrm{H}_{2} \mathrm{O}$ and $\mathrm{HCl}$ fractions were highest in non-flooded cores, and decreased significantly in flooded cores (Table 3.9).

\subsubsection{Correlations}

Stepwise linear regression analysis was conducted on molar ratios of $\mathrm{Fe}: \mathrm{P} /{ }^{32} \mathrm{P}$ vs. $\mathrm{Al}: \mathrm{P} /{ }^{32} \mathrm{P}, \mathrm{Fe}: \mathrm{P}$ vs. Al:P, and $\mathrm{Fe}:{ }^{32} \mathrm{P}$ vs. $\mathrm{Al}:{ }^{32} \mathrm{P}$ to examine relationships between total $\mathrm{Al}$ or $\mathrm{Fe}$ and $\mathrm{P}$ content or ${ }^{32} \mathrm{P}$ recovered in each soil fraction. Results of these analyses are presented in Table 3.10. Both total $\mathrm{P}$ and ${ }^{32} \mathrm{P}$ in the $\mathrm{H}_{2} \mathrm{O}-\mathrm{P}$ fraction were strongly correlated with total $\mathrm{Al}$ extracted in the same fraction $\left(r^{2}=0.92\right.$ and 0.86 , respectively, Figure 3.3 a-b). Total ${ }^{32} \mathrm{P}$ recovered was significantly 
positively correlated with total $\mathrm{Al}$ extracted in the $\mathrm{NaOH}-\mathrm{P}$ fraction $\left(\mathrm{r}^{2}=0.53\right.$, Figure $\left.3.3 \mathrm{c}\right)$, and the proportion of ${ }^{32} \mathrm{P}_{\mathrm{i}}$ associated with this fraction was strongly correlated with soil clay content $\left(\mathrm{r}^{2}=0.89\right)$ (Figure $\left.3.3 \mathrm{~d}\right)$. A significant correlation $\left(\mathrm{r}^{2}=0.84\right)$ also was observed between total ${ }^{32} \mathrm{P}$ recovered and total $\mathrm{Al}$ extracted from the Res-P fraction (Figure $3.3 \mathrm{e}$ ). Total ${ }^{32} \mathrm{P}$ recovered was significantly positively correlated with total $\mathrm{Fe}$ in the BD- and HCl-extractable fractions $\left(\mathrm{r}^{2}\right.$ $=0.72$ and 0.66 , respectively, Figure $3.3 \mathrm{f}-\mathrm{g})$. Total $\mathrm{Al}$ and Fe extracted and total ${ }^{32} \mathrm{P}$ extracted in the HA-P fraction was significantly positively correlated, and by removing a single outlier point (circled, Figure $3.3 \mathrm{~h}$ ), the correlation between $\mathrm{Fe}:{ }^{32} \mathrm{P}$ and $\mathrm{Al}:{ }^{32} \mathrm{P}$ associated with this fraction decreased from $\mathrm{a} \mathrm{r}^{2}$ value of 0.82 to 0.38 (Table 3.10). 


\subsection{DISCUSSION}

\subsubsection{General soil chemistry}

Total soil P, C, and $\mathrm{N}$ were within the ranges reported for forested wetland soils in the southern US (c.f. Lockaby and Walbridge 1998, Bedford et al. 1999) (Table 3.3). Lockaby and Walbridge (1998) used differences in $\mathrm{N}$ and $\mathrm{P}$ stoichiometric ratios in litterfall to estimate nutrient limitation in FF of the SE US, and suggested that N:P ratios $>12$ or $<12$ represent $\mathrm{P}$ and $\mathrm{N}$ limitation to productivity, respectively. Molar N:P ratios in soil cores ranged from 1.3-29.7, and were generally higher in BW (average $\mathrm{N}: \mathrm{P}$ of 13) compared to AL FF (N:P=3), suggesting that AL soils are likely to be more strongly N limited than BW soils (Lockaby and Walbridge 1998).

Total P estimated by sequential fractionation was predominantly associated with the $\mathrm{NaOH}-$, Res, BD-, and HA-extractable fractions (Table 3.5). A similar rank order in dominant soil P fractions has been observed in other forested wetland (Axt and Walbridge 1999, D'Angelo 2005, Loeb et al. 2008), freshwater wetland (Ivanoff et al. 1998, Paludan and Morris 1999, Nguyen 2000, Qiu and McComb 2000, Hogan et al. 2004, Surridge et al. 2007), and coastal marsh soils (Paludan and Morris 1999, Morse et al. 2004), as well as lake sediments (Reitzel et al. 2006, Hu et al. 2007, Lake et al. 2007). Although total P content did not differ between non-flooded and flooded soils, a small but significant release of P from the BD-extractable fraction was observed in flooded cores. The release of $\mathrm{P}$ from this fraction may have contributed to the significant increase of total dissolved P observed in drainwaters compared to headwaters. The molar ratio of $\mathrm{Fe}: \mathrm{Al}$ was 27 in the $\mathrm{BD}$ extractable fraction, and although total Fe did not differ significantly over the flooding period, flood induced reduction and dissolution of Fe (III) phosphates to 
soluble Fe (Bossio et al. 2006) may have resulted in reduced P sorption capacity within this fraction (Kuo and Mikkelsen 1979, Paludan and Jensen 1995, Darke et al. 1997, Lockaby and Walbridge 1998, Darke and Walbridge 2000, Hogan et al. 2004, Quintero et al. 2007, Surridge et al. 2007, Loeb et al. 2008). Total $\mathrm{Fe}$ content in the $\mathrm{H}_{2} \mathrm{O}$ and $\mathrm{HCl}$ extractable fractions, however, decreased significantly in flooded cores, and may have contributed to reduced $\mathrm{P}$ sorption capacity in these fractions. Decreases in $\mathrm{Al}$ extracted from the $\mathrm{H}_{2} \mathrm{O}, \mathrm{BD}$, and $\mathrm{NaOH}$ fractions also were observed. Darke and Walbridge (2000) reported decreases in total Al with seasonal flooding in the Ogeechee FF soils, and suggested that this loss may have occurred due to the suspension of particulates and/or the solubilization of $\mathrm{Al}$ with flooding. In the current study, total $\mathrm{Al}$ and $\mathrm{Fe}$ (sum of all soil fractions) did not differ between non-flooded cores and cores flooded for $40 \mathrm{~h}$ and $8 \mathrm{~d}$, and as such there were no net losses of $\mathrm{Al}$ and $\mathrm{Fe}$ from the soils (to drain- or headwaters) in mesocosm cores.

\subsection{3 ${ }^{32} P$ transformation in river-, head-, and drain-waters}

Total dissolved $\mathrm{P}$ and MRP concentrations were similar in water samples collected from the AL and $\mathrm{BW}$ rivers, but within $2 \mathrm{hr}$ of ${ }^{32} \mathrm{P}$ addition, up to $77 \%$ of added ${ }^{32} \mathrm{PO}_{4}{ }^{3-}$ was transformed to organic form in $\mathrm{BW}$ river waters. In $\mathrm{Al}$ river waters, all added ${ }^{32} \mathrm{P}$ remained in inorganic form. As predicted (in hypothesis $2 a$ ) the transformation of ${ }^{32} \mathrm{PO}_{4}{ }^{3-}$ to ${ }^{32} \mathrm{P}_{\mathrm{o}}$ occurred only in $\mathrm{BW}$ river waters where TOC concentrations were significantly higher than in Al river waters. The relatively low TOC content in AL compared to BW river waters, which potentially includes bacterial cells associated as particulate organic $\mathrm{C}$ in the water column, may have not been

sufficient for detectable rates of $\mathrm{P}$ transformation in the $2 \mathrm{~h}$ post ${ }^{32} \mathrm{P}$-label addition. As a proxy 
for OM content, TOC in both $\mathrm{AL}$ and $\mathrm{BW}$ rivers was significantly correlated with the proportion of ${ }^{32} \mathrm{P}_{\mathrm{o}}$ in river waters $\left(\mathrm{r}^{2}=0.81, F=66.313, P<0.000\right)$, suggesting that transformation of $\mathrm{P}$ in the water column may be due to microbial uptake of ${ }^{32} \mathrm{PO}_{4}{ }^{3-}$ and subsequent release as ${ }^{32} \mathrm{P}_{0}$, and/or formation of OM-metal- ${ }^{32} \mathrm{P}$ complexes.

In the liquid-extraction method developed by Jayachandran et al. (1992), isobutanol and acidified molybdate used for partitioning inorganic from organic ${ }^{32} \mathrm{P}$, free orthophosphate reacts with molybdenum forming phosphomolybdate which is extracted and quantified in the isobutanol phase, whereas ${ }^{32} \mathrm{P}_{\mathrm{o}}$ remains in the aqueous phase. Inorganic ${ }^{32} \mathrm{P}$ activity in the isobutanol phase was measured by liquid scintillation, and the proportion of ${ }^{32} \mathrm{P}_{\mathrm{o}}$ was determined as the difference between total ${ }^{32} \mathrm{P}$ and $\mathrm{MR}-{ }^{32} \mathrm{P}$. The use of acidified molybdate in this procedure may result in two potentially important sources of error. First, complex inorganic $\mathrm{P}$ forms such as pyrophosphate and polyphosphate (Figure $2.2 \mathbf{b}$-c) are not molybdate-reactive, and are therefore included in the organic P fraction (McKelvie et al. 1995, Turner et al. 2005). Second, a majority of $\mathrm{P}$ complexed with $\mathrm{OM}$ via metal $(\mathrm{Al}, \mathrm{Fe})$ ligands $(\mathrm{OM}-$ metal-P) is released by hydrolysis upon reaction with molybdate, and OM-metal-P is determined as free orthophosphate in solution (Bedrock et al. 1997, Gerke 2010). These errors are usually assumed to be negligible in freshwaters, although neither sources of error has been investigated systematically for river waters. While a majority of the ${ }^{32} \mathrm{P}_{\mathrm{o}}$ detected using this method may have resulted from biological transformation and are considered "true" organic P compounds, I can only conclude that the mechanisms involved in the transformation of ${ }^{32} \mathrm{P}-$ label in $\mathrm{BW}$ rivers are a combination (as stated in hypothesis 1c) of the biotic uptake of ${ }^{32} \mathrm{PO}_{4}{ }^{3-}$ and subsequent release as ${ }^{32} \mathrm{P}_{\mathrm{o}}$ (hypothesis $1 a$ ) as well as the OM-metal- ${ }^{32} \mathrm{P}$ complexation (hypothesis $1 b$ ). 
Sabater et al. (1993) observed a high degree of correspondence between bacterial numbers and high/intermediate molecular weight DOC in a BW river (Ogeechee River, GA). The higher OM content, and larger microbial biomass and bacterial production rates documented in $\mathrm{BW}$ vs. $\mathrm{AL}$ rivers (Edwards and Meyer 1986, Leff and Meyer 1991, Basu and Pick 1997, Ensign and Mallin 2001, Castillo et al. 2004, Ochs et al. 2010) may have contributed to the significantly larger proportion of ${ }^{32} \mathrm{PO}_{4}{ }^{3-}$ transformed to ${ }^{32} \mathrm{P}_{\mathrm{o}}$ forms in $\mathrm{BW}$ compared to AL rivers. As much as 90 $\%$ of added ${ }^{32} \mathrm{PO}_{4}{ }^{3-}$ has been shown to be removed from the water column, $>50 \%$ of which may be incorporated in microbial biomass (Newbold et al. 1983, Mulholland et al. 1985, Freeman and Lock 1995, Tate et al. 1995).

Upon flooding mesocosm cores, sustained inorganic to organic ${ }^{32} \mathrm{P}$ transformation was observed in ${ }^{32} \mathrm{P}$-labeled river water (headwaters) used to flood cores. A majority of the ${ }^{32} \mathrm{P}$ in headwaters was converted to organic form, averaging $71 \%$ of total ${ }^{32} \mathrm{P}$ activity after $40 \mathrm{~h}$ and $77 \%$ after $8 \mathrm{~d}$ of incubation across all AL and BW cores. Similar to transformations observed within the water column in BW river water samples, upon contact with the soil surface nearly all added ${ }^{32} \mathrm{PO}_{4}{ }^{3-}$ was transformed to ${ }^{32} \mathrm{P}_{\mathrm{o}}$ in both $\mathrm{AL}(68 \%)$ and $\mathrm{BW}(80 \%)$ headwaters. Although a majority of the ${ }^{32} \mathrm{P}_{\mathrm{o}}$ in $\mathrm{BW}$ headwaters resulted from transformations in river waters occurring within $2 \mathrm{~h}$ post labeling, river waters used to flood $\mathrm{AL}$ soil cores contained only inorganic ${ }^{32} \mathrm{P}$, the subsequent transformation to ${ }^{32} \mathrm{P}_{\mathrm{o}}$ may be attributed to increased biogeochemical reactivity on contact with the soil surface or due to microbial uptake. The proportion of ${ }^{32} \mathrm{P}_{\mathrm{o}}$ increased significantly in headwaters as compared to river waters, upon contact with the soil surface, 
averaging $18 \%$ (DC cores), $41 \%$ (Brandao et al. 2011), $58 \%$ (WT), and by as much as $85 \%$ (PD) in cores (two-sample t-test, $p<0.000$ ). Microbial activity (estimated by the amount of total ${ }^{32} \mathrm{P}$ and the proportion of ${ }^{32} \mathrm{P}_{\mathrm{o}}$ incorporated in microbial biomass, Table 3.3 and 3.7, respectively) and total soil C did not differ significantly between AL and BW soils, suggesting similar transformation rates in $\mathrm{AL}$ and $\mathrm{BW}$ systems. Rapid transformation of $\mathrm{P}_{\mathrm{i}}$ on contact with surface soil/sediment has been documented in rice paddies that were drained and flooded with $\mathrm{Ca}\left(\mathrm{H}_{2} \mathrm{PO}_{4}\right)_{2}-\mathrm{H}_{2} \mathrm{O}$ (Sah and Mikkelsen 1986), and with carrier-free $\mathrm{H}_{3}{ }^{32} \mathrm{PO}_{4}$ added to surface sediment suspensions of a shallow lake (Istvanovics 1993). Istvanovics (1993) noted that ${ }^{32} \mathrm{P}_{\mathrm{i}}$ transformation to ${ }^{32} \mathrm{P}_{\mathrm{o}}$ was completely inhibited in sterilized (formalin-treated) sediment, highlighting the importance of biological P transformation. In Chapter 2, I observed higher NMR-visible total DIP concentrations in natural floodwaters entering the floodplain, along with the net increase in biogenic DOP forms in outflow waters. These results in addition to the transformation or ${ }^{32} \mathrm{P}_{\mathrm{i}}$ to ${ }^{32} \mathrm{P}_{\mathrm{o}}$ in headwaters (observed in the current study) upon contact with the soil surface are consistent with the theory that FFs regulate river water nutrient concentrations through the biotic transformation of nutrients during flooding events (Lockaby and Walbridge 1998, Hupp et al. 2005). Although ${ }^{32} \mathrm{P}$ transformation has been observed in other freshwater wetlands (Sah and Mikkelsen 1986, Istvanovics 1993), this study presents primary insight into the rapid and substantial transformation of inorganic to organic $\mathrm{P}$ in the water column, within the river waters in BW systems, and upon contact with the associated FF soils in AL systems. These findings underline the importance of these unique wetlands, their capacity to improve water quality downstream, as well as key differences in AL and BW system functions in the SE US. 
Total ${ }^{32} \mathrm{P}$ recovered in headwaters averaged $12 \%$ across all cores and was significantly lower in drainwaters $(0.5 \%)$, amounting to a 22 fold decrease over the $8 \mathrm{~d}$ incubation period. Similar to headwaters, a majority of the ${ }^{32} \mathrm{P}$ recovered in drainwaters was organic, averaging $82 \%$ of total ${ }^{32} \mathrm{P}$ activity. This helps to clarify that ${ }^{32} \mathrm{PO}_{4}{ }^{3-}$ transformed to ${ }^{32} \mathrm{P}_{\mathrm{o}}$ is preferentially released to drainwaters, and that this occurs in both $\mathrm{AL}$ and BW soils. The proportion of ${ }^{32} \mathrm{P}_{\mathrm{i}}$ and ${ }^{32} \mathrm{P}_{\mathrm{o}}$ in cores (sum of $\mathrm{P}$ in the soil fractions + microbial biomass + roots + drainwaters) averaged 69 and $31 \%$ in AL compared to 53 and $47 \%$ of total ${ }^{32} \mathrm{P}$ recovered in BW cores. These results suggest that while physico-chemical processes (hypothesis $1 b$ ) dominate the retention of $\mathrm{P}$ in $\mathrm{AL}$ soils, $\mathrm{P}$ transformation and retention in BW systems are likely a combination of both biological and physico-chemical processes (hypothesis 1c) in BW soils.

\subsubsection{Distribution and mechanism(s) of ${ }^{32} P$ retention in soils:}

Despite transformation of $\mathrm{P}_{\mathrm{o}}$, a substantial proportion $(88 \%)$ of ${ }^{32} \mathrm{P}$ added to artificial floodwaters was recovered in soil pools, distributed within the soil fractions (averaging $73 \%$ ), microbial biomass $(9 \%)$ and roots $(6 \%)$ across all $\mathrm{AL}$ and BW cores. A number of studies have described the rapid and substantial incorporation of ${ }^{32} \mathrm{P}$ or ${ }^{33} \mathrm{P}$ into wetland soil/sediment $\mathrm{P}$ pools (Richardson and Marshall 1986, Furumai et al. 1989, Walbridge 1991, Cooke 1992, Istvanovics 1993, Nguyen 2000, Kellogg and Bridgham 2003, Scinto and Reddy 2003, Vu et al. 2010) and mineral soil P fractions (Di et al. 1997, He and Zhu 1997, Daroub et al. 2000, Blake et al. 2002, Buehler et al. 2002, Asfary et al. 2004, Bunemann et al. 2004, Olander and Vitousek 2004). The proportion of microbial P recovered ranged from 2 to $15 \%$ of total ${ }^{32} \mathrm{P}$ extracted from soils, and was comparable to estimates of P in depressional wetlands (4 - 6\%; Craft and Chiang 2002), fen 
peatlands (12 - $13 \%$; Richardson and Marshall 1986), and other forested wetland soils (averaging 21 and $29 \%$; Wright et al. 2001, Hogan et al. 2004, respectively), but substantially less than ${ }^{32} \mathrm{P}$ immobilized in the microbial biomass in pocosin soils (averaging $90 \%$; Walbridge 1991). Surface roots are equally important in the removal of added ${ }^{32} \mathrm{P}$ from soil porewater, and although only $6 \%$ of the added label was associated with the root biomass in the current study, which is comparable to the $2-4 \%$ associated with the root and rhizosphere in the Everglades (Davis 1991), as much as $60 \%$ of added ${ }^{32} \mathrm{P}$ was found to be associated with the root biomass in peatland soils (Jonasson and Chapin 1991).

My overall objective was to identify the major mechanisms of $\mathrm{P}$ retention and transformation in FFs. I found that a majority of added ${ }^{32} \mathrm{P}$ introduced in artificial floodwaters was recovered in the NaOH-, BD-, Res, and HA-extractable fractions. Of the few studies that have used a detailed sequential $\mathrm{P}$ fractionation scheme to track the fate of ${ }^{32} \mathrm{P}$ introduced to wetland soils, similarly high ${ }^{32} \mathrm{P}$ recoveries in the $\mathrm{NaOH}$ and bicarbonate extractable fractions were observed in sewage impacted (Nguyen 2000) and coastal (Vu et al. 2010) wetland soils. Yet to my knowledge, results presented in this chapter, represent the first attempt to identify dominant fates of ${ }^{32} \mathrm{P}$ and the mechanisms of ${ }^{32} \mathrm{P}$ retention and transformation in FFs during flooding. The ${ }^{32} \mathrm{P}$-label delivered in headwaters was predominantly organic (averaging $74 \%$ across all cores), and a significantly larger proportion of the ${ }^{32} \mathrm{P}$ recovered in drain waters was also organic (averaging $82 \%$ across all cores), resulting from additional ${ }^{32} \mathrm{PO}_{4}{ }^{3-}$ transformation to ${ }^{32} \mathrm{P}_{\mathrm{o}}$ within the soil profile. 
The majority of the total ${ }^{32} \mathrm{P}$ recovered in the $\mathrm{NaOH}-\mathrm{P}$ and BD-P fractions was inorganic (Table 3.7). The substantial $P$ retention capacity of wetland soils has been variously attributed to $P$ sorption by soil $\mathrm{Al}$ and clay minerals, $\mathrm{Fe}, \mathrm{Ca}$, and $\mathrm{OM}$ content (Richardson 1985, Furumai et al. 1989, Paludan and Jensen 1995, Nguyen 2000, Hoffmann et al. 2009, Vu et al. 2010). The assumption is that the correlation of $\mathrm{P}$ sorption with $\mathrm{Al}$ and clay minerals, $\mathrm{Fe}, \mathrm{Ca}$, and $\mathrm{OM}$, indicates that $\mathrm{P}$ is likely bound to these elements. Many wetland studies have cited $\mathrm{Al}$ (total $\mathrm{Al}$, including oxalate-extractable Al) as the best predictor of P sorption (Richardson 1985, Axt 1997, Darke and Walbridge 2000, Hogan et al. 2004); soils in these studies had higher Al than Fe contents. More $\mathrm{Al}$ than $\mathrm{Fe}$ was extracted in the $\mathrm{NaOH}(\mathrm{Al}: \mathrm{Fe}=12)$, $\mathrm{Res}(\mathrm{Al}: \mathrm{Fe}=4)$, and $\mathrm{HA}$ fractions $(\mathrm{Al}: \mathrm{Fe}=2)$, however, a higher $\mathrm{Fe}$ content was associated with the $\mathrm{BD}$ extractable fraction (molar ratio of $\mathrm{Fe}: \mathrm{Al}=27$ ), across all cores.

The $\mathrm{BD}$ and $\mathrm{HCl}$ extractable fractions comprised 43 and $13 \%$, respectively of the total $\mathrm{Fe}$ extracted in soil fractions across all $\mathrm{AL}$ and $\mathrm{BW}$ cores. Molar ratios of $\mathrm{Fe}:{ }^{32} \mathrm{P}$ vs. $\mathrm{Al}:{ }^{32} \mathrm{P}$ extracted from the $\mathrm{BD}$ and $\mathrm{HCl}$ fractions resulted in a significant positive correlation between total ${ }^{32} \mathrm{P}$ recovered and total $\mathrm{Fe}\left(\mathrm{r}^{2}=0.72\right.$ and 0.66 , respectively, Figure $3.3 \mathbf{f}$, g) extracted, consistent with the generally higher Fe content associated with these fractions. Phosphorus associated with the $\mathrm{HCl}$ extractable fraction is primarily sorbed to $\mathrm{Ca}$ in alkaline soils, however, in acidic soils (typical of FF in the SE US) Ca-phosphates are unstable and P sorption to Fe and/or Al are favored (Freeman and Rowell 1981, Pierzynski et al. 1990). The predominance of Fe compared to $\mathrm{Al}$ content, and a strong positive correlation between $\mathrm{Fe}$ and $\mathrm{P}$ in these fractions has been reported in soils analyzed from riparian wetlands (Qiu and McComb 2000, Wang et al. 2006), freshwater wetlands (Nguyen 2000, Hansen et al. 2003), coastal lagoons (Lopez 2004), 
salt marshes (Paludan and Jensen 1995, Paludan and Morris 1999, Coelho et al. 2004), and rice paddies (Sah and Mikkelsen 1986).

The largest proportion of ${ }^{32} \mathrm{P}$ recovered in soils was in the $\mathrm{NaOH}$-extractable fraction, averaging $58 \%$ of total ${ }^{32} \mathrm{P}$ recovered in all sequentially extracted soil fractions, and consistent with studies conducted on lake sediments (Furumai et al. 1989), wetland soils (Nguyen 2000, Vu et al. 2010). The dominance of $\mathrm{P}$ recovered by $\mathrm{NaOH}$ extraction was also reported for bottomland forested wetlands adjacent to the Tradewater river watershed in $\mathrm{KY}$, where $90 \%$ of added $\mathrm{KH}_{2} \mathrm{PO}_{4}$ in artificial floodwaters was recovered in this fraction (D'Angelo 2005). Soil P extracted using $\mathrm{NaOH}$ is primarily inorganic and considered bioavailable - loosely sorbed to Al and clay minerals. The proportion of ${ }^{32} \mathrm{P}_{\mathrm{i}}$ associated with the $\mathrm{NaOH}$-extractable fraction correlated best with clay content $\left(\mathrm{r}^{2}=0.89\right)$ across FF soils (Figure 3.3 d). Significant positive correlations between clay content and P sorption have been reported in floodplain soils along the Ogeechee River, GA (Darke and Walbridge 2000) and Danube River, FR (Lair et al. 2009). As expected, more $\mathrm{Al}$ than $\mathrm{Fe}$ was extracted from the $\mathrm{Al} /$ clay bound fraction, and total $\mathrm{Al}$ extracted was significantly correlated to total ${ }^{32} \mathrm{P}$ recovered in this fraction $\left(\mathrm{r}^{2}=0.53\right.$, Figure $\left.3.3 \mathrm{c}\right)$. Although the predominance of total $\mathrm{Al}$ (over $\mathrm{Fe}$ ) in the $\mathrm{NaOH}$ fraction, and a significant positive correlation between $\mathrm{Al}$ and $\mathrm{P}$ or ${ }^{32} \mathrm{P}$ associated with this fractions has been reported in freshwater wetland (Paludan and Jensen 1995, Nguyen 2000), coastal swamps (Qiu and McComb 2000), lagoon (Lopez 2004), lake sediment (Reitzel et al. 2005). The current study is the first to document that similar mechanisms for the rapid (within $40 \mathrm{~h}$ of incubation) incorporation of $\mathrm{NaOH}$-extractable $\mathrm{P}$ apply to FF wetland soils as well, in which ( $\mathrm{NaOH}$ fraction) the largest 
amount of ${ }^{32} \mathrm{P}$ introduced with flood waters was recovered $\left(58 \%\right.$ of total ${ }^{32} \mathrm{P}$ extracted in soils fractions).

While a majority of the total ${ }^{32} \mathrm{P}$ in soils was retained in the $\mathrm{NaOH}$-extractable fraction, the Res fraction accounted for $13 \%$ of the total ${ }^{32} \mathrm{P}$ extracted from soils and had the largest proportion of total $\mathrm{Al}$ in all fractions, accounting for $72 \%$ of total $\mathrm{Al}$ extracted by the Paludan and Jensen (1995) procedure. The predominance of Al relative to Fe in the Res-P fraction has been reported in other wetland soils (Axt and Walbridge 1999, Paludan and Morris 1999, Hogan et al. 2004). Molar ratios of $\mathrm{Fe}:{ }^{32} \mathrm{P}$ vs. $\mathrm{Al}:{ }^{32} \mathrm{P}$ in the Res fraction resulted in a significant correlation between total ${ }^{32} \mathrm{P}$ and $\mathrm{Al}\left(\mathrm{r}^{2}=0.84\right.$, Figure 3.3 e), consistent with the higher $\mathrm{Al}$ content associated with this fraction. Since a majority of the Res-P pool represents refractory organic P, these results suggest that $\mathrm{OM}$-metal-P complexation via $\mathrm{Al}$ (more than $\mathrm{Fe}$ ) ligands may be an important mechanism of $\mathrm{P}_{\mathrm{i}}$ retention within this soil fraction (Axt and Walbridge 1999, Darke and Walbridge 2000, Hogan et al. 2004). Similarly, higher Al than Fe was associated with the $\mathrm{H}_{2} \mathrm{O}-$ extractable fraction $(\mathrm{Al}: \mathrm{Fe}=3)$, and total $\mathrm{Al}$ extracted was strongly correlated to both total $\mathrm{P}$ and ${ }^{32} \mathrm{P}$ recovered in this fraction $\left(\mathrm{r}^{2}=0.92\right.$ and 0.86 , respectively). As the most readily available and loosely sorbed fraction, a majority of $\mathrm{P}$ retained within the $\mathrm{H}_{2} \mathrm{O}-\mathrm{P}$ fraction would be complexed with OM via Al in FF soils (Axt and Walbridge 1999, Darke and Walbridge 2000, Hogan et al. 2004).

Although total $\mathrm{Al}$ and $\mathrm{Fe}$ measured were clearly defined by higher $\mathrm{Al}$ or higher $\mathrm{Fe}$ extracted from most soil fractions, the HA-P fraction was one exception, where more Al than Fe was 
associated with the HA-P fraction in BW soils and higher concentrations Fe were extracted from this fraction in AL soil cores (Figure $3.3 \mathbf{~ h}$ ). These results clearly indicate that the Paludan and Jensen (1995) sequential P fractionation procedure is an effective method for sequentially extracting both sorbed $\mathrm{P}$ and the associated cations $(\mathrm{Al}$ and $\mathrm{Fe}$ ) in each fraction, but is also able account for differences in soption properties between different (AL vs. BW FF) soils within a fraction. Hogan et al. (2004) found similar shifts in the dominance of $\mathrm{Al}$ or Fe content in two forested wetlands (Braun vs. Barnstable sites) adjacent to the Chesapeake Bay, Kent Island, MD. In the current study, HA-Al was significantly correlated with total ${ }^{32} \mathrm{P}$ recovered in $\mathrm{BW}$ soils, whereas Fe extracted from the same fraction was correlated to total ${ }^{32} \mathrm{P}$ recovered in $\mathrm{AL}$ soils. BW floodplain soils generally contain higher levels of $\mathrm{OM}$, and $\mathrm{Al}$ (compared to $\mathrm{Fe}$ ) has a greater tendency to form OM-metal-P complexes (Paludan and Jensen 1995, Axt 1997, Hogan et al. 2004), which may be reflected in the predominance of $\mathrm{Al}$ associated with the humic acid fraction in BW soils.

\subsubsection{Specific activity (ratio of ${ }^{32} \mathrm{P} / \mathrm{P}$ ) in soil pools}

After $8 \mathrm{~d}$ of flooding, the $\mathrm{SAs}$ of $\mathrm{BD}, \mathrm{NaOH}, \mathrm{HA}, \mathrm{HCl}$, and Res extractable fractions were similar and comparable to the average SA of the combined pools (soil fractions: indicated by a solid line and soil fractions + roots: indicated by a dashed line, Figure 3.2), suggesting that equilibrium with respect to $\mathrm{P}$ transfer between these fraction was being approached. After $40 \mathrm{~h}$ of flooding, the SAs of $\mathrm{H}_{2} \mathrm{O}$ extractable fraction, microbial biomass and root/rhizosphere pools were comparatively larger than the average combined SAs of the soil fractions/pools (Figure 3.2). As the $\mathrm{P}$ content of these biologically mediated pools $\left(\mathrm{H}_{2} \mathrm{O}-\mathrm{P}\right.$, root and microbial $\left.\mathrm{P}\right)$ 
remained constant, the transfer of ${ }^{32} \mathrm{P}$ suggests $\mathrm{P}$ uptake among these fractions and pools. While significant decreases in SAs were observed between $40 \mathrm{~h}$ and $8 \mathrm{~d}$ of flooding in certain soil fractions/pools in PD and DC soils (Figure 3.2 a, d), when averaged across all sites, SAs of each soil pool/fraction did not differ significantly over $40 \mathrm{~h}$ and $8 \mathrm{~d}$ of incubation.

Although a majority of the ${ }^{32} \mathrm{P}$ added to soils was recovered in the $\mathrm{NaOH}, \mathrm{BD}$, Res, and HA extractable fractions, the highest SAs were observed in the $\mathrm{H}_{2} \mathrm{O}$ extractable fraction, root/rhizosphere and microbial biomass pools (Table 3.10). These results clearly indicate that the biologically dominant and most available $\mathrm{P}$ pools (porewater, root/rhizosphere, and microbial) are important short-term sinks for P introduced in floodwaters. Overall, SAs in these pools did not statistically differ over incubation time, by site, or floodplain type, and as predicted in hypothesis $1 a$, these biologically mediated pools are effective at retaining $\mathrm{P}$ in both $\mathrm{AL}$ and BW FF soils over the entire period of flooding. 


\subsection{CONCLUSIONS}

The dominant mechanism(s) of P retention in AL and BW FFs in the SE US Coastal Plain, or transformation in the water column and/or at the sediment/soil interface, was assessed in an artificial flooding experiment, with the addition of ${ }^{32} \mathrm{PO}_{4}{ }^{3-}$ to river waters prior to flooding soils over a 8 d incubation period, and using a modified Paludan and Jensen (1995) P sequential fractionation procedure to assess the fate of $\mathrm{P}$ in soil fractions. A majority of the ${ }^{32} \mathrm{PO}_{4}{ }^{3-}$ introduced to riverwaters was transformed to ${ }^{32} \mathrm{P}_{\mathrm{o}}$ in $\mathrm{BW}$ river column, or in headwaters (AL and BW cores) upon contact with the soil surface. This rapid and substantial transformation of $\mathrm{P}$ suggests biotic uptake of ${ }^{32} \mathrm{PO}_{4}{ }^{3-}$ and subsequent release as ${ }^{32} \mathrm{P}_{\mathrm{o}}$ in floodwaters. Higher proportions of ${ }^{32} \mathrm{P}_{\mathrm{i}}$ (69\% of total ${ }^{32} \mathrm{P}$ recovered) recovered in $\mathrm{AL}$ cores (sum of $\mathrm{P}$ in the soil fractions + microbial biomass + roots + drainwaters) indicate that physico-chemical processes dominate $\mathrm{P}$ retention in $\mathrm{AL}$ soils, but similar proportions of ${ }^{32} \mathrm{P}_{\mathrm{i}}(53 \%)$ and ${ }^{32} \mathrm{P}_{\mathrm{o}}(47 \%)$ in $\mathrm{BW}$ cores, suggests that both biological and physico-chemical processes contribute to P retention and transformation in BW soils. The majority of ${ }^{32} \mathrm{P}$ recovered in soils was associated with the $\mathrm{NaOH}-, \mathrm{BD}-$, Res, and HA-extractable fractions. Phosphorus introduced with floodwaters was either sorbed to $\mathrm{Al}$ and/or clay minerals in the $\mathrm{NaOH}-$, Res, and $\mathrm{H}_{2} \mathrm{O}$-extractable fractions, or strongly associated with $\mathrm{Fe}$ in the BD- and $\mathrm{HCl}$-extractable fractions in both $\mathrm{AL}$ and BW soils. The ${ }^{32} \mathrm{P}$ extracted from the HA fraction, however, differed between AL and BW soils; HA-Al was significantly correlated with HA-extractable ${ }^{32} \mathrm{P}$ in BW soils; HA-Fe was significantly correlated with HA-extractable ${ }^{32} \mathrm{P}$ in $\mathrm{AL}$ soils. Average total ${ }^{32} \mathrm{P}$ recoveries in the root/rhizosphere and microbial pool and sequentially extracted soil fractions did not differ significantly by floodplain type, site, or incubation time, which suggests that $\mathrm{AL}$ and $\mathrm{BW}$ FF soils are equally effective at retaining and transforming P introduced with floodwaters. Although 
a majority of the ${ }^{32} \mathrm{P}$ added to soils was recovered in the $\mathrm{NaOH}, \mathrm{BD}$, Res, and HA extractable fractions, the highest SAs were observed in biologically dominant and most available P pools $\left(\mathrm{H}_{2} \mathrm{O}\right.$ extractable fraction, root/rhizosphere and microbial biomass pools), indicative of the sink strengths of these pool and their effectiveness at removing and storing P from floodwaters, thus reducing $\mathrm{P}$ inputs to aquatic systems downstream of these FFs in the SE US Coastal Plain. 


\subsection{REFERENCES}

Asfary, A. F., R. Al-Merey, and M. Al-Hameish. 2004. Fractionation of applied P-32 labeled TSP in calcareous soils. Plant and Soil 264:171-183.

Axt, J. R. 1997. Phosphorus retention and distribution in non-tidal palustrine forested wetlands and adjacent uplands of Virginia. George Mason University, Fairfax, VA, USA.

Axt, J. R. and M. R. Walbridge. 1999. Phosphate removal capacity of palustrine forested wetlands and adjacent uplands in Virginia. Soil Science Society of America Journal 63:1019-1031.

Basu, B. K. and F. R. Pick. 1997. Factors related to heterotrophic bacterial and flagellate abundance in temperate rivers. Aquatic Microbial Ecology 12:123-129.

Bedford, B. L., M. R. Walbridge, and A. Aldous. 1999. Patterns in nutrient availability and plant diversity of temperate North American wetlands. Ecology 80:2151-2169.

Bedrock, C. N., M. V. Cheshire, and C. A. Shand. 1997. The involvement of iron and aluminum in the bonding of phosphorus to soil humic acid. Communications in Soil Science and Plant Analysis 28:961-971.

Blake, L., N. Hesketh, S. Fortune, and P. C. Brookes. 2002. Assessing phosphorus 'ChangePoints' and leaching potential by isotopic exchange and sequential fractionation. Soil Use and Management 18:199-207.

Bossio, D. A., J. A. Fleck, K. M. Scow, and R. Fujii. 2006. Alteration of soil microbial communities and water quality in restored wetlands. Soil Biology \& Biochemistry 38:1223-1233.

Bouyoucos, G. J. 1962. Hydrometer method improved for making particle size analyses of soils. Agronomy Journal 54:464-465.

Brandao, L. R., D. Libkind, A. B. M. Vaz, L. C. E. Santo, M. Moline, V. de Garcia, M. van Broock, and C. A. Rosa. 2011. Yeasts from an oligotrophic lake in Patagonia 
(Argentina): diversity, distribution and synthesis of photoprotective compounds and extracellular enzymes. FEMS Microbiology Ecology 76:1-13.

Brinson, M. M. 1993. Changes in the functioning of wetlands along environmental gradients. Wetlands 13:65-74.

Brookes, P. C., D. S. Powlson, and D. S. Jenkinson. 1982. Measurement of microbial biomass phosphorus in soil. Soil Biology and Biochemistry 14:319-329.

Buehler, S., A. Oberson, I. M. Rao, D. K. Friesen, and E. Frossard. 2002. Sequential phosphorus extraction of a P-33-labeled oxisol under contrasting agricultural systems. Soil Science Society of America Journal 66:868-877.

Bunemann, E. K., F. Steinebrunner, P. C. Smithson, E. Frossard, and A. Oberson. 2004. Phosphorus dynamics in a highly weathered soil as revealed by isotopic labeling techniques. Soil Science Society of America Journal 68:1645-1655.

Castillo, M. M., J. D. Allan, R. L. Sinsabaugh, and G. W. Kling. 2004. Seasonal and interannual variation of bacterial production in lowland rivers of the Orinoco basin. Freshwater Biology 49:1400-1414.

Castillo, M. M., G. W. Kling, and J. D. Allan. 2003. Bottom-up controls on bacterial production in tropical lowland rivers. Limnology and Oceanography 48:1466-1475.

Cembella, A. D., N. J. Antia, and P. J. Harrison. 1984a. The utilization of inorganic and organic phosphorus-compounds as nutrients by eukaryotic microalgae - A multidisciplinary perspective .1. CRC Critical Reviews in Microbiology 10:317-391.

Cembella, A. D., N. J. Antia, and P. J. Harrison. 1984b. The utilization of inorganic and organic phosphorus-compounds as nutrients by eukaryotic microalgae - A multidisciplinary perspective .2. CRC Critical Reviews in Microbiology 11:13-81.

Chu, S. P. 1946. Utilization of organic phosphorus by phytoplankton. Jouranal of the Marine Biological Association of the UK 26:285-295. 
Coelho, J. P., M. R. Flindt, H. S. Jensen, A. I. Lillebo, and M. A. Pardal. 2004. Phosphorus speciation and availability in intertidal sediments of a temperate estuary: relation to eutrophication and annual P-fluxes. Estuarine Coastal and Shelf Science 61:583-590.

Cooke, J. G. 1992. Phosphorus removal processes in a wetland after a decade of receiving a sewage effluent. Journal of Environmental Quality 21:733-739.

Craft, C. B. and W. P. Casey. 2000. Sediment and nutrient accumulation in floodplain and depressional freshwater wetlands of Georgia, USA. Wetlands 20:323-332.

Craft, C. B. and C. Chiang. 2002. Forms and amounts of soil nitrogen and phosphorus across a longleaf pine-depressional wetland landscape. Soil Science Society of America Journal 66:1713-1721.

Cross, A. F. and W. H. Schlesinger. 1995. A literature review and evaluation of the. Hedley fractionation: Applications to the biogeochemical cycle of soil phosphorus in natural ecosystems. Geoderma 64:197-214.

D'Angelo, E. M. 2005. Phosphorus sorption capacity and exchange by soils from mitigated and late successional bottomland forest wetlands. Wetlands 25:297-305.

Darke, A. K. and M. R. Walbridge. 2000. Al and Fe biogeochemistry in a floodplain forest: Implications for P retention. Biogeochemistry 51:1-32.

Darke, A. K., M. R. Walbridge, and B. G. Lockaby. 1997. Changes in Al and Fe crystallinity and $\mathrm{P}$ sorption capacity in a flood-plain forest soil subjected to artificially manipulated flooding regimes in field mesocosms. Wetlands Ecology and Management 4:235-244.

Daroub, S. H., F. J. Pierce, and B. G. Ellis. 2000. Phosphorus fractions and fate of phosphorus33 in soils under plowing and no-tillage. Soil Science Society of America Journal 64:170176.

Davis, S. M. 1991. Patterns of radiophosphorus accumulation in the Everglades after its introduction into surface water. Bulletin of the Ecological Society of America 72:97. 
Di, H. J., L. M. Condron, and E. Frossard. 1997. Isotope techniques to study phosphorus cycling in agricultural and forest soils: A review. Biology and Fertility of Soils 24:1-12.

Dunne, E. J., K. R. Reddy, and M. W. Clark. 2006. Phosphorus release and retention by soils of natural isolated wetlands. International Journal of Environment and Pollution 28:496516.

Edwards, R. T. and J. L. Meyer. 1986. Production and turnover of planktonic bacteria in two southeastern blackwater rivers. Applied and Environmental Microbiology 52:1317-1323.

Edwards, R. T., J. L. Meyer, and S. E. G. Findlay. 1990. The relative contribution of benthic and suspended bacteria to system biomass, production, and metabolism in a low-gradient blackwater river. Journal of the North American Benthological Society 9:216-228.

Elder, J. F. 1985. Nitrogen and phosphorus speciation and flux in a large Florida river wetland system. Water Resources Research 21:724-732.

Ensign, S. H. and M. A. Mallin. 2001. Stream water quality changes following timber harvest in a coastal plain swamp forest. Water Research 35:3381-3390.

Entry, J. A. 2000. Influence of nitrogen on cellulose and lignin mineralization in blackwater and redwater forested wetland soils. Biology and Fertility of Soils 31:436-440.

Flynn, A. M. 2008. Organic Matter and Nutrient Cycling in a Coastal Plain Estuary: Carbon, Nitrogen, and Phosphorus Distributions, Budgets, and Fluxes. Journal of Coastal Research:76-94.

Freeman, C. and M. A. Lock. 1995. Isotope dilution analysis and rates of P32 incorporation into phospholipid as a measure of microbial growth rates in biofilms. Water Research 29:789792.

Freeman, J. S. and D. L. Rowell. 1981. The adsorption and precipitation of phosphate onto calcite. Journal of Soil Science 32:75-84. 
Furumai, H., T. Kondo, and S. Ohgaki. 1989. Phosphorus exchange kinetics and exchangeable phosphorus forms in sediments. Water Research 23:685-691.

Gerke, J. 2010. Humic (Organic Matter)-Al(Fe)-Phosphate Complexes: An Underestimated Phosphate Form in Soils and Source of Plant-Available Phosphate. Soil Science 175:417425 .

Hansen, J., K. Reitzel, H. S. Jensen, and F. O. Andersen. 2003. Effects of aluminum, iron, oxygen and nitrate additions on phosphorus release from the sediment of a Danish softwater lake. Hydrobiologia 492:139-149.

He, Z. L. and J. Zhu. 1997. Transformation and bioavailability of specifically sorbed phosphate on variable-charge minerals in soils. Biology and Fertility of Soils 25:175-181.

Hedley, M. J., J. W. B. Stewart, and B. S. Chauhan. 1982. Changes in inorganic and organic soil phosphorus fractions induced by cultivation practices and by laboratory incubations. Soil Science Society of America Journal 46:970-976.

Hoffmann, C. C., C. Kjaergaard, J. Uusi-Kamppa, H. C. B. Hansen, and B. Kronvang. 2009. Phosphorus Retention in Riparian Buffers: Review of Their Efficiency. Journal of Environmental Quality 38:1942-1955.

Hogan, D. M., T. E. Jordan, and M. R. Walbridge. 2004. Phosphorus retention and soil organic carbon in restored and natural freshwater wetlands. Wetlands 24:573-585.

House, W. A., F. H. Denison, and P. D. Armitage. 1995. Comparison of the uptake of inorganic phosphorus to a suspended and stream bed-sediment. Water Research 29:767-779.

Hu, J., Q. Shen, Y. Liu, and J. T. Liu. 2007. Mobility of different phosphorus pools in the sediment of Lake Dianchi during cyanobacterial blooms. Environmental Monitoring and Assessment 132:141-153.

Hupp, C. R. and E. E. Morris. 1990. A dendrogeomorphic approach to measurement of sedimentation in a forested wetland, Black Swamp, Arkansas. Wetlands 10:107-124. 
Hupp, C. R., M. R. Walbridge, and B. G. Lockaby. 2005. Fluvial geomorphic processes and landforms, water quality, and nutrients in Bottomland Hardwood Forests of southeastern USA. Pages 37-55 in L. H. Fredrickson, S. L. King, and R. M. Kaminski, editors. Ecology and Management of Bottomland Hardwood Systems. University of Missouri, Puxico, MO.

Istvanovics, V. 1993. Transformations between organic and inorganic sediment phosphorus in Lake Balaton. Hydrobiologia 253:193-206.

Ivanoff, D. B., K. R. Reddy, and S. Robinson. 1998. Chemical fractionation of organic phosphorus in selected histosols. Soil Science 163:36-45.

Jayachandran, K., A. P. Schwab, and B. A. D. Hetrick. 1992. Partitioning of dissolved inorganic and organic phosphorus using acidified molybdate and isobutanol. Soil Science Society of America Journal 56:762-765.

Jonasson, S. and F. S. Chapin. 1991. Seasonal uptake and allocation of phosphorus in Eriophorum vaginatum $\mathrm{L}$ measured by labelling with ${ }^{32} \mathrm{P}$. New Phytologist 118:349-357.

Kellogg, L. E. and S. D. Bridgham. 2003. Phosphorus retention and movement across an ombrotrophic-minerotrophic peatland gradient. Biogeochemistry 63:299-315.

Kleiss, B. A. 1996. Sediment retention in a bottomland hardwood wetland in Eastern Arkansas. Wetlands 16:321-333.

Kuo, S. and D. S. Mikkelsen. 1979. Distribution of iron and phosphorus in flooded and unflooded soil profiles and their relation to phosphorus adsorption. Soil Science 127:1825.

Lair, G. J., F. Zehetner, Z. H. Khan, and M. H. Gerzabek. 2009. Phosphorus sorption-desorption in alluvial soils of a young weathering sequence at the Danube River. Geoderma 149:3944.

Lake, B. A., K. M. Coolidge, S. A. Norton, and A. Amirbahman. 2007. Factors contributing to the internal loading of phosphorus from anoxic sediments in six Maine, USA, lakes. Science of the Total Environment 373:534-541. 
Leff, L. G. and J. L. Meyer. 1991. Biological availability of dissolved organic carbon along the Ogeechee River. Limnology and Oceanography 36:315-323.

Levy, E. T. and W. H. Schlesinger. 1999. A comparison of fractionation methods for forms of phosphorus in soils. Biogeochemistry 47:25-38.

Lockaby, B. G. and M. R. Walbridge. 1998. Biogeochemistry.in M. G. Messina and W. H. Conner, editors. Southern Forested Wetlands: Ecology and Management. Lewis Publishers, Boca Raton, FL, USA.

Loeb, R., L. P. M. Lamers, and J. G. M. Roelofs. 2008. Prediction of phosphorus mobilisation in inundated floodplain soils. Environmental Pollution 156:325-331.

Lopez, P. 2004. Spatial distribution of sedimentary P pools in a Mediterranean coastal lagoon 'Albufera d'es Grau' (Minorca Island, Spain). Marine Geology 203:161-176.

Mallin, M. A., L. B. Cahoon, D. C. Parsons, and S. H. Ensign. 2001. Effect of nitrogen and phosphorus loading on plankton in coastal plain blackwater rivers. Journal of Freshwater Ecology 16:455-466.

Mallin, M. A., M. R. McIver, S. H. Ensign, and L. B. Cahoon. 2004. Photosynthetic and heterotrophic impacts of nutrient loading to blackwater streams. Ecological Applications 14:823-838.

McKelvie, I. D., D. M. W. Peat, and P. J. Worsfold. 1995. Techniques for the quantification and speciation of phosphorus in natural waters. Analytical Proceedings 32:437-445.

Meyer, J. L. 1990. A blackwater perspective on riverine ecosystems. Bioscience 40:643-651.

Mitsch, W. J. and J. G. Gosselink. 2007. Wetlands. 4th edition. John Wiley \& Sons, New York.

Mohamed, M. N., J. R. Lawrence, and R. D. Robarts. 1998. Phosphorus limitation of heterotrophic biofilms from the Fraser River, British Columbia, and the effect of pulp mill effluent. Microbial Ecology 36:121-130. 
Morse, J. L., J. P. Megonigal, and M. R. Walbridge. 2004. Sediment nutrient accumulation and nutrient availability in two tidal freshwater marshes along the Mattaponi River, Virginia, USA. Biogeochemistry 69:175-206.

Mulholland, P. J., J. D. Newbold, J. W. Elwood, L. A. Ferren, and J. R. Webster. 1985. Phosphorus spiralling in a woodland stream: Seasonal variations. Ecology 66:1012-1023.

Murphy, J. and J. P. Riley. 1962. A modified single solution method for determination of phosphate in natural waters. Analytica Chimica Acta 27:31-36.

Newbold, J. D., J. W. Elwood, R. V. Oneill, and A. L. Sheldon. 1983. Phosphorus dynamics in a woodland stream ecosystem: A study of nutrient spiraling. Ecology 64:1249-1265.

Nguyen, L. M. 2000. Phosphate incorporation and transformation in surface sediments of a sewage-impacted wetland as influenced by sediment sites, sediment $\mathrm{pH}$ and added phosphate concentration. Ecological Engineering 14:139-155.

Nguyen, L. M., J. G. Cooke, and G. B. McBride. 1997. Phosphorus retention and release characteristics of sewage-impacted wetland sediments. Water Air and Soil Pollution 100:163-179.

Noe, G. B. and C. R. Hupp. 2007. Seasonal variation in nutrient retention during inundation of a short-hydroperiod floodplain. River Research and Applications 23:1088-1101.

Ochs, C. A., H. E. Capello, and O. Pongruktham. 2010. Bacterial production in the Lower Mississippi River: importance of suspended sediment and phytoplankton biomass. Hydrobiologia 637:19-31.

Olander, L. P. and P. M. Vitousek. 2004. Biological and geochemical sinks for phosphorus in soil from a wet tropical forest. Ecosystems 7:404-419.

Olsen, S. R. and L. E. Sommers. 1982. Phosphorus. Pages 403-430 In A. L. Page et al. (editiors). Methods of soil analysis. Part 2. $2^{\text {nd }}$ edition. Agronomy Monographs. ASA. SSSA, Madison, WI. 
Pakulski, J. D., R. Benner, T. Whitledge, R. Amon, B. Eadie, L. Cifuentes, J. Ammerman, and D. Stockwell. 2000. Microbial metabolism and nutrient cycling in the Mississippi and Atchafalaya River plumes. Estuarine Coastal and Shelf Science 50:173-184.

Paludan, C. and H. S. Jensen. 1995. Sequential extraction of phosphorus in freshwater wetland and lake sediment: Significance of humic acids. Wetlands 15:365-373.

Paludan, C. and J. T. Morris. 1999. Distribution and speciation of phosphorus along a salinity gradient in intertidal marsh sediments. Biogeochemistry 45:197-221.

Parkinson, J. A. and S. E. Allen. 1975. A wet oxidation procedure suitable for the determination of nitrogen and mineral nutrients in biological material. Communications in Soil Science and Plant Analysis 6:1-11.

Peretyazhko, T. and G. Sposito. 2005. Iron(III) reduction and phosphorous solubilization in humid tropical forest soils. Geochimica et Cosmochimica Acta 69:3643-3652.

Pierzynski, G. M., T. J. Logan, S. J. Traina, and J. M. Bigham. 1990. Phosphorus chemistry and mineralogy in excessively fertilized soils: quantitative analysis of phosphorus-rich particles. Soil Science Society of America Journal 54:1576-1583.

Pretty, J. N., C. F. Mason, D. B. Nedwell, R. E. Hine, S. Leaf, and R. Dils. 2003. Environmental costs of freshwater eutrophication in England and Wales. Environmental Science \& Technology 37:201-208.

Psenner, R., R. Pucsko, and M. Sager. 1984. Fractionation of organic and inorganic phosphorus compounds in lake sediments: An attempt to characterize ecologically important fractions. Archiv fuer Hydrobiologie Supplement 70:111-155.

Qiu, S. and A. McComb. 2000. Properties of sediment phosphorus in seven wetlands of the Swan Coastal Plain, South-Western Australia. Wetlands 20:267-279.

Qualls, R. G. 1989. The biogeochemical properties of dissolved organic matter in a hardwood forest ecosystem: their influence on the retention of nitrogen, phosphorus and carbon. University of Georgia, Athens, Georgia, USA. 
Quintero, C. E., F. H. Gutierrez-Boem, M. R. Befani, and N. G. Boschetti. 2007. Effects of soil flooding on $\mathrm{P}$ transformations in soils of the Mesopotamia region, Argentina. Journal of Plant Nutrition and Soil Science-Zeitschrift Für Pflanzenernahrung und Bodenkunde 170:500-505.

Reddy, K. R., R. H. Kadlec, E. Flaig, and P. M. Gale. 1999. Phosphorus retention in streams and wetlands: A review. Critical Reviews in Environmental Science and Technology 29:83146.

Reitzel, K., J. Ahlgren, A. Gogoll, H. S. Jensen, and E. Rydin. 2006. Characterization of phosphorus in sequential extracts from lake sediments using P-31 nuclear magnetic resonance spectroscopy. Canadian Journal of Fisheries and Aquatic Sciences 63:16861699.

Reitzel, K., J. Hansen, F. O. Andersen, K. S. Hansen, and H. S. Jensen. 2005. Lake restoration by dosing aluminum relative to mobile phosphorus in the sediment. Environmental Science \& Technology 39:4134-4140.

Richardson, C. J. 1985. Mechanisms controlling phosphorus retention capacity in freshwater wetlands. Science 228:1424-1427.

Richardson, C. J. and P. E. Marshall. 1986. Processes controling movement, storage, and export of phosphorus in a fen peatland. Ecological Monographs 56:279-302.

Ridal, J. J. and R. M. Moore. 1993. Resistance to UV and persulphate oxidation of dissolved organic carbon produced by selected marine phytoplankton. Marine Chemistry 42:167188.

Sabater, F., J. L. Meyer, and R. T. Edwards. 1993. Longitudinal patterns of dissolved organic carbon concentration and suspended bacterial density along a blackwater river. Biogeochemistry 21:73-93.

Sah, R. N. and D. S. Mikkelsen. 1986. Transformations of inorganic phosphorus during the flooding and draining cycles of soil. Soil Science Society of America Journal 50:62-67. 
Scinto, L. J. and K. R. Reddy. 2003. Biotic and abiotic uptake of phosphorus by periphyton in a subtropical freshwater wetland. Aquatic Botany 77:203-222.

Stanturf, J. A. and S. H. Schoenholtz. 1998. Soils and landforms. Pages 123-147 in M. G. Messina and W. H. Conner, editors. Southern forrested wetlands: Ecology and management. Lewis Publ., New York.

Stoeckel, D. M. and M. S. Miller-Goodman. 2001. Seasonal nutrient dynamics of forested floodplain soil influenced by microtopography and depth. Soil Science Society of America Journal 65:922-931.

Surridge, B. W. J., A. L. Heathwaite, and A. J. Baird. 2007. The release of phosphorus to porewater and surface water from river riparian sediments. Journal of Environmental Quality 36:1534-1544.

Tate, C. M., R. E. Broshears, and D. M. McKnight. 1995. Phosphate dynamics in an acidic mountain stream: Interactions involving algal uptake, sorption by iron oxide and photoreduction. Limnology and Oceanography 40:938-946.

Tiessen, H. and J. O. Moir. 1993. Characterization of available $\mathrm{P}$ by sequential extraction. Pages 75-86 in M. R. Carter, editor. Soil sampling and methods of analysis. Lewis Publishers, Boca Raton, FL.

Turner, B. L., B. J. Cade-Menun, L. M. Condron, and S. Newman. 2005. Extraction of soil organic phosphorus. Talanta 66:294-306.

Turner, B. L. and S. Newman. 2005. Phosphorus cycling in wetland soils: The importance of phosphate diesters. Journal of Environmental Quality 34:1921-1929.

van Beusekom, J. E. E. and U. H. Brockmann. 1998. Transformation of phosphorus in the Elbe estuary. Estuaries 21:518-526.

Van Der Lee, G. E. M., H. O. Venterink, and N. E. M. Asselman. 2004. Nutrient retention in floodplains of the Rhine distributaries in The Netherlands. River Research and Applications 20:315-325. 
Vu, D. T., C. Tang, and R. D. Armstrong. 2010. Transformations and availability of phosphorus in three contrasting soil types from native and farming systems: A study using fractionation and isotopic labeling techniques. Journal of Soils and Sediments 10:18-29.

Walbridge, M. R. 1991. Phosphorus availability in acid organic soils of the lower North-Carolina coastal-plain. Ecology 72:2083-2100.

Walbridge, M. R. and B. G. Lockaby. 1994. Effects of forest management on biogeochemical functions in southern forested wetlands. Wetlands 14:10-17.

Walbridge, M. R. and J. P. Struthers. 1993. Phosphorus retention in non-tidal palustrine forested wetlands of the mid-Atlantic region. Wetlands 13:84-94.

Walbridge, M. R. and P. M. Vitousek. 1987. Phosphorus mineralization potential in acid organic soils - Processes affecting $\left(\mathrm{PO}_{4}{ }^{3-}\right)-\mathrm{P}-32$ isotope-dilution measurements. Soil Biology \& Biochemistry 19:709-717.

Wang, G. P., J. S. Liu, J. D. Wang, and J. B. Yu. 2006. Soil phosphorus forms and their variations in depressional and riparian freshwater wetlands (Sanjiang Plain, Northeast China). Geoderma 132:59-74.

Wharton, C. H. and M. M. Brinson. 1979. Characteristics of southeastern river systems. Pages 32-40 in R. R. Johnson and J. F. McCormick, editors. Strategies for protection and management of floodplain wetlands and other riparian ecosystems. USDA Forest Service, Washington, DC.

Wright, R. B., B. G. Lockaby, and M. R. Walbridge. 2001. Phosphorus availability in an artificially flooded southeastern floodplain forest soil. Soil Science Society of America Journal 65:1293-1302. 
Figure 3.1: Sequential fractionation method used to extract $\mathrm{P}$ and ${ }^{32} \mathrm{P}$ from floodplain forest soils (Paludan and Jensen 1995). 


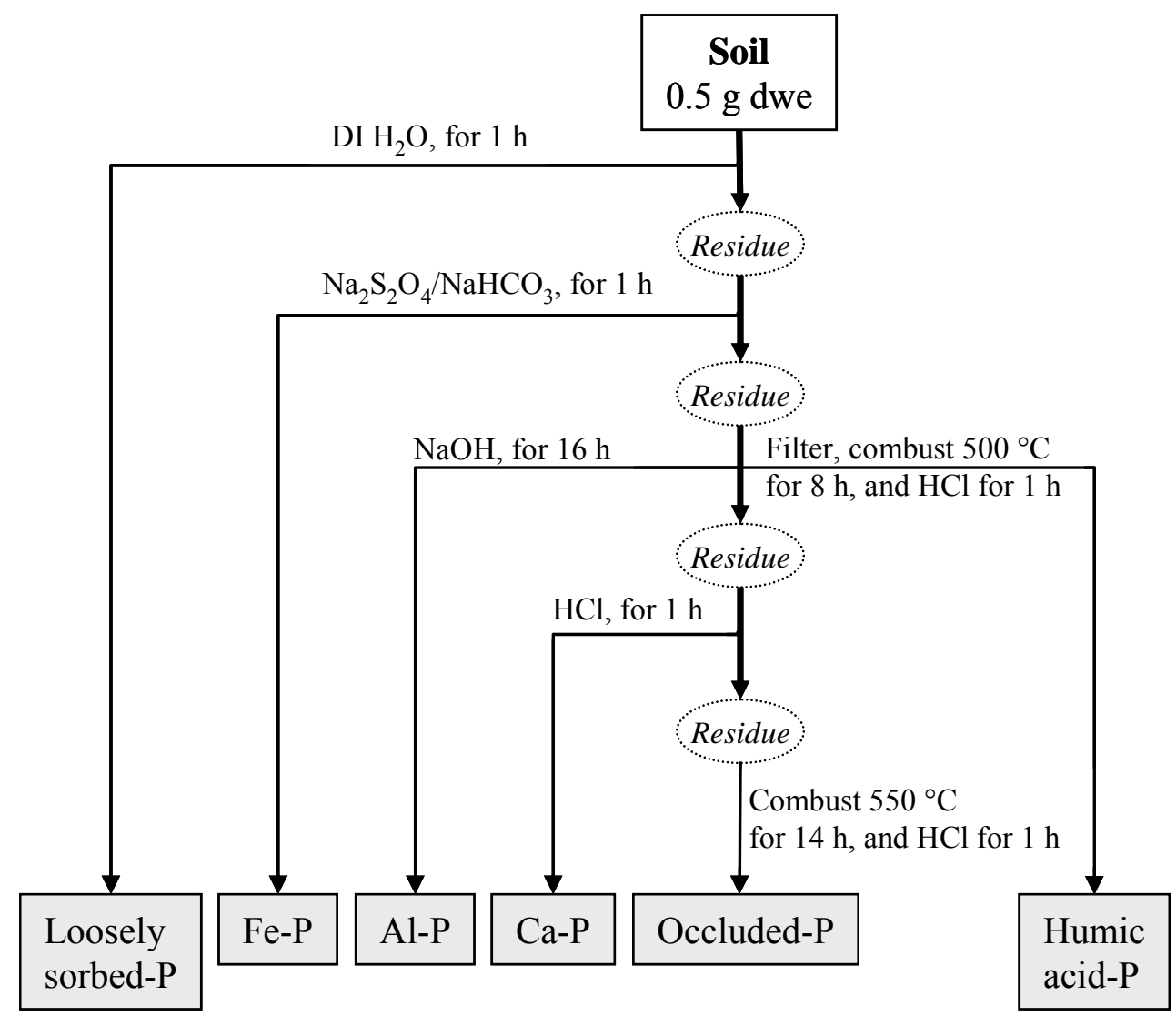


Figure 3.2: Specific activity $\left(\mathrm{SA}:{ }^{32} \mathrm{P} / \mathrm{P} ; \mathrm{SA}_{\mathrm{i}} \cdot{ }^{32} \mathrm{P}_{\mathrm{i}} / \mathrm{P}_{\mathrm{i}} ; \mathrm{SA}_{\mathrm{o}}:{ }^{32} \mathrm{P}_{\mathrm{o}} / \mathrm{P}_{\mathrm{o}}\right)$ of soil pools/fractions in flooded (for $40 \mathrm{~h}$ and $8 \mathrm{~d}$ ) soil cores collected from the a. Pee Dee R., b. Wateree R., c. Black R., d. Drowning Crk. sites, and e. average of all cores across FF sites. Average combined SA of Paludan and Jensen sequentially extracted fractions (indicated by a solid line) and sequentially extracted fractions + roots (indicated by dotted line) indicative of isotopic equilibrium (IE) within exchangeable soil pools/fractions. * Indicates significant differences $(p \leq 0.05)$ in SA between the $40 \mathrm{~h}$ and $8 \mathrm{~d}$ incubation period (for ANOVA results see Appendix Table 3.5). 


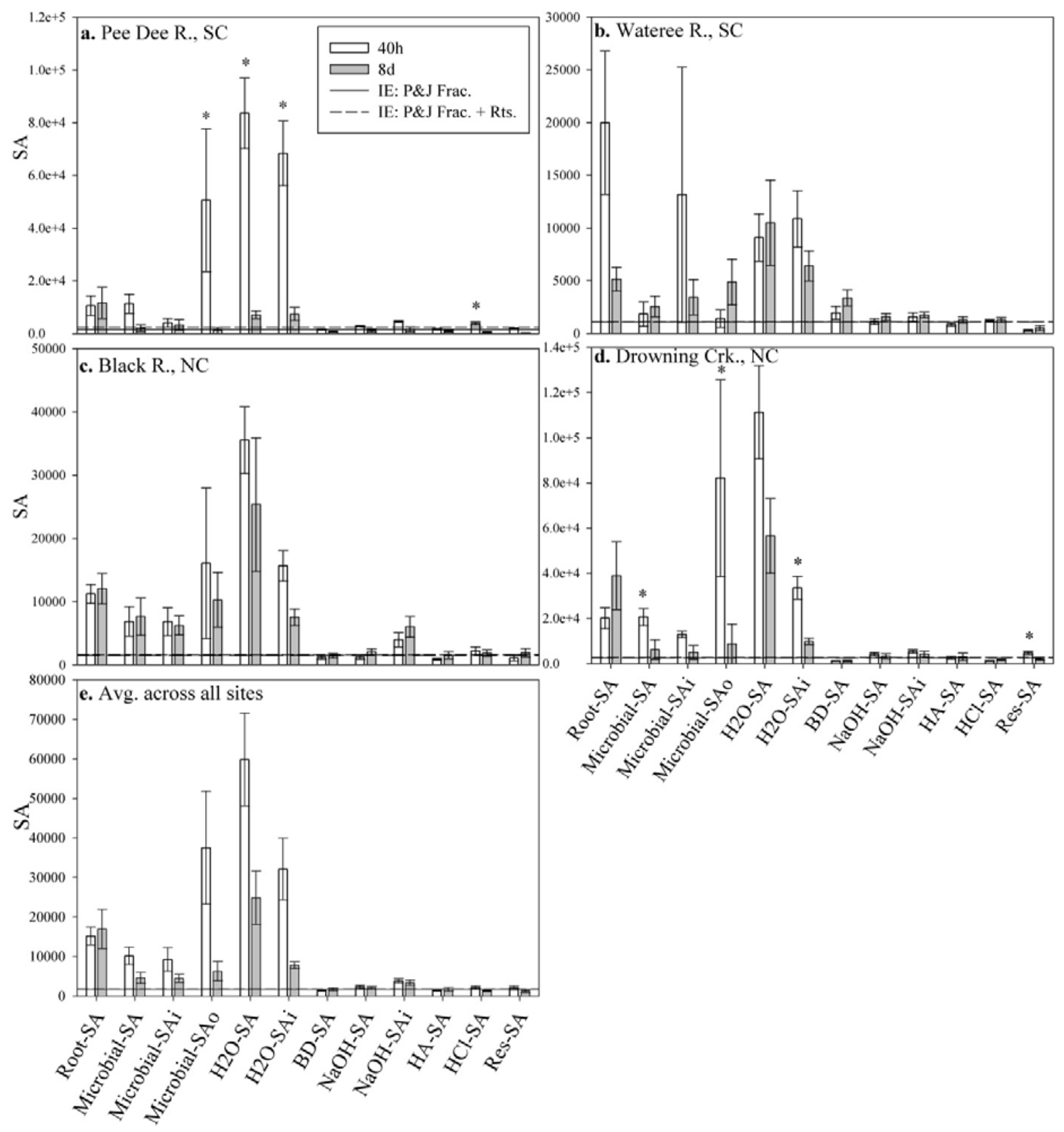


Figure 3.3: Comparison of the molar ratio of Fe:P vs $\mathrm{Al}: \mathrm{P}$ in $\mathrm{H}_{2} \mathrm{O}(\mathbf{a}-\mathbf{b}), \mathrm{NaOH}(\mathbf{c}), \mathrm{Res}(\mathbf{e})$, $\mathrm{BD}(\mathbf{f}), \mathrm{HCl}(\mathbf{g}), \mathrm{HA}(\mathbf{h})$ extractable fractions and $\mathrm{NaOH}_{-}{ }^{32} \mathrm{P}_{\mathrm{i}}$ vs soil clay content associated with the Al/clay vs. soil clay content (d) in cores collected from AL and BW FFs. Solid line represents a ratio $=1$ between variables. 

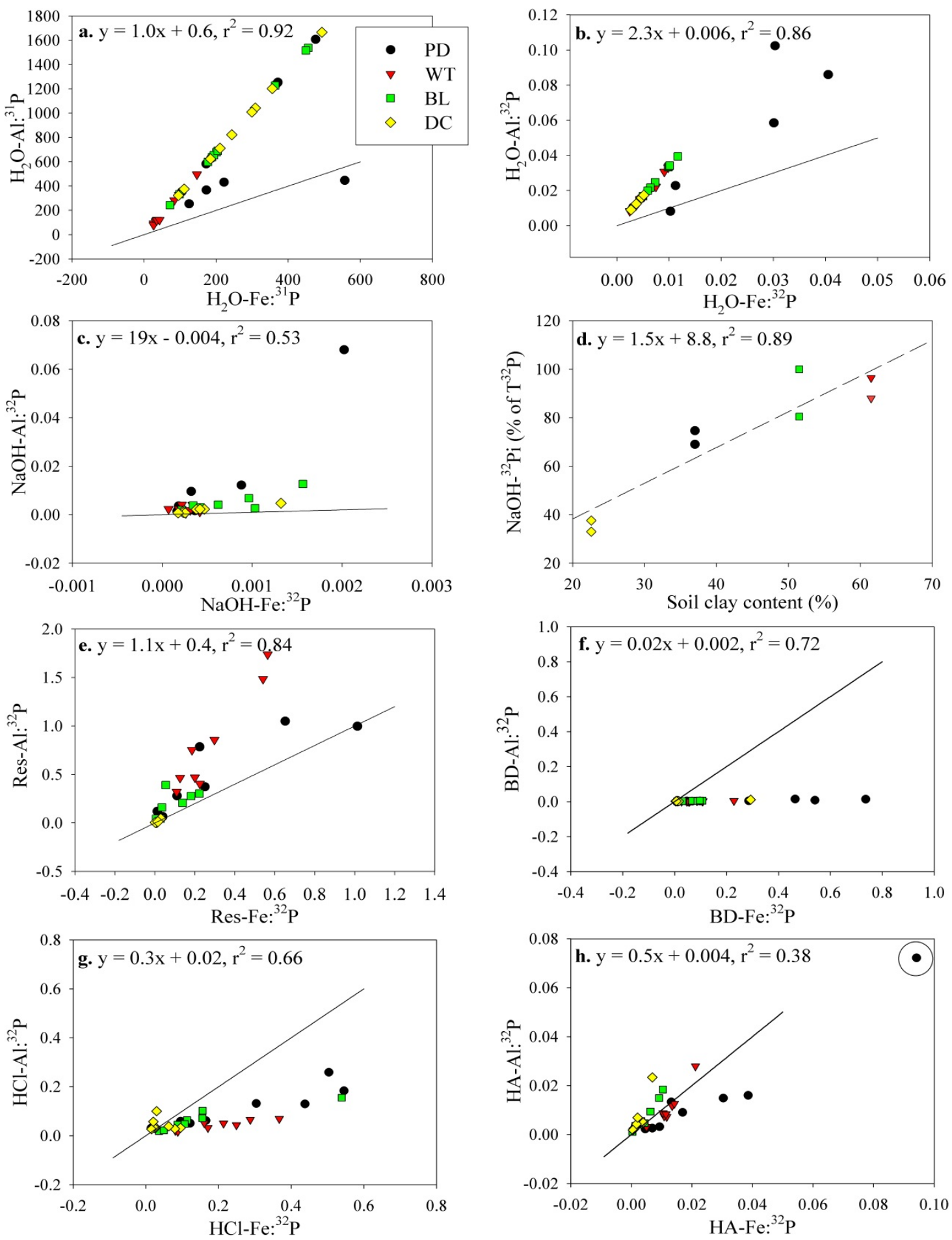
Table 3.1: Locations and characteristics of the study sites. Soils data were obtained from regional soil maps (USDA/NRCS); drainage areas are from the USGS web interface for the National Water Information System (http://waterdata.usgs.gov) 


\begin{tabular}{l|l|l|l|l|l|l}
\hline River & Site & Latitude & Longitude & Drainage area $\left.\mathbf{( k m}^{2}\right)$ & Soil Class & †Dominant Vegetation \\
\hline AL & PD & $34^{\circ} 12^{\prime} \mathrm{N}$ & $79^{\circ} 32^{\prime} \mathrm{W}$ & 22,870 & Aquic Quartzipsamments & Cypress, Tupelo \\
& WT & $33^{\circ} 49^{\prime} \mathrm{N}$ & $80^{\circ} 37^{\prime} \mathrm{W}$ & 14,478 & Fluvaquentic Dystrochrepts & Cypress, River Birch, Willow Oak \\
\hline BW & BL & $34^{\circ} 45^{\prime} \mathrm{N}$ & $78^{\circ} 18^{\prime} \mathrm{W}$ & 1,751 & Typic Fluvaquent & Sweetgum, Tupelo \\
& DC & $35^{\circ} 03^{\prime} \mathrm{N}$ & $79^{\circ} 29^{\prime} \mathrm{W}$ & 474 & Fluvaquentic Dystrochrepts/Typic Fluvaquents & River Birch, Sweetgum \\
\hline
\end{tabular}

†The dominant woody vegetation at all four sites is mixed deciduous bottomland forest dominated by bald cypress (Taxodium distichum), sweetgum (Liquidambar styracifula), river birch (Betula nigra), water tupelo (Nyssa aquatica), and willow oak (Quercus phellos) (Dress et al. in preparation). 
Table 3.2: Total $\mathrm{P}$ and ${ }^{32} \mathrm{P}$, inorganic (MR-P) and organic $\mathrm{P}$ and ${ }^{32} \mathrm{P}$, and $\mathrm{TOC}, \mathrm{TN}$, and $\mathrm{pH}$ in river waters collected at each $\mathrm{AL}$ and BW floodplain forest. * Indicates significant differences $(P \leq 0.05)$ in measured components between alluvial and blackwater rivers using a two-sample t-test analysis. 


\begin{tabular}{|c|c|c|c|c|c|c|c|c|c|}
\hline \multirow{2}{*}{$\begin{array}{l}\text { River water chemistry } \\
\text { Site and FF type }\end{array}$} & \multicolumn{3}{|c|}{$P$ concentrations } & \multicolumn{3}{|l|}{${ }^{32} \mathbf{P}$ activity } & \multicolumn{3}{|c|}{ Chemical parameter } \\
\hline & $\begin{array}{l}\text { TDP } \\
\left(\mu \mathrm{g} \mathrm{l}^{-2}\right)\end{array}$ & $\begin{array}{l}\text { MRP } \\
\left(\mu \mathrm{g} \mathrm{l}^{-2}\right)\end{array}$ & $\begin{array}{l}\mathbf{P}_{\mathbf{o}} \\
\left(\mu \mathrm{g} \mathrm{l}^{-2}\right)\end{array}$ & $\begin{array}{l}\text { Total }^{32} \mathbf{P} \\
\left(\mu \mathrm{Ci} \text { core }^{-1}\right)\end{array}$ & $\begin{array}{l}\mathbf{M R}^{32} \mathbf{P} \\
\left(\mu \mathrm{Ci} \text { core }^{-1}\right)\end{array}$ & $\begin{array}{l}{ }^{32} \mathbf{P}_{\mathbf{o}} \\
\left(\mu \mathrm{Ci} \text { core }^{-1}\right)\end{array}$ & $\begin{array}{l}\text { TOC } \\
\left(\mathrm{mg} \mathrm{l}^{-2}\right)\end{array}$ & $\begin{array}{l}\mathbf{T N} \\
\left(\mathrm{mg} \mathrm{l}^{-2}\right)\end{array}$ & pH \\
\hline PD & 44.3 & 21.9 & 22.4 & 190.9 & 208.8 & 0.0 & 4.3 & 1.0 & 6.9 \\
\hline WT & 51.3 & 32.6 & 18.7 & 201.2 & 206.7 & 0.0 & 4.3 & 0.9 & 7.1 \\
\hline$A L F F-m e a n$ & $47.8(3.5)$ & $27.3(5.4)$ & $20.6(1.9)$ & $196.0(1.9)^{*}$ & $207.7(0.4)^{*}$ & 0.0 & $4.3(0.0)$ & $0.9(0.0)$ & $7.0^{*}$ \\
\hline$\overline{B L}$ & 61.2 & 37.0 & 24.2 & 186.0 & 141.4 & 44.7 & 12.3 & 1.1 & 6.4 \\
\hline $\mathrm{DC}$ & 12.9 & 3.9 & 9.0 & 177.8 & 40.3 & 137.5 & 9.2 & 0.4 & 5.0 \\
\hline BWFF-mean & $37.1(24.2)$ & $20.5(16.6)$ & $16.6(7.6)$ & $181.9(1.6)$ & $90.8(19.1)$ & $91.1(17.5)$ & $10.8(0.6)^{*}$ & $0.8(0.1)$ & 5.7 \\
\hline
\end{tabular}


Table 3.3: Mean $( \pm \mathrm{SE})$ total $\mathrm{P}$ content and ${ }^{32} \mathrm{P}$ activity recovered in headwater, soils, and drainwater in $\mathrm{AL}$ and $\mathrm{BW}$ cores, nonflooded, and cores flooded for $40 \mathrm{~h}$ and $8 \mathrm{~d}$. Values shown in bold with different superscript letters correspond to means that are significantly different (ANOVA, $P<0.05$ following Tukey's HSD test). For complete results showing significant effects and interaction terms of the 2-way ANOVA see Appendix Table 3.1. * Indicates significant differences $(\mathrm{p} \leq 0.05)$ in measured components between head- and drain-water samples using a paired t-test analysis. 


\begin{tabular}{|c|c|c|c|c|c|c|c|c|c|c|}
\hline \multirow{2}{*}{$\begin{array}{l}\text { Total } P \text { and }{ }^{32} P \\
\text { Site and FF type }\end{array}$} & \multicolumn{2}{|c|}{ Head-water } & \multicolumn{2}{|c|}{ Drain-water } & \multicolumn{2}{|l|}{ Root } & \multicolumn{2}{|c|}{ Microbial biomass } & \multicolumn{2}{|c|}{ Soil fractions } \\
\hline & $\begin{array}{l}\mathbf{P} \\
\left(\mu \mathrm{g} \mathrm{l}^{-2}\right)\end{array}$ & $\begin{array}{l}{ }^{32} \mathbf{P} \\
\text { (\% Recov.) }\end{array}$ & $\begin{array}{l}\mathbf{P} \\
\left(\mu g \mathrm{l}^{-2}\right)\end{array}$ & $\begin{array}{l}{ }^{32} \mathbf{P} \\
\text { (\% Recov.) }\end{array}$ & $\begin{array}{l}\mathbf{P} \\
\left(\mathrm{g} \mathrm{m}^{-2}\right)\end{array}$ & $\begin{array}{l}{ }^{32} \mathbf{P} \\
\text { (\% Recov.) }\end{array}$ & $\begin{array}{l}\mathbf{P} \\
\left(\mathrm{g} \mathrm{m}^{-2}\right)\end{array}$ & $\begin{array}{l}{ }^{32} \mathbf{P} \\
(\% \text { Recov.) }\end{array}$ & $\begin{array}{l}\mathbf{P} \\
\left(\mathrm{g} \mathrm{m}^{-2}\right)\end{array}$ & $\begin{array}{l}{ }^{32} \mathbf{P} \\
\text { (\% Recov.) }\end{array}$ \\
\hline $\begin{array}{l}\mathrm{PD} \\
\mathrm{WT}\end{array}$ & $\begin{array}{l}24.3(3.3) \\
60.5(14.8)\end{array}$ & $\begin{array}{l}17.4(5.4) \\
3.8(1.4)\end{array}$ & $\begin{array}{l}69.8(14.8) \\
83.5(6.6)\end{array}$ & $\begin{array}{l}0.1(0.0) \\
0.7(0.3)\end{array}$ & $\begin{array}{l}0.3(0.1) \\
0.3(0.1)\end{array}$ & $\begin{array}{l}6.7(1.9) \\
3.1(0.9) \\
\end{array}$ & $\begin{array}{l}0.6(0.1) \\
0.7(0.2)\end{array}$ & $\begin{array}{l}6.0(1.9) \\
1.9(0.7) \\
\end{array}$ & $\begin{array}{l}34.2(5.1)^{B} \\
74.7(3.5)^{A}\end{array}$ & $\begin{array}{l}69.7(5.6) \\
90.5(1.7) \\
\end{array}$ \\
\hline$A L$ - mean & $42.4(8.7)$ & $10.6(3.2)$ & $78.2(6.9)$ & $0.4(0.2)$ & $0.3(0.0)$ & $4.9(1.1)$ & $0.6(0.1)$ & $4.0(1.1)$ & $54.5(5.5)$ & $80.1(4.0)$ \\
\hline $\begin{array}{l}\mathrm{BL} \\
\mathrm{DC} \\
\end{array}$ & $\begin{array}{l}18.5(4.4) \\
5.3(0.7) \\
\end{array}$ & $\begin{array}{l}7.8(1.7) \\
18.9(2.2) \\
\end{array}$ & $\begin{array}{l}81.7(19.4) \\
47.4(7.2) \\
\end{array}$ & $\begin{array}{l}0.6(0.3) \\
0.6(0.2) \\
\end{array}$ & $\begin{array}{l}0.4(0.1) \\
0.1(0.0) \\
\end{array}$ & $\begin{array}{l}7.8(1.9) \\
6.1(2.1) \\
\end{array}$ & $\begin{array}{l}0.8(0.1) \\
0.7(0.0) \\
\end{array}$ & $\begin{array}{l}12.3(4.2) \\
15.5(3.9) \\
\end{array}$ & $\begin{array}{l}38.0(2.3)^{B} \\
18.9(2.2)^{B}\end{array}$ & $\begin{array}{l}71.5(4.8) \\
59.0(4.9) \\
\end{array}$ \\
\hline BW-mean & $11.9(2.7)$ & $13.4(2.0)$ & $64.6(10.9)$ & $0.6(0.2)$ & $0.2(0.1)$ & $6.9(1.4)$ & $(0.8)(0.1)$ & $13.9(2.8)$ & $28,5(2.7)$ & $65.2(3.7)$ \\
\hline Overall - mean & $27.2(5.2)$ & $12.0(1.9)^{*}$ & $70.7(6.8) *$ & $0.5(0.1)$ & $0.3(0.0)$ & $5.9(0.9)$ & $0.7(0.1)$ & $8.9(1.7)$ & $41.5(3.7)$ & $72.7(3.0)$ \\
\hline $\begin{array}{l}\text { Incubation } \\
\text { Non-flooded } \\
40 \mathrm{~h} \\
8 \mathrm{~d}\end{array}$ & $\begin{array}{l}--- \\
22.3(3.9) \\
32.0(9.8)\end{array}$ & $\begin{array}{l}--- \\
10.7(1.8) \\
13.3(3.3)\end{array}$ & $\begin{array}{l}--- \\
74.4(8.6) \\
66.1(11.1)\end{array}$ & $\begin{array}{l}--- \\
0.5(0.2) \\
0.5(0.2)\end{array}$ & $\begin{array}{l}--- \\
0.3(0.1) \\
0.2(0.0)\end{array}$ & $\begin{array}{l}--- \\
5.9(1.3) \\
6.0(1.3)\end{array}$ & $\begin{array}{l}0.9(0.2) \\
0.7(0.1) \\
0.6(0.1)\end{array}$ & $\begin{array}{l}--- \\
11.1(2.3) \\
6.8(2.5)\end{array}$ & $\begin{array}{l}53.4(6.0) \\
39.8(5.9) \\
37.1(6.2)\end{array}$ & $\begin{array}{l}--- \\
71.9(3.6) \\
73.5(4.8)\end{array}$ \\
\hline
\end{tabular}


Table 3.4: Mean ( \pm SE) total P content (analyzed by Kjeldahl digest) and general soil physical and chemical characteristics in control cores (unlabeled), and cores inundated for $40 \mathrm{~h}$ and $8 \mathrm{~d}$ across all $\mathrm{AL}$ and BW cores. Values shown in bold with different superscript letters correspond to means that are significantly different (ANOVA, $P<0.05$ following Tukey's HSD test). For complete results showing significant effects and interaction terms of the 2-way ANOVA see Appendix Table 3.2. 


\begin{tabular}{|c|c|c|c|c|c|c|}
\hline & \multicolumn{6}{|l|}{ Soil chemistry } \\
\hline Site and FF type & Total P $\left(\mathrm{g} \mathrm{m}^{-2}\right)$ & $\mathbf{C}\left(\mathrm{g} \mathrm{m}^{-2}\right)$ & $\mathbf{N}\left(\mathrm{g} \mathrm{m}^{-2}\right)$ & pH & Moisture (\%) & Clay (\%) \\
\hline PD & $30.8(3.3)^{B}$ & $1,833.9(309.0)$ & $112.7(18.2)$ & 5.1 & $27.7(1.1)^{\text {B }}$ & 37.0 \\
\hline WT & $92.9(5.1)^{A}$ & $2,593.5(226.0)$ & $189.0(16.8)$ & 5.2 & $35.1(2.2)^{A B}$ & 61.5 \\
\hline$A L F F-m e a n$ & $61.8(7.7)$ & $2,213.7$ (205.7) & $150.8(14.9)$ & $5.1^{A}$ & $31.4(1.5)$ & $49.3(2.8)$ \\
\hline BL & $34.5(1.4)^{B}$ & $3,357.4(212.8)$ & $242.2(17.3)$ & 4.7 & $43.4(1.9)^{A}$ & 51.5 \\
\hline $\mathrm{DC}$ & $14.0(1.5)^{\mathrm{B}}$ & $2,093.4(167.8)$ & $233.3(10.6)$ & 4.8 & $27.6(1.6)^{B}$ & 22.6 \\
\hline BWFF-mean & $24.3(2.6)$ & $2,725.4$ (196.0) & 237.7 (9.9) & $4.8^{B}$ & $35.5(2.2)$ & 37.1 (3.3) \\
\hline Incubation & & & & & & \\
\hline Non-flooded & $44.4(9.6)$ & $3,046.5(268.7)$ & $213.8(19.6)$ & $4.8^{A}$ & $31.0(1.6)$ & --- \\
\hline $40 \mathrm{~h}$ & $45.8(9.3)$ & $2,505.5(242.2)$ & $211.1(18.7)$ & $5.0^{\mathrm{B}}$ & $32.1(2.1)$ & --- \\
\hline $8 \mathrm{~d}$ & $39.6(7.3)$ & $2,145.2(212.2)$ & $167.7(17.4)$ & $5.0^{B}$ & $36.0(2.5)$ & --- \\
\hline
\end{tabular}


Table 3.5: Mean ( \pm SE) of total P content in sequentially extracted fractions (Paludan and Jensen 1995) within control cores (not flooded) and soils flooded for $40 \mathrm{~h}$ and $8 \mathrm{~d}$ across all $\mathrm{AL}$ and BW cores. Values shown in bold with different upper case superscripts correspond to means that are significantly different (ANOVA, $P<0.05$ following Tukey's HSD test). For complete results showing significant effects and interaction terms of the 2-way ANOVA see Appendix Table 3.3. Overall means represents the relative proportion $(\%)$ of total $\mathrm{P}$ in soil fractions across all AL and BW cores, where values shown with different lower case superscripts correspond to means that are significantly different (ANOVA, $P<0.05$ following Duncan's multiple range test). 


\begin{tabular}{|c|c|c|c|c|c|c|}
\hline \multirow{2}{*}{$\frac{P\left(\mathrm{~g} \mathrm{~m}^{-2}\right)}{\text { Site }}$} & \multicolumn{6}{|c|}{ Distribution in soil fractions } \\
\hline & $\mathrm{H}_{2} \mathrm{O}-\mathrm{P}$ & BD-P & NaOH-P & HA-P & HCl-P & Res-P \\
\hline $\mathrm{PD}$ & $0.0(0.0)^{B}$ & $5.2(0.6)^{B C}$ & $17.7(3.3)^{A B}$ & $4.1(0.7){ }^{A B}$ & $0.5(0.1)^{\mathrm{B}}$ & $7.3(1.5)^{B}$ \\
\hline WT & $0.1(0.0)^{A}$ & $6.2(0.4)^{\mathrm{A}} \mathrm{B}$ & $32.2(1.7)^{\mathrm{A}}$ & $7.6(0.5)^{A}$ & $1.7(0.1)^{A}$ & $27.5(3.0)^{A}$ \\
\hline$A L F F-m e a n$ & $0.1(0.0)$ & $5.7(0.4)$ & $24.9(2.5)$ & $5.9(0.6)$ & $1.1(0.2)$ & $17.4(2.8)$ \\
\hline$\overline{\mathrm{BL}}$ & $0.0(0.0)^{B}$ & $3.7(0.2)^{C}$ & $22.1(1.7)^{A B}$ & $5.6(0.4)^{A B}$ & $0.8(0.2)^{A B}$ & $6.5(0.5)^{\mathrm{B}}$ \\
\hline DC & $0.0(0.0)^{B}$ & $7.6(0.6)^{A}$ & $7.9(1.1)^{B}$ & $2.1(0.3)^{B}$ & $0.4(0.1)^{\mathrm{B}}$ & $1.6(0.2)^{C}$ \\
\hline$B W F F-m e a n$ & $0.0(0,0)$ & $5.7(0.5)$ & $15.0(1.9)$ & $3.9(0.5)$ & $0.6(0.1)$ & $4.1(0.6)$ \\
\hline Overall-mean (\% Prop.) & $0.1(0.0)^{d}$ & $18.7(2.2)^{b}$ & $47.2(1.4)^{a}$ & $12.0(0.6)^{c}$ & $1.9(0.1)^{d}$ & $20.2(1.9)^{b}$ \\
\hline \multicolumn{7}{|l|}{ Incubation } \\
\hline Non-flooded & $0.1(0.0)$ & $6.5(0.8)^{\mathrm{A}}$ & $28.8(3.4)$ & $6.0(0.7)$ & $1.3(0.1)$ & $11.6(2.9)$ \\
\hline $40 \mathrm{~h}$ & $0.0(0.0)$ & $6.3(0.5)^{A}$ & $18.0(2.3)$ & $4.9(0.6)$ & $0.7(0.1)$ & $10.6(3.2)$ \\
\hline $8 \mathrm{~d}$ & $0.0(0.0)$ & $4.6(0.4)^{\mathrm{B}}$ & $17.5(2.8)$ & $4.3(0.7)$ & $0.7(0.2)$ & $10.5(3.0)$ \\
\hline
\end{tabular}


Table 3.6: Mean $\left( \pm\right.$ SE) ${ }^{32} \mathrm{P}$ recovered in sequentially extracted fractions (Paludan and Jensen 1995) within control cores (not flooded) and soils flooded for $40 \mathrm{~h}$ and $8 \mathrm{~d}$ across all $\mathrm{AL}$ and BW cores. Results showing significant effects and interaction terms of the 2-way ANOVA are listed in Appendix Table 3.4. Values shown with different lower case superscripts correspond to means that are significantly different (ANOVA, $P<0.05$ following Duncan's multiple range test). 


\begin{tabular}{c|l|l|l|l|l|l}
\hline${ }^{32} \mathbf{P}(\%$ recovery) & \multicolumn{6}{|l}{ Distribution in soil fractions } \\
\hline Site and FF type & $\mathbf{H}_{2} \mathbf{O}-{ }^{32} \mathbf{P}$ & $\mathbf{B D}-{ }^{32} \mathbf{P}$ & $\mathbf{N a O H}-{ }^{32} \mathbf{P}$ & $\mathbf{H A}-{ }^{32} \mathbf{P}$ & $\mathbf{H C l}-{ }^{32} \mathbf{P}$ & Res $^{32} \mathbf{P}$ \\
PD & $1.5(0.2)$ & $16.1(2.4)$ & $60.4(2.2)$ & $10.8(0.4)$ & $1.2(0.2)$ & $10.0(0.8)$ \\
WT & $0.9(0.1)$ & $18.9(1.1)$ & $54.9(1.6)$ & $10.4(0.4)$ & $2.9(0.3)$ & $11.9(1.3)$ \\
\hline $\boldsymbol{A L} \boldsymbol{F F}-\boldsymbol{m e a n}$ & $1.2(0.1)$ & $17.5(1.3)$ & $57.6(1.5)$ & $10.6(0.3)$ & $2.1(0.3)$ & $11.0(0.8)$ \\
\hline BL & $0.8(0.1)$ & $9.3(0.5)$ & $61.0(1.0)$ & $11.9(0.2)$ & $2.4(0.4)$ & $14.7(1.2)$ \\
DC & $3.4(0.9)$ & $20.4(1.3)$ & $55.2(1.1)$ & $9.7(0.7)$ & $1.0(0.1)$ & $10.3(1.3)$ \\
\hline $\boldsymbol{B W} \boldsymbol{F F}-\boldsymbol{m e a n}$ & $2.1(0.5)$ & $14.8(1.6)$ & $58.1(1.0)$ & $10.8(0.5)$ & $1.7(0.3)$ & $12.5(1.0)$ \\
\hline Overall - mean & $1.7(0.3)^{d}$ & $16.2(1.0)^{b}$ & $57.9(0.9)^{a}$ & $10.7(0.3)^{c}$ & $1.9(0.2)^{d}$ & $11.7(0.6)^{c}$ \\
\hline Incubation & & & & & & \\
$40 \mathrm{~h}$ & $1.6(0.2)$ & $15.8(1.2)$ & $57.3(1.0)$ & $10.5(0.3)$ & $2.1(0.3)$ & $12.7(0.6)$ \\
$8 \mathrm{~d}$ & $1.8(0.5)$ & $16.6(1.7)$ & $58.5(1.5)$ & $10.9(0.4)$ & $1.6(0.2)$ & $10.7(1.1)$ \\
\hline
\end{tabular}


Table 3.7: Mean ( \pm SE) of the proportion of organic P in TP measured in headwater, drainwater, microbial biomass, and sequentially extracted soil fractions within control cores (not flooded) and soils flooded for $40 \mathrm{~h}$ and $8 \mathrm{~d}$ across all AL and BW cores. Values shown in bold with different superscript letters correspond to means that are significantly different (ANOVA, $P<0.05$ following Tukey's HSD test). For complete results showing significant effects and interaction terms of the 2-way ANOVA see Appendix Table 3.5. †Soil sum represents the sum of ${ }^{32} \mathrm{P}_{\mathrm{o}}$ extracted from the six soil fractions in the Paludan and Jensen scheme + microbial biomass + root associated + drainwater. 


\begin{tabular}{|c|c|c|c|c|c|c|c|c|c|c|c|}
\hline \multirow{2}{*}{$\frac{P_{0}(\% \text { Prop. of TP })}{\text { Site and FF type }}$} & \multirow{2}{*}{$\begin{array}{l}\text { Headwater } \\
{ }^{32} \mathbf{P}_{0}\end{array}$} & \multirow{2}{*}{$\begin{array}{l}\text { Drainwater } \\
{ }^{32} \mathbf{P}_{\mathbf{0}} \\
\end{array}$} & \multicolumn{2}{|c|}{ Microbial biomass } & \multicolumn{2}{|c|}{$\mathrm{H}_{2} \mathrm{O}-\mathrm{P}$} & \multirow{2}{*}{$\begin{array}{l}\text { BD-P } \\
{ }^{32} \mathbf{P}_{0} \\
\end{array}$} & \multicolumn{2}{|c|}{ NaOH-P } & \multirow{2}{*}{$\begin{array}{l}\text { HCl-P } \\
{ }^{32} \mathbf{P}_{0} \\
\end{array}$} & \multirow{2}{*}{$\begin{array}{l}\text { †Soil sum } \\
{ }^{32} \mathbf{P}_{\mathbf{0}}\end{array}$} \\
\hline & & & $\mathbf{P}_{\mathbf{0}}$ & ${ }^{32} \mathbf{P}_{\mathbf{0}}$ & $\mathbf{P}_{\mathbf{o}}$ & ${ }^{32} \mathbf{P}_{\mathbf{o}}$ & & $\mathbf{P}_{\mathbf{0}}$ & ${ }^{32} \mathbf{P}_{0}$ & & \\
\hline $\mathrm{PD}$ & 85.0 & 86.4 & 18.1 & 46.6 & 6.1 & 16.8 & 21.5 & 52.1 & 28.2 & 0.0 & 38.2 \\
\hline WT & 50.8 & 81.1 & 59.0 & 42.9 & 11.5 & 4.8 & 2.4 & 32.0 & 7.8 & 0.0 & 24.6 \\
\hline$A L F F-$ mean & 67.9 & 83.6 & 38.5 & 44.7 & 8.8 & 10.8 & 11.9 & 42.1 & 18.0 & 0.0 & 31.4 \\
\hline$\overline{B L}$ & 65.3 & 78.5 & 49.7 & 48.4 & 4.1 & 26.4 & 29.8 & 68.5 & 9.8 & 2.8 & 32.9 \\
\hline $\mathrm{DC}$ & 95.4 & 81.2 & 18.0 & 29.7 & 1.2 & 39.2 & 58.1 & 72.8 & 64.7 & 8.9 & 61.2 \\
\hline$B W F F-$ mean & 80.4 & 79.9 & 33.9 & 39.0 & 2.6 & 32.8 & 43.0 & 70.7 & 37.2 & 5.9 & 47.1 \\
\hline Overall-mean & 74.1 & 81.7 & 36.2 & 41.9 & 5.7 & 21.8 & 27.0 & 56.4 & 27.6 & 2.9 & 39.2 \\
\hline \multicolumn{12}{|l|}{ Incubation } \\
\hline Non-flooded & --- & --- & --- & --- & 6.0 & --- & --- & 59.3 & --- & --- & \\
\hline $40 \mathrm{~h}$ & 71.2 & 76.3 & 45.8 & 48.2 & 7.5 & 14.1 & 24.2 & 57.9 & 27.5 & 4.7 & 37.8 \\
\hline $8 \mathrm{~d}$ & 77.0 & 87.3 & 26.6 & 35.5 & 3.8 & 29.5 & 30.0 & 53.3 & 27.7 & 1.1 & 40.6 \\
\hline
\end{tabular}


Table 3.8: Specific Activity $\left(\mathrm{SA}:{ }^{32} \mathrm{P} / \mathrm{P}, \mathrm{SA}_{\mathrm{i}}:{ }^{32} \mathrm{P}_{\mathrm{i}} / \mathrm{P}_{\mathrm{i}}, \mathrm{SA}_{\mathrm{o}}:{ }^{32} \mathrm{P}_{\mathrm{o}} / \mathrm{P}_{\mathrm{o}}\right)$ in sequentially extracted fractions (Paludan and Jensen 1995$)$ in soils flooded for $40 \mathrm{~h}$ and $8 \mathrm{~d}$ across all $\mathrm{AL}$ and BW cores. Results showing significant effects and interaction terms of the 2-way ANOVA are listed in Appendix Table 3.5. Values shown with different lower case superscripts correspond to means that are significantly different (ANOVA, $P<0.05$ following Duncan's multiple range test). 


\begin{tabular}{|c|c|c|c|c|c|c|c|c|c|c|c|c|}
\hline \multirow{3}{*}{$\begin{array}{c}\text { SA } \\
\text { AL FF }\end{array}$} & \multicolumn{12}{|c|}{ Soil pools and fractions } \\
\hline & \multirow{3}{*}{$\begin{array}{l}\text { Root } \\
\text { SA } \\
11,091.9\end{array}$} & \multicolumn{3}{|c|}{ Microbial } & \multicolumn{2}{|c|}{$\mathrm{H}_{2} \mathrm{O}$} & \multirow{3}{*}{$\begin{array}{l}\text { BD } \\
\text { SA } \\
1,123.5\end{array}$} & \multicolumn{2}{|c|}{$\mathrm{NaOH}$} & \multirow{3}{*}{$\begin{array}{l}\text { HA } \\
\text { SA } \\
1,270.1\end{array}$} & \multirow{3}{*}{$\begin{array}{l}\text { HCl } \\
\text { SA } \\
2,211.0\end{array}$} & \multirow{3}{*}{$\begin{array}{l}\text { Res } \\
\text { SA } \\
1,154.1\end{array}$} \\
\hline & & SA & $\mathrm{SA}_{\mathrm{i}}$ & $\mathrm{SA}_{\mathrm{o}}$ & SA & $\mathrm{SA}_{\mathrm{i}}$ & & SA & $\mathrm{SA}_{\mathrm{i}}$ & & & \\
\hline PD & & $6,699.8$ & $3,697.4$ & $25,900.4$ & $45,364.6$ & $37,905.8$ & & $2,038.9$ & $3,125.1$ & & & \\
\hline WT & $11,502.4$ & $2,204.0$ & $8,285.9$ & $3,139.3$ & $9,796.1$ & $8,634.7$ & $2,656.5$ & $1,352.4$ & $1,658.2$ & $1,091.1$ & $1,239.2$ & 398.5 \\
\hline \multicolumn{13}{|l|}{ BW FF } \\
\hline BL & $11,640.6$ & $7,263.1$ & $6,548.5$ & $13,200.1$ & $30,445.4$ & $11,605.5$ & $1,331.6$ & $1,673.0$ & $5,000.4$ & $1,221.0$ & $2,048.7$ & $1,525.6$ \\
\hline $\mathrm{DC}$ & $29,541.2$ & $13,448.0$ & $8,955.0$ & $45,416.3$ & $83,908.1$ & $21,704.3$ & $1,233.4$ & $3,761.1$ & $4,786.9$ & $2,824.0$ & $1,456.0$ & $3,430.2$ \\
\hline Overall - & $16,087.3$ & $7,403.7$ & $6,871.7$ & $21,914.0$ & $42,378.5$ & $19,962.6$ & $1,586.2$ & $2,206.4$ & $3,642.7$ & $1,601.5$ & $1,738.7$ & $1,627.1$ \\
\hline \multicolumn{13}{|l|}{ Incubation } \\
\hline $40 \mathrm{~h}$ & $15,167.6$ & $10,169.1$ & $9,250.8$ & $37,540.2$ & $59,868.5$ & $32,117.0$ & $1,459.9$ & $2,379.2$ & $3,894.8$ & $1,520.2$ & $2,138.6$ & $2,049.2$ \\
\hline $8 \mathrm{~d}$ & $16,949.5$ & $4,638.4$ & $4,492.4$ & $6,287.8$ & $24,888.6$ & $7,808.2$ & $1,712.6$ & $2,033.5$ & $3,390.5$ & $1,662.8$ & $1,338.8$ & $1,205.0$ \\
\hline
\end{tabular}


Table 3.9: Mean ( \pm SE) distribution of total Al and Fe in sequentially extracted fractions (Paludan and Jensen 1995) within control cores (not flooded) and soils flooded for $40 \mathrm{~h}$ and $8 \mathrm{~d}$ across all $\mathrm{AL}$ and BW cores. Values shown in bold with different superscript letters correspond to means that are significantly different (ANOVA, $P<0.05$ following Tukey's HSD test). For complete results showing significant effects and interaction terms of the 2-way ANOVA see Appendix Table 3.8. Values shown with different lower case superscripts (* for proportion of total Al) correspond to means that are significantly different (ANOVA, $P<0.05$ following Duncan's multiple range test). 


\begin{tabular}{|c|c|c|c|c|c|c|c|c|c|c|c|c|}
\hline \multicolumn{3}{|l|}{$\mathrm{Al}$ and $\mathrm{Fe}\left(\mathrm{g} \mathrm{m}^{-2}\right)$} & \multicolumn{10}{|c|}{ Distribution of $\mathrm{Al}$ and $\mathrm{Fe}$ in soil fractions } \\
\hline & \multicolumn{2}{|l|}{$\mathbf{H}_{2} \mathbf{O}$} & \multicolumn{2}{|c|}{ BD } & \multicolumn{2}{|c|}{$\mathrm{NaOH}$} & \multicolumn{2}{|l|}{ HA } & \multicolumn{2}{|l|}{ HCl } & \multicolumn{2}{|l|}{ Res } \\
\hline Site and FF type & $\mathrm{Al}$ & $\mathrm{Fe}$ & $\mathrm{Al}$ & $\mathrm{Fe}$ & $\mathrm{Al}$ & $\mathrm{Fe}$ & $\mathrm{Al}$ & $\mathrm{Fe}$ & $\mathrm{Al}$ & $\mathrm{Fe}$ & $\mathrm{Al}$ & $\mathrm{Fe}$ \\
\hline $\mathrm{PD}$ & 13.6 & 6.3 & 24.2 & 889.4 & 125.1 & 7.5 & 63.5 & 67.5 & 55.4 & 182.3 & $1,901.2$ & 939.3 \\
\hline WT & 12.7 & 3.9 & 21.9 & $1,013.2$ & 100.3 & 11.6 & 63.8 & 92.2 & 83.8 & 490.9 & $5,550.5$ & $1,840.5$ \\
\hline$A L F F-m e a n$ & 13.1 & 5.1 & 23.0 & $951.3^{A}$ & 112.7 & 9.6 & 63.6 & 79.9 & 69.6 & 336.6 & $3,725.8$ & $1,389.9$ \\
\hline $\mathrm{BL}$ & 11.0 & 3.2 & 17.1 & 250.0 & 133.8 & 18.2 & 34.9 & 17.9 & 60.4 & 157.3 & $1,433.6$ & 403.4 \\
\hline $\mathrm{DC}$ & 15.4 & 4.6 & 23.7 & 157.0 & 62.3 & 7.9 & 26.6 & 7.8 & 16.1 & 17.6 & 106.5 & 37.8 \\
\hline BWFF-mean & 13.2 & 3.9 & 20.4 & 203.5 & 98.0 & 13.0 & 30.7 & 12.8 & 38.2 & 87.4 & 770.1 & 220.6 \\
\hline Overall - mean (\% Prop.) & 2.9 & 0.9 & 4.5 & 43.2 & 11.2 & 1.9 & 4.8 & 3.3 & 4.7 & 13.1 & 71.9 & 37.6 \\
\hline Incubation & & & & & & & & & & & & \\
\hline Non-flooded & 17.9 & 5.4 & 28.0 & 546.9 & 188.5 & 14.5 & 73.3 & 52.2 & 63.0 & 412.8 & $2,827.4$ & 528.8 \\
\hline $40 \mathrm{~h}$ & 12.5 & 4.7 & 21.2 & 548.8 & 65.0 & 10.7 & 41.5 & 47.0 & 52.5 & 159.4 & $1,880.1$ & 739.1 \\
\hline $8 \mathrm{~d}$ & 11.4 & 3.9 & 19.1 & 621.2 & 104.2 & 10.4 & 39.8 & 42.8 & 50.7 & 164.3 & $2,326.1$ & $1,009.6$ \\
\hline
\end{tabular}


Table 3.10: Relationships between soil properties, $\mathrm{Al}, \mathrm{Fe}$, and ${ }^{32} \mathrm{P}$ activity, $\mathrm{P}$ concentrations, and $\mathrm{SA}$ were determined by Pearson's correlation analysis with Bonferroni probabilities reported. Data are log transformed where necessary. 


\begin{tabular}{|c|c|c|c|c|c|c|c|c|}
\hline & & $\mathrm{H}_{2} \mathrm{O}$ & BD & $\mathrm{NaOH}$ & HA & $\mathrm{HCl}$ & Res & Sum of fractions \\
\hline Fe:P vs. Al:P & $\begin{array}{l}\mathrm{r}^{2} \\
\mathrm{~F} \\
P\end{array}$ & $\begin{array}{c}0.92 \\
420.818 \\
\leq 0.0001\end{array}$ & $\begin{array}{c}0.39 \\
25.858 \\
\leq 0.0001\end{array}$ & $\begin{array}{c}--- \\
\text { n.s. } \\
---\end{array}$ & $\begin{array}{c}0.09 \\
4.758 \\
0.035\end{array}$ & $\begin{array}{c}0.36 \\
22.546 \\
\leq 0.0001\end{array}$ & $\begin{array}{c}0.37 \\
23.403 \\
\leq 0.0001\end{array}$ & $\begin{array}{c}0.51 \\
41.795 \\
\leq 0.0001\end{array}$ \\
\hline Fe: ${ }^{32} \mathrm{P}$ vs. Al: ${ }^{32} \mathrm{P}$ & $\begin{array}{l}\mathrm{r}^{2} \\
\mathrm{~F} \\
P\end{array}$ & $\begin{array}{c}0.86 \\
189.125 \\
\leq 0.0001 \\
\end{array}$ & $\begin{array}{c}0.72 \\
80.113 \\
\leq 0.0001\end{array}$ & $\begin{array}{c}0.53 \\
35.644 \\
\leq 0.0001 \\
\end{array}$ & $\begin{array}{c}0.38 \\
19.404 \\
\leq 0.0001 \\
\end{array}$ & $\begin{array}{c}0.66 \\
61.648 \\
\leq 0.0001\end{array}$ & $\begin{array}{c}0.84 \\
166.779 \\
\leq 0.0001\end{array}$ & $\begin{array}{c}0.81 \\
136.823 \\
\leq 0.0001\end{array}$ \\
\hline Fe:P $\left.\right|^{32} \mathbf{P}$ vs. Al:P $\left.\right|^{32} \mathbf{P}$ & $\begin{array}{l}\mathrm{r}^{2} \\
\mathrm{~F} \\
P\end{array}$ & $\begin{array}{c}0.95 \\
544 . .286 \\
\leq 0.0001\end{array}$ & $\begin{array}{c}0.72 \\
81.844 \\
\leq 0.0001\end{array}$ & $\begin{array}{c}0.47 \\
28.977 \\
\leq 0.0001\end{array}$ & $\begin{array}{c}0.55 \\
39.064 \\
\leq 0.0001\end{array}$ & $\begin{array}{c}0.70 \\
73.762 \\
\leq 0.0001\end{array}$ & $\begin{array}{c}0.80 \\
123.156 \\
\leq 0.0001\end{array}$ & $\begin{array}{c}0.81 \\
134.504 \\
\leq 0.0001\end{array}$ \\
\hline
\end{tabular}




\section{CHAPTER 4}

Microbial Diversity and Function in Floodplain Forests of the Southeastern US 


\begin{abstract}
Floodplain forests (FFs) play an important role in improving water quality in downstream aquatic ecosystems through the retention and transformation of phosphorus $(\mathrm{P})$ received via both upland hydrologic discharge and overbank flooding. Through a variety of processes (sediment deposition, soil adsorption, plant uptake, and microbial immobilization), FFs remove phosphates from the water column, storing them within the wetland ecosystem or converting them to less biologically active organic forms. While microorganisms are known to represent important short-term sinks for phosphate in freshwater wetland ecosystems, little is known about how microbial community composition affects $\mathrm{P}$ retention and transformation. This chapter focuses on understanding the physical and soil chemical factors (floodplain type and microtopographic relief within the floodplain) that control variations in bacterial and fungal community composition in FFs, and how these variations might influence the retention and transformation of $\mathrm{P}$ received in floodwaters. My specific objectives are to: 1) investigate in the detail soil microbial community composition across microtopographic gradients in two FFs; and 2) compare changes in microbial community composition as a function of floodplain type and microtopographic elevation in eight FFs. To address these objectives, I carried out a geographically extensive sampling of both alluvial (AL) and blackwater (BW) floodplain sites in the southeastern US; within these sites, I examined how variations in microtopographic elevation (ridge (RD) vs. swale (SW)) and soil nutrient status affect microbial community composition. The microbial community was assessed by combining bacterial-16S-rDNA and fungal-18S/ITSrDNA cloning with denaturing gradient gel electrophoresis (DGGE) fingerprinting to screen clone libraries and identify dominant group members. Cluster analysis of DGGE profiles using Jaccards coefficient and UPGMA dendrograms, divided soils into two clusters that corresponded with differences in floodplain type (AL vs. BW floodplain soils). Detrended correspondence analysis (DCA) and cluster analysis of DGGE profiles were in close agreement and clearly separated the bacterial and fungal community composition of AL floodplain soils from BW floodplain soils. The bacterial community detected in the clone-library consisted of Alpha-, Beta-, Gamma-, Delta-proteobacteria, Acidobacteria, Actinobacteria, Gemmatimonadetes, Firmicutes, Chloroflexi, Nitrospirae, and Bacteroidetes bacterial groups; fungal taxa belonged to Ascomycota, Basidiomycota, Zygomycota, and Chytridiomycota subdivisions. In both the clone
\end{abstract}


library and DGGE fingerprint data, the dominant bacterial taxa belonged to the Acidobacteria and Alphaproteobacteria groups, and the most prevalent fungal taxa belonged to the Ascomycota and Basidiomycota subdivisions. Two-way ANOVA of soil chemical properties indicated that total P (TP) concentrations were significantly higher in AL compared to BW soils, whereas total $\mathrm{C}$ (TC), N:P, and C:P ratios were significantly higher in BW compared to AL floodplain soils. The DCA analyses of DGGE fingerprint data and the subsequent fitting of environmental variables (soil moisture, $\mathrm{pH}, \mathrm{TC}, \mathrm{TP}$, total nitrogen, and microbial biomass $\mathrm{P}$ ) to ordination plots, revealed that $\mathrm{TP}$ and $\mathrm{pH}$ were associated with the composition of bacterial and fungal communities in AL soils, whereas, TC was strongly correlated with the microbial community profiles in BW FFs. The combined results of these two studies provide taxonomic identification of the dominant bacteria and fungi in these floodplain soils, and show that differences in floodplain type (AL vs. BW) are associated with differences in soil TC, TP and $\mathrm{pH}$, that are important predictors of microbial composition. Results should be broadly applicable to FFs in the southeastern US. 


\subsection{INTRODUCTION}

Anthropogenic inputs of phosphorus (P) from agricultural activities and land use change have led to dramatic shifts in global $\mathrm{P}$ cycling, with considerable impacts on water quality and downstream aquatic ecosystems (Carpenter 2008). Because $\mathrm{P}$ is the most common limiting nutrient in freshwater ecosystems (Schindler 1978), increased $\mathrm{P}$ loading in runoff from agricultural and urban areas can lead to eutrophication of freshwater ecosystems and its associated effects -- degraded water quality, toxic algal blooms, anoxia, and loss of aquatic biodiversity (Carpenter 2005). Riparian wetlands, including floodplain forest (FF) ecosystems, physically and biogeochemically linking adjacent uplands and streams, and can therefore play a key role in ameliorating anthropogenic nutrient (i.e., P) loadings from both upstream and upslope sources (Lockaby and Walbridge 1998, Hupp et al. 2005). Floodplain forests (FFs) remove P from incident surface and subsurface waters, storing it within the wetland ecosystem (retention), and/or converting it to less biologically active form (transformation) (Walbridge and Struthers 1993, Hupp et al. 2005, Noe and Hupp 2009). Although it is well established that P retention and transformation processes are a function of both the abiotic sorption potential of soil aluminum ( $\mathrm{Al})$, iron $(\mathrm{Fe})$, clay minerals and biotic uptake, microbes also strongly influence $\mathrm{P}$ immobilization in wetlands. A substantial proportion of total P (TP) in FF soils (21-29\%) may be stored in microbial biomass (Wright et al. 2001, Hogan et al. 2004), while as much as 75-90 $\%$ of TP in fen peatlands and pocosins may be in microbial form (Richardson and Marshall 1986, Walbridge 1991, Bedford et al. 1999). Despite the significant role of microorganisms in soil P dynamics, little is known about the metabolic processes or taxonomic composition of the bacteria and fungi involved in the retention and transformation of $\mathrm{P}$ in wetlands, especially FFs. 


\subsubsection{Phosphorus retention and transformation in FFs of the southeastern US}

Wetlands cover 570 million ha (or $6 \%$ ) of the Earth's surface, approximately $15 \%$ of which are FFs (Thorsell et al. 1997). An estimated 11 million ha of FFs remain in the US, a number that has declined by $50 \%$ since the late 1970s, primarily due to land use changes (Mitsch and Gosselink 2007). In the southeastern (SE) US, FF ecosystems are associated primarily with two types of river systems: 1) Alluvial (AL) rivers, whose waters arise in Piedmont or montane physiographic provinces; and 2) Blackwater (BW) rivers, whose waters arise entirely in the Coastal Plain (Wharton and Brinson 1979, Hupp et al. 2005). Blackwater rivers tend to be smaller than AL systems, with lower gradient flows that have limited potential to entrain or erode sediments (i.e., Lockaby and Walbridge 1998). Alluvial rivers have higher sediment loads and higher concentrations of inorganic ions (including P), but lower concentrations of total organic carbon (C) compared to BW rivers; $\mathrm{pH}$, hardness, and specific conductance also tend to be higher in AL than in BW rivers (Wharton and Brinson 1979; Hupp et al. 2005).

Both AL and BW FFs in SE US experience frequent flooding events (see Chapter 2) that can occur at any time during the year, but approximately $60 \%$ of annual flooding events occur between January and April (Dress et al. in preparation). A number of studies have found that $\mathrm{P}$ pools in river waters flowing on to a floodplain are often dominated by inorganic $\mathrm{P}$ forms, while P pools in outflow floodwaters are dominated by organic P forms (Elder 1985, Craft and Casey 2000, Darke and Walbridge 2000, Stoeckel and Miller-Goodman 2001, Bruland and Richardson 2004, Van Der Lee et al. 2004, Bruland and Richardson 2005). Because they require extensive 188 
enzymatic hydrolysis before they can be utilized by aquatic microorganisms, high molecular weight organic $\mathrm{P}$ forms carried with floodwaters that exit these wetlands generally are less bioavailable than DIP forms, and are thus less likely to cause the eutrophication of downstream aquatic ecosystems (Pant et al. 2002, McDowell and Koopmans 2006). Therefore, FFs are frequently thought of both as sinks for inorganic $\mathrm{P}$ and sources of organic $\mathrm{P}$ forms (Richardson et al. 1988, Brinson 1993, Lockaby and Walbridge 1998, Darke and Walbridge 2000, Bruland and Richardson 2004, Hupp et al. 2005). Floodplain forests improve water quality by retaining phosphates received in floodwaters within the wetland, and/or transforming them to organic form and then exporting them from the wetland ecosystem via hydrologic pathways (Richardson 1989, Lockaby and Walbridge 1998, Mitsch and Gosselink 2007). While it has been well-established that $\mathrm{P}$ retention in wetland soils is attributed to abiotic processes of sedimentation, sorption by $\mathrm{Al}, \mathrm{Fe}$, organic matter $-\mathrm{Al} / \mathrm{Fe}-\mathrm{P}$ complexation, and clay mineral interactions in soil fractions (Richardson 1985, Furumai et al. 1989, Paludan and Jensen 1995, Nguyen 2000, Hoffmann et al. 2009, $\mathrm{Vu}$ et al. 2010), biotic processes (i.e., plant and microbial $\mathrm{P}$ immobilization), and particularly the composition of FF soil microbial communities, have been relatively understudied. To date, a detailed assessment of the linkages between the taxonomic identity of bacterial and/or fungi, and the biogeochemical cycling of $\mathrm{P}$ in southeastern US FFs has not been done.

\subsubsection{Microbial Community Composition and Ecosystem Function}

Bacteria and fungi play a critical role in the global cycling of P (Pierrou 1976, Ruttenberg 2005, Filippelli 2008, Liu et al. 2008), which is coupled with the cycling of C, N, S, and oxygen in 
both aquatic and terrestrial ecosystems (Kump and Mackenzie 1996, VanCappellen and Ingall 1996, Lenton and Watson 2000). Although recent reviews have synthesized the importance of linking taxonomic diversity (of bacterial and/or fungi) and biogeochemical function with respect to C, N and S cycling in soils/sediments (Jetten 2008, Muyzer and Stams 2008, Barton and Fauque 2009, Conrad 2009, Murrell and Jetten 2009, Canfield et al. 2010, McCarren et al. 2010), the specific link between functional diversity and $\mathrm{P}$ cycling is commonly overlooked (Gutknecht et al. 2006, Falkowski et al. 2008). This is especially true in wetlands, with previous work largely limited to estimations of biomass nutrient content (microbially incorporated $\mathrm{C}, \mathrm{N}$, and $\mathrm{P}$ ) or the culturable microbes involved in C, N, S, and Fe cycling (Gutknecht et al. 2006, Hartman et al. 2008). To understand how changes in $\mathrm{C}, \mathrm{N}$, and $\mathrm{P}$ availability impact ecosystems requires comprehensive knowledge of how bacterial and/or fungal communities respond to changes in both nutrient concentrations and their stoichiometric ratios in soils (Grimm et al. 2003, Zak et al. 2006, Dinsdale et al. 2008).

Since FFs are depositional systems, the differences in the characteristics between AL and BW river waters could influence the amount and type of nutrients entering the floodplain. Blackwater rivers generally carry lower sediment loads compared to AL rivers, but have higher concentrations of dissolved organic carbon (DOC) (Wharton and Brinson 1979, Hupp et al. 2005). The amount, source, and quality of DOC can affect bacterial numbers, respiration rates, and overall microbial production (Findlay et al. 2003, Wiegner and Seitzinger 2004, Bossio et al. 2006, Jasser et al. 2009, Kobayashi et al. 2009, Adame et al. 2012). Soil C:N:P ratios can also affect key microbial processes, including rates of decomposition, denitrification, sulfate 
reduction, P solubilization, and nutrient uptake in general (Golterman 1995, Kuehn et al. 2000, Sterner and Elser 2002, Mander et al. 2003, Zak et al. 2006, Corstanje et al. 2007, Yang et al. 2007, Burgin et al. 2011, Sorrell et al. 2011). In a depressional wetland in southweastern Georgia, Craft and Chiang (2002) reported a critical C:N ratio of 20:1 to indicate N limitation for microbial processes. Lockaby and Walbridge (1998) used differences in N and P stoichiometric ratios in litterfall to estimate nutrient limitation, suggesting that in the southeastern US, BW FFs $(\mathrm{N}: \mathrm{P}>12)$ tend to be more $\mathrm{P}$ limited than AL FFs $(\mathrm{N}: \mathrm{P}<12)$ FFs. The higher sediment associated P inputs carried by AL as opposed to BW floodwaters are thought to be are thought to be at least partly responsible for the lower N:P ratios observed in AL FFs. Differences in soil C:P ratios may also affect rates of microbial $\mathrm{P}$ retention and transformation. Gao and Heath (2005) found that DOC content in lake sediments can influence P uptake and cellular P concentrations. When sediment DOC concentrations are low, $\mathrm{P}$ was taken up at much higher rates and stored in the cell as polyphosphates (poly-P), creating a higher $\mathrm{P}$ quota for cells, whereas higher sediment DOC content resulted in reduced $\mathrm{P}$ uptake and lower \% $\mathrm{P}$ incorporation in bacterial cells. Similarly, differences in soil C and P content in AL vs. BW FF soils could induce microbial population shifts associated with different efficiencies in $\mathrm{P}$ retention and transformation. Tezuka (1990) inoculated bacteria from lake sediments with a range of substrates varying in $\mathrm{C} / \mathrm{P}$ concentrations, and reported that $\mathrm{P}$ immobilization rates were high $(\sim 60 \%$ of total $\mathrm{P}$ in media) when substrate $\mathrm{C}: \mathrm{P}$ ratios were $<40$, but decreased abruptly with increasing substrate $\mathrm{C} / \mathrm{P}$ concentrations until $\mathrm{P}$ uptake rates reached zero when $\mathrm{C}: \mathrm{P}$ ratios were $>60$. Microorganisms incorporate phosphate into cellular constituents and both bacteria and fungi are capable of luxury P consumption, where poly-P is stored is specialized vacuoles, significantly influencing P concentrations in the substrate or water column (Davelaar 1993, Khoshmanesh et 
al. 2002, Hupfer et al. 2007, Szabo et al. 2011, Diaz et al. 2012). As much as $91 \%$ of total P retention in a woodland stream (Elwood et al. 1981), and 75-90\% of total P in fen peatlands and pocosins (Richardson and Marshall 1986, Walbridge 1991) has been attributed to microbial uptake. A considerable amount of interest in identifying and characterizing poly-P accumulating microorganisms (PAO), is due partly for their ability to remove DIP from effluents in sewage treatment plants, commonly termed enhanced biological phosphorus removal (EBPR) systems (Serafim et al. 2002, Oehmen et al. 2007, Hupfer et al. 2008, Hirota et al. 2010). Taxa belonging to major bacterial subdivisions (Acidobacteria, Alpha-, Beta-, Gammaproteobacteria, Actinobacteria, Bacteroidetes, and Nitrospirae) efficient at P removal in EBPR systems also have also been detected in terrestrial, aquatic, and wetland ecosystems (Blackall et al. 2002, Hirota et al. 2010, Gebremariam et al. 2011).

Rates of $\mathrm{P}$ retention and transformation by soil microorganisms can vary spatially within a FF ecosystem (Wright 1998; Stoeckel and Miller-Goodman 2001), as well as temporally with seasonal changes in temperature and moisture availability (Wright et al. 2001). Floodplain forests are topographically heterogeneous environments in which microsite elevation has a direct influence on hydroperiod (Walbridge and Lockaby 1994, Stanturf and Schoenholtz 1998). Seasonal flooding appears to increase $\mathrm{P}$ availability in low-lying swale microsites by both physical transport of materials and decreased biological nutrient demand under prolonged anaerobic conditions (Mitsch and Gosselink 2000; Stoeckel and Miller-Goodman 2001). In general, topographic lows (swales) have comparatively long hydroperiods and fine-textured, clayey soils typical of sediments underlying low energy waters (Hupp and Morris 1990, Craft 
and Casey 2000); topographic highs (ridges), such as remnants of old levees and meander scrolls, have comparatively short hydroperiods and coarse, sandy soils typical of sediments underlying higher energy waters (Stoeckel and Miller-Goodman 2001, Hupp et al. 2005). Because total P concentrations are consistently higher in swale microsites, swales may function as 'hotspots' of $\mathrm{P}$ retention and transformation (Stoeckel and Miller-Goodman 2001, Wright et al. 2001).

\subsubsection{Current understanding of the microbial community composition in FF soils}

Most attempts to assess the microbial contribution to biogeochemical function in floodplain soils have been limited to estimates of microbial biomass (Wainright et al. 1992, Ellis et al. 1998, Gessner et al. 1998, Simonovic and Simonovicova 1999, Baldwin and Mitchell 2000, Robinson et al. 2000, Stoeckel and Miller-Goodman 2001, Mubyana et al. 2003, Kutuzova et al. 2009, Teixeira et al. 2011, Palijan 2012), enrichment techniques such as BIOLOG-ecoplates (Kamitani et al. 2006), or culture based characterizations of specific bacterial species (Leff and Meyer 1991). While these methods provide estimates of microbial productivity, they do not provide information on the taxonomic and physiological distinctions of bacteria and/or fungi within complex soil communities (Rosado et al. 1997, Anderson and Cairney 2004, Nocker et al. 2007). Culture-independent methods like 16S rRNA terminal restriction fragment length polymorphism (Besemer et al. 2005, Song et al. 2008) or phospholipid fatty acid profiles (Rinklebe and Langer 2006, Miletto et al. 2008, Langer and Rinklebe 2009, Frohne et al. 2012), while providing estimates of bacterial vs. fungal contribution to soil community structure, are only capable of resolving microbial groups to within subdivision-level taxonomic identity (Muyzer 1999, Zelles 1999, Anderson and Cairney 2004, Simon and Daniel 2011). Taxonomic surveys of the complete bacterial and/or fungal community structure using molecular techniques are 
comparatively rare in FF soils, and are limited to using specific PCR-primers to target only for sulfate-reducing (Acha et al. 2005, Miletto et al. 2008), methanogenic (Kemnitz et al. 2004), methanotrophic (Ross et al. 1997), or mercury-reducing (Oregaard and Sorensen 2007) prokaryotes. However, Lowell et al. (2009) utilized universal 16S-rDNA PCR-primers and denaturing gradient gel electrophoresis (DGGE) to target eubacterial populations in a small-scale flooplain adjacent to the Flathead River in Northwestern Montana. Sequence analysis of DGGE bands in this study, detected several operational taxonomic units (OTUs) belonging to the Alpha, Beta-proteobacteria, Acidobacteria, Actinobacteria, and Planctomycete bacterial subdivisions. To date, a similar detailed assessment of fungal community structure in FF soils has not been attempted. More importantly, assessments that include soil chemical properties, and/or their stoichiometries, and their relationships to bacterial and/or fungal community structure and/or $\mathrm{P}$ retention and transformation processes in FF soils, have not been conducted.

\subsubsection{Objectives and Hypotheses}

The overall objective of this study was to examine variations in bacterial and/or fungal community structure as a function of floodplain type ( $A L$ vs. BW), microsite elevation ( $R D$ vs. SW), and associated varions in soil chemical parameters (total C, $N, P$, microbial $P$, soil $p H$ and moisture content) in FFs of the southeastern US, and how these variations, in turn, might affect the retention and transformation of $\mathrm{P}$. I used a molecular approach to identify dominant organisms in floodplain soils that combined bacterial 16S-rDNA and fungal 18S/ITS-rDNA cloning and DGGE fingerprinting. First proposed by Burr et al. (2006), this combined protocol takes advantage of the ability of cloning to package DNA and provide full-length sequence information for assessing the taxonomic identity of organisms, and of DGGE to display the 
community profile of all organisms present, while screening for the presence-absence of dominant organisms in soil samples. I accomplished this objective, through two separate studies that used a combination of biogeochemical and molecular microbial techniques.

Study 1 - Topographic variation in bacterial and fungal community structure in an AL and a $B W F F$ :

A detailed characterization of the bacterial and fungal community composition in ridge (RD, less-frequently flooded topographic highs, $\mathrm{n}=6$ composite ridge soils per floodplain type) and swale (SW, more-frequently flooded topographic lows, $\mathrm{n}=6$ composite swale soils per floodplain type) soils in one AL and one BW floodplain forest.

Study 2 - A comparative analysis of bacterial and fungal community composition across eight FFs:

Assess changes in bacterial and fungal community composition as a function of floodplain type (AL vs. BW) and microsite elevation (RD vs. SW) in eight FFs ( $\mathrm{n}=4$ per floodplain type), sampling sites in VA, NC, SC, and GA, that represented a range of soil chemical and physical parameters in $\mathrm{AL}$ vs. BW FFs, to capture a range of conditions likely to affect bacterial and fungal community composition and diversity.

To my knowledge, this research is the first attempt at linking microbial community composition and ecosystem function with respect to $\mathrm{P}$ retention and transformation processes across several FFs in the southeastern US. A molecular microbial approach that combines bacterial 16S-rDNA and fungal 18S/ITS-rDNA cloning and DGGE fingerprinting to identify dominant group 
members has broad potential applicability in terrestrial and wetland ecosystem ecology. Soil chemical ( $\mathrm{pH}, \%$ moisture, $\mathrm{C}, \mathrm{N}, \mathrm{P}$, and microbial biomass $\mathrm{P}$ ) analysis conducted on subsamples of soil in which the microbial community profiles were assessed provided a spatially extensive survey within and across floodplain types, maximizing variation in these factors in order to examine their effects on microbial community composition. I used a multivariate statistical approach (Oksanen et al. 2011) to compare changes in bacterial and fungal community structure with variations in soil chemical properties. Both studies addressed the overall hypothesis that distributions of bacterial and fungal taxonomic groups in FFs can be predicted based on variations in the physical environment (i.e., floodplain type, microsite elevation) and soil chemical parameters ( $\mathrm{pH}, \%$ moisture, $C, N, P$, and microbial biomass $P$ ), and that resulting variations in microbial community composition affect processes of $P$ retention and transformation in southeastern US FFs. Based on a general understanding of the characteristics of AL and BW rivers and their associated FFs, I also tested the following specific hypotheses: 1) that bacterial species diversity would consistently exceed fungal species diversity in all soils; 2) that bacterial and/or fungal community composition would vary predictably as a function of floodplain type (AL vs. BW) and microsite elevation (RD vs. SW) in FFs of the southeastern US; 3) that differences in C:N:P stoichiometry, $p H$ and moisture content in $A L$ vs. BW floodplain soils would co-vary with differences in bacterial and/or fungal community structure, revealing dominant microorganisms known for diverse metabolic activities related to $C$ and $N$ cycling and P immobilization;and 4) that bacterial and/or fungal community structure would vary spatially with changes in microsite elevation, with more frequently flooded SW soils that experience prolonged periods of anaerobic conditions revealing dominant organisms that immobilize $P$. 
A primary focus of this research is to contribute to the basic understanding of the potential controls over bacterial and fungal community structure, the microbial contribution to $\mathrm{P}$ retention and transformation, and overall metabolic function in FF soils. Particularly with respect to $\mathrm{P}$ cycling, microbial metabolic processes in wetlands are poorly understood and in need of synthesis (Gutknecht et al. 2006, Zak et al. 2006, Falkowski et al. 2008, Hartman et al. 2008, Oksanen et al. 2011). In order to associate metabolic function and relevant processes in wetlands to the taxonomic identity of microbes detected in FF soils, I conducted a broad literature comparison (phylum-, class-, order-, family-specific) of bacterial and fungal taxa with known biogeochemical functions in terrestrial, aquatic, and wetland ecosystems. Such comparisons may benefit our understanding of biogeochemical processes and microbial ecology across all ecosystems (Ruttenberg 2005, Zak et al. 2006, Filippelli 2008, Liu et al. 2008). 


\subsection{METHODS}

\subsubsection{Site Descriptions, Experimental Design, Sample Collection and Preparation}

Two studies were conducted to understand the soil chemical factors associated with variations in bacterial and fungal community composition in FFs (i.e., floodplain type and microsite elevation), and how these variations, in turn, might be related to the retention and transformation of $\mathrm{P}$ received in floodwaters. A total of eight sites (Table 4.1) used in these two studies were established within $5 \mathrm{~km}$ of USGS gaging stations that continuously monitor river height. The Nottaway River (NT), Sebrell, VA; the Ocmulgee River (OC), Lumber City, GA; Pee Dee River (PD), Pee Dee, SC; and the Wateree River (WT), Eastover, SC, are FFs adjacent to AL rivers. The Black River (BL), Tomahawk, NC; Drowning Creek (DC), Hoffman, NC; the Salkehatchie River (SK), Miley, SC; and the Satilla River (ST), Waycross, GA, are FFs adjacent to BW rivers. Drainage area, soil type, and dominant woody vegetation at each site are described in Table 4.1. Study sites, experimental design, and sampling schemes for two studies were as follows:

\section{Study 1 - Topographic variation in bacterial (TB) and fungal (TF) communities: To} investigate soil microbial community composition across microtopographic gradients and variations in flooded conditions, rectangular plots 3 (BL) and 12 ha (WT) in size were established at one AL (WT) and one BW (BL) FF. Each plot was further divided into three $20 \times 50 \mathrm{~m}$ subplots. Within each subplot, three surface $(0-10 \mathrm{~cm})$ soil samples were collected at each of four randomly chosen locations, and composited by location to produce 12 discrete soil samples per site, representing either low lying swale microsites, generally closer to the river bank, or less frequently flooded ridge microsites. All plots were established in summer 2002 and soils were collected in summer 2003. 
Study 2 - Multi-site variation in bacterial (MB) and fungal (MF) communities: To compare changes in microbial community composition as a function of floodplain type, microsite elevation, and variations in flooded conditions. Similar to Study 1, rectangular plots ( 0.3 to 12 ha depending on site size) were established in each of four AL (NT, OC, PD, and WT) and four BW (BL, DC, SK, ST) sites. Each plot was divided into three $20 \times 50 \mathrm{~m}$ subplots, and three surface soils samples (top $5 \mathrm{~cm}$ ) were collected at four randomly chosen locations in each subplot, and then composited by location to produce 12 discrete soil samples per site. Plots were established in 2002 and 2003; soils were collected in summer 2003. To reduce the number of DGGE gel analyses, two composite soils from each site, representing one SW and one RD location, were chosen randomly for microbial community analysis.

All soils were collected using sterile $50 \mathrm{~mL}$ centrifuge tubes, sealed in sterile plastic bags, and stored on ice until returning to the lab where they were homogenized and extracted for genomic DNA within 24 hrs. Soil samples that were flooded when collected were maintained under anaerobic conditions during transport and once in the lab were processed under a $\mathrm{H}_{2} / \mathrm{N}_{2}$ atmosphere in a glove box (Coy Laboratory Products Inc., Grass Lake, MI).

\subsubsection{Soil Chemical analysis}

Soil moisture content was determined gravimetrically by drying a $5 \mathrm{~g}$ of aliquot of each soil 199 
sample to a constant mass at $80^{\circ} \mathrm{C}$ in a drying oven. Soil $\mathrm{pH}$ was measured using a $\mathrm{pH}$ electrode in a 2:1 deionized water:soil slurry solution. Soils were analyzed for total P (TP) by digesting $1.0 \mathrm{~g}$ of soil with $\mathrm{H}_{2} \mathrm{SO}_{4}$ and lithium sulfate-selenium-hydrogen peroxide for $2.5 \mathrm{~h}$ at $360^{\circ} \mathrm{C}$ (Parkinson and Allen 1975). Digests were analyzed for TP colorimetrically using a Bran+Luebbe Autonalyzer 3 (Bran+Luebbe Method \# G-103-93, SEAL analytical, Mequon, WI). Microbial biomass P was determined on subsamples of each homogenized soil sample by the chloroform-fumigation direct extraction technique (Brookes et al. 1982). Duplicate $0.5 \mathrm{~g}$ sub-samples of soil were taken from each sample. One sub-sample was extracted directly with $0.5 \mathrm{M} \mathrm{NaHCO}{ }_{3}$ after 16 hours of shaking. The second sample was fumigated with $\mathrm{CHCl}_{3}$ in a tightly capped centrifuge tube overnight, and then extracted with $\mathrm{NaHCO}_{3}$. Total $\mathrm{P}$ was determined for both samples, and microbial biomass $\mathrm{P}(\mathrm{MicP})$ was calculated as the difference between the fumigated sample and the non-fumigated sample. For total soil C (TC) and N (TN), subsamples of each soil sample were dried at $80^{\circ} \mathrm{C}$ to a constant mass and then finely ground with a mortar and pestle. Approximately $0.10-0.12 \mathrm{mg}$ of each ground sample were analyzed for total C and total N using a Carlo Erba NA $1500 \mathrm{C} / \mathrm{N}$ analyzer (CE Elantech Inc., Lakewood, NJ).

\subsubsection{Genomic DNA Isolation and PCR amplification of 16S and 18S-ITS rDNA genes}

Total genomic DNA was extracted from $10 \mathrm{~g}$ soil subsamples using the Mo-Bio PowerMax soil DNA isolation kit (Mo Bio Laboratories, Solana Beach, CA), according to the manufacturer's instructions, to give a final volume of $100 \mu \mathrm{L}$ of genomic DNA per sample. Yield and purity of total genomic DNA extractions were estimated on agarose gels $(1.5 \% \mathrm{w} / \mathrm{v})$ with $0.5 \mu \mathrm{g} \mathrm{mL}^{-1}$ ethidium bromide and by measuring absorbance at 260/280 nm using UV/VIS 
spectrophotometry (Nanodrop 1000, Thermo Scientific, Wilmington, DE). Total soil genomic DNA was extracted from all soil samples individually. The resulting DNA preparations were either pooled for PCR and plasmid cloning to provide full-length sequence information for detecting dominant organisms, or analyzed separately by PCR-DGGE to provide community profile of all organisms present in addition to screening for the presence - absence of dominant organisms in soil samples. For each study, pooled genomic DNA was prepared by combining $250 \mu \mathrm{L}$ of genomic DNA from individual soil samples either by site (in Study 1, WT vs. BL) or microsite elevation across sites (in Study 2, RD vs. SW). Therefore the total number of pooled genomic DNA preparations for establishing the plasmid clone library was two in both studies 1 and 2 .

Approximately $10 \mathrm{ng}$ of extracted genomic DNA from individual soil samples or pooled DNA preparations of multiple soil extracts (as described above) served as a template for PCRamplification of internal fragments of the bacterial 16S rDNA and fungal 18S rDNA and ITS regions. Universal bacterial (63-F and 1387-R) and fungal (ITS1-F and ITS4-R) primers were used to PCR-amplify as broad a range of bacterial or fungal taxa from soils, respectively, and to produce near full-length bacterial 16S rDNA $(\sim 1300 \mathrm{bp})$ and fungal 18S rDNA/ITS $(\sim 800 \mathrm{bp})$ amplicons. The products of five PCR reactions per individual soil sample or pooled DNA preparation were combined and purified using the Mo Bio UltraClean PCR Clean-Up kit (Mo Bio Laboratories, Solana Beach, CA) according to the manufacturer's instructions. These purified full-length amplification products were used as template $(2 \mu \mathrm{L})$ in a nested PCR (using bacterial $341 \mathrm{~F} / 534 \mathrm{R}$ and fungal ITS1F/ITS2 primer) to produce shorter products $(\sim 200 \mathrm{bp}$ for 
bacteria and $\sim 300 \mathrm{bp}$ for fungi) suitable for DGGE analysis. Primers 341-F and ITS1-F were synthesized with a 5' 40-bp GC clamp to stabilize the melting behavior of the PCR products analyzed using DGGE (Table 4.2).

All PCR reactions were performed under sterile conditions (PCR hood, ESCO Airstream PCR Station, Hatboro, PA) in autoclaved and UV irradiated $0.2 \mathrm{~mL}$ tubes (TKR Biotech Products, Huntington Valley, PA) using a Hybaid PCR-Express 2 (Hybaid USA, Franklin, MA) thermal cycler. The reaction mixture (final volume of $50 \mu \mathrm{L}$ ) contained $25 \mu \mathrm{L}$ of PCR Master Mix (Promega Corp., Madison, WI), $1.0 \mu \mathrm{L}$ of each primer ( 20 pmol final concentration), and $21 \mu \mathrm{L}$ of molecular grade nuclease-free water (Promega Corp., Madison, WI). Negative controls were included with all PCR reactions by substituting $2.0 \mu \mathrm{L}$ nuclease-free water for template DNA. In nested PCR reactions additional negative control tubes from the first stage were diluted $1 / 10$ for use as template in second stage (nested PCR) negative controls. Positive controls used molecular grade DNA extracts from either S. cerevisiae or E. coil (Sigma-Aldrich, St. Louise, MO) for the template. Only PCR reactions giving the expected results in all controls were used. All PCR products were visualized on agarose gels $(1.5 \% \mathrm{w} / \mathrm{v})$ with $0.5 \mu \mathrm{gL}^{-1}$ ethidium bromide and quantified by measuring absorbance at 260/280 nm using UV/VIS spectrophotometry (Nanodrop 1000, Thermo Scientific, Wilmington, DE). 


\subsubsection{Cloning, Sequencing, and Phylogenetic Analysis of $16 S$ and $18 S-I T S$ rDNA genes}

Composite PCR products of near full-length bacterial 16S rDNA $(\sim 1300 \mathrm{bp}$, primers $63-\mathrm{F}$ and 1387-R) and fungal 18S rDNA/ITS ( $800 \mathrm{bp}$, primer ITS1-F and ITS4-R) amplifications from pooled DNA preparations of multiple soil extracts (as described above for each study), were cloned into plasmid vectors pCR 2.1 using a TOPO TA Cloning kit (Invitrogen Corp., Carlsbad, CA), following the manufacturers protocol. White colonies were subcultured in Terrific Broth containing kanamycin (96 well plates), incubated overnight at $35^{\circ} \mathrm{C}$, and the plasmids harvested using an alkaline lysis technique (SeqPrep, EdgeBiosystems, Gaithersburg, MD), following the manufacturers protocol. Purified plasmid-inserts were sequenced with primers 63-F for the bacterial and ITS4-R for the fungal library using the BigDye Terminator Cycle Sequencing Kit on an automated DNA sequencer (ABI Model 3130, Applied Biosystems, Foster City, CA).

Conserved motifs of near-full length bacterial 16S rDNA or fungal $18 \mathrm{~S}$ rDNA-ITS, were identified independently for each study, and the sequences were trimmed (of vector contamination) to ensure that all sequences had the same start and end point. Chimeric sequences resulting from PCR artifacts were identified using the online program Check-Chimera from the Ribosomal Database Project II (http://rdp8.cme.msu.edu) and removed prior to subsequent analyses. Pair-wise similarity values were generated for all bacterial or fungal sequence libraries in each study using the online program Needle in the Emboss software suite (http://www.ebi.ac.uk). Operational taxonomic units (OTU) were defined as a group of sequences sharing $\geq 97 \%$ similarity within bacterial or fungal sequence libraries in each study. Representative sequences of each OTU were submitted to GenBank using the Blastn search 
engine, and the resulting subjects, along with the queries, aligned by the automated multiple alignment software ClustalX 2.0.11 (European Molecular Biology Network). Final bacterial or fungal alignments for each study were used to perform phylogenetic tree searches using the maximum-parsimony method in PAUP 4.0b10. Maximum-parsimony analysis was performed under heuristic search methods using tree bisection-reconnection (TBR), and 1000 random, stepwise addition replicates.

\subsubsection{Denaturing gradient gel electrophoresis}

The DGGE (Muyzer et al. 1993) analysis was performed on a D-Code Universal Mutation Detection System (Bio-Rad Laboratories, Hercules, CA). Composite PCR products ( $500 \mathrm{ng}$ ) were loaded on polyacrylamide gels $(8 \%)$ prepared with denaturing conditions that were optimized based on preliminary results, either $45-65 \%$ for bacterial or $30-50 \%$ for fungal PCR products, where $100 \%$ denaturant is defined as $7 \mathrm{M}$ urea and $40 \% \mathrm{v} / \mathrm{v}$ formamide. Electrophoresis was performed in tris-acetate buffer at $75 \mathrm{~V}$ and $60{ }^{\circ} \mathrm{C}$ for $16 \mathrm{hr}$. Gels were stained with $0.5 \mu \mathrm{g} \mathrm{mL}{ }^{-1}$ ethidium bromide and visualized with UV trans-illumination using gel documentation software (Quantity One, Bio-Rad Laboratories, Hercules, CA). A selection of clone sequences representing some of the dominant OTUs retrieved from the clone-library of each study were reamplified with bacterial 341F/534R or fungal ITS1F/ITS2 DGGE primers and pooled to construct reference standards. These reference standards (M1 - M2) were loaded on DGGE gels flanking soil DNA-PCR products, to help with the identification of prominent DGGE bands in the environmental samples and serve as external standards when combining and anchoring (normalization) multiple gels for densitometry analysis. 
Amplicons of interest that generated prominent DGGE bands were excised and selected for cloning and sequencing. Dominant bands were excised from DGGE gels, and acrylamide slices were crushed and resuspended overnight at $4{ }^{\circ} \mathrm{C}$ in $20 \mu \mathrm{L}$ of sterile water to elute the DNA and subsequently used as templates for PCR using the bacterial or fungal DGGE primers as described above. Amplicons of excised bands were re-run on steeper DGGE gradient gels against the initial soil DNA-PCR sample to ensure purity, co-migration, and that the target band had been amplified. Re-amplified PCR products showing single bands during DGGE analysis were purified, cloned, and the inserts sequenced as described above with either the bacterial 534-R or fungal ITS2-R primer. Similarity ( $>97 \%$ ) between dominant clone-library sequences and sequences derived from prominent DGGE bands were analyzed using Needle in the Emboss software suite.

\subsubsection{Soil chemical and DGGE profile data analysis}

The DGGE banding patterns were converted to qualitative and quantitative matrices using GelCompar II v6.5 (Applied Maths, Inc., Austin, TX) to facilitate comparison of the soil samples in a gel profile. Two tables were constructed (with samples as rows and DGGE bands as columns): 1) a qualitative binary table where bands were scored as present (score $=1$ ) or absent $($ score $=0)$; and 2) a quantitative analysis that took into account the relative intensity of each band in a sample (or DGGE lane). The matrix generated by calculating the relative intensity of bands was used for further analysis to eliminate the bias caused by any minor differences in PCR product amount loaded in the gels (Salles et al. 2004). Band intensities (peak area) were 205 
normalized by dividing each band's absolute intensity by the total intensity of bands per lane. Diversity indices (Shannon-Wiener index, $\boldsymbol{H}$ ) were calculated from the presence/absence and relative band intensities per sample using the following equation:

$$
H=\sum_{i=1}^{S}\left(P_{i}\right)\left(\ln P_{i}\right),
$$

where $\boldsymbol{S}$ is the number of species in the sample and $\boldsymbol{P}_{\boldsymbol{i}}$ is the relative intensity of each individual band divided by the total intensity of bands per lane. Evenness $(\boldsymbol{E})$, a measure of how similar the abundances of different OTUs was calculated as $E=H / \log (S)$.

Dendrograms were constructed (using GelCompar II v6.5 software) by the Jaccard correlation coefficient $\left(\boldsymbol{S}_{j}\right)$ calculated for each pair of samples (DGGE lanes) within a gel, and cluster analysis was performed by the unweighted pair group method with average linkages (UPGMA), to determine if OTU similarities resulted in clustering patterns that could be related to floodplain type, study site, and/or topographic variation in microbial communities. The similarity of two samples was assessed using the presence/absence and relative intensities in banding patterns using the following equation:

$$
S_{j}=n_{A B} /\left(n_{A}+n_{B}\right)-n_{A B},
$$

where $\boldsymbol{n}_{\boldsymbol{A} \boldsymbol{B}}$ is the number of bands common to both samples (lanes) $\mathbf{A}$ and $\mathbf{B}, \boldsymbol{n}_{\boldsymbol{A}}$ is the total number of bands in sample $\mathbf{A}$, and $\boldsymbol{n}_{\boldsymbol{B}}$ is the total number of bands in sample $\mathbf{B}$. 
Significant differences in soil $\mathrm{pH}$, moisture, total $\mathrm{C}, \mathrm{N}, \mathrm{P}$, and microbial $\mathrm{P}$ at each site were determined using a two-way ANOVA $(\alpha=0.05)$, with main effects of floodplain type (AL vs. BW) and microsite elevation (RD vs. SW), with site nested within floodplain type, and the interaction terms. Data were $\log$ transformed where necessary to meet the assumption of normality. For each study, to correlate differences in chemical characteristics and microbial community structure in these soils, a multivariate statistical analysis was applied to the matrix containing the relative intensity values of DGGE bands (OTUs). The model underlying the relationships among the bacterial and fungal community compositions (DGGE banding patterns) and the soil chemical variables is often written as:

$$
\mathrm{Y}=\mathrm{XB}+\mathrm{ZC}+\mathrm{E}
$$

where $\mathbf{Y}_{(n, p)}$ represents the community composition data for the $p$ species (bacterial or fungal bands, OTUs), $\mathbf{X}$ represents the design matrix for the factors relating to floodplain type and/or topography, $\mathrm{Z}_{(n, q)}$ represents the $q$ soil chemical characteristics, and $\mathbf{E}$ represents the $n \times p$ error matrix. Classically, the problem reduces to estimating the parameter matrices $\mathbf{B}$ and $\mathbf{C}$ based on appropriate error terms. Unfortunately, the classical model does not hold for the following reasons (Harner, J.E. personal communication):

- The number of OTUs is large and is greater than the number of observations, i.e., $p>$ $n$. As a result, classical estimation theory does not work.

- The DGGE gel images (analyzed with GelCompar II v 4.06) are coded by the relative intensities (Dinsdale et al. 2008) of each band $(j)$ within the $i^{\text {th }}$ soil profile. Therefore, $\Sigma y_{i j}=1$, i.e., the total intensities for each profile sum to 1 and the species compositional data matrix $\mathbf{Y}$ is singular. 
- A high proportion of intensities are 0 for some OTUs.

- The components of the error matrix $\mathbf{E}$ are not normal.

The approaches in the literature (e.g., Fromin et al. 2002, Ramette 2007) have fallen short on a number of fronts, e.g., the analyses have been restricted to just the presence/absence of OTUs (Y) and environmental data (Z). These analyses have generally taken two approaches: 1) relating the separate $\mathbf{Y}$ and $\mathbf{Z}$ matrix decompositions, e.g., principal component analysis or correspondence analysis, in an ad hoc manner; and 2) using canonical correspondence analysis or redundancy analysis to directly relate the chemistry variables to the species variables (Fromin et al. 2002). Generally, the intensity data have been reduced (with a loss of information) to presence (1) / absence (0) binary data to remove the compositional restriction, i.e., $y_{i j}=0$ or 1 for all $i$ and $j$ (Ramette 2007).

The principal hypotheses in this work are to relate the effects of the floodplain type and/or microsite elevation to species (or OTU) composition (relative intensity of bands), after adjusting for soil chemical effects. Due to the requirements of this project and the analytical difficulties listed above, I used detrended correspondence analysis (DCA - decorana function) as implemented in the Vegan 2.0 (Oksanen et al. 2011) package for R v. 2.13. The envfit and ordiellipse functions were used to create a secondary matrix, from which the soil chemical variables (spatially visualized as vectors) were combined with the band intensity ordinations. The data matrices containing relative band intensities were $\log (\mathrm{x}+1)$ transformed before analysis. The significance $(P \leq 0.05)$ of correlation between explanatory variables and microbial community composition are based on 999 random permutations of the data. Confidence ellipses 
(ordiellipse) at the 0.95 level for soil samples were included in ordinations to examine the variability of floodplain type, site, and/or topographic variation within each ordination.

\subsection{RESULTS}

\subsubsection{Soil chemistry}

Soil pH across RD and SW microsite elevations in the BL and WT floodplain sites (Study 1) ranged from 5.1 to 6.1, averaging 5.4 in BW and 5.6 in AL soils (Table 4.3). Other factors important to microbial growth, including TC (averaged $596 \mathrm{~kg} \mathrm{ha}^{-1}$ in BW and $261 \mathrm{~kg} \mathrm{ha}^{-1}$ in AL soils) and soil moisture (averaged $45 \%$ in BW and $29 \%$ in AL soils) content were significantly higher in the BW soils, whereas soil TP content (averaged $4 \mathrm{~kg} \mathrm{ha}^{-1}$ in BW and $12 \mathrm{~kg} \mathrm{ha}^{-1}$ in AL soils) was significantly higher in the AL FF (Table 4.3a,b). Total C, TN and moisture content were significantly higher in topographic lows ( $\mathrm{SW}$ soils) compared to RD soils.

Across multiple FF sites (Study 2), soil TC content (averaged $811 \mathrm{~kg} \mathrm{ha}^{-1}$ in BW and $298 \mathrm{~kg} \mathrm{ha}^{-1}$ in AL soils) was significantly higher in BW sites; soil TP (averaging $4 \mathrm{~kg} \mathrm{ha}^{-1}$ in BW and $9 \mathrm{~kg}$ $\mathrm{ha}^{-1}$ in $\mathrm{AL}$ soils) was significantly higher in AL floodplain soils (Table 4.4a,b). Moisture content was significantly higher in SW compared to RD soils in both AL and BW FFs. In both Study 1 and 2, microbial biomass P averaged $0.1 \mathrm{~kg} \mathrm{ha}^{-1}$ in both AL and BW floodplain soils, and did not differ significantly in AL versus BW or RD versus SW soils (Tables 4.3, 4.4). 


\subsubsection{Clone library construction and phylogenetic distribution of clones}

4.3.2.1 Description of libraries across microsite elevations in an AL and a BW floodplain site

In study 1, a total of 399 non-chimeric $16 \mathrm{~S}$ rDNA bacterial sequences comprised 187 unique OTUs, and were placed in 10 major taxa: Alpha-, Beta-, Gamma-, Deltaproteobacteria, Acidobacteria, Actinobacteria, Gemmatimonadetes, Firmicutes, Chloroflexi, and Bacteroidetes. Acidobacteria and Alphaproteobacteria were the most prevalent groups based on sequence analysis, accounting for 45 and $28 \%$ of the library, respectively (Figure 4.1a; Appendix Table 4.1a). A total of 320 fungal ITS sequences comprised of 147 unique OTUs placed in 4 major taxa: Ascomycota, Basidiomycota, Zygomycota, and Chytridiomycota. The majority of fungal sequences belonged to the Basidiomycota (47\%) and Ascomycota (45\%) divisions (Figure 4.1b; Appendix Table 4.1b).

\subsubsection{Description of libraries in four $A L$ and four BW FFs}

In Study 2, a total of 448 non-chimeric 16S rDNA bacterial sequences comprised 320 unique OTUs, and were placed in 10 major taxa: Alpha-, Beta-, Gamma-, Deltaproteobacteria, Acidobacteria, Actinobacteria, Firmicutes, Chloroflexi, Nitrospirae, and Bacteroidetes. Similar to Study 1, Acidobacteria (43\%) and Alphaproteobacteria (26\%) were the most prevalent groups (Figure 4.2a; Appendix Table 4.2a). A total of 377 fungal ITS sequences comprised of 114 unique OTUs placed in the 4 major taxa outlined above, and a majority of fungal sequences belonged to the Ascomycota (51 \%) and Basidiomycota (40 \%) divisions (Figure 4.2b; Appendix Table 4.2b). 


\subsubsection{Bacterial and fungal community analysis using PCR-DGGE}

\subsubsection{Bacterial community composition in DGGE profiles}

A total of 27 and 30 dominant bands were successfully excised, cloned, and sequenced from the DGGE profiles representing study 1-TB (topographic variation in soil one AL and one BW site) and study 2-MB (four AL and four BW floodplain sites), respectively (Figures 4.3, 4.5, Tables 4.5a, 4.6a). A majority of the bacterial bands sequenced from the study 1-TB and study 2-MB gels belong to the Acidobacteria (47 and $53 \%$, respectively) and Alphaproteobacteria (30 and $27 \%$, respectively) subdivisions.

\subsubsection{Fungal community composition in DGGE profiles}

A total of 34 and 26 dominant bands were successfully excised, cloned, and sequenced from the DGGE profiles representing Study 1-TF (topographic variation in one AL and one BW site) and Study 2-MF (four AL and four BW floodplain sites), respectively (Figures 4.4, 4.6; Tables 4.5b, 4.6b). A majority of the fungal bands sequenced from the study 1-TF and study2-MF gels belong to the Basidiomycota (62 and $50 \%$, respectively) and Ascomycota (32 and $38 \%$, respectively) subdivisions.

\subsubsection{Diversity, evenness, and UPGMA-Jaccards similarity analysis of DGGE gels.}

Diversity $(H)$, number of OTUs or bands $(S)$, and evenness values were not statistically significant between floodplain type or by microtopographic elevation in most DGGE-gels, with the exception of the fungal DGGE profile in study 1-MF, where $H$ and $S$ were significantly 
higher in AL compared to BW soils (Table 4.7).

UPGMA-Jaccards similarity dendrograms generated from presence/absence and relative intensity of DGGE bands, returned similar evaluations of floodplain type patterns on soil bacterial and fungal community composition (Figures 4.7a,b and 4.8a,b). The two main clusters detected in the analysis of all gels in both Study 1 and 2, separated both bacterial and fungal community composition profiles by floodplain type (AL versus BW).

4.3.3.4 Multivariate analysis to correlate microbial community composition in DGGE profiles with soil chemical properties

For both bacterial and fungal communities, detrended correspondence analysis (DCA) resulted in a clear sorting of soil samples by floodplain type (AL versus BW) (with $95 \%$ confidence levels) rather than by microsite elevation (Figures 4.9 a,b, and 4.10 a,b). In this indirect ordination technique, the variations in microbial community structure are derived from the OTU (DGGE band) data independently of the environmental variables. In the DCA of the microbial community structure of Study 1, the first two axes explained 69 and $19 \%$ of the bacterial and 72 and $58 \%$ of the fungal OTU distribution in soils, and show a clear separation between AL and BW soil communities ( $p=0.001$, Figures 4.9a,b). Simiarly in Study 2, eigenvalues for the first two axes explained 23 and $17 \%$ (bacterial) and 66 and $53 \%$ (fungal) of the community variation in soils, differentiating soil communities by both floodplain type $(p=0.001)$ and site $(p=0.001$, Figures 4.10a,b). In both studies, topographic variations in soil bacterial and fungal community profiles were not statistically significant in all DCA ordination results. 
Correlating soil chemistry with DCA ordinations of the microbial profiles was achieved by fitting soil $\mathrm{pH}$, moisture content, $\mathrm{TC}, \mathrm{TN}, \mathrm{TP}$, and microbial $\mathrm{P}$ vectors onto the ordination space using the envfit function in Vegan. Fitting of soil chemical variables onto ordinations revealed that TP and TC correlated significantly $(P<0.05)$ with bacterial and fungal community profiles in both studies 1 and 2 (Figures 4.9a,b and 4.10a,b). When comparing soils collected from the BL and WT floodplain sites (Study 1; Figure 4.9b), soil pH was significantly $(P<0.011)$ correlated with the fungal community ordination. In vector fitting, a soil chemical variable is represented in the resulting ordination plot by an arrow that points in the direction of the most rapid change in that variable, and the length of the arrow being proportional to the correlation between microbial community ordination and the soil chemical variable (Oksanen et al. 2011). In both Study 1 and 2, the subsequent fitting of variable onto the ordination revealed that TP was associated with AL FFs, whereas TC was significantly correlated with BW FFs (Figures 4.9a,b and 4.10a,b). In the one instance where soil $\mathrm{pH}$ was significantly correlated with the fungal community ordination (Figure 4.9b), variation in soil $\mathrm{pH}$ was associated with changes in fungal community structure in AL floodplain soils. 


\subsection{DISCUSSION}

\subsubsection{Microbial community composition in FF soils - clone library analysis}

Fungal ITS sequences isolated from Study 1-TF and Study 2-MF represented 147 and 114 unique OTUs, respectively, belonging to Ascomycota, Basidiomycota, Zygomycota, and Chytridiomycota divisions (Figures 4.1b, 4.2b; Appendix Tables 4.1b, 4.2b). The majority of fungal sequences belonged to the Ascomycota (45\% in the TF and $51 \%$ in the MF libraries) and Basidiomycota (47 and $40 \%$, respectively) divisions. Bacterial 16S rDNA sequences isolated from Study 1-TB and Study 2-MB represented 187 and 320 unique OTUs, respectively, belonging to Alpha-, Beta-, Gamma-, Deltaproteobacteria, Acidobacteria, Actinobacteria, Gemmatimonadetes, Firmicutes, Chloroflexi, Nitrospirae, and Bacteroidetes groups (Figures 4.1a, 4.2a; Appendix Tables 4.1a, 4.2a). A similar bacterial community structure was detected in soils collected from a small-scale flooplain adjacent to the Flathead River in Northwestern Montana using DGGE analysis (Lowell et al. 2009). In the current study, Acidobacteria (45\% in the TB and $43 \%$ in the MB libraries) and Alphaproteobacteria (28 \% and $26 \%$, respectively) were the most prevalent groups based on sequence analysis. The predominance of Acidobacteria and Alphaproteobacteria phyla (OTUs) in bacterial 16S rDNA libraries has been detected in a wide variety of terrestrial soils (i.e., Rosch and Bothe 2009, Kumar and Khanna 2010, Lin et al. 2010, Michel and Williams 2011, Chen et al. 2012b, Zhao et al. 2012), wetland (i.e., Kim et al. 2004, Hartman et al. 2008, Yang et al. 2008, Tian et al. 2009, Ben Said et al. 2010, Sun et al. 2011, Song et al. 2012), and marine (Dang et al. 2009, Li et al. 2009, Polymenakou et al. 2009, Gao et al. 2011) sediments. Identifying the taxonomic diversity of bacteria and fungi in FF soils is the first step towards linking microbial diversity and ecosystem function. As a second step, linking structure to biogeochemical function requires a comprehensive search in the literature to 
produce a database identifying the dominant metabolic function of each taxa present (Grimm et al. 2003, Zak et al. 2006, Dinsdale et al. 2008). Although it has been demonstrated that soil biogeochemical function and microbial ecology vary considerably between and even within ecosystems, a comparative assessment of the controls over the distribution and relative abundance of microbial communities across other ecosystems is an important step in determing structure-function relationships within welands. In an attempt to associate metabolic function and relevant processes with respect to $\mathrm{C}, \mathrm{N}, \mathrm{P}, \mathrm{S}$, and Fe cycling in wetlands to the taxonomic identity of microbes sequenced in this study, I conducted a broad comparison of the bacterial and fungal taxa with known biogeochemical function(s) in terrestrial, aquatic, and wetland ecosystems in the literature.

\subsubsection{Organic matter decomposition}

Cellulose and lignin are the products of photosynthesis, and their degradation by microbially produced ligno-cellulolytic enzymes represents the major carbon flow from fixed carbon sinks to atmospheric $\mathrm{CO}_{2}$ in terrestrial and wetland ecosystems (Cullen and Kersten 2004, Thatoi et al. 2012). The Ascomycota sequenced in both the TF and MF libraries were primarily of the subdivision Pezizomycotina (Appendix Tables 4.1b, 4.2b), which are ecologically diverse fungi occurring in aquatic (Jones et al. 2009, Schoch et al. 2009) and terrestrial habitats (Ruibal et al. 2008, Damon et al. 2010, Unterseher and Schnittler 2010, Gottel et al. 2011). Pezizomycotina are either saprophytic chemoheterotrophs, capable of obtaininig $\mathrm{C}$ nutrition by litter/wood decomposition (class: Dothideomycetes, Eurotiomycetes, Leotiomycetes, and Sordariomycetes), or form endotrophic-mycorrhizal associations with living plants (class: Dothideomycetes, 
Pezizomycetes, and Sordariomycetes) (Spatafora et al. 2006, Edwards et al. 2011). Dothideomycetes (order: Capnodiales and Pleosporales), Eurotiomycetes (Chaetothyriales and Eurotiales,), Leotiomycetes (Helotiales) and Sordariomycetes (Hypocreales and Sordariales) have broadly similar abilities of obtaining $\mathrm{C}$ by degrading complex carbohydrates (cellulose, hemicelluloses, pectin, starch) in litter (Midgley et al. 2004, Raja et al. 2010, Badali et al. 2011, Zifcakova et al. 2011). One taxa within Sordariomycetes (order: Hypocreales; family: Nectriaceae) OTU (1-MF-346) was found to dominate clones sequenced from the MF library, accounting for 133 of the total 377 clones isolated in the library (Appendix Table 4.2b). Some species of Nectriaceae also occur as parasites of trees (Schmidt and Panstruga 2011, Hopkins et al. 2012). A majority of the Basidiomycota sequenced in both libraries belonged to the Agaricomycotina subdivision (Appendix Tables 4.1b, 4.2b). Similar to the Ascomycota found in these soils, Agaricomycotina (class: Agaricomycetes and Tremellomycetes) are either saprophytic and/or form mycorrhizal associations with living plants (Dighton et al. 1990, Selosse et al. 2002, Edwards and Zak 2010). Agaricomycetes (order: Agaricales, Boletales, Corticiales, Polyporales, Russulales) contains a large number of saprophytic taxa (Hibbett 2006, Lawrey et al. 2008), producing extracellular ligno-cellulolytic (endocellulase, cellobiohydrolase, glucosidase, endoxylanase, and $\mathrm{N}$-acetylglucosaminidase) enzymes that degrade complex carbohydrates into $\mathrm{C}$ and energy sources that are required by these fungi (Gibertoni and Drechsler-Santos 2010). Although proportions of Zygomycota isolated in clone libraries accounted for only $7 \%$ of the TF and MF studies (Figures $4.1 \mathrm{~b}, 4.2 \mathrm{~b}$ ), a majority of the taxa belonged to the Mucoromycotina subdivision and were of the Mortierellales order which live exclusively as saprotrophs is soils, contributing to the turnover of soil $\mathrm{C}$ by decaying litter and other soil organic matter (Kurakov et al. 2008, Murase et al. 2012). 
In soils rich in organic material, the decomposition of cellulose and lignin involves complex communities of interacting microorganisms, including bacteria (Hoffman and Arnold 2010, Huang et al. 2010, DeAngelis et al. 2011). Acidobacteria (order: Acidobacteriales, Holophagales, and Solibacterales, Appendix Tables 4.1a, 4.2a) possess a large range of extracellular enzymes involved in the solubilization of complex carbohydrates (xylan, cellulose, hemicelluloses, pectin, starch, and chitin) and utilization of C (Ward et al. 2009, DeAngelis et al. 2011, Tang et al. 2011, Eichorst and Kuske 2012, Pankratov et al. 2012, Stursova et al. 2012, Talia et al. 2012). Alphaproteobacteria (order: Caulobacterales, Rhizobiales, and Rhodospirillales) are equally diverse in soil biogeochemical processes, including a fundamental role in driving $\mathrm{C}$ turnover by decomposing organic matter and solubilizing/utilizing complex carbohydrates (Beloqui et al. 2010, Hutcheson et al. 2011, Lucena et al. 2012, Teeling et al. 2012), some of which are polycyclic aromatic hydrocarbons that are toxic compounds in soils/sediments (Schleheck et al. 2000, Kanamori et al. 2002, Rockne and Strand 2003, Kwon et al. 2005, Liu et al. 2011, Chen et al. 2012a).

4.4.1.2 Nutrient uptake by saprophytic and root-rhizosphere associated bacteria and fungi

Saprophytic Ascomycota: Dothideomycetes (order: Capnodiales and Pleosporales), Eurotiomycetes (Chaetothyriales and Eurotiales,), Leotiomycetes (Helotiales), Sordariomycetes (Hypocreales and Sordariales) and Basidiomycota: Agaricomycetes (order: Agaricales, Boletales, Corticiales, Polyporales, Russulales) (Hibbett 2006, Lawrey et al. 2008), produce extracellular nitrogenases, phosphatases, and arylsulfatases to access insoluble organic $\mathrm{N}, \mathrm{P}$, and 
S from organic substrates in soil (Delabastide et al. 1995, Zifcakova et al. 2011). In an assessment of biomass P content in common soil fungi, select taxa within Agaricales, Boletales, and Russulales averaged $8.2 \mathrm{~g}$ P per kg dry mass; biomass P content was highest (10.7 g P per kg dry mass) in Agaricales species (Vetter 1994).

In contrast to saprophytic nutrition, mycorrhizae associated taxa within the Ascomycota: Dothideomycetes (Venturiales), Sordariomycetes (order: Hypocreales), as well as class Pezizomycetes (Pezizales) (Spatafora et al. 2006, Edwards et al. 2011) and Basidiomycota: Agaricomycetes (order: Agaricales, Boletales, Russulales, Thelephorales) (Yorou and Agerer 2011, Porter et al. 2008, Gottel et al. 2011) colonize the roots of grasses, herbaceous plants, and some trees, providing $\mathrm{N}$ and $\mathrm{P}$ to the host, who in return supply $\mathrm{C}$ to the associated fungus (Maia et al. 1996, Sanon et al. 1997, Selosse et al. 2002, Dokmetzian et al. 2005, Hoffman and Arnold 2010, Zifcakova et al. 2011). Tremellomycetes (order: Cystofilobasidiales, Tremellales) are teleomorphic and anamorphic yeasts, which are nutritionally heterogeneous fungi comprising saprophytes, plant and fungal endophytes, as well as plant and animal pathogens (Mouhamadou et al. 2011, Takashima et al. 2011, Millanes et al. 2012). A Tremellomycete (order: Tremellales; family: Cryptococcus) OTU, 1-TF-67 and 2-MF-271 was a dominant clone sequenced from both the TF and MF libraries (Appendix Tables 4.1b, 4.2b). Cryptococcus species have been sequenced in diverse environments including forest soils (Wieferich et al. 2011, Stursova et al. 2012), agriculture soils (Botha 2011, Yurkov et al. 2012), and wetland sediments (Slavikova and Vadkertiova 1997, Rojas et al. 2009, Brandao et al. 2011), and are largely associated with lignocellulolytic activity (Jimenez et al. 1991, Arora and Sharma 2010, Zifcakova et al. 2011) as 
well as inorganic $\mathrm{N}$ and $\mathrm{P}$ solubilization and uptake from soil organic matter and sediment (Greenwood and Lewis 1977, Boby et al. 2008, Cloete et al. 2010, Botha 2011, Singh and Singh 2012).

Acidobacteria (order: Acidobacteriales, (Appendix Tables 4.1a, 4.2a) isolates are also known to play an important role in iron redox reactions and the uptake and metabolism of iron from various substrates (Rowe et al. 2007, Blothe et al. 2008, Kleinsteuber et al. 2008, Ward et al. 2009). Some taxa within the Acidobacteria phylum (primarily Acidobacteriales and Holophagales) are capable of nitrate and nitrite reduction (Hall et al. 2008, Navarro et al. 2009, Van Trump et al. 2011), but not N-fixation or denitrification (Ward et al. 2009). However a majority of Rhizobiales (family: Bradyrhizobiaceae, Hyphomicrobiaceae, Methylocystaceae, Xanthobacteraceae) within the Alphaproteobacteria subdivision, are symbiotic N-fixers or denitrifiers that have been isolated from the rhizosphere of terrestrial (i.e., Anderson et al. 2011, Chen et al. 2012b, Eichorst and Kuske 2012, Montana et al. 2012) and wetland plants (Valenzuela-Encinas et al. 2009, Jin et al. 2011, Wang et al. 2012). Although Rhizobiales are primarily involved in the $\mathrm{N}$ cycle, taxa within Bradyrhizobiaceae and Xanthobacteraceae are capable of utilizing specific enzymes for the solubilization and uptake of phosphate in the rhizosphere (Mikanova and Kubat 1994, Vazquez et al. 2000, Sridevi and Mallaiah 2009, Dodd et al. 2010, Hayat et al. 2010, Palaniappan et al. 2010, Zafar et al. 2011, Pooja 2012, Salvador Montana et al. 2012). Although I did not specifically target for the methanogenic microbial community, which are predominantly archaebacteria, flood induced anaerobic conditions typical of FF soils are ideally suited for methanogenic archaea that are obligate anaerobes. However, 
methanotrophic microbes (i.e., Methylocystaceae; Appendix Tables 4.1a, 4.2a) that utilize methane as their sole $\mathrm{C}$ source, many of which are found within the eubacterial kingdom, were captured using the universal 16S rDNA primers in the current study (Knief et al. 2006, Lau et al. 2007, Chen et al. 2008, Kolb 2009, Stein et al. 2011). A majority of the taxa within Rhodospirillales are denitrifying or $\mathrm{N}$-fixing, and phosphate-solubilizing organisms, that are either associated with the root-rhizosphere (family: Acetobacteraceae) (Loganathan and Nair 2004, Samaddar et al. 2011) or photosynthetic free-living purple non-sulfur bacteria (Rhodospirillaceae) (Madigan et al. 1984, Wang et al. 2008, Diaz-Cardenas et al. 2010).

Although the remaining eubacterial subdivisions contribute to a relatively minor component, totaling $27 \%$ of the TB and $31 \%$ of the MB clone libraries (Figures 4.1a, 4.2a), these taxa may also play important roles in $\mathrm{C}, \mathrm{N}$, and P biogeochemistry of floodplain soils. Many taxa within Betaproteobacteria (order: Burkholderiales and Rhodocyclales), Deltaproteobacteria (Myxococcales), Gammaproteobacteria (Chromatiales), and Actinobacteria (Actinomycetales, Acidimicrobiales) (Appendix Tables 4.1a, 4.2a) are associated with the solubilization of $\mathrm{N}$ and P from organic matter and the metabolism of complex carbohydrates (lingo-cellulolytic activity), polycyclic aromatic hydrocarbons, proteins, and lipids, and produce catalytic enzymes, such as phosphatases, glycosyltransferases, dehydrogenases, methyltransferases, dehydratases and epoxide hydrolases (Nielsen et al. 2002, Tanahashi et al. 2005, Vinas et al. 2005, Anderson et al. 2011, Farina et al. 2012, Montana et al. 2012, Stursova et al. 2012). 
Other taxa within Betaproteobacteria (order: Burkholderiales and Rhodocyclales) and Deltaproteobacteria (Desulfuromonadales) are heterotrophic N-fixing and/or denitrifying bacteria (Xie et al. 2003, Weon et al. 2008, Zhang et al. 2008), whereas Betaproteobacteria (Rhodocyclales) are capable of chemolithoautotrophic ferric iron oxidation (Sobolev and Roden 2004), and many taxa within Actinobacteria (Acidimicrobiales) and Deltaproteobacteria (Myxococcales, Desulfuromonadales, Syntrophobacterales) are syntrophic ferric iron or sulfate reducing bacteria in soils and sediments (Tourova et al. 1998, Bowman and McCuaig 2003, Weber et al. 2006, Da Silva et al. 2007, Chao et al. 2010, Itoh et al. 2011, Schmidtova and Baldwin 2011).

\subsubsection{Polyphosphate accumulating (micro)-organisms (PAO) in enhanced biological phosphorus removal (EBPR) systems}

Many of the bacteria sequenced in Studies 1 and 2 have been identified as efficient phosphate accumulating organisms in EBPR systems. Enhanced biological phosphorus removal is a technology that exploits the microbial (primarily bacterial) removal P from wastewater (Blackall et al. 2002, Hirota et al. 2010, Gebremariam et al. 2011). The removal of P in wastewater effluent EBPR sludge reactor systems is dependent on the capability of select microorganisms to remove phosphate from the liquid phase and convert it to sludge in the form of intracellular polyphosphates (Oehmen et al. 2007, Hupfer et al. 2008, Hirota et al. 2010). These polyphosphate accumulating organisms (PAOs) are capable of luxury uptake/consumption; the accumulation of phosphorus beyond what is required for growth, and storing them in specialized vacuoles within the cell (Serafim et al. 2002, Zheng et al. 2004, Oehmen et al. 2007, Szabo et al. 
2011). The most commonly isolated PAOs in EBPR systems are Acidobacteria (order: Acidobacteriales) (Crocetti et al. 2002, Ahn et al. 2008), and Rhizobiales (family: Hyphomicrobiaceae) (Zhang et al. 2011) and Rhodospirillales (Acetobacteraceae, Rhodospirillaceae) (Levantesi et al. 2002, Wong et al. 2004, Wong and Liu 2007, Nittami et al. 2009, Zhang et al. 2011) within the Alphaproteobacteria (Wilmes and Bond 2006, Gu et al. 2008, Lopez-Vazquez et al. 2009a, Lanham et al. 2011, Ren et al. 2011, Sanchez et al. 2011) subdivision, and possess large poly-phosphate containing vacuoles within their cytoplasm, thus are well adapted for the luxury consumption of phosphate from wastewater effluent. With the assumption that the TB and MB libraries were dominated by a similar functional diversity of Acidobacteria and Alphaproteobacteria taxa (Appendix Tables 4.1a, 4.2a), these organisms may be the most efficient at P removal at the interface between floodwaters and the soil surface in FFs. Although the remaining subdivisions are relatively minor contributors to the overall community composition of FF soils in this study, Betaproteobacteria (order: Burkholderiales, and Rhodocyclales) (Ruiz-Lozano and Bonfante 1999, Mullan et al. 2002, Wu et al. 2009, Datta and Goel 2010, Zhang et al. 2011), Gammaproteobacteria (Xanthomonadales and Chromatiales) (Kong et al. 2006, Martin et al. 2006, Kim et al. 2011), Actinobacteria (Actinomycetales and Acidimicrobiales) (Kong et al. 2005, Beer et al. 2006), Bacteroidetes (Flavobacteriales, Sphingobacteriales, and Cytophagales) (Kawaharasaki et al. 1999, Liu et al. 2001, Liu et al. 2005), and Nitrospirae (Nielsen et al. 2010, Onnis-Hayden et al. 2011) taxa accumulate $\mathrm{P}$ and have been isolated from functioning EBPR systems. A fungal species found to dominate the TF and MF libraries (Tremellomycete, order Tremellales, family: Cryptococcus) in the current study has also been isolated from sewage granules, has been found to contribute to polyphosphate utilization from wastewater in an aerobic sewage treatment plant, and is regarded 
as useful in microbial biofilm formation in EBPR systems (Kacprzak and Stanczyk-Mazanek 2003, Weber et al. 2009).

Although EBPR systems are well established in Australia and Europe, here in the US functional reactor plants remain operationally unstable, primarily because of a lack of understanding of the microbiology of these EBPR systems (Hupfer et al. 2008, Hirota et al. 2010, Gebremariam et al. 2011). Efforts to establish EBPR reactors in the US have largely been seeded and cultured with mixed PAOs imported from European systems (Zheng et al. 2004, Oehmen et al. 2007, Gebremariam et al. 2011). An alternative strategy would be to use PAOs that are native to US soils which are adapted to changing environmental and/or operational factors, including seasonal changes in temperature, $\mathrm{pH}$, anaerobic-aerobic contact time, and organic loading rate, and may increase the success rate of developing EBPR systems in the US (Lopez-Vazquez et al. 2009b). Similar efforts have been successful in establishing large-scale EBPR batch reactors by culturing PAOs isolated from regional wetland sediments and forest soils (Krishnaswamy et al. 2009, Nielsen et al. 2012).

\subsubsection{Bacterial and fungal PCR-DGGE profiles}

A majority of the bacterial bands excised, cloned, and sequenced from Study 1-TB (topographic variation in soil from one $\mathrm{AL}$ and one $\mathrm{BW}$ site) and Study 2-MB (four $\mathrm{AL}$ and four $\mathrm{BW}$ floodplain sites) belong to the Acidobacteria (47 and $53 \%$, respectively) and Alphaproteobacteria (30 and $27 \%$, respectively) subdivisions (Table 4.5a). The fungal bands 
successfully sequenced from the study 1-TF and study 2-MF gels were predominantly Basidiomycota (62 and $50 \%$, respectively) and Ascomycota (32 and $38 \%$, respectively) (Table 4.5b). Similar trends in dominant OTUs were also observed in the clone-library analysis of pooled soil DNA samples (Appendix Tables 4.1, 4.2), substantiating the effectiveness of combining DGGE fingerprint analysis with the plasmid cloning method (i.e., Dias et al. 2011, Knapp et al. 2011, Gorra et al. 2012, Perez-Leblic et al. 2012, Yi et al. 2012, Zhou et al. 2012).

Similar to trends seen with other PCR-based metagenomic assessments of soil microbial ecology (i.e., von Wintzingerode et al. 1997, Amann and Ludwig 2000, Forney et al. 2004, Nocker et al. 2007), average bacterial diversity estimates (Shannon diversity, $H$ ) were generally higher than fungal diversity in AL and BW soils (Tables 4.7, 4.8). There were few differences in the absolute numbers of bands (OTUs) or Shannon diversity and evenness estimations (presence/absence of bands) between topographic relief (RD vs. SW, for bacteria and fungi in both studies) or floodplain type (AL vs. BW, for bacteria in TB and MB gels and the fungal TB gel), with the exception of the fungal DGGE profile in the MF study. Both the number of OTUs $(p=0.009, F=8.250)$ and diversity values $(p=0.007, F=8.880)$ were significantly higher in AL compared to BW soils in the MF DGGE profile. Although only a few differences were detected by estimating diversity using the presence/absence of bands, the inclusion of relative intensity measurements for each band (estimating relative abundance or dominance of OTUs) and Jaccards similarity coefficient, generated UPGMA dendrograms showing two distinct clusters in the microbial community structure (Figures 4.7, 4.8). Both the bacterial and fungal DGGE profiles were clearly separated by floodplain type (AL vs. BW) in Studies 1 and 2, but 
there were no divergent clusters separating the microbial community by variations in microsite elevation. The ability for DGGE fingerprinting in combination with UPGMA-Jaccards similarity analysis to discern complex bacterial and/or fungal profiles in environmental samples has been well documented (i.e., Clegg et al. 2003, Kang and Mills 2003, Knupp et al. 2009, Bouskill et al. 2010, Nadarajah et al. 2010, dos Santos et al. 2012).

\subsubsection{Multivariate analysis correlating DGGE profiles with differences in TC and TP content in $A L$ vs. BW floodplain soils}

Using DCA to examine variations in microbial community composition (presence/absence and relative intensity of DGGE bands) produced a clear sorting of soil samples according to floodplain type (with $95 \%$ confidence levels) for both the bacterial and fungal communities but not according to microsite elevation (Figures 4.9, 4.10). Total soil $\mathrm{C}$ content was significantly higher in BW than in AL soils (ANOVA Tables 4.3 , 4.4), averaging $596.2 \pm 77.2$ and $811.4 \pm$ $43.3 \mathrm{~kg} \mathrm{ha}^{-1}$ in BW and $261 \pm 17.0$ and $298.4 \pm 46.9 \mathrm{~kg} \mathrm{ha}^{-1}$ in AL soils measured in Studies 1 and 2, respectively. Total soil P content in Studies 1 and 2, however, was significantly higher in $\operatorname{AL}\left(11.6 \pm 0.3\right.$ and $8.7 \pm 1.1 \mathrm{~kg} \mathrm{ha}^{-1}$, respectively) compared to BW $(4.4 \pm 0.2$ and $4.4 \pm 0.9 \mathrm{~kg}$ $\mathrm{ha}^{-1}$, respectively) FF soils. These results are supportive of the trend that AL floodplain soils have higher TP contents, primarily due greater inputs of $\mathrm{P}$ with sediment deposition compared to BW systems, while BW floodplain soils typically have higher TC contents than AL soils (Lockaby and Walbridge 1998, Hupp et al. 2005, Noe and Hupp 2005). Soil TN concetrations did not differ significantly by floodplain type (Tables 4.3b, 4.4b). Craft and Chiang (2002) reported a critical C:N ratio of $20: 1$ to indicate $\mathrm{N}$ availability for microbial processes. In the 
current study C:N ratios of AL and BW floodplain soils were 17:1 and 12:1, respectively, suggesting sufficient $\mathrm{N}$ availability for microbial productivity. Soil N:P ratios were significantly higher in $\mathrm{BW}(\mathrm{N}: \mathrm{P}=13.6)$ compared AL $(\mathrm{N}: \mathrm{P}=3.4)$ FF (ANOVA $P<0.0001, F=45.4367)$, suggesting that BW floodplain soils may either be $\mathrm{P}$ limited or co-limted by both $\mathrm{N}$ and $\mathrm{P}$ (Lockaby and Walbridge 1998).

Multivariate statistical analyses correlating soil chemistry $(\mathrm{pH}$, moisture content, $\mathrm{TC}, \mathrm{TN}, \mathrm{TP}$, and microbial P) with the DCA ordination analysis representing DGGE community profiles (using the envfit function in Vegan) revealed that $\mathrm{TP}$ and $\mathrm{TC}$ were the most influential parameters associated with observed differences in AL vs. BW bacterial and fungal soil community structure (Figures 4.9, 4.10). Similar to ANOVA results (Tables 4.3, 4.4), the subsequent fitting of environmental variables onto ordination plots revealed that TP was associated with the diversity and composition of bacterial and fungal communities in AL FF soils, while TC was significantly correlated with the microbial community profiles in BW FFs. The effect of TP and/or TC on the diversity and composition of bacterial or fungal communities has been previously reported in terrestrial (van der Heijden et al. 1999, Corbett and Anderson 2006, Edwards et al. 2006, Xiong et al. 2010) and wetland (Garono et al. 1996, Olapade et al. 2005, Zeng et al. 2009, Cao et al. 2011, Kolmonen et al. 2011, Zhao et al. 2011, de Figueiredo et al. 2012) soils and sediments. Similar to trends seen with soil N:P content, C:P ratios were significantly higher in $\mathrm{BW}(\mathrm{C}: \mathrm{P}=234.0)$ than in $\mathrm{AL}(\mathrm{N}: \mathrm{P}=36.2)$ FF soils (ANOVA $P<0.0001$, $F=45.4367$ ), and also indicative of the higher likelihood that BW soils are P limited than AL floodplain soils. Tezuka (1990) suggested that the C:P ratio of substrate determines if P limits microbial productivity, and demonstrated that $\mathrm{P}$ immobilization rates were high when substrate 
$\mathrm{C}: \mathrm{P}$ ratios are $<40$, but decreased abruptly with increasing substrate $\mathrm{C} / \mathrm{P}$ concentrations, until $\mathrm{P}$ uptake rates reached zero when $\mathrm{C}: \mathrm{P}$ ratio $>60$. Although in the current study, $\mathrm{P}$ incorporated in soil microbial biomass (fumigation experiment) averaged $0.1 \mathrm{~kg} \mathrm{ha}^{-1}$ and did not differ significantly by floodplain type (Tables $4.3,4.4$ ), soil TP and C:P ratios did suggest differences in $\mathrm{P}$ availability, with larger soil $\mathrm{P}$ pools in AL than in BW FF soils. These results could indicate that microbial communities in AL floodplains are more efficient at phosphate immobilization (Kairesalo et al. 1995, Bridgham and Richardson 2003, Schultz and Urban 2008, Roberts et al. 2012), while mineralization associated with the decay of C-rich organic matter may dominate microbial processes in BW floodplain soils (Jana et al. 2001, Schultz and Urban 2008, Webster et al. 2009).

Although TN and soil moisture content differed by microsite elevation and were significantly higher in SW compared to RD soils (ANOVA; Tables 4.3, 4.4), multivariate analyses of DGGE profiles were not significantly correlated with either soil moisture or TN content (Figures 4.9, 4.10). In both studies, the bacterial and fungal community profiles did not statistically differ (DCA analysis) between microsite elevations, and were not significantly correlated with any soil chemical parameter measured. Seasonal flooding events have been shown to increase P availability in low-lying SW microsites (Mitsch and Gosselink 2000; Stoeckel and MillerGoodman 2001), producing conditions that favor soil microbial communities dominated by obligate anaerobic organisms (Stoeckel and Miller-Goodman 2001) and suggesting that swales may function as 'hotspots' of P retention and transformation (Wright et al. 2001; Stoeckel and Miller-Goodman 2001). However in the current study, soil TP, microbial biomass P (Tables 4.3, 4.4), and bacterial and fungal community structure (Figures 4.9, 4.10) did not differ significantly 
in RD versus SW soils. This provides a second line of evidence that differences in soil TP (differing only by floodplain type) are a good predictor of microbial community structure in FFs in the southeastern US. Soil $\mathrm{pH}$ however, was significantly correlated with the fungal community ordination in study 1 (Figure 4.14), and the variation in $\mathrm{pH}$ along with TP content in soil was associated with the variation in fungal community structure in AL floodplain soils. Although average soil $\mathrm{pH}$ did not differ between $\mathrm{AL}$ and $\mathrm{BW}$ floodplains, $\mathrm{pH}$ measured in indivudual soils ranged from 5.1 to 6.1 , and since microbes vary in their sensitivity to soil $\mathrm{pH}$, minor changes in $\mathrm{pH}$ may correspond with substantial differences in fungal community structure. The effect of soil $\mathrm{pH}$ significantly contributing to the variation in fungal community composition has been reported previously in terrestrial soils (van der Heijden et al. 1999, Krivtsov et al. 2003, Hamman et al. 2007, Lopes et al. 2011). Similarly, Hartman et al. (2008) reported that soil pH was an important predictor of the variation in bacterial community composition, followed by land use, restoration status, and differences in soil nutrient content across several freshwater wetlands in the North Carolina coastal plain and Florida Everglades. 


\subsection{CONCLUSIONS}

This study provides primary insight into the diversity and composition of dominant bacteria and fungi in FFs of the southeastern US. Results reveal shifts in the composition of bacterial and fungal communities, and the abundance of specific taxanomic groups, with changes in soil $\mathrm{C}$ and $\mathrm{P}$ content and to lesser extent $\mathrm{pH}$, that may reflect changes in biogeochemical cycling. Phylogenetic analysis of the clone library resulted in diverse OTUs, belonging to Alpha-, Beta-, Gamma-, Delta-proteobacteria, Acidobacteria, Actinobacteria, Gemmatimonadetes, Firmicutes, Chloroflexi, Nitrospirae, and Bacteroidetes bacterial groups, and Ascomycota, Basidiomycota, Zygomycota, and Chytridiomycota fungal divisions. In both the clone library and DGGE fingerprint data a majority of the bacterial sequences belonged to the Acidobacteria and Alphaproteobacteria groups, and the most prevalent fungal taxa belonged to the Ascomycota and Basidiomycota subdivisions. As hypothesized (hypothesis 1), average bacterial diversity was higher than average fungal diversity in both the AL and BW soils. The UPGMA-dendrograms generated by calculating Jaccards similarity coefficient of the presence/absence and relative intensity of bands on DGGE profiles show two distinct clusters in the bacterial and fungal community structure. Also as hypothesized (hypothesis 2), both bacterial and fungal DGGE profiles were clearly separated by floodplain type (AL vs. BW), but there were no distinct clusters dividing higher elevation RD from lower elevation SW soils. The composition of dominant bacterial (Acidobacteria and Alphaproteobacteria) and fungal (Ascomycota and Basidiomycota) taxa grouped as a function of environmental characteristics (TP, TC, $\mathrm{pH}$ ) describing the availability of nutrients in FFs. Total soil C content was significantly higher in BW soils, whereas TP content was significantly higher in AL FF soils. Soil N:P and C:P ratios

were significantly higher in BW than in AL FF soils, suggesting that BW soils are more likely to 
be $\mathrm{P}$ limited or co-limited by both $\mathrm{N}$ and $\mathrm{P}$. In support of hypothesis 3, the subsequent fitting of environmental variables onto the ordination plots showed that TP and $\mathrm{pH}$ were associated with the diversity and composition of bacterial and fungal communities in AL FF soils, while TC was most strongly correlated with the microbial community profiles in BW FFs. Although I had expected the microbial community structure to vary spatially with changes in microsite elevation (hypothesis 4), soil TP, microbial biomass $\mathrm{P}$, and bacterial and fungal community structure did not differ between RD and SW soils. Many of the bacterial and fungal OTUs detected in this study possess diverse metabolic functions associated with soil C, N, S, and Fe cycling in a variety of ecosystems, and may potentially have similar structure-function relationships in FF soils. More importantly, several bacterial taxa (within Acidobacteria, Alpha-, Beta-, Gammaproteobacteria, Actinobacteria, Bacteroidetes and Nitrospirae groups) sequenced in floodplain soils have also been detected in EBPR systems and are efficient at the solubilization and uptake of $\mathrm{P}$ and the storage polyphosphates. The abundance of these taxa in AL and BW soils, and their ability to efficiently remove $\mathrm{P}$, suggests a link between microbial species composition and $\mathrm{P}$ retention and transformation processes in FF soils. The realationship between soil $\mathrm{pH}$ and $\mathrm{C}, \mathrm{P}$ concentrations and composition of dominant microorganisms were consistent across four AL and four BW FFs in the southeastern US. The taxonomic indentity of bacteria and fungi in floodplain soils, and their link to P retention and transformation processes, is critical to assessing the sustainability of these ecosystem services; the specific composition of microbial communities may be a useful biological indicator to aid in assessing the successful replication of these processes in wetland creation and/or restoration efforts. 


\subsection{REFERENCES}

Acha, D., V. Iniguez, M. Roulet, J. R. D. Guimaraes, R. Luna, L. Alanoca, and S. Sanchez. 2005. Sulfate-reducing bacteria in floating macrophyte rhizospheres from an Amazonian floodplain lake in Bolivia and their association with $\mathrm{Hg}$ methylation. Applied and Environmental Microbiology 71:7531-7535.

Adame, M. F., R. Reef, J. A. Herrera-Silveira, and C. E. Lovelock. 2012. Sensitivity of dissolved organic carbon exchange and sediment bacteria to water quality in mangrove forests. Hydrobiologia 691:239-253.

Ahlgren, J., H. De Brabandere, K. Reitzel, E. Rydin, A. Gogoll, and M. Waldeback. 2007. Sediment phosphorus extractants for phosphorus-31 nuclear magnetic resonance analysis: A quantitative evaluation. Journal of Environmental Quality 36:892-898.

Ahn, C. H., H. D. Park, Y. O. Lee, and J. K. Park. 2008. Appearance of novel G-bacteria belonging to Acidobacteria in a dairy wastewater treatment plant. Environmental Technology 29:497-504.

Amann, R. and W. Ludwig. 2000. Ribosomal RNA-targeted nucleic acid probes for studies in microbial ecology. FEMS Microbiology Reviews 24:555-565.

Anderson, C. R., L. M. Condron, T. J. Clough, M. Fiers, A. Stewart, R. A. Hill, and R. R. Sherlock. 2011. Biochar induced soil microbial community change: Implications for biogeochemical cycling of carbon, nitrogen and phosphorus. Pedobiologia 54:309-320.

Anderson, I. C. and J. W. G. Cairney. 2004. Diversity and ecology of soil fungal communities: increased understanding through the application of molecular techniques. Environmental Microbiology 6:769-779.

Arora, D. S. and R. K. Sharma. 2010. Ligninolytic Fungal Laccases and Their Biotechnological Applications. Applied Biochemistry and Biotechnology 160:1760-1788.

Badali, H., F. X. Prenafeta-Boldu, J. Guarro, C. H. Klaassen, J. F. Meis, and G. S. De Hoog. 2011. Cladophialophora psammophila, a novel species of Chaetothyriales with a potential 
use in the bioremediation of volatile aromatic hydrocarbons. Fungal Biology 115:10191029.

Baldwin, D. S. and A. M. Mitchell. 2000. The effects of drying and re-flooding on the sediment and soil nutrient dynamics of lowland river-floodplain systems: A synthesis. Regulated Rivers-Research \& Management 16:457-467.

Barton, L. L. and G. D. Fauque. 2009. Biochemistry, physiology and biotechnology of sulfatereducing bacteria. Advances in Applied Microbiology68:41-98

Bedford, B. L., M. R. Walbridge, and A. Aldous. 1999. Patterns in nutrient availability and plant diversity of temperate North American wetlands. Ecology 80:2151-2169.

Beer, M., H. M. Stratton, P. C. Griffiths, and R. J. Seviour. 2006. Which are the polyphosphate accumulating organisms in full-scale activated sludge enhanced biological phosphate removal systems in Australia? Journal of Applied Microbiology 100:233-243.

Beloqui, A., T. Y. Nechitaylo, N. Lopez-Cortes, A. Ghazi, M. E. Guazzaroni, J. Polaina, A. W. Strittmatter, O. Reva, A. Waliczek, M. M. Yakimov, O. V. Golyshina, M. Ferrer, and P. N. Golyshin. 2010. Diversity of Glycosyl Hydrolases from Cellulose-Depleting Communities Enriched from Casts of Two Earthworm Species. Applied and Environmental Microbiology 76:5934-5946.

Ben Said, O., M. Goni-Urriza, M. El Bour, P. Aissa, and R. Duran. 2010. Bacterial Community Structure of Sediments of the Bizerte Lagoon (Tunisia), a Southern Mediterranean Coastal Anthropized Lagoon. Microbial Ecology 59:445-456.

Besemer, K., M. M. Moeseneder, J. M. Arrieta, G. J. Herndl, and P. Peduzzi. 2005. Complexity of bacterial communities in a river-floodplain system (Danube, Austria). Applied and Environmental Microbiology 71:609-620.

Blackall, L. L., G. Crocetti, A. M. Saunders, and P. L. Bond. 2002. A review and update of the microbiology of enhanced biological phosphorus removal in wastewater treatment plants. Antonie Van Leeuwenhoek International Journal of General and Molecular Microbiology 81:681-691. 
Blothe, M., D. M. Akob, J. E. Kostka, K. Goschel, H. L. Drake, and K. Kusel. 2008. pH Gradient-Induced Heterogeneity of Fe (III)-Reducing Microorganisms in Coal MiningAssociated Lake Sediments. Applied and Environmental Microbiology 74:1019-1029.

Boby, V. U., A. N. Balakrishna, and D. J. Bagyaraj. 2008. Interaction between Glomus mosseae and soil yeasts on growth and nutrition of cowpea. Microbiological Research 163:693700 .

Bossio, D. A., J. A. Fleck, K. M. Scow, and R. Fujii. 2006. Alteration of soil microbial communities and water quality in restored wetlands. Soil Biology \& Biochemistry 38:1223-1233.

Botha, A. 2011. The importance and ecology of yeasts in soil. Soil Biology \& Biochemistry 43:1-8.

Bouskill, N. J., J. Barker-Finkel, T. S. Galloway, R. D. Handy, and T. E. Ford. 2010. Temporal bacterial diversity associated with metal-contaminated river sediments. Ecotoxicology 19:317-328.

Bowman, J. P. and R. D. McCuaig. 2003. Biodiversity, community structural shifts, and biogeography of prokaryotes within Antarctic continental shelf sediment. Applied and Environmental Microbiology 69:2463-2483.

Brandao, L. R., D. Libkind, A. B. M. Vaz, L. C. E. Santo, M. Moline, V. de Garcia, M. van Broock, and C. A. Rosa. 2011. Yeasts from an oligotrophic lake in Patagonia (Argentina): diversity, distribution and synthesis of photoprotective compounds and extracellular enzymes. FEMS Microbiology Ecology 76:1-13.

Bridgham, S. D. and C. J. Richardson. 2003. Endogenous versus exogenous nutrient control over decomposition and mineralization in North Carolina peatlands. Biogeochemistry 65:151178.

Brinson, M. M. 1993. Changes in the functioning of wetlands along environmental gradients. Wetlands 13:65-74. 
Brookes, P. C., D. S. Powlson, and D. S. Jenkinson. 1982. Measurement of microbial biomass phosphorus in soil. Soil Biology and Biochemistry 14:319-329.

Bruland, G. L. and C. J. Richardson. 2004. A spatially explicit investigation of phosphorus sorption and related soil properties in two riparian wetlands. Journal of Environmental Quality 33:785-794.

Bruland, G. L. and C. J. Richardson. 2005. Hydrologic, edaphic, and vegetative responses to microtopographic reestablishment in a restored wetland. Restoration Ecology 13:515523.

Burgin, A. J., W. H. Yang, S. K. Hamilton, and W. L. Silver. 2011. Beyond carbon and nitrogen: how the microbial energy economy couples elemental cycles in diverse ecosystems. Frontiers in Ecology and the Environment 9:44-52.

Burr, M. D., S. J. Clark, C. R. Spear, and A. K. Camper. 2006. Denaturing gradient gel electrophoresis can rapidly display the bacterial diversity contained in 16S rDNA clone libraries. Microbial Ecology 51:479-486.

Canfield, D. E., A. N. Glazer, and P. G. Falkowski. 2010. The Evolution and Future of Earth's Nitrogen Cycle. Science 330:192-196.

Cao, H. L., M. Li, Y. G. Hong, and J. D. Gu. 2011. Diversity and abundance of ammoniaoxidizing archaea and bacteria in polluted mangrove sediment. Systematic and Applied Microbiology 34:513-523.

Carpenter, S. R. 2005. Eutrophication of aquatic ecosystems: Bistability and soil phosphorus. Proceedings of the National Academy of Sciences of the United States of America 102:10002-10005.

Carpenter, S. R. 2008. Phosphorus control is critical to mitigating eutrophication. Proceedings of the National Academy of Sciences of the United States of America 105:11039-11040. 
Chao, T.-C., J. Kalinowski, J. Nyalwidhe, and N. Hansmeier. 2010. Comprehensive proteome profiling of the $\mathrm{Fe}(\mathrm{III})$-reducing myxobacterium Anaeromyxobacter dehalogenans $2 \mathrm{CP}-\mathrm{C}$ during growth with fumarate and ferric citrate. Proteomics 10:1673-1684.

Chen, W.-M., Y.-Q. Tang, K. Mori, and X.-L. Wu. 2012a. Distribution of culturable endophytic bacteria in aquatic plants and their potential for bioremediation in polluted waters. Aquatic Biology 15:99-110.

Chen, X. B., Y. R. Su, X. Y. He, Y. W. Wei, W. X. Wei, and J. S. Wu. 2012b. Soil bacterial community composition and diversity respond to cultivation in Karst ecosystems. World Journal of Microbiology \& Biotechnology 28:205-213.

Chen, Y., M. G. Dumont, N. P. McNamara, P. M. Chamberlain, L. Bodrossy, N. Stralis-Pavese, and J. C. Murrell. 2008. Diversity of the active methanotrophic community in acidic peatlands as assessed by mRNA and SIP-PLFA analyses. Environmental Microbiology 10:446-459.

Clegg, C. D., R. D. L. Lovell, and P. J. Hobbs. 2003. The impact of grassland management regime on the community structure of selected bacterial groups in soils. FEMS Microbiology Ecology 43:263-270.

Cloete, K. J., W. J. Przybylowicz, J. Mesjasz-Przybylowicz, A. D. Barnabas, A. J. Valentine, and A. Botha. 2010. Micro-particle-induced X-ray emission mapping of elemental distribution in roots of a Mediterranean-type sclerophyll, Agathosma betulina (Berg.) Pillans, colonized by Cryptococcus laurentii. Plant Cell and Environment 33:1005-1015.

Conrad, R. 2009. The global methane cycle: recent advances in understanding the microbial processes involved. Environmental Microbiology Reports 1:285-292.

Corbett, E. and R. C. Anderson. 2006. Landscape analysis of Illinois and Wisconsin remnant prairies. Journal of the Torrey Botanical Society 133:267-279.

Corstanje, R., K. R. Reddy, J. P. Prenger, S. Newman, and A. V. Ogram. 2007. Soil microbial eco-physiological response to nutrient enrichment in a sub-tropical wetland. Ecological Indicators 7:277-289. 
Craft, C. B. and W. P. Casey. 2000. Sediment and nutrient accumulation in floodplain and depressional freshwater wetlands of Georgia, USA. Wetlands 20:323-332.

Craft, C. B. and C. Chiang. 2002. Forms and amounts of soil nitrogen and phosphorus across a longleaf pine-depressional wetland landscape. Soil Science Society of America Journal 66:1713-1721.

Crocetti, G. R., J. F. Banfield, J. Keller, P. L. Bond, and L. L. Blackall. 2002. Glycogenaccumulating organisms in laboratory-scale and full-scale wastewater treatment processes. Microbiology 148:3353-3364.

Cullen, D. and P. J. Kersten. 2004. Enzymology and molecular biology of lignin degradation. Springer-Verlag, Berlin.

Da Silva, M. L. B., R. L. Johnson, and P. J. J. Alvarez. 2007. Microbial characterization of groundwater undergoing treatment with a permeable reactive iron barrier. Environmental Engineering Science 24:1122-1127.

Damon, C., G. Barroso, C. Ferandon, J. Ranger, L. Fraissinet-Tachet, and R. Marmeisse. 2010. Performance of the COX1 gene as a marker for the study of metabolically active Pezizomycotina and Agaricomycetes fungal communities from the analysis of soil RNA. FEMS Microbiology Ecology 74:693-705.

Dang, H. Y., J. Li, M. N. Chen, T. G. Li, Z. G. Zeng, and X. B. Yin. 2009. Fine-scale vertical distribution of bacteria in the East Pacific deep-sea sediments determined via 16S rRNA gene T-RFLP and clone library analyses. World Journal of Microbiology \& Biotechnology 25:179-188.

Darke, A. K. and M. R. Walbridge. 2000. Al and Fe biogeochemistry in a floodplain forest: Implications for P retention. Biogeochemistry 51:1-32.

Datta, T. and R. Goel. 2010. Evidence and long-term feasibility of enhanced biological phosphorus removal in oxidation-ditch type of aerated-anoxic activated sludge systems. Journal of Environmental Engineering-Asce 136:1237-1247. 
Davelaar, D. 1993. Ecological significance of bacterial polyphosphate metabolism in sediments. Hydrobiologia 253:179-192.

de Figueiredo, D. R., R. V. Ferreira, M. Cerqueira, T. C. de Melo, M. J. Pereira, B. B. Castro, and A. Correia. 2012. Impact of water quality on bacterioplankton assemblage along C,rtima River Basin (central western Portugal) assessed by PCR-DGGE and multivariate analysis. Environmental Monitoring and Assessment 184:471-485.

DeAngelis, K. M., M. Allgaier, Y. Chavarria, J. L. Fortney, P. Hugenholtz, B. Simmons, K. Sublette, W. L. Silver, and T. C. Hazen. 2011. Characterization of Trapped LigninDegrading Microbes in Tropical Forest Soil. Plos One 6: e19306. doi:10.1371/journal.pone.0019306.

Delabastide, P. Y., B. R. Kropp, and Y. Piche. 1995. Population structure and mycelial phenotypic variability of the ectomycorrhizal basidiomycete Laccaria bicolor (Maire) Orton. Mycorrhiza 5:371-379.

Dias, A. C. F., F. Dini-Andreote, R. G. Taketani, S. M. Tsai, J. L. Azevedo, I. S. de Melo, and F. D. Andreote. 2011. Archaeal communities in the sediments of three contrasting mangroves. Journal of Soils and Sediments 11:1466-1476.

Diaz-Cardenas, C., B. K. C. Patel, and S. Baena. 2010. Tistlia consotensis gen. nov., sp nov., an aerobic, chemoheterotrophic, free-living, nitrogen-fixing alphaproteobacterium, isolated from a Colombian saline spring. International Journal of Systematic and Evolutionary Microbiology 60:1437-1443.

Diaz, J. M., E. D. Ingall, S. D. Snow, C. R. Benitez-Nelson, M. Taillefert, and J. A. Brandes. 2012. Potential role of inorganic polyphosphate in the cycling of phosphorus within the hypoxic water column of Effingham Inlet, British Columbia. Global Biogeochemical Cycles 26.

Dighton, J., P. A. Mason, and A. F. Harrison. 1990. Field use of 32P tracer to measure phosphate uptake by birch mycorrhizas. Agriculture Ecosystems \& Environment 28:95-99. 
Dinsdale, E. A., R. A. Edwards, D. Hall, F. Angly, M. Breitbart, J. M. Brulc, M. Furlan, C. Desnues, M. Haynes, L. Li, L. McDaniel, M. A. Moran, K. E. Nelson, C. Nilsson, R. Olson, J. Paul, B. R. Brito, Y. Ruan, B. K. Swan, R. Stevens, D. L. Valentine, R. V. Thurber, L. Wegley, B. A. White, and F. Rohwer. 2008. Functional metagenomic profiling of nine biomes. Nature 455:830-830.

Dodd, I. C., N. Y. Zinovkina, V. I. Safronova, and A. A. Belimov. 2010. Rhizobacterial mediation of plant hormone status. Annals of Applied Biology 157:361-379.

Dokmetzian, D. A., M. E. Ranalli, and B. O. Saidman. 2005. Isozyme analysis of twelve species of the genus Ascobolus. Mycotaxon 92:295-309.

dos Santos, A. C. F., E. L. S. Marques, E. Gross, S. S. Souza, J. C. T. Dias, M. Brendel, and R. P. Rezende. 2012. Detection by denaturing gradient gel electrophoresis of ammoniaoxidizing bacteria in microcosms of crude oil-contaminated mangrove sediments. Genetics and Molecular Research 11:190-201.

Edwards, I. P., H. Burgmann, C. Miniaci, and J. Zeyer. 2006. Variation in microbial community composition and culturability in the rhizosphere of Leucanthemopsis alpina (L.) heywood and adjacent bare soil along an alpine chronosequence. Microbial Ecology 52:679-692.

Edwards, I. P. and D. R. Zak. 2010. Phylogenetic similarity and structure of Agaricomycotina communities across a forested landscape. Molecular Ecology 19:1469-1482.

Edwards, I. P., D. R. Zak, H. Kellner, S. D. Eisenlord, and K. S. Pregitzer. 2011. Simulated atmospheric $\mathrm{N}$ deposition alters fungal community composition and suppresses ligninolytic gene expression in a northern hardwood forest. Plos One 6:1-10.

Eichorst, S. A. and C. R. Kuske. 2012. Identification of Cellulose-Responsive Bacterial and Fungal Communities in Geographically and Edaphically Different Soils by Using Stable Isotope Probing. Applied and Environmental Microbiology 78:2316-2327.

Elder, J. F. 1985. Nitrogen and phosphorus speciation and flux in a large Florida river wetland system. Water Resources Research 21:724-732. 
Ellis, B. K., J. A. Stanford, and J. V. Ward. 1998. Microbial assemblages and production in alluvial aquifers of the Flathead River, Montana, USA. Journal of the North American Benthological Society 17:382-402.

Elwood, J. W., J. D. Newbold, A. F. Trimble, and R. W. Stark. 1981. The limiting role of phosphorus in a woodland stream ecosystem: Effects of $\mathrm{P}$ enrichment on leaf decomposition and primary producers. Ecology 62:146-158.

Falkowski, P. G., T. Fenchel, and E. F. Delong. 2008. The microbial engines that drive Earth's biogeochemical cycles. Science 320:1034-1039.

Farina, R., A. Beneduzi, A. Ambrosini, S. B. de Camposa, B. B. Lisboa, V. Wendisch, L. K. Vargas, and L. M. P. Passaglia. 2012. Diversity of plant growth-promoting rhizobacteria communities associated with the stages of canola growth. Applied Soil Ecology 55:4452.

Filippelli, G. M. 2008. The global phosphorus cycle: Past, present, and future. Elements 4:89-95.

Findlay, S. E. G., R. L. Sinsabaugh, W. V. Sobczak, and M. Hoostal. 2003. Metabolic and structural response of hyporheic microbial communities to variations in supply of dissolved organic matter. Limnology and Oceanography 48:1608-1617.

Forney, L. J., X. Zhou, and C. J. Brown. 2004. Molecular microbial ecology: land of the oneeyed king. Current Opinion in Microbiology 7:210-220.

Frohne, T., J. Rinklebe, U. Langer, G. Du Laing, S. Mothes, and R. Wennrich. 2012. Biogeochemical factors affecting mercury methylation rate in two contaminated floodplain soils. Biogeosciences 9:493-507.

Fromin, N., J. Hamelin, S. Tarnawski, D. Roesti, K. Jourdain-Miserez, N. Forestier, S. TeyssierCuvelle, F. Gillet, M. Aragno, and P. Rossi. 2002. Statistical analysis of denaturing gel electrophoresis (DGE) fingerprinting patterns. Environmental Microbiology 4:634-643.

Furumai, H., T. Kondo, and S. Ohgaki. 1989. Phosphorus exchange kinetics and exchangeable phosphorus forms in sediments. Water Research 23:685-691. 
Gao, X. Q. and R. T. Heath. 2005. Relationship between labile dissolved organic carbon (LDOC), bacterioplankton cell phosphorus quota, and bacterial phosphate uptake rate in lakes. Journal of Great Lakes Research 31:125-137.

Gao, Z., X. Wang, A. K. Hannides, F. J. Sansone, and G. Y. Wang. 2011. Impact of redoxstratification on the diversity and distribution of bacterial communities in sandy reef sediments in a microcosm. Chinese Journal of Oceanology and Limnology 29:1209-1223.

Gardes, M. and T. D. Bruns. 1993. ITS primers with enhanced specificity for basidiomycetes: Application to the identification of mycorrhizae and rusts. Molecular Ecology 2:113-118.

Garono, R. J., R. T. Heath, and S. J. Hwang. 1996. Detrended correspondence analysis of phytoplankton abundance and distribution in Sandusky Bay and Lake Erie. Journal of Great Lakes Research 22:818-829.

Gebremariam, S. Y., M. W. Beutel, D. Christian, and T. F. Hess. 2011. Research Advances and Challenges in the Microbiology of Enhanced Biological Phosphorus Removal-A Critical Review. Water Environment Research 83:195-219.

Gessner, M. O., C. T. Robinson, and J. V. Ward. 1998. Leaf breakdown in streams of an alpine glacial floodplain: dynamics of fungi and nutrients. Journal of the North American Benthological Society 17:403-419.

Gibertoni, T. B. and E. R. Drechsler-Santos. 2010. Lignocellulolytic Agaricomycetes from the Brazilian Cerrado biome. Mycotaxon 111:87-90.

Golterman, H. L. 1995. The labyrinth of nutrient cycles and buffers in wetlands: Results based on research in the Camargue (southern France). Hydrobiologia 315:39-58.

Gorra, R., G. Webster, M. Martin, L. Celi, F. Mapelli, and A. J. Weightman. 2012. Dynamic Microbial Community Associated with Iron-Arsenic Co-Precipitation Products from a Groundwater Storage System in Bangladesh. Microbial Ecology 64:171-186.

Gottel, N. R., H. F. Castro, M. Kerley, Z. M. Yang, D. A. Pelletier, M. Podar, T. Karpinets, E. Uberbacher, G. A. Tuskan, R. Vilgalys, M. J. Doktycz, and C. W. Schadt. 2011. Distinct 
Microbial Communities within the Endosphere and Rhizosphere of Populus deltoides Roots across Contrasting Soil Types. Applied and Environmental Microbiology 77:59345944.

Greenwood, A. J. and D. H. Lewis. 1977. Phosphatases and the utilisation of inositol hexaphosphate by soil yeasts of the genus Cryptococcus. Soil Biology \& Biochemistry 9:161-166.

Grimm, N. B., S. E. Gergel, W. H. McDowell, E. W. Boyer, C. L. Dent, P. Groffman, S. C. Hart, J. Harvey, C. Johnston, E. Mayorga, M. E. McClain, and G. Pinay. 2003. Merging aquatic and terrestrial perspectives of nutrient biogeochemistry. Oecologia 137:485-501.

Gu, A. Z., A. Saunders, J. B. Neethling, H. D. Stensel, and L. L. Blackall. 2008. Functionally relevant microorganisms to enhanced biological phosphorus removal performance at fullscale wastewater treatment plants in the United States. Water Environment Research 80:688-698.

Gutknecht, J. L. M., R. M. Goodman, and T. C. Balser. 2006. Linking soil process and microbial ecology in freshwater wetland ecosystems. Plant and Soil 289:17-34.

Hall, J. R., K. R. Mitchell, O. Jackson-Weaver, A. S. Kooser, B. R. Cron, L. J. Crossey, and C. D. Takacs-Vesbach. 2008. Molecular characterization of the diversity and distribution of a thermal spring microbial community by using rRNA and metabolic genes. Applied and Environmental Microbiology 74:4910-4922.

Hamman, S. T., I. C. Burke, and M. E. Stromberger. 2007. Relationships between microbial community structure and soil environmental conditions in a recently burned system. Soil Biology \& Biochemistry 39:1703-1711.

Hartman, W. H., C. J. Richardson, R. Vilgalys, and G. L. Bruland. 2008. Environmental and anthropogenic controls over bacterial communities in wetland soils. Proceedings of the National Academy of Sciences of the United States of America 105:17842-17847.

Hayat, R., S. Ali, U. Amara, R. Khalid, and I. Ahmed. 2010. Soil beneficial bacteria and their role in plant growth promotion: a review. Annals of Microbiology 60:579-598. 
Hibbett, D. S. 2006. A phylogenetic overview of the Agaricomycotina. Mycologia 98:917-925.

Hirota, R., A. Kuroda, J. Kato, and H. Ohtake. 2010. Bacterial phosphate metabolism and its application to phosphorus recovery and industrial bioprocesses. Journal of Bioscience and Bioengineering 109:423-432.

Hoffman, M. T. and A. E. Arnold. 2010. Diverse Bacteria Inhabit Living Hyphae of Phylogenetically Diverse Fungal Endophytes. Applied and Environmental Microbiology 76:4063-4075.

Hoffmann, C. C., C. Kjaergaard, J. Uusi-Kamppa, H. C. B. Hansen, and B. Kronvang. 2009. Phosphorus Retention in Riparian Buffers: Review of Their Efficiency. Journal of Environmental Quality 38:1942-1955.

Hogan, D. M., T. E. Jordan, and M. R. Walbridge. 2004. Phosphorus retention and soil organic carbon in restored and natural freshwater wetlands. Wetlands 24:573-585.

Hopkins, A. J. M., C. L. Todoroki, and D. Pont. 2012. Assessment of the effect of Nectria flute canker on wood quality within mature Pinus radiata using multiple methods. European Journal of Forest Research 131:485-491.

Huang, D. L., G. M. Zeng, C. L. Feng, S. Hu, C. Lai, M. H. Zhao, F. F. Su, L. Tang, and H. L. Liu. 2010. Changes of microbial population structure related to lignin degradation during lignocellulosic waste composting. Bioresource Technology 101:4062-4067.

Hupfer, M., S. Gloess, and H. P. Grossart. 2007. Polyphosphate-accumulating microorganisms in aquatic sediments. Aquatic Microbial Ecology 47:299-311.

Hupfer, M., S. Gloss, P. Schmieder, and H.-P. Grossart. 2008. Methods for detection and quantification of polyphosphate and polyphosphate accumulating microorganisms in aquatic sediments. International Review of Hydrobiology 93:1-30.

Hupp, C. R. and E. E. Morris. 1990. A dendrogeomorphic approach to measurement of sedimentation in a forested wetland, Black Swamp, Arkansas. Wetlands 10:107-124. 
Hupp, C. R., M. R. Walbridge, and B. G. Lockaby. 2005. Fluvial geomorphic processes and landforms, water quality, and nutrients in Bottomland Hardwood Forests of southeastern USA. Pages 37-55 in L. H. Fredrickson, S. L. King, and R. M. Kaminski, editors. Ecology and Management of Bottomland Hardwood Systems. University of Missouri, Puxico, MO.

Hutcheson, S. W., H. T. Zhang, and M. Suvorov. 2011. Carbohydrase systems of saccharophagus degradans degrading marine complex polysaccharides. Marine Drugs 9:645-665.

Itoh, T., K. Yamanoi, T. Kudo, M. Ohkuma, and T. Takashina. 2011. Aciditerrimonas ferrireducens gen. nov., sp nov., an iron-reducing thermoacidophilic actinobacterium isolated from a solfataric field. International Journal of Systematic and Evolutionary Microbiology 61:1281-1285.

Jana, B. B., P. Chakraborty, J. K. Biswas, and S. Ganguly. 2001. Biogeochemical cycling bacteria as indices of pond fertilization: importance of CNP ratios of input fertilizers. Journal of Applied Microbiology 90:733-740.

Jasser, I., I. Kostrzewska-Szlakowska, J. Ejsmont-Karabin, K. Kalinowska, and T. Weglenska. 2009. Autotrophic versus heterotrophic production and components of trophic chain in humic lakes: the role of microbial communities. Polish Journal of Ecology 57:423-439.

Jetten, M. S. M. 2008. The microbial nitrogen cycle. Environmental Microbiology 10:29032909.

Jimenez, M., A. E. Gonzalez, M. J. Martinez, A. T. Martinez, and B. E. Dale. 1991. Screening of yeasts isolated from decayed wood for lignocellulose-degrading enzyme activities. Mycological Research 95:1299-1302.

Jin, L., K. K. Kim, S. H. Baek, and S. T. Lee. 2011. Kaistia geumhonensis sp nov and Kaistia dalseonensis sp nov., two members of the class Alphaproteobacteria. International Journal of Systematic and Evolutionary Microbiology 61:2577-2581. 
Jones, E. B. G., A. Zuccaro, J. Mitchell, A. Nakagiri, I. Chatmala, and K. L. Pang. 2009. Phylogenetic position of freshwater and marine Sigmoidea species: introducing a marine hyphomycete Halosigmoidea gen. nov (Halosphaeriales). Botanica Marina 52:349-359.

Kacprzak, M. and E. Stanczyk-Mazanek. 2003. Changes in the structure of fungal communities of soil treated with sewage sludge. Biology and Fertility of Soils 38:89-95.

Kairesalo, T., L. Tuominen, H. Hartikainen, and K. Rankinen. 1995. The role of bacteria in the nutrient exchange between sediment and water in a flow-through system. Microbial Ecology 29:129-144.

Kamitani, T., H. Oba, and N. Kaneko. 2006. Microbial biomass and tolerance of microbial community on an aged heavy metal polluted floodplain in Japan. Water Air and Soil Pollution 172: 185-200.

Kanamori, T., N. Rashid, M. Morikawa, H. Atomi, and T. Imanaka. 2002. Oleomonas sagaranensis gen. nov., sp nov., represents a novel genus in the alpha-Proteobacteria. Fems Microbiology Letters 217:255-261.

Kang, S. and A. Mills. 2003. Controlling factors in soil microbial community structure. Abstracts of the General Meeting of the American Society for Microbiology 103:N-003.

Kawaharasaki, M., H. Tanaka, T. Kanagawa, and K. Nakamura. 1999. In situ identification of polyphosphate-accumulating bacteria in activated sludge by dual staining with rRNAtargeted oligonucleotide probes and 4 ',6-diamidino-2-phenylindol (DAPI) at a polyphosphate-probing concentration. Water Research 33:257-265.

Kemnitz, D., K. J. Chin, P. Bodelier, and R. Conrad. 2004. Community analysis of methanogenic archaea within a riparian flooding gradient. Environmental Microbiology 6:449-461.

Khoshmanesh, A., B. T. Hart, A. Duncan, and R. Beckett. 2002. Luxury uptake of phosphorus by sediment bacteria. Water Research 36:774-778. 
Kim, B. S., H. M. Oh, H. Kang, S. S. Park, and J. Chun. 2004. Remarkable bacterial diversity in the tidal flat sediment as revealed by $16 \mathrm{~S}$ rDNA analysis. Journal of Microbiology and Biotechnology 14:205-211.

Kim, J. M., H. J. Lee, D. S. Lee, K. Lee, and C. O. Jeon. 2011. Identification of a novel subgroup of uncultured gammaproteobacterial glycogen-accumulating organisms in enhanced biological phosphorus removal sludge. Microbiology 157:2287-2296.

Kleinsteuber, S., F. D. Muller, A. Chatzinotas, K. Wendt-Potthoff, and H. Harms. 2008. Diversity and in situ quantification of Acidobacteria subdivision 1 in an acidic mining lake. Fems Microbiology Ecology 63:107-117.

Knapp, B. A., A. Rief, and J. Seeber. 2011. Microbial communities on litter of managed and abandoned alpine pastureland. Biology and Fertility of Soils 47:845-851.

Knief, C., S. Kolb, P. L. E. Bodelier, A. Lipski, and P. F. Dunfield. 2006. The active methanotrophic community in hydromorphic soils changes in response to changing methane concentration. Environmental Microbiology 8:321-333.

Knupp, A. M., C. M. Martins, J. C. de Faria, N. G. Rumjanek, and G. R. Xavier. 2009. Bacterial community as an indicator of genetically modified common bean effect on nontarget organisms. Pesquisa Agropecuaria Brasileira 44:1692-1699.

Kobayashi, T., D. S. Ryder, G. Gordon, I. Shannon, T. Ingleton, M. Carpenter, and S. J. Jacobs. 2009. Short-term response of nutrients, carbon and planktonic microbial communities to floodplain wetland inundation. Aquatic Ecology 43:843-858.

Kolb, S. 2009. The quest for atmospheric methane oxidizers in forest soils. Environmental Microbiology Reports 1:336-346.

Kolmonen, E., K. Haukka, A. Rantala-Ylinen, P. Rajaniemi-Wacklin, L. Lepisto, and K. Sivonen. 2011. Bacterioplankton community composition in 67 Finnish lakes differs according to trophic status. Aquatic Microbial Ecology 62:241-U249. 
Kong, Y. H., J. L. Nielsen, and P. H. Nielsen. 2005. Identity and ecophysiology of uncultured actinobacterial polyphosphate-accumulating organisms in full-scale enhanced biological phosphorus removal plants. Applied and Environmental Microbiology 71:4076-4085.

Kong, Y. H., Y. Xia, J. L. Nielsen, and P. H. Nielsen. 2006. Ecophysiology of a group of uncultured Gammaproteobacterial glycogen-accumulating organisms in full-scale enhanced biological phosphorus removal wastewater treatment plants. Environmental Microbiology 8:479-489.

Krishnaswamy, U., M. Muthusamy, and L. Perumalsamy. 2009. Studies on the efficiency of the removal of phosphate using bacterial consortium for the biotreatment of phosphate wastewater. European Journal of Applied Sciences 1: 06-15.

Krivtsov, V., J. B. Illian, K. Liddell, A. Garside, T. Bezginova, R. Salmond, J. Thompson, B. Griffiths, H. J. Staines, R. Watling, A. Brendler, and J. W. Palfreyman. 2003. Some aspects of complex interactions involving soil mesofauna: analysis of the results from a Scottish woodland. Ecological Modelling 170:441-452.

Kuehn, K. A., M. J. Lemke, K. Suberkropp, and R. G. Wetzel. 2000. Microbial biomass and production associated with decaying leaf litter of the emergent macrophyte Juncus effusus. Limnology and Oceanography 45:862-870.

Kumar, M. and S. Khanna. 2010. Diversity of 16S rRNA and dioxygenase genes detected in coal-tar-contaminated site undergoing active bioremediation. Journal of Applied Microbiology 108:1252-1262.

Kump, L. R. and F. T. Mackenzie. 1996. Regulation of atmospheric $\mathrm{O}_{2}$ : Feedback in the microbial feedbag. Science 271:459-460.

Kurakov, A. V., R. B. Lavrent'ev, T. Y. Nechitailo, P. N. Golyshin, and D. G. Zvyagintsev. 2008. Diversity of facultatively anaerobic microscopic mycelial fungi in soils. Microbiology 77:90-98. 
Kutuzova, R. S., N. I. Vorob'ev, M. V. Gamova, L. A. Popova, and Y. V. Kruglov. 2009. Microbiological characterization of soddy soils of the Severnaya Dvina River floodplain. Eurasian Soil Science 42:225-234.

Kwon, K. K., H. S. Lee, S. H. Yang, and S. J. Kim. 2005. Kordiimonas gwangyangensis gen. nov., sp nov., a marine bacterium isolated from marine sediments that forms a distinct phyletic lineage (Kordiimonadales ord. nov.) in the 'Alphaproteobacteria'. International Journal of Systematic and Evolutionary Microbiology 55:2033-2037.

Langer, U. and J. Rinklebe. 2009. Lipid biomarkers for assessment of microbial communities in floodplain soils of the Elbe River (Germany). Wetlands 29:353-362.

Lanham, A. B., R. Moita, P. C. Lemos, and M. A. M. Reis. 2011. Long-term operation of a reactor enriched in Accumulibacter clade I DPAOs: performance with nitrate, nitrite and oxygen. Water Science and Technology 63:352-359.

Lau, E., A. Ahmad, P. A. Steudler, and C. M. Cavanaugh. 2007. Molecular characterization of methanotrophic communities in forest soils that consume atmospheric methane. FEMS Microbiology Ecology 60:490-500.

Lawrey, J. D., P. Diederich, M. Sikaroodi, and P. M. Gillevet. 2008. Remarkable nutritional diversity of basidiomycetes in the Corticiales, including a new foliicolous species of Marchandiomyces (Anamorphic Basidiomycota, Corticiaceae) from Australia. American Journal of Botany 95:816-823.

Leff, L. G. and J. L. Meyer. 1991. Biological availability of dissolved organic carbon along the Ogeechee River. Limnology and Oceanography 36:315-323.

Lenton, T. M. and A. J. Watson. 2000. Redfield revisited 1. Regulation of nitrate, phosphate, and oxygen in the ocean. Global Biogeochemical Cycles 14:225-248.

Levantesi, C., L. S. Serafim, G. R. Crocetti, P. C. Lemos, S. Rossetti, L. L. Blackall, M. A. M. Reis, and V. Tandoi. 2002. Analysis of the microbial community structure and function of a laboratory scale enhanced biological phosphorus removal reactor. Environmental Microbiology 4:559-569. 
Li, H. R., Y. Yu, W. Luo, Y. X. Zeng, and B. Chen. 2009. Bacterial diversity in surface sediments from the Pacific Arctic Ocean. Extremophiles 13:233-246.

Lin, Y. T., Y. J. Huang, S. L. Tang, W. B. Whitman, D. C. Coleman, and C. Y. Chiu. 2010. Bacterial Community Diversity in Undisturbed Perhumid Montane Forest Soils in Taiwan. Microbial Ecology 59:369-378.

Liu, W. T., A. T. Nielsen, J. H. Wu, C. S. Tsai, Y. Matsuo, and S. Molin. 2001. In situ identification of polyphosphate- and polyhydroxyalkanoate-accumulating traits for microbial populations in a biological phosphorus removal process. Environmental Microbiology 3:110-122.

Liu, Y., G. Villalba, R. U. Ayres, and H. Schroder. 2008. Global phosphorus flows and environmental impacts from a consumption perspective. Journal of Industrial Ecology 12:229-247.

Liu, Y., T. Zhang, and H. H. P. Fang. 2005. Microbial community analysis and performance of a phosphate-removing activated sludge. Bioresource Technology 96:1205-1214.

Liu, Y. J., S. J. Liu, H. L. Drake, and M. A. Horn. 2011. Alphaproteobacteria dominate active 2methyl-4-chlorophenoxyacetic acid herbicide degraders in agricultural soil and drilosphere. Environmental Microbiology 13:991-1009.

Lockaby, B. G. and M. R. Walbridge. 1998. Biogeochemistry. In M. G. Messina and W. H. Conner, editors. Southern Forested Wetlands: Ecology and Management. Lewis Publishers, Boca Raton, FL, USA.

Loganathan, P. and S. Nair. 2004. Swaminathania salitolerans gen. nov., sp nov., a salt-tolerant, nitrogen-fixing and phosphate-solubilizing bacterium from wild rice (Porteresia coarctata Tateoka). International Journal of Systematic and Evolutionary Microbiology 54:1185-1190.

Lopes, A. R., C. Faria, A. Prieto-Fernandez, C. Trasar-Cepeda, C. M. Manaia, and O. C. Nunes. 2011. Comparative study of the microbial diversity of bulk paddy soil of two rice fields subjected to organic and conventional farming. Soil Biology \& Biochemistry 43:115-125. 
Lopez-Vazquez, C. M., A. Oehmen, C. M. Hooijmans, D. Brdjanovic, H. J. Gijzen, Z. Yuan, and M. C. M. van Loosdrecht. 2009a. Modeling the PAO-GAO competition: Effects of carbon source, $\mathrm{pH}$ and temperature. Water Research 43:450-462.

Lopez-Vazquez, C. M., A. Oehmen, C. M. Hooijmans, D. Brdjanovic, H. J. Gijzen, Z. G. Yuan, and M. C. M. van Loosdrecht. 2009b. Modeling the PAO-GAO competition: Effects of carbon source, $\mathrm{pH}$ and temperature. Water Research 43:450-462.

Lowell, J. L., N. Gordon, D. Engstrom, J. A. Stanford, W. E. Holben, and J. E. Gannon. 2009. Habitat Heterogeneity and Associated Microbial Community Structure in a Small-Scale Floodplain Hyporheic Flow Path. Microbial Ecology 58:611-620.

Lucena, T., M. J. Pujalte, M. A. Ruvira, E. Garay, M. C. Macian, and D. R. Arahal. 2012. Tropicibacter multivorans sp nov., an aerobic alphaproteobacterium isolated from surface seawater. International Journal of Systematic and Evolutionary Microbiology 62:844848.

Madigan, M., S. S. Cox, and R. A. Stegeman. 1984. Nitrogen fixation and nitrogenase activities in members of the family Rhodospirillaceae. Journal of Bacteriology 157:73-78.

Maia, L. C., A. M. Yano, and J. W. Kimbrough. 1996. Species of Ascomycota forming ectomycorrhizae. Mycotaxon 57:371-390.

Mander, U., S. Teiter, V. Kuusemets, K. Lohmus, M. Oovel, K. Nurk, and J. Augustin. 2003. Nitrogen and phosphorus budgets in a subsurface flow wastewater treatment wetland. Pages 135-148 in C. A. Brebbia, editor. Water Resources Management II, WIT Press, Boston

Marchesi, J. R., A. J. Weightman, B. A. Cragg, R. J. Parkes, and J. C. Fry. 2001. Methanogen and bacterial diversity and distribution in deep gas hydrate sediments from the Cascadia Margin as revealed by $16 \mathrm{~S}$ rRNA molecular analysis. FEMS Microbiology Ecology 34:221-228.

Martin, H. G., N. Ivanova, V. Kunin, F. Warnecke, K. W. Barry, A. C. McHardy, C. Yeates, S. M. He, A. A. Salamov, E. Szeto, E. Dalin, N. H. Putnam, H. J. Shapiro, J. L. Pangilinan, 
I. Rigoutsos, N. C. Kyrpides, L. L. Blackall, K. D. McMahon, and P. Hugenholtz. 2006. Metagenomic analysis of two enhanced biological phosphorus removal (EBPR) sludge communities. Nature Biotechnology 24:1263-1269.

McCarren, J., J. W. Becker, D. J. Repeta, Y. Shi, C. R. Young, R. R. Malmstrom, S. W. Chisholm, and E. F. DeLong. 2010. Microbial community transcriptomes reveal microbes and metabolic pathways associated with dissolved organic matter turnover in the sea. Proceedings of the National Academy of Sciences of the United States of America 107:16420-16427.

McDowell, R. W. and G. F. Koopmans. 2006. Assessing the bioavailability of dissolved organic phosphorus in pasture and cultivated soils treated with different rates of nitrogen fertiliser. Soil Biology \& Biochemistry 38:61-70.

Michel, H. M. and M. A. Williams. 2011. Soil Habitat and Horizon Properties Impact Bacterial Diversity and Composition. Soil Science Society of America Journal 75:1440-1448.

Midgley, D. J., S. M. Chambers, and J. W. G. Cairney. 2004. Inorganic and organic substrates as sources of nitrogen and phosphorus for multiple genotypes of two ericoid mycorrhizal fungal taxa from Woollsia pungens and Leucopogon parviflorus (Ericaceae). Australian Journal of Botany 52:63-71.

Mikanova, O. and J. Kubat. 1994. Phosphorus solubilization from hardly soluble phosphates by soil microflora. Rostlinna Vyroba 40:833-840.

Miletto, M., A. Loy, A. M. Antheunisse, R. Loeb, P. L. E. Bodelier, and H. J. Laanbroek. 2008. Biogeography of sulfate-reducing prokaryotes in river floodplains. FEMS Microbiology Ecology 64:395-406.

Millanes, A. M., M. Westberg, M. Wedin, and P. Diederich. 2012. Tremella diploschistina (Tremellales, Basidiomycota, Fungi), a new lichenicolous species growing on Diploschistes. Lichenologist 44:321-332.

Mitsch, W. J. and J. G. Gosselink. 2007. Wetlands. 4th edition. John Wiley \& Sons, New York. 
Montana, J. S., D. J. Jimenez, M. Hernandez, T. Angel, and S. Baena. 2012. Taxonomic and functional assignment of cloned sequences from high Andean forest soil metagenome. Antonie Van Leeuwenhoek International Journal of General and Molecular Microbiology 101:205-215.

Mouhamadou, B., C. Molitor, F. Baptist, L. Sage, J. C. Clement, S. Lavorel, A. Monier, and R. A. Geremia. 2011. Differences in fungal communities associated to Festuca paniculata roots in subalpine grasslands. Fungal Diversity 47:55-63.

Mubyana, T., M. Krah, O. Totolo, and M. Bonyongo. 2003. Influence of seasonal flooding on soil total nitrogen, organic phosphorus and microbial populations in the Okavango Delta, Botswana. Journal of Arid Environments 54:359-369.

Mullan, A., J. P. Quinn, and J. W. McGrath. 2002. Enhanced phosphate uptake and polyphosphate accumulation in Burkholderia cepacia grown under low-pH conditions. Microbial Ecology 44:69-77.

Murase, J., M. Shibata, C. G. Lee, T. Watanabe, S. Asakawa, and M. Kimura. 2012. Incorporation of plant residue-derived carbon into the microeukaryotic community in a rice field soil revealed by DNA stable-isotope probing. FEMS Microbiology Ecology 79:371-379.

Murrell, J. C. and M. S. M. Jetten. 2009. The microbial methane cycle. Environmental Microbiology Reports 1:279-284.

Muyzer, G. 1999. DGGE/TGGE a method for identifying genes from natural ecosystems. Current Opinion in Microbiology 2:317-322.

Muyzer, G., E. C. Dewaal, and A. G. Uitterlinden. 1993. Profiling of complex microbialpopulations by denaturing gradient gel-electrophoresis: Analysis of polymerase chain reaction amplified genes-coding for $16 \mathrm{~S}$ ribosomal-RNA. Applied and Environmental Microbiology 59:695-700.

Muyzer, G. and A. J. M. Stams. 2008. The ecology and biotechnology of sulphate-reducing bacteria. Nature Reviews Microbiology 6:441-454. 
Nadarajah, N., D. G. Allen, and R. R. Fulthorpe. 2010. Composition of activated sludge settling and planktonic bacterial communities treating industrial effluent and their correlation to settling problems. Applied Microbiology and Biotechnology 88:1205-1214.

Navarro, J., D. Moser, A. Flores, C. Ross, M. Rosen, H. L. Dong, G. G. Zhang, and B. Hedlund. 2009. Bacterial succession within an ephemeral hypereutrophic Mojave Desert playa lake. Microbial Ecology 57:307-320.

Nguyen, L. M. 2000. Phosphate incorporation and transformation in surface sediments of a sewage-impacted wetland as influenced by sediment sites, sediment $\mathrm{pH}$ and added phosphate concentration. Ecological Engineering 14:139-155.

Nielsen, J. L., S. Juretschko, M. Wagner, and P. H. Nielsen. 2002. Abundance and phylogenetic affiliation of iron reducers in activated sludge as assessed by fluorescence in situ hybridization and microautoradiography. Applied and Environmental Microbiology 68:4629-4636.

Nielsen, J. L., H. Nguyen, R. L. Meyer, and P. H. Nielsen. 2012. Identification of glucosefermenting bacteria in a full-scale enhanced biological phosphorus removal plant by stable isotope probing Microbiology 10.1099/mic.0.058818-0

Nielsen, P. H., A. T. Mielczarek, C. Kragelund, J. L. Nielsen, A. M. Saunders, Y. H. Kong, A. A. Hansen, and J. Vollertsen. 2010. A conceptual ecosystem model of microbial communities in enhanced biological phosphorus removal plants. Water Research 44:5070-5088.

Nittami, T., S. McIlroy, E. M. Seviour, S. Schroeder, and R. J. Seviour. 2009. Candidatus Monilibacter spp., common bulking filaments in activated sludge, are members of Cluster III Defluviicoccus. Systematic and Applied Microbiology 32:480-489.

Nocker, A., M. Burr, and A. K. Camper. 2007. Genotypic microbial community profiling: A critical technical review. Microbial Ecology 54:276-289.

Noe, G. B. and C. R. Hupp. 2005. Carbon, nitrogen, and phosphorus accumulation in floodplains of Atlantic Coastal Plain rivers, USA. Ecological Applications 15:1178-1190. 
Noe, G. B. and C. R. Hupp. 2009. Retention of riverine sediment and nutrient loads by coastal plain floodplains. Ecosystems 12:728-746.

Oehmen, A., P. C. Lemos, G. Carvalho, Z. Yuan, J. Keller, L. L. Blackall, and M. A. M. Reis. 2007. Advances in enhanced biological phosphorus removal: From micro to macro scale. Water Research 41:2271-2300.

Oksanen, J., F. G. Blanchet, R. Kindt, P. Legendre, P. R. Minchin, R. B. O’Hara, G. L. Simpson, P. Solymos, M. Henry, H. Stevens, and H. Wagner. 2011. Vegan: Community Ecology Package v2.0-1. Available at http://cran.r-project.org, http://vegan.r-forge.r-project.org/.

Olapade, O. A., X. Gao, and L. G. Leff. 2005. Abundance of three bacterial populations in selected streams. Microbial Ecology 49:461-467.

Onnis-Hayden, A., N. Majed, A. Schramm, and A. Z. Gu. 2011. Process optimization by decoupled control of key microbial populations: Distribution of activity and abundance of polyphosphate-accumulating organisms and nitrifying populations in a full-scale IFASEBPR plant. Water Research 45:3845-3854.

Oregaard, G. and S. J. Sorensen. 2007. High diversity of bacterial mercuric reductase genes from surface and sub-surface floodplain soil (Oak Ridge, USA). International Society for Microbial Ecology Journal 1:453-467.

Palaniappan, P., P. S. Chauhan, V. S. Saravanan, R. Anandham, and T. Sa. 2010. Isolation and characterization of plant growth promoting endophytic bacterial isolates from root nodule of Lespedeza sp. Biology and Fertility of Soils 46:807-816.

Palijan, G. 2012. Abundance and biomass responses of microbial food web components to hydrology and environmental gradients within a floodplain of the River Danube. Microbial Ecology 64:39-53.

Paludan, C. and H. S. Jensen. 1995. Sequential extraction of phosphorus in freshwater wetland and lake sediment: Significance of humic acids. Wetlands 15:365-373. 
Pankratov, T. A., L. A. Kirsanova, E. N. Kaparullina, V. V. Kevbrin, and S. N. Dedysh. 2012. Telmatobacter bradus gen. nov., sp nov., a cellulolytic facultative anaerobe from subdivision 1 of the Acidobacteria, and emended description of Acidobacterium capsulatum Kishimoto et al. 1991. International Journal of Systematic and Evolutionary Microbiology 62:430-437.

Pant, H. K., K. R. Reddy, and F. E. Dierberg. 2002. Bioavailability of organic phosphorus in a submerged aquatic vegetation-dominated treatment wetland. Journal of Environmental Quality 31:1748-1756.

Parkinson, J. A. and S. E. Allen. 1975. A wet oxidation procedure suitable for the determination of nitrogen and mineral nutrients in biological material. Communications in Soil Science and Plant Analysis 6:1-11.

Perez-Leblic, M. I., A. Turmero, M. Hernandez, A. J. Hernandez, J. Pastor, A. S. Ball, J. Rodriguez, and M. E. Arias. 2012. Influence of xenobiotic contaminants on landfill soil microbial activity and diversity. Journal of Environmental Management 95:S285-S290.

Pierrou, U. 1976. The global phosphorus cycle. Svensson, B. H. And R. Soderlund (Ed.). Ecological Bulletins Nfr (Statens Naturvetenskapliga Forskiningsrad), No. 22. Nitrogen, Phosphorus and Sulphur--Global Cycles, Scope (Scientific Committee on Problems of the Environment) Report 7. Meeting. Orsundsbro, Sweden, Dec. 14-18, 1975. 192p. Illus. Maps. Swedish Natural Science Research Council: Stockholm, Sweden. ISBN 91-5460202-5:75-88.

Polymenakou, P. N., N. Lampadariou, M. Mandalakis, and A. Tselepides. 2009. Phylogenetic diversity of sediment bacteria from the southern Cretan margin, Eastern Mediterranean Sea. Systematic and Applied Microbiology 32:17-26.

Pooja, A. 2012. Molecular Identification of root nodule bacteria from Cicer arietinum. Research Journal of Biotechnology 7:73-79.

Porter, T. M., J. E. Skillman, and J. M. Moncalvo. 2008. Fruiting body and soil rDNA sampling detects complementary assemblage of Agaricomycotina (Basidiomycota, Fungi) in a hemlock-dominated forest plot in southern Ontario. Molecular Ecology 17:3037-3050. 
Raja, H. A., H. A. Violi, and C. A. Shearer. 2010. Freshwater ascomycetes: Alascospora evergladensis, a new genus and species from the Florida Everglades. Mycologia 102:3338.

Ramette, A. 2007. Multivariate analyses in microbial ecology. FEMS Microbiology Ecology 62:142-160.

Ren, N., H. Kang, X. Wang, and N. Li. 2011. Short-term effect of temperature variation on the competition between PAOs and GAOs during acclimation period of an EBPR system. Frontiers of Environmental Science \& Engineering in China 5:277-282.

Richardson, C. J. 1985. Mechanisms controlling phosphorus retention capacity in freshwater wetlands. Science 228:1424-1427.

Richardson, C. J. 1989. Freshwater wetlands: Transformers, filters or sinks? Pages 25-46 in Freshwater Wetlands and Wildlife. Conf-8603101. DOE Symposium Series NO. 61, U.S. DOE. Oak Ridge, TN.

Richardson, C. J. and P. E. Marshall. 1986. Processes controling movement, storage, and export of phosphorus in a fen peatland. Ecological Monographs 56:279-302.

Richardson, C. J., M. R. Walbridge, and A. Burns. 1988. Soil chemistry and phosphorus retention capacity of North Carolina coastal plain swamps receiving sewage effluent., Water Resources Research Institute of the University of North Carolina, Raleigh, NC.

Rinklebe, J. and U. Langer. 2006. Microbial diversity in three floodplain soils at the Elbe River (Germany). Soil Biology \& Biochemistry 38:2144-2151.

Roberts, W. M., M. I. Stutter, and P. M. Haygarth. 2012. Phosphorus retention and remobilization in vegetated buffer strips: A Review. Journal of Environmental Quality 41:389-399.

Robinson, C. T., M. O. Gessner, K. A. Callies, C. Jolidon, and J. V. Ward. 2000. Larch needle breakdown in contrasting streams of an alpine glacial floodplain. Journal of the North American Benthological Society 19:250-262. 
Rockne, K. J. and S. E. Strand. 2003. Amplification of marine methanotrophic enrichment DNA with 16S rDNA PCR primers for Type II alpha proteobacteria methanotrophs. Journal of Environmental Science and Health Part a-Toxic/Hazardous Substances \& Environmental Engineering 38:1877-1887.

Rojas, J. L., J. Martin, J. R. Tormo, F. Vicente, M. Brunati, I. Ciciliato, D. Losi, S. Van Trappen, J. Mergaert, J. Swings, F. Marinelli, and O. Genilloud. 2009. Bacterial diversity from benthic mats of Antarctic lakes as a source of new bioactive metabolites. Marine Genomics 2:33-41.

Rosado, A. S., G. F. Duarte, L. Seldin, and J. D. Van Elsas. 1997. Molecular microbial ecology: A minireview. Revista de Microbiologia 28:135-147.

Rosch, C. and H. Bothe. 2009. Diversity of total, nitrogen-fixing and denitrifying bacteria in an acid forest soil. European Journal of Soil Science 60:883-894.

Ross, J. L., P. I. Boon, P. Ford, and B. T. Hart. 1997. Detection and quantification with 16S rRNA probes of planktonic methylotrophic bacteria in a floodplain lake. Microbial Ecology 34:97-108.

Rowe, O. F., J. Sanchez-Espana, K. B. Hallberg, and D. B. Johnson. 2007. Microbial communities and geochemical dynamics in an extremely acidic, metal-rich stream at an abandoned sulfide mine (Huelva, Spain) underpinned by two functional primary production systems. Environmental Microbiology 9:1761-1771.

Ruibal, C., G. Platas, and G. F. Bills. 2008. High diversity and morphological convergence among melanised fungi from rock formations in the Central Mountain System of Spain. Persoonia 21:93-110.

Ruiz-Lozano, J. M. and P. Bonfante. 1999. Identification of a putative P-transporter operon in the genome of a Burkholderia strain living inside the arbuscular mycorrhizal fungus Gigaspora margarita. Journal of Bacteriology 181:4106-4109.

Ruttenberg, K. C. 2005. The global phosphorus cycle. Pages 585-644 in W. H. Schlesinger, editor. Treatise on Geochemistry: Biogeochemistry. 
Salles, J. F., J. A. van Veen, and J. D. van Elsas. 2004. Multivariate analyses of Burkholderia species in soil: Effect of crop and land use history. Applied and Environmental Microbiology 70:4012-4020.

Salvador Montana, J., D. Javier Jimenez, M. Hernandez, T. Angel, and S. Baena. 2012. Taxonomic and functional assignment of cloned sequences from high Andean forest soil metagenome. Antonie Van Leeuwenhoek International Journal of General and Molecular Microbiology 101:205-215.

Samaddar, N., A. Paul, S. Chakravorty, W. Chakraborty, J. Mukherjee, D. Chowdhuri, and R. Gachhui. 2011. Nitrogen fixation in Asaia sp (Family Acetobacteraceae). Current Microbiology 63:226-231.

Sanchez, O., L. Garrido, I. Forn, R. Massana, M. Ignacio Maldonado, and J. Mas. 2011. Molecular characterization of activated sludge from a seawater-processing wastewater treatment plant. Microbial Biotechnology 4:628-642.

Sanon, K. B., A. M. Ba, and J. Dexheimer. 1997. Mycorrhizal status of some fungi fruiting beneath indigenous trees in Burkina Faso. Forest Ecology and Management 98:61-69.

Schindler, D. W. 1978. Factors regulating phytoplankton production and standing crop in the world's freshwaters. Limnology and Oceanography 23:478-486.

Schleheck, D., W. B. Dong, K. Denger, E. Heinzle, and A. M. Cook. 2000. An alphaproteobacterium converts linear alkylbenzenesulfonate surfactants into sulfophenylcarboxylates and linear alkyldiphenyletherdisulfonate surfactants into sulfodiphenylethercarboxylates. Applied and Environmental Microbiology 66:19111916.

Schmidt, S. M. and R. Panstruga. 2011. Pathogenomics of fungal plant parasites: what have we learnt about pathogenesis? Current Opinion in Plant Biology 14:392-399.

Schmidtova, J. and S. A. Baldwin. 2011. Correlation of bacterial communities supported by different organic materials with sulfate reduction in metal-rich landfill leachate. Water Research 45:1115-1128. 
Schoch, C. L., P. W. Crous, J. Z. Groenewald, E. W. A. Boehm, T. I. Burgess, J. de Gruyter, G. S. de Hoog, L. J. Dixon, M. Grube, C. Gueidan, Y. Harada, S. Hatakeyama, K. Hirayama, T. Hosoya, S. M. Huhndorf, K. D. Hyde, E. B. G. Jones, J. Kohlmeyer, A. Kruys, Y. M. Li, R. Lucking, H. T. Lumbsch, L. Marvanova, J. S. Mbatchou, A. H. McVay, A. N. Miller, G. K. Mugambi, L. Muggia, M. P. Nelsen, P. Nelson, C. A. Owensby, A. J. L. Phillips, S. Phongpaichit, S. B. Pointing, V. Pujade-Renaud, H. A. Raja, E. R. Plata, B. Robbertse, C. Ruibal, J. Sakayaroj, T. Sano, L. Selbmann, C. A. Shearer, T. Shirouzu, B. Slippers, S. Suetrong, K. Tanaka, B. Volkmann-Kohlmeyer, M. J. Wingfield, A. R. Wood, J. H. C. Woudenberg, H. Yonezawa, Y. Zhang, and J. W. Spatafora. 2009. A class-wide phylogenetic assessment of Dothideomycetes. Studies in Mycology 64:1-15.

Schultz, P. and N. R. Urban. 2008. Effects of bacterial dynamics on organic matter decomposition and nutrient release from sediments: A modeling study. Ecological Modelling 210:1-14.

Selosse, M. A., R. Bauer, and B. Moyersoen. 2002. Basal hymenomycetes belonging to the Sebacinaceae are ectomycorrhizal on temperate deciduous trees. New Phytologist 155:183-195.

Serafim, L. S., P. C. Lemos, C. Levantesi, V. Tandoi, H. Santos, and M. A. M. Reis. 2002. Methods for detection and visualization of intracellular polymers stored by polyphosphate-accumulating microorganisms. Journal of Microbiological Methods 51:118.

Simon, C. and R. Daniel. 2011. Metagenomic analyses: Past and F=future trends. Applied and Environmental Microbiology 77:1153-1161.

Simonovic, V. and A. Simonovicova. 1999. Some production-ecological and microbiological characteristics of floodplain forests in the Morava river inundation area. EkologiaBratislava 18:341-349.

Singh, P. and S. M. Singh. 2012. Characterization of yeast and filamentous fungi isolated from cryoconite holes of Svalbard, Arctic. Polar Biology 35:575-583.

Slavikova, E. and R. Vadkertiova. 1997. Yeasts and yeast-like organisms occurring in the river Morava. Food Technology and Biotechnology 35:293-297. 
Sobolev, D. and E. E. Roden. 2004. Characterization of a neutrophilic, chemolithoautotrophic $\mathrm{Fe}(\mathrm{II})$-oxidizing beta-proteobacterium from freshwater wetland sediments. Geomicrobiology Journal 21:1-10.

Song, H., Z. Li, B. Du, G. Wang, and Y. Ding. 2012. Bacterial communities in sediments of the shallow Lake Dongping in China. Journal of Applied Microbiology 112:79-89.

Song, Y., S. P. Deng, V. Acosta-Martinez, and E. Katsalirou. 2008. Characterization of redoxrelated soil microbial communities along a river floodplain continuum by fatty acid methyl ester (FAME) and 16S rRNA genes. Applied Soil Ecology 40:499-509.

Sorrell, B. K., C. Chague-Goff, L. M. Basher, and T. R. Partridge. 2011. N:P ratios, delta ${ }^{15} \mathrm{~N}$ fractionation and nutrient resorption along a nitrogen to phosphorus limitation gradient in an oligotrophic wetland complex. Aquatic Botany 94:93-101.

Spatafora, J. W., G. H. Sung, D. Johnson, C. Hesse, B. O'Rourke, M. Serdani, R. Spotts, F. Lutzoni, V. Hofstetter, J. Miadlikowska, V. Reeb, C. Gueidan, E. Fraker, T. Lumbsch, R. Lucking, I. Schmitt, K. Hosaka, A. Aptroot, C. Roux, A. N. Miller, D. M. Geiser, J. Hafellner, G. Hestmark, A. E. Arnold, B. Budel, A. Rauhut, D. Hewitt, W. A. Untereiner, M. S. Cole, C. Scheidegger, M. Schultz, H. Sipman, and C. L. Schoch. 2006. A five-gene phylogeny of Pezizomycotina. Mycologia 98:1018-1028.

Sridevi, M. and K. V. Mallaiah. 2009. Phosphate solubilization by Rhizobium strains. Indian Journal of Microbiology 49:98-102.

Stanturf, J. A. and S. H. Schoenholtz. 1998. Soils and landforms. Pages 123-147 in M. G. Messina and W. H. Conner, editors. Southern forested wetlands: Ecology and management. Lewis Publ., New York.

Stein, L. Y., F. Bringel, A. A. DiSpirito, S. Han, M. S. M. Jetten, M. G. Kalyuzhnaya, K. D. Kits, M. G. Klotz, H. J. M. O. den Camp, J. D. Semrau, S. Vuilleumier, D. C. Bruce, J.-F. Cheng, K. W. Davenport, L. Goodwin, S. Han, L. Hauser, A. Lajus, M. L. Land, A. Lapidus, S. Lucas, C. Medigue, S. Pitluck, and T. Woyke. 2011. Genome Sequence of the Methanotrophic Alphaproteobacterium Methylocystis sp Strain Rockwell (ATCC 49242). Journal of Bacteriology 193:2668-2669. 
Sterner, R. W. and J. J. Elser. 2002. Ecological Stoichiometry: The Biology of Elements from Molecules to the Biosphere. Princeton University Press, Princeton, NJ.

Stoeckel, D. M. and M. S. Miller-Goodman. 2001. Seasonal nutrient dynamics of forested floodplain soil influenced by microtopography and depth. Soil Science Society of America Journal 65:922-931.

Stursova, M., L. Zifcakova, M. B. Leigh, R. Burgess, and P. Baldrian. 2012. Cellulose utilization in forest litter and soil: identification of bacterial and fungal decomposers. FEMS Microbiology Ecology 80:735-746.

Sun, F. L., Y. S. Wang, M. L. Wu, Y. T. Wang, and Q. P. Li. 2011. Spatial heterogeneity of bacterial community structure in the sediments of the Pearl River estuary. Biologia 66:574-584.

Szabo, G., B. Khayer, A. Rusznyak, I. Tatrai, G. Devai, K. Marialigeti, and A. K. Borsodi. 2011. Seasonal and spatial variability of sediment bacterial communities inhabiting the large shallow Lake Balaton. Hydrobiologia 663:217-232.

Takashima, M., B. H. Van, K. D. An, and M. Ohkuma. 2011. Dioszegia rishiriensis sp nov., a novel yeast species from soil collected on Rishiri Island, Hokkaido, Japan. International Journal of Systematic and Evolutionary Microbiology 61:1736-1739.

Talia, P., S. M. Sede, E. Campos, M. Rorig, D. Principi, D. Tosto, H. E. Hopp, D. Grasso, and A. Cataldi. 2012. Biodiversity characterization of cellulolytic bacteria present on native Chaco soil by comparison of ribosomal RNA genes. Research in Microbiology 163:221232.

Tanahashi, T., J. Murase, K. Matsuya, M. Hayashi, M. Kimura, and S. Asakawa. 2005. Bacterial communities responsible for the decomposition of rice straw compost in a Japanese rice paddy field estimated by DGGE analysis of amplified 16S rDNA and 16S rRNA fragments. Soil Science and Plant Nutrition 51:351-360.

Tang, Y. S., L. Wang, J. W. Jia, X. H. Fu, Y. Q. Le, X. Z. Chen, and Y. Sun. 2011. Response of soil microbial community in Jiuduansha wetland to different successional stages and its 
implications for soil microbial respiration and carbon turnover. Soil Biology \& Biochemistry 43:638-646.

Teeling, H., B. M. Fuchs, D. Becher, C. Klockow, A. Gardebrecht, C. M. Bennke, M. Kassabgy, S. X. Huang, A. J. Mann, J. Waldmann, M. Weber, A. Klindworth, A. Otto, J. Lange, J. Bernhardt, C. Reinsch, M. Hecker, J. Peplies, F. D. Bockelmann, U. Callies, G. Gerdts, A. Wichels, K. H. Wiltshire, F. O. Glockner, T. Schweder, and R. Amann. 2012. Substrate-Controlled Succession of Marine Bacterioplankton Populations Induced by a Phytoplankton Bloom. Science 336:608-611.

Teixeira, M. C., N. F. Santana, J. C. R. de Azevedo, and T. A. Pagioro. 2011. Bacterioplankton features and its relations with doc characteristics and other limnological variables in Paraná river floodplain environments (PR/MS-Brazil). Brazilian Journal of Microbiology 42:897-908.

Tezuka, Y. 1990. Bacterial regeneration of ammonium and phosphate as affected by the carbon:nitrogen:phosphorus ratio of organic substrates. Microbial Ecology 19:227-238.

Thatoi, H., B. Behera, R. Mishra, and S. Dutta. 2012. Biodiversity and biotechnological potential of microorganisms from mangrove ecosystems: a review. Annals of Microbiology 63:119.

Thorsell, J., R. F. Levy, and T. Sigaty. 1997. A global overview of wetland and marine protected areas on the World Heritage list. International Union for Conservation of Nature (IUCN) - Natural Heritage Programme, Gland, Switzerland.

Tian, F., Y. Yu, B. Chen, H. R. Li, Y. F. Yao, and X. K. Guo. 2009. Bacterial, archaeal and eukaryotic diversity in Arctic sediment as revealed by 16S rRNA and 18S rRNA gene clone libraries analysis. Polar Biology 32:93-103.

Tourova, T. P., T. N. Nazina, A. B. Poltaraus, and G. A. Osipov. 1998. Phylogenetic position and chemotaxonomic characteristics of sulfate-reducing bacteria of the genus Desulfomicrobium. Microbiology 67:663-669. 
Unterseher, M. and M. Schnittler. 2010. Species richness analysis and ITS rDNA phylogeny revealed the majority of cultivable foliar endophytes from beech (Fagus sylvatica). Fungal Ecology 3:366-378.

Valenzuela-Encinas, C., I. Neria-Gonzalez, R. J. Alcantara-Hernandez, I. Estrada-Alvarado, F. de la Serna, L. Dendooven, and R. Marsch. 2009. Changes in the bacterial populations of the highly alkaline saline soil of the former lake Texcoco (Mexico) following flooding. Extremophiles 13:609-621.

van der Heijden, E. W., F. W. Vries, and T. W. Kuyper. 1999. Mycorrhizal associations of Salix repens L. communities in succession of dune ecosystems. I. Above-ground and belowground views of ectomycorrhizal fungi in relation to soil chemistry. Canadian Journal of Botany-Revue Canadienne De Botanique 77:1821-1832.

Van Der Lee, G. E. M., H. O. Venterink, and N. E. M. Asselman. 2004. Nutrient retention in floodplains of the Rhine distributaries in The Netherlands. River Research and Applications 20:315-325.

Van Trump, J. I., K. C. Wrighton, J. C. Thrash, K. A. Weber, G. L. Andersen, and J. D. Coates. 2011. Humic acid-oxidizing, nitrate-reducing bacteria in agricultural soils. mBio 2(4):e0044-11. doi:10.1128/mBio.00044-11.

VanCappellen, P. and E. D. Ingall. 1996. Redox stabilization of the atmosphere and oceans by phosphorus-limited marine productivity. Science 271:493-496.

Vazquez, P., G. Holguin, M. E. Puente, A. Lopez-Cortes, and Y. Bashan. 2000. Phosphatesolubilizing microorganisms associated with the rhizosphere of mangroves in a semiarid coastal lagoon. Biology and Fertility of Soils 30:460-468.

Vetter, J. 1994. Phosphorus content of edible wild mushrooms of Hungary. Acta Alimentaria 23:331-336.

Vinas, M., J. Sabate, M. J. Espuny, and A. M. Solanas. 2005. Bacterial community dynamics and polycyclic aromatic hydrocarbon degradation during bioremediation of heavily creosotecontaminated soil. Applied and Environmental Microbiology 71:7008-7018. 
von Wintzingerode, F., U. B. Gobel, and E. Stackebrandt. 1997. Determination of microbial diversity in environmental samples: pitfalls of PCR-based rRNA analysis. FEMS Microbiology Reviews 21:213-229.

Vu, D. T., C. Tang, and R. D. Armstrong. 2010. Transformations and availability of phosphorus in three contrasting soil types from native and farming systems: A study using fractionation and isotopic labeling techniques. Journal of Soils and Sediments 10:18-29.

Wainright, S. C., C. A. Couch, and J. L. Meyer. 1992. Fluxes of bacteria and organic matter into a blackwater river from river sediments and floodplain soils. Freshwater Biology 28:3748.

Walbridge, M. R. 1991. Phosphorus availability in acid organic soils of the lower North-Carolina coastal-plain. Ecology 72:2083-2100.

Walbridge, M. R. and B. G. Lockaby. 1994. Effects of forest management on biogeochemical functions in southern forested wetlands. Wetlands 14:10-17.

Walbridge, M. R. and J. P. Struthers. 1993. Phosphorus retention in non-tidal palustrine forested wetlands of the mid-Atlantic region. Wetlands 13:84-94.

Wang, S., G. P. Pablo, J. Ye, and D. F. Huang. 2012. Abundance and diversity of nitrogen-fixing bacteria in rhizosphere and bulk paddy soil under different duration of organic management. World Journal of Microbiology \& Biotechnology 28:493-503.

Wang, X. L., R. J. Zeng, Y. Dai, Y. Z. Peng, and Z. G. Yuan. 2008. The denitrification capability of cluster 1 Defluviioccus vanus-related glycogen-accumulating organisms. Biotechnology and Bioengineering 99:1329-1336.

Ward, N. L., J. F. Challacombe, P. H. Janssen, B. Henrissat, P. M. Coutinho, M. Wu, G. Xie, D. H. Haft, M. Sait, J. Badger, R. D. Barabote, B. Bradley, T. S. Brettin, L. M. Brinkac, D. Bruce, T. Creasy, S. C. Daugherty, T. M. Davidsen, R. T. Deboy, J. C. Detter, R. J. Dodson, A. S. Durkin, A. Ganapathy, M. Gwinn-Giglio, C. S. Han, H. Khouri, H. Kiss, S. P. Kothari, R. Madupu, K. E. Nelson, W. C. Nelson, I. Paulsen, K. Penn, Q. H. Ren, M. J. Rosovitz, J. D. Selengut, S. Shrivastava, S. A. Sullivan, R. Tapia, L. S. Thompson, 
K. L. Watkins, Q. Yang, C. H. Yu, N. Zafar, L. W. Zhou, and C. R. Kuske. 2009. Three genomes from the phylum Acidobacteria provide insight into the lifestyles of these microorganisms in soils. Applied and Environmental Microbiology 75:2046-2056.

Weber, K. A., M. M. Urrutia, P. F. Churchill, R. K. Kukkadapu, and E. E. Roden. 2006. Anaerobic redox cycling of iron by freshwater sediment microorganisms. Environmental Microbiology 8:100-113.

Weber, S. D., A. Hofmann, M. Pilhofer, G. Wanner, R. Agerer, W. Ludwig, K. H. Schleifer, and J. Fried. 2009. The diversity of fungi in aerobic sewage granules assessed by $18 \mathrm{~S}$ rRNA gene and ITS sequence analyses. FEMS Microbiology Ecology 68:246-254.

Webster, J. R., J. D. Newbold, S. A. Thomas, H. M. Valett, and P. J. Mulholland. 2009. Nutrient Uptake and Mineralization during Leaf Decay in Streams - a Model Simulation. International Review of Hydrobiology 94:372-390.

Weon, H. Y., B. Y. Kim, S. H. Yoo, S. W. Kwon, S. J. Go, and E. Stackebrandt. 2008. Uliginosibacterium gangwonense gen. nov., sp nov., isolated from a wetland, Yongneup, in Korea. International Journal of Systematic and Evolutionary Microbiology 58:131135.

Wharton, C. H. and M. M. Brinson. 1979. Characteristics of southeastern river systems. Pages 32-40 in R. R. Johnson and J. F. McCormick, editors. Strategies for protection and management of floodplain wetlands and other riparian ecosystems. USDA Forest Service, Washington, DC.

White, T. J., T. D. Bruns, S. B. Lee, and J. W. Taylor. 1990. Amplification and direct sequencing of fungal ribosomal RNA Genes for phylogenetics. Pages 315-322 in M. A. Innis, D. H. Gelfand, J. J. Sninsky, and W. T. J., editors. PCR - Protocols and Applications - A Laboratory Manual. Academic Press New York.

Wieferich, D. J., D. G. McCullough, D. B. Hayes, and N. J. Schwalm. 2011. Distribution of American Beech (Fagus grandifolia) and Beech Scale (Cryptococcus fagisuga Lind.) in Michigan from 2005 to 2009. Northern Journal of Applied Forestry 28:173-179. 
Wiegner, T. N. and S. P. Seitzinger. 2004. Seasonal bioavailability of dissolved organic carbon and nitrogen from pristine and polluted freshwater wetlands. Limnology and Oceanography 49:1703-1712.

Wilmes, P. and P. L. Bond. 2006. Towards exposure of elusive metabolic mixed-culture processes: the application of metaproteomic analyses to activated sludge. Water Science and Technology 54:217-226.

Wong, M.-T. and W.-T. Liu. 2007. Ecophysiology of Defluviicoccus-related tetrad-forming organisms in an anaerobic-aerobic activated sludge process. Environmental Microbiology 9:1485-1496.

Wong, M. T., F. M. Tan, W. J. Ng, and W. T. Liu. 2004. Identification and occurrence of tetradforming Alphaproteobacteria in anaerobic-aerobic activated sludge processes. Microbiology 150:3741-3748.

Wright, R. B., B. G. Lockaby, and M. R. Walbridge. 2001. Phosphorus availability in an artificially flooded southeastern floodplain forest soil. Soil Science Society of America Journal 65:1293-1302.

Wu, G., K. B. Sorensen, M. Rodgers, and X. Zhan. 2009. Microbial community associated with glucose-induced enhanced biological phosphorus removal. Water Science and Technology 60:2105-2113.

Xie, G. H., M. Y. Cai, G. C. Tao, and Y. Steinberger. 2003. Cultivable heterotrophic $\mathrm{N}_{2}$-fixing bacterial diversity in rice fields in the Yangtze River Plain. Biology and Fertility of Soils 37:29-38.

Xiong, J. B., L. Y. Wu, S. X. Tu, J. D. Van Nostrand, Z. L. He, J. Z. Zhou, and G. J. Wang. 2010. Microbial communities and functional genes associated with soil arsenic contamination and the rhizosphere of the arsenic-hyperaccumulating plant Pteris vittata L. Applied and Environmental Microbiology 76:7277-7284. 
Yang, D. Q., J. H. Wang, Y. Bai, S. J. Xu, and L. Z. An. 2008. Diversity and distribution of the prokaryotic community in near-surface permafrost sediments in the Tianshan Mountains, China. Canadian Journal of Microbiology 54:270-280.

Yang, H. J., Z. M. Shen, S. H. Zhu, and W. H. Wang. 2007. Vertical and temporal distribution of nitrogen and phosphorus and relationship with their influencing factors in aquaticterrestrial ecotone: a case study in Taihu Lake, China. Journal of Environmental Sciences-China 19:689-695.

Yi, J., H. Y. Wu, J. Wu, C. Y. Deng, R. Zheng, and Z. Chao. 2012. Molecular phylogenetic diversity of Bacillus community and its temporal-spatial distribution during the swine manure of composting. Applied Microbiology and Biotechnology 93:411-421.

Yorou, N. S. and R. Agerer. 2011. Rhizomorphic resupinate Thelephorales (Agaricomycetes, Basidiomycota) from Italy. Nova Hedwigia 92:177-204.

Yurkov, A. M., M. Kemler, and D. Begerow. 2012. Assessment of yeast diversity in soils under different management regimes. Fungal Ecology 5:24-35.

Zafar, M., M. K. Abbasi, N. Rahim, A. Khaliq, A. Shaheen, M. Jamil, and M. Shahid. 2011. Influence of integrated phosphorus supply and plant growth promoting rhizobacteria on growth, nodulation, yield and nutrient uptake in Phaseolus vulgaris. African Journal of Biotechnology 10:16793-16807.

Zak, D. R., C. B. Blackwood, and M. P. Waldrop. 2006. A molecular dawn for biogeochemistry. Trends in Ecology \& Evolution 21:288-295.

Zelles, L. 1999. Fatty acid patterns of phospholipids and lipopolysaccharides in the characterisation of microbial communities in soil: A review. Biology and Fertility of Soils 29:111-129.

Zeng, J., L. Y. Yang, J. Y. Li, Y. Liang, L. Xiao, L. J. Jiang, and D. Y. Zhao. 2009. Vertical distribution of bacterial community structure in the sediments of two eutrophic lakes revealed by denaturing gradient gel electrophoresis (DGGE) and multivariate analysis techniques. World Journal of Microbiology \& Biotechnology 25:225-233. 
Zhang, B., M. Ji, Z. Qiu, H. Liu, J. Wang, and J. Li. 2011. Microbial population dynamics during sludge granulation in an anaerobic-aerobic biological phosphorus removal system. Bioresource Technology 102:2474-2480.

Zhang, Y. Y., J. D. Dong, Z. H. Yang, S. Zhang, and Y. S. Wang. 2008. Phylogenetic diversity of nitrogen-fixing bacteria in mangrove sediments assessed by PCR-denaturing gradient gel electrophoresis. Archives of Microbiology 190:19-28.

Zhao, D. Y., T. Ma, J. Zeng, W. M. Yan, J. Q. Wang, R. Huang, and M. Wang. 2011. Effects of lake water chemistry on bacterioplankton community structures of three lakes. African Journal of Microbiology Research 5:4820-4831.

Zhao, J., X. B. Wu, C. P. Nie, T. Wu, W. H. Dai, H. Liu, and R. Y. Yang. 2012. Analysis of unculturable bacterial communities in tea orchard soils based on nested PCR-DGGE. World Journal of Microbiology \& Biotechnology 28:1967-1979.

Zheng, J., W. Ran, Z. Zhong, and J. He. 2004. Research Advance in polyphosphateaccumulating microorganisms in enhanced biological phosphorus removal process. Yingyong Shengtai Xuebao 15:1487-1490.

Zhou, L. S., H. Li, Y. Zhang, Y. F. Wang, S. Q. Han, and H. Xu. 2012. Abundance and diversity of Sphingomonas in Shenfu petroleum-wastewater irrigation zone, China. Environmental Science and Pollution Research 19:282-294.

Zifcakova, L., P. Dobiasova, Z. Kolarova, O. Koukol, and P. Baldrian. 2011. Enzyme activities of fungi associated with Picea abies needles. Fungal Ecology 4:427-436. 
Figure 4.1: Maximum-parsimony tree showing phylogenetic relationships of cloned (a) bacterial 16S rDNA, and (b) fungal ITS sequences, from pooled DNA in soils collected in an alluvial (AL, Wateree R., SC) and a blackwater (BW, Black R., NC) FF, to related sequences from GenBank. The bacterial tree is rooted with Aquifex pyrophilus; the fungal tree is rooted with Suberites ficus, Antipathes elegans, and Beroe ovata as a monophyletic outgroup. Detailed subtrees of each taxanomic group are provided in Appendix Figures 4.1 , 4.2. The inset figure shows the proportional distribution of different taxonomic groups in the respective clone libraries. 
Figure 4.1 a: Maximum-parsimony tree showing phylogenetic relationships of cloned bacterial 16S rDNA sequences.

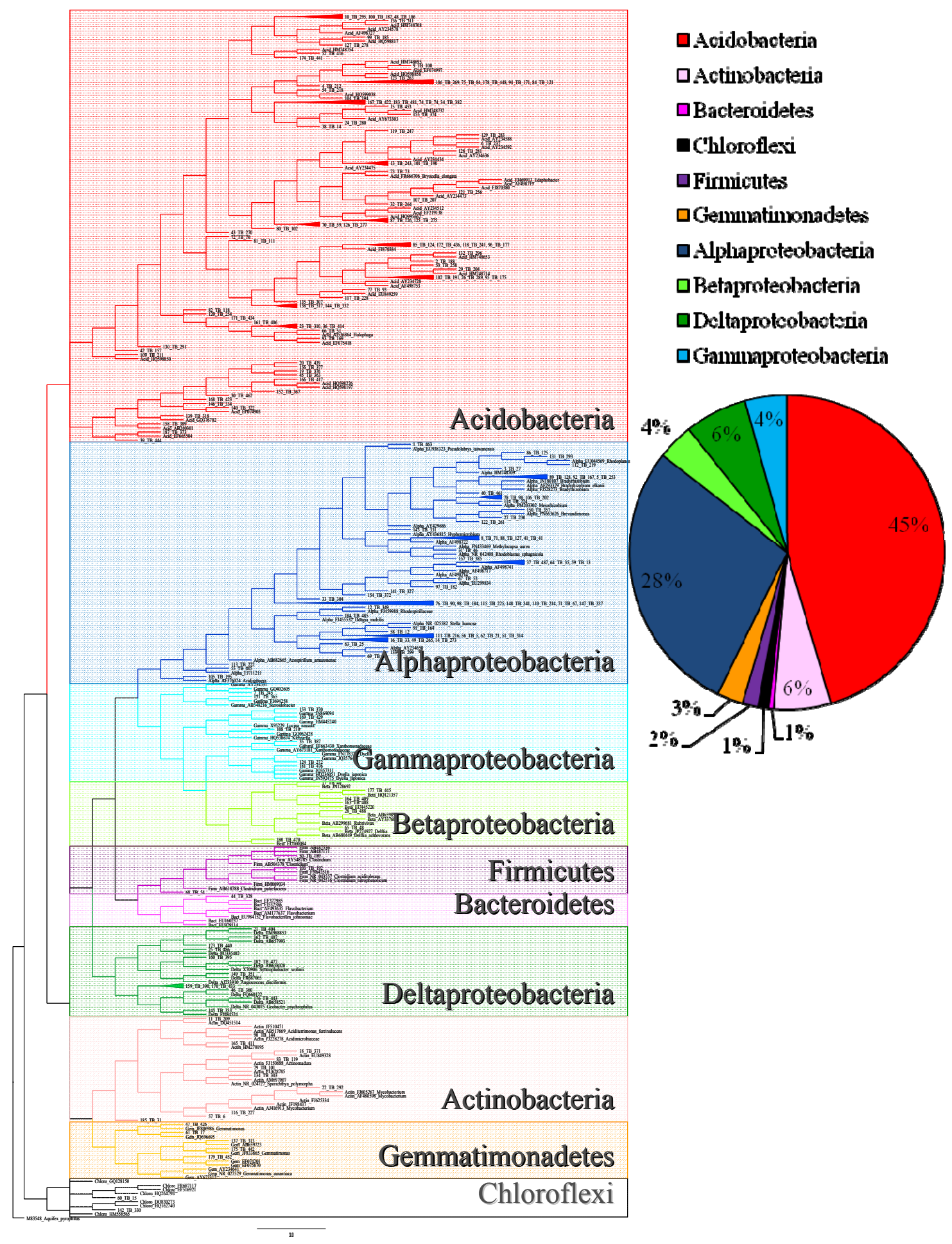


Figure 4.1 b: Maximum-parsimony tree showing phylogenetic relationships of cloned fungal ITS sequences.

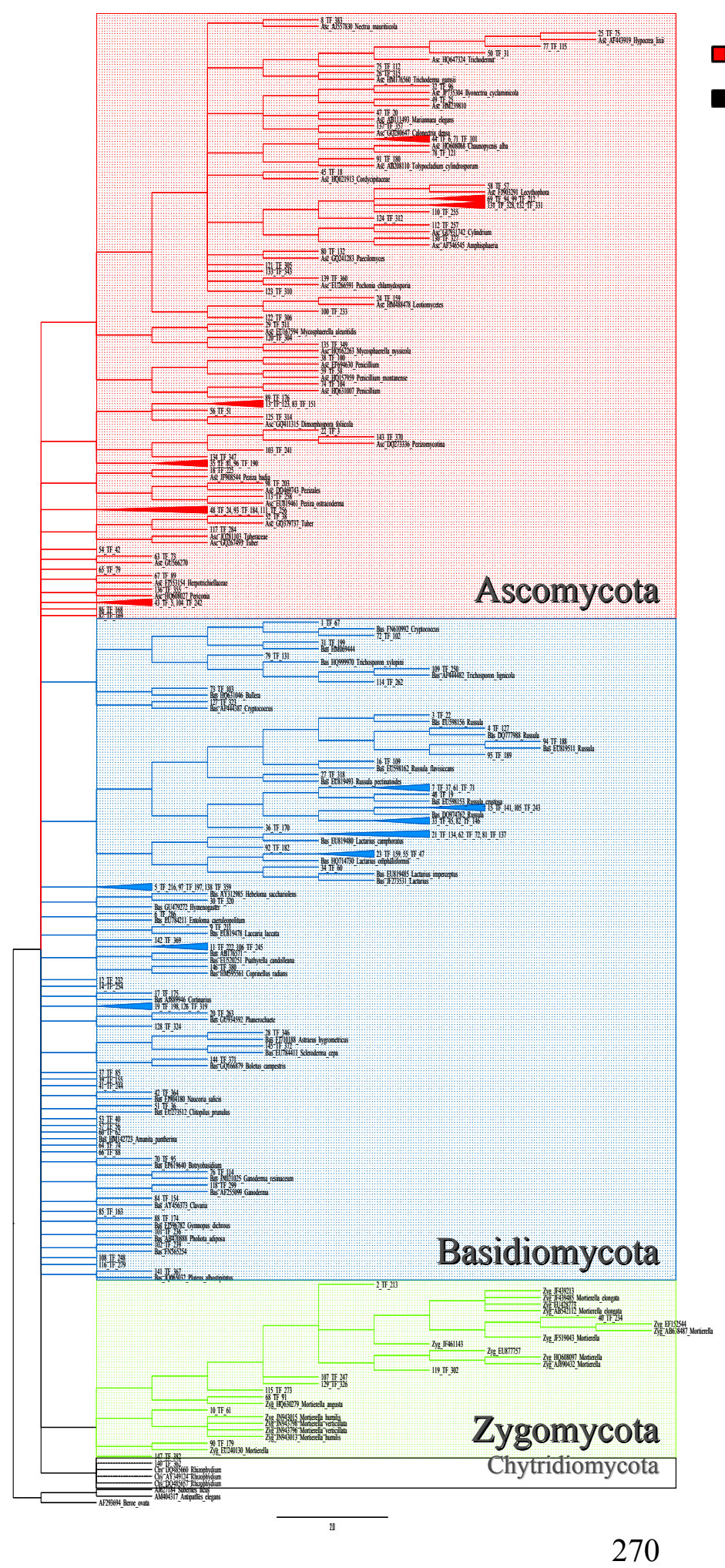

-Ascomycota $\square$ Basidiomycota

Chytridiomycota $\square$ Zygomycota

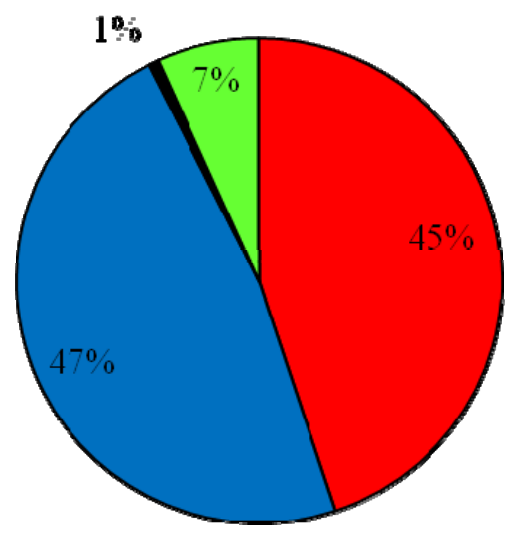


Figure 4.2: Maximum-parsimony tree showing phylogenetic relationships of cloned (a) bacterial 16S rDNA, and (b) fungal ITS sequences, from from ridge and swale soils in four alluvial (AL) (Wateree R., SC; Pee Dee R., SC; Nottaway R., VA; Ocmulgee R., GA) and four blackwater (BW) (Black R., NC; Drowning Cr., NC; Satilla R., GA; Salkehatchie R., SC) FFs, to related sequences from GenBank. The bacterial tree is rooted with Aquifex pyrophilus; the fungal tree is rooted with Suberites ficus, Antipathes elegans, and Beroe ovata as a monophyletic outgroup. Detailed sub-trees of each taxonomic group are provided in Appendix Figures 4.3, 4.4. The inset figure shows the proportional distribution of different taxonomic groups in the respective clone libraries. 
Figure 4.2 a: Maximum-parsimony tree showing phylogenetic relationships of cloned bacterial 16S rDNA sequences.

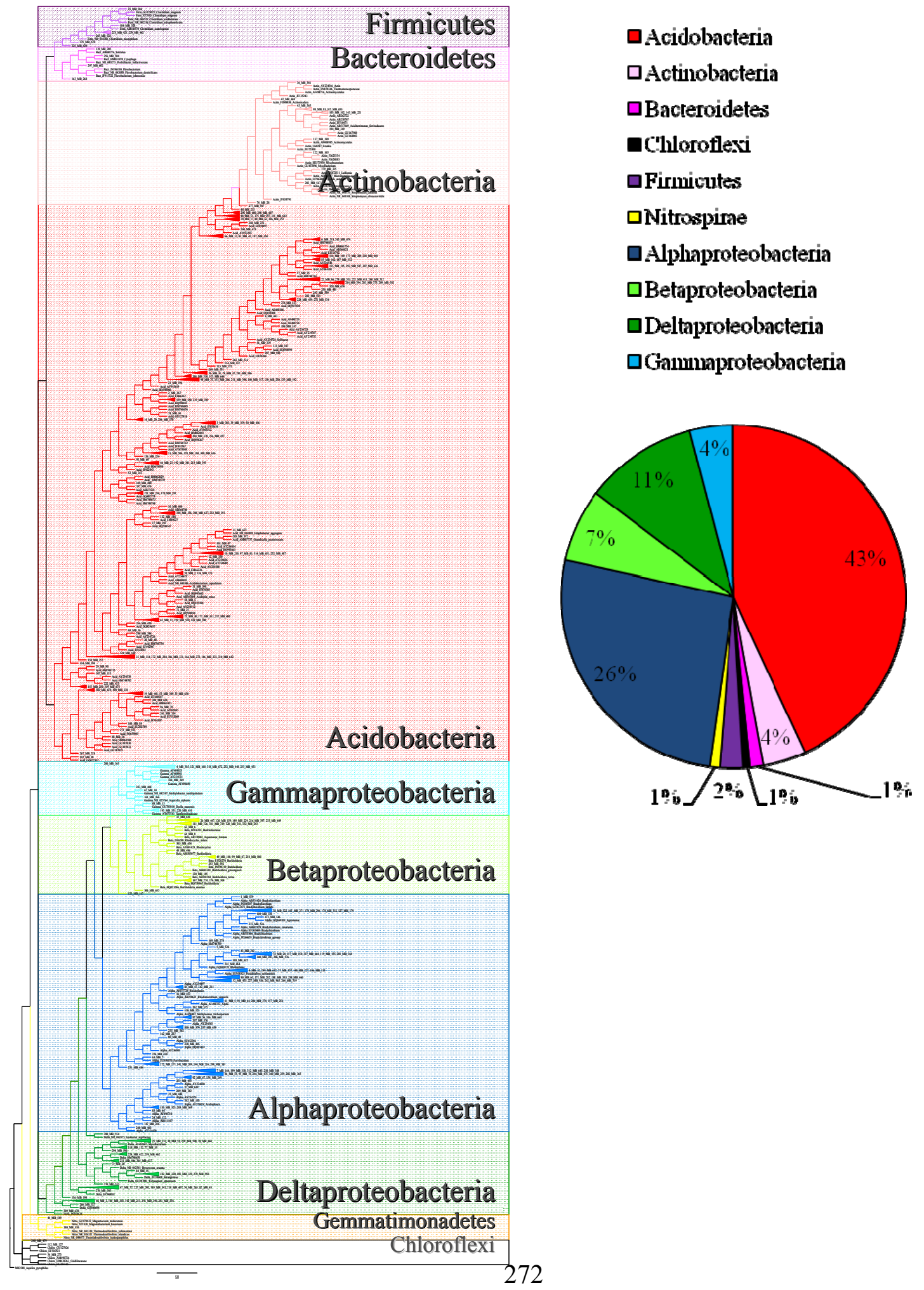


Figure $4.2 \mathrm{~b}$ : Maximum-parsimony tree showing phylogenetic relationships of cloned fungal ITS sequences.
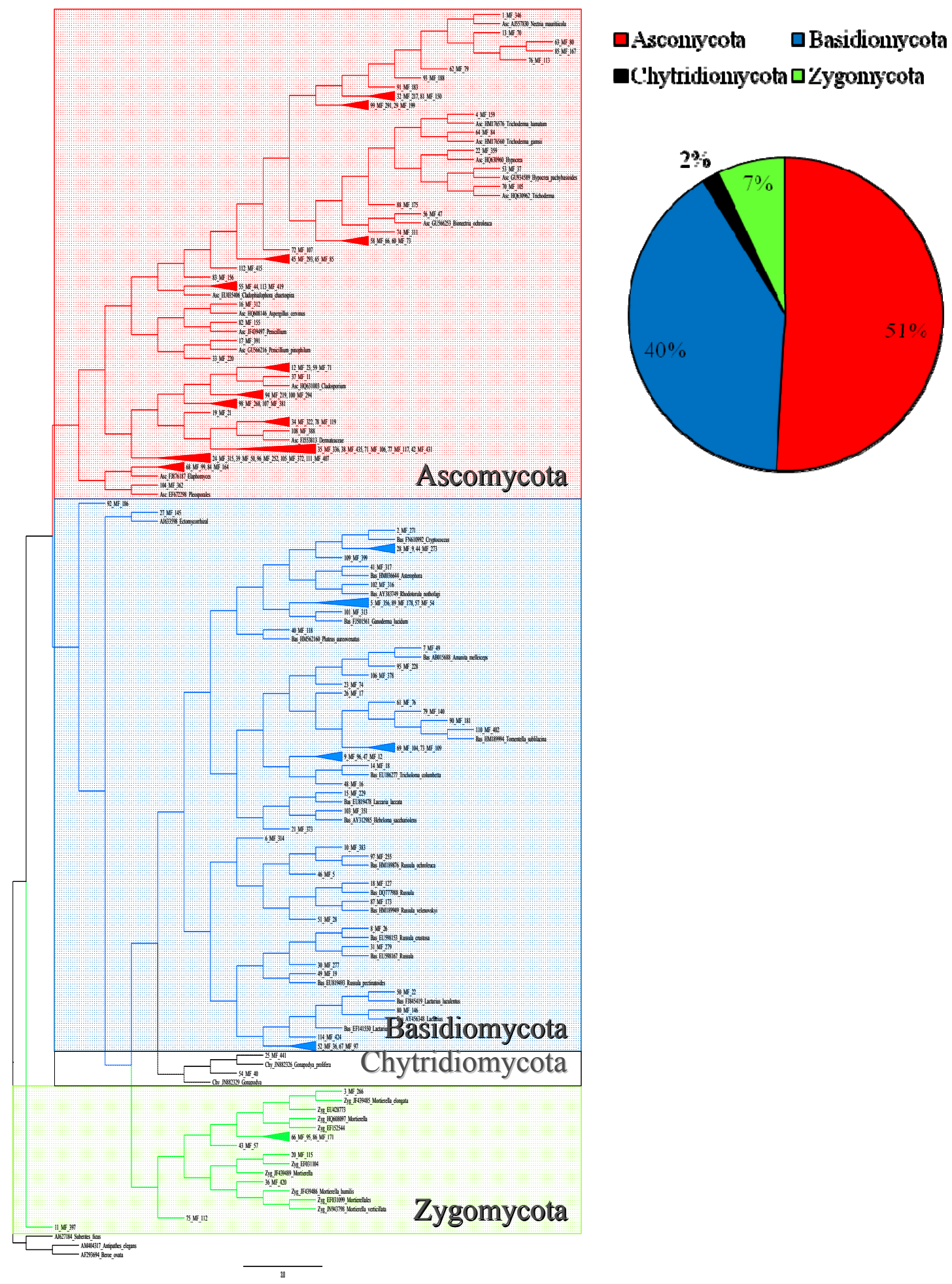
Figure 4.3: Bacterial 16S rDNA DGGE fingerprint profile of soils collected from one alluvial (AL) (Wateree R., SC) and one blackwater (BW) (Black R., NC) FF. Lanes 2-7 represent ridge (RD) soils, 8-9 dry swales (SWD), and 10-13 flooded swales (SWF), collected from the Black R., NC, FF. Lanes 16-21 represent ridge (RD) soils, and 22-27 dry swales (SWD), collected from the Wateree R., SC, FF. Lanes 1, 15 (M1), 14, and 28 (M2) are reference standards of dominant clones retrieved from the pooled library and re-amplified with primers GC-341-F and 534-R for DGGE analysis. Clone library sequences used to construct standards M1 and M2 are A: 5-TB; B: 4-TB; C: 12-TB; D: 15-TB; E: 12-TB; F: 6-TB; G: 1-TB; H: 2-TB; I: 3-TB; J: 10-TB. Band B was used construct M1 and M2 as an external standard to anchor gels for densitometry analysis. Arrows and numbers mark prominent bands referred to in Table 4.5a, that were excised, cloned, and sequenced for comparison with the clone library. 
Blaethatar Rtver - BL

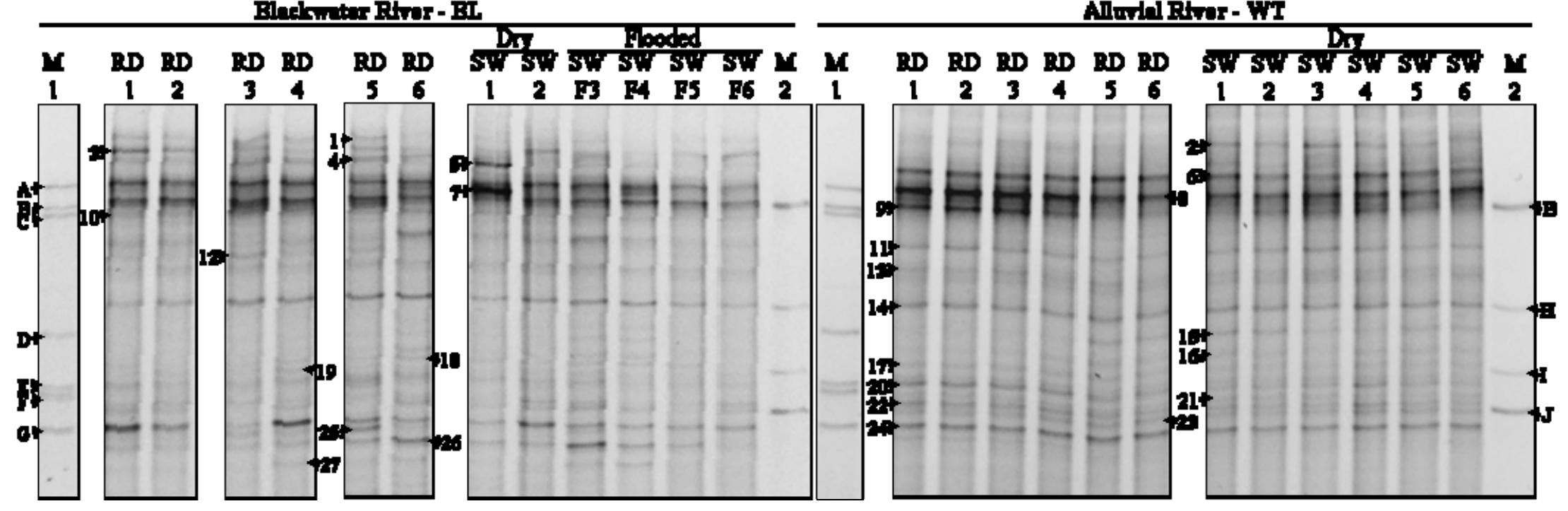


Figure 4.4: Fungal ITS rDNA DGGE fingerprint profile of soils collected from one alluvial (AL) (Wateree R., SC) and one blackwater (BW) (Black R., NC) FF. Lanes 2-7 represent ridge (RD) soils, 8-9 dry swales (SWD), and 10-13 flooded swales (SWF), collected from the Black R., NC FF. Lanes 16-21 represent ridge (RD) soils, and 22-27 dry swales (SW), collected from the Wateree R., SC, FF. Lanes 1, 15 (M1), 14, and 28 (M2) are reference standards of dominant clones retrieved from the pooled library and reamplified with primers GC-ITS1-F and ITS2-R for DGGE analysis. Clone library sequences used to construct standards M1 and M2 are A: 10-TF; B: 3-TF; C: 12-TF; D: 14-TF; E: 7-TF; F: 4-TF; G: 46-TF; H: 26-TF; I: 22-TF; J: 19-TF; K: 2-TF; L: 15-TF; M: 23-TF; N: 19-TF; O: 12-TF; P: 18-TF; Q: 21-TF. Arrows and numbers mark the prominent bands referred to in Table 4.5 b that were excised, cloned, and sequenced for comparison with the clone library. 


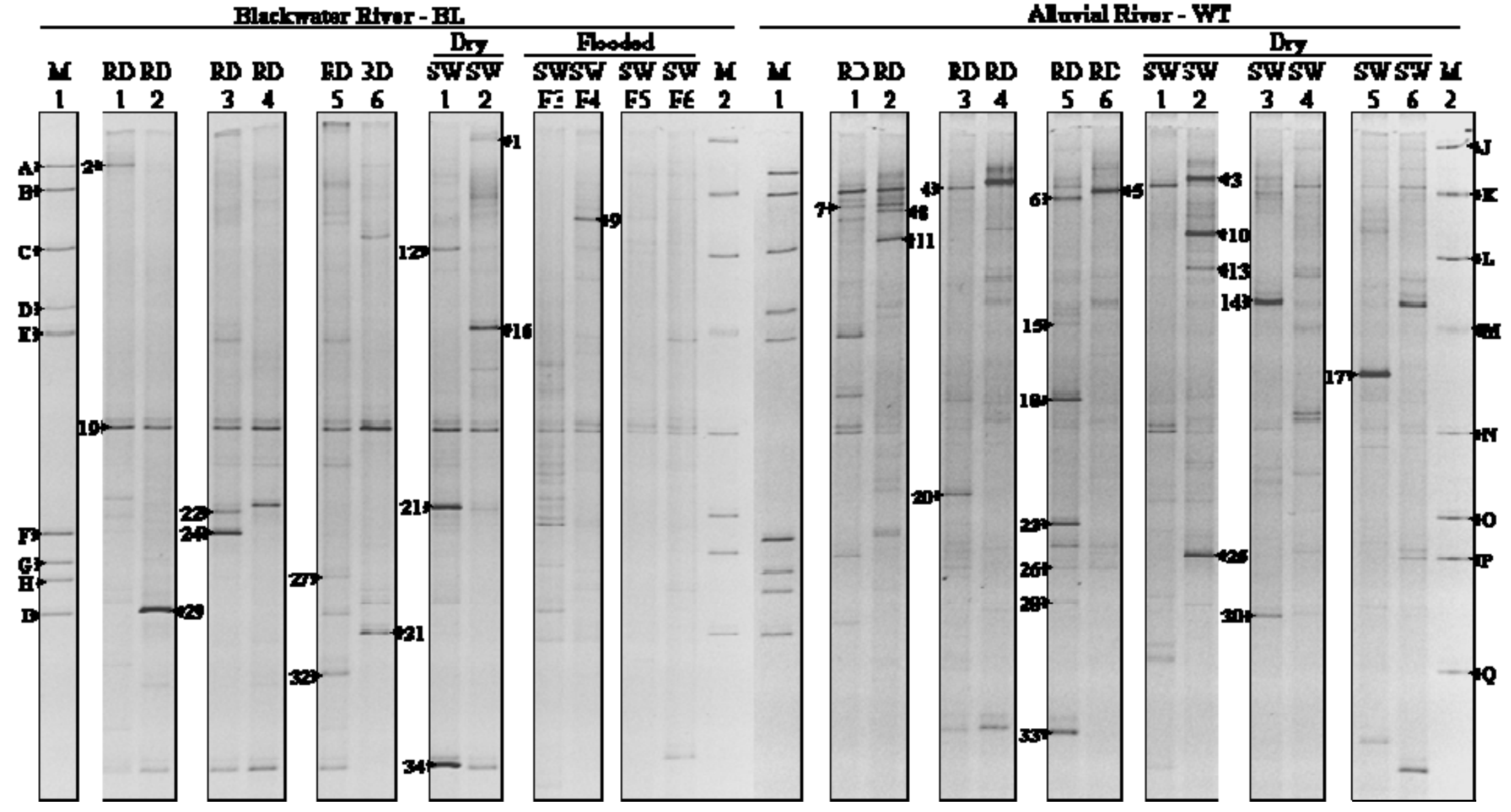


Figure 4.5: Bacterial 16S rDNA DGGE fingerprint profile of soils collected from four alluvial (WT: Wateree R., SC; PD: Pee Dee R., SC; NT: Nottaway R., VA; and OC: Ocmulgee R., GA) and four blackwater (BL: Black R., NC; DC: Drowning Cr., NC; ST: Satilla R. GA; and SK: Salkehatchie R., SC) FF. Lanes marked RD represent ridge soils, SWD are dry swales, and SWF are flooded swales. Lanes $1(\mathrm{M} 1)$ and $18(\mathrm{M} 2)$ are reference standards of dominant clones retrieved from the pooled library and re-amplified with primers GC-341-F and 534-R for DGGE analysis. Clone library sequences used to construct standards M1 and M2 are a: 4-MB; b: 7-MB; c: 12-MB; d: 19-MB; e: 16-MB; f: 3-MB; g: 5-MB; h: 38-MB; i: 1-MB; j: 2-MB; k: 9-MB; 1: 6-MB; m: 32-MB; n: 39-MB. Bands a and g were used construct M1 and M2 as external standards to anchor gels for densitometry analysis. Arrows and numbers mark the prominent bands referred to in Table 4.6a, that were excised, cloned, and sequenced for comparison with the clone library. 


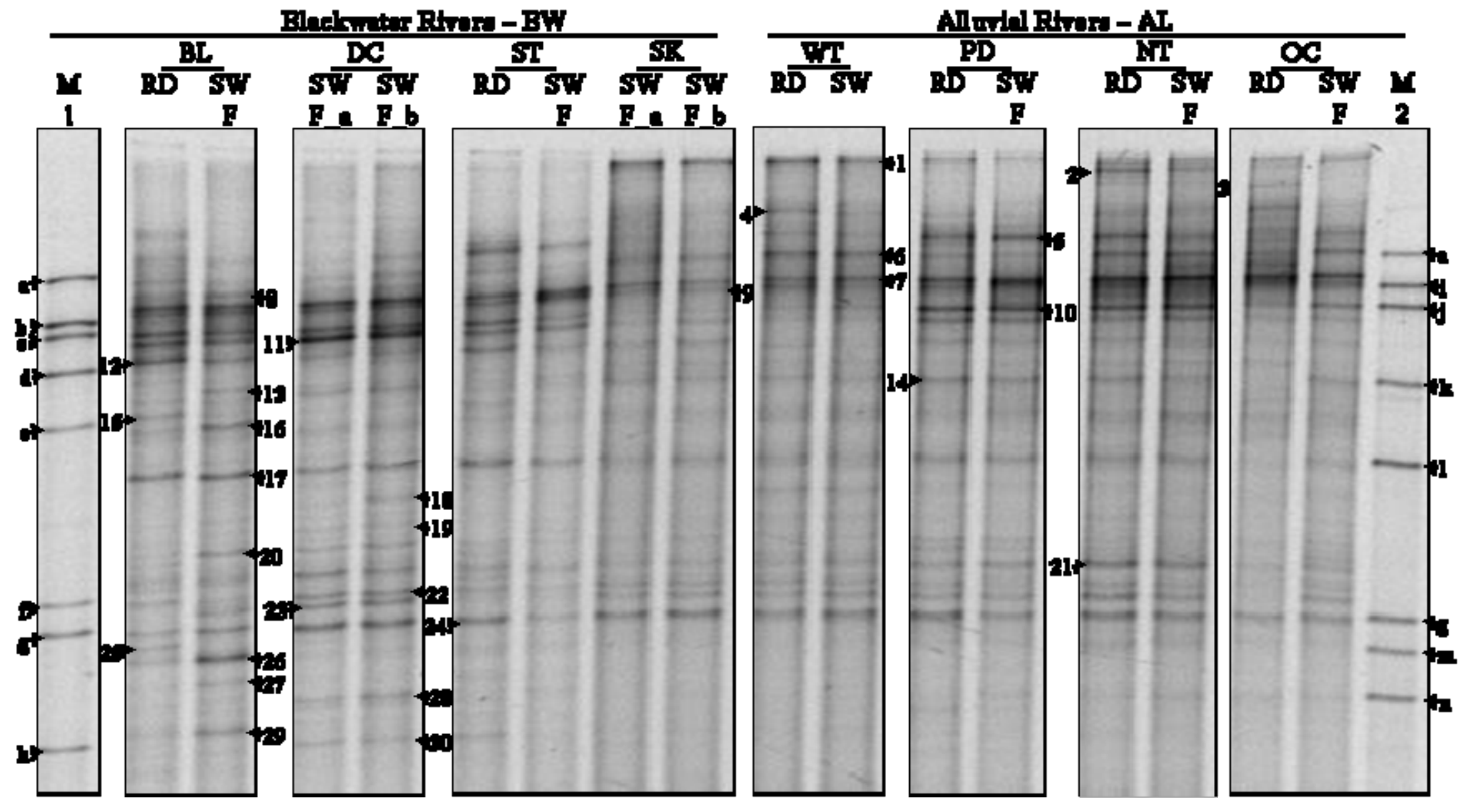


Figure 4.6: Fungal ITS rDNA DGGE fingerprint profile of soils collected from four alluvial (WT: Wateree R., SC; PD: Pee Dee R., SC; NT: Nottaway R., VA; and OC: Ocmulgee R., GA) and four blackwater (BL: Black R., NC; DC: Drowning Cr., NC; ST: Satilla R. GA; and SK: Salkehatchie R., SC) FFs. Lanes marked RD represent ridge soils, SWD are dry swales, and SWF are flooded swales. Lanes $1(\mathrm{M} 1)$ and $18(\mathrm{M} 2)$ are reference standards of dominant clones retrieved from the pooled library and re-amplified with primers GC-ITS1-F and ITS2-R for DGGE analysis. Clone library sequences used to construct standards M1 and M2 are a: 3-MF; b: 27-MF; c: 2-MF; d: 25-MF; e: 18-MF; f: 12-MF; g: 32-MF; h: 1-MF; i: 48-MF; j: 6-MF; k: 38-MF; 1: 22-MF; m: 33-MF; n: 8-MF; o: 4-MF. Band c was used to construct M1 and M2 as an external standard to anchor gels for densitometry analysis. Arrows and numbers mark the prominent bands referred to in Table 4.6b that were excised, cloned, and sequenced for comparison with the clone library. 


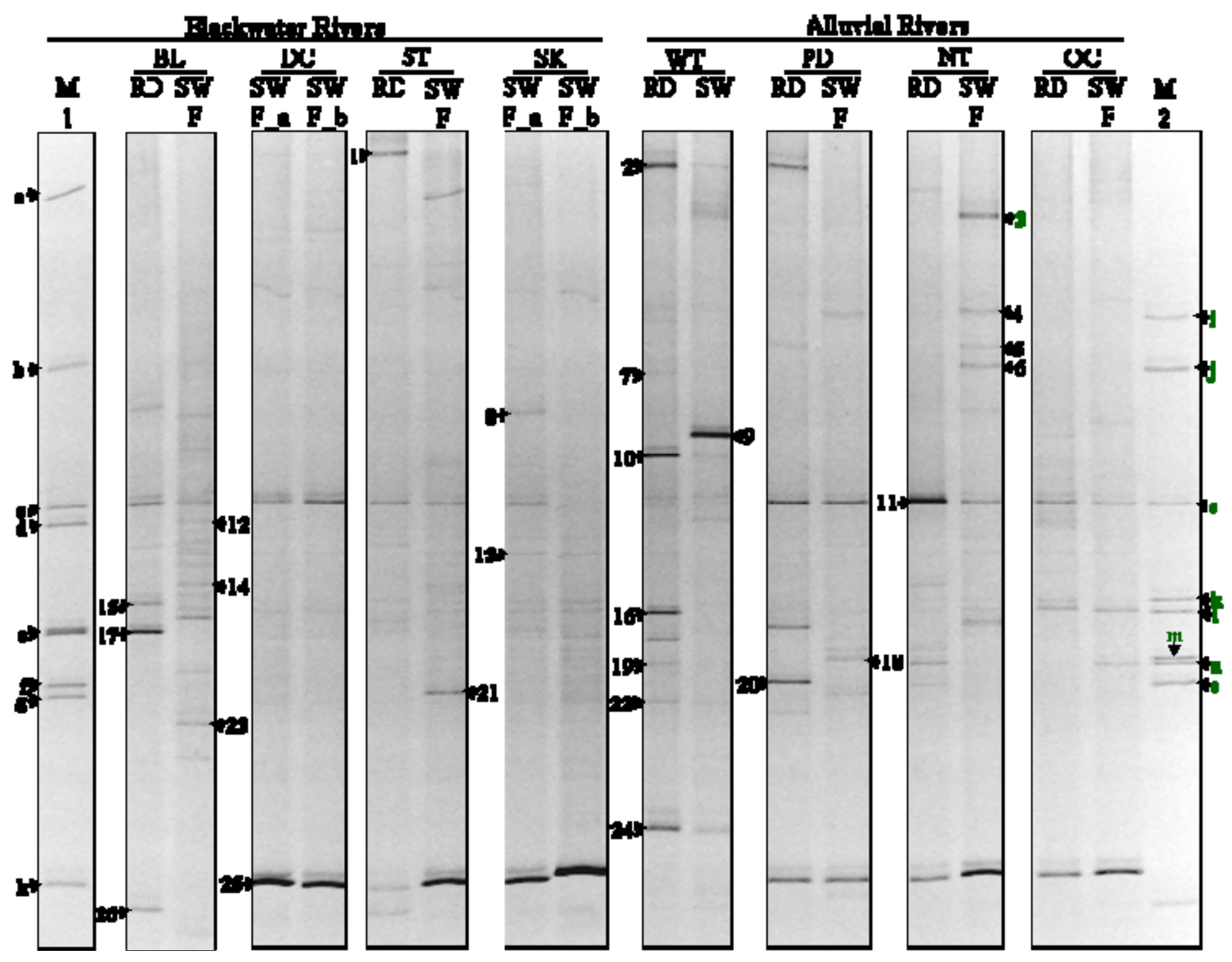


Figure 4.7: Dendrogram showing clustering of (a) bacterial 16S rDNA, and (b) fungal ITS rDNA DGGE fingerprint profiles of soils collected from one alluvial (AL) (Wateree R., SC) and one blackwater (BW) (Black R., NC) FF. Lanes marked RD are ridge soils, SWD are dry swales, and SWF are flooded swales. The UPGMA clustering of DGGE profiles is based on presence/absence and relative intensities of bands as calculated by Jaccard's similarity coefficient. The scale represents percent similarity between samples. 
Figure 4.7 a: Dendrogram showing clustering of bacterial 16S rDNA DGGE fingerprint profile

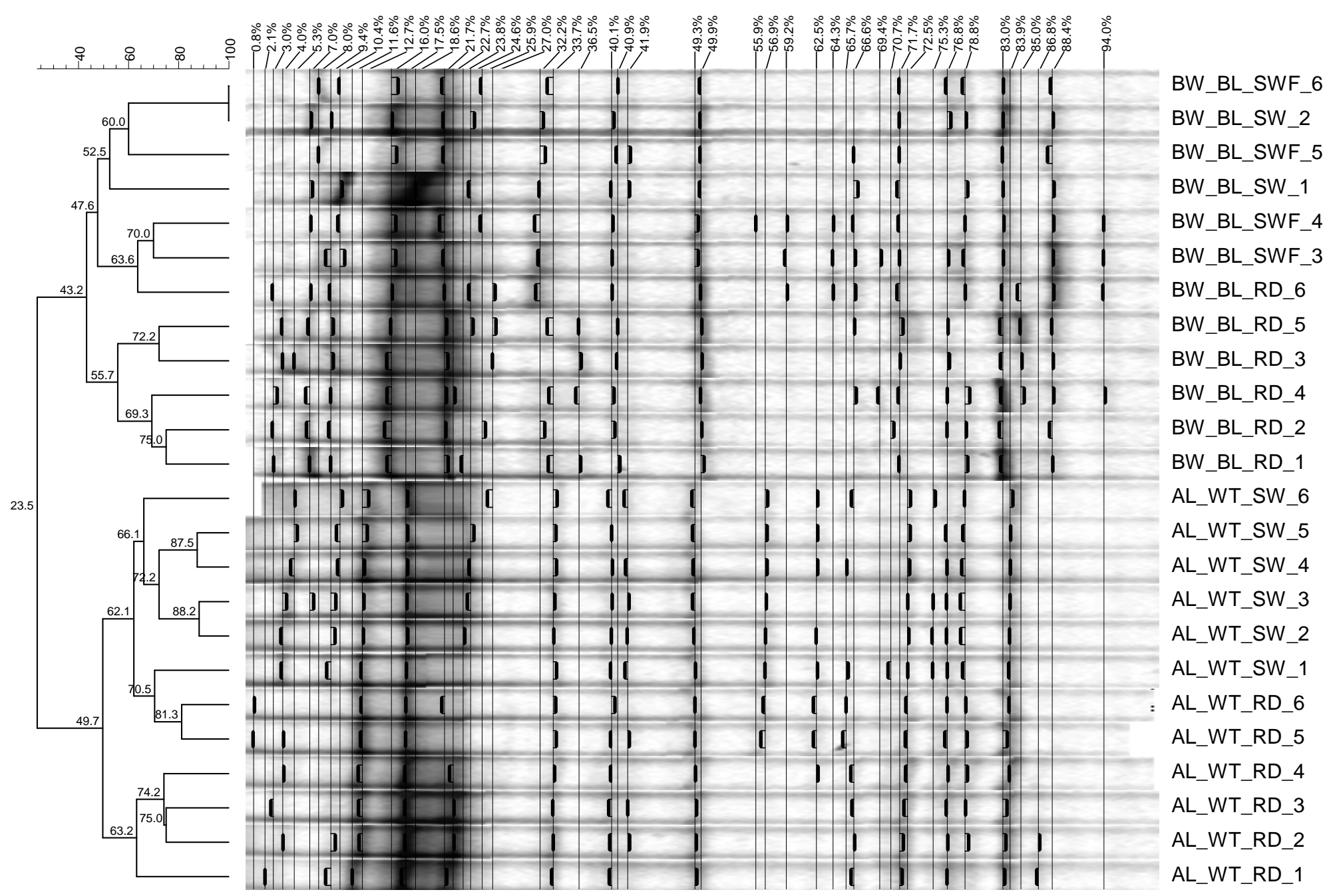


Figure 4.7 b: Dendrogram showing clustering of fungal ITS rDNA DGGE fingerprint profile

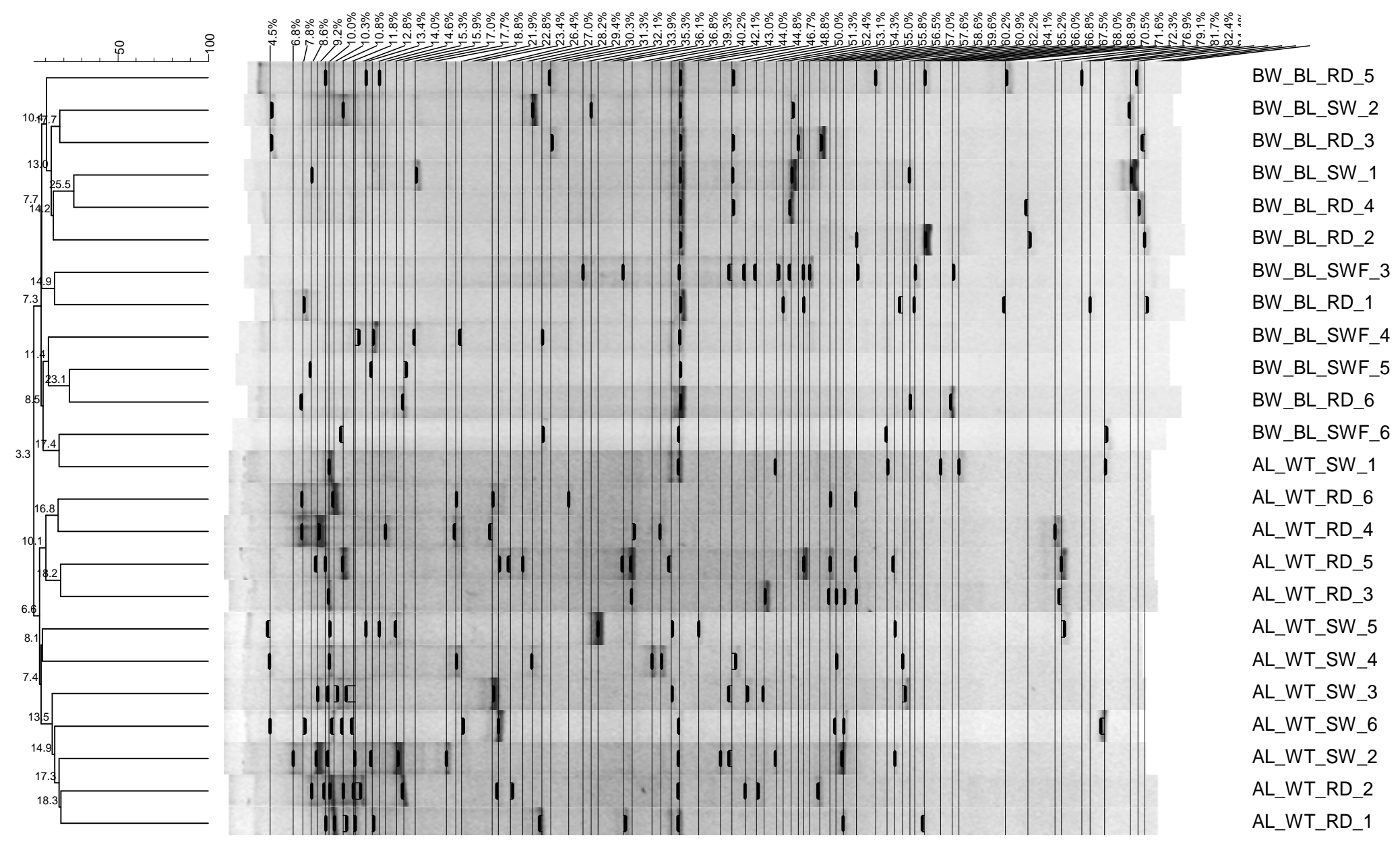


Figure 4.8: Dendrogram showing clustering of (a) bacterial 16S rDNA, and (b) fungal ITS rDNA DGGE fingerprint profiles, of four alluvial (WT: Wateree R., SC; PD: Pee Dee R., SC; NT: Nottaway R., VA; and OC: Ocmulgee R., GA) and four blackwater (BL: Black R., NC; DC: Drowning Cr., NC; ST: Satilla R., GA; and SK: Salkehatchie R., SC) FFs. Lanes marked RD are ridge soils, SWD are dry swales, and SWF are flooded swales. The UPGMA clustering of DGGE profiles is based on presence/absence and relative intensities of bands as calculated by Jaccard's similarity coefficient. The scale represents percent similarity between samples. 
Figure 4.8 a: Dendrogram showing clustering of bacterial 16S rDNA DGGE fingerprint profile

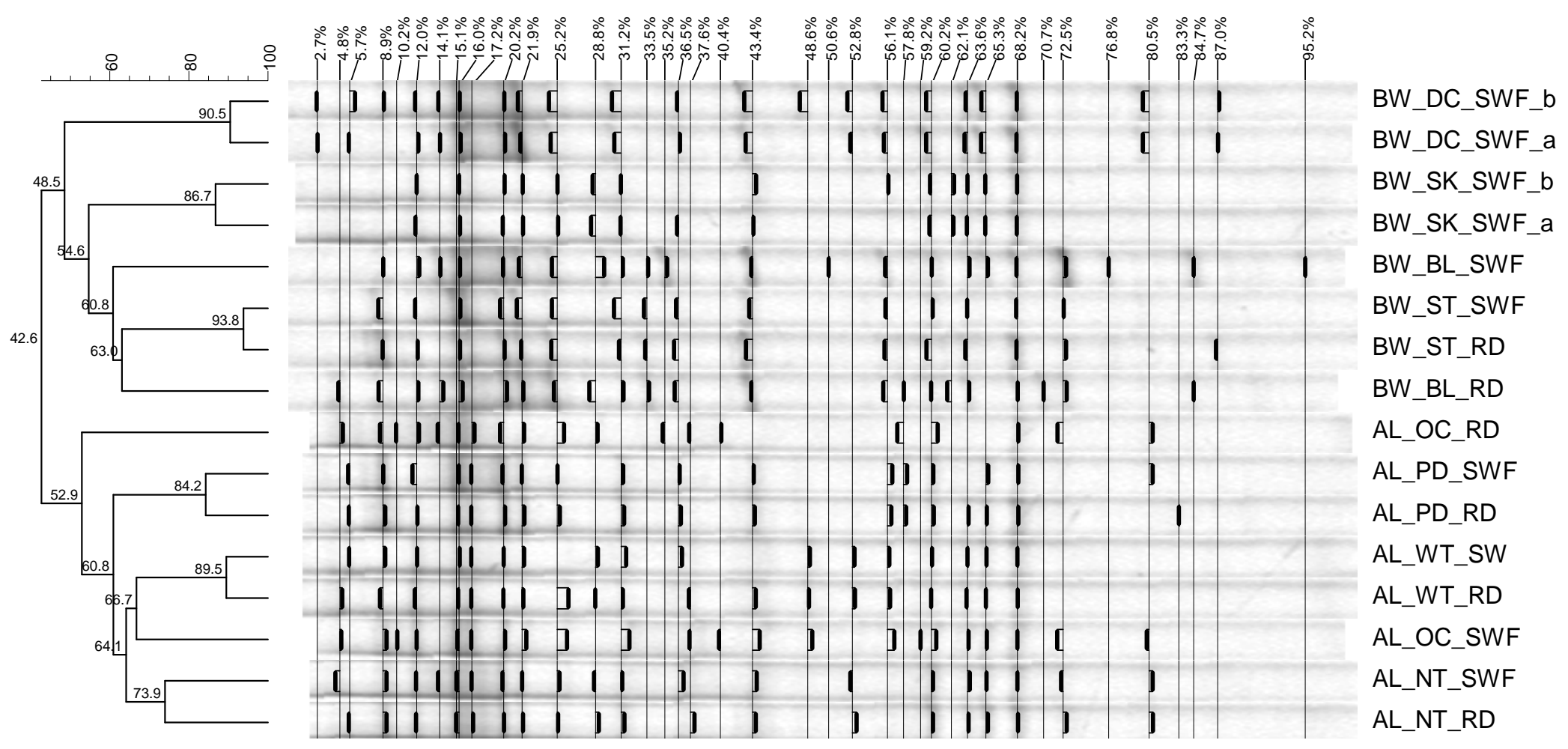


Figure 4.8 b: Dendrogram showing clustering of fungal ITS rDNA DGGE fingerprint profile

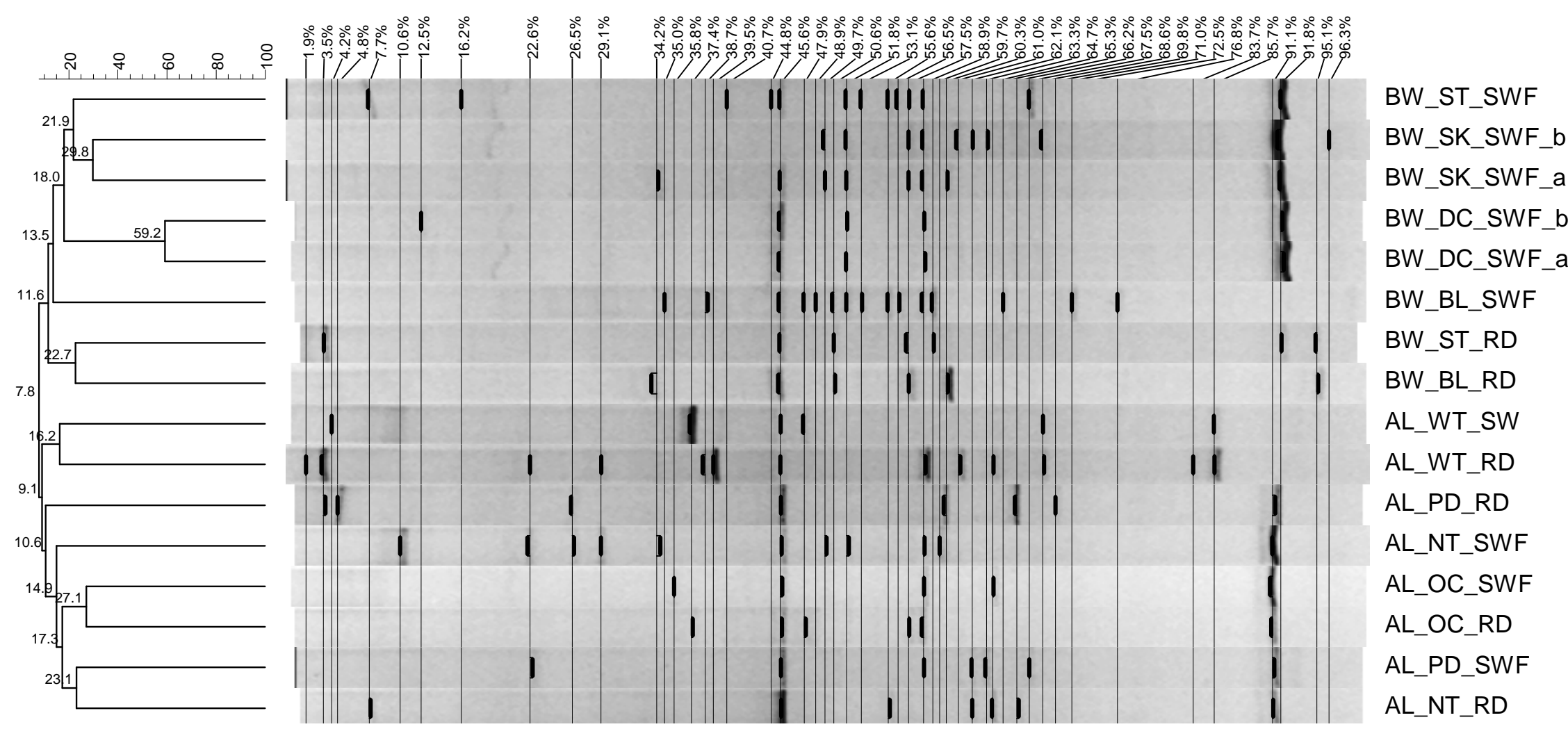


Figure 4.9: Detrended correspondence analysis (DCA) ordination diagram of (a) bacteria, and (b) fungal communities, associated with environmental variables (soil moisture, TN, TC, TP, microbial P, and pH) in soils collected from one alluvial (AL) (Wateree R., SC) and one blackwater (BW) (Black R., NC) FF. Arrows represent significant $(P \leq 0.05)$ correlations between environmental variables and microbial community composition. The inset table shows the results of the DCA analysis of the variation in microbial community structure applied to soil chemical parameters. Significant ordinations $(P \leq 0.05)$ are represented by bold and italisized font. 
Figure 4.9a: Detrended correspondence analysis (DCA) ordination diagram of the bacterial community structure associated with environmental variables (soil moisture, TN, TC, TP, microbial $\mathrm{P}$, and $\mathrm{pH}$ ) in soils.

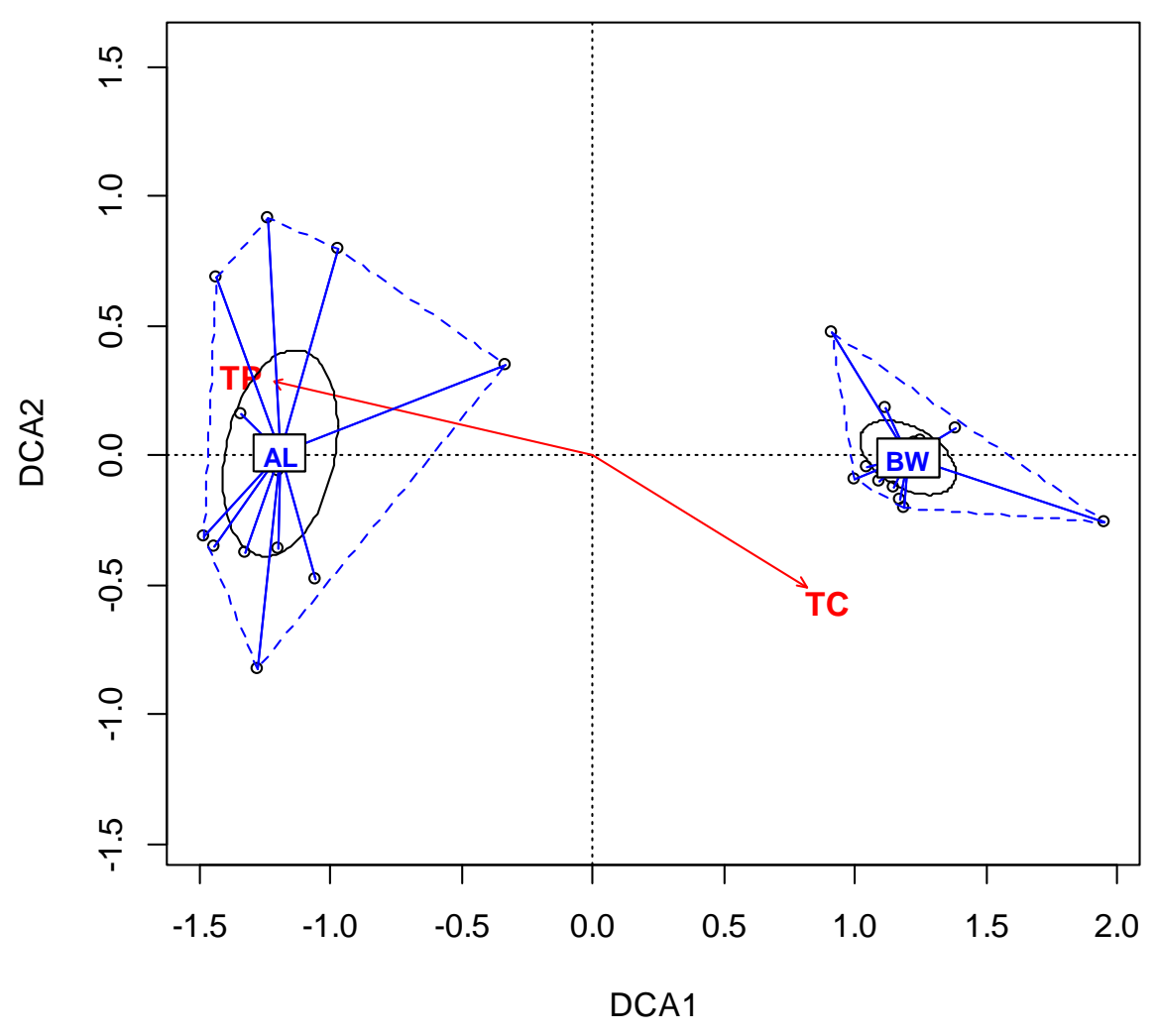

\begin{tabular}{|c|c|c|c|c|}
\hline & Axis 1 & Axis 2 & Axis 3 & Axis 4 \\
\hline Eigenvalues & 0.69 & 0.19 & 0.12 & 0.09 \\
\hline \multicolumn{5}{|c|}{ DGGE band intensity-soil chemical variable correlations } \\
\hline & Axis 1 & Axis 2 & $\mathbf{R}^{2}$ & $\boldsymbol{P}$ \\
\hline $\mathrm{TP}$ & -0.97 & 0.23 & 0.88 & 0.001 \\
\hline $\mathrm{MicP}$ & -0.12 & -0.99 & 0.03 & 0.684 \\
\hline $\mathrm{TN}$ & 0.54 & -0.84 & 0.11 & 0.283 \\
\hline TC & 0.85 & -0.53 & 0.52 & 0.002 \\
\hline $\mathrm{pH}$ & -0.84 & 0.55 & 0.17 & 0.124 \\
\hline Moisture & 0.90 & 0.45 & 0.18 & 0.131 \\
\hline Floodplain Type & & & 0.86 & 0.001 \\
\hline Topography & & & 0.032 & 0.40 \\
\hline
\end{tabular}

Figure 4.9b: Detrended correspondence analysis (DCA) ordination diagram of the fungal community structure associated with 
environmental variables (soil moisture, TN, TC, TP, microbial $\mathrm{P}$, and $\mathrm{pH}$ ) in soils.

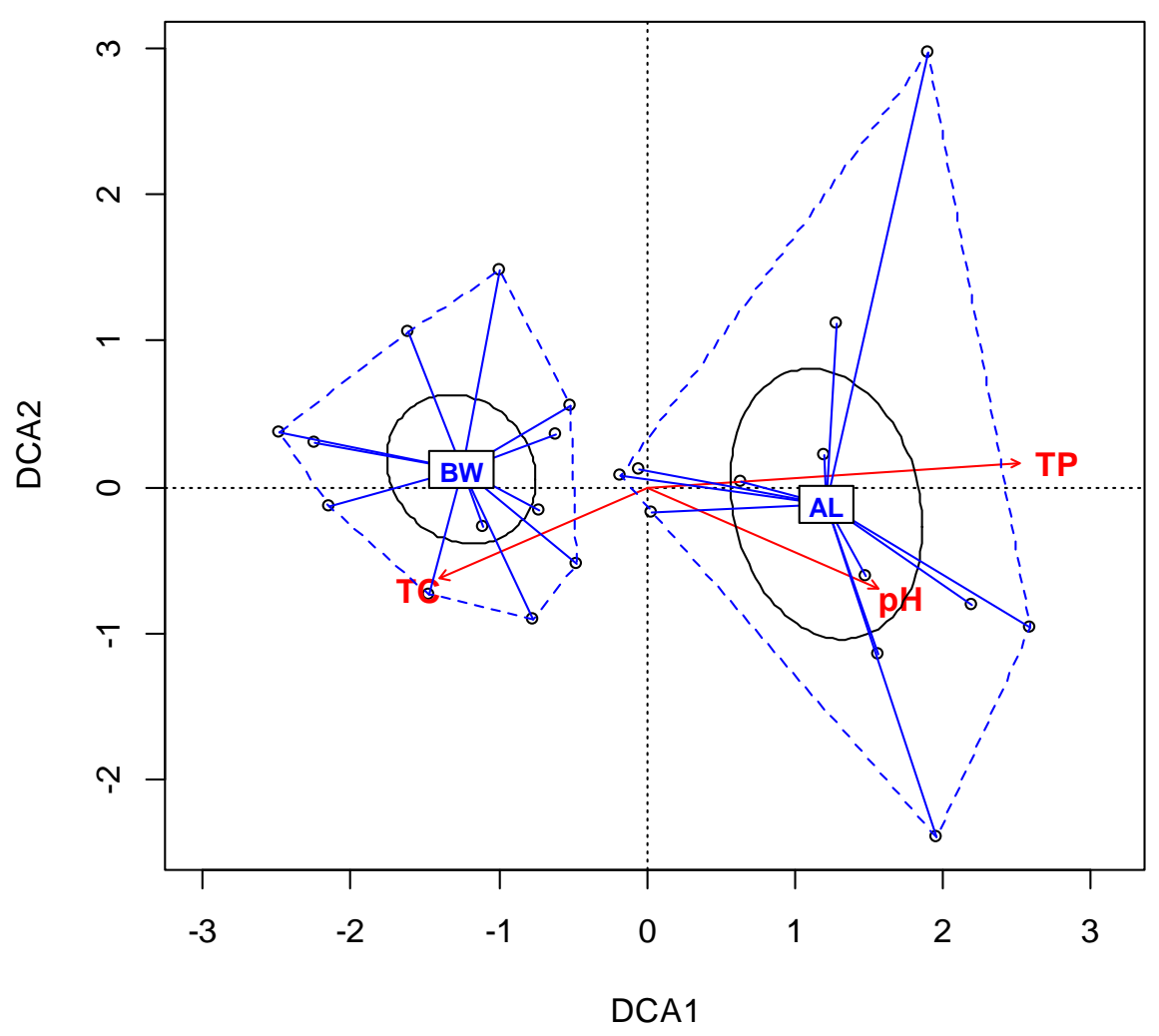

\begin{tabular}{|c|c|c|c|c|}
\hline & Axis 1 & Axis 2 & Axis 3 & Axis 4 \\
\hline Eigenvalues & 0.72 & 0.58 & 0.50 & 0.38 \\
\hline \multicolumn{5}{|c|}{ DGGE band intensity-soil chemical variable correlations } \\
\hline & Axis 1 & Axis 2 & $\mathbf{R}^{2}$ & $P$ \\
\hline $\mathrm{TP}$ & 0.99 & 0.07 & 0.72 & 0.001 \\
\hline MicP & 0.63 & 0.77 & 0.03 & 0.709 \\
\hline TN & -0.61 & -0.79 & 0.05 & 0.579 \\
\hline TC & -0.91 & -0.41 & 0.27 & 0.029 \\
\hline $\mathrm{pH}$ & 0.91 & -0.41 & 0.33 & 0.011 \\
\hline Moisture & -0.70 & -0.71 & 0.08 & 0.400 \\
\hline Floodplain Type & & & 0.48 & 0.001 \\
\hline Topography & & & 0.01 & 0.781 \\
\hline
\end{tabular}


Figure 4.10: Detrended correspondence analysis (DCA) ordination diagram of (a) bacteria, and (b) fungal, communities associated with environmental variables (soil moisture, TN, TC, TP, microbial P, and $\mathrm{pH}$ ) in soils collected from four alluvial (WT: Wateree R., SC; PD: Pee Dee R., SC; NT: Nottaway R., VA; and OC: Ocmulgee R., GA) and four blackwater (BL: Black R., NC; DC: Drowning Cr., NC; ST: Satilla R., GA; and SK: Salkehatchie R., SC) FFs. Arrows represent significant $(P \leq 0.05)$ correlations between environmental variables and microbial community composition. The inset table provides results of the DCA analysis of the variation in microbial community structure applied to soil chemical parameters. Significant ordinations $(P \leq 0.05)$ are represented by bold and italisized font.

Figure 4.10a: Detrended correspondence analysis (DCA) ordination diagram of the bacterial community structure associated with 
environmental variables (soil moisture, TN, TC, TP, microbial $\mathrm{P}$, and $\mathrm{pH}$ ) in soils.

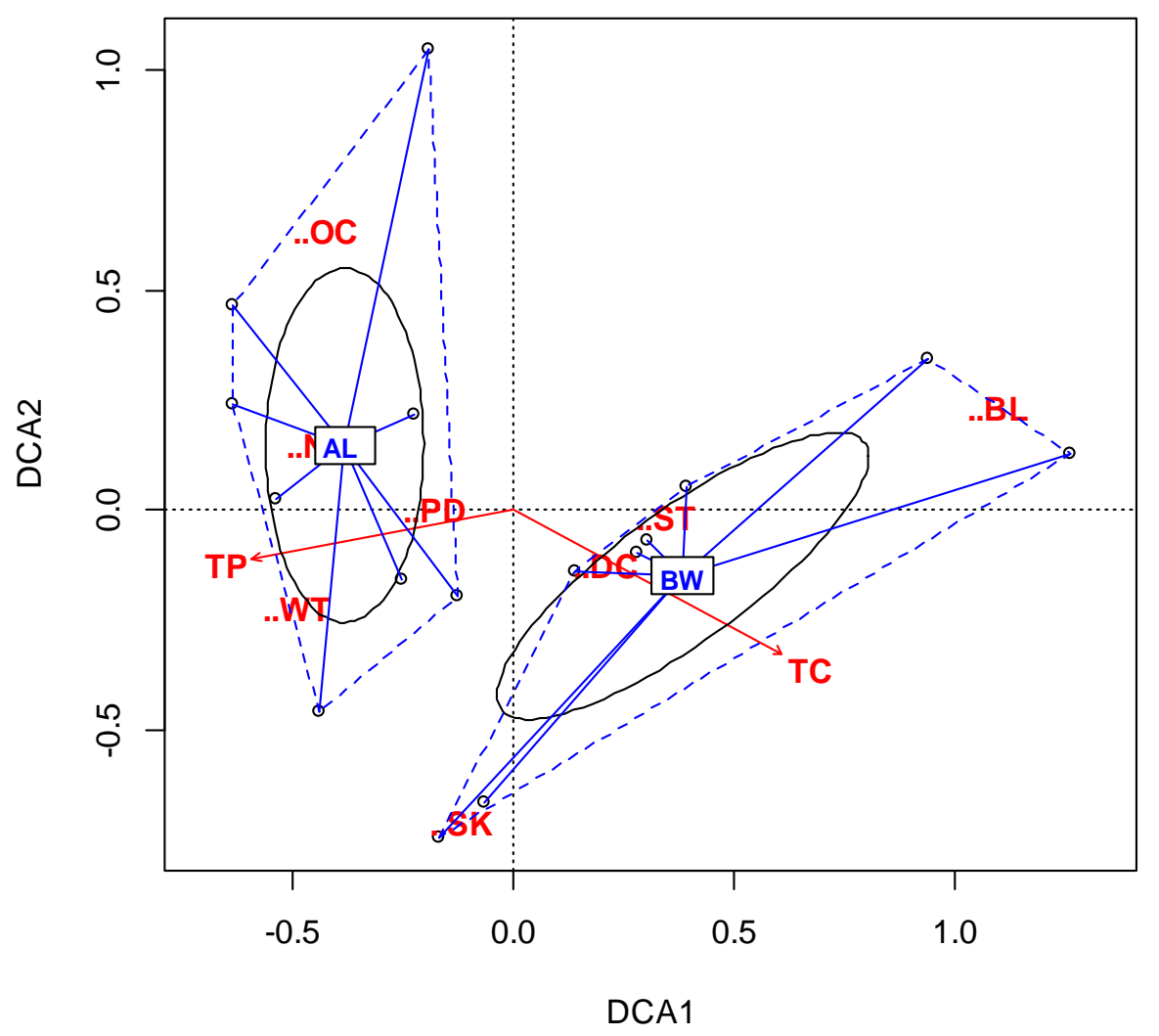

\begin{tabular}{|c|c|c|c|c|}
\hline & Axis 1 & Axis 2 & Axis 3 & Axis 4 \\
\hline Eigenvalues & 0.23 & 0.17 & 0.12 & 0.05 \\
\hline \multicolumn{5}{|c|}{ DGGE band intensity-soil chemical variable correlations } \\
\hline & Axis 1 & Axis 2 & $\mathbf{R}^{2}$ & $\boldsymbol{P}$ \\
\hline TP & -0.98 & -0.18 & 0.48 & 0.013 \\
\hline MicP & -0.49 & -0.87 & 0.14 & 0.370 \\
\hline $\mathrm{TN}$ & 0.83 & -0.56 & 0.29 & 0.107 \\
\hline TC & 0.88 & -0.47 & 0.64 & 0.002 \\
\hline $\mathrm{pH}$ & 0.03 & -0.99 & 0.11 & 0.498 \\
\hline Moisture & 0.36 & -0.93 & 0.25 & 0.160 \\
\hline Floodplain Type & & & 0.38 & 0.001 \\
\hline Site & & & 0.86 & 0.001 \\
\hline Topography & & & 0.03 & 0.707 \\
\hline
\end{tabular}

Figure 4.10b: Detrended correspondence analysis (DCA) ordination diagram of the fungal community structure associated with 
environmental variables (soil moisture, TN, TC, TP, microbial $\mathrm{P}$, and $\mathrm{pH}$ ) in soils.

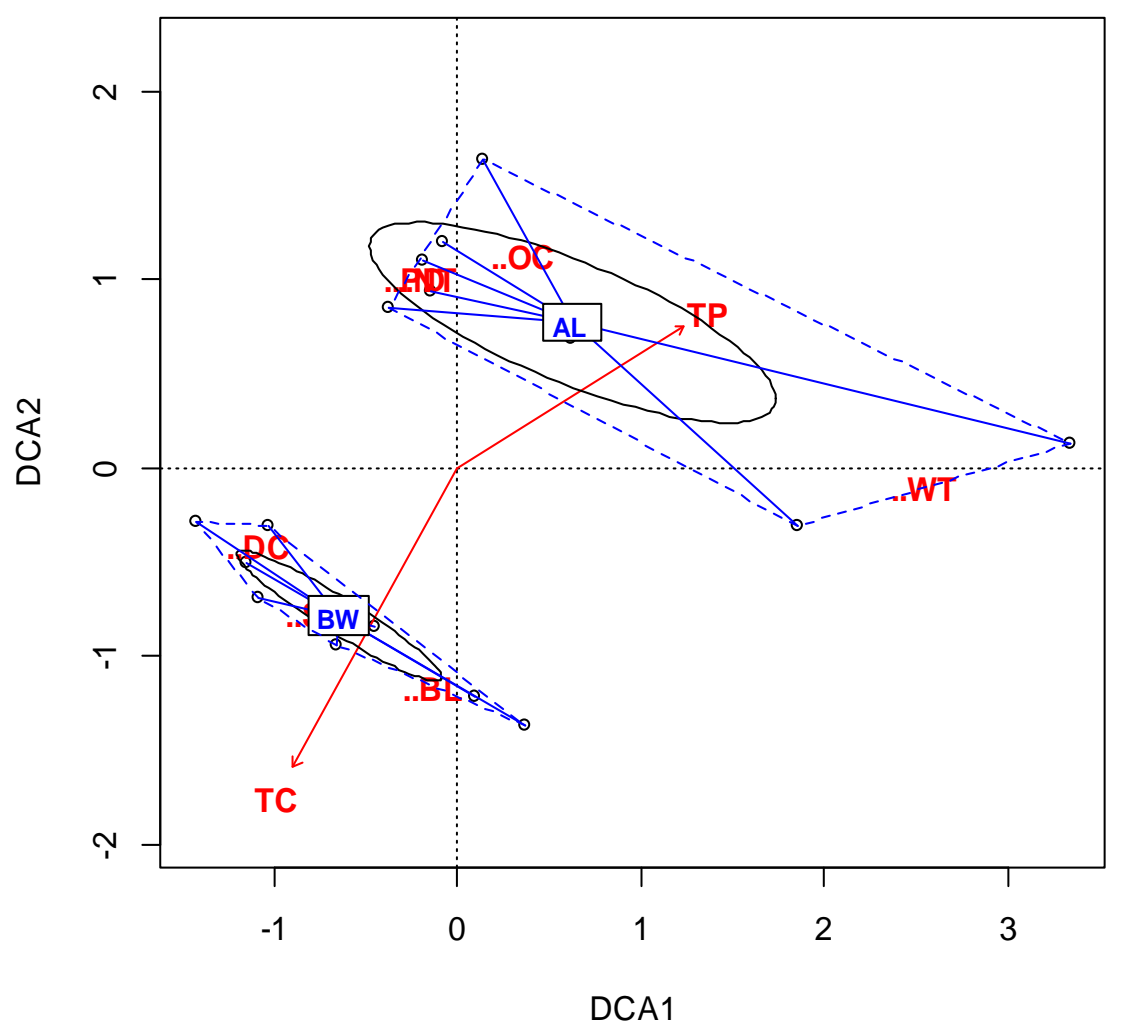

\begin{tabular}{|c|c|c|c|c|}
\hline & Axis 1 & Axis 2 & Axis 3 & Axis 4 \\
\hline Eigenvalues & 0.66 & 0.53 & 0.50 & 0.25 \\
\hline \multicolumn{5}{|c|}{ DGGE band intensity-soil chemical variable correlations } \\
\hline & Axis 1 & Axis 2 & $\mathbf{R}^{2}$ & $\boldsymbol{P}$ \\
\hline TP & 0.85 & 0.52 & 0.49 & 0.013 \\
\hline MicP & 0.96 & -0.27 & 0.21 & 0.220 \\
\hline TN & -0.35 & -0.94 & 0.31 & 0.097 \\
\hline TC & -0.49 & -0.87 & -0.77 & 0.001 \\
\hline $\mathrm{pH}$ & -0.65 & -0.76 & 0.18 & 0.298 \\
\hline Moisture & -0.58 & -0.81 & 0.13 & 0.395 \\
\hline Floodplain Type & & & 0.47 & 0.001 \\
\hline Site & & & 0.87 & 0.001 \\
\hline Topography & & & 0.02 & 0.780 \\
\hline
\end{tabular}


Table 4.1. Locations and characteristics of the study sites. Soils data were obtained from USDA/NRCS regional soil maps; drainage areas are from the USGS web interface for the National Water Information System (http://waterdata.usgs.gov). 


\begin{tabular}{l|l|l|l|l|l|l}
\hline Study & Site & River type & Lat/Long & Drainage & Soil Class & †Dominant \\
\hline 2 & Nottaway & Alluvial & $36^{\circ} 46^{\prime} 13^{\prime \prime}$ & 3,732 & Typic & Cypress, Tupelo \\
2 & Pee Dee & $---"--$ & $34^{\circ} 12^{\prime} 15^{\prime \prime}$ & 22,870 & Aquic Quartzipsamments & Cypress, Tupelo \\
2 & Ocmulgee & $---"--$ & $31^{\circ} 55^{\prime} 12^{\prime \prime}$ & 13,416 & Typic Paleudults & Cypress, \\
1,2 & Wateree & $---"--$ & $33^{\circ} 49^{\prime} 42^{\prime \prime}$ & 14,478 & Fluvaquentic Dystrochrepts & Cypress, River \\
\hline 1,2 & Black River, & Blackwater & $34^{\circ} 45^{\prime} 18^{\prime \prime}$ & 1,751 & Typic Fluvaquent & Sweetgum, \\
2 & Drowning & $---"--$ & $35^{\circ} 03^{\prime} 40^{\prime \prime}$ & 474 & Fluvaquentic & River Birch, \\
2 & Salkehatchie & $---n^{---}$ & $32^{\circ} 59^{\prime} 20^{\prime \prime}$ & 883 & Typic Haplohumods/Typic & Tupelo, \\
2 & Satilla River, & $---n^{---}$ & $31^{\circ} 14^{\prime} 17^{\prime \prime}$ & 3,108 & Fluvaquentic Dystrochrepts & Sycamore, Bald \\
\hline
\end{tabular}

†The dominant woody vegetation at all eight sites is mixed deciduous bottomland forest dominated by bald cypress (Taxodium distichum), sweetgum (Liquidambar styracifula), river birch (Betula nigra), water tupelo (Nyssa aquatica), and willow oak (Quercus phellos) (Frederick and Walbridge, unpublished data). 
Table 4.2. Oligonucleotide primers for targeting bacterial $16 \mathrm{~S}$ rDNA and fungal $18 \mathrm{~S}$ rDNA/ITS genes from total genomic DNA extracted from soils. 


\begin{tabular}{|c|c|c|c|c|}
\hline Primers & Sequence (5' to 3') & Target gene (bp) & Thermal cycling conditions & Reference \\
\hline $\begin{array}{l}63-\mathrm{F} \\
1387-\mathrm{R}\end{array}$ & $\begin{array}{llll}\text { CAG } & \text { GCC } & \text { TAA } & \text { CAC } \\
\text { GGG } & \text { CGG } & \text { WGT } & \text { GTA }\end{array}$ & $\begin{array}{l}\text { Bacterial 16S rDNA } \\
(1300)\end{array}$ & \multirow{2}{*}{$\begin{array}{l}95^{\circ} \mathrm{C} 5 \mathrm{~min} \rightarrow 95^{\circ} \mathrm{C} 60 \mathrm{~s}, \\
55^{\circ} \mathrm{C} 60 \mathrm{~s}, 72^{\circ} \mathrm{C} 90 \mathrm{~s} \times 35 \\
\text { cycles } \rightarrow 72^{\circ} \mathrm{C} 10 \mathrm{~min}\end{array}$} & $\begin{array}{l}\text { (Marchesi et al. } \\
\text { 2001) }\end{array}$ \\
\hline $\begin{array}{l}{ }^{*} 341-\mathrm{F} \\
534-\mathrm{R}\end{array}$ & $\begin{array}{llll}\text { CCT ACG } & \text { GGA } & \text { GGC } \\
\text { ATT } & \text { ACC } & \text { GCG GCT } & \text { GCT }\end{array}$ & --- " & & $\begin{array}{lll}\text { Muyzer et al. } \\
1993 \text { ) }\end{array}$ \\
\hline $\begin{array}{l}{ }^{*} \text { ITS1-F } \\
\text { ITS4-R }\end{array}$ & $\begin{array}{l}\text { CTT GGT CAT TTA GAG } \\
\text { TCC TCC GCT TAT TGA }\end{array}$ & $\begin{array}{l}\text { Fungal 18S rDNA- } \\
\text { ITS (800) }\end{array}$ & \multirow{2}{*}{$\begin{array}{l}94^{\circ} \mathrm{C} 5 \mathrm{~min} \rightarrow 94^{\circ} \mathrm{C} 30 \mathrm{~s}, \\
54^{\circ} \mathrm{C} 30 \mathrm{~s}, 72^{\circ} \mathrm{C} 30 \mathrm{~s} \times 35 \\
\text { cycles } \rightarrow 72^{\circ} \mathrm{C} 10 \mathrm{~min}\end{array}$} & \multirow{2}{*}{$\begin{array}{l}\text { (White et al. 1990, } \\
\text { Gardes and Bruns } \\
1993 \text { ) }\end{array}$} \\
\hline ITS2-R & GCT GCG TTC TTC ATC & --- "--- (300) & & \\
\hline
\end{tabular}

*DGGE primers 341-F and ITS1-F were synthesized with a 5' end 40 bp GC clamp to stabilize the melting behavior of the DNA fragments. The GC clamp CGC CCG CCG CGC GCG GCG GGC GGG GCG GGG GCA CGG GGG G was added to the bacterial primer 341-F, and CGC CCG CCG CGC CCC GCG CCC GTC CCG CCG CCC CCG CCC $\mathrm{G}$ was added to the fungal primer ITS1-F. 
Table 4.3. (a) Chemical analysis of soils sampled in ridge (RD), dry swale (SWD), and/or flooded swale (SWF) microsite elevations in one alluvial (AL) and one blackwater (BW) FF; and (b) Results of a 2-way ANOVA for the effects of floodplain type (AL, BW), ridge (RD) or swale (SW) microsite elevations, and the interaction term, on soil chemical characteristics. When necessary, data were $\log$ transformed to meet the assumptions of normality. Significant effects and interaction terms $(P<0.05)$ are shown in bold. 
Table 4.3 a: Chemical analysis of FF soils.

\begin{tabular}{|c|c|c|c|c|c|c|c|}
\hline BW Floodplain & Topo. & TP & MicP & $\mathbf{T N}$ & TC & $\mathbf{p H}$ & Moisture \\
\hline Black R., NC & RD 1 & 5.1 & 0.17 & 27.9 & 437.4 & 5.2 & 28.3 \\
\hline --- " --- & $\mathrm{RD} 2$ & 4.6 & 0.09 & 37.5 & 458.1 & 5.3 & 32.1 \\
\hline --- " --- & $\mathrm{RD} 3$ & 4.6 & 0.10 & 80.2 & 952.1 & 5.7 & 29.6 \\
\hline --- " --- & $\mathrm{RD} 4$ & 3.7 & 0.01 & 20.6 & 326.4 & 5.5 & 25.1 \\
\hline --- " --- & $\mathrm{RD} 5$ & 4.5 & 0.03 & 17.1 & 238.9 & 5.5 & 19.3 \\
\hline --- " --- & RD 6 & 3.7 & 0.14 & 19.1 & 335.8 & 5.2 & 19.2 \\
\hline BW-RD Mean (SE) & & 4.4 & 0.09 & 33.7 & 458.1 & 5.4 & 25.6 \\
\hline Black R., NC & SW 1 & 3.7 & 0.17 & 60.5 & 408.3 & 5.2 & 36.6 \\
\hline --- " --- & SW 2 & 4.7 & 0.06 & 74.4 & 897.8 & 5.2 & 30.4 \\
\hline --- " --- & SWF 3 & 3.5 & 0.11 & 49.1 & 917.2 & 5.8 & 83.9 \\
\hline --- " --- & SWF 4 & 3.6 & 0.04 & 71.2 & 845.5 & 5.7 & 84.3 \\
\hline --- " --- & SWF 5 & 4.9 & 0.10 & 61.1 & 820.7 & 5.4 & 79.8 \\
\hline --- " --- & SWF 6 & 6.5 & 0.48 & 40.1 & 515.6 & 5.6 & 69.3 \\
\hline BW-SW Mean (SE) & & 4.5 & 0.2 & 59.4 & 734.2 & 5.5 & 64.1 \\
\hline BW-Overall Mean (SE) & & 4.4 & 0.1 & 46.6 & 596.2 & 5.4 & 44.8 \\
\hline \multicolumn{8}{|l|}{ AL Floodplain } \\
\hline Wateree R., SC & RD 1 & 12.7 & 0.13 & 21.1 & 298.7 & 5.2 & 29.8 \\
\hline --- " --- & $\mathrm{RD} 2$ & 11.2 & 0.22 & 20.0 & 177.6 & 5.3 & 29.3 \\
\hline --- " --- & RD 3 & 10.7 & 0.04 & 44.9 & 155.9 & 6.1 & 26.1 \\
\hline --- " --- & $\mathrm{RD} 4$ & 11.8 & 0.10 & 22.1 & 222.7 & 5.8 & 27.8 \\
\hline --- "--- & RD 5 & 13.5 & 0.08 & 47.7 & 283.3 & 5.7 & 30.1 \\
\hline --- " --- & RD 6 & 12.9 & 0.05 & 23.5 & 305.1 & 6.0 & 27.9 \\
\hline AL-RD Mean (SE) & & 12.1 & 0.1 & 29.9 & 240.6 & 5.7 & 28.5 \\
\hline Wateree R., SC & SW 1 & 10.6 & 0.09 & 47.4 & 260.1 & 5.1 & 28.7 \\
\hline --- "--- & SW 2 & 11.0 & 0.11 & 43.5 & 371.4 & 5.8 & 32.6 \\
\hline --- " --- & SW 3 & 9.5 & 0.10 & 49.0 & 280.4 & 5.7 & 29.0 \\
\hline --- " --- & SW 4 & 11.2 & 0.14 & 22.8 & 225.7 & 5.9 & 27.5 \\
\hline --- " --- & SW 5 & 12.6 & 0.25 & 25.1 & 290.3 & 5.2 & 29.4 \\
\hline --- " --- & SW 6 & 11.7 & 0.11 & 25.1 & 263.8 & 5.8 & 27.2 \\
\hline AL-SW Mean (SE) & & 11.1 & 0.1 & 35.5 & 281.9 & 5.6 & 29.1 \\
\hline$A L-$ Overall Mean $(S E)$ & & 11.6 & 0.1 & 32.7 & 261.2 & 5.6 & 28.8 \\
\hline AL \& BW - RD Mean (SE) & & 8.2 & 0.1 & 31.8 & 349.3 & 5.5 & 27.1 \\
\hline AL \& BW - SW Mean (SE) & & 7.8 & 0.1 & 47.4 & 508.1 & 5.5 & 46.6 \\
\hline
\end{tabular}


Table $4.3 \mathrm{~b}$ : Results of the 2-way ANOVA

\begin{tabular}{|c|c|c|c|c|c|c|c|c|}
\hline & d. f. & & TP & MicP & TN & TC & pH & Moisture \\
\hline Floodplain type, $\mathrm{F}$ & 1 & $\mathrm{~F}$ & $\begin{array}{l}245.4013 \\
<0.0001\end{array}$ & $\begin{array}{l}0.3579 \\
0.5564\end{array}$ & $\begin{array}{l}2.8958 \\
0.1043\end{array}$ & $\begin{array}{l}30.0095 \\
<0.0001\end{array}$ & $\begin{array}{l}2.8735 \\
0.1056\end{array}$ & $\begin{array}{l}9.8291 \\
0.0052\end{array}$ \\
\hline Topography, T & 1 & $\bar{F}$ & $\begin{array}{l}0.3804 \\
0.5444\end{array}$ & $\begin{array}{l}2.1006 \\
0.1627\end{array}$ & $\begin{array}{l}7.2033 \\
0.0143\end{array}$ & $\begin{array}{l}6.6798 \\
0.0177\end{array}$ & $\begin{array}{l}0.0023 \\
0.9625\end{array}$ & $\begin{array}{l}14.5393 \\
0.0011\end{array}$ \\
\hline $\mathrm{F} \times \mathrm{T}$ & 1 & $\mathrm{~F}$ & $\begin{array}{l}0.6428 \\
0.4321\end{array}$ & $\begin{array}{l}0.0989 \\
0.7564\end{array}$ & $\begin{array}{l}2.3073 \\
0.1444\end{array}$ & $\begin{array}{l}1.5981 \\
0.2207\end{array}$ & $\begin{array}{l}0.7242 \\
0.4049\end{array}$ & $\begin{array}{l}13.7190 \\
0.0014\end{array}$ \\
\hline
\end{tabular}


Table 4.4. (a) Chemical analysis of soils sampled in ridge (RD), dry swale (SWD), and/or flooded swale (SWF) microsite elevations in soils collected from four alluvial (WT: Wateree R., SC; PD: Pee Dee R., SC; NT: Nottaway R., VA; and OC: Ocmulgee R., GA) and four blackwater (BL: Black R., NC; DC: Drowning Cr., NC; ST: Satilla R., GA; and SK: Salkehatchie R., SC) FFs; and (b) Results of the 2-way ANOVA of the effects of floodplain type (AL and $\mathrm{BW})$, microsite elevation (ridge (RD) or swale (SW)), and the interaction term, on soil chemical characteristics. When necessary, data were log transformed to meet the assumption of normality. Significant effects and interaction terms $(P<0.05)$ are shown in bold. 
Table 4.4 a: Chemical analysis of FF soils.

\begin{tabular}{ll|l|l|l|l|l|l}
\hline BW Floodplain & Topo. & TP & MicP & TN & TC & pH & Moisture \\
\hline Black R., NC & RD & 4.6 & 0.10 & 80.2 & 952.1 & 5.7 & 29.6 \\
--- --- & SWF & 3.5 & 0.11 & 49.1 & 917.2 & 5.8 & 83.9 \\
Drowning Creek, NC & SWF a & 2.7 & 0.01 & 33.3 & 834.3 & 5.5 & 59.4 \\
--- --- & SWF b & 2.3 & 0.04 & 41.4 & 768.8 & 5.5 & 67.3 \\
Satilla River, GA & RD & 1.6 & 0.12 & 31.0 & 552.1 & 5.6 & 16.9 \\
--- --- & SWF & 4.2 & 0.06 & 56.4 & 873.7 & 5.6 & 28.4 \\
\hline Salkehatchie River, SC & SWF a & 9.3 & 0.08 & 47.5 & 792.9 & 6.5 & 54.4 \\
--- --- & SWF b & 6.9 & 0.17 & 62.5 & 800.3 & 6.9 & 40.3 \\
\hline BW-RD Mean (SE) & & 3.1 & 0.1 & 55.6 & 752.1 & 5.6 & 23.2 \\
\hline BW-SW Mean (SE) & & 4.8 & 0.08 & 48.4 & 831.2 & 5.9 & 55.6 \\
\hline BW - Overall Mean (SE) & & 4.4 & 0.09 & 50.2 & $\mathbf{8 1 1 . 4}$ & 5.9 & 47.5 \\
\hline AL Floodplain & & & & & & & \\
Wateree R., SC & RD & 13.5 & 0.08 & 47.7 & 283.3 & 5.7 & 30.1 \\
--- --- & SW & 12.6 & 0.25 & 25.1 & 290.3 & 5.2 & 29.4 \\
Pee Dee River, SC & RD & 4.4 & 0.02 & 6.4 & 149.8 & 5.6 & 21.1 \\
--- --- & SWF & 5.5 & 0.01 & 17.1 & 321.5 & 5.4 & 37.5 \\
Nottaway River, VA & RD & 8.5 & 0.18 & 60.2 & 433.1 & 5.7 & 36.4 \\
--- --- & SWF & 10.1 & 0.20 & 44.9 & 533.7 & 5.9 & 40.6 \\
Ocmulgee River, Ga & RD & 6.3 & 0.01 & 15.7 & 153.4 & 5.9 & 6.4 \\
--- --- & SWF & 8.9 & 0.10 & 26.3 & 222.4 & 5.4 & 32.2 \\
\hline AL-RD Mean (SE) & & 8.2 & 0.07 & 32.5 & 254.9 & 5.7 & 23.5 \\
\hline AL-SW Mean (SE) & & 9.3 & 0.1 & 28.3 & 342.0 & 5.5 & 34.9 \\
\hline AL - Overall Mean (SE) & & $\mathbf{8 . 7}$ & 0.1 & 30.4 & $\mathbf{2 9 8 . 4}$ & 5.6 & 29.2 \\
\hline AL \& BW - RD Mean (SE) & & 6.5 & 0.09 & 40.2 & 420.6 & 5.7 & $\mathbf{2 3 . 4}$ \\
\hline AL \& BW - SW Mean (SE) & & 6.6 & 0.1 & 40.3 & 635.5 & 5.8 & $\mathbf{4 7 . 3}$ \\
\hline & & & & & & & \\
\hline & & & & & & \\
\hline
\end{tabular}


Table 4.4 b: Results of the 2-way ANOVA

\begin{tabular}{l|l|l|l|l|l|l|l|l}
\hline & d. f. & & TP & MicP & TN & TC & pH & Moisture \\
\hline Floodplain type, F & 1 & F & $\mathbf{6 . 0 0 8 5}$ & 0.0710 & 3.1708 & $\mathbf{1 9 . 9 5 3 7}$ & 0.8284 & 1.1960 \\
& & $P$ & $\mathbf{0 . 0 4 7 3}$ & 0.7980 & 0.1176 & $\mathbf{0 . 0 0 3 6}$ & 0.3962 & 0.3105 \\
\hline Site [F] & & F & $\mathbf{5 . 5 5 8 9}$ & 3.8662 & 1.9625 & $\mathbf{5 . 3 9 3 3}$ & 7.2777 & 2.2243 \\
& & $P$ & $\mathbf{0 . 0 2 7 8}$ & 0.0622 & 0.2162 & $\mathbf{0 . 0 2 9 9}$ & 0.0146 & 0.1768 \\
\hline Topography, T & 1 & $\mathrm{~F}$ & 2.0506 & 0.4486 & 0.1431 & 5.7279 & 0.2843 & $\mathbf{9 . 7 7 7 1}$ \\
& & $P$ & 0.2021 & 0.5279 & 0.7182 & 0.0538 & 0.6131 & $\mathbf{0 . 0 2 0 4}$ \\
\hline F $\times$ T & 1 & F & 0.1986 & 2.2765 & 0.0050 & 0.3229 & 1.4990 & 2.3090 \\
& & $P$ & 0.6715 & 0.1821 & 0.9462 & 0.5905 & 0.2667 & 0.1794 \\
\hline
\end{tabular}


Table 4.5. Similarities of dominant (a) bacterial 16S rDNA: and (b) fungal ITS rDNA, sequences from excised DGGE bands, to clone library sequences (Appendix Table 4.1) and their closes relatives to sequences retrieved from GenBank, of soils collected from one alluvial (AL) (Wateree R., SC) and one blackwater (BW) (Black R., NC) FF (Figures 4.3, 4.4). 
Table 4.5a. Dominant bacterial 16S rDNA sequences from excised DGGE bands.

\begin{tabular}{|c|c|c|c|c|c|c|c|c|c|c|c|}
\hline $\begin{array}{l}\vec{Z} \\
\tilde{\Xi} \\
\mathscr{\Xi}\end{array}$ & OTU & Access. \# & 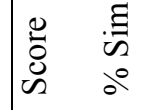 & Phylum & Class & Order & Family & Genus & $\vec{n}$ & 3 & 吾 \\
\hline 1 & 31-TB-46 & FN433469 & $850 / 95$ & Proteobacteria & Alphaproteobacteria & Rhizobiales & Beijerinckiaceae & Methylocapsa & 2 & & 2 \\
\hline 2 & 18-TB-371 & FJ529710 & $784 / 94$ & Actinobacteria & Actinobacteria & Actinomycetales & Thermomonosporaceae & Actinomadura & & 4 & 4 \\
\hline 3 & 11-TB-209 & JF510471 & $1459 / 90$ & Actinobacteria & Actinobacteria & Acidimicrobiales & Acidimicrobineae & Aciditerrimonas & 7 & & 7 \\
\hline 4 & 42-TB-157 & EF219138 & $636 / 87$ & Acidobacteria & Acidobacteria & Acidobacteriales & Acidobacteriaceae & & 2 & & 2 \\
\hline 5 & 48-TB-186 & AF498727 & $1424 / 92$ & Acidobacteria & Acidobacteria & Acidobacteriales & Acidobacteriaceae & & 2 & & 2 \\
\hline 6 & 7-TB-245 & AF409023 & $1629 / 93$ & Proteobacteria & Gammaproteoba & Chromatiales & & & 2 & 6 & 8 \\
\hline 7 & 29-TB-204 & HM748714 & $1596 / 94$ & Acidobacteria & Acidobacteria & Solibacterales & Solibacteraceae & & 1 & 2 & 3 \\
\hline 8 & 5-TB-253 & AB531426 & $1764 / 95$ & Proteobacteria & Alphaproteobacteria & Rhizobiales & Bradyrhizobiaceae & Bradyrhizobiu & 3 & 10 & 13 \\
\hline 9 & 4-TB-212 & HM748695 & $1731 / 95$ & Acidobacteria & Acidobacteria & Acidobacteriales & Acidobacteriaceae & & 11 & 5 & 16 \\
\hline 10 & 13-TB-243 & AY234636 & $1757 / 95$ & Acidobacteria & Acidobacteria & Acidobacteriales & Acidobacteriaceae & & 6 & & 6 \\
\hline 11 & 26-ТВ-289 & AF498753 & $1519 / 91$ & Acidobacteria & Acidobacteria & Acidobacteriales & Acidobacteriaceae & & & 3 & 3 \\
\hline 12 & $17-\mathrm{TB}-40$ & AM503077 & $7985 / 99$ & Proteobacteria & Betaproteobacteria & Burkholderiales & Burkholderiaceae & Burkholderia & 4 & & 4 \\
\hline 13 & $14-\mathrm{TB}-273$ & AY234650 & $1275 / 92$ & Proteobacteria & Alphaproteobacteria & Rhodospirillales & Rhodospirillaceae & Azospirillum & 5 & 1 & 6 \\
\hline 14 & $2-\mathrm{TB}-188$ & HM748653 & $1461 / 95$ & Acidobacteria & Acidobacteria & Solibacterales & Solibacteraceae & Solibacter & 13 & 7 & 20 \\
\hline 15 & $15-\mathrm{TB}-453$ & HM748732 & 942/97 & Acidobacteria & Acidobacteria & Acidobacteriales & Acidobacteriaceae & & & 5 & 5 \\
\hline 16 & 20-TB-439 & GU187030 & $652 / 90$ & Acidobacteria & Acidobacteria & Acidobacteriales & Acidobacteriaceae & & & 4 & 4 \\
\hline 17 & 3-TB-27 & HM748709 & $885 / 96$ & Proteobacteria & Alphaproteobacteria & Rhizobiales & Hyphomicrobiaceae & & 12 & 4 & 16 \\
\hline 18 & 49-TB-265 & AY234650 & $1356 / 89$ & Proteobacteria & Alphaproteobacteria & Rhodospirillales & Acetobacteraceae & & 2 & & 2 \\
\hline 19 & 16-TB-33 & NR-025582 & $2713 / 91$ & Proteobacteria & Alphaproteobacteria & Rhodospirillales & Acetobacteraceae & & 2 & 2 & 4 \\
\hline 20 & 12-TB-349 & FJ459988 & $813 / 97$ & Proteobacteria & Alphaproteobacteria & Rhodospirillales & Rhodospirillaceae & & 4 & 3 & 7 \\
\hline 21 & 6-TB-237 & AY234592 & $1688 / 95$ & Acidobacteria & Acidobacteria & Acidobacteriales & Acidobacteriaceae & & 7 & 3 & 10 \\
\hline 22 & 9-TB-100 & EF074997 & $870 / 95$ & Acidobacteria & Acidobacteria & Acidobacteriales & Acidobacteriaceae & & 3 & 4 & 7 \\
\hline 23 & 10-TB-295 & AF498727 & $1458 / 91$ & Acidobacteria & Acidobacteria & Acidobacteriales & Acidobacteriaceae & & 6 & 1 & 7 \\
\hline 24 & $1-\mathrm{TB}-463$ & GQ369128 & $931 / 98$ & Proteobacteria & Alphaproteobacteria & Rhizobiales & Xanthobacteraceae & Pseudolabrys & 11 & 21 & 32 \\
\hline 25 & 24-TB-280 & HM748732 & $1245 / 88$ & Acidobacteria & Acidobacteria & Acidobacteriales & Acidobacteriaceae & & 2 & 1 & 3 \\
\hline
\end{tabular}




\begin{tabular}{|l|l|l|l|l|l|l|l|l|l|l|l|}
\hline 26 & 8 -TB-71 & AF498722 & $806 / 94$ & Proteobacteria & Alphaproteobacteria & Rhizobiales & Methylocystaceae & Methylocystis & 7 & 7 \\
\hline 27 & $32-$-TB-264 & FJ469913 & $1546 / 95$ & Acidobacteria & Acidobacteria & Acidobacteriales & Acidobacteriaceae & & 2 & 2 \\
\hline
\end{tabular}


Table 4.5b. Dominant fungal ITS rDNA sequences from excised DGGE bands.

\begin{tabular}{|c|c|c|c|c|c|c|c|c|c|c|c|c|}
\hline 急 & OTU & Access. \# & 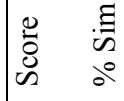 & Phylum & Subphylum & Class & Order & Family & Genus & $\vec{m}$ & 5 & $\begin{array}{l}\bar{\pi} \\
0 \\
\Theta\end{array}$ \\
\hline 1 & 19-TF-198 & FJ554185 & $826 / 93$ & Basidiomycota & aAgaricomycotina & Agaricomycetes & Agaricales & Tricholomataceae & & 3 & 1 & 4 \\
\hline 2 & $10-\mathrm{TF}-61$ & JN943015 & $1062 / 99$ & Zygomycota & Mucoromycotina & & Mortierellales & s Mortierellaceae & Mortierella & 7 & & 7 \\
\hline 3 & $20-\mathrm{TF}-263$ & GU934592 & $1053 / 97$ & Basidiomycota & a Agaricomycotina & Agaricomycetes & Corticiales & Corticiaceae & Phanerochaete & & 3 & 3 \\
\hline 4 & 3-TF-22 & EU598156 & $1037 / 99$ & Basidiomycota & a Agaricomycotina & Agaricomycetes & Russulales & Russulaceae & Russula & 10 & 2 & 12 \\
\hline 5 & 6-TF-286 & EU784211 & $909 / 95$ & Basidiomycota & aAgaricomycotina & Agaricomycetes & Agaricales & Entolomataceae & Entoloma & & 8 & 8 \\
\hline 6 & 2-TF-213 & JF439485 & $1138 / 99$ & Zygomycota & Mucoromycotina & & Mortierellales & s Mortierellaceae & Mortierella & 3 & 15 & 18 \\
\hline 7 & $11-\mathrm{TF}-222$ & AB176571 & $1081 / 97$ & Basidiomycota & aAgaricomycotina & Agaricomycetes & Polyporales & & Daedaleopsis & & 6 & 6 \\
\hline 8 & $30-\mathrm{TF}-320$ & GU479272 & $928 / 94$ & Basidiomycota & aAgaricomycotina & Agaricomycetes & Agaricales & Hymenogastraceae & Hymenogaster & & 3 & 3 \\
\hline 9 & 16-TF-109 & EU598162 & $983 / 97$ & Basidiomycota & a Agaricomycotina & Agaricomycetes & Russulales & Russulaceae & Russula & 5 & & 5 \\
\hline 10 & $5-\mathrm{TF}-216$ & AY312985 & 1088,98 & Basidiomycota & a Agaricomycotina & Agaricomycetes & Agaricales & Cortinariaceae & Hebeloma & & 9 & 9 \\
\hline 11 & $12-\mathrm{TF}-232$ & AY656948 & $870 / 92$ & Basidiomycota & a Agaricomycotina & Agaricomycetes & Thelephorales & s Thelephoraceae & & & 6 & 6 \\
\hline 12 & $15-\mathrm{TF}-141$ & JF834358 & $896 / 97$ & Basidiomycota & a Agaricomycotina & Agaricomycetes & Russulales & Russulaceae & Russula & 5 & & 5 \\
\hline 13 & $17-\mathrm{TF}-175$ & FJ554007 & $965 / 97$ & Basidiomycota & aAgaricomycotina & Agaricomycetes & Agaricales & Cortinariaceae & Cortinarius & 0 & 4 & 4 \\
\hline 14 & $14-\mathrm{TF}-254$ & AJ633598 & $1050 / 97$ & Basidiomycota & & & & & & & 5 & 5 \\
\hline 15 & $23-\mathrm{TF}-159$ & HQ714730 & $939 / 96$ & Basidiomycota & aAgaricomycotina & Agaricomycetes & Russulales & Russulaceae & Lactarius & 3 & & 3 \\
\hline 16 & $7-\mathrm{TF}-37$ & EU598194 & $752 / 91$ & Basidiomycota & Agaricomycotina & Agaricomycetes & Russulales & Russulaceae & Russula & 6 & 2 & 8 \\
\hline 17 & $9-\mathrm{TF}-211$ & EU819478 & $1116 / 99$ & Basidiomycota & aAgaricomycotina & Agaricomycetes & Agaricales & Tricholomataceae & Laccaria & 3 & 5 & 8 \\
\hline 18 & 27-TF-318 & EU819493 & $1140 / 99$ & Basidiomycota & a Agaricomycotina & Agaricomycetes & Russulales & Russulaceae & Russula & & 3 & 3 \\
\hline 19 & $1-\mathrm{TF}-67$ & FN428924 & $926 / 100$ & Basidiomycota & aAgaricomycotina & Tremellomycete & s Tremellales & & Cryptococcus & 18 & 8 & 26 \\
\hline 20 & $29-\mathrm{TF}-311$ & EU167594 & $966 / 99$ & Ascomycota & Pezizomycotina & Dothideomycete & sCapnodiales & Mycosphaerellaceae & eMycosphaerella & & 3 & 3 \\
\hline 21 & 24-TF-206 & HM488478 & 390298 & Ascomycota & Pezizomycotina & Leotiomycetes & & & & 1 & 2 & 3 \\
\hline 22 & $13-\mathrm{TF}-123$ & HQ157874 & $750 / 92$ & Ascomycota & Pezizomycotina & Leotiomycetes & Helotiales & Helotiaceae & & 5 & & 5 \\
\hline 23 & 25-TF-75 & HQ630960 & $1051 / 99$ & Ascomycota & Pezizomycotina & Sordariomycetes & Hypocreales & Hypocreaceae & Hypocrea & 1 & 2 & 3 \\
\hline 24 & 4-TF-127 & DQ777988 & $1051 / 99$ & Basidiomycota & aAgaricomycotina & Agaricomycetes & Russulales & Russulaceae & Russula & 9 & 1 & 10 \\
\hline 25 & $18-\mathrm{TF}-225$ & JF908544 & $961 / 95$ & Ascomycota & Pezizomycotina & Pezizomycetes & Pezizales & Pezizaceae & Peziza & & 4 & 4 \\
\hline
\end{tabular}




\begin{tabular}{|c|c|c|c|c|c|c|c|c|c|c|c|c|}
\hline 26 & 46-TF-19 & EU598153 & $992 / 99$ & Basidiomycota & Agaricomycotina & Agaricomycetes & Russulales & Russulaceae & Russula & 1 & & 1 \\
\hline 27 & 26-TF-315 & HM176560 & $01079 / 99$ & Ascomycota & Pezizomycotina & Sordariomycetes & Hypocreales & Hypocreaceae & Trichoderma & 2 & 1 & 3 \\
\hline 28 & 32-TF-96 & JF735304 & $987 / 99$ & Ascomycota & Pezizomycotina & Sordariomycetes & Hypocreales & Nectriaceae & Ilyonectria & 2 & & 2 \\
\hline 29 & $22-\mathrm{TF}-3$ & U57496 & $715 / 91$ & Ascomycota & Pezizomycotina & Leotiomycetes & Helotiales & Hyaloscyphaceae & Arachnopeziza & 3 & & 3 \\
\hline 30 & $123-\mathrm{TF}-310$ & FJ612884 & $684 / 91$ & Ascomycota & Pezizomycotina & Sordariomycetes & & & & & 1 & 1 \\
\hline 31 & 21-TF-134 & EU819480 & $957 / 97$ & Basidiomycota & Agaricomycotina & Agaricomycetes & Russulales & Russulaceae & Lactarius & 3 & & 3 \\
\hline 32 & $38-\mathrm{TF}-100$ & EF694630 & $968 / 99$ & Ascomycota & Pezizomycotina & Eurotiomycetes & Eurotiales & Trichocomaceae & Penicillium & 2 & & 2 \\
\hline 33 & 31-TF-199 & HM189876 & $6893 / 98$ & Basidiomycota & Agaricomycotina & Tremellomycetes & Tremellales & & & 1 & 1 & 2 \\
\hline 34 & 8-TF-381 & AJ557830 & $1059 / 99$ & Ascomycota & Pezizomycotina & Sordariomycetes & Hypocreales & Nectriaceae & Nectria & 6 & 2 & 8 \\
\hline
\end{tabular}


Table 4.6. Similarities of dominant (a) bacterial 16S rDNA; and (b) fungal ITS rDNA, sequences from excised DGGE bands, to clone library sequences (Appendix Table 4.2) and their closes relatives, to sequences retrieved from GenBank, of soils collected from four alluvial (WT: Wateree R., SC; PD: Pee Dee R., SC; NT: Nottaway R., VA; and OC: Ocmulgee R., GA) and four blackwater (BL: Black R., NC; DC: Drowning Cr., NC; ST: Satilla R., GA; and SK: Salkehatchie R., SC) FFs (Figures 4.5, 4.6). 
Table 4.6a. Dominant bacterial 16S rDNA sequences from excised DGGE bands.

\begin{tabular}{|c|c|c|c|c|c|c|c|c|c|c|c|}
\hline $\begin{array}{l}\vec{\Xi} \\
\stackrel{\vec{I}}{\oplus}\end{array}$ & OTU & Accession \# & 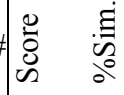 & Phylum & Class & Order & Family & Genus & $\frac{8}{00}$ & $\frac{0}{\frac{0}{\pi}}$ & 㞼 \\
\hline 1 & $10-\mathrm{MB}-440$ & AF498727 & $1672 / 93$ & Acidobacteria & Acidobacteria & Acidobacteriales & Acidobacteriaceae & & 2 & 3 & 5 \\
\hline 2 & 20-MB-68 & HM748754 & $1709 / 98$ & Acidobacteria & Acidobacteria & Acidobacteriales & Acidobacteriaceae & & 3 & & 3 \\
\hline 3 & 30-MB-59 & AF482687 & $1587 / 92$ & Proteobacteria & Deltaproteobacteria & Myxococcales & & & 2 & & 2 \\
\hline 4 & 15-MB-641 & D16209 & $1387 / 91$ & Proteobacteria & Betaproteobacteria & Rhodocyclales & Rhodocyclaceae & Rhodocyclus & 3 & & 3 \\
\hline 5 & $11-\mathrm{MB}-627$ & NR-043898 & $1764 / 95$ & Acidobacteria & Acidobacteria & Acidobacteriales & Acidobacteriaceae & Edaphobacter & 3 & 1 & 4 \\
\hline 6 & 4-MB-385 & AF409023 & $1807 / 95$ & Proteobacteria & Gammaproteobacteria & aChromatiales & & & 2 & 6 & 8 \\
\hline 7 & 1-MB-559 & AB531426 & $1997 / 98$ & Proteobacteria & Alphaproteobacteria & Rhizobiales & Bradyrhizobiaceae & Bradyrhizobium & 6 & 11 & 17 \\
\hline 8 & 36-MB-381 & AY234546 & $1620 / 96$ & Actinobacteria & Actinobacteria & Actinomycetales & sThermomonosporaceae & & & 2 & 2 \\
\hline 9 & 7-MB-164 & AY234650 & $1506 / 91$ & Proteobacteria & Alphaproteobacteria & Rhodospirillales & Acetobacteraceae & & 4 & 2 & 6 \\
\hline 10 & 2-MB-367 & HM748695 & $1783 / 97$ & Acidobacteria & Acidobacteria & Acidobacteriales & sAcidobacteriaceae & & 4 & 8 & 12 \\
\hline 11 & $12-\mathrm{MB}-350$ & AY234636 & $1978 / 97$ & Acidobacteria & Acidobacteria & Acidobacteriales & Acidobacteriaceae & & 2 & 2 & 4 \\
\hline 12 & 19-MB-441 & GU187030 & $1526 / 91$ & Acidobacteria & Acidobacteria & Holophagales & Holophagaceae & & 1 & 2 & 3 \\
\hline 13 & 22-MB-86 & HM748653 & $1681 / 94$ & Acidobacteria & Acidobacteria & Solibacterales & Solibacteraceae & & 2 & & 2 \\
\hline 14 & 9-MB-443 & AF498753 & $1923 / 96$ & Acidobacteria & Acidobacteria & Acidobacteriales & Acidobacteriaceae & & 3 & 2 & 5 \\
\hline 15 & 43-MB-496 & AM503077 & $1615 / 98$ & Proteobacteria & Betaproteobacteria & Burkholderiales & Burkholderiaceae & Burkholderia & 1 & 1 & 2 \\
\hline 16 & $16-\mathrm{MB}-453$ & AB250621 & $1657 / 92$ & Proteobacteria & Alphaproteobacteria & Rhizobiales & Hyphomicrobiaceae & Rhodomicrobium & & 3 & 3 \\
\hline 17 & 6-MB-513 & HM748653 & $1993 / 96$ & Acidobacteria & Acidobacteria & Solibacterales & Solibacteraceae & Solibacter & 4 & 2 & 6 \\
\hline 18 & 13-MB-506 & HM748732 & $1770 / 95$ & Acidobacteria & Acidobacteria & Acidobacteriales & Acidobacteriaceae & & 2 & 1 & 3 \\
\hline 19 & 42-MB-469 & AY234546 & $1701 / 94$ & Actinobacteria & Actinobacteria & Actinomycetales & sThermomonosporaceae & & & 2 & 2 \\
\hline 20 & 53-MB-389 & GU187030 & $1229 / 91$ & Acidobacteria & Acidobacteria & Acidobacteriales & Acidobacteriaceae & & & 2 & 2 \\
\hline 21 & 8-MB-32 & EU938323 & $1893 / 95$ & Proteobacteria & Alphaproteobacteria & Rhizobiales & Xanthobacteraceae & Pseudolabrys & 3 & 2 & 5 \\
\hline 22 & 3-MB-383 & HM748732 & $1714 / 93$ & Acidobacteria & Acidobacteria & Acidobacteriales & Acidobacteriaceae & & 3 & 5 & 8 \\
\hline 23 & 17-MB-392 & AF498727 & $1472 / 91$ & Acidobacteria & Acidobacteria & Acidobacteriales & Acidobacteriaceae & & 1 & 2 & 3 \\
\hline 24 & 5-MB-526 & GQ369128 & $1760 / 95$ & Proteobacteria & Alphaproteobacteria & Rhizobiales & Hyphomicrobiaceae & Rhodoplanes & 3 & 4 & 7 \\
\hline 25 & 18-MB-210 & AY234475 & $1456 / 93$ & Acidobacteria & Acidobacteria & Acidobacteriales & Acidobacteriaceae & & 3 & & 3 \\
\hline
\end{tabular}




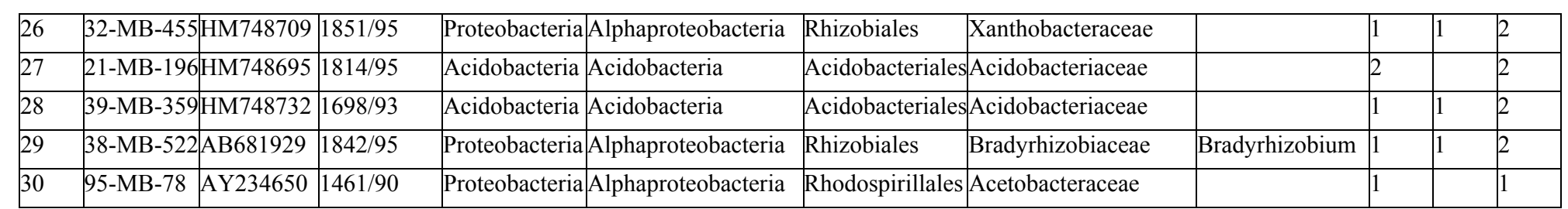


Table 4.6b. Dominant fungal ITS rDNA sequences from excised DGGE bands.

\begin{tabular}{|c|c|c|c|c|c|c|c|c|c|c|c|c|}
\hline 㱒 & OTU & Accession & 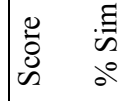 & Phylum & Subphylum & Class & Order & Family & Genus & 元 & 3 & 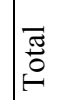 \\
\hline 1 & 14-MF-18 & EU186277 & $1266 / 99$ & Basidiomycota & Agaricomycotina & Agaricomycetes & Agaricales & Tricholomataceae & Tricholoma & 4 & & 4 \\
\hline 2 & 3-MF-266 & JF439485 & $1181 / 99$ & Zygomycota & Mucoromycotina & & Mortierellales & Mortierellaceae & Mortierella & 5 & 7 & 12 \\
\hline 3 & 103-MF-351 & $1 \mathrm{AY} 312985$ & $1140 / 99$ & Basidiomycota & Agaricomycotina & Agaricomycetes & Agaricales & Cortinariaceae & Hebeloma & & 1 & 1 \\
\hline 4 & $48-\mathrm{MF}-16$ & FJ554007 & $987 / 96$ & Basidiomycota & Agaricomycotina & Agaricomycetes & Agaricales & Cortinariaceae & Cortinarius & 1 & & 1 \\
\hline 5 & 11-MF-397 & HQ873381 & $425 / 88$ & Zygomycota & & & & & & 1 & 3 & 4 \\
\hline 6 & 6-MF-314 & DQ195594 & $763 / 86$ & Basidiomycota & Agaricomycotina & Agaricomycetes & Russulales & Russulaceae & & & 6 & 6 \\
\hline 7 & 27-MF-145 & AJ633598 & $1064 / 97$ & Basidiomycota & & & & & & 2 & & 2 \\
\hline 8 & 21-MF-373 & JF908140 & $638 / 84$ & Basidiomycota & Agaricomycotina & Agaricomycetes & Agaricales & Inocybaceae & Inocybe & & 3 & 3 \\
\hline 9 & 15-MF-229 & EU819478 & $1267 / 99$ & Basidiomycota & Agaricomycotina & Agaricomycetes & Agaricales & Tricholomataceae & Laccaria & & 4 & 4 \\
\hline 10 & 7-MF-49 & EU819493 & $1120 / 97$ & Basidiomycota & Agaricomycotina & Agaricomycetes & Agaricales & Amanitaceae & Amanita & 6 & & 6 \\
\hline 11 & 2-MF-271 & FN428924 & $935 / 99$ & Basidiomycota & Agaricomycotina & Tremellomycetes & Tremellales & & Cryptococcus & 18 & 12 & 30 \\
\hline 12 & 25-MF-441 & JN882326 & $364 / 81$ & Chytridiomycota & & Monoblepharidomycetes & sMonoblepharidales & Sonapodyaceae & Gonapodya & 2 & & 2 \\
\hline 13 & 9-MF-96 & FJ845443 & $678 / 85$ & Basidiomycota & Agaricomycotina & Agaricomycetes & Agaricales & Tricholomataceae & eTricholoma & 1 & 4 & 5 \\
\hline 14 & $105-\mathrm{MF}-372$ & 2 HM488478 & $872 / 96$ & Ascomycota & Pezizomycotina & Leotiomycetes & & & & & 1 & 1 \\
\hline 15 & 38-MF-435 & HQ157874 & $763 / 92$ & Ascomycota & Pezizomycotina & Leotiomycetes & Helotiales & Helotiaceae & & 1 & 1 & 2 \\
\hline 16 & 22-MF-359 & HQ630960 & $1131 / 99$ & Ascomycota & Pezizomycotina & Sordariomycetes & Hypocreales & Hypocreaceae & Hypocrea & 3 & & 3 \\
\hline 17 & $18-\mathrm{MF}-127$ & DQ777988 & $1192 / 99$ & Basidiomycota & Agaricomycotina & Agaricomycetes & Russulales & Russulaceae & Russula & 3 & & 3 \\
\hline 18 & 33-MF-220 & FN397177 & $492 / 84$ & Ascomycota & & & & & & & 2 & 2 \\
\hline 19 & 8-MF-26 & EU598153 & $1140 / 99$ & Basidiomycota & Agaricomycotina & Agaricomycetes & Russulales & Russulaceae & Russula & 2 & 3 & 5 \\
\hline 20 & 4-MF-159 & HM176576 & $1101 / 99$ & Ascomycota & Pezizomycotina & Sordariomycetes & Hypocreales & Hypocreaceae & Trichoderma & 8 & & 8 \\
\hline 21 & $12-\mathrm{MF}-23$ & AM084698 & $928 / 99$ & Ascomycota & Pezizomycotina & Dothideomycetes & & & Cenococcum & 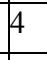 & 1 & 5 \\
\hline 22 & 32-MF-217 & JF735304 & $989 / 99$ & Ascomycota & Pezizomycotina & Sordariomycetes & Hypocreales & Nectriaceae & Ilyonectria & 2 & & 2 \\
\hline 23 & 17-MF-391 & GU566216 & $1016 / 98$ & Ascomycota & Pezizomycotina & Eurotiomycetes & Eurotiales & Trichocomaceae & Penicillium & & 4 & 4 \\
\hline 24 & 10-MF-383 & HM189876 & $985 / 92$ & Basidiomycota & Agaricomycotin & Tremellomycetes & Tremellales & & & 3 & 2 & 5 \\
\hline 25 & $1-\mathrm{MF}-346$ & AJ557830 & $1075 / 99$ & Ascomycota & Pezizomycotina & Sordariomycetes & Hypocreales & Nectriaceae & Nectria & 36 & 97 & 133 \\
\hline
\end{tabular}


Table 4.7. Shannon diversity index $(H)$, richness $(\mathrm{S})$, and evenness $(E)$, of bacterial and fungal DGGE fingerprint profiles, in soils from ridge (RD), dry swale (SWD), and/or flooded swale (SWF) microsite elevations, from one alluvial (AL) and one blackwater (BW) FF. 


\begin{tabular}{|c|c|c|c|c|c|c|c|}
\hline \multirow[b]{2}{*}{ BW Floodplain } & \multirow[b]{2}{*}{ Topo. } & \multicolumn{3}{|c|}{ Bacterial DGGE profile } & \multicolumn{3}{|c|}{ Fungal DGGE profile } \\
\hline & & $\boldsymbol{H}$ & $\mathbf{S}$ & $E_{H}$ & $H$ & S & $E_{H}$ \\
\hline Black R., NC & $\mathrm{RD} 1$ & 2.25 & 14 & 0.85 & 1.77 & 9 & 0.81 \\
\hline --- " --- & $\mathrm{RD} 2$ & 2.12 & 14 & 0.80 & 1.22 & 5 & 0.76 \\
\hline --- " --- & $\mathrm{RD} 3$ & 2.01 & 14 & 0.76 & 1.77 & 7 & 0.91 \\
\hline --- " --- & $\mathrm{RD} 4$ & 2.36 & 19 & 0.80 & 1.40 & 5 & 0.87 \\
\hline --- " --- & RD 5 & 2.45 & 17 & 0.86 & 2.25 & 11 & 0.94 \\
\hline --- " --- & $\mathrm{RD} 6$ & 2.51 & 19 & 0.85 & 1.29 & 5 & 0.80 \\
\hline Black R., NC & SW 1 & 1.56 & 13 & 0.61 & 1.60 & 7 & 0.82 \\
\hline --- " --- & SW 2 & 2.31 & 13 & 0.90 & 1.75 & 7 & 0.90 \\
\hline --- " --- & SWF 3 & 2.37 & 17 & 0.84 & 2.48 & 13 & 0.96 \\
\hline --- " --- & SWF 4 & 2.05 & 17 & 0.72 & 1.54 & 6 & 0.86 \\
\hline --- " --- & SWF 5 & 1.89 & 11 & 0.79 & 1.30 & 4 & 0.93 \\
\hline --- " --- & SWF 6 & 2.25 & 13 & 0.88 & 1.50 & 5 & 0.93 \\
\hline BW-Overall Mean & & 2.18 & 15 & 0.81 & $* 1.66^{B}$ & $* * 7^{B}$ & 0.87 \\
\hline AL Floodplain & & & & & & & \\
\hline Wateree R., SC & $\mathrm{RD} 1$ & 2.05 & 13 & 0.80 & 2.22 & 10 & 0.96 \\
\hline --- " --- & $\mathrm{RD} 2$ & 2.23 & 15 & 0.83 & 2.25 & 13 & 0.88 \\
\hline --- " --- & $\mathrm{RD} 3$ & 2.03 & 13 & 0.79 & 2.02 & 8 & 0.97 \\
\hline --- " --- & $\mathrm{RD} 4$ & 2.00 & 13 & 0.78 & 1.71 & 8 & 0.82 \\
\hline --- " --- & RD 5 & 2.27 & 15 & 0.84 & 2.38 & 14 & 0.90 \\
\hline --- " --- & $\mathrm{RD} 6$ & 2.19 & 14 & 0.83 & 1.57 & 7 & 0.81 \\
\hline Wateree R., SC & SW 1 & 2.42 & 17 & 0.85 & 1.69 & 7 & 0.87 \\
\hline --- " --- & SW 2 & 2.41 & 16 & 0.87 & 2.28 & 13 & 0.89 \\
\hline --- " --- & SW 3 & 2.28 & 16 & 0.82 & 2.08 & 10 & 0.90 \\
\hline --- " --- & SW 4 & 2.45 & 16 & 0.88 & 2.11 & 9 & 0.96 \\
\hline --- " --- & SW 5 & 2.23 & 14 & 0.84 & 2.15 & 10 & 0.93 \\
\hline --- " --- & SW 6 & 2.23 & 16 & 0.81 & 2.18 & 11 & 0.91 \\
\hline$A L-$ Overall Mean & & 2.23 & 15 & 0.83 & $* 2.05^{A}$ & $* * 10^{A}$ & 0.90 \\
\hline AL \& BW - RD Mean & & 2.21 & 15 & 0.82 & 1.82 & 9 & 0.87 \\
\hline AL \& BW - SW Mean & & 2.20 & 15 & 0.82 & 1.89 & 9 & 0.91 \\
\hline
\end{tabular}

${ }^{*} p=0.007, F=8.880,{ }^{* *} p=0.009, F=8.250$ 
Table 4.8. Shannon diversity index $(H)$, richness $(\mathrm{S})$, and evenness $(E)$, of bacterial and fungal DGGE fingerprint profiles of soils from ridge (RD), dry swale (SWD), and/or flooded swale (SWF) microsites in four alluvial (AL) and four blackwater (BW) FFs. 


\begin{tabular}{|c|c|c|c|c|c|c|c|}
\hline \multirow[b]{2}{*}{ BW Floodplain } & \multirow[b]{2}{*}{ Topo. } & \multicolumn{3}{|c|}{ Bacterial DGGE profile } & \multicolumn{3}{|c|}{ Fungal DGGE profile } \\
\hline & & $\boldsymbol{H}$ & $\mathbf{S}$ & $E_{H}$ & $\boldsymbol{H}$ & $\mathbf{S}$ & $E_{H}$ \\
\hline Black R., NC & $\mathrm{RD}$ & 2.44 & 22 & 0.79 & 1.60 & 6 & 0.89 \\
\hline --- " --- & SWF & 2.82 & 22 & 0.91 & 2.54 & 15 & 0.94 \\
\hline Drowning Creek, NC & SWF a & 2.60 & 19 & 0.88 & 0.70 & 4 & 0.50 \\
\hline --- " --- & SWF b & 2.75 & 21 & 0.90 & 1.00 & 5 & 0.62 \\
\hline Satilla River, GA & $\mathrm{RD}$ & 2.51 & 16 & 0.90 & 1.69 & 7 & 0.87 \\
\hline --- " --- & SWF & 2.19 & 15 & 0.81 & 1.79 & 13 & 0.70 \\
\hline Salkehatchie River, SC & SWF a & 2.45 & 14 & 0.93 & 1.32 & 8 & 0.63 \\
\hline --- " --- & SWF b & 2.49 & 14 & 0.94 & 1.69 & 10 & 0.74 \\
\hline BW-Overall Mean & & 2.53 & 18 & 0.88 & 1.54 & 9 & 0.74 \\
\hline AL Floodplain & & & & & & & \\
\hline Wateree R., SC & $\mathrm{RD}$ & 2.81 & 19 & 0.95 & 2.27 & 13 & 0.89 \\
\hline --- " --- & SW & 2.66 & 17 & 0.94 & 1.11 & 6 & 0.62 \\
\hline Pee Dee River, SC & $\mathrm{RD}$ & 2.73 & 18 & 0.95 & 1.90 & 8 & 0.92 \\
\hline --- " --- & SWF & 2.44 & 17 & 0.86 & 1.63 & 7 & 0.84 \\
\hline Nottaway River, VA & $\mathrm{RD}$ & 2.76 & 19 & 0.94 & 1.44 & 7 & 0.74 \\
\hline --- "--- & SWF & 2.71 & 21 & 0.89 & 1.95 & 11 & 0.82 \\
\hline Ocmulgee River, Ga & $\mathrm{RD}$ & 2.64 & 19 & 0.90 & 1.59 & 6 & 0.89 \\
\hline --- " --- & SWF & 2.91 & 22 & 0.94 & 1.16 & 5 & 0.72 \\
\hline$A L-$ Overall Mean & & 2.71 & 19 & 0.92 & 1.63 & 8 & 0.80 \\
\hline AL \& BW - RD Mean & & 2.65 & 19 & 0.90 & 1.75 & 8 & $\overline{0.87}$ \\
\hline AL \& BW - SW Mean & & 2.60 & 18 & 0.90 & 1.49 & 8 & 0.71 \\
\hline
\end{tabular}




\section{CHAPTER 5}

\section{General Conclusions}

Although the vulnerability of natural waters to anthropogenic phosphorus (P) enrichment has long been recognized, successful remediation strategies to provide a sound basis for the management of aquatic ecosystems are much needed (Fisher et al. 1995, Costanza et al. 1997). The nutrient retention and transformation capacities of riparian wetlands (including floodplain forests (FFs) may be one mode of defense against reducing water-associated contaminants and excess nutrients (such as $\mathrm{P}$ ), to achieve the required $\mathrm{P}$ load reduction in riverine systems, and mitigate the consequent eutrophication of aquatic ecosystems. The goal of this dissertation was to improve our understanding of the dominant mechanisms of $\mathrm{P}$ retention and transformation in floodplain forests of the southeastern (SE) US.

To explore these processes of $\mathrm{P}$ retention and transformation during flooding events, I characterized the various forms and relative proportions of inorganic and organic $\mathrm{P}$ chemistries (using ${ }^{31} \mathrm{P}$ nuclear magnetic resonance (NMR) spectroscopy) in inflow and outflow floodwaters in two Alluvial (AL) and two Blackwater (BW) FFs (Chapter 2), and assessed the dominant fate(s) of inorganic $\mathrm{P}$ received in floodwaters by adding ${ }^{32} \mathrm{PO}_{4}{ }^{3-}$ to soil (collected at $2 \mathrm{AL}$ and 2 BW FFs) mesocosms during simulated flooding events in the laboratory (Chapter 3). Despite the significant role of microorganisms in soil $\mathrm{P}$ dynamics, little is known about the metabolic processes or taxonomic composition of the bacteria and fungi involved in the retention and transformation of $\mathrm{P}$ in FFs. To approach this poorly explored subject, I examined variations in bacterial and/or fungal community structure as a function of floodplain type (4 AL vs. $4 \mathrm{BW}$ ), microsite elevation (high elevation ridge, $\mathrm{RD}$ vs. low elevation $\mathrm{SW}$ ), and associated variations in 
soil chemical parameters (total carbon $(\mathrm{C})$, nitrogen $(\mathrm{N}), \mathrm{P}$, microbial $\mathrm{P}$, soil $\mathrm{pH}$ and moisture content) in FFs, and how these variations, in turn, might affect the retention and transformation of P (Chapter 4).

A number of studies have examined rates of P retention and transformation in FFs (Mitsch et al. 1979, Brinson et al. 1984, Craft and Casey 2000, Stoeckel and Miller-Goodman 2001, Bruland and Richardson 2005, Noe and Hupp 2007), and yet none have detailed the various forms and concentrations of $\mathrm{P}$, particularly organic $\mathrm{P}$, in inflow versus outflow floodwaters during overbank flooding. We developed an improved method in the use of ${ }^{31} \mathrm{P}$ NMR spectroscopy to characterize both dissolved and particulate forms of inorganic and organic $\mathrm{P}$ in freshwaters (Cade-Menun et al. 2006), which facilitates these types of analyses in floodwaters entering FFs in the SE US (Chapter 2). Total P (the sum of dissolved P (DP) and particulate P (PP)) concentrations were similar in floodwaters collected at both the river inlet (RI) and within the floodplain (FP) at $\mathrm{AL}$ and $\mathrm{BW}$ floodplain types, which suggests that $\mathrm{TP}$ pools were neither an overall sink nor source from AL and BW floodplains. But rather an indication of the transformation of $\mathrm{P}$ (from inorganic $\left(\mathrm{P}_{\mathrm{i}}\right)$ to organic $\left(\mathrm{P}_{\mathrm{o}}\right)$ form) carried with floodwaters prior to exiting the FF. During these spring flooding events, AL and BW floodplains transformed 21 and $11 \%$ of the sum of NMR-visible dissolved inorganic P (DIP) forms, respectively, and of these DIP forms, the most readily bioavailable - orthophosphate in river waters was transformed at rates of 26 and $17 \%$ within $\mathrm{AL}$ and $\mathrm{BW}$ floodplains, respectively. While total dissolved $\mathrm{P}$ (TDP) and dissolved orthophosphate concentrations declined from RI to FP, total dissolved organic P (DOP) and dissolved pyrophosphate concentrations were significantly higher in FP than in RI waters. Similarly, orthophosphate monoesters (comprising the majority of the DOP 
pool) were significantly higher in FP than in RI floodwaters in both AL and BW systems. This conversion of DIP forms (e.g. orthophosphate) to dissolved condensed inorganic P forms (pyrophosphates) and low molecular weight DOP compounds (e.g. orthophosphate monoesters) suggests biological $\mathrm{P}$ transformation, an important process occurring during flooding events likely leads to less available P forms being carried with floodwaters exiting these FFs, thus reducing their potential to cause the eutrophication of downstream waters.

To assess the dominant fate(s) of inorganic $\mathrm{P}$ received in floodwaters, I determined the distribution of $\mathrm{P}$ in soils (by a detailed sequential soil $\mathrm{P}$ fractionation procedure) after adding ${ }^{32} \mathrm{PO}_{4}{ }^{3-}$ to soil mesocosms during simulated flooding events in the laboratory (Chapter 3). While a majority of the ${ }^{32} \mathrm{PO}_{4}{ }^{3-}$ introduced in floodwaters was transformed to organic $\mathrm{P}$ forms $\left({ }^{32} \mathrm{P}_{\mathrm{o}}\right)$ in the river water column in $\mathrm{BW}$ rivers, a substantial amount of added ${ }^{32} \mathrm{PO}_{4}{ }^{3-}$ was additionally transformed to ${ }^{32} \mathrm{P}_{\mathrm{o}}$ in headwaters upon contact with the soils surface in $\mathrm{AL}$ and $\mathrm{BW}$ cores. This rapid and substantial transformation of $\mathrm{P}$ suggests biotic uptake of ${ }^{32} \mathrm{PO}_{4}{ }^{3-}$ in floodwaters. Floodplain soils had superior P retention capacities, retaining an average $88 \%$ of ${ }^{32} \mathrm{P}$ label introduced with floodwaters that was distributed within the soil fractions (73\%), microbial biomass, $(9 \%)$ and associated with the root/rhizosphere $(6 \%)$ across $\mathrm{AL}$ and $\mathrm{BW}$ soil cores. Most of the ${ }^{32} \mathrm{P}$ retained was associated with the $\mathrm{NaOH}, \mathrm{BD}$, Res, and $\mathrm{HA}$ extractable soil fractions, sorbed to aluminum (Al) and/or clay minerals in the $\mathrm{NaOH}$, Res, and $\mathrm{H}_{2} \mathrm{O}$ extractable fractions, or strongly associated with iron $(\mathrm{Fe})$ in the $\mathrm{BD}$ and $\mathrm{HCl}$ fractions in both $\mathrm{AL}$ and $\mathrm{BW}$ soils. The ${ }^{32} \mathrm{P}$ extracted from the HA-P fraction, however, differed between AL and BW soils; the accumulation of ${ }^{32} \mathrm{P}$ in the HA fraction in BW soils was more strongly linked to the presence of $\mathrm{Al}$, whereas the accumulation of ${ }^{32} \mathrm{P}$ in the $\mathrm{HA}$ fraction in $\mathrm{AL}$ soils was more strongly linked 
to the presence of Fe. The fact that concentrations of HA-Fe in AL soils were not significantly reduced with prolonged flooding (i.e., over the 8 day experimental period), suggests that they may represent stable $\mathrm{Fe}^{+2}$ humic compounds.

Results also suggest that floodplain soils act as a second line of defense protecting water quality, by retaining P inputs that are not initially transformed within the water column (river- and headwaters) during flooding events. Although a majority of the ${ }^{32} \mathrm{P}$ added to soils was recovered in the plant available $(\mathrm{NaOH}, \mathrm{BD}$, and $\mathrm{HA})$ and occluded-P (Res) fractions, the highest specific activities (ratio of ${ }^{32} \mathrm{P}$ activity/P concentration) were observed in biologically dominant and available $\mathrm{P}$ pools $\left(\mathrm{H}_{2} \mathrm{O}\right.$ extractable fraction, root/rhizosphere and microbial biomass pools), suggesting the importance of these pools in removing and/or transforming $\mathrm{P}_{\mathrm{i}}$ inputs received in floodwaters. In combination, these processes reduce $\mathrm{P}_{\mathrm{i}}$ inputs to aquatic systems downstream.

Despite our knowledge of the significant role of microorganisms in wetland (including FF) soil P dynamics (Richardson and Marshall 1986, Walbridge 1991, Bedford et al. 1999, Wright et al. 2001, Hogan et al. 2004), little is known about the metabolic processes or taxonomic composition of the bacteria and fungi involved in the retention and transformation of $\mathrm{P}$ in wetlands, especially FFs. In Chapter 4, I compared in detail soil microbial community composition (using a protocol combining bacterial-16S-rDNA and fungal-18S/ITS-rDNA cloning with denaturing gradient gel electrophoresis, DGGE) as a function of microtopographic elevation and FF type in SE US, as related to soil chemical parameters (i.e., pH, C, N, P, and microbial biomass $\mathrm{P}$ ), to examine their effects on microbial community structure. Jaccards 
similarity assessment of DGGE profiles divided soils into two clusters that corresponded with differences in floodplain type (AL vs. BW). In both the clone library and DGGE fingerprint data, the dominant bacterial taxa belonged to the Acidobacteria and Alphaproteobacteria groups, and the most prevalent fungal taxa belonged to the Ascomycota and Basidiomycota subdivisions. Detrended correspondence analysis of DGGE fingerprint data and the subsequent fitting of soil chemical parameters to ordination plots, were in close agreement with the results obtained by cluster analysis, and revealed that soil $\mathrm{P}$ and $\mathrm{pH}$ were associated with the composition of bacterial and fungal communities in AL FFs, whereas, soil C was strongly correlated with the microbial community profiles in BW FFs. These results provide taxonomic identification of the dominant bacteria and fungi in FF soils, and show that differences in floodplain type (AL vs. BW systems of the SE US) are associated with differences in soil $\mathrm{C}, \mathrm{P}$ and $\mathrm{pH}$, that are important predictors of microbial composition.

The central goal of the research presented in this dissertation was to improve our understanding of the dominant mechanisms of $\mathrm{P}$ retention and transformation in FFs of the southeastern (SE) US. To accomplish this goal I used state-of-the-art technologies and novel approaches to examine $\mathrm{P}$ retention and transformation capacities in these unique wetlands. My findings clearly indicate that these floodplain wetlands are indeed valuable ecosystems that have profound effects on the biogeochemical retention and transformation of excess $\mathrm{P}$ loadings carried with floodwaters, playing an important role in maintaining water quality in downstream aquatic ecosystems. It is forecasted that by 2025 as much as two-thirds (an estimated 5 out of the 8 billion people) of the world population will experience severe water scarcity due to climate change impacts and poor water quality resulting from the eutrophication of potable freshwater 
reservoirs (Bennett et al. 2001, Arnell 2004, Conley et al. 2009, Erwin 2009, Hoekstra et al. 2012). North America is likely to be impacted by these trends (Arnell 2004, Conley et al. 2009, Hoekstra et al. 2012), and as such future policy decisions may be dependent on the prioritization of riparian wetlands (particularly FFs) based on their ecosystems functions and values. Yet, wetlands in the US are lost at an alarming rate, (Kress et al. 1996, Mitsch and Gosselink 2007), and freshwater marshes and forested wetlands are the hardest hit, with loss rates of 7 and $5 \%$ per decade, respectively. Despite their importance, in the southern US alone, bottomland hardwood forests (including FFs) continue to be lost at a rapid rate, having declined by 6.5 million ha (77 \% loss) between 1883 - 1991 (Mitsch and Gosselink 2007). In fact, three of the ten FFs studied in this dissertation have been destroyed in the past four years, by draining and clearing forests for timber (Nottaway River, VA), agriculture (Black River, NC), or conversion to pine plantation forestrys (Wateree River, SC). This destruction of FF wetlands and their associated biogeochemical function is likely to add substantially to the eutrophication problem (Carpenter 2005, Mitsch and Gosselink 2007, Dodds et al. 2009), and will continue to do so unless measures are taken to assess the sustainability of the ecosystem services they provide, and successfully replicate them through conservation, creation, and/or restoration of these wetland types. 


\section{REFERENCES}

Arnell, N. W. 2004. Climate change and global water resources: SRES emissions and socioeconomic scenarios. Global Environmental Change-Human and Policy Dimensions 14:31-52.

Bedford, B. L., M. R. Walbridge, and A. Aldous. 1999. Patterns in nutrient availability and plant diversity of temperate North American wetlands. Ecology 80:2151-2169.

Bennett, E. M., S. R. Carpenter, and N. F. Caraco. 2001. Human impact on erodable phosphorus and eutrophication: A global perspective. Bioscience 51:227-234.

Brinson, M. M., H. D. Bradshaw, and E. S. Kane. 1984. Nutrient assimilative-capacity of an alluvial floodplain swamp. Journal of Applied Ecology 21:1041-1057.

Bruland, G. L. and C. J. Richardson. 2005. Hydrologic, edaphic, and vegetative responses to microtopographic reestablishment in a restored wetland. Restoration Ecology 13:515523.

Cade-Menun, B. J., J. A. Navaratnam, and M. R. Walbridge. 2006. Characterizing dissolved and particulate phosphorus in water with P-31 nuclear magnetic resonance spectroscopy. Environmental Science \& Technology 40:7874-7880.

Carpenter, S. R. 2005. Eutrophication of aquatic ecosystems: Bistability and soil phosphorus. Proceedings of the National Academy of Sciences of the United States of America 102:10002-10005.

Conley, D. J., H. W. Paerl, R. W. Howarth, D. F. Boesch, S. P. Seitzinger, K. E. Havens, C. Lancelot, and G. E. Likens. 2009. ECOLOGY Controlling Eutrophication: Nitrogen and Phosphorus. Science 323:1014-1015.

Costanza, R., R. dArge, R. deGroot, S. Farber, M. Grasso, B. Hannon, K. Limburg, S. Naeem, R. V. Oneill, J. Paruelo, R. G. Raskin, P. Sutton, and M. vandenBelt. 1997. The value of the world's ecosystem services and natural capital. Nature 387:253-260. 
Craft, C. B. and W. P. Casey. 2000. Sediment and nutrient accumulation in floodplain and depressional freshwater wetlands of Georgia, USA. Wetlands 20:323-332.

Dodds, W. K., W. W. Bouska, J. L. Eitzmann, T. J. Pilger, K. L. Pitts, A. J. Riley, J. T. Schloesser, and D. J. Thornbrugh. 2009. Eutrophication of US Freshwaters: Analysis of Potential Economic Damages. Environmental Science \& Technology 43:12-19.

Erwin, K. L. 2009. Wetlands and global climate change: the role of wetland restoration in a changing world. Wetlands Ecology and Management 17:71-84.

Fisher, S. G., J. L. Melack, J. U. Grobbelaar, and R. W. Howarth. 1995. Nutrient limitation of phytoplankton and eutrophication of inland, estuarine and marine waters Pages 301-322 in H. Tiessen, editor. Phosphorus in the Global Environment - Transfers, Cycles and Management. Wiley \& Sons, Chichester.

Hoekstra, A. Y., M. M. Mekonnen, A. K. Chapagain, R. E. Mathews, and B. D. Richter. 2012. Global Monthly Water Scarcity: Blue Water Footprints versus Blue Water Availability. Plos One 7.

Hogan, D. M., T. E. Jordan, and M. R. Walbridge. 2004. Phosphorus retention and soil organic carbon in restored and natural freshwater wetlands. Wetlands 24:573-585.

Kress, M. R., M. R. Graves, and S. G. Bourne. 1996. Loss of bottomland hardwood forests and forested wetlands in the Cache River Basin, Arkansas. Wetlands 16:258-263.

Mitsch, W. J., C. L. Dorge, and J. R. Wiemhoff. 1979. Ecosystem dynamics and a phosphorus budget of an Alluvial cypress swamp in Southern Illinois. Ecology 60:1116-1124.

Mitsch, W. J. and J. G. Gosselink. 2007. Wetlands. 4th edition. John Wiley \& Sons, New York.

Noe, G. B. and C. R. Hupp. 2007. Seasonal variation in nutrient retention during inundation of a short-hydroperiod floodplain. River Research and Applications 23:1088-1101.

Richardson, C. J. and P. E. Marshall. 1986. Processes controling movement, storage, and export of phosphorus in a fen peatland. Ecological Monographs 56:279-302. 
Stoeckel, D. M. and M. S. Miller-Goodman. 2001. Seasonal nutrient dynamics of forested floodplain soil influenced by microtopography and depth. Soil Science Society of America Journal 65:922-931.

Walbridge, M. R. 1991. Phosphorus availability in acid organic soils of the lower North-Carolina coastal-plain. Ecology 72:2083-2100.

Wright, R. B., B. G. Lockaby, and M. R. Walbridge. 2001. Phosphorus availability in an artificially flooded southeastern floodplain forest soil. Soil Science Society of America Journal 65:1293-1302. 


\section{APPENDICES}

\section{CHAPTER 2:}

Appendix Table 2.1: Results of a 2-way ANOVA for floodplain type (AL and BW) and sampling location (RI and FP) (and interaction term) in: a) dissolved and particulate Total $\mathrm{P}, \mathrm{MRP}, \mathrm{C}, \mathrm{Al}, \mathrm{Fe}, \mathrm{pH}$, and conductivity measured by chemical analysis, b) NMR visible dissolved $\mathrm{P}$ forms, and c) NMR visible particulate $\mathrm{P}$ forms. Data were $\log$ transformed where necessary to meet the assumptions of normality. Significant effects and interaction terms $(P<0.05)$ are shown in bold. Abbreviations: TDP, total dissolved $\mathrm{P}$; MRP, molybdate reactive $\mathrm{P}$; $\mathrm{C}$, carbon; $\mathrm{Al}$, aluminum; Fe, iron; Cond, conductivity; TPP, total particulate $\mathrm{P}$; orthoP, orthophosphate; pyroP, pyrophosphate; polyP, polyphosphate; PA, phytate; scyllo-IP, scyllo-inositol phosphate; GP, glycerophosphate; DNA, deoxyribonucleic acid; phon, phosphonate. 
Table 2.1 a: Dissolved and particulate Total P, MRP, C, Al, Fe, as well as pH and conductivity.

\begin{tabular}{|c|c|c|c|c|c|c|c|c|c|c|c|}
\hline \multicolumn{2}{|c|}{ Measured Components } & \multicolumn{10}{|c|}{ Dissolved } \\
\hline & & TDP & & SRP & & $\mathrm{C}$ & & $\mathrm{Al}$ & & $\mathrm{Fe}$ & \\
\hline & d. f. & $\mathrm{F}$ & $P$ & $\mathrm{~F}$ & $P$ & $\mathrm{~F}$ & $P$ & $\mathrm{~F}$ & $P$ & & $P$ \\
\hline Floodplain type, F & 1 & 1.896 & 0.218 & 0.117 & 0.744 & 9.856 & 0.020 & 12.787 & 0.012 & 11.676 & 0.014 \\
\hline RI/FP location, L & 1 & 2.794 & 0.146 & 4.796 & 0.071 & 0.054 & 0.823 & 13.602 & 0.010 & 0.429 & 0.537 \\
\hline $\mathrm{F} \times \mathrm{L}$ & 1 & 15.912 & 0.007 & 0.214 & 0.660 & 1.834 & 0.224 & 13.735 & 0.010 & 0.183 & 0.684 \\
\hline \multirow[t]{4}{*}{ Site $[F]$} & 6 & 20.205 & 0.001 & 6.820 & 0.017 & 0.951 & 0.524 & 7.353 & 0.014 & 2.697 & 0.126 \\
\hline & & \multicolumn{4}{|c|}{ Dissolved cont. } & \multicolumn{6}{|c|}{ Particulate } \\
\hline & & $\mathrm{pH}$ & & Cond. & & TPP & & $\mathrm{C}$ & & & \\
\hline & d. f. & $\mathrm{F}$ & $P$ & $\mathrm{~F}$ & $P$ & $\mathrm{~F}$ & $P$ & $\mathrm{~F}$ & $P$ & & \\
\hline Floodplain type, F & 1 & 24.272 & 0.003 & 0.107 & 0.754 & 2.044 & 0.203 & 1.342 & 0.300 & & \\
\hline RI/FP location, L & 1 & 1.116 & 0.331 & 0.621 & 0.461 & 0.001 & 0.973 & 0.666 & 0.452 & & \\
\hline $\mathrm{F} \times \mathrm{L}$ & 1 & 1.415 & 0.280 & 0.033 & 0.862 & 4.704 & 0.073 & 0.822 & 0.406 & & \\
\hline Site $[\mathrm{F}]$ & 1 & 0.6526 & 0.691 & 9.208 & 0.008 & 19.078 & 0.001 & 4.878 & 0.053 & & \\
\hline
\end{tabular}


Table 2.1 b: NMR visible dissolved P forms.

\begin{tabular}{|c|c|c|c|c|c|c|c|c|c|c|c|c|c|c|c|}
\hline \multicolumn{2}{|l|}{ Dissolved P forms } & \multicolumn{8}{|c|}{ Inorganic $\mathbf{P}$} & \multicolumn{6}{|c|}{ Orthophosphate monoesters } \\
\hline & & orthoP & & pyroP & & Polyp & & $\sum \mathrm{P}_{\mathrm{i}}$ & & PA & & scyllo & & GP & \\
\hline & d. f. & $\mathrm{F}$ & $P$ & $\mathrm{~F}$ & $P$ & $\mathrm{~F}$ & $P$ & $\mathrm{~F}$ & $P$ & $\mathrm{~F}$ & $P$ & $\mathrm{~F}$ & $P$ & $\mathrm{~F}$ & $P$ \\
\hline Floodplain type, $\mathrm{F}$ & 1 & 0.441 & 0.531 & 3.279 & 0.120 & 2.695 & 0.152 & 0.055 & 0.822 & 0.286 & 0.612 & 0.808 & 0.403 & 0.041 & 0.846 \\
\hline RI/FP location, $\mathrm{L}$ & 1 & 10.145 & 0.019 & 9.996 & 0.020 & 2.695 & 0.152 & 6.449 & 0.044 & 18.127 & 0.005 & 1.468 & 0.271 & 3.496 & 0.111 \\
\hline $\mathrm{F} \times \mathrm{L}$ & 1 & 0.854 & 0.391 & 0.001 & 0.972 & 2.695 & 0.152 & 0.786 & 0.409 & 0.307 & 0.854 & 2.675 & 0.153 & 0.691 & 0.438 \\
\hline \multirow[t]{4}{*}{ Site $[F]$} & 6 & 5.333 & 0.031 & 3.836 & 0.063 & 1.000 & 0.500 & 7.699 & 0.013 & 17.309 & 0.001 & 0.890 & 0.554 & 6.558 & 0.019 \\
\hline & & \multicolumn{4}{|c|}{ Orthophosphate monoesters cont. } & \multicolumn{6}{|c|}{ Orthophosphate diesters } & & & & \\
\hline & & Other & & $\sum \mathrm{mol}$ & & $\overline{\text { DNA }}$ & & $\overline{\text { other } \mathrm{d}}$ & & $\sum \mathrm{di}$ & & phon & & $\sum \mathrm{P}_{\mathrm{o}}$ & \\
\hline & d. f. & $\mathrm{F}$ & $P$ & $\mathrm{~F}$ & $P$ & $\mathrm{~F}$ & $P$ & $\mathrm{~F}$ & $P$ & $\mathrm{~F}$ & $P$ & $\mathrm{~F}$ & $P$ & & $P$ \\
\hline Floodplain type, F & 1 & 0.001 & 0.975 & 0.041 & 0.847 & 0.022 & 0.887 & 0.258 & 0.629 & 0.118 & 0.742 & 1.000 & 0.356 & 0.055 & 0.822 \\
\hline RI/FP location, L & 1 & 1.968 & 0.210 & 5.831 & 0.048 & 3.107 & 0.128 & 0.039 & 0.850 & 2.315 & 0.179 & 1.000 & 0.356 & 6.449 & 0.044 \\
\hline $\mathrm{F} \times \mathrm{L}$ & 1 & 1.216 & 0.312 & 0.824 & 0.399 & 0.194 & 0.675 & 0.135 & 0.726 & 0.009 & 0.926 & 1.000 & 0.356 & 0.786 & 0.409 \\
\hline Site $[F]$ & 6 & 5.720 & 0.026 & 8.159 & 0.011 & 2.732 & 0.123 & 0.696 & 0.665 & 1.958 & 0.217 & 1.000 & 0.500 & 7.699 & 0.013 \\
\hline
\end{tabular}


Table 2.1 c: NMR visible particulate P forms.

\begin{tabular}{|c|c|c|c|c|c|c|c|c|c|c|c|c|c|c|c|}
\hline \multicolumn{2}{|l|}{ Particulate $P$ forms } & \multicolumn{8}{|c|}{ Inorganic $\mathbf{P}$} & \multicolumn{6}{|c|}{ Orthophosphate monoesters } \\
\hline & & orthoP & & pyroP & & Polyp & & $\sum \mathrm{P}_{\mathrm{i}}$ & & PA & & scyllo-I & & GP & \\
\hline & d. f. & $\mathrm{F}$ & $P$ & $\mathrm{~F}$ & $P$ & $\mathrm{~F}$ & $P$ & $\overrightarrow{\mathrm{F}}$ & $P$ & $\mathrm{~F}$ & $P$ & $\mathrm{~F}$ & $P$ & $\mathrm{~F}$ & $P$ \\
\hline Floodplain type, F & 1 & 3.924 & 0.095 & 0.002 & 0.960 & 1.000 & 0.356 & 4.843 & 0.070 & 0.806 & 0.404 & 13.040 & 0.011 & 2.129 & 0.195 \\
\hline RI/FP location, L & 1 & 0.066 & 0.806 & 1.600 & 0.253 & 1.000 & 0.356 & 0.016 & 0.905 & 5.128 & 0.064 & 1.112 & 0.332 & 0.349 & 0.576 \\
\hline $\mathrm{F} \times \mathrm{L}$ & 1 & 1.158 & 0.323 & 5.627 & 0.055 & 1.000 & 0.356 & 0.832 & 0.397 & 6.000 & 0.049 & 1.095 & 0.336 & 0.444 & 0.530 \\
\hline \multirow[t]{4}{*}{ Site $[F]$} & 6 & 6.525 & 0.019 & 10.737 & 0.005 & 1.000 & 0.500 & 5.379 & 0.030 & 9.879 & 0.007 & 6.437 & 0.020 & 4.229 & 0.051 \\
\hline & & \multicolumn{4}{|c|}{ Orthophosphate monoesters cont. } & \multicolumn{6}{|c|}{ Orthophosphate diesters } & & & & \\
\hline & & other mo & & $\sum$ mono & & DNA & & other $\mathrm{d}$ & & $\sum \mathrm{di}$ & & phon & & $\sum \mathrm{P}_{\mathrm{o}}$ & \\
\hline & d. f. & $\mathrm{F}$ & $P$ & $\vec{F}$ & $P$ & & $P$ & $\mathrm{~F}$ & $P$ & & $P$ & & $P$ & & $P$ \\
\hline Floodplain type, F & 1 & 1.485 & 0.269 & 6.847 & 0.040 & 0.994 & 0.357 & 1.105 & 0.334 & 1.056 & 0.344 & 2.979 & 0.135 & 4.843 & 0.070 \\
\hline RI/FP location, L & 1 & 0.164 & 0.699 & 0.004 & 0.950 & 0.644 & 0.453 & 0.489 & 0.511 & 0.629 & 0.458 & 0.005 & 0.945 & 0.016 & 0.905 \\
\hline $\mathrm{F} \times \mathrm{L}$ & 1 & 1.735 & 0.236 & 0.318 & 0.593 & 3.424 & 0.114 & 3.880 & 0.096 & 3.622 & 0.106 & 0.005 & 0.945 & 0.832 & 0.397 \\
\hline Site $[F]$ & 6 & 11.568 & 0.004 & 4.111 & 0.055 & 9.837 & 0.007 & 9.506 & 0.007 & 9.684 & 0.007 & 0.503 & 0.788 & 5.379 & 0.030 \\
\hline
\end{tabular}




\section{CHAPTER 3:}

Appendix Table 3.1: Results of a 2-way ANOVA for floodplain type (AL and BW), incubation period (non-flooded, 40 h, $8 \mathrm{~d}$ ), and interaction term for total $\mathrm{P}$ concentration and ${ }^{32} \mathrm{P}$ activity recovered in soils, headwater, and drainwater (Table 3.3). Data were log transformed where necessary to meet the assumptions of normality. Significant effects and interaction terms $(P<0.05)$ are shown in bold.

\begin{tabular}{|c|c|c|c|c|c|c|c|c|c|c|c|c|}
\hline & & & \multicolumn{2}{|c|}{ Head-water } & \multicolumn{2}{|l|}{ Root } & \multicolumn{2}{|c|}{ Microbial biomass } & \multicolumn{2}{|c|}{ Soil fractions } & \multicolumn{2}{|c|}{ Drain-water } \\
\hline & d. f. & & $\begin{array}{l}\mathbf{P} \\
\left(\mu \mathrm{g} \mathrm{l}^{-2}\right)\end{array}$ & $\begin{array}{l}{ }^{32} \mathbf{P} \\
\text { (\% Recov.) }\end{array}$ & $\begin{array}{l}\mathbf{P} \\
\left(\mathrm{g} \mathrm{m}^{-2}\right)\end{array}$ & $\begin{array}{l}{ }^{32} \mathbf{P} \\
\text { (\% Recov.) }\end{array}$ & $\begin{array}{l}\mathbf{P} \\
\left(\mathrm{g} \mathrm{m}^{-2}\right)\end{array}$ & $\begin{array}{l}{ }^{32} \mathbf{P} \\
(\% \text { Recov.) }\end{array}$ & $\begin{array}{l}\mathbf{P} \\
\left(\mathrm{g} \mathrm{m}^{-2}\right)\end{array}$ & $\begin{array}{l}{ }^{32} \mathbf{P} \\
(\% \text { Recov.) }\end{array}$ & $\begin{array}{l}\mathbf{P} \\
\left(\mu \mathrm{g} \mathrm{l}^{-2}\right)\end{array}$ & $\begin{array}{l}{ }^{32} \mathbf{P} \\
\text { (\% Recov.) }\end{array}$ \\
\hline Floodplain type, $\mathrm{F}$ & 1 & $\begin{array}{l}\mathrm{F} \\
P\end{array}$ & $\begin{array}{l}3.3251 \\
0.2098\end{array}$ & $\begin{array}{l}0.5878 \\
0.5234\end{array}$ & $\begin{array}{l}0.1216 \\
0.7606\end{array}$ & $\begin{array}{l}1.0993 \\
0.4044\end{array}$ & $\begin{array}{l}0.0470 \\
0.8485\end{array}$ & $\begin{array}{l}8.2108 \\
0.1033\end{array}$ & $\begin{array}{l}1.6732 \\
0.3251\end{array}$ & $\begin{array}{l}1.5405 \\
0.3404\end{array}$ & $\begin{array}{l}0.0063 \\
0.9439\end{array}$ & $\begin{array}{l}0.5641 \\
0.5309\end{array}$ \\
\hline Site $[F]$ & 2 & $\begin{array}{l}\mathrm{F} \\
P\end{array}$ & $\begin{array}{l}8.7834 \\
0.1022\end{array}$ & $\begin{array}{l}1.9719 \\
0.3365\end{array}$ & $\begin{array}{l}2.9534 \\
0.2529\end{array}$ & $\begin{array}{l}0.4789 \\
0.6762\end{array}$ & $\begin{array}{l}0.3078 \\
0.7502\end{array}$ & $\begin{array}{l}0.4543 \\
0.6876\end{array}$ & $\begin{array}{l}13.9388 \\
0.0147\end{array}$ & $\begin{array}{l}3.5830 \\
0.2182\end{array}$ & $\begin{array}{l}0.6637 \\
0.6011\end{array}$ & $\begin{array}{l}1.9504 \\
0.3389\end{array}$ \\
\hline Incubation, I & 1 & $\begin{array}{l}\mathrm{F} \\
P\end{array}$ & $\begin{array}{l}0.0668 \\
0.8202\end{array}$ & $\begin{array}{l}0.0244 \\
0.8902\end{array}$ & $\begin{array}{l}0.7023 \\
0.4901\end{array}$ & $\begin{array}{l}0.0004 \\
0.9866\end{array}$ & $\begin{array}{l}2.4443 \\
0.2025\end{array}$ & $\begin{array}{l}1.5480 \\
0.3395\end{array}$ & $\begin{array}{l}2.6812 \\
0.1825\end{array}$ & $\begin{array}{l}0.1618 \\
0.7264\end{array}$ & $\begin{array}{l}0.7603 \\
0.4738\end{array}$ & $\begin{array}{l}0.4653 \\
0.5655\end{array}$ \\
\hline $\mathrm{I} \times \mathrm{F}$ & 1 & $\begin{array}{l}\mathrm{F} \\
P\end{array}$ & $\begin{array}{l}0.0054 \\
0.9479 \\
\end{array}$ & $\begin{array}{l}0.4573 \\
0.5686 \\
\end{array}$ & $\begin{array}{l}0.1142 \\
0.7675\end{array}$ & $\begin{array}{l}0.1005 \\
0.7812 \\
\end{array}$ & $\begin{array}{l}7.4280 \\
0.0450 \\
\end{array}$ & $\begin{array}{l}0.0001 \\
0.9939 \\
\end{array}$ & $\begin{array}{l}0.0240 \\
0.9764\end{array}$ & $\begin{array}{l}0.9324 \\
0.4361 \\
\end{array}$ & $\begin{array}{l}0.8381 \\
0.4552 \\
\end{array}$ & $\begin{array}{l}0.2048 \\
0.6951 \\
\end{array}$ \\
\hline $\mathrm{I} \times$ Site $[\mathrm{F}]$ & 2 & $\begin{array}{l}\mathrm{F} \\
P\end{array}$ & $\begin{array}{l}1.8194 \\
0.1838\end{array}$ & $\begin{array}{l}8.2375 \\
0.0019\end{array}$ & $\begin{array}{l}2.7887 \\
0.0823\end{array}$ & $\begin{array}{l}4.9135 \\
0.0163\end{array}$ & $\begin{array}{l}2.1301 \\
0.1035\end{array}$ & $\begin{array}{l}3.1413 \\
0.0614\end{array}$ & $\begin{array}{l}4.4840 \\
0.0063\end{array}$ & $\begin{array}{l}3.1114 \\
0.0629\end{array}$ & $\begin{array}{l}9.4145 \\
0.0012\end{array}$ & $\begin{array}{l}2.3648 \\
0.1164\end{array}$ \\
\hline
\end{tabular}


Appendix Table 3.2: Results of a 2-way ANOVA for floodplain type (AL and BW), incubation period (control, $40 \mathrm{~h}, 8 \mathrm{~d}$ ), and interaction term for total P content (analyzed by Kjeldahl digest) and soil chemical and physical characteristics (Table 3.4). Data were $\log$ transformed where necessary to meet the assumptions of normality. Significant effects and interaction terms $(P<0.05)$ are shown in bold.

\begin{tabular}{l|l|l|l|l|l|l|l}
\hline \multicolumn{4}{l|}{} & \multicolumn{5}{|c}{ Distribution of P in Soil, Head-water and Drain-water pools } \\
\hline & d. f. & & Total P & $\mathbf{C}$ & $\mathbf{N}$ & $\mathbf{p H}$ & Moisture \\
\hline Floodplain type, F & 1 & $\mathrm{~F}$ & 1.4677 & 0.4249 & 4.4280 & $\mathbf{7 5 . 1 8 2 8}$ & 0.2057 \\
& & $P$ & 0.3494 & 0.5814 & 0.1700 & $\mathbf{0 . 0 1 3 0}$ & 0.6946 \\
\hline Site [F] & 2 & $\mathrm{~F}$ & $\mathbf{3 6 . 3 9 5 4}$ & 5.2152 & 5.3730 & 1.3635 & $\mathbf{8 . 0 4 8 4}$ \\
& & $P$ & $\mathbf{0 . 0 0 2 3}$ & 0.0717 & 0.0656 & 0.3377 & $\mathbf{0 . 0 3 7 3}$ \\
\hline Incubation, I & 1 & $\mathrm{~F}$ & 0.6509 & 2.6310 & 4.1750 & $\mathbf{1 4 . 9 0 3 6}$ & 1.1707 \\
& & $P$ & 0.5692 & 0.1865 & 0.1049 & $\mathbf{0 . 0 1 4 0}$ & 0.3979 \\
\hline I $\times$ F & 1 & $\mathrm{~F}$ & 0.2388 & 0.6583 & 1.9323 & 2.8341 & 0.1600 \\
& & $P$ & 0.7980 & 0.5660 & 0.2587 & 0.1712 & 0.8573 \\
\hline I $\times$ Site [F] & 2 & $\mathrm{~F}$ & $\mathbf{3 . 5 0 8 6}$ & 2.1086 & 1.1435 & 0.5956 & $\mathbf{3 . 6 1 6 1}$ \\
& & $P$ & $\mathbf{0 . 0 3 2 9}$ & 0.1063 & 0.3566 & 0.6687 & $\mathbf{0 . 0 1 6 9}$ \\
\hline
\end{tabular}


Appendix Table 3.3: Results of a 2-way ANOVA for floodplain type (AL and BW), incubation period (control, $40 \mathrm{~h}, 8 \mathrm{~d}$ ), and interaction term for total P content in sequentially extracted fractions (Paludan and Jensen 1995) (Table 3.5). Data were log transformed where necessary to meet the assumptions of normality. Significant effects and interaction terms $(P<0.05)$ are shown in bold.

\begin{tabular}{c|c|c|c|c|l|l|l|l}
\hline \multicolumn{2}{c|}{$\mathbf{P}\left(\mathbf{g ~ m}^{-2}\right)$} & \multicolumn{6}{|c}{ Distribution in soil fractions } \\
\hline & d. f. & & $\mathbf{H}_{\mathbf{2}} \mathbf{O - P}$ & $\mathbf{B D - P}$ & $\mathbf{N a O H - P}$ & $\mathbf{H A - P}$ & HCl-P & Res-P \\
\hline Floodplain type, F & 1 & $\mathrm{~F}$ & 1.9856 & 0.0000 & 1.2134 & 0.9648 & 0.5969 & 1.9580 \\
& & $P$ & 0.2942 & 0.9961 & 0.3855 & 0.4295 & 0.5206 & 0.2967 \\
\hline Site [F] & 2 & $\mathrm{~F}$ & $\mathbf{1 1 . 5 1 8 3}$ & $\mathbf{2 7 . 9 2 9 9}$ & $\mathbf{8 . 7 9 5 4}$ & $\mathbf{8 . 9 4 5 1}$ & $\mathbf{1 3 . 0 1 6 0}$ & $\mathbf{1 9 . 5 3 9 3}$ \\
& & $P$ & $\mathbf{0 . 0 1 6 8}$ & $\mathbf{0 . 0 0 2 9}$ & $\mathbf{0 . 0 3 3 2}$ & $\mathbf{0 . 0 3 0 4}$ & $\mathbf{0 . 0 1 7 2}$ & $\mathbf{0 . 0 0 7 1}$ \\
\hline Incubation, I & 1 & $\mathrm{~F}$ & 6.1987 & $\mathbf{1 0 . 6 0 9 2}$ & 4.0701 & 1.4565 & 5.7828 & 1.7125 \\
& & $P$ & 0.0595 & $\mathbf{0 . 0 2 5 2}$ & 0.1086 & 0.3348 & 0.0660 & 0.2902 \\
\hline I $\times \mathrm{F}$ & 1 & $\mathrm{~F}$ & 1.0773 & 2.8471 & 2.2623 & 0.2977 & 0.9947 & 0.1468 \\
& & $P$ & 0.4224 & 0.1703 & 0.7816 & 0.7577 & 0.4460 & 0.8679 \\
\hline $\mathrm{I} \times$ Site [F] & 2 & $\mathrm{~F}$ & 1.0578 & 1.1119 & $\mathbf{6 . 8 5 9 7}$ & 2.5082 & 9.8096 & 1.9711 \\
& & $P$ & 0.3957 & 0.3706 & $\mathbf{0 . 0 0 0 6}$ & 0.0645 & $<0.0001$ & 0.1264 \\
\hline
\end{tabular}


Appendix Table 3.4: Results of a 2-way ANOVA for floodplain type (AL and BW), incubation period (control, $40 \mathrm{~h}, 8 \mathrm{~d}$ ), and interaction term for ${ }^{32} \mathrm{P}$ recovered in sequentially extracted fractions (Paludan and Jensen 1995) (Table 3.6). Data were log transformed where necessary to meet the assumptions of normality. Significant effects and interaction terms $(P<0.05)$ are shown in bold.

\begin{tabular}{|c|c|c|c|c|c|c|c|c|}
\hline \multicolumn{3}{|l|}{${ }^{32} \mathrm{P}$ (\% recovery) } & \multicolumn{6}{|c|}{ Distribution in soil fractions } \\
\hline & d. f. & & $\mathrm{H}_{2} \mathrm{O}_{-}{ }^{32} \mathrm{P}$ & BD- ${ }^{32} \mathbf{P}$ & $\mathrm{NaOH}-{ }^{32} \mathrm{P}$ & $\mathrm{HA}^{32} \mathbf{P}$ & $\mathrm{HCl}^{-32} \mathrm{P}$ & Res $^{32} \mathbf{P}$ \\
\hline \multirow[t]{2}{*}{ Floodplain type, F } & 1 & $\mathrm{~F}$ & 0.2348 & 0.2154 & 0.0067 & 0.0040 & 0.1406 & 0.4182 \\
\hline & & $P$ & 0.6759 & 0.6882 & 0.9421 & 0.9555 & 0.7437 & 0.5841 \\
\hline \multirow[t]{2}{*}{ Site $[\mathrm{F}]$} & 2 & $\mathrm{~F}$ & 15.8860 & 11.5738 & 16.8031 & 10.8736 & 7.1238 & 1.9834 \\
\hline & & $P$ & 0.0592 & 0.0795 & 0.0562 & 0.0842 & 0.1230 & 0.3352 \\
\hline \multirow[t]{2}{*}{ Incubation, I } & 1 & $\mathrm{~F}$ & 1.0341 & 0.1939 & 1.8800 & 0.6899 & 1.4797 & 1.4033 \\
\hline & & $P$ & 0.4162 & 0.7027 & 0.3039 & 0.4936 & 0.3479 & 0.3579 \\
\hline \multirow[t]{2}{*}{$\mathrm{I} \times \mathrm{F}$} & 1 & $\mathrm{~F}$ & 3.7131 & 0.2809 & 4.3658 & 0.4603 & 0.3096 & 0.2167 \\
\hline & & $P$ & 0.1938 & 0.6491 & 0.1719 & 0.5674 & 0.6339 & 0.6873 \\
\hline \multirow{2}{*}{$\mathrm{I} \times$ Site $[\mathrm{F}]$} & 2 & $\mathrm{~F}$ & 1.7844 & 1.2830 & 0.4113 & 0.5560 & 3.1260 & 2.5093 \\
\hline & & $P$ & 0.1895 & 0.2955 & 0.6674 & 0.5807 & 0.0622 & 0.1024 \\
\hline
\end{tabular}


Appendix Table 3.5: Results of a 2-way ANOVA for floodplain type (AL and BW), incubation period (control, $40 \mathrm{~h}, 8 \mathrm{~d}$ ), and interaction term for the proportion of organic $\mathrm{P}$ in TP measured in headwater, drainwater, microbial biomass, and sequentially extracted soil fractions (Table 3.7). Data were log transformed where necessary to meet the assumptions of normality. Significant effects and interaction terms $(P<0.05)$ are shown in bold.

\begin{tabular}{|c|c|c|c|c|c|c|c|c|c|c|c|c|c|}
\hline & & & Headwater & Drainwater & Microb & biomass & $\mathrm{H}_{2} \mathrm{O}-\mathrm{P}$ & & BD-P & NaOH-F & & HCI-P & Soil sum \\
\hline Floodplain type, F & $\begin{array}{c}\text { d. f. } \\
1\end{array}$ & $\begin{array}{l}\mathrm{F} \\
\mathrm{P}\end{array}$ & $\begin{array}{l}{ }^{32} \mathbf{P}_{\mathbf{o}} \\
0.3004 \\
0.6387\end{array}$ & $\begin{array}{l}{ }^{32} \mathbf{P}_{\mathbf{o}} \\
1.7748 \\
0.3139\end{array}$ & $\begin{array}{l}\mathbf{P}_{\mathbf{o}} \\
0.0326 \\
0.8734\end{array}$ & $\begin{array}{l}{ }^{32} \mathbf{P}_{\mathbf{o}} \\
0.3581 \\
0.6103\end{array}$ & $\begin{array}{l}\mathbf{P}_{\mathbf{o}} \\
2.6053 \\
0.2479\end{array}$ & $\begin{array}{l}{ }^{32} \mathbf{P}_{\mathbf{o}} \\
6.3207 \\
0.1284\end{array}$ & $\begin{array}{l}{ }^{32} \mathbf{P}_{\mathbf{o}} \\
3.5260 \\
0.2012\end{array}$ & $\begin{array}{l}\mathbf{P}_{\mathbf{o}} \\
6.8360 \\
0.1204\end{array}$ & $\begin{array}{l}{ }^{32} \mathbf{P}_{\mathbf{o}} \\
0.4317 \\
0.5786\end{array}$ & $\begin{array}{l}{ }^{32} \mathbf{P}_{\mathbf{o}} \\
0.3416 \\
0.1966\end{array}$ & $\begin{array}{l}{ }^{32} \mathbf{P}_{\mathbf{o}} \\
0.9678 \\
0.4289\end{array}$ \\
\hline Site $[\mathrm{F}]$ & 2 & $\begin{array}{l}\mathrm{F} \\
\mathrm{P}\end{array}$ & $\begin{array}{l}10.0308 \\
0.0907\end{array}$ & $\begin{array}{l}0.2778 \\
0.7826\end{array}$ & $\begin{array}{l}7.5368 \\
0.1171\end{array}$ & $\begin{array}{l}0.3162 \\
0.7598\end{array}$ & $\begin{array}{l}1.4219 \\
0.3301\end{array}$ & $\begin{array}{l}3.2508 \\
0.2353\end{array}$ & $\begin{array}{l}29.7833 \\
0.0325\end{array}$ & $\begin{array}{l}18.0156 \\
0.0091\end{array}$ & $\begin{array}{l}23.0879 \\
0.0415\end{array}$ & $\begin{array}{l}0.3870 \\
0.7210\end{array}$ & $\begin{array}{l}251.0598 \\
0.0040\end{array}$ \\
\hline Incubation, I & 1 & $\begin{array}{l}\mathrm{F} \\
\mathrm{P}\end{array}$ & $\begin{array}{l}0.6472 \\
0.5056\end{array}$ & $\begin{array}{l}3.7426 \\
0.1926\end{array}$ & $\begin{array}{l}4.1842 \\
0.1774\end{array}$ & $\begin{array}{l}0.5621 \\
0.5316\end{array}$ & $\begin{array}{l}0.4665 \\
0.6575\end{array}$ & $\begin{array}{l}9.9714 \\
0.0873\end{array}$ & $\begin{array}{l}6.4306 \\
0.1257\end{array}$ & $\begin{array}{l}2.0199 \\
0.2475\end{array}$ & $\begin{array}{l}0.0012 \\
0.9757\end{array}$ & $\begin{array}{l}0.5447 \\
0.5373\end{array}$ & $\begin{array}{l}9.2996 \\
0.0928\end{array}$ \\
\hline $\mathrm{I} \times \mathrm{F}$ & 1 & $\begin{array}{l}\mathrm{F} \\
\mathrm{P}\end{array}$ & $\begin{array}{l}0.9482 \\
0.4329\end{array}$ & $\begin{array}{l}0.5764 \\
0.5270\end{array}$ & $\begin{array}{l}4.5154 \\
0.1675\end{array}$ & $\begin{array}{l}0.0767 \\
0.8078\end{array}$ & $\begin{array}{l}3.6984 \\
0.1232\end{array}$ & $\begin{array}{l}19.4218 \\
0.0478\end{array}$ & $\begin{array}{l}4.7183 \\
0.1610\end{array}$ & $\begin{array}{l}0.7529 \\
0.5278\end{array}$ & $\begin{array}{l}1.4074 \\
0.3573\end{array}$ & $\begin{array}{l}0.5447 \\
0.5373\end{array}$ & $\begin{array}{l}15.7167 \\
0.0581\end{array}$ \\
\hline $\mathrm{I} \times$ Site $[\mathrm{F}]$ & 2 & $\begin{array}{l}\mathrm{F} \\
\mathrm{P}\end{array}$ & $\begin{array}{l}1.7875 \\
0.1889\end{array}$ & $\begin{array}{l}3.3399 \\
0.0533\end{array}$ & $\begin{array}{l}2.2545 \\
0.1267\end{array}$ & $\begin{array}{l}2.7649 \\
0.0831\end{array}$ & $\begin{array}{l}0.8752 \\
0.4912\end{array}$ & $\begin{array}{l}0.6766 \\
0.5178\end{array}$ & $\begin{array}{l}0.4283 \\
0.6567\end{array}$ & $\begin{array}{l}3.8693 \\
0.0126\end{array}$ & $\begin{array}{l}2.9326 \\
0.0725\end{array}$ & $\begin{array}{l}2.9424 \\
0.0720\end{array}$ & $\begin{array}{l}0.2021 \\
0.8184\end{array}$ \\
\hline
\end{tabular}


Appendix Table 3.6: Results of a 2-way ANOVA for floodplain type (AL and BW), incubation period (control, 40 h, $8 \mathrm{~d}$ ), and interaction term for Specific Activity $\left(\mathrm{SA}:{ }^{32} \mathrm{P} / \mathrm{P}, \mathrm{SA}_{\mathrm{i}}:{ }^{32} \mathrm{P}_{\mathrm{i}} / \mathrm{P}_{\mathrm{i}}, \mathrm{SA}_{\mathrm{o}}:{ }^{32} \mathrm{P}_{\mathrm{o}} / \mathrm{P}_{\mathrm{o}}\right)$ in sequentially extracted fractions (Paludan and Jensen 1995) (Table 3.8). Data were log transformed where necessary to meet the assumptions of normality. Significant effects and interaction terms $(P<0.05)$ are shown in bold.

\begin{tabular}{|c|c|c|c|c|c|c|c|c|c|c|c|c|c|c|}
\hline \multirow[t]{3}{*}{ Specific Activity } & \multicolumn{14}{|c|}{ Soil pools and fractions } \\
\hline & \multirow[t]{2}{*}{ d. f. } & & \multirow{2}{*}{$\begin{array}{c}\text { Root } \\
\text { SA }\end{array}$} & \multicolumn{3}{|c|}{ Microbial } & \multicolumn{2}{|c|}{$\mathrm{H}_{2} \mathrm{O}$} & \multirow{2}{*}{$\begin{array}{l}\text { BD } \\
\text { SA }\end{array}$} & \multicolumn{2}{|c|}{$\mathrm{NaOH}$} & \multirow{2}{*}{$\begin{array}{l}\text { HA } \\
\text { SA }\end{array}$} & \multirow{2}{*}{$\begin{array}{l}\text { HCl } \\
\text { SA }\end{array}$} & \multirow{2}{*}{$\begin{array}{l}\text { Res } \\
\text { SA }\end{array}$} \\
\hline & & & & SA & $\mathrm{SA}_{\mathrm{i}}$ & $\mathrm{SA}_{\mathrm{o}}$ & SA & $\mathrm{SA}_{\mathrm{i}}$ & & SA & $\mathrm{SA}_{\mathrm{i}}$ & & & \\
\hline \multirow[t]{2}{*}{ Floodplain type, $\mathrm{F}$} & 1 & $\mathrm{~F}$ & 3.0957 & 2.3845 & 4.9961 & 5.8229 & 2.5597 & 0.0358 & 0.6256 & 1.4912 & 15.0367 & 0.9528 & 0.0023 & 2.7584 \\
\hline & & $P$ & 0.2204 & 0.2625 & 0.1549 & 0.1327 & 0.2508 & 0.8675 & 0.5119 & 0.3465 & 0.0605 & 0.4320 & 0.9661 & 0.2386 \\
\hline \multirow[t]{2}{*}{ Site $[\mathrm{F}]$} & 2 & $\mathrm{~F}$ & 1.9869 & 0.7124 & 0.0540 & 1.2331 & 1.2702 & 1.4610 & 1.9873 & 0.7457 & 0.4340 & 1.4395 & 0.4418 & 1.0454 \\
\hline & & $P$ & 0.3348 & 0.5840 & 0.9488 & 0.4478 & 0.4405 & 0.4063 & 0.3347 & 0.5728 & 0.5777 & 0.4099 & 0.6936 & 0.4889 \\
\hline \multirow[t]{2}{*}{ Incubation, I } & 1 & $\mathrm{~F}$ & 0.6100 & 1.4910 & 1,5215 & 0.0245 & 2.2078 & 7.1371 & 0.2151 & 0.2452 & 0.5119 & 0.0869 & 0.8725 & 0.7099 \\
\hline & & $P$ & 0.5163 & 0.3465 & 0.3427 & 0.8900 & 0.2756 & 0.1162 & 0.6884 & 0.6696 & 0.5486 & 0.7960 & 0.4489 & 0.4882 \\
\hline \multirow[t]{2}{*}{$\mathrm{I} \times \mathrm{F}$} & 1 & $\mathrm{~F}$ & 3.4881 & 0.0783 & 0.1189 & 3.4694 & 0.2161 & 0.1989 & 0.0249 & 0.4181 & 0.2573 & 0.2303 & 0.8639 & 0.0033 \\
\hline & & $P$ & 0.2024 & 0.8058 & 0.7631 & 0.2036 & 0.6877 & 0.6993 & 0.8892 & 0.5842 & 0.7953 & 0.6787 & 0.4508 & 0.9591 \\
\hline \multirow[t]{2}{*}{$\mathrm{I} \times$ Site $[\mathrm{F}]$} & 2 & $\bar{F}$ & 1.0735 & 5.2129 & 5.5526 & 0.4314 & 11.1452 & 7.7346 & 3.3002 & 5.0217 & 3.7789 & 2.0440 & 9.1993 & 9.3571 \\
\hline & & $P$ & 0.3538 & 0.0132 & 0.0104 & 0.6545 & 0.0004 & 0.0026 & 0.0542 & 0.0151 & 0.0374 & 0.1515 & 0.0011 & 0.0010 \\
\hline
\end{tabular}


Appendix Table 3.7: Results of a 2-way ANOVA for floodplain type (AL and BW), incubation period (control, $40 \mathrm{~h}, 8 \mathrm{~d}$ ), and interaction term for the distribution of total $\mathrm{Al}$ and Fe in sequentially extracted fractions (Paludan and Jensen 1995) (Table 3.9). Data were $\log$ transformed where necessary to meet the assumptions of normality. Significant effects and interaction terms $(P<0.05)$ are shown in bold.

\begin{tabular}{|c|c|c|c|c|c|c|c|c|c|c|c|c|c|c|}
\hline \multicolumn{3}{|l|}{$\mathrm{Al}$ and $\mathrm{Fe}\left(\mathrm{g} \mathrm{m}^{-2}\right)$} & \multicolumn{12}{|c|}{ Distribution of $\mathrm{Al}$ and $\mathrm{Fe}$ in soil fractions } \\
\hline & d. f. & & $\mathrm{H}_{2} \mathbf{O}$ & & BD & & $\mathrm{NaOH}$ & & HA & & $\mathrm{HCl}$ & & Res & \\
\hline & & & $\mathrm{Al}$ & $\mathrm{Fe}$ & $\mathrm{Al}$ & $\mathrm{Fe}$ & $\mathrm{Al}$ & $\mathrm{Fe}$ & $\mathrm{Al}$ & $\mathrm{Fe}$ & $\mathrm{Al}$ & $\mathrm{Fe}$ & $\mathrm{Al}$ & $\mathrm{Fe}$ \\
\hline Floodplain type, $\mathrm{F}$ & 1 & $\begin{array}{l}\mathrm{F} \\
P\end{array}$ & $\begin{array}{l}0.0014 \\
0.9740 \\
\end{array}$ & $\begin{array}{l}0.4475 \\
0.5724 \\
\end{array}$ & $\begin{array}{l}0.3578 \\
0.6105 \\
\end{array}$ & $\begin{array}{l}20.3181 \\
0.0459 \\
\end{array}$ & $\begin{array}{l}0.1214 \\
0.7607 \\
\end{array}$ & $\begin{array}{l}0.5793 \\
0.5261 \\
\end{array}$ & $\begin{array}{l}15.4385 \\
0.0591 \\
\end{array}$ & $\begin{array}{l}26.9253 \\
0.0352 \\
\end{array}$ & $\begin{array}{l}1.5054 \\
0.3447 \\
\end{array}$ & $\begin{array}{l}2.5331 \\
0.2525 \\
\end{array}$ & $\begin{array}{l}2.2680 \\
0.2449 \\
\end{array}$ & $\begin{array}{l}2.8421 \\
0.2339 \\
\end{array}$ \\
\hline Site $[\mathrm{F}]$ & 2 & $\begin{array}{l}\mathrm{F} \\
P \\
\end{array}$ & $\begin{array}{l}11.1668 \\
0.0188 \\
\end{array}$ & $\begin{array}{l}10.3977 \\
0.0101 \\
\end{array}$ & $\begin{array}{l}11.2383 \\
0.0163 \\
\end{array}$ & $\begin{array}{l}6.2002 \\
0.0461 \\
\end{array}$ & $\begin{array}{l}4.5098 \\
0.0859 \\
\end{array}$ & $\begin{array}{l}9.3701 \\
0.0242 \\
\end{array}$ & $\begin{array}{l}0.1269 \\
0.8842 \\
\end{array}$ & $\begin{array}{l}6.8422 \\
0.0217 \\
\end{array}$ & $\begin{array}{l}14.8862 \\
0.0092 \\
\end{array}$ & $\begin{array}{l}15.9911 \\
0.0101 \\
\end{array}$ & $\begin{array}{l}15.2433 \\
0.0105 \\
\end{array}$ & $\begin{array}{l}21.0406 \\
0.0052 \\
\end{array}$ \\
\hline Incubation, I & 1 & $\begin{array}{l}\mathrm{F} \\
P\end{array}$ & $\begin{array}{l}21.7885 \\
0.0071 \\
\end{array}$ & $\begin{array}{l}11.1876 \\
0.0230 \\
\end{array}$ & $\begin{array}{l}17.1963 \\
0.0109 \\
\end{array}$ & $\begin{array}{l}0.3250 \\
0.7400 \\
\end{array}$ & $\begin{array}{l}15.4412 \\
0.0131 \\
\end{array}$ & $\begin{array}{l}2.0259 \\
0.2468 \\
\end{array}$ & $\begin{array}{l}0.4889 \\
0.6457 \\
\end{array}$ & $\begin{array}{l}1.2557 \\
0.3774 \\
\end{array}$ & $\begin{array}{l}1.0636 \\
0.4262 \\
\end{array}$ & $\begin{array}{l}10.1877 \\
0.0269 \\
\end{array}$ & $\begin{array}{l}1.2125 \\
0.3876 \\
\end{array}$ & $\begin{array}{l}0.1909 \\
0.8333 \\
\end{array}$ \\
\hline $\mathrm{I} \times \mathrm{F}$ & 1 & $\begin{array}{l}\mathrm{F} \\
P\end{array}$ & $\begin{array}{l}1.6274 \\
0.3040\end{array}$ & $\begin{array}{l}1.5289 \\
0.3212\end{array}$ & $\begin{array}{l}1.8262 \\
0.2732\end{array}$ & $\begin{array}{l}0.6950 \\
0.5508\end{array}$ & $\begin{array}{l}0.3578 \\
0.7195 \\
\end{array}$ & $\begin{array}{l}0.2353 \\
0.8005\end{array}$ & $\begin{array}{l}0.0821 \\
0.9227\end{array}$ & $\begin{array}{l}2.6863 \\
0.1821\end{array}$ & $\begin{array}{l}1.1365 \\
0.4066\end{array}$ & $\begin{array}{l}4.7313 \\
0.0883\end{array}$ & $\begin{array}{l}1.0854 \\
0.4202\end{array}$ & $\begin{array}{l}4.9921 \\
0.0818\end{array}$ \\
\hline $\bar{I} \times$ Site $[\mathrm{F}]$ & 2 & $\begin{array}{l}\mathrm{F} \\
P\end{array}$ & $\begin{array}{l}1.3221 \\
0.2861 \\
\end{array}$ & $\begin{array}{l}0.2549 \\
0.9042\end{array}$ & $\begin{array}{l}0.8087 \\
0.5302\end{array}$ & $\begin{array}{l}0.6546 \\
0.6286\end{array}$ & $\begin{array}{l}1.3431 \\
0.2787 \\
\end{array}$ & $\begin{array}{l}0.9719 \\
0.4385\end{array}$ & $\begin{array}{l}4.5723 \\
0.0057\end{array}$ & $\begin{array}{l}0.1899 \\
0.9417\end{array}$ & $\begin{array}{l}0.7852 \\
0.5445\end{array}$ & $\begin{array}{l}1.7591 \\
0.1652 \\
\end{array}$ & $\begin{array}{l}1.3789 \\
0.26666\end{array}$ & $\begin{array}{l}1.0817 \\
0.3844\end{array}$ \\
\hline
\end{tabular}




\section{CHAPTER 4:}

Appendix Figure 4.1: Maximum-parsimony tree showing phylogenetic relationships of bacterial 16S rDNA sequences cloned from soils from one alluvial (AL) (Wateree R., SC) and one blackwater (BL) (Black R., NC) FF, to related sequences from GenBank: (a) Acidobacteria; (b) Alpha- and Gamma-proteobacteria; (c) Actinobacteria, Bacteroidetes, Chlorofelxi, Fimicutes, Gemmatimonadetes, Beta-, and Delta-proteobacteria. 


\section{Appendix Figure 4.1 a}

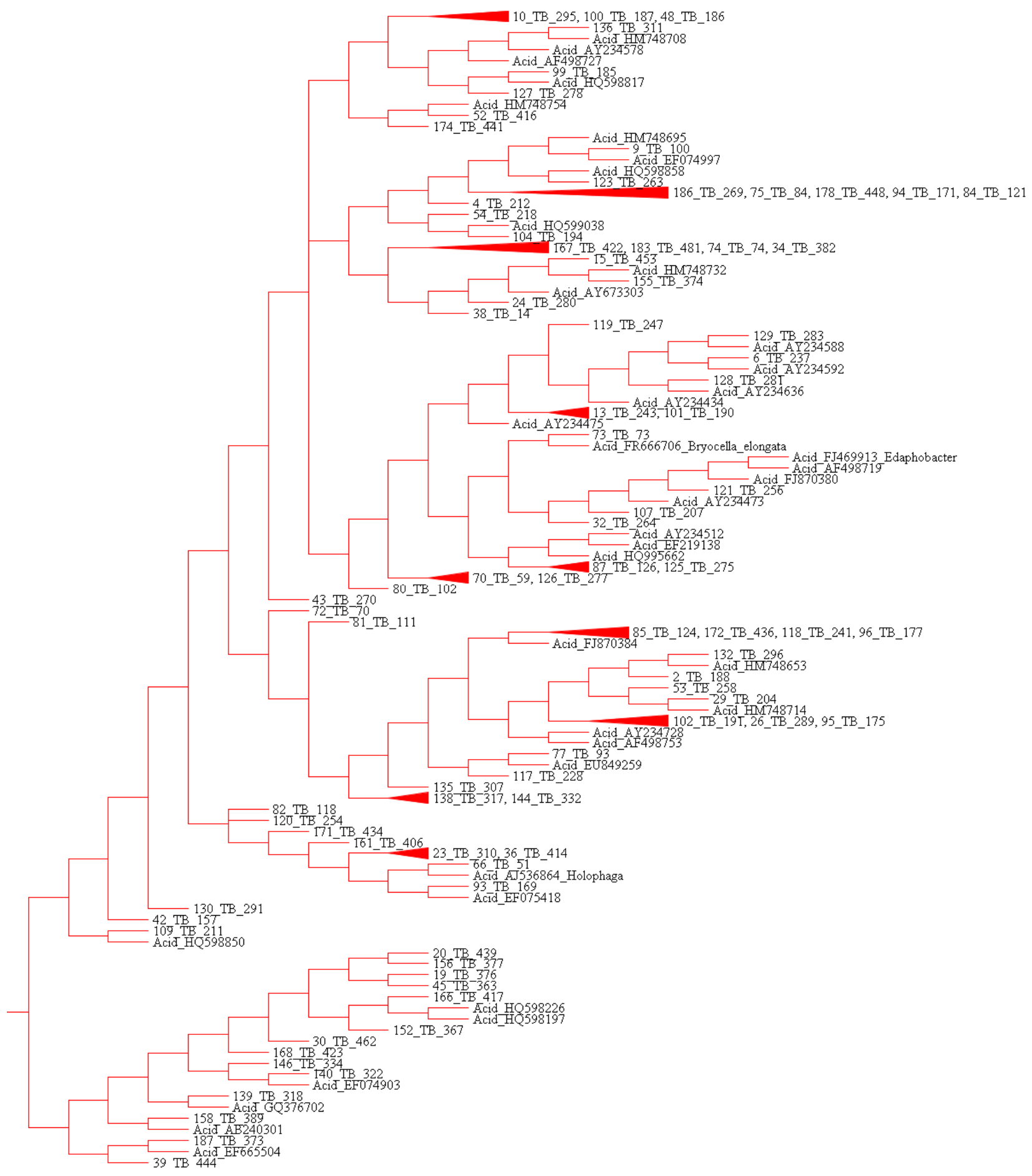




\section{Appendix Figure 4.1 b}

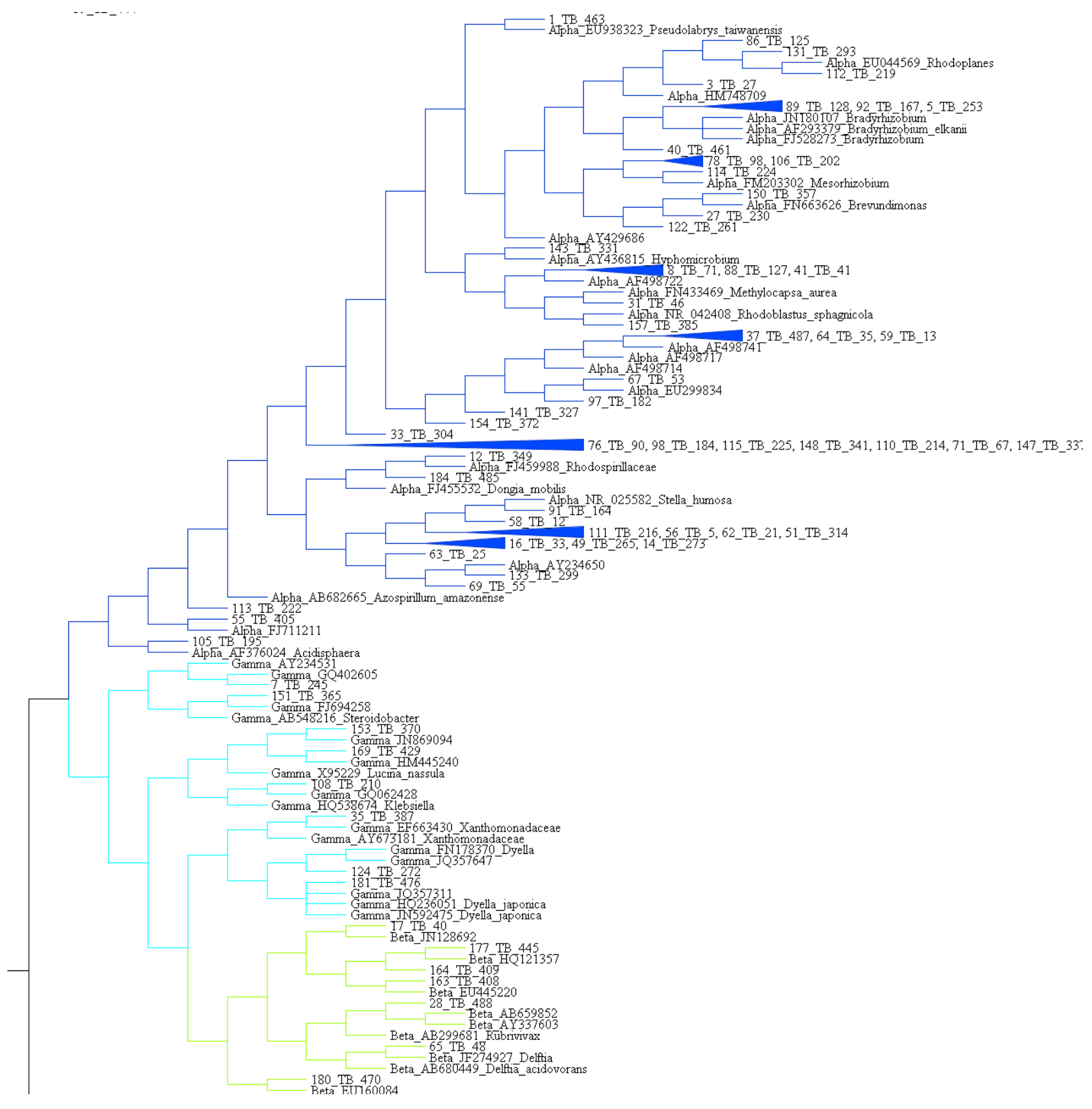




\section{Appendix Figure $4.1 \mathrm{c}$}

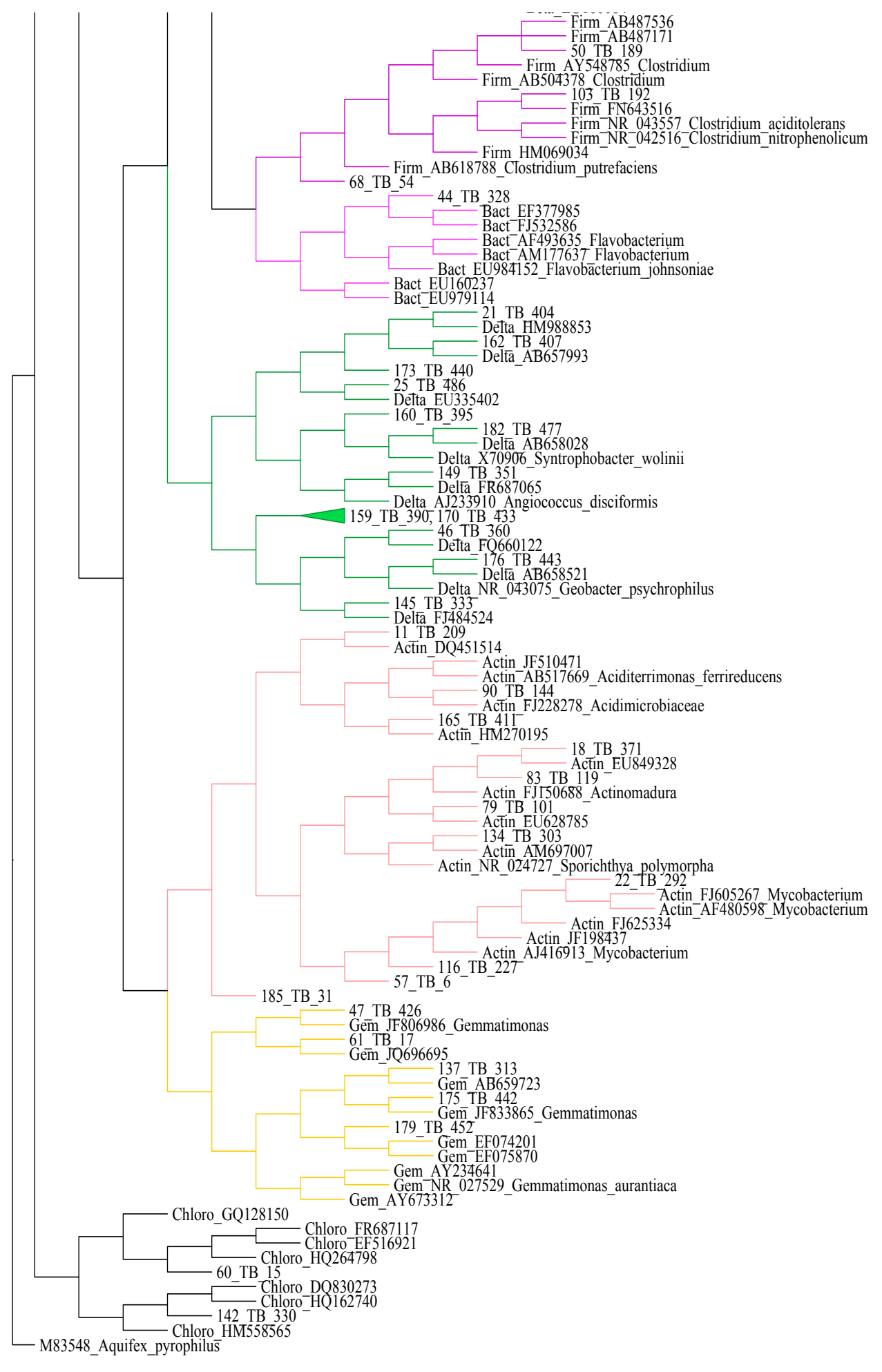


Appendix Figure 4.2: Maximum-parsimony tree showing phylogenetic relationships of fungal ITS sequences cloned from soils from one alluvial (AL) (Wateree R., SC) and one blackwater (BL) (Black R., NC) FF, to related sequences from GenBank: (a) Ascomycota; (b) Basidiomycota, Chytridiomycota, and Zygomycota. 


\section{Appendix Figure 4.2 a}

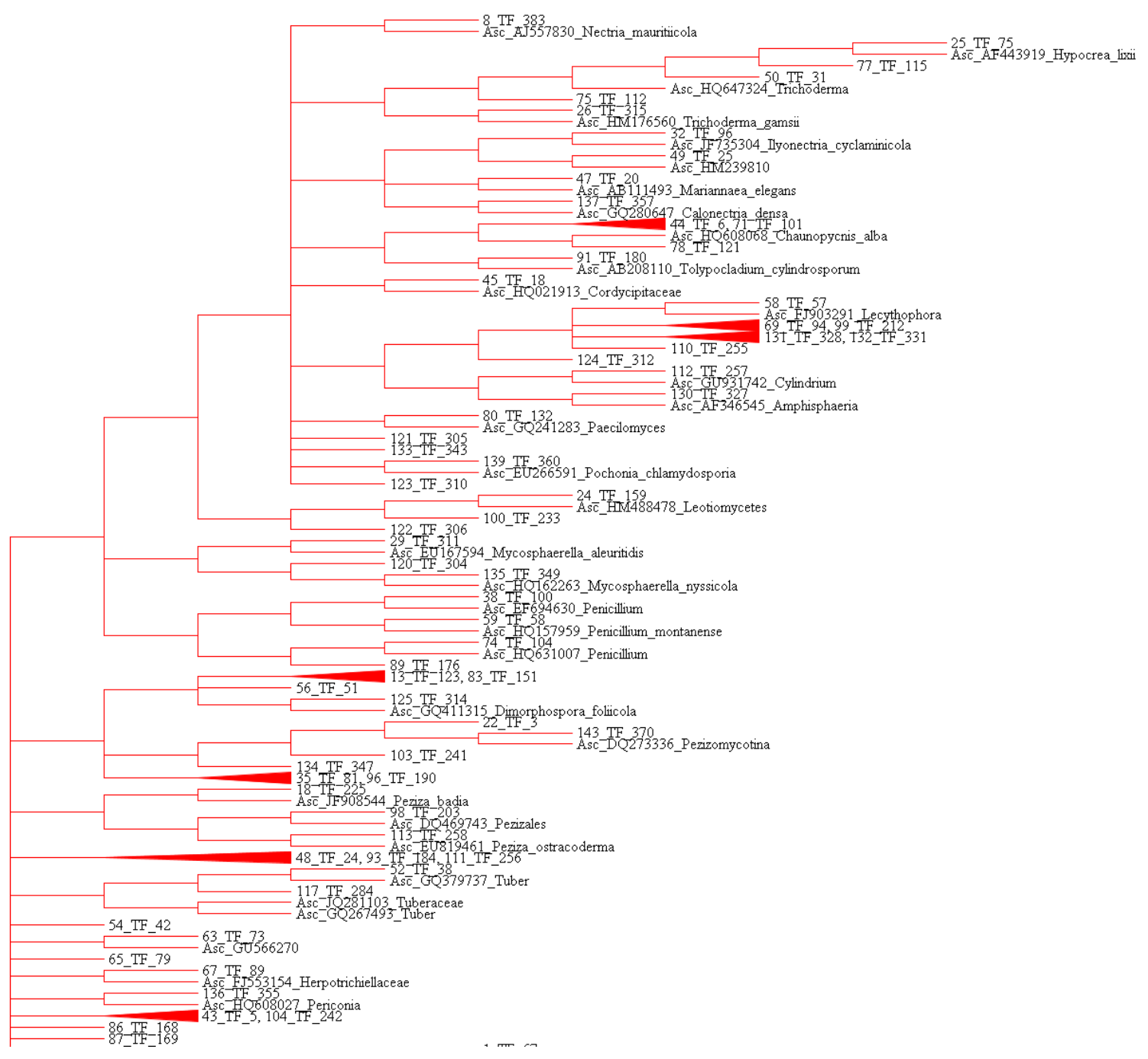




\section{Appendix Figure $4.2 \mathrm{~b}$}

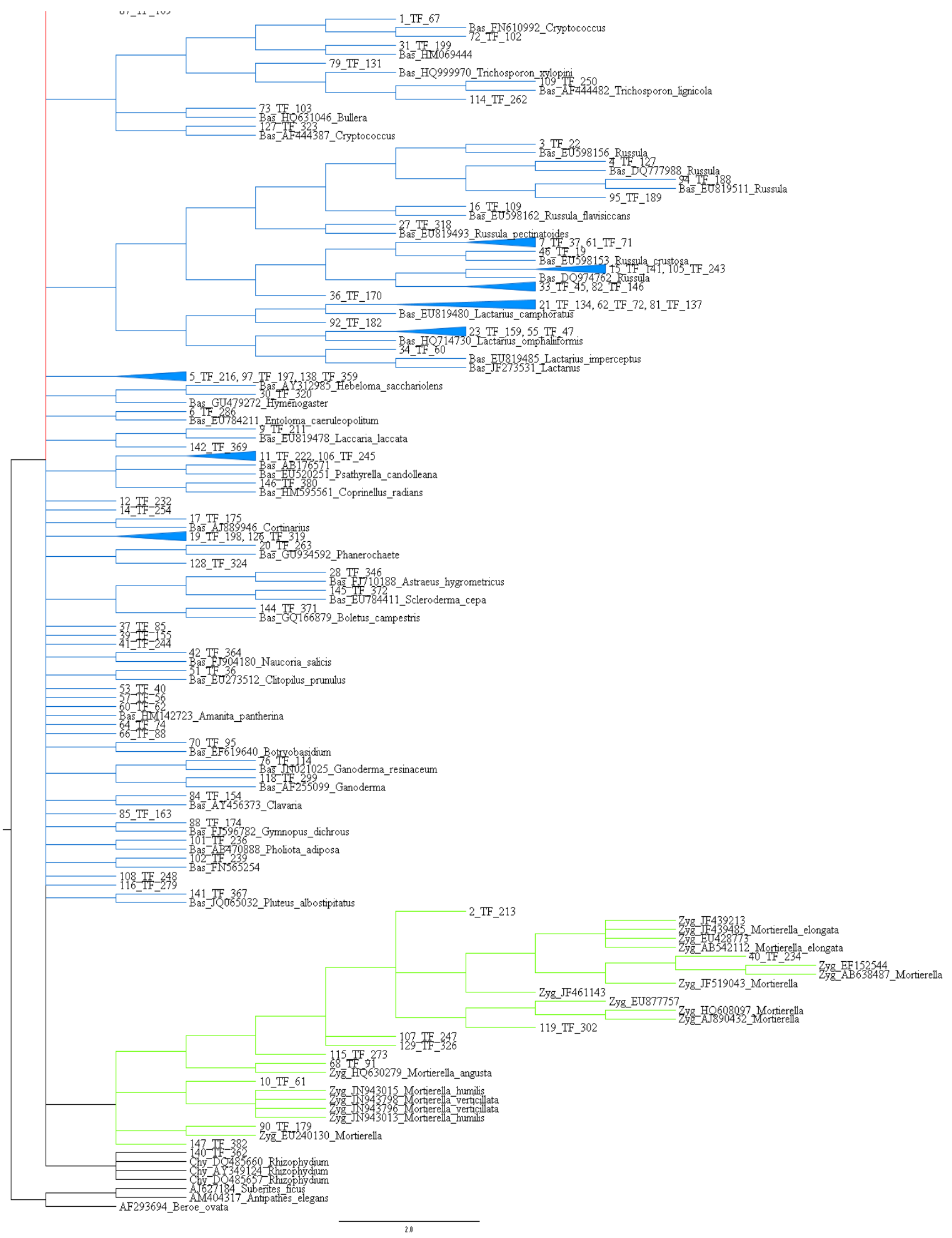


Appendix Figure 4.3. Maximum-parsimony tree showing phylogenetic relationships of bacterial 16S rDNA sequences cloned from soils from ridge and swale microsite elevations in four alluvial (AL) (Wateree R., SC; Pee Dee R., SC; Nottaway R., VA; Ocmulgee R., GA) and four blackwater (BL) (Black R., NC; Drowning Cr., NC; Satilla R., GA; Salkehatchie R., SC) FFs, to related sequences from GenBank: (a) Actinobacteria Bacteroidetes, Fimicutes;

(b) Acidobacteria; (c) Chlorofelxi, Nitrospirae; Alpha-, Beta-, and Gamma-proteobacteria. 


\section{Appendix Figure 4.3 a}
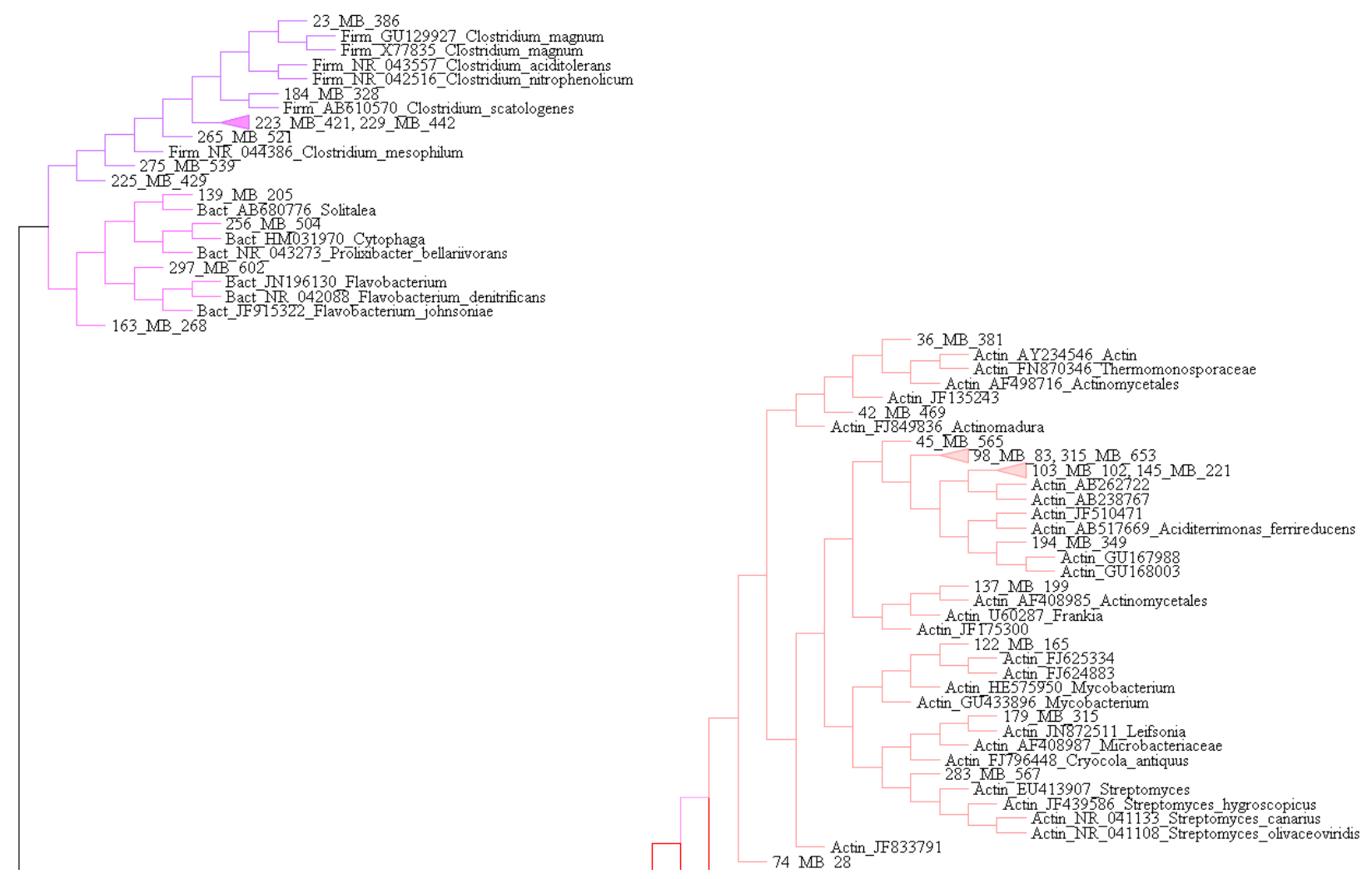


\section{Appendix Figure $4.3 \mathrm{~b}$}

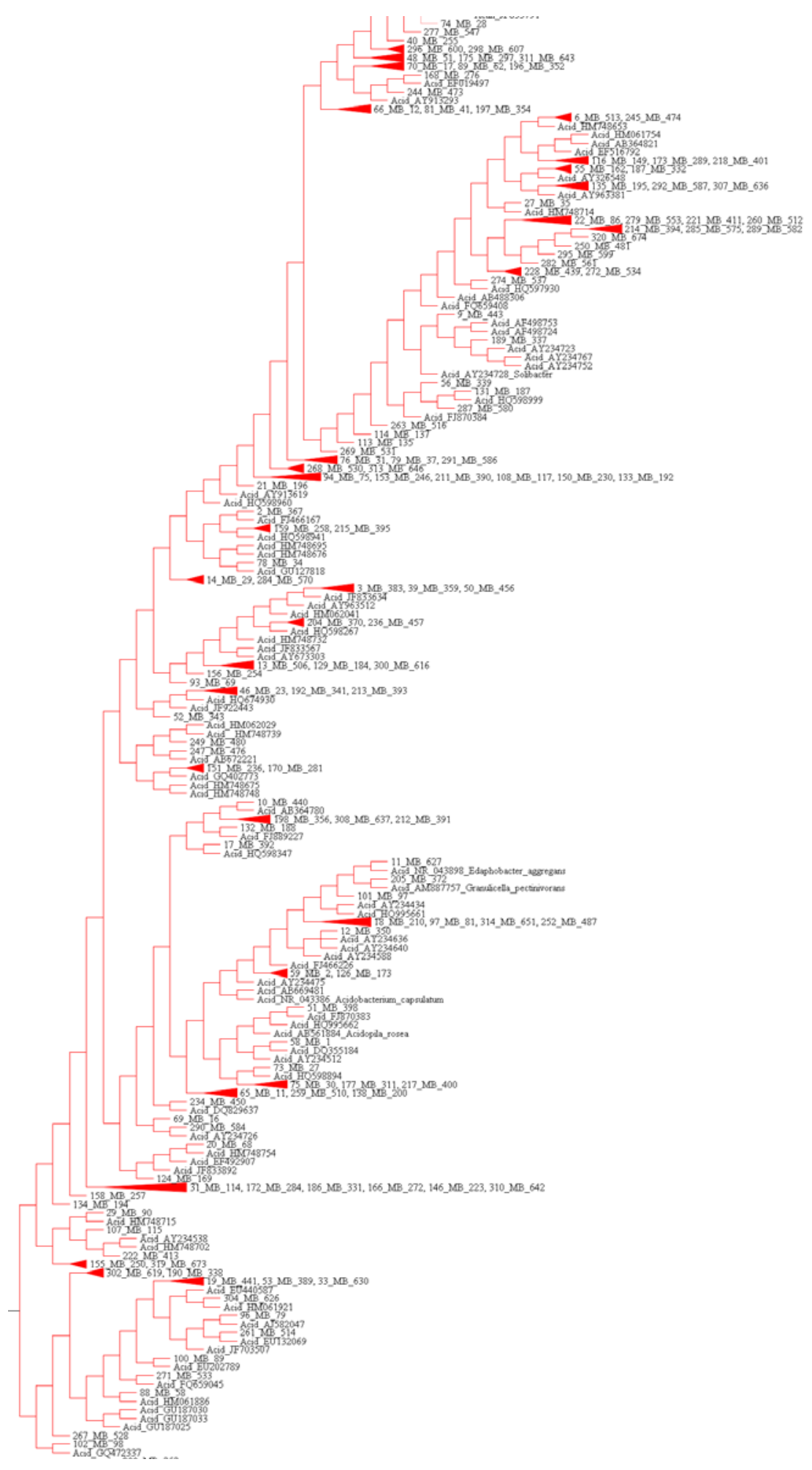




\section{Appendix Figure 4.3 c}

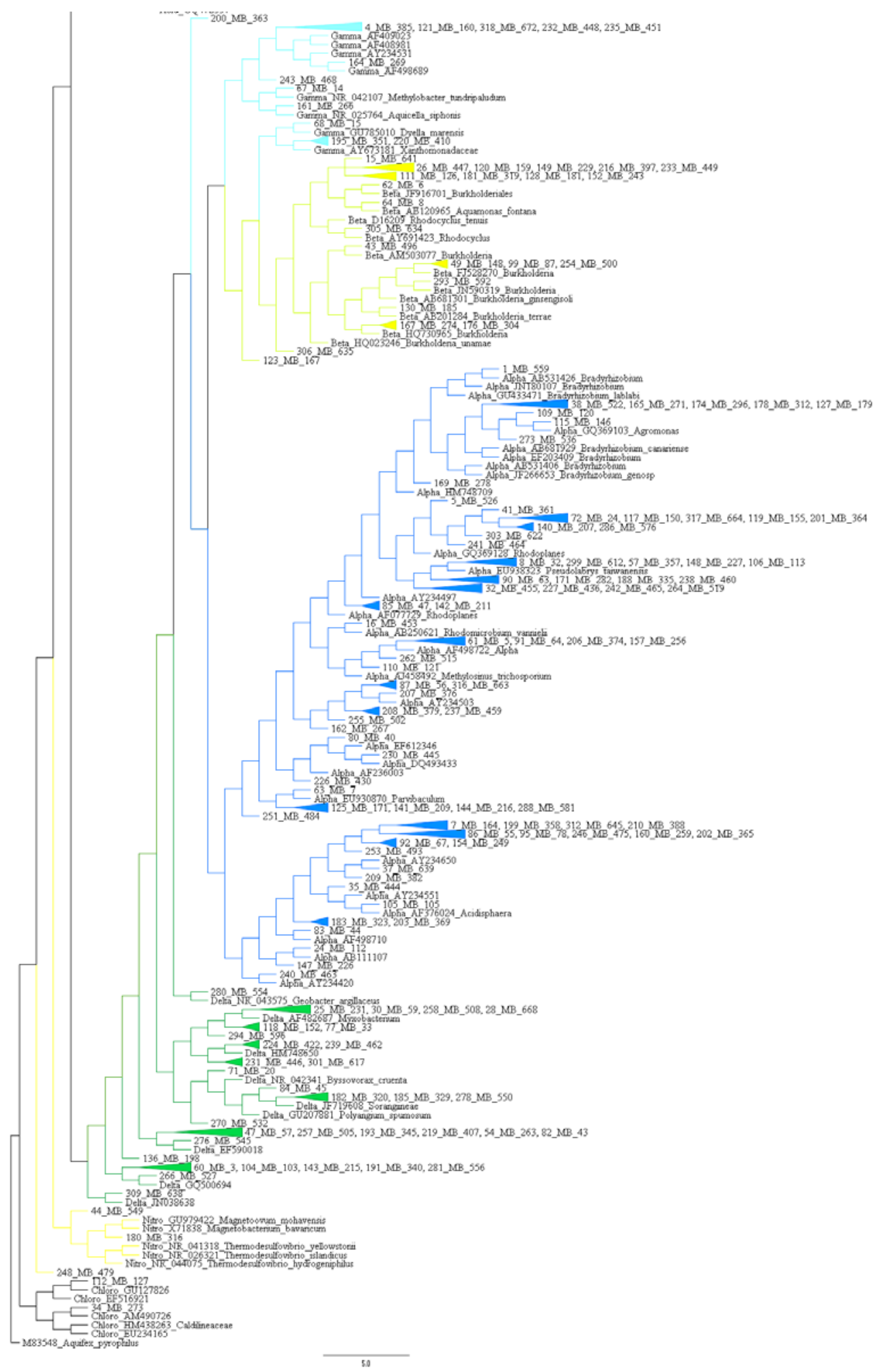


Appendix Figure 4.4. Maximum-parsimony tree showing phylogenetic relationships of fungal ITS sequences cloned from soils from ridge and swale microsites in four alluvial (AL) (Wateree R., SC; Pee Dee R., SC; Nottaway R., VA; Ocmulgee R., GA) and four blackwater (BL) (Black R., NC; Drowning Cr., NC; Satilla R., GA; Salkehatchie R., SC) FFs, to related sequences from GenBank: (a) Ascomycota; (b) Basidiomycota, Chytridiomycota, and Zygomycota. 


\section{Appendix Figure 4.4 a}

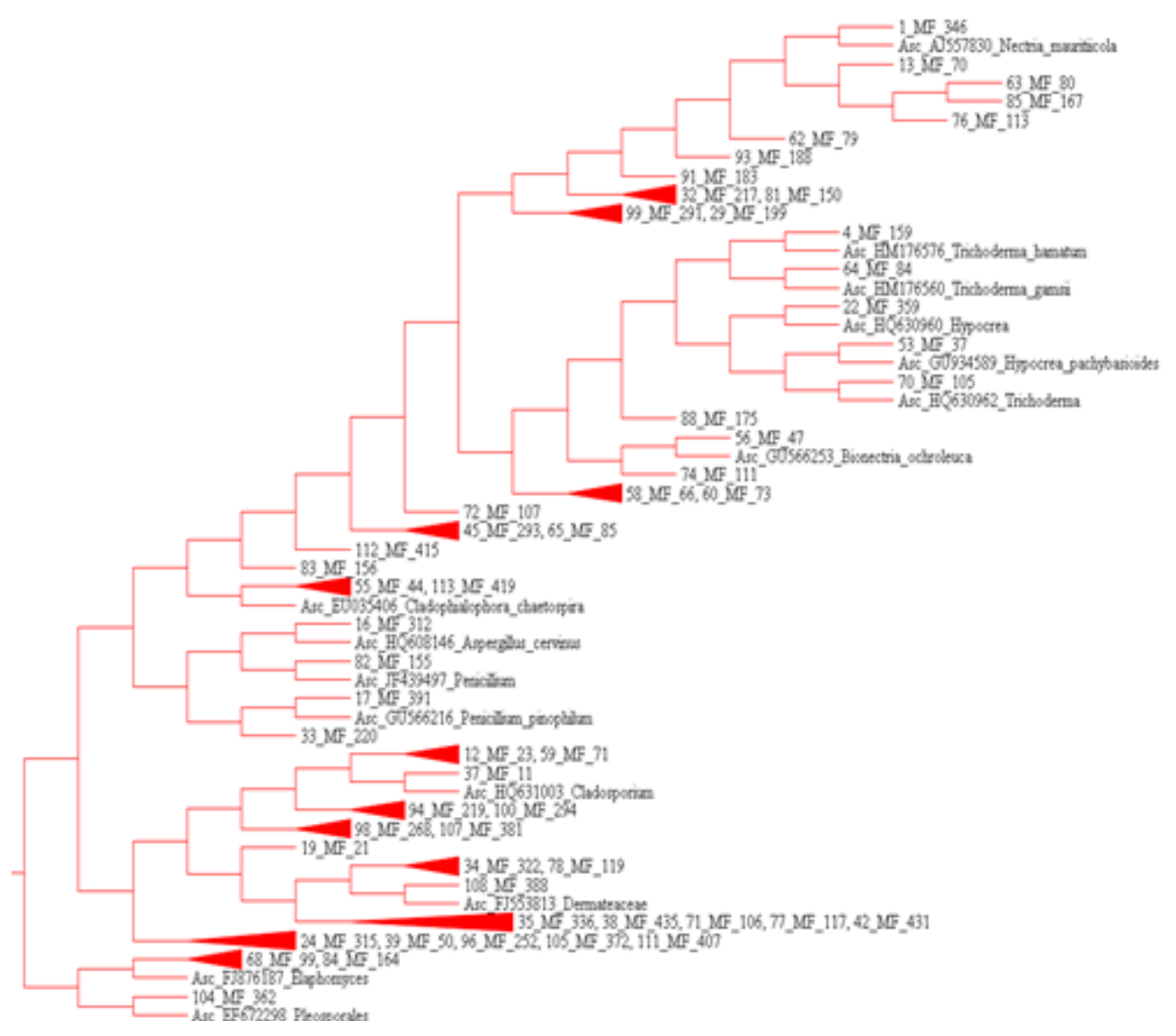




\section{Appendix Figure $4.4 \mathrm{~b}$}

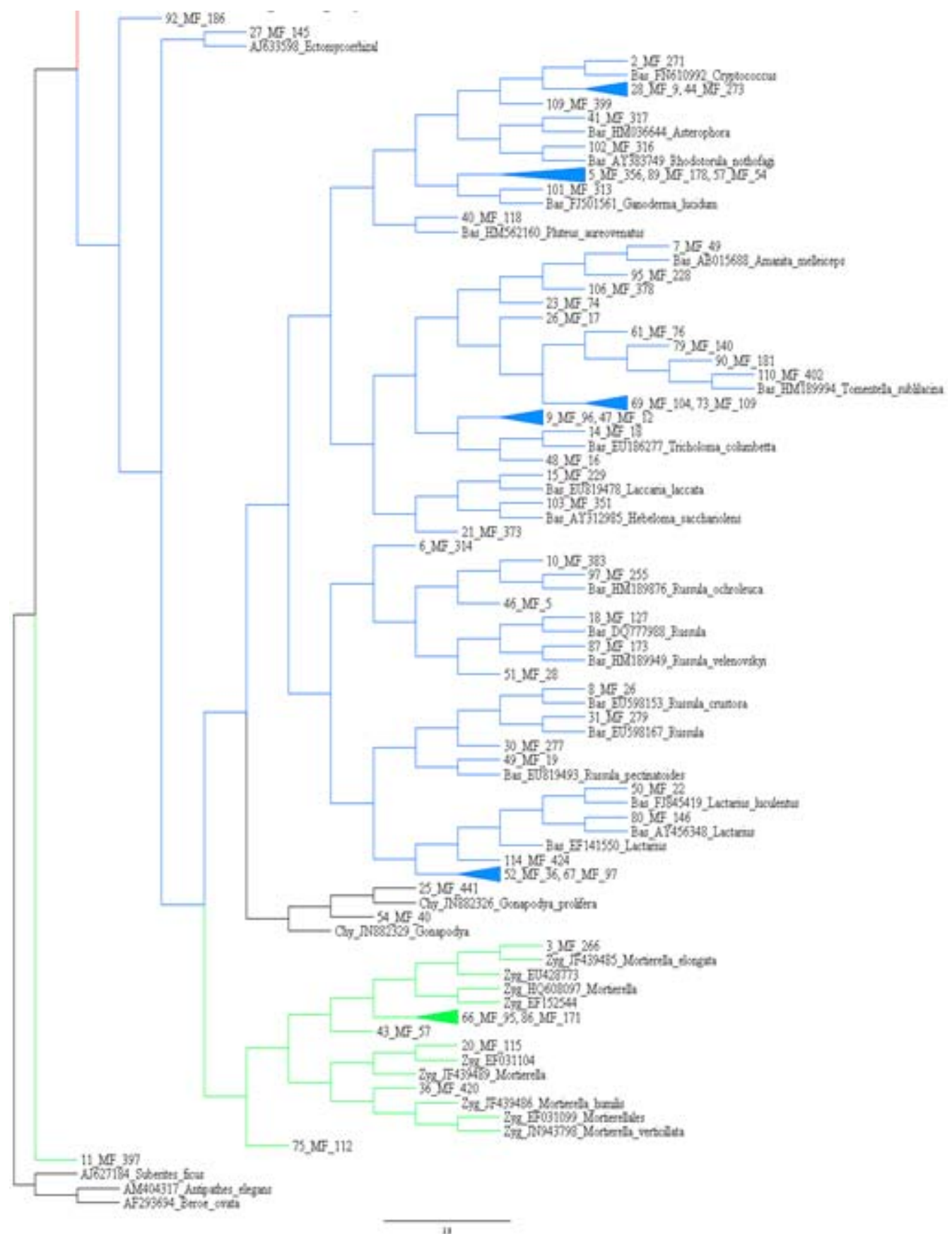


Appendix Table 4.1. Identities of (a) bacterial 16S rDNA, and (b) fungal ITS rDNA, OTUs in clone libraries in soils collected from one alluvial (AL) (Wateree R., SC) and one blackwater (BW) (Black R., NC) FF.

\section{Appendix Table 4.1a}

\begin{tabular}{|c|c|c|c|c|c|c|c|c|c|c|}
\hline out & Access. \# & 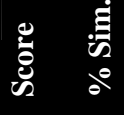 & Phylum & Class & Order & Family & Genus & 电 & 3 & 홈 \\
\hline $1-\mathrm{TB}-463$ & GQ369128 & $931 / 98$ & Proteobacteria & Alphaproteobacteria & Rhizobiales & Xanthobacteraceae & Pseudolabrys & 11 & 21 & 32 \\
\hline 2-TB-188 & HM748653 & $1461 / 95$ & Acidobacteria & Acidobacteria & Solibacterales & Solibacteraceae & Solibacter & 13 & 7 & 20 \\
\hline $3-\mathrm{TB}-27$ & HM748709 & $885 / 96$ & Proteobacteria & Alphaproteobacteria & Rhizobiales & Hyphomicrobiaceae & & 12 & 4 & 16 \\
\hline 4-TB-212 & HM748695 & $1731 / 95$ & Acidobacteria & Acidobacteria & Acidobacteriales & Acidobacteriaceae & & 11 & 5 & 16 \\
\hline 5-TB-253 & AB531426 & $1764 / 95$ & Proteobacteria & Alphaproteobacteria & Rhizobiales & Bradyrhizobiaceae & Bradyrhizobium & 3 & 10 & 13 \\
\hline 6-TB-237 & AY234592 & $1688 / 95$ & Acidobacteria & Acidobacteria & Acidobacteriales & Acidobacteriaceae & & 7 & 3 & 10 \\
\hline 7-TB-245 & AF409023 & $1629 / 93$ & Proteobacteria & Gammaproteobacteria & Chromatiales & & & 2 & 6 & 8 \\
\hline $8-\mathrm{TB}-71$ & AF498722 & $806 / 94$ & Proteobacteria & Alphaproteobacteria & Rhizobiales & Methylocystaceae & Methylocystis & 7 & & 7 \\
\hline $9-\mathrm{TB}-100$ & EF074997 & $870 / 95$ & Acidobacteria & Acidobacteria & Acidobacteriales & Acidobacteriaceae & & 3 & 4 & 7 \\
\hline 10-TB-295 & AF498727 & $1458 / 91$ & Acidobacteria & Acidobacteria & Acidobacteriales & Acidobacteriaceae & & 6 & 1 & 7 \\
\hline 11-TB-209 & JF510471 & $1459 / 90$ & Actinobacteria & Actinobacteria & Acidimicrobiales & Acidimicrobineae & Aciditerrimonas & 7 & & 7 \\
\hline 12-TB-349 & FJ459988 & $813 / 97$ & Proteobacteria & Alphaproteobacteria & Rhodospirillales & Rhodospirillaceae & & 4 & 3 & 7 \\
\hline $13-\mathrm{TB}-243$ & AY234636 & $1757 / 95$ & Acidobacteria & Acidobacteria & Acidobacteriales & Acidobacteriaceae & & 6 & & 6 \\
\hline 14-TB-273 & AY234650 & $1275 / 92$ & Proteobacteria & Alphaproteobacteria & Rhodospirillales & Rhodospirillaceae & Azospirillum & 5 & 1 & 6 \\
\hline $15-\mathrm{TB}-453$ & HM748732 & $942 / 97$ & Acidobacteria & Acidobacteria & Acidobacteriales & Acidobacteriaceae & & & 5 & 5 \\
\hline $16-\mathrm{TB}-33$ & NR-025582 & $713 / 91$ & Proteobacteria & Alphaproteobacteria & Rhodospirillales & Acetobacteraceae & & 2 & 2 & 4 \\
\hline $17-\mathrm{TB}-40$ & AM503077 & $985 / 99$ & Proteobacteria & Betaproteobacteria & Burkholderiales & Burkholderiaceae & Burkholderia & 4 & & 4 \\
\hline $18-\mathrm{TB}-371$ & FJ529710 & $784 / 94$ & Actinobacteria & Actinobacteria & Actinomycetales & Thermomonosporaceae & Actinomadura & & 4 & 4 \\
\hline $19-\mathrm{TB}-376$ & HQ597220 & $937 / 99$ & Acidobacteria & Acidobacteria & Acidobacteriales & Acidobacteriaceae & & & 4 & 4 \\
\hline 20-TB-439 & GU187030 & $652 / 90$ & Acidobacteria & Acidobacteria & Acidobacteriales & Acidobacteriaceae & & & 4 & 4 \\
\hline $21-\mathrm{TB}-404$ & AB268315 & $575 / 86$ & Proteobacteria & Deltaproteobacteria & Desulfuromonadales & Geobacteraceae & Geothermobacter & & 4 & 4 \\
\hline 22-TB-292 & FJ605267 & $1264 / 92$ & Actinobacteria & Actinobacteria & Actinomycetales & Mycobacteriaceae & Mycobacterium & 3 & & 3 \\
\hline
\end{tabular}




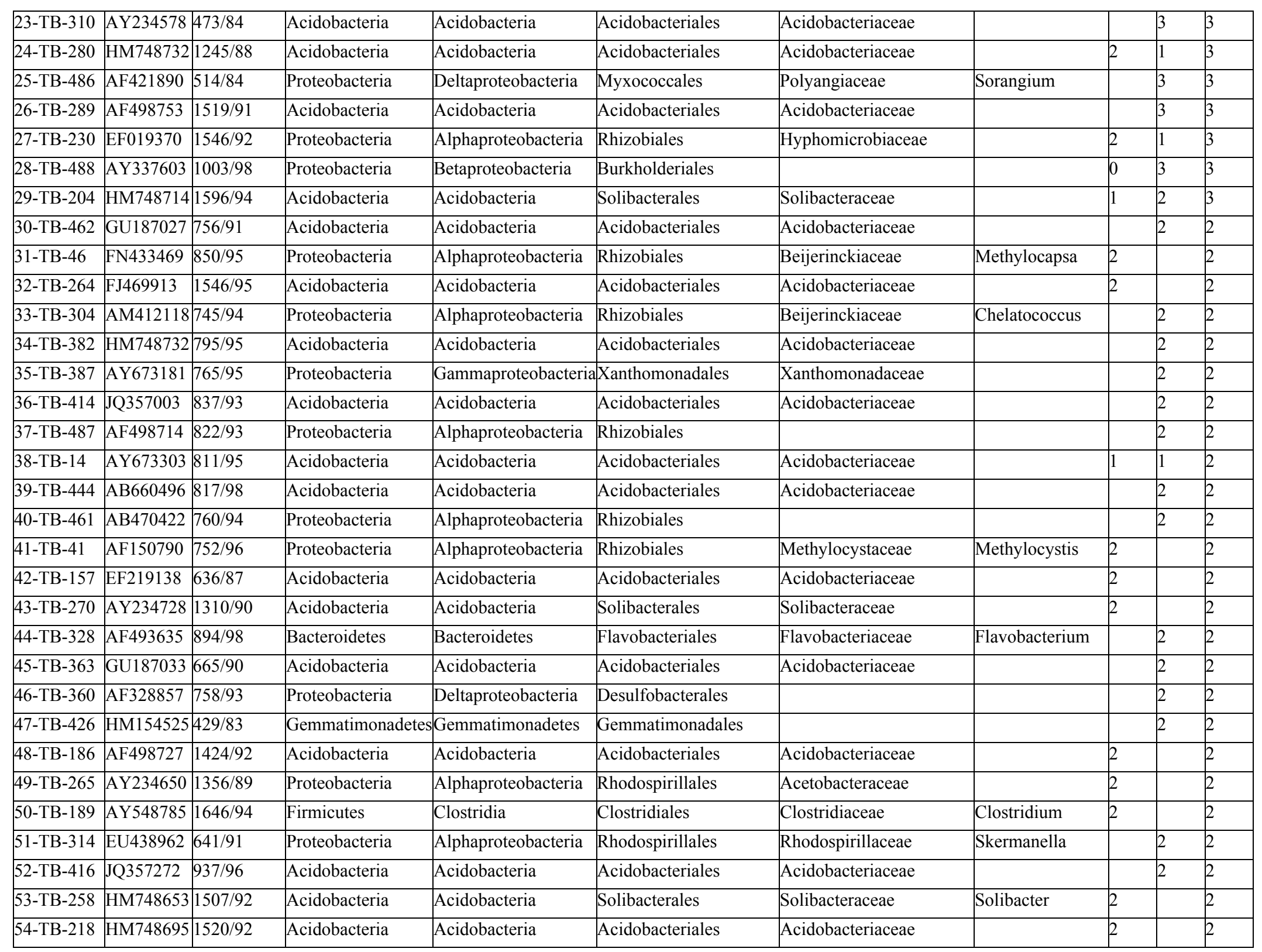




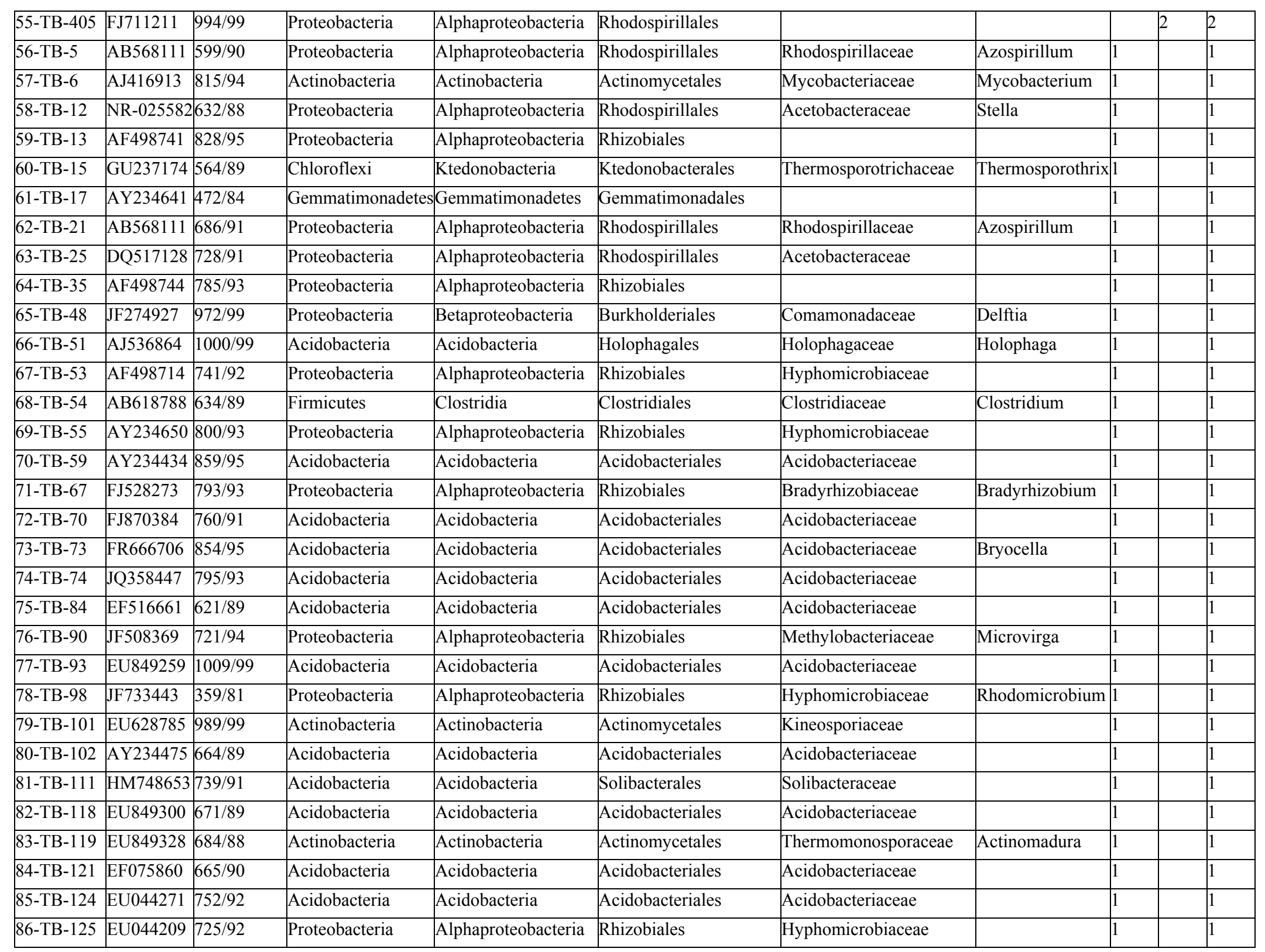




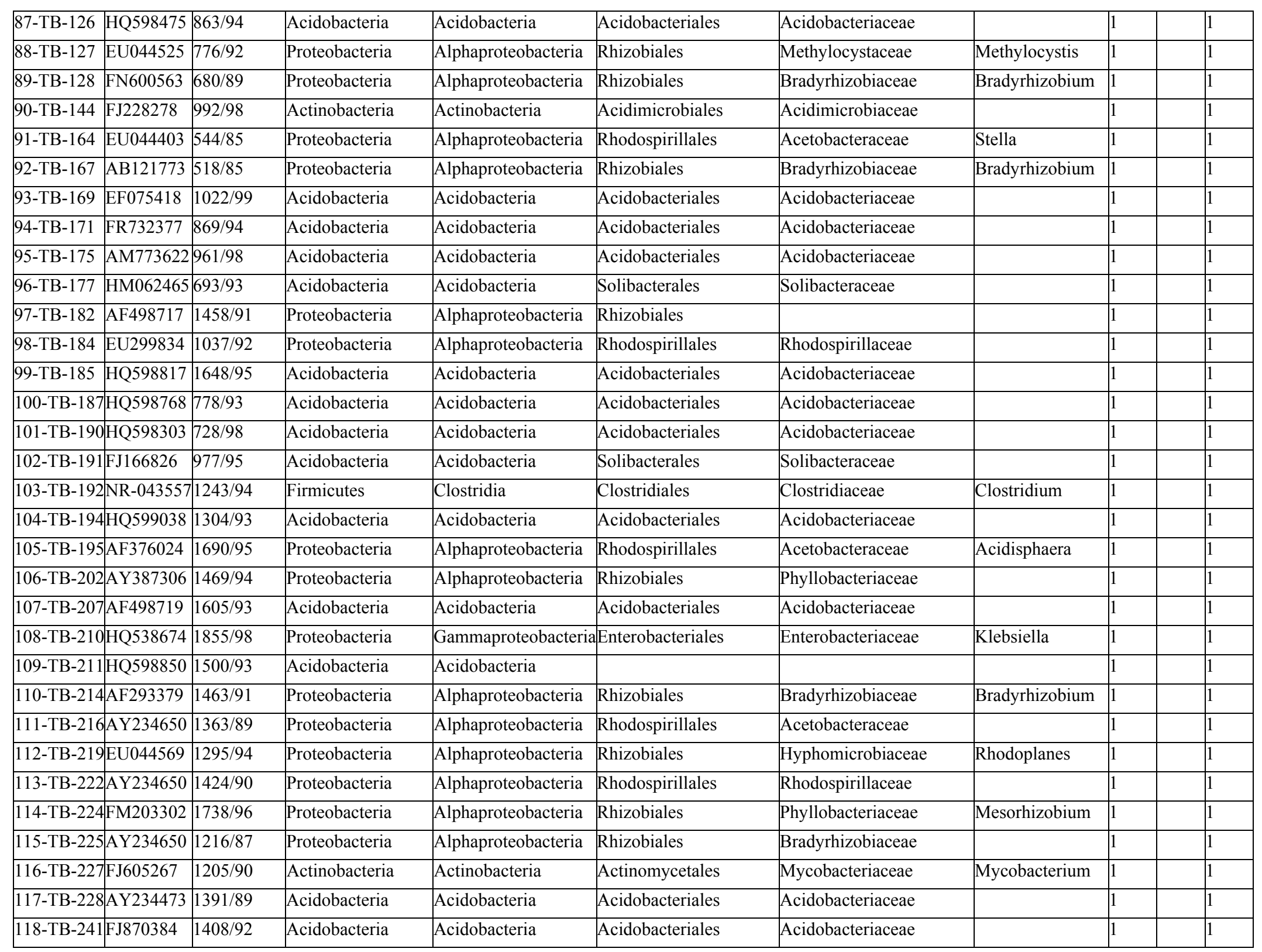




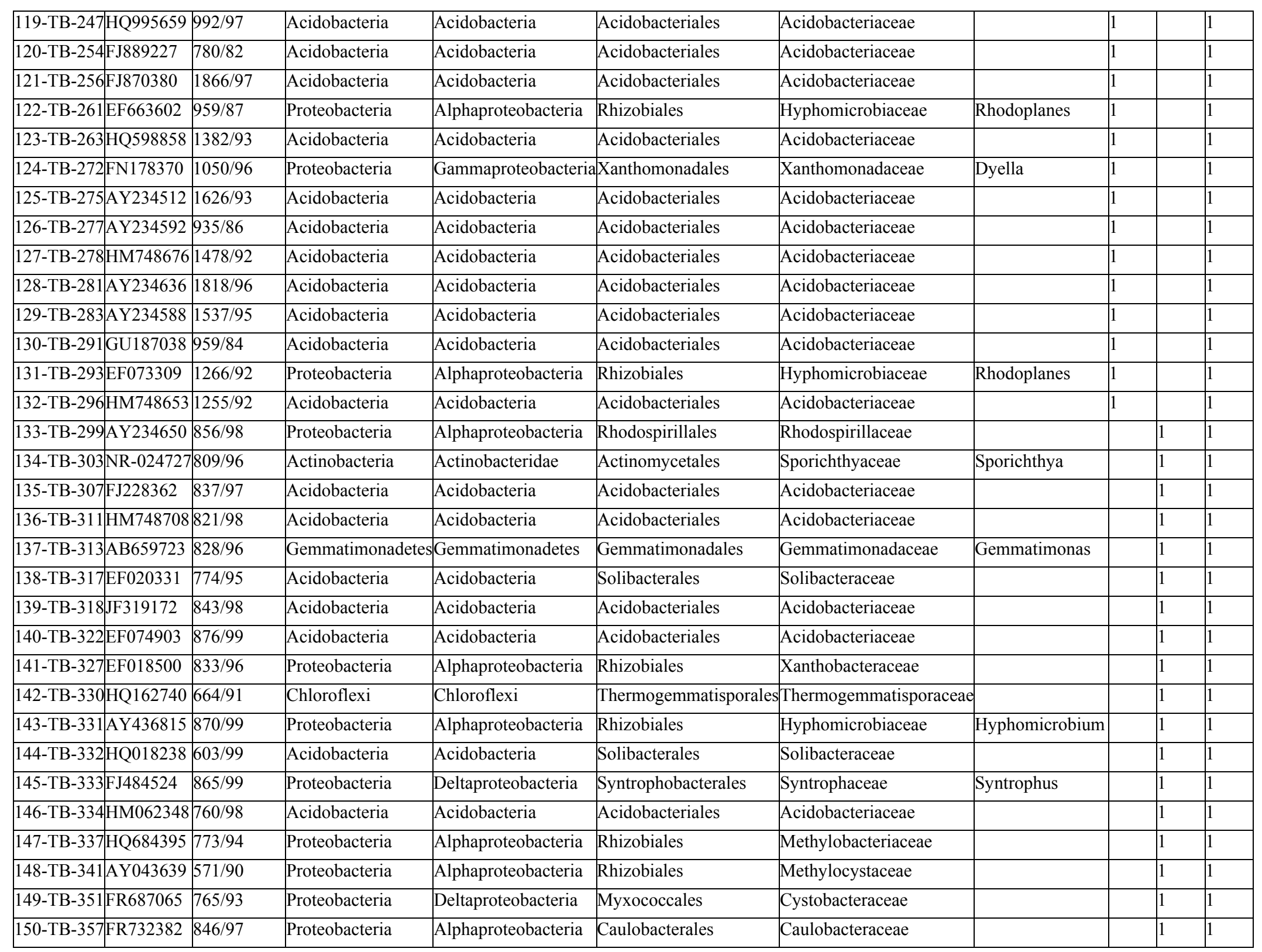




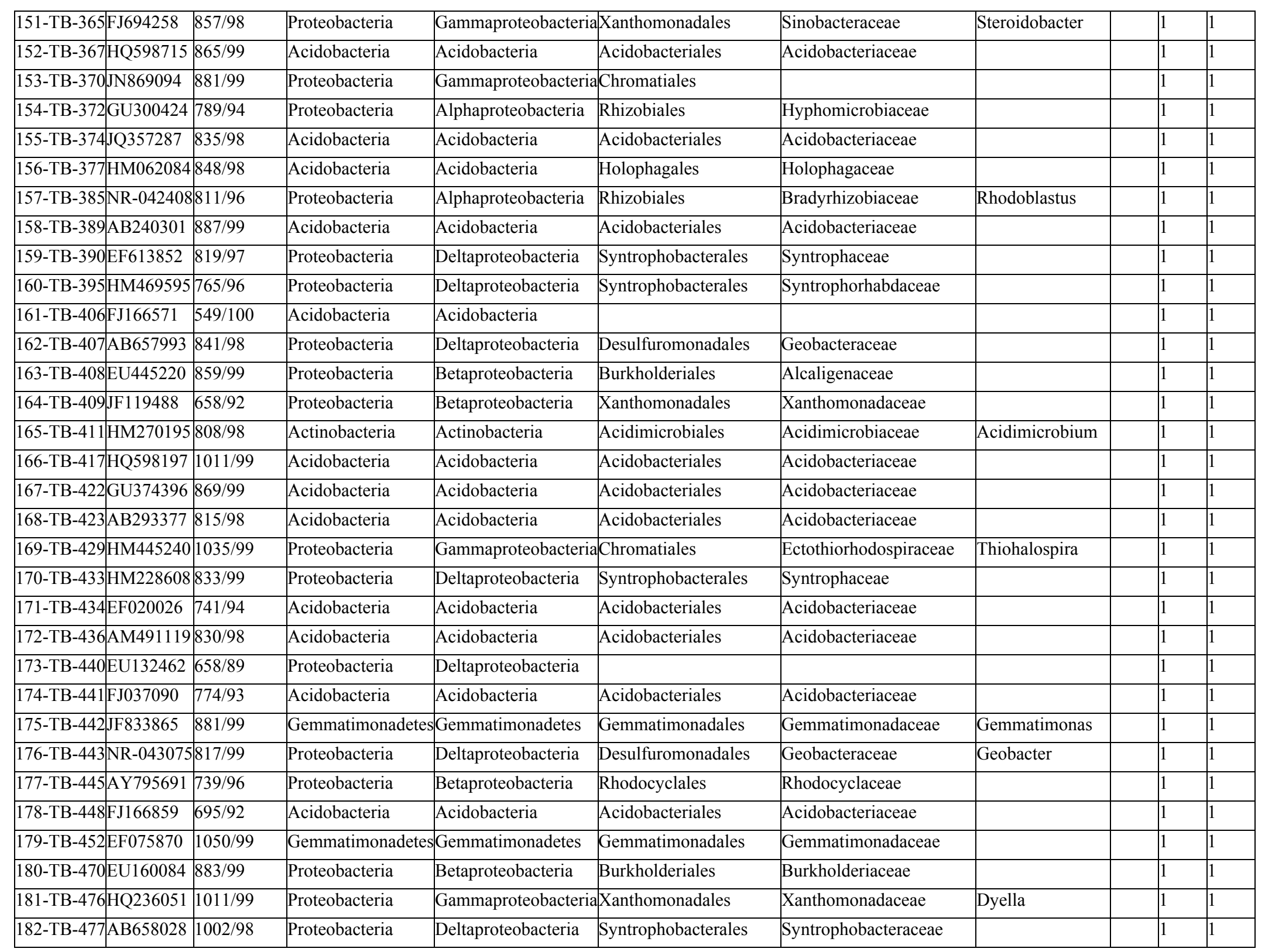




\begin{tabular}{|l|l|l|l|l|l|l|l|l|l|}
\hline 183-TB-481 HQ674934 & $863 / 99$ & Acidobacteria & Acidobacteria & Acidobacteriales & Acidobacteriaceae & 1 \\
\hline 184-TB-485JN389687 & $922 / 99$ & Proteobacteria & Alphaproteobacteria & Rhodospirillales & Rhodospirillaceae & \\
\hline 185-TB-31 & GQ402743 & $634 / 95$ & Actinobacteria & Actinobacteria & Actinomycetales & Nocardiaceae & 1 \\
\hline 186-TB-269JF904128 & $723 / 99$ & Acidobacteria & Acidobacteria & Acidobacteriales & Acidobacteriaceae & 1 & 1 \\
\hline $187-$ TB-373EF665504 & $948 / 99$ & Acidobacteria & Acidobacteria & Holophagales & Holophagaceae & Holophaga & 1 & 1 \\
\hline
\end{tabular}




\section{Appendix Table 4.1b}

\begin{tabular}{|c|c|c|c|c|c|c|c|c|c|c|c|}
\hline OTU & Access. \# & $\begin{array}{l}\text { 音 } \\
0^{\circ}\end{array}$ & Phylum & Subphylum & Class & Order & Family & Genus & p & $\frac{5}{3}$ & एँّ \\
\hline $1-\mathrm{TF}-67$ & FN428924 & $926 / 100$ & Basidiomycota & Agaricomycotina & Tremellomycetes & Tremellales & & Cryptococcus & 18 & 8 & 26 \\
\hline $2-\mathrm{TF}-213$ & JF439485 & $1138 / 99$ & Zygomycota & Mucoromycotina & & Mortierellales & Mortierellaceae & Mortierella & 3 & 15 & 18 \\
\hline $3-\mathrm{TF}-22$ & EU598156 & $1037 / 99$ & Basidiomycota & Agaricomycotina & Agaricomycetes & Russulales & Russulaceae & Russula & 10 & 2 & 12 \\
\hline $4-\mathrm{TF}-127$ & DQ777988 & $1051 / 99$ & Basidiomycota & Agaricomycotina & Agaricomycetes & Russulales & Russulaceae & Russula & 9 & 1 & 10 \\
\hline 6-TF-286 & EU784211 & 909/95 & Basidiomycota & Agaricomycotina & Agaricomycetes & Agaricales & Entolomataceae & Entoloma & & 8 & 8 \\
\hline 7-TF-37 & EU598194 & $752 / 91$ & Basidiomycota & Agaricomycotina & Agaricomycetes & Russulales & Russulaceae & Russula & 6 & 2 & 8 \\
\hline $8-\mathrm{TF}-381$ & AJ557830 & $1059 / 99$ & Ascomycota & Pezizomycotina & Sordariomycetes & Hypocreales & Nectriaceae & Nectria & 6 & 2 & 8 \\
\hline 9-TF-211 & EU819478 & $1116 / 99$ & Basidiomycota & Agaricomycotina & Agaricomycetes & Agaricales & Tricholomataceae & Laccaria & 3 & 5 & 8 \\
\hline $10-\mathrm{TF}-61$ & JN943015 & $1062 / 99$ & Zygomycota & Mucoromycotina & & Mortierellales & Mortierellaceae & Mortierella & 7 & & 7 \\
\hline 11-TF-222 & AB176571 & $1081 / 97$ & Basidiomycota & Agaricomycotina & Agaricomycetes & Polyporales & & Daedaleopsis & & 6 & 6 \\
\hline 13-TF-123 & HQ157874 & $750 / 92$ & Ascomycota & Pezizomycotina & Leotiomycetes & Helotiales & Helotiaceae & & 5 & & 5 \\
\hline 14-TF-254 & AJ633598 & $1050 / 97$ & Basidiomycota & & & & & & & 5 & 5 \\
\hline 15-TF-141 & JF834358 & $896 / 97$ & Basidiomycota & Agaricomycotina & Agaricomycetes & Russulales & Russulaceae & Russula & 5 & & 5 \\
\hline 16-TF-109 & EU598162 & $983 / 97$ & Basidiomycota & Agaricomycotina & Agaricomycetes & Russulales & Russulaceae & Russula & 5 & & 5 \\
\hline 17-TF-175 & FJ554007 & $965 / 97$ & Basidiomycota & Agaricomycotina & Agaricomycetes & Agaricales & Cortinariaceae & Cortinarius & 0 & 4 & 4 \\
\hline $18-\mathrm{TF}-225$ & JF908544 & $961 / 95$ & Ascomycota & Pezizomycotina & Pezizomycetes & Pezizales & Pezizaceae & Peziza & & 4 & 4 \\
\hline 19-TF-198 & FJ554185 & $826 / 93$ & Basidiomycota & Agaricomycotina & Agaricomycetes & Agaricales & Tricholomataceae & & 3 & 1 & 4 \\
\hline $20-\mathrm{TF}-263$ & GU934592 & $1053 / 97$ & Basidiomycota & Agaricomycotina & Agaricomycetes & Corticiales & Corticiaceae & Phanerochaete & & 3 & 3 \\
\hline 21-TF-134 & EU819480 & 957/97 & Basidiomycota & Agaricomycotina & Agaricomycetes & Russulales & Russulaceae & Lactarius & 3 & & 3 \\
\hline $22-\mathrm{TF}-3$ & U57496 & $715 / 91$ & Ascomycota & Pezizomycotina & Leotiomycetes & Helotiales & Hyaloscyphaceae & Arachnopeziza & 3 & & 3 \\
\hline 23-TF-159 & HQ714730 & 939/96 & Basidiomycota & Agaricomycotina & Agaricomycetes & Russulales & Russulaceae & Lactarius & 3 & & 3 \\
\hline 24-TF-206 & HM488478 & 90298 & Ascomycota & Pezizomycotina & Leotiomycetes & & & & 1 & 2 & 3 \\
\hline $25-\mathrm{TF}-75$ & HQ630960 & $1051 / 99$ & Ascomycota & Pezizomycotina & Sordariomycetes & Hypocreales & Hypocreaceae & Hypocrea & 3 & & 3 \\
\hline
\end{tabular}




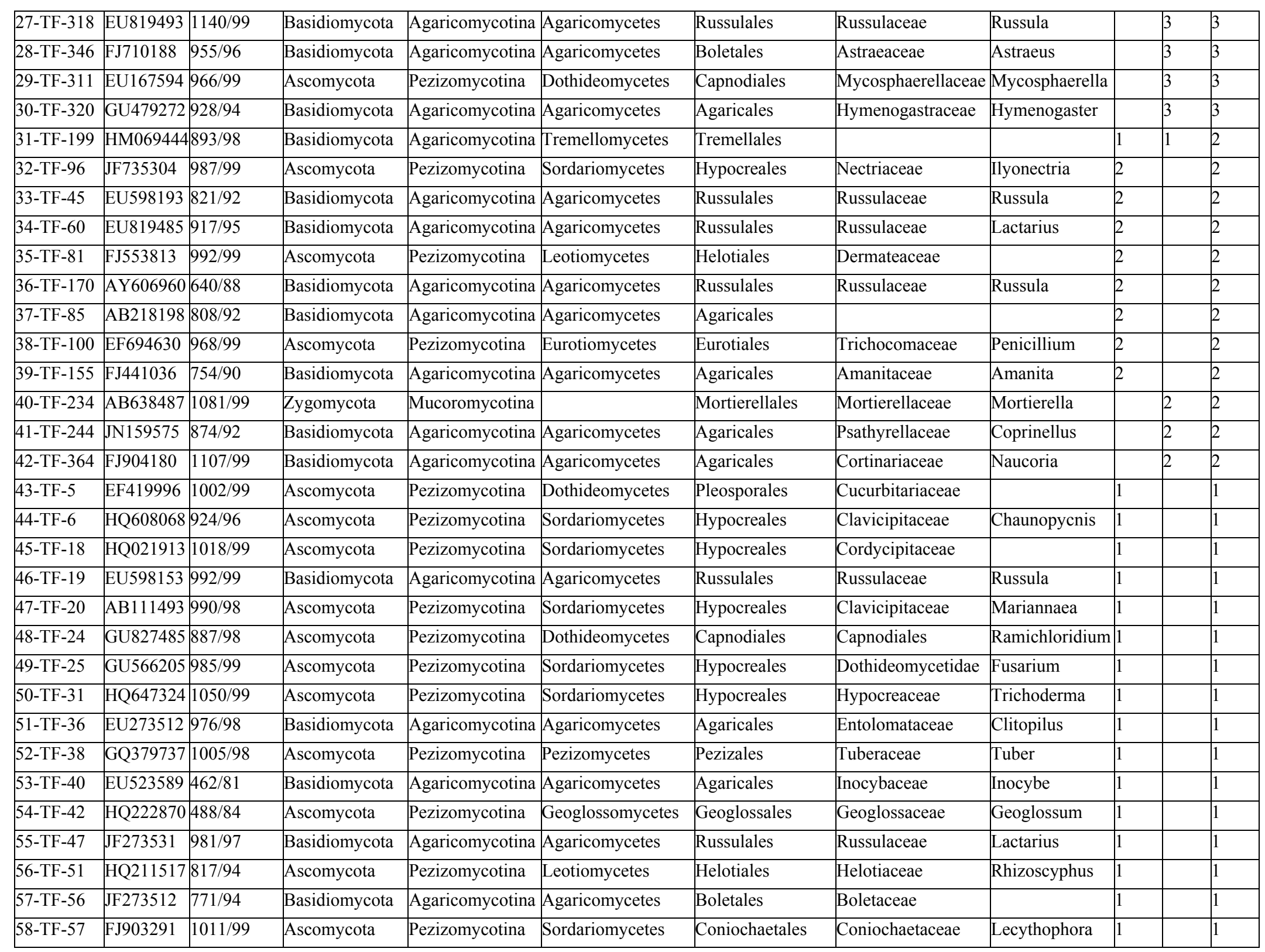




\begin{tabular}{|c|c|c|c|c|c|c|c|c|c|c|}
\hline 59-TF-58 & HQ157959 & $1040 / 99$ & Ascomycota & Pezizomycotina & Eurotiomycetes & Eurotiales & Trichocomaceae & Penicillium & 1 & 1 \\
\hline 60-TF-62 & HM142723 & $920 / 96$ & Basidiomycota & Agaricomycotina & Agaricomycetes & Agaricales & Amanitaceae & Amanita & 1 & 1 \\
\hline 61-TF-71 & GQ359820 & $586 / 88$ & Basidiomycota & Agaricomycotina & Agaricomycetes & Russulales & Russulaceae & & 1 & 1 \\
\hline $62-\mathrm{TF}-72$ & EU819480 & $880 / 94$ & Basidiomycota & Agaricomycotina & Agaricomycetes & Russulales & Russulaceae & Lactarius & 1 & 1 \\
\hline 63-TF-73 & GU566270 & $950 / 97$ & Ascomycota & Pezizomycotina & Dothideomycetes & Pleosporales & Massarinaceae & & 1 & 1 \\
\hline 64-TF-74 & FJ553334 & $569 / 86$ & Basidiomycota & Agaricomycotina & Agaricomycetes & Agaricales & Agaricomycetidae & & 1 & 1 \\
\hline $65-\mathrm{TF}-79$ & GQ272612 & $872 / 97$ & Ascomycota & Pezizomycotina & Leotiomycetes & & & & 1 & 1 \\
\hline 67-TF-89 & FJ553154 & $941 / 95$ & Ascomycota & Pezizomycotina & Eurotiomycetes & Chaetothyriales & Herpotrichiellaceae & & 1 & 1 \\
\hline 68-TF-91 & HQ630279 & $1075 / 99$ & Zygomycota & Mucoromycotina & & Mortierellales & Mortierellaceae & & 1 & 1 \\
\hline 69-TF-94 & HM239883 & $795 / 92$ & Ascomycota & Pezizomycotina & Sordariomycetes & Sordariales & & & 1 & 1 \\
\hline $70-\mathrm{TF}-95$ & EF619640 & $1042 / 99$ & Basidiomycota & Agaricomycotina & Agaricomycetes & Cantharellales & Botryobasidiaceae & Botryobasidium & 1 & 1 \\
\hline 71-TF-101 & HQ608068 & $946 / 97$ & Ascomycota & Pezizomycotina & Sordariomycetes & Hypocreales & Clavicipitaceae & Chaunopycnis & 1 & 1 \\
\hline 72-TF-102 & FN428906 & $725 / 98$ & Basidiomycota & Agaricomycotina & Tremellomycetes & Tremellales & & & 1 & 1 \\
\hline 74-TF-104 & HQ631007 & $963 / 97$ & Ascomycota & Pezizomycotina & Eurotiomycetes & Eurotiales & Trichocomaceae & Penicillium & 1 & 1 \\
\hline 75-TF-112 & GU046494 & $612 / 92$ & Ascomycota & Pezizomycotina & Sordariomycetes & Hypocreales & Hypocreaceae & Hypocrea & 1 & 1 \\
\hline 76-TF-114 & JN021025 & $990 / 98$ & Basidiomycota & Agaricomycotina & Agaricomycetes & Polyporales & Ganodermataceae & Ganoderma & 1 & 1 \\
\hline 77-TF-115 & JF439515 & $730 / 99$ & Ascomycota & Pezizomycotina & Sordariomycetes & Hypocreales & Hypocreaceae & Hypocrea & 1 & 1 \\
\hline 78-TF-121 & HQ608141 & $1013 / 99$ & Ascomycota & Pezizomycotina & Sordariomycetes & Hypocreales & Clavicipitaceae & Chaunopycnis & 1 & 1 \\
\hline 79-TF-131 & FJ553896 & $713 / 92$ & Basidiomycota & Agaricomycotina & Tremellomycetes & Tremellales & & & 1 & 1 \\
\hline $80-\mathrm{TF}-132$ & GQ241283 & $1035 / 99$ & Ascomycota & Pezizomycotina & Sordariomycetes & Hypocreales & Clavicipitaceae & Paecilomyces & 1 & 1 \\
\hline $81-\mathrm{TF}-137$ & AY456348 & $911 / 97$ & Basidiomycota & Agaricomycotina & Agaricomycetes & Russulales & Russulaceae & Lactarius & 1 & 1 \\
\hline 82-TF-146 & EU819437 & $830 / 93$ & Basidiomycota & Agaricomycotina & Agaricomycetes & Russulales & Russulaceae & Russula & 1 & 1 \\
\hline $83-T F-151$ & HQ157874 & $595 / 87$ & Ascomycota & Pezizomycotina & Leotiomycetes & Helotiales & Helotiaceae & & 1 & 1 \\
\hline 84-TF-154 & AY456373 & $1038 / 98$ & Basidiomycota & Agaricomycotina & Agaricomycetes & Agaricales & Clavariaceae & Clavaria & 1 & 1 \\
\hline $85-\mathrm{TF}-163$ & AJ889946 & $721 / 90$ & Basidiomycota & Agaricomycotina & Agaricomycetes & Agaricales & Cortinariaceae & Cortinarius & 1 & 1 \\
\hline 86-TF-168 & EF040864 & $939 / 97$ & Ascomycota & Pezizomycotina & Eurotiomycetes & Eurotiales & & & 1 & 1 \\
\hline 89-TF-176 & L14526 & $811 / 93$ & Ascomycota & Pezizomycotina & Eurotiomycetes & Eurotiales & Trichocomaceae & Talaromyces & 1 & 1 \\
\hline 90-TF-179 & EU240130 & $889 / 95$ & Zygomycota & Mucoromycotina & & Mortierellales & Mortierellaceae & & 1 & 1 \\
\hline
\end{tabular}




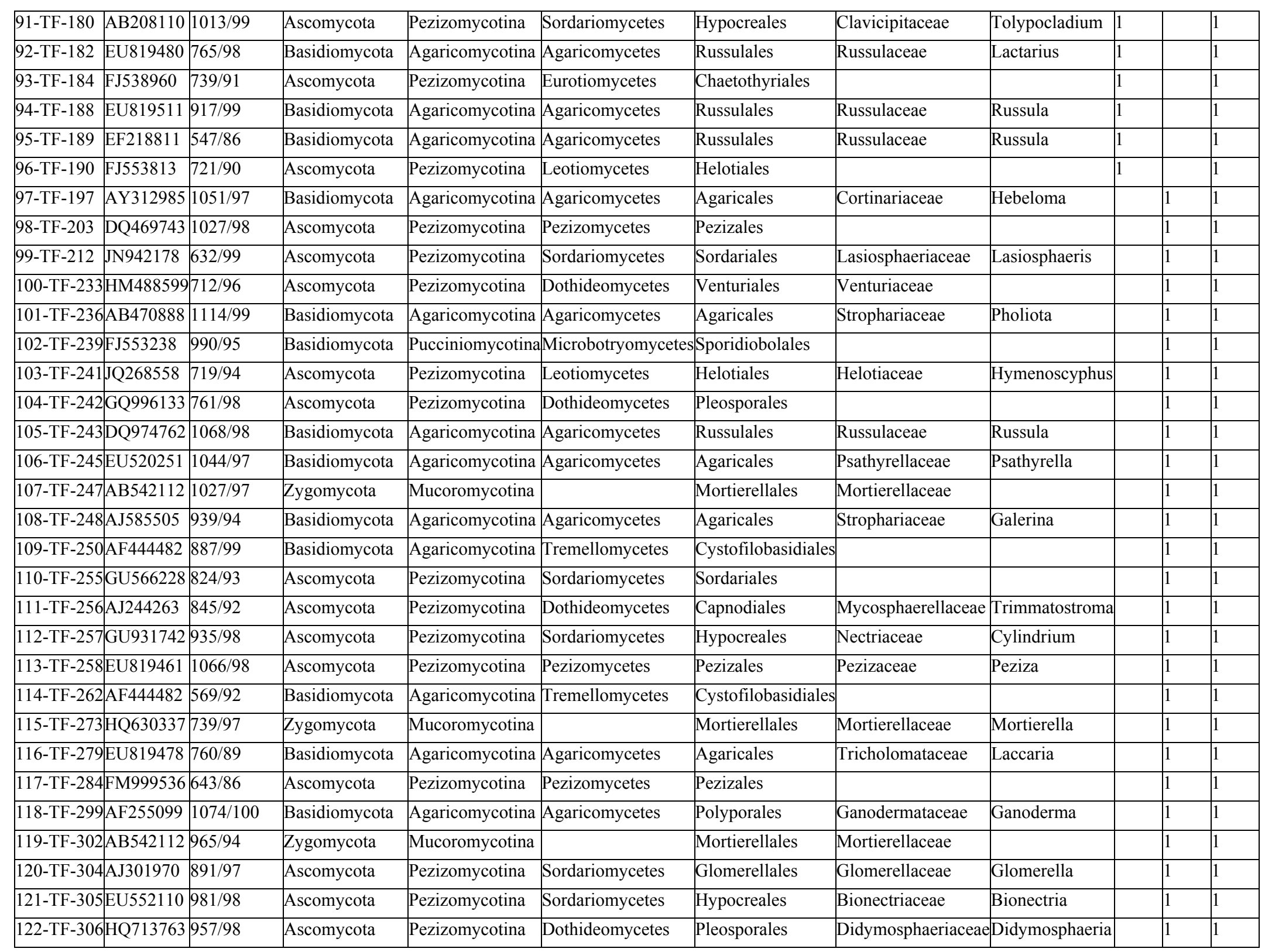




\begin{tabular}{|c|c|c|c|c|c|c|c|c|c|}
\hline \begin{tabular}{|l|l|} 
123-TF-310FJ612884 \\
\end{tabular} & $684 / 91$ & Ascomycota & Pezizomycotina & Sordariomycetes & Sordariales & & & 1 & 1 \\
\hline \begin{tabular}{|l|l|} 
124-TF-312 & AJ875391 \\
\end{tabular} & $933 / 97$ & Ascomycota & Pezizomycotina & Sordariomycetes & Sordariales & & & 1 & 1 \\
\hline 125-TF-314GQ411315 & $1022 / 98$ & Ascomycota & Pezizomycotina & Leotiomycetes & Helotiales & Helotiaceae & Dimorphospora & 1 & 1 \\
\hline 126-TF-319DQ421269 & $1011 / 96$ & Basidiomycota & Agaricomycotina & Agaricomycetes & & & & 1 & 1 \\
\hline \begin{tabular}{|l|l|}
$127-T F-323$ & AF444387 \\
\end{tabular} & $819 / 97$ & Basidiomycota & Agaricomycotina & Tremellomycetes & Tremellales & & & 1 & 1 \\
\hline \begin{tabular}{|l|l|}
$128-T F-324$ & GU062271
\end{tabular} & $789 / 96$ & Basidiomycota & Agaricomycotina & Agaricomycetes & Corticiales & & & 1 & 1 \\
\hline 129-TF-326|HQ608097 & $889 / 96$ & Zygomycota & Mucoromycotina & & Mortierellales & Mortierellaceae & & 1 & 1 \\
\hline \begin{tabular}{|l|l|}
$131-T F-328$ HQ829334 \\
\end{tabular} & $789 / 93$ & Ascomycota & Pezizomycotina & Sordariomycetes & Sordariales & & & 1 & 1 \\
\hline 132-TF-331 HQ829334 & $778 / 93$ & Ascomycota & Pezizomycotina & Sordariomycetes & Sordariales & & & 1 & 1 \\
\hline \begin{tabular}{|l|l|}
$133-T F-343$ HQ623459 \\
\end{tabular} & $913 / 98$ & Ascomycota & Pezizomycotina & Sordariomycetes & Sordariales & & & 1 & 1 \\
\hline \begin{tabular}{|l|l|} 
134-TF-347 & AJ879645 \\
\end{tabular} & $628 / 88$ & Ascomycota & Pezizomycotina & Pezizomycetes & Pezizales & Helvellaceae & & 1 & 1 \\
\hline 135-TF-349HQ162263 & $928 / 99$ & Ascomycota & Pezizomycotina & Dothideomycetes; & Capnodiales & Mycosphaerellaceae & Mycosphaerella & 1 & 1 \\
\hline \begin{tabular}{|l|l|}
$136-T F-355$ & HQ608027
\end{tabular} & $953 / 99$ & Ascomycota & Pezizomycotina & Sordariomycetes & Microascales & Halosphaeriaceae & Periconia & 1 & 1 \\
\hline \begin{tabular}{|l|l|}
$138-T F-359$ & AY312985 \\
\end{tabular} & $920 / 93$ & Basidiomycota & Agaricomycotina & Agaricomycetes & Agaricales & Cortinariaceae & Hebeloma & 1 & 1 \\
\hline \begin{tabular}{|l|l|} 
139-TF-360 EU266591 \\
\end{tabular} & $1068 / 99$ & Ascomycota & Pezizomycotina & Sordariomycetes & Hypocreales & Clavicipitaceae & Pochonia & 1 & 1 \\
\hline \begin{tabular}{|l|l|}
$140-T F-362$ & $D Q 485660$
\end{tabular} & $1009 / 99$ & Chytridiomycota & & Chytridiomycetes & Rhizophydiales & Rhizophydiaceae & Rhizophydium & 1 & 1 \\
\hline 141-TF-367JQ065032 & $989 / 96$ & Basidiomycota & Agaricomycotina & Agaricomycetes & Agaricales & Pluteaceae & Pluteus & 1 & 1 \\
\hline \begin{tabular}{|l|l|}
$142-\mathrm{TF}-369$ & $\mathrm{EU} 819478$ \\
\end{tabular} & $782 / 91$ & Basidiomycota & Agaricomycotina & Agaricomycetes & Agaricales & Tricholomataceae & Laccaria & 1 & 1 \\
\hline 143-TF-370DQ273336 & $924 / 98$ & Ascomycota & Pezizomycotina & Leotiomycetes & Helotiales & & & 1 & 1 \\
\hline \begin{tabular}{|l|l|} 
144-TF-371 & GQ166879 \\
\end{tabular} & $1033 / 97$ & Basidiomycota & Agaricomycotina & Agaricomycetes & Boletales & Boletaceae & Boletus & 1 & 1 \\
\hline \begin{tabular}{|l|l|}
$145-T F-372$ & EU784411
\end{tabular} & $1094 / 99$ & Basidiomycota & Agaricomycotina & Agaricomycetes & Boletales & Sclerodermataceae & Scleroderma & 1 & 1 \\
\hline 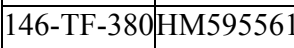 & $1 \mid 1103 / 99$ & Basidiomycota & Agaricomycotina & Agaricomycetes & Agaricales & Psathyrellaceae & Coprinellus & 1 & 1 \\
\hline \begin{tabular}{|l|l|}
$147-T F-382 \mathrm{DQ} 093730$ \\
\end{tabular} & $774 / 94$ & Zygomycota & Mucoromycotina & & Mortierellales & & & 1 & 1 \\
\hline
\end{tabular}


Appendix Table 4.2. Identities of (a) bacterial 16S rDNA, and (b) fungal ITS rDNA, OTUs in clone libraries in soils collected from four alluvial (WT: Wateree R., SC; PD: Pee Dee R., SC; NT: Nottaway R., VA; and OC: Ocmulgee R., GA) and four blackwater (BL: Black R., NC; DC: Drowning Cr., NC; ST: Satilla R., GA; SK: Salkehatchie R., SC) FFs.

\section{Appendix Table 4.2a}

\begin{tabular}{|c|c|c|c|c|c|c|c|c|c|c|}
\hline OTU & Accession \# & 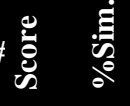 & Phylum & Class & Order & Family & Genus & 范 & 荧 & 륨 \\
\hline 1-MB-559 & AB531426 & $1997 / 98$ & Proteobacteria & Alphaproteobacteria & Rhizobiales & Bradyrhizobiaceae & Bradyrhizobium & 6 & 11 & 17 \\
\hline 2-MB-367 & HM748695 & $1783 / 97$ & Acidobacteria & Acidobacteria & Acidobacteriales & Acidobacteriaceae & & 4 & 8 & 12 \\
\hline 3-MB-383 & HM748732 & $1714 / 93$ & Acidobacteria & Acidobacteria & Acidobacteriales & Acidobacteriaceae & & 3 & 5 & 8 \\
\hline 4-MB-385 & AF409023 & $1807 / 95$ & Proteobacteria & Gammaproteobacteria & Chromatiales & & & 2 & 6 & 8 \\
\hline 5-MB-526 & GQ369128 & $1760 / 95$ & Proteobacteria & Alphaproteobacteria & Rhizobiales & Hyphomicrobiaceae & Rhodoplanes & 3 & 4 & 7 \\
\hline 6-MB-513 & HM748653 & $1993 / 96$ & Acidobacteria & Acidobacteria & Solibacterales & Solibacteraceae & Solibacter & 4 & 2 & 6 \\
\hline 7-MB-164 & AY234650 & $1506 / 91$ & Proteobacteria & Alphaproteobacteria & Rhodospirillales & Acetobacteraceae & & 4 & 2 & 6 \\
\hline 8-MB-32 & EU938323 & $1893 / 95$ & Proteobacteria & Alphaproteobacteria & Rhizobiales & Xanthobacteraceae & Pseudolabrys & 3 & 2 & 5 \\
\hline 9-MB-443 & AF498753 & $1923 / 96$ & Acidobacteria & Acidobacteria & Acidobacteriales & Acidobacteriaceae & & 3 & 2 & 5 \\
\hline $10-\mathrm{MB}-440$ & AF498727 & $1672 / 93$ & Acidobacteria & Acidobacteria & Acidobacteriales & Acidobacteriaceae & & 2 & 3 & 5 \\
\hline 11-MB-627 & NR-043898 & $1764 / 95$ & Acidobacteria & Acidobacteria & Acidobacteriales & Acidobacteriaceae & Edaphobacter & 3 & 1 & 4 \\
\hline 12-MB-350 & AY234636 & $1978 / 97$ & Acidobacteria & Acidobacteria & Acidobacteriales & Acidobacteriaceae & & 2 & 2 & 4 \\
\hline 13-MB-506 & HM748732 & $1770 / 95$ & Acidobacteria & Acidobacteria & Acidobacteriales & Acidobacteriaceae & & 2 & 1 & 3 \\
\hline 14-MB-29 & HM748695 & $1602 / 91$ & Acidobacteria & Acidobacteria & Acidobacteriales & Acidobacteriaceae & & 3 & & 3 \\
\hline 15-MB-641 & D16209 & $1387 / 91$ & Proteobacteria & Betaproteobacteria & Rhodocyclales & Rhodocyclaceae & Rhodocyclus & 3 & & 3 \\
\hline 16-MB-453 & AB250621 & $1657 / 92$ & Proteobacteria & Alphaproteobacteria & Rhizobiales & Hyphomicrobiaceae & Rhodomicrobium & & 3 & 3 \\
\hline 17-MB-392 & AF498727 & $1472 / 91$ & Acidobacteria & Acidobacteria & Acidobacteriales & Acidobacteriaceae & & 1 & 2 & 3 \\
\hline $18-\mathrm{MB}-210$ & AY234475 & $1456 / 93$ & Acidobacteria & Acidobacteria & Acidobacteriales & Acidobacteriaceae & & 3 & & 3 \\
\hline 19-MB-441 & GU187030 & $1526 / 91$ & Acidobacteria & Acidobacteria & Holophagales & Holophagaceae & & 1 & 2 & 3 \\
\hline 20-MB-68 & HM748754 & $1709 / 98$ & Acidobacteria & Acidobacteria & Acidobacteriales & Acidobacteriaceae & & 3 & & 3 \\
\hline
\end{tabular}




\begin{tabular}{|c|c|c|c|c|c|c|c|c|c|c|}
\hline 21-MB-196 & HM748695 & $1814 / 95$ & Acidobacteria & Acidobacteria & Acidobacteriales & Acidobacteriaceae & & 2 & & 2 \\
\hline 22-MB-86 & HM748653 & $1681 / 94$ & Acidobacteria & Acidobacteria & Solibacterales & Solibacteraceae & & 2 & & 2 \\
\hline $23-\mathrm{MB}-386$ & GU129927 & $1842 / 96$ & Firmicutes & Clostridia & Clostridiales & Clostridiaceae & Clostridium & 1 & 1 & 2 \\
\hline 24-MB-112 & AB111107 & $1626 / 94$ & Proteobacteria & Alphaproteobacteria & Rhodospirillales & Rhodospirillaceae & & 2 & & 2 \\
\hline $25-\mathrm{MB}-231$ & FJ190062 & $1068 / 89$ & Proteobacteria & Deltaproteobacteria & Myxococcales & Myxococcaceae & Anaeromyxobacter & 2 & & 2 \\
\hline 26-MB-447 & AB552842 & $1472 / 89$ & Proteobacteria & Betaproteobacteria & Rhodocyclales & Rhodocyclaceae & Sulfuritalea & & 2 & 2 \\
\hline 27-MB-35 & HM748714 & $1674 / 93$ & Acidobacteria & Acidobacteria & Solibacterales & Solibacteraceae & & 2 & & 2 \\
\hline 28-MB-668 & EU331408 & $1319 / 88$ & Proteobacteria & Deltaproteobacteria & Myxococcales & Myxococcaceae & Anaeromyxobacter & 2 & & 2 \\
\hline 29-MB-90 & HM748715 & $1687 / 93$ & Acidobacteria & Acidobacteria & Acidobacteriales & Acidobacteriaceae & & 2 & & 2 \\
\hline $30-\mathrm{MB}-59$ & AF482687 & $1587 / 92$ & Proteobacteria & Deltaproteobacteria & Myxococcales & & & 2 & & 2 \\
\hline 31-MB-114 & HM748754 & $1496 / 91$ & Acidobacteria & Acidobacteria & Acidobacteriales & Acidobacteriaceae & & 2 & & 2 \\
\hline 32-MB-455 & HM748709 & $1851 / 95$ & Proteobacteria & Alphaproteobacteria & Rhizobiales & Xanthobacteraceae & & 1 & 1 & 2 \\
\hline $33-\mathrm{MB}-630$ & GU187033 & $1428 / 89$ & Acidobacteria & Acidobacteria & Holophagales & Holophagaceae & & 2 & & 2 \\
\hline 34-MB-273 & AB598278 & $941 / 83$ & Chloroflexi & Chloroflexi & Anaerolineales & Anaerolineaceae & & 2 & & 2 \\
\hline $35-\mathrm{MB}-444$ & AY234551 & $1685 / 93$ & Proteobacteria & Alphaproteobacteria & Rhodospirillales & Acetobacteraceae & & 1 & 1 & 2 \\
\hline 36-MB-381 & AY234546 & $1620 / 96$ & Actinobacteria & Actinobacteria & Actinomycetales & Thermomonosporaceae & & & 2 & 2 \\
\hline 37-MB-639 & AY234650 & $1923 / 97$ & Proteobacteria & Alphaproteobacteria & Rhodospirillales & Rhodospirillaceae & & 2 & & 2 \\
\hline $38-\mathrm{MB}-522$ & AB681929 & $1842 / 95$ & Proteobacteria & Alphaproteobacteria & Rhizobiales & Bradyrhizobiaceae & Bradyrhizobium & 1 & 1 & 2 \\
\hline 39-MB-359 & HM748732 & $1698 / 93$ & Acidobacteria & Acidobacteria & Acidobacteriales & Acidobacteriaceae & & 1 & 1 & 2 \\
\hline $40-\mathrm{MB}-255$ & AB669481 & $1223 / 87$ & Acidobacteria & Acidobacteria & Acidobacteriales & Acidobacteriaceae & & 2 & & 2 \\
\hline 41-MB-361 & HM748709 & $1701 / 95$ & Proteobacteria & Alphaproteobacteria & Rhizobiales & Hyphomicrobiaceae & & & 2 & 2 \\
\hline 42-MB-469 & AY234546 & $1701 / 94$ & Actinobacteria & Actinobacteria & Actinomycetales & Thermomonosporaceae & & & 2 & 2 \\
\hline 43-MB-496 & AM503077 & $1615 / 98$ & Proteobacteria & Betaproteobacteria & Burkholderiales & Burkholderiaceae & Burkholderia & 1 & 1 & 2 \\
\hline 44-MB-549 & FP929063 & $1061 / 89$ & Nitrospirae & Nitrospirae & Nitrospirales & Nitrospiraceae & & & 2 & 2 \\
\hline $45-\mathrm{MB}-565$ & DQ490442 & $1615 / 95$ & Actinobacteria & Actinobacteria & Actinomycetales & Frankiaceae & & & 2 & 2 \\
\hline $46-\mathrm{MB}-23$ & HM748695 & $1615 / 93$ & Acidobacteria & Acidobacteria & Acidobacteriales & Acidobacteriaceae & & 1 & 1 & 2 \\
\hline 47-MB-57 & FJ190062 & 1173,86 & Proteobacteria & Deltaproteobacteria & Myxococcales & Myxococcaceae & Anaeromyxobacter & 2 & & 2 \\
\hline 48-MB-51 & HM748739 & $1360 / 89$ & Acidobacteria & Acidobacteria & Acidobacteriales & Acidobacteriaceae & & 2 & & 2 \\
\hline 49-MB-148 & AB681301 & $1799 / 95$ & Proteobacteria & Betaproteobacteria & Burkholderiales & Burkholderiaceae & Burkholderia & & 2 & 2 \\
\hline 50-MB-456 & HM748732 & $1666 / 93$ & Acidobacteria & Acidobacteria & Acidobacteriales & Acidobacteriaceae & & 1 & 1 & 2 \\
\hline 51-MB-398 & HQ995662 & $1895 / 97$ & Acidobacteria & Acidobacteria & Acidobacteriales & Acidobacteriaceae & & & 2 & 2 \\
\hline 52-MB-343 & HM748739 & $1652 / 94$ & Acidobacteria & Acidobacteria & Acidobacteriales & Acidobacteriaceae & & 1 & 1 & 2 \\
\hline
\end{tabular}




\begin{tabular}{|c|c|c|c|c|c|c|c|c|c|c|}
\hline 53-MB-389 & GU187030 & $1229 / 91$ & Acidobacteria & Acidobacteria & Acidobacteriales & Acidobacteriaceae & & & 2 & 2 \\
\hline 54-MB-263 & AB268315 & $1134 / 86$ & Proteobacteria & Deltaproteobacteria & Desulfuromonadales & Seobacteraceae & Geothermobacter & & 2 & 2 \\
\hline 55-MB-162 & HM748653 & $1607 / 94$ & Acidobacteria & Acidobacteria & Acidobacteriales & Acidobacteriaceae & & 2 & & 2 \\
\hline 56-MB-339 & FJ870384 & $1637 / 92$ & Acidobacteria & Acidobacteria & Acidobacteriales & Acidobacteriaceae & & & 2 & 2 \\
\hline 57-MB-357 & EU938323 & $1731 / 95$ & Proteobacteria & Alphaproteobacteria & Rhizobiales & Xanthobacteraceae & & 1 & 1 & 2 \\
\hline 58-MB-1 & DQ35518 & $1652 / 96$ & Acidobacteria & Acidobacteria & Acidobacteriales & Acidobacteriaceae & & 1 & & 1 \\
\hline 59-MB-2 & AF200698 & $1729 / 94$ & Acidobacteria & Acidobacteria & Acidobacteriales & Acidobacteriaceae & Acidobacterium & 1 & & 1 \\
\hline 60-MB-3 & GU205283 & $1526 / 91$ & Proteobacteria & Deltaproteobacteria & & & & 1 & & 1 \\
\hline 61-MB-5 & AF498722 & $1430 / 95$ & Proteobacteria & Alphaproteobacteria & Rhizobiales & Methylocystaceae & & 1 & & 1 \\
\hline 62-MB-6 & JF916701 & $1816 / 95$ & Proteobacteria & Betaproteobacteria & Burkholderiales & & & 1 & & 1 \\
\hline 63-MB-7 & EU930870 & $1443 / 90$ & Proteobacteria & Alphaproteobacteria & Rhizobiales & Phyllobacteriaceae & Parvibaculum & 1 & & 1 \\
\hline 64-MB-8 & AB120965 & $1605 / 92$ & Proteobacteria & Betaproteobacteria & Burkholderiales & Comamonadaceae & Aquamonas & 1 & & 1 \\
\hline 65-MB-11 & EF072379 & $1327 / 96$ & Acidobacteria & Acidobacteria & Acidobacteriales & Acidobacteriaceae & & 1 & & 1 \\
\hline 66-MB-12 & EF075894 & $1038 / 93$ & Acidobacteria & Acidobacteria & Acidobacteriales & Acidobacteriaceae & & 1 & & 1 \\
\hline 67-MB-14 & NR-042107 & $1650 / 93$ & Proteobacteria & Gammaproteobacteria & a Methylococcales & Methylococcaceae & Methylobacter & 1 & & 1 \\
\hline 68-MB-15 & GU785010 & $1797 / 95$ & Proteobacteria & Gammaproteobacteria & aXanthomonadales & Xanthomonadaceae & Dyella & 1 & & 1 \\
\hline 69-MB-16 & AY234726 & $1587 / 93$ & Acidobacteria & Acidobacteria & Acidobacteriales & Acidobacteriaceae & & 1 & & 1 \\
\hline 70-MB-17 & HM061991 & $1053 / 90$ & Acidobacteria & Acidobacteria & Acidobacteriales & Acidobacteriaceae & & 1 & & 1 \\
\hline 71-MB-20 & NR-042341 & $1735 / 94$ & Proteobacteria & Deltaproteobacteria & Myxococcales & Polyangiaceae & & 1 & & 1 \\
\hline 72-MB-24 & EF019370 & $1609 / 93$ & Proteobacteria & Alphaproteobacteria & Rhizobiales & Hyphomicrobiaceae & & 1 & & 1 \\
\hline 73-MB-27 & HQ995662 & $1387 / 95$ & Acidobacteria & Acidobacteria & Acidobacteriales & Acidobacteriaceae & & 1 & & 1 \\
\hline 74-MB-28 & GU205304 & $1423 / 92$ & Actinobacteria & Actinobacteria & Actinomycetales & Thermomonosporaceae & & 1 & & 1 \\
\hline $75-\mathrm{MB}-30$ & AY234512 & $1683 / 95$ & Acidobacteria & Acidobacteria & Acidobacteriales & Acidobacteriaceae & & 1 & & 1 \\
\hline 76-MB-31 & EU359919 & $1120 / 94$ & Acidobacteria & Acidobacteria & Acidobacteriales & Acidobacteriaceae & & 1 & & 1 \\
\hline 77-MB-33 & JN409187 & $1531 / 96$ & Proteobacteria & Deltaproteobacteria & Myxococcales & Myxococcaceae & & 1 & & 1 \\
\hline 78-MB-34 & HM748695 & $1707 / 94$ & Acidobacteria & Acidobacteria & Acidobacteriales & Acidobacteriaceae & & 1 & & 1 \\
\hline 79-MB-37 & FJ166294 & $1033 / 95$ & Acidobacteria & Acidobacteria & Acidobacteriales & Acidobacteriaceae & & 1 & & 1 \\
\hline $80-\mathrm{MB}-40$ & EF612346 & $1666 / 94$ & Proteobacteria & Alphaproteobacteria & Caulobacterales & Caulobacteraceae & & 1 & & 1 \\
\hline 81-MB-41 & DQ450715 & $1310 / 91$ & Acidobacteria & Acidobacteria & Acidobacteriales & Acidobacteriaceae & & 1 & & 1 \\
\hline 82-MB-43 & AM935097 & $1881 / 95$ & Proteobacteria & Deltaproteobacteria & Syntrophobacterales & & & 1 & & 1 \\
\hline 83-MB-44 & AF498710 & $1895 / 97$ & Proteobacteria & Alphaproteobacteria & Rhodospirillales & Rhodospirillaceae & & 1 & & 1 \\
\hline $84-\mathrm{MB}-45$ & GU207881 & $1585 / 91$ & Proteobacteria & Deltaproteobacteria & Myxococcales & Polyangiaceae & Polyangium & 1 & & 1 \\
\hline
\end{tabular}




\begin{tabular}{|c|c|c|c|c|c|c|c|c|c|}
\hline 85-MB-47 & AF077729 & $1749 / 95$ & Proteobacteria & Alphaproteobacteria & Rhizobiales & Hyphomicrobiaceae & Rhodoplanes & 1 & 1 \\
\hline $86-\mathrm{MB}-55$ & EU043719 & $1685 / 93$ & Proteobacteria & Alphaproteobacteria & Rhodospirillales & Acetobacteraceae & & 1 & 1 \\
\hline $87-\mathrm{MB}-56$ & EF019707 & $1607 / 95$ & Proteobacteria & Alphaproteobacteria & Rhizobiales & & & 1 & 1 \\
\hline $88-\mathrm{MB}-58$ & HM061886 & $1967 / 97$ & Acidobacteria & Acidobacteria & Holophagales & Holophagaceae & & 1 & 1 \\
\hline 89-MB-62 & AM162403 & $1256 / 88$ & Proteobacteria & Alphaproteobacteria & Rhodospirillales & Acetobacteraceae & & 1 & 1 \\
\hline 90-MB-63 & AY234497 & $1626 / 94$ & Proteobacteria & Alphaproteobacteria & Rhizobiales & Xanthobacteraceae & & 1 & 1 \\
\hline 91-MB-64 & EF020321 & $1426 / 92$ & Proteobacteria & Alphaproteobacteria & Rhizobiales & Methylocystaceae & & 1 & 1 \\
\hline 92-MB-67 & AY395352 & $1685 / 93$ & Proteobacteria & Alphaproteobacteria & Rhodospirillales & Acetobacteraceae & & 1 & 1 \\
\hline 93-MB-69 & HM748695 & $1613 / 91$ & Acidobacteria & Acidobacteria & Acidobacteriales & Acidobacteriaceae & & 1 & 1 \\
\hline 94-MB-75 & EF019164 & $1428 / 90$ & Acidobacteria & Acidobacteria & Acidobacteriales & Acidobacteriaceae & & 1 & 1 \\
\hline 95-MB-78 & AY234650 & $1461 / 90$ & Proteobacteria & Alphaproteobacteria & Rhodospirillales & Acetobacteraceae & & 1 & 1 \\
\hline 96-MB-79 & AJ582047 & $1768 / 95$ & Acidobacteria & Acidobacteria & Holophagales & Holophagaceae & & 1 & 1 \\
\hline 97-MB-81 & AY234588 & $1803 / 95$ & Acidobacteria & Acidobacteria & Acidobacteriales & Acidobacteriaceae & & 1 & 1 \\
\hline 98-MB-83 & AJ277699 & $1458 / 94$ & Actinobacteria & Actinobacteria & Acidimicrobiales & Acidimicrobineae & & 1 & 1 \\
\hline 99-MB-87 & FJ528270 & $1831 / 96$ & Proteobacteria & Betaproteobacteria & Burkholderiales & Burkholderiaceae & Burkholderia & 1 & 1 \\
\hline 100-MB-89 & EU202789 & $1877 / 95$ & Acidobacteria & Acidobacteria & Holophagales & Holophagaceae & & 1 & 1 \\
\hline 101-MB-97 & AY234434 & $1703 / 94$ & Acidobacteria & Acidobacteria & Acidobacteriales & Acidobacteriaceae & & 1 & 1 \\
\hline 102-MB-98 & FJ517007 & $1646 / 97$ & Acidobacteria & Acidobacteria & Acidobacteriales & Acidobacteriaceae & & 1 & 1 \\
\hline 103-MB-102 & JF510471 & $1391 / 90$ & Actinobacteria & Actinobacteria & Acidimicrobiales & Acidimicrobineae & & 1 & 1 \\
\hline 104-MB-103 & EU445211 & $1323 / 90$ & Proteobacteria & Deltaproteobacteria & & & & 1 & 1 \\
\hline 105-MB-105 & AF376024 & $1770 / 96$ & Proteobacteria & Alphaproteobacteria & Rhodospirillales & Acetobacteraceae & Acidisphaera & 1 & 1 \\
\hline 106-MB-113 & EF019150 & $1688 / 94$ & Proteobacteria & Alphaproteobacteria & Rhizobiales & Hyphomicrobiaceae & & 1 & 1 \\
\hline 107-MB-115 & AY234538 & $1653 / 94$ & Acidobacteria & Acidobacteria & Acidobacteriales & Acidobacteriaceae & & 1 & 1 \\
\hline 108-MB-117 & 7 EF019164 & $1308 / 90$ & Acidobacteria & Acidobacteria & Acidobacteriales & Acidobacteriaceae & & 1 & 1 \\
\hline 109-MB-120 & EF203409 & $1343 / 92$ & Proteobacteria & Alphaproteobacteria & Rhizobiales & Bradyrhizobiaceae & Bradyrhizobium & 1 & 1 \\
\hline 110-MB-121 & GQ402716 & $1286 / 92$ & Proteobacteria & Alphaproteobacteria & Rhizobiales & Methylocystaceae & & 1 & 1 \\
\hline 111-MB-126 & AB426201 & $1515 / 93$ & Proteobacteria & Betaproteobacteria & Burkholderiales & & & 1 & 1 \\
\hline 112-MB-127 & 7 EF516921 & $1535 / 90$ & Chloroflexi & Chloroflexi & Ktedonobacterales & Ktedonobacteraceae & & 1 & 1 \\
\hline 113-MB-135 & HM062036 & $1485 / 90$ & Acidobacteria & Acidobacteria & Solibacterales & Solibacteraceae & & 1 & 1 \\
\hline 114-MB-137 & 7 EF019194 & $1452 / 90$ & Acidobacteria & Acidobacteria & Acidobacteriales & Acidobacteriaceae & & 1 & 1 \\
\hline 115-MB-146 & GQ369103 & $1604 / 93$ & Proteobacteria & Alphaproteobacteria & Rhizobiales & Bradyrhizobiaceae & Agromonas & 1 & 1 \\
\hline 116-MB-149 & EU299862 & $1040 / 91$ & Acidobacteria & Acidobacteria & Solibacterales & Solibacteraceae & & 1 & 1 \\
\hline
\end{tabular}




\begin{tabular}{|c|c|c|c|c|c|c|c|c|c|}
\hline 117-MB-150 & AY395368 & $1186 / 93$ & Proteobacteria & Alphaproteobacteria & Rhizobiales & Hyphomicrobiaceae & & 1 & 1 \\
\hline $\mid 118-\mathrm{MB}-152$ & AF482687 & $1254 / 88$ & Proteobacteria & Deltaproteobacteria & Myxococcales & & & 1 & 1 \\
\hline $\mid 119-\mathrm{MB}-155 \mathrm{E}$ & EF111055 & $1094 / 88$ & Proteobacteria & Alphaproteobacteria & Rhizobiales & Xanthobacteraceae & & 1 & 1 \\
\hline 120-MB-159 & AB252927 & $1365 / 91$ & Proteobacteria & Betaproteobacteria & Rhodocyclales & Rhodocyclaceae & & 1 & 1 \\
\hline 121-MB-160 & AY234531 & $1317 / 90$ & Proteobacteria & Gammaproteobacteria & & & & 1 & 1 \\
\hline $122-\mathrm{MB}-165 \mathrm{I}$ & HE575950 & $1428 / 93$ & Actinobacteria & Actinobacteria & Actinomycetales & Mycobacteriaceae & Mycobacterium & 1 & 1 \\
\hline$|123-\mathrm{MB}-167|$ & EF018409 & $1544 / 94$ & Proteobacteria & Betaproteobacteria & Burkholderiales & Burkholderiaceae & & 1 & 1 \\
\hline $\mid 124-\mathrm{MB}-169 \mathrm{E}$ & EF074395 & $1190 / 92$ & Acidobacteria & Acidobacteria & Acidobacteriales & Acidobacteriaceae & & 1 & 1 \\
\hline$|125-\mathrm{MB}-171| \mathrm{I}$ & FM253597 & $1572 / 91$ & Proteobacteria & Alphaproteobacteria & Rhizobiales & & & 1 & 1 \\
\hline 126-MB-173 & AY234640 & $1376 / 89$ & Acidobacteria & Acidobacteria & Acidobacteriales & Acidobacteriaceae & & 1 & 1 \\
\hline 127-MB-179 & GU433471 & $1153 / 85$ & Proteobacteria & Alphaproteobacteria & Rhizobiales & Bradyrhizobiaceae & Bradyrhizobium & 1 & 1 \\
\hline $\mid 128-\mathrm{MB}-181 \mathrm{I}$ & DQ419959 & $1227 / 87$ & Proteobacteria & Betaproteobacteria & Burkholderiales & Burkholderiaceae & Burkholderia & 1 & 1 \\
\hline 129-MB-184 & AY673303 & $1129 / 91$ & Acidobacteria & Acidobacteria & Acidobacteriales & Acidobacteriaceae & & 1 & 1 \\
\hline $130-\mathrm{MB}-185$ & $\mathrm{AB} 201284$ & $1829 / 96$ & Proteobacteria & Betaproteobacteria & Burkholderiales & Burkholderiaceae & Burkholderia & 1 & 1 \\
\hline $\mid 131-\mathrm{MB}-187 \mathrm{H}$ & HM062175 & $1297 / 94$ & Acidobacteria & Acidobacteria & Acidobacteriales & Acidobacteriaceae & & 1 & 1 \\
\hline $\mid 132-\mathrm{MB}-188 \mathrm{E}$ & FJ889227 & $1764 / 97$ & Acidobacteria & Acidobacteria & Acidobacteriales & Acidobacteriaceae & & 1 & 1 \\
\hline 133-MB-192 & EF019164 & $1653 / 94$ & Acidobacteria & Acidobacteria & Acidobacteriales & Acidobacteriaceae & & 1 & 1 \\
\hline $\mid 134-\mathrm{MB}-194$ & AJ519370 & $1495 / 91$ & Acidobacteria & Acidobacteria & Holophagales & Holophagaceae & Holophaga & 1 & 1 \\
\hline $135-\mathrm{MB}-195 \mathrm{I}$ & HM062367 & $1714 / 94$ & Acidobacteria & Acidobacteria & Solibacterales & Solibacteraceae & & 1 & 1 \\
\hline 136-MB-198 & AY607127 & $1064 / 88$ & Proteobacteria & Deltaproteobacteria & Syntrophobacterales & s Syntrophobacteraceae & Syntrophobacter & 1 & 1 \\
\hline 137-MB-199 & AF408985 & $1788 / 95$ & Actinobacteria & Actinobacteria & Actinomycetales & & & 1 & 1 \\
\hline $\mid 138-\mathrm{MB}-200 \mathrm{I}$ & EF072647 & $1074 / 90$ & Acidobacteria & Acidobacteria & Acidobacteriales & Acidobacteriaceae & & 1 & 1 \\
\hline 139-MB-205 & AM114444 & $1365 / 91$ & Bacteroidetes & Bacteroidetes & Sphingobacteriales & Sphingobacteriaceae & & 1 & 1 \\
\hline $\mid$\begin{tabular}{|l|}
$140-\mathrm{MB}-207 \mathrm{I}$ \\
\end{tabular} & EF075552 & $1491 / 96$ & Proteobacteria & Alphaproteobacteria & Rhizobiales & Bradyrhizobiaceae & & 1 & 1 \\
\hline 141-MB-209 & CU919466 & $1670 / 97$ & Proteobacteria & Alphaproteobacteria & Rhizobiales & Hyphomicrobiaceae & & 1 & 1 \\
\hline 142-MB-211| & EF018422 & $1851 / 94$ & Proteobacteria & Alphaproteobacteria & Rhizobiales & Hyphomicrobiaceae & & 1 & 1 \\
\hline $143-\mathrm{MB}-215 \mathrm{I}$ & EU445211 & $1380 / 92$ & Proteobacteria & Deltaproteobacteria & & & & 1 & 1 \\
\hline 144-MB-216 & AJ458492 & $1140 / 90$ & Proteobacteria & Alphaproteobacteria & Rhizobiales & Methylocystaceae & Methylosinus & 1 & 1 \\
\hline $\mid 145-\mathrm{MB}-221$ & GQ203308 & $1768 / 96$ & Actinobacteria & Actinobacteria & Acidimicrobiales & Acidimicrobineae & & 1 & 1 \\
\hline $\mid 146-\mathrm{MB}-223 \mathrm{I}$ & EF072661 & $1249 / 94$ & Acidobacteria & Acidobacteria & Acidobacteriales & Acidobacteriaceae & & 1 & 1 \\
\hline 147-MB-226I & EF520430 & $1426 / 92$ & Proteobacteria & Alphaproteobacteria & Rhodospirillales & Rhodospirillaceae & & 1 & 1 \\
\hline $148-\mathrm{MB}-227 \mathrm{~F}$ & EF019150 & $1168 / 87$ & Proteobacteria & Alphaproteobacteria & Rhizobiales & Hyphomicrobiaceae & & 1 & 1 \\
\hline
\end{tabular}




\begin{tabular}{|c|c|c|c|c|c|c|c|c|c|}
\hline \begin{tabular}{|l|l|} 
149-MB-229 & EF019009
\end{tabular} & $1570 / 94$ & Proteobacteria & Betaproteobacteria & Rhodocyclales & Rhodocyclaceae & & 1 & & 1 \\
\hline 150-MB-230|HM061991 & $1352 / 93$ & Acidobacteria & Acidobacteria & Acidobacteriales & Acidobacteriaceae & & 1 & & 1 \\
\hline \begin{tabular}{|l|l|} 
151-MB-236 HM061739 \\
\end{tabular} & $1424 / 91$ & Acidobacteria & Acidobacteria & Acidobacteriales & Acidobacteriaceae & & 1 & & 1 \\
\hline \begin{tabular}{|l|l|}
$152-M B-243$ & EU440612 \\
\end{tabular} & $1157 / 89$ & Acidobacteria & Acidobacteria & Acidobacteriales & Acidobacteriaceae & & 1 & & 1 \\
\hline 153-MB-246 HM061759 & $1417 / 94$ & Acidobacteria & Acidobacteria & Acidobacteriales & Acidobacteriaceae & & 1 & & 1 \\
\hline \begin{tabular}{|l|l|} 
154-MB-249EU300005 \\
\end{tabular} & $1173 / 93$ & Proteobacteria & Alphaproteobacteria & Rhodospirillales & Acetobacteraceae & & 1 & & 1 \\
\hline \begin{tabular}{|l|l|} 
155-MB-250 AY963511 \\
\end{tabular} & $1042 / 88$ & Acidobacteria & Acidobacteria & Acidobacteriales & Acidobacteriaceae & & 1 & & 1 \\
\hline 156-MB-254|DQ450700 & $1694 / 93$ & Acidobacteria & Acidobacteria & Acidobacteriales & Acidobacteriaceae & & 1 & & 1 \\
\hline \begin{tabular}{|l|l|} 
157-MB-256 & EU359940 \\
\end{tabular} & $1367 / 93$ & Proteobacteria & Alphaproteobacteria & Rhizobiales & Methylocystaceae & & 1 & & 1 \\
\hline \begin{tabular}{|l|l|}
$158-M B-257$ & EU680452
\end{tabular} & $1362 / 91$ & Acidobacteria & Acidobacteria & Acidobacteriales & Acidobacteriaceae & & 1 & & 1 \\
\hline 159-MB-258DQ450715 & $1661 / 97$ & Acidobacteria & Acidobacteria & Acidobacteriales & Acidobacteriaceae & & 1 & & 1 \\
\hline \begin{tabular}{|l|l|}
$160-M B-259$ & EU043719 \\
\end{tabular} & $1639 / 92$ & Proteobacteria & Alphaproteobacteria & Rhodospirillales & Acetobacteraceae & & 1 & & 1 \\
\hline \begin{tabular}{|l|l|}
$161-M B-266$ & NR-025764 \\
\end{tabular} & $1668 / 94$ & Proteobacteria & Gammaproteobacteria & Legionellales & Coxiellaceae & Aquicella & 1 & & 1 \\
\hline \begin{tabular}{|l|l|}
$162-M B-267$ & EU202832 \\
\end{tabular} & $1236 / 86$ & Proteobacteria & Alphaproteobacteria & Caulobacterales & Caulobacteraceae & Caulobacter & 1 & & 1 \\
\hline \begin{tabular}{|l|l|}
$163-M B-268$ & AJ519407 \\
\end{tabular} & $1439 / 90$ & Bacteroidetes & Bacteroidetes & & Rhodothermaceae & & 1 & & 1 \\
\hline \begin{tabular}{|l|l|} 
164-MB-269 & AF49868 \\
\end{tabular} & $1910 / 96$ & Proteobacteria & Gammaproteobacteria & Xanthomonadales & & & 1 & & 1 \\
\hline \begin{tabular}{|l|l|}
$165-M B-271$ & GU433471 \\
\end{tabular} & $1622 / 95$ & Proteobacteria & Alphaproteobacteria & Rhizobiales & Bradyrhizobiaceae & Bradyrhizobium & 1 & & 1 \\
\hline \begin{tabular}{|l|l|} 
166-MB-272 & AF498727 \\
\end{tabular} & $1347 / 91$ & Acidobacteria & Acidobacteria & Acidobacteriales & Acidobacteriaceae & & 1 & & 1 \\
\hline \begin{tabular}{|l|l|}
$167-M B-274$ & HQ730965 \\
\end{tabular} & $1906 / 97$ & Proteobacteria & Betaproteobacteria & Burkholderiales & Burkholderiaceae & Burkholderia & 1 & & 1 \\
\hline \begin{tabular}{|l|l|}
$168-M B-276$ & EF019497
\end{tabular} & $1375 / 90$ & Acidobacteria & Acidobacteria & Acidobacteriales & Acidobacteriaceae & & 1 & & 1 \\
\hline \begin{tabular}{|l|l|}
$169-M B-278$ & AB531406 \\
\end{tabular} & $1565 / 92$ & Proteobacteria & Alphaproteobacteria & Rhizobiales & Bradyrhizobiaceae & Bradyrhizobium & 1 & & 1 \\
\hline 170-MB-281 HM748732 & $1524 / 93$ & Acidobacteria & Acidobacteria & Acidobacteriales & Acidobacteriaceae & & 1 & & 1 \\
\hline \begin{tabular}{|l|l|} 
171-MB-282 & AY921819 \\
\end{tabular} & $1509 / 92$ & Proteobacteria & Alphaproteobacteria & Rhizobiales & Xanthobacteraceae & & 1 & & 1 \\
\hline \begin{tabular}{|l|l|} 
172-MB-284|HM062260 \\
\end{tabular} & $1452 / 94$ & Acidobacteria & Acidobacteria & Acidobacteriales & Acidobacteriaceae & & 1 & & 1 \\
\hline \begin{tabular}{|l|l|} 
173-MB-289 & HM062367 \\
\end{tabular} & $1264 / 94$ & Acidobacteria & Acidobacteria & Solibacterales & Solibacteraceae & & 1 & & 1 \\
\hline \begin{tabular}{|l|l|} 
174-MB-296 & GU433471 \\
\end{tabular} & $1218 / 90$ & Proteobacteria & Alphaproteobacteria & Rhizobiales & Bradyrhizobiaceae & Bradyrhizobium & 1 & & 1 \\
\hline \begin{tabular}{|l|l|}
$175-M B-297$ & EF018307
\end{tabular} & $1279 / 89$ & Acidobacteria & Acidobacteria & Acidobacteriales & Acidobacteriaceae & & 1 & & 1 \\
\hline \begin{tabular}{|l|l|l|} 
176-MB-304 & AB191225 \\
\end{tabular} & $1681 / 98$ & Proteobacteria & Betaproteobacteria & Burkholderiales & Burkholderiaceae & Burkholderia & 1 & & 1 \\
\hline \begin{tabular}{|l|l|} 
177-MB-311 DQ829647 \\
\end{tabular} & $1430 / 93$ & Acidobacteria & Acidobacteria & Acidobacteriales & Acidobacteriaceae & & 1 & & 1 \\
\hline 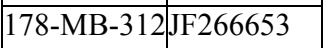 & $1544 / 94$ & Proteobacteria & Alphaproteobacteria & Rhizobiales & Bradyrhizobiaceae & Bradyrhizobium & 1 & & 1 \\
\hline \begin{tabular}{|l|l|} 
179-MB-315 & AF408987 \\
\end{tabular} & $1890 / 96$ & Actinobacteria & Actinobacteria & Actinomycetales & Micrococcineae & Microbacteriaceae & & 1 & 1 \\
\hline \begin{tabular}{|l|l|}
$180-M B-316$ & EF464628
\end{tabular} & $1155 / 92$ & Nitrospirae & Nitrospirae & Nitrospirales & Nitrospiraceae & & & 1 & 1 \\
\hline
\end{tabular}




\begin{tabular}{|c|c|c|c|c|c|c|c|c|c|}
\hline 181-MB-319F & FJ535110 & $1504 / 91$ & Proteobacteria & Betaproteobacteria & Burkholderiales & Alcaligenaceae & & 1 & 1 \\
\hline $\mid 182-\mathrm{MB}-320$ & EU193067 & $1592 / 91$ & Proteobacteria & Deltaproteobacteria & Myxococcales & Sorangiineae & Polyangiaceae & 1 & 1 \\
\hline \begin{tabular}{|l|}
$183-\mathrm{MB}-323$ \\
\end{tabular} & AY921916 & $1838 / 95$ & Proteobacteria & Alphaproteobacteria & Rhodospirillales & Rhodospirillaceae & & 1 & 1 \\
\hline 184-MB-328I & DQ114945 & $1731 / 94$ & Firmicutes & Clostridia & Clostridiales & Clostridiaceae & Clostridium & 1 & 1 \\
\hline 185-MB-329 & AY395395 & $1345 / 90$ & Proteobacteria & Deltaproteobacteria & Myxococcales & & & 1 & 1 \\
\hline $\mid 186-\mathrm{MB}-331 \mathrm{I}$ & EU359920 & $1437 / 92$ & Acidobacteria & Acidobacteria & Acidobacteriales & Acidobacteriaceae & & 1 & 1 \\
\hline 187-MB-332 & EU665032 & $1718 / 98$ & Acidobacteria & Acidobacteria & Solibacterales & Solibacteraceae & & 1 & 1 \\
\hline $\mid 188-\mathrm{MB}-335$ & AY963313 & $1672 / 95$ & Proteobacteria & Alphaproteobacteria & Rhizobiales & Xanthobacteraceae & & 1 & 1 \\
\hline $\mid 189-\mathrm{MB}-337$ & AY234723 & $1805 / 94$ & Acidobacteria & Acidobacteria & Acidobacteriales & Acidobacteriaceae & & 1 & 1 \\
\hline $\mid 190-\mathrm{MB}-338$ & GU187033 & $1519 / 91$ & Acidobacteria & Acidobacteria & Holophagales & Holophagaceae & & 1 & 1 \\
\hline$|191-\mathrm{MB}-340|$ & EU445198 & $1426 / 91$ & Proteobacteria & Deltaproteobacteria & & & & 1 & 1 \\
\hline $\mid 192-M B-341$ & AJ519365 & $1242 / 87$ & Acidobacteria & Acidobacteria & Holophagales & Holophagaceae & Holophaga & 1 & 1 \\
\hline 193-MB-345 & AJ518801 & $1679 / 93$ & Proteobacteria & Deltaproteobacteria & Desulfuromonadales & seobacteraceae & & 1 & 1 \\
\hline 194-MB-349 & GU167988 & $1906 / 97$ & Actinobacteria & Actinobacteria & Acidimicrobiales & Acidimicrobineae & & 1 & 1 \\
\hline 195-MB-351 & AY673181 & $1690 / 93$ & Proteobacteria & Gammaproteobacteria & aXanthomonadales & Xanthomonadaceae & & 1 & 1 \\
\hline $\mid 196-\mathrm{MB}-352$ & EF019854 & $1203 / 86$ & Proteobacteria & Alphaproteobacteria & Rhodospirillales & Acetobacteraceae & & 1 & 1 \\
\hline 197-MB-354 & GU172191 & $1469 / 90$ & Acidobacteria & Acidobacteria & Acidobacteriales & Acidobacteriaceae & & 1 & 1 \\
\hline 198-MB-356| & HM062040 & $1495 / 93$ & Acidobacteria & Acidobacteria & Acidobacteriales & Acidobacteriaceae & & 1 & 1 \\
\hline 199-MB-358I & DQ450764 & $1604 / 95$ & Proteobacteria & Alphaproteobacteria & Rhodospirillales & Acetobacteraceae & & 1 & 1 \\
\hline $200-\mathrm{MB}-363$ & FJ542862 & $1469 / 90$ & Proteobacteria & Deltaproteobacteria & Bdellovibrionales & Bdellovibrionaceae & Bdellovibrio & 1 & 1 \\
\hline $201-\mathrm{MB}-364$ & EF018995 & $1415 / 90$ & Proteobacteria & Alphaproteobacteria & Rhizobiales & Methylocystaceae & & 1 & 1 \\
\hline $202-\mathrm{MB}-365$ & EU043719 & $1807 / 95$ & Proteobacteria & Alphaproteobacteria & Rhodospirillales & Acetobacteraceae & & 1 & 1 \\
\hline 203-MB-369 & AJ534615 & $1437 / 92$ & Proteobacteria & Alphaproteobacteria & Rhodospirillales & Rhodospirillaceae & & 1 & 1 \\
\hline $\mid 204-\mathrm{MB}-370 \mathrm{E}$ & EF018936 & $1491 / 94$ & Acidobacteria & Acidobacteria & Acidobacteriales & Acidobacteriaceae & & 1 & 1 \\
\hline $205-\mathrm{MB}-372$ & AM887757 & $1493 / 95$ & Acidobacteria & Acidobacteria & Acidobacteriales & Acidobacteriaceae & Granulicella & 1 & 1 \\
\hline 206-MB-374| & EF020321 & $1568 / 92$ & Proteobacteria & Alphaproteobacteria & Rhizobiales & Methylocystaceae & & 1 & 1 \\
\hline $207-\mathrm{MB}-376$ & AY234503 & $1816 / 95$ & Proteobacteria & Alphaproteobacteria & Rhizobiales & Methylocystaceae & & 1 & 1 \\
\hline 208-MB-379 & AJ518771 & $1583 / 92$ & Proteobacteria & Alphaproteobacteria & Rhizobiales & Methylocystaceae & & 1 & 1 \\
\hline $209-\mathrm{MB}-382 \mathrm{|}$ & EF018987 & $1668 / 93$ & Proteobacteria & Alphaproteobacteria & Rhodospirillales & Rhodospirillaceae & & 1 & 1 \\
\hline $210-\mathrm{MB}-388 \mathrm{E}$ & EU043719 & $1628 / 92$ & Proteobacteria & Alphaproteobacteria & Rhodospirillales & Acetobacteraceae & & 1 & 1 \\
\hline 211-MB-390E & EF075624 & $1325 / 95$ & Acidobacteria & Acidobacteria & Acidobacteriales & Acidobacteriaceae & & 1 & 1 \\
\hline $\mid 212-\mathrm{MB}-391 \mathrm{I}$ & HM061755 & $1648 / 96$ & Acidobacteria & Acidobacteria & Acidobacteriales & Acidobacteriaceae & & 1 & 1 \\
\hline
\end{tabular}




\begin{tabular}{|c|c|c|c|c|c|c|c|c|c|}
\hline 213-MB-393 & $3 \mid$\begin{tabular}{|l} 
EU359920 \\
\end{tabular} & $1635 / 95$ & Acidobacteria & Acidobacteria & Acidobacteriales & Acidobacteriaceae & & 1 & 1 \\
\hline 214-MB-394 & \begin{tabular}{|l|l|} 
HM061754 \\
\end{tabular} & $1397 / 92$ & Acidobacteria & Acidobacteria & Solibacterales & Solibacteraceae & & 1 & 1 \\
\hline 215-MB-395 & 5 DQ450715 & $1535 / 96$ & Acidobacteria & Acidobacteria & Acidobacteriales & Acidobacteriaceae & & 1 & 1 \\
\hline 216-MB-397 & 7 AF293007 & $1520 / 94$ & Proteobacteria & Betaproteobacteria & Burkholderiales & Burkholderiaceae & Ralstonia & 1 & 1 \\
\hline 217-MB-400 & DQ829647 & $1042 / 93$ & Acidobacteria & Acidobacteria & Acidobacteriales & Acidobacteriaceae & & 1 & 1 \\
\hline 218-MB-401 & 1 HM062276 & $1694 / 96$ & Acidobacteria & Acidobacteria & Solibacterales & Solibacteraceae & & 1 & 1 \\
\hline 219-MB-407 & $7 \mid$ EU440668 & $1419 / 92$ & Proteobacteria & Deltaproteobacteria & Desulfuromonadales & Geobacteraceae & & 1 & 1 \\
\hline $220-\mathrm{MB}-410$ & FJ889345 & $1099 / 89$ & Proteobacteria & Gammaproteobacteria & Xanthomonadales & Xanthomonadaceae & Dokdonella & 1 & 1 \\
\hline 221-MB-411 & AY395390 & $1208 / 92$ & Acidobacteria & Acidobacteria & Acidobacteriales & Acidobacteriaceae & & 1 & 1 \\
\hline 222-MB-413 & HM748702 & $1546 / 91$ & Acidobacteria & Acidobacteria & Acidobacteriales & Acidobacteriaceae & & 1 & 1 \\
\hline 223-MB-421 & AF281142 & $1753 / 95$ & Firmicutes & Clostridia & Clostridiales & Clostridiaceae & Clostridium & 1 & 1 \\
\hline 224-MB-422 & HM748650 & $1679 / 93$ & Proteobacteria & Deltaproteobacteria & Myxococcales & Kofleriaceae & & 1 & 1 \\
\hline 225-MB-429 & HM187222 & $1371 / 89$ & Firmicutes & Clostridia & Clostridiales & Clostridiaceae & Clostridium & 1 & 1 \\
\hline 226-MB-430 & AF236003 & $1821 / 95$ & Proteobacteria & Alphaproteobacteria & Caulobacterales & Caulobacteraceae & & 1 & 1 \\
\hline 227-MB-436 & EU043855 & $1408 / 95$ & Proteobacteria & Alphaproteobacteria & Rhizobiales & Hyphomicrobiaceae & Rhodoplanes & 1 & 1 \\
\hline 228-MB-439 & AF498724 & $1616 / 92$ & Acidobacteria & Acidobacteria & Acidobacteriales & Acidobacteriaceae & & 1 & 1 \\
\hline 229-MB-442 & X77835 & $1844 / 96$ & Firmicutes & Clostridia & Clostridiales & Clostridiaceae & & 1 & 1 \\
\hline $230-\mathrm{MB}-445$ & DQ493433 & $1772 / 95$ & Proteobacteria & Alphaproteobacteria & Caulobacterales & Caulobacteraceae & & 1 & 1 \\
\hline 231-MB-446 & HM748650 & $1321 / 87$ & Proteobacteria & Deltaproteobacteria & Myxococcales & Kofleriaceae & & 1 & 1 \\
\hline 232-MB-448 & AF408981 & $1469 / 96$ & Proteobacteria & Gammaproteobacteria & Xanthomonadales & & & 1 & 1 \\
\hline 233-MB-449 & AJ518781 & $1755 / 94$ & Proteobacteria & Betaproteobacteria & Rhodocyclales & Rhodocyclaceae & & 1 & 1 \\
\hline 234-MB-450 & DQ829637 & $1714 / 95$ & Acidobacteria & Acidobacteria & Acidobacteriales & Acidobacteriaceae & & 1 & 1 \\
\hline 235-MB-451 & AY921812 & $1949 / 96$ & Proteobacteria & Gammaproteobacteria & Xanthomonadales & & & 1 & 1 \\
\hline 236-MB-457 & EF018936 & $1858 / 95$ & Acidobacteria & Acidobacteria & Acidobacteriales & Acidobacteriaceae & & 1 & 1 \\
\hline 237-MB-459 & AM114436 & $1768 / 95$ & Proteobacteria & Alphaproteobacteria & Rhizobiales & Hyphomicrobiaceae & & 1 & 1 \\
\hline 238-MB-460 & EF019150 & $1635 / 96$ & Proteobacteria & Alphaproteobacteria & Rhizobiales & Hyphomicrobiaceae & & 1 & 1 \\
\hline 239-MB-462 & FN811194 & $1620 / 91$ & Proteobacteria & Deltaproteobacteria & Myxococcales & Kofleriaceae & & 1 & 1 \\
\hline $240-\mathrm{MB}-463$ & AY234420 & $1801 / 95$ & Proteobacteria & Alphaproteobacteria & Rhodospirillales & & & 1 & 1 \\
\hline 241-MB-464 & AY395432 & $1814 / 95$ & Proteobacteria & Alphaproteobacteria & Rhizobiales & Hyphomicrobiaceae & & 1 & 1 \\
\hline 242-MB-465 & AJ534617 & $1452 / 95$ & Proteobacteria & Alphaproteobacteria & Rhizobiales & Hyphomicrobiaceae & & 1 & 1 \\
\hline 243-MB-468 & GU983323 & $1267 / 93$ & Proteobacteria & Gammaproteobacteria & Chromatiales & Ectothiorhodospiraceae & & 1 & 1 \\
\hline 244-MB-473 & EF019452 & $1452 / 89$ & Acidobacteria & Acidobacteria & Acidobacteriales & Acidobacteriaceae & & 1 & 1 \\
\hline
\end{tabular}




\begin{tabular}{|c|c|c|c|c|c|c|c|c|c|}
\hline 245-MB-474 & 4 HM062167 & $1672 / 94$ & Acidobacteria & Acidobacteria & Solibacteres & Solibacterales & & 1 & 1 \\
\hline 246-MB-475 & \begin{tabular}{|l|l|} 
EF074954 \\
\end{tabular} & $1181 / 93$ & Proteobacteria & Alphaproteobacteria & Rhodospirillales & Rhodospirillaceae & & 1 & 1 \\
\hline 247-MB-476 & 6 HM062470 & $1572 / 96$ & Acidobacteria & Acidobacteria & Acidobacteriales & Acidobacteriaceae & & 1 & 1 \\
\hline 248-MB-479 & 9 AB672176 & $1061 / 91$ & Nitrospirae & Nitrospirae & & & & 1 & 1 \\
\hline 249-MB-480 & 0 EF018602 & $1666 / 93$ & Acidobacteria & Acidobacteria & Acidobacteriales & Acidobacteriaceae & & 1 & 1 \\
\hline 250-MB-481 & 1 HM062456 & $1375 / 93$ & Acidobacteria & Acidobacteria & Solibacteres & Solibacterales & & 1 & 1 \\
\hline 251-MB-484 & \begin{tabular}{l|l|}
4 & CU922792
\end{tabular} & $1469 / 92$ & Proteobacteria & Alphaproteobacteria & Rhizobiales & Methylocystaceae & & 1 & 1 \\
\hline 252-MB-487 & 7HM062092 & $1478 / 97$ & Acidobacteria & Acidobacteria & Acidobacteriales & Acidobacteriaceae & & 1 & 1 \\
\hline 253-MB-493 & GU120600 & $1399 / 96$ & Proteobacteria & Alphaproteobacteria & Rhodospirillales & Rhodospirillaceae & & 1 & 1 \\
\hline 254-MB-500 & AB303630 & $1521 / 93$ & Proteobacteria & Betaproteobacteria & Burkholderiales & Burkholderiaceae & Burkholderia & 1 & 1 \\
\hline 255-MB-502 & AJ518779 & $1853 / 96$ & Proteobacteria & Alphaproteobacteria & Caulobacterales & Caulobacteraceae & & 1 & 1 \\
\hline 256-MB-504 & GU472718 & $1382 / 94$ & Bacteroidetes & Bacteroidia & Cytophagales & Cytophagaceae & & 1 & 1 \\
\hline 257-MB-505 & \begin{tabular}{|l|l|} 
AJ518803 \\
\end{tabular} & $1502 / 92$ & Proteobacteria & Deltaproteobacteria & Myxococcales & Myxococcaceae & & 1 & 1 \\
\hline 258-MB-508 & EF075146 & $1214 / 94$ & Proteobacteria & Deltaproteobacteria & Myxococcales & Myxococcaceae & & 1 & 1 \\
\hline 259-MB-510 & EF074811 & $1120 / 91$ & Acidobacteria & Acidobacteria & Acidobacteriales & Acidobacteriaceae & & 1 & 1 \\
\hline $260-\mathrm{MB}-512$ & AY234728 & $1661 / 93$ & Acidobacteria & Acidobacteria & Solibacteres & Solibacterales & Solibacteraceae & 1 & 1 \\
\hline 261-MB-514 & \begin{tabular}{|l|l|} 
AJ582047
\end{tabular} & $1192 / 88$ & Acidobacteria & Acidobacteria & Acidobacteriales & Acidobacteriaceae & & 1 & 1 \\
\hline 262-MB-515 & X97077 & $1947 / 95$ & Proteobacteria & Alphaproteobacteria & Rhizobiales & Methylocystaceae & & 1 & 1 \\
\hline $263-\mathrm{MB}-516$ & EF019194 & $1345 / 90$ & Acidobacteria & Acidobacteria & Acidobacteriales & Acidobacteriaceae & & 1 & 1 \\
\hline 264-MB-519 & EF111055 & $1676 / 95$ & Proteobacteria & Alphaproteobacteria & Rhizobiales & Xanthobacteraceae & & 1 & 1 \\
\hline 265-MB-521 & EU297133 & $1162 / 94$ & Firmicutes & Clostridia & Clostridiales & Clostridiaceae & Clostridium & 1 & 1 \\
\hline 266-MB-527 & 7GQ500694 & $1797 / 96$ & Proteobacteria & Deltaproteobacteria & Myxococcales & Myxococcaceae & & 1 & 1 \\
\hline 267-MB-528 & GU187025 & $1496 / 90$ & Acidobacteria & Acidobacteria & Acidobacteriales & Acidobacteriaceae & & 1 & 1 \\
\hline 268-MB-530 & HM062470 & $1555 / 94$ & Acidobacteria & Acidobacteria & Acidobacteriales & Acidobacteriaceae & & 1 & 1 \\
\hline 269-MB-531 & HM061759 & $1476 / 93$ & Acidobacteria & Acidobacteria & Acidobacteriales & Acidobacteriaceae & & 1 & 1 \\
\hline 270-MB-532 & CU921195 & $1430 / 91$ & Proteobacteria & Deltaproteobacteria & Myxococcales & Polyangiaceae & & 1 & 1 \\
\hline 271-MB-533 & FJ516999 & $1620 / 93$ & Acidobacteria & Acidobacteria & Holophagales & Holophagaceae & & 1 & 1 \\
\hline 272-MB-534 & HM061754 & $1727 / 94$ & Acidobacteria & Acidobacteria & Solibacteres & Solibacterales & & 1 & 1 \\
\hline 273-MB-536 & JN180107 & $1705 / 94$ & Proteobacteria & Alphaproteobacteria & Rhizobiales & Bradyrhizobiaceae & Bradyrhizobium & 1 & 1 \\
\hline 274-MB-537 & HM062457 & $1720 / 93$ & Acidobacteria & Acidobacteria & Solibacteres & Solibacterales & & 1 & 1 \\
\hline 275-MB-539 & AB486908 & $1186 / 92$ & Firmicutes & Clostridia & Clostridiales & Clostridiaceae & & 1 & 1 \\
\hline 276-MB-545 & FJ485076 & $1650 / 95$ & Proteobacteria & Deltaproteobacteria & Desulfobacterales & Desulfobacteraceae & & 1 & 1 \\
\hline
\end{tabular}




\begin{tabular}{|c|c|c|c|c|c|c|c|c|c|}
\hline \begin{tabular}{|l|l|} 
277-MB-547|EF018851 & \\
\end{tabular} & $1297 / 87$ & Actinobacteria & Actinobacteria & Actinomycetales & Thermomonosporaceae & Actinocorallia & & 1 & 1 \\
\hline \begin{tabular}{|l|l|} 
278-MB-550 & GQ249356 \\
\end{tabular} & $1485 / 91$ & Proteobacteria & Deltaproteobacteria & Myxococcales & Sorangiineae & & & 1 & 1 \\
\hline \begin{tabular}{|l|l|} 
279-MB-553 & HM061754 \\
\end{tabular} & $1790 / 95$ & Acidobacteria & Acidobacteria & Solibacteres & Solibacterales & & & 1 & 1 \\
\hline 280-MB-554DQ450810 & $1674 / 94$ & Proteobacteria & Deltaproteobacteria & Desulfuromonadales & seobacteraceae & Geobacter & & 1 & 1 \\
\hline \begin{tabular}{|l|l|} 
281-MB-556 EU445198 \\
\end{tabular} & $1478 / 93$ & Proteobacteria & Deltaproteobacteria & Myxococcales & & & & 1 & 1 \\
\hline \begin{tabular}{|l|l|} 
282-MB-561 & AY234728 \\
\end{tabular} & $1480 / 94$ & Acidobacteria & Acidobacteria & Solibacterales & Solibacteraceae & Solibacter & & 1 & 1 \\
\hline \begin{tabular}{|l|l|} 
283-MB-567 EU413907 \\
\end{tabular} & $1439 / 90$ & Actinobacteria & Actinobacteria & Actinomycetales & Streptomycetaceae & Streptomyces & & 1 & 1 \\
\hline \begin{tabular}{|l|l|} 
284-MB-570 AF524860 \\
\end{tabular} & $1384 / 91$ & Acidobacteria & Acidobacteria & Acidobacteriales & Acidobacteriaceae & & & 1 & 1 \\
\hline \begin{tabular}{|l|l|}
$285-\mathrm{MB}-575$ & HM061856 \\
\end{tabular} & $1352 / 91$ & Acidobacteria & Acidobacteria & Acidobacteriales & Acidobacteriaceae & & & 1 & 1 \\
\hline \begin{tabular}{|l|l|} 
286-MB-576 & EF075552 \\
\end{tabular} & $1480 / 96$ & Proteobacteria & Alphaproteobacteria & Rhizobiales & Bradyrhizobiaceae & & & 1 & 1 \\
\hline 287-MB-580|HM062175 & $1589 / 92$ & Acidobacteria & Acidobacteria & Acidobacteriales & Acidobacteriaceae & & & 1 & 1 \\
\hline \begin{tabular}{|l|l|} 
288-MB-581 & EF018331
\end{tabular} & $1415 / 89$ & Proteobacteria & Alphaproteobacteria & Rhizobiales & Bradyrhizobiaceae & & & 1 & 1 \\
\hline \begin{tabular}{|l|l|} 
289-MB-582 HM062058 \\
\end{tabular} & $1533 / 94$ & Acidobacteria & Acidobacteria & Acidobacteriales & Acidobacteriaceae & & & 1 & 1 \\
\hline \begin{tabular}{|l|l|}
$290-M B-584$ & AY234726 \\
\end{tabular} & $1666 / 98$ & Acidobacteria & Acidobacteria & Acidobacteriales & Acidobacteriaceae & & & 1 & 1 \\
\hline \begin{tabular}{|l|l|} 
291-MB-586 & EF019164
\end{tabular} & $717 / 81$ & Acidobacteria & Acidobacteria & Acidobacteriales & Acidobacteriaceae & & & 1 & 1 \\
\hline 292-MB-587|HM062367 & $1868 / 96$ & Acidobacteria & Acidobacteria & Acidobacteriales & Acidobacteriaceae & & & 1 & 1 \\
\hline \begin{tabular}{|l|l|} 
293-MB-592 JN590319 \\
\end{tabular} & $1869 / 96$ & Proteobacteria & Betaproteobacteria & Burkholderiales & Burkholderiaceae & Burkholderia & & 1 & 1 \\
\hline \begin{tabular}{|l|l|} 
294-MB-596 DQ109933 \\
\end{tabular} & $1216 / 89$ & Proteobacteria & Deltaproteobacteria & Myxococcales & Myxococcaceae & & 1 & & 1 \\
\hline \begin{tabular}{|l|l|} 
295-MB-599 & EF125937
\end{tabular} & $1561 / 93$ & Acidobacteria & Acidobacteria & Acidobacteriales & Acidobacteriaceae & & 1 & & 1 \\
\hline \begin{tabular}{|l|l|} 
296-MB-600 & EU680452 \\
\end{tabular} & $985 / 84$ & Acidobacteria & Acidobacteria & Acidobacteriales & Acidobacteriaceae & & 1 & & 1 \\
\hline 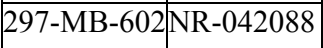 & $1247 / 88$ & Bacteroidetes & Flavobacteria & Flavobacteriales & Flavobacteriaceae & Flavobacterium & 1 & & 1 \\
\hline \begin{tabular}{|l|l|} 
298-MB-607 & EF020306
\end{tabular} & $1208 / 88$ & Proteobacteria & Gammaproteobacteria & aXanthomonadales & Xanthomonadaceae & & 1 & & 1 \\
\hline \begin{tabular}{|l|l|} 
299-MB-612 & EF019150 \\
\end{tabular} & $1844 / 96$ & Proteobacteria & Alphaproteobacteria & Rhizobiales & Hyphomicrobiaceae & & 1 & & 1 \\
\hline \begin{tabular}{|l|l|}
$300-M B-616$ & HM061936 \\
\end{tabular} & $1755 / 93$ & Acidobacteria & Acidobacteria & Acidobacteriales & Acidobacteriaceae & & 1 & & 1 \\
\hline \begin{tabular}{|l|l|}
$301-M B-617$ & EU440666 \\
\end{tabular} & $1557 / 94$ & Proteobacteria & Deltaproteobacteria & Myxococcales & & & 1 & & 1 \\
\hline \begin{tabular}{|l|l|}
$302-M B-619$ & EF019026
\end{tabular} & $1118 / 86$ & Proteobacteria & Alphaproteobacteria & Rhizobiales & Hyphomicrobiaceae & & 1 & & 1 \\
\hline \begin{tabular}{|l|l|}
$303-M B-622$ & EF019506
\end{tabular} & $1476 / 91$ & Proteobacteria & Alphaproteobacteria & Rhizobiales & Hyphomicrobiaceae & & 1 & & 1 \\
\hline \begin{tabular}{|l|l|}
$304-M B-626$ & HM061921 \\
\end{tabular} & $1469 / 95$ & Acidobacteria & Acidobacteria & Holophagales & Holophagaceae & & 1 & & 1 \\
\hline \begin{tabular}{|l|l|l|} 
305-MB-634 & AY691423 \\
\end{tabular} & $1537 / 97$ & Proteobacteria & Betaproteobacteria & Rhodocyclales & Rhodocyclaceae & Rhodocyclus & 1 & & 1 \\
\hline 306-MB-635 $\mathrm{HQ023246}$ & $1391 / 93$ & Proteobacteria & Betaproteobacteria & Burkholderiales & Burkholderiaceae & Burkholderia & 1 & & 1 \\
\hline \begin{tabular}{|l|l|} 
307-MB-636 AY395390 \\
\end{tabular} & $1755 / 94$ & Acidobacteria & Acidobacteria & Solibacterales & Solibacteraceae & & 1 & & 1 \\
\hline \begin{tabular}{|l|l|}
$308-M B-637$ & EF020280
\end{tabular} & $1376 / 94$ & Acidobacteria & Acidobacteria & Acidobacteriales & Acidobacteriaceae & & 1 & & 1 \\
\hline
\end{tabular}




\begin{tabular}{|c|c|c|c|c|c|c|c|c|c|}
\hline 309-MB-638 & DQ110051 & $1338 / 96$ & Proteobacteria & Deltaproteobacteria & Desulfuromonadale & Pelobacteraceae & & 1 & 1 \\
\hline 310-MB-642 & 2 HM062268 & $1450 / 89$ & Acidobacteria & Acidobacteria & Acidobacteriales & Acidobacteriaceae & & 1 & 1 \\
\hline 311-MB-643 & 3 AJ582046 & $1478 / 91$ & Acidobacteria & Acidobacteria & Acidobacteriales & Acidobacteriaceae & & 1 & 1 \\
\hline 312-MB-645 & 5 EU043719 & $1659 / 92$ & Proteobacteria & Alphaproteobacteria & Rhodospirillales & Acetobacteraceae & & 1 & 1 \\
\hline 313-MB-646 & 6 DQ450717 & $1663 / 94$ & Acidobacteria & Acidobacteria & Acidobacteriales & Acidobacteriaceae & & 1 & 1 \\
\hline 314-MB-651 & EF074384 & $1496 / 97$ & Acidobacteria & Acidobacteria & Acidobacteriales & Acidobacteriaceae & & 1 & 1 \\
\hline 315-MB-653 & 3 GQ369058 & $1504 / 95$ & Actinobacteria & Actinobacteria & Acidimicrobiales & Iamiaceae & Iamia & 1 & 1 \\
\hline 316-MB-663 & EF665816 & $1441 / 97$ & Proteobacteria & Alphaproteobacteria & Rhizobiales & & & 1 & 1 \\
\hline 317-MB-664 & AY395368 & $1327 / 96$ & Proteobacteria & Alphaproteobacteria & Rhizobiales & Hyphomicrobiaceae & & 1 & 1 \\
\hline 318-MB-672 & EU043922 & $1131 / 91$ & Proteobacteria & Gammaproteobacteri & aXanthomonadales & Sinobacteraceae & & 1 & 1 \\
\hline 319-MB-673 & AY673350 & $1075 / 89$ & Acidobacteria & Acidobacteria & & & & 1 & 1 \\
\hline 320-MB-674 & EU665032 & $1275 / 92$ & Acidobacteria & Acidobacteria & & & & 1 & 1 \\
\hline
\end{tabular}




\section{Appendix Table 4.2b}

\begin{tabular}{|c|c|c|c|c|c|c|c|c|c|c|c|}
\hline OTU & Accession & 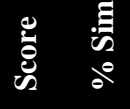 & Phylum & Subphylum & Class & Order & Family & Genus & 胥 & 3 & 륨 \\
\hline $1-\mathrm{MF}-346$ & AJ557830 & $1075 / 99$ & Ascomycota & Pezizomycotina & Sordariomycetes & Hypocreales & Nectriaceae & Nectria & 36 & 97 & 133 \\
\hline 2-MF-271 & FN428924 & $935 / 99$ & Basidiomycota & Agaricomycotina & Tremellomycetes & Tremellales & & Cryptococcus & 18 & 12 & 30 \\
\hline 3-MF-266 & JF439485 & $1181 / 99$ & Zygomycota & Mucoromycotina & & Mortierellales & Mortierellaceae & Mortierella & 5 & 7 & 12 \\
\hline 4-MF-159 & HM176576 & $1101 / 99$ & Ascomycota & Pezizomycotina & Sordariomycetes & Hypocreales & Hypocreaceae & Trichoderma & 8 & & 8 \\
\hline $5-\mathrm{MF}-356$ & AY854068 & $569 / 100$ & Basidiomycota & Agaricomycotina & Agaricomycetes & Boletales & Boletaceae & Strobilomyces & & 6 & 6 \\
\hline 6-MF-314 & DQ195594 & $763 / 86$ & Basidiomycota & Agaricomycotina & Agaricomycetes & Russulales & Russulaceae & & & 6 & 6 \\
\hline 7-MF-49 & EU819493 & $1120 / 97$ & Basidiomycota & Agaricomycotina & Agaricomycetes & Agaricales & Amanitaceae & Amanita & 6 & & 6 \\
\hline 8-MF-26 & EU598153 & $1140 / 99$ & Basidiomycota & Agaricomycotina & Agaricomycetes & Russulales & Russulaceae & Russula & 2 & 3 & 5 \\
\hline $9-\mathrm{MF}-96$ & FJ845443 & $678 / 85$ & Basidiomycota & Agaricomycotina & Agaricomycetes & Agaricales & Tricholomataceae & Tricholoma & 1 & 4 & 5 \\
\hline 10-MF-383 & HM189876 & $985 / 92$ & Basidiomycota & Agaricomycotina & Tremellomycetes & Tremellales & & & & 5 & 5 \\
\hline 11-MF-397 & HQ873381 & $425 / 88$ & Zygomycota & & & & & & 1 & 3 & 4 \\
\hline 12-MF-23 & AM084698 & $928 / 99$ & Ascomycota & Pezizomycotina & Dothideomycetes & & & Cenococcum & 4 & 1 & 5 \\
\hline 13-MF-70 & EU557361 & $950 / 99$ & Ascomycota & Pezizomycotina & Sordariomycetes & Microascales & Halosphaeriaceae & Sigmoidea & 4 & & 4 \\
\hline 14-MF-18 & EU186277 & $1266 / 99$ & Basidiomycota & Agaricomycotina & Agaricomycetes & Agaricales & Tricholomataceae & Tricholoma & 4 & & 4 \\
\hline 15-MF-229 & EU819478 & $1267 / 99$ & Basidiomycota & Agaricomycotina & Agaricomycetes & Agaricales & Tricholomataceae & Laccaria & & 4 & 4 \\
\hline 16-MF-312 & HQ608146 & $1074 / 99$ & Ascomycota & Pezizomycotina & Eurotiomycetes & Eurotiales & Trichocomaceae & Aspergillus & & 4 & 4 \\
\hline 17-MF-391 & GU566216 & $1016 / 98$ & Ascomycota & Pezizomycotina & Eurotiomycetes & Eurotiales & Trichocomaceae & Penicillium & & 4 & 4 \\
\hline 18-MF-127 & DQ777988 & $1192 / 99$ & Basidiomycota & Agaricomycotina & Agaricomycetes & Russulales & Russulaceae & Russula & 3 & & 3 \\
\hline 19-MF-21 & GU212410 & $701 / 93$ & Ascomycota & Pezizomycotina & Sordariomycetes & Magnaporthales & & & 3 & & 3 \\
\hline 20-MF-115 & JF439489 & $1166 / 99$ & Zygomycota & Mucoromycotina & & Mortierellales & Mortierellaceae & Mortierella & 1 & 2 & 3 \\
\hline 21-MF-373 & JF908140 & $638 / 84$ & Basidiomycota & Agaricomycotina & Agaricomycetes & Agaricales & Inocybaceae & Inocybe & & 3 & 3 \\
\hline 22-MF-359 & HQ630960 & $1131 / 99$ & Ascomycota & Pezizomycotina & Sordariomycetes & Hypocreales & Hypocreaceae & Hypocrea & & 3 & 3 \\
\hline 23-MF-74 & HQ604626 & $706 / 86$ & Basidiomycota & Agaricomycotina & Agaricomycetes & Agaricales & Inocybaceae & Inocybe & 3 & & 3 \\
\hline 24-MF-315 & EU035459 & $785 / 92$ & Ascomycota & Pezizomycotina & Dothideomycetes & Venturiales & Venturiaceae & Venturia & & 3 & 3 \\
\hline \multirow[t]{2}{*}{ 25-MF-441 } & JN882326 & $364 / 81$ & Chytridiomycota & & Monoblepharidomycetes & Monoblepharidales & Gonapodyaceae & Gonapodya & 2 & & 2 \\
\hline & & & & & & Agaricales & & & & & \\
\hline
\end{tabular}




\begin{tabular}{|c|c|c|c|c|c|c|c|c|c|c|c|}
\hline 27-MF-145 & AJ633598 & $1064 / 97$ & Basidiomycota & & & & & & 2 & & 2 \\
\hline 28-MF-9 & FJ475798 & $355 / 82$ & Basidiomycota & Agaricomycotina & Agaricomycetes & Agaricales & & & 2 & & 2 \\
\hline 29-MF-199 & FJ612884 & $736 / 94$ & Ascomycota & Pezizomycotina & Sordariomycetes & & & & & 2 & 2 \\
\hline 30-MF-277 & EU598167 & $832 / 91$ & Basidiomycota & Agaricomycotina & Agaricomycetes & Russulales & Russulaceae & Russula & & 2 & 2 \\
\hline 31-MF-279 & EU598167 & $1164 / 100$ & Basidiomycota & Agaricomycotina & Agaricomycetes & Russulales & Russulaceae & Russula & & 2 & 2 \\
\hline 32-MF-217 & JF735304 & $989 / 99$ & Ascomycota & Pezizomycotina & Sordariomycetes & Hypocreales & Nectriaceae & Ilyonectria & & 2 & 2 \\
\hline 33-MF-220 & FN397177 & $492 / 84$ & Ascomycota & Pezizomycotina & Eurotiomycetes & Eurotiales & & & & 2 & 2 \\
\hline 34-MF-322 & FJ000401 & $948 / 99$ & Ascomycota & Pezizomycotina & Leotiomycetes & Helotiales & & Angulospora & & 2 & 2 \\
\hline $35-\mathrm{MF}-336$ & GU997932 & $896 / 96$ & Ascomycota & Pezizomycotina & Leotiomycetes & Helotiales & Helotiaceae & & & 2 & 2 \\
\hline 36-MF-420 & JF439486 & $1181 / 99$ & Zygomycota & Mucoromycotina & & Mortierellales & Mortierellaceae & Mortierella & & 2 & 2 \\
\hline 37-MF-11 & HQ631003 & $1013 / 99$ & Ascomycota & Pezizomycotina & Dothideomycetes & Capnodiales & Davidiellaceae & Cladosporium & 1 & 1 & 2 \\
\hline 38-MF-435 & HQ157874 & $763 / 92$ & Ascomycota & Pezizomycotina & Leotiomycetes & Helotiales & Helotiaceae & & 1 & 1 & 2 \\
\hline $39-M F-50$ & EF619863 & $771 / 94$ & Ascomycota & Pezizomycotina & Dothideomycetes & Venturiales & & & 2 & & 2 \\
\hline 40-MF-118 & HM562160 & $01136 / 97$ & Basidiomycota & Agaricomycotina & Agaricomycetes & Agaricales & Pluteaceae & Pluteus & 2 & & 2 \\
\hline 41-MF-317 & HM036644 & $41072 / 99$ & Basidiomycota & Agaricomycotina & Agaricomycetes & Agaricales & Lyophyllaceae & Asterophora & & 2 & 2 \\
\hline 42-MF-431 & DQ431175 & $846 / 98$ & Ascomycota & Pezizomycotina & Leotiomycetes & Helotiales & Helotiaceae & Hymenoscyphus & & 2 & 2 \\
\hline 43-MF-57 & HQ608097 & $760 / 98$ & Zygomycota & Mucoromycotina & & Mortierellales & Mortierellaceae & Mortierella & 2 & & 2 \\
\hline 44-MF-273 & FM999581 & $357 / 78$ & Basidiomycota & Agaricomycotina & Tremellomycetes & Tremellales & & & & 2 & 2 \\
\hline $45-\mathrm{MF}-293$ & FJ196771 & $750 / 94$ & Ascomycota & Pezizomycotina & Sordariomycetes & Sordariales & Lasiosphaeriaceae & Arnium & & 2 & 2 \\
\hline $46-\mathrm{MF}-5$ & AF418616 & $977 / 93$ & Basidiomycota & Agaricomycotina & Agaricomycetes & Russulales & Russulaceae & Russula & 1 & & 1 \\
\hline 47-MF-12 & GU234137 & $507 / 84$ & Basidiomycota & Agaricomycotina & Agaricomycetes & Agaricales & Lyophyllaceae & Lyophyllum & 1 & & 1 \\
\hline $48-\mathrm{MF}-16$ & FJ554007 & $987 / 96$ & Basidiomycota & Agaricomycotina & Agaricomycetes & Agaricales & Cortinariaceae & Cortinarius & 1 & & 1 \\
\hline 49-MF-19 & EU819493 & $1266 / 99$ & Basidiomycota & Agaricomycotina & Agaricomycetes & Russulales & Russulaceae & Russula & 1 & & 1 \\
\hline $50-\mathrm{MF}-22$ & FJ378813 & $1123 / 95$ & Basidiomycota & Agaricomycotina & Agaricomycetes & Russulales & Russulaceae & Lactarius & 1 & & 1 \\
\hline 51-MF-28 & JF908706 & $514 / 83$ & Basidiomycota & Agaricomycotina & Agaricomycetes & Russulales & Russulaceae & Russula & 1 & & 1 \\
\hline $52-\mathrm{MF}-36$ & AY456364 & $979 / 94$ & Basidiomycota & Agaricomycotina & Agaricomycetes & Russulales & Russulaceae & Russula & 1 & & 1 \\
\hline $53-\mathrm{MF}-37$ & GU934589 & $1105 / 98$ & Ascomycota & Pezizomycotina & Sordariomycetes & Hypocreales & Hypocreaceae & Hypocrea & 1 & & 1 \\
\hline 54-MF-40 & JN882326 & $363 / 81$ & Chytridiomycota & & Monoblepharidomycetes & sMonoblepharidales & Gonapodyaceae & Gonapodya & 1 & & 1 \\
\hline 55-MF-44 & EU035406 & $843 / 91$ & Ascomycota & Pezizomycotina & Eurotiomycetes & Chaetothyriales & Herpotrichiellaceae & Cladophialophora & 1 & & 1 \\
\hline $56-\mathrm{MF}-47$ & GU566253 & $1035 / 99$ & Ascomycota & Pezizomycotina & Sordariomycetes & Hypocreales & Bionectriaceae & Bionectria & 1 & & 1 \\
\hline $57-M F-54$ & FJ403209 & $580 / 83$ & Basidiomycota & Agaricomycotina & Agaricomycetes & Polyporales & & Daedalea & 1 & & 1 \\
\hline 58-MF-66 & FJ589646 & $994 / 99$ & Ascomycota & Pezizomycotina & Sordariomycetes & Hypocreales & Clavicipitaceae & Metarhizium & 1 & & 1 \\
\hline
\end{tabular}




\begin{tabular}{|c|c|c|c|c|c|c|c|c|c|c|}
\hline 59-MF-71 & HM069466 & $346 / 82$ & Ascomycota & Pezizomycotina & Eurotiomycetes & Eurotiales & Eurotiomycetidae & Elaphomyces & 1 & 1 \\
\hline 60-MF-73 & FJ770373 & $756 / 90$ & Ascomycota & Pezizomycotina & Sordariomycetes & Hypocreales & Hypocreomycetidae & Acremonium & 1 & 1 \\
\hline 61-MF-76 & EU625924 & $743 / 98$ & Basidiomycota & Agaricomycotina & Agaricomycetes & Thelephorales & Thelephoraceae & & 1 & 1 \\
\hline 62-MF-79 & HQ637272 & $640 / 98$ & Ascomycota & Pezizomycotina & Sordariomycetes & Hypocreales & Hypocreomycetidae & & 1 & 1 \\
\hline 63-MF-80 & AJ557830 & $730 / 99$ & Ascomycota & Pezizomycotina & Sordariomycetes & Hypocreales & Hypocreomycetidae & Nectria & 1 & 1 \\
\hline 64-MF-84 & HM176567 & $1070 / 98$ & Ascomycota & Pezizomycotina & Sordariomycetes & Hypocreales & Hypocreaceae & Trichoderma & 1 & 1 \\
\hline 65-MF-85 & FJ440938 & $833 / 93$ & Ascomycota & Pezizomycotina & Sordariomycetes & Sordariales & Sordariomycetidae & & 1 & 1 \\
\hline 66-MF-95 & HM240099 & $815 / 91$ & Zygomycota & Mucoromycotina & & Mortierellales & Mortierellaceae & Mortierella & 1 & 1 \\
\hline 67-MF-97 & AY456364 & $706 / 86$ & Basidiomycota & Agaricomycotina & Agaricomycetes & Russulales & Russulaceae & Russula & 1 & 1 \\
\hline 68-MF-99 & FJ876187 & $1096 / 96$ & Ascomycota & Pezizomycotina & Eurotiomycetes & Eurotiales & Eurotiomycetidae & Elaphomyces & 1 & 1 \\
\hline 69-MF-104 & EU625924 & $579 / 92$ & Basidiomycota & Agaricomycotina & Agaricomycetes & Thelephorales & Thelephoraceae & & 1 & 1 \\
\hline 70-MF-105 & FJ613023 & $1074 / 98$ & Ascomycota & Pezizomycotina & Sordariomycetes & Hypocreales & Hypocreomycetidae & Trichoderma & 1 & 1 \\
\hline 71-MF-106 & HQ599581 & $922 / 96$ & Ascomycota & Pezizomycotina & Leotiomycetes & Helotiales & & & 1 & 1 \\
\hline 72-MF-107 & EF029220 & $918 / 98$ & Ascomycota & Pezizomycotina & Sordariomycetes & Chaetosphaeriales & Chaetosphaeriaceae & Chloridium & 1 & 1 \\
\hline 73-MF-109 & AB218096 & $525 / 95$ & Basidiomycota & Agaricomycotina & Agaricomycetes & Agaricales & & & 1 & 1 \\
\hline 74-MF-111 & AM944351 & $933 / 98$ & Ascomycota & Pezizomycotina & Sordariomycetes & Hypocreales & Bionectriaceae & Bionectria & 1 & 1 \\
\hline 75-MF-112 & HQ392603 & $769 / 94$ & Zygomycota & Mucoromycotina & & Mortierellales & Mortierellaceae & Mortierella & 1 & 1 \\
\hline 76-MF-113 & AJ557830 & $769 / 91$ & Ascomycota & Pezizomycotina & Sordariomycetes & Hypocreales & Hypocreomycetidae & Nectria & 1 & 1 \\
\hline 77-MF-117 & AY789432 & $745 / 92$ & Ascomycota & Pezizomycotina & Leotiomycetes & Helotiales & Helotiaceae & Hymenoscyphus & 1 & 1 \\
\hline 78-MF-119 & EU998926 & $874 / 95$ & Ascomycota & Pezizomycotina & Leotiomycetes & Helotiales & Helotiaceae & Articulospora & 1 & 1 \\
\hline 79-MF-140 & EU625924 & $1205 / 99$ & Basidiomycota & Agaricomycotina & Agaricomycetes & Thelephorales & Thelephoraceae & & 1 & 1 \\
\hline $80-\mathrm{MF}-146$ & AY456348 & $1208 / 99$ & Basidiomycota & Agaricomycotina & Agaricomycetes & Russulaceae & Russulaceae & Lactarius & 1 & 1 \\
\hline $81-\mathrm{MF}-150$ & DQ178166 & $972 / 99$ & Ascomycota & Pezizomycotina & Sordariomycetes & Hypocreales & Nectriaceae & Ilyonectria & 1 & 1 \\
\hline 82-MF-155 & JF439497 & $1016 / 98$ & Ascomycota & Pezizomycotina & Eurotiomycetes & Eurotiales & Trichocomaceae & Penicillium & 1 & 1 \\
\hline 83-MF-156 & AY587914 & $475 / 82$ & Ascomycota & Pezizomycotina & Sordariomycetes & Sordariales & Lasiosphaeriaceae & Lasiosphaeria & 1 & 1 \\
\hline 84-MF-164 & EU784197 & $800 / 92$ & Ascomycota & Pezizomycotina & Eurotiomycetes & Eurotiales & Elaphomycetaceae & Elaphomyces & 1 & 1 \\
\hline $85-\mathrm{MF}-167$ & AJ557830 & $745 / 97$ & Ascomycota & Pezizomycotina & Sordariomycetes & Hypocreales & Nectriaceae & Neonectria & 1 & 1 \\
\hline 86-MF-171 & GU327518 & $929 / 93$ & Zygomycota & Mucoromycotina & & Mortierellales & Mortierellaceae & & 1 & 1 \\
\hline 87-MF-173 & AJ534905 & $1157 / 96$ & Basidiomycota & Agaricomycotina & Agaricomycetes & Russulales & Russulaceae & Russula & 1 & 1 \\
\hline $88-M F-175$ & AB258369 & $883 / 92$ & Ascomycota & Pezizomycotina & Sordariomycetes & Hypocreales & Clavicipitaceae & Paecilomyces & 1 & 1 \\
\hline 89-MF-178 & FJ554109 & $588 / 85$ & Basidiomycota & Pucciniomycotina & Pucciniomycetes & Pucciniales & & & 1 & 1 \\
\hline & AJ534912 & & & Agaricomycotina & Agaricomycetes & Thelephorales & Thelephoraceae & Tomentella & & \\
\hline
\end{tabular}




\begin{tabular}{|c|c|c|c|c|c|c|c|c|c|c|c|}
\hline 91-MF-183 & FJ876187 & $416 / 90$ & Ascomycota & Pezizomycotina & Eurotiomycetes & Eurotiales & Elaphomycetaceae & Elaphomyces & 1 & & 1 \\
\hline 92-MF-186 & JN225930 & $424 / 81$ & Ascomycota & Pezizomycotina & Dothideomycetes & & & & 1 & & 1 \\
\hline 93-MF-188 & JN098488 & $610 / 99$ & Ascomycota & Pezizomycotina & Sordariomycetes & Hypocreales & & & 1 & & 1 \\
\hline 94-MF-219 & HМ051159 & $9641 / 95$ & Ascomycota & Pezizomycotina & Dothideomycetes & Capnodiales & Dothideomycetidae & Capnodiales & & 1 & 1 \\
\hline 95-MF-228 & FM999707 & $854 / 91$ & Basidiomycota & Agaricomycotina & Agaricomycetes & Agaricales & & & & 1 & 1 \\
\hline 96-MF-252 & EU449953 & $606 / 89$ & Ascomycota & Pezizomycotina & Dothideomycetes & Venturiales & & & & 1 & 1 \\
\hline 97-MF-255 & HM189876 & $61134 / 96$ & Basidiomycota & Agaricomycotina & Agaricomycetes & Russulales & Russulaceae & Russula & & 1 & 1 \\
\hline 98-MF-268 & EU167594 & $915 / 98$ & Ascomycota & Pezizomycotina & Dothideomycetes & Capnodiales & Mycosphaerellaceae & Mycosphaerella & & 1 & 1 \\
\hline 99-MF-291 & GU566205 & $992 / 99$ & Ascomycota & Pezizomycotina & Sordariomycetes & Hypocreales & Hypocreomycetidae & Fusarium & & 1 & 1 \\
\hline 100-MF-294 & HM051159 & $9765 / 95$ & Ascomycota & Pezizomycotina & Dothideomycetes & Capnodiales & & & & 1 & 1 \\
\hline 101-MF-313 & FJ501561 & $878 / 99$ & Basidiomycota & Agaricomycotina & Agaricomycetes & Polyporales & Ganodermataceae & Ganoderma & & 1 & 1 \\
\hline 102-MF-316 & AY383749 & $1051 / 99$ & Basidiomycota & Pucciniomycotina & Microbotryomycetes & & Microbotryomycetidae & Rhodotorula & & 1 & 1 \\
\hline 103-MF-351 & AY312985 & $1140 / 99$ & Basidiomycota & Agaricomycotina & Agaricomycetes & Agaricales & Cortinariaceae & Hebeloma & & 1 & 1 \\
\hline 104-MF-362 & EF672298 & $977 / 99$ & Ascomycota & Pezizomycotina & Dothideomycetes & Pleosporales & Pleosporomycetidae & Pleosporales & & 1 & 1 \\
\hline 105-MF-372 & HM488478 & $872 / 96$ & Ascomycota & Pezizomycotina & Leotiomycetes & & & & & 1 & 1 \\
\hline 106-MF-378 & GU233360 & $560 / 84$ & Basidiomycota & Agaricomycotina & Agaricomycetes & Agaricales & Cortinariaceae & Astrosporina & & 1 & 1 \\
\hline 107-MF-381 & EU019284 & $913 / 98$ & Ascomycota & Pezizomycotina & Dothideomycetes & Capnodiales & Mycosphaerellaceae & Ramularia & & 1 & 1 \\
\hline 108-MF-388 & FJ553813 & $1007 / 99$ & Ascomycota & Pezizomycotina & Leotiomycetes & Helotiales & Dermateaceae & & & 1 & 1 \\
\hline 109-MF-399 & EU444535 & $874 / 95$ & Basidiomycota & Agaricomycotina & Agaricomycetes & Corticiales & Corticiaceae & Sistotrema & & 1 & 1 \\
\hline 110-MF-402 & HM189994 & $41024 / 94$ & Basidiomycota & Agaricomycotina & Agaricomycetes & Thelephorales & Thelephoraceae & Tomentella & & 1 & 1 \\
\hline 111-MF-407 & EU520616 & $438 / 82$ & Ascomycota & Pezizomycotina & Dothideomycetes & Venturiales & Venturiaceae & & & 1 & 1 \\
\hline 112-MF-415 & AB505408 & $425 / 81$ & Ascomycota & Pezizomycotina & Sordariomycetes & Diaporthales & Valsaceae & Phomopsis & & 1 & 1 \\
\hline 113-MF-419 & HQ634614 & $632 / 84$ & Ascomycota & Pezizomycotina & Eurotiomycetes & Chaetothyriales & Chaetothyriomycetidae & & & 1 & 1 \\
\hline 114-MF-424 & EF141550 & $1112 / 92$ & Basidiomycota & Agaricomycotina & Agaricomycetes & Russulales & Russulaceae & Lactarius & & 1 & 1 \\
\hline
\end{tabular}

